\title{
Results of 1999 Spectral Gamma-Ray and Neutron Moisture Monitoring of Boreholes at Specific Retention Facilities in the $\mathbf{2 0 0}$ East Area, Hanford Site
}

D. G. Horton

R. R. Randall ${ }^{(a)}$

January 2000

Prepared for the U.S. Department of Energy under Contract DE-AC06-76RLO 1830

Pacific Northwest National Laboratory Richland, Washington 99352

\footnotetext{
$\overline{(\mathrm{a})}$ Three Rivers Scientific

West Richland, Washington
} 

- 


\section{DISCLAIMER}

This report was prepared as an account of work sponsored by an agency of the United States Government. Neither the United States Government nor any agency thereof, nor any of their employees, make any warranty, express or implied, or assumes any legal liability or responsibility for the accuracy, completeness, or usefulness of any information, apparatus, product, or process disclosed, or represents that its use would not infringe privately owned rights. Reference herein to any specific commercial product, process, or service by trade name, trademark, manufacturer, or otherwise does not necessarily constitute or imply its endorsement, recommendation, or favoring by the United States Government or any agency thereof. The views and opinions of authors expressed herein do not necessarily state or reflect those of the United States Government or any agency thereof. 


\section{DISCLAIMER}

Portions of this document may be illegible in electronic image products. Images are produced from the best available original document. 


\section{Summary}

Twenty-eight wells and boreholes in the 200 East Area, Hanford Site, Washington were monitored in 1999. The monitored facilities were past-practice liquid waste disposal facilities and consisted of six cribs and nineteen "specific retention" cribs and trenches. Monitoring consisted of spectral gamma-ray and neutron moisture logging. All data are included in Appendix B.

The isotopes ${ }^{137} \mathrm{Cs},{ }^{60} \mathrm{Co},{ }^{235} \mathrm{U},{ }^{238} \mathrm{U}$, and ${ }^{154} \mathrm{Eu}$ were identified on spectral gamma logs from boreholes monitoring the PUREX specific retention facilities; the isotopes ${ }^{137} \mathrm{Cs},{ }^{60} \mathrm{Co},{ }^{125} \mathrm{Sb}$, and ${ }^{154} \mathrm{Eu}$ were identified on the logs from boreholes at the $\mathrm{BC}$ Controlled Area cribs and trenches; and ${ }^{137} \mathrm{Cs},{ }^{60} \mathrm{Co}$, and ${ }^{125} \mathrm{Sb}$ were identified on the logs from boreholes at the BX specific retention trenches.

Three boreholes in the BC Controlled Area and one at the BX trenches had previous spectral gamma logs available for comparison with 1999 logs. Two of those logs showed that changes in the subsurface distribution of ${ }^{137} \mathrm{Cs}$ and/or ${ }^{60} \mathrm{Co}$ had occurred since 1992. Although the changes are not great, they do point to continued movement of contaminants in the vadose zone. The logs obtained in 1999 create a larger baseline for comparison with future logs.

Numerous historical gross gamma logs exist from most of the boreholes logged. Qualitative comparison of those logs with the 1999 logs show many substantial changes, most of which reflect the decay of deeper short-lived isotopes, such as ${ }^{106} \mathrm{Ru}$ and ${ }^{125} \mathrm{Sb}$, and the much slower decay of shallower and longerlived isotopes such as ${ }^{137} \mathrm{Cs}$.

The radionuclides ${ }^{137} \mathrm{Cs}$ and ${ }^{60} \mathrm{Co}$ have moved in two boreholes since 1992 . Given the amount of movement and the half-lives of the isotopes, it is expected that they will decay to insignificant amounts before reaching groundwater. However, gamma ray logging cannot detect many of the contaminants of interest such as ${ }^{99} \mathrm{Tc}, \mathrm{NO}_{3}$, or ${ }^{129} \mathrm{I}$, all of which can be highly mobile in the vadose zone and, for the radionuclides, have long half-lives. 
. 


\section{Contents}

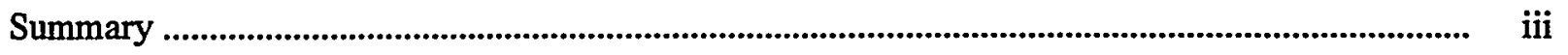

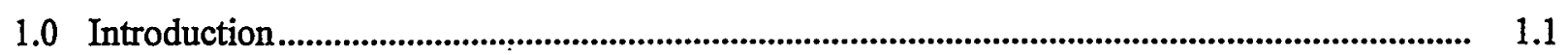

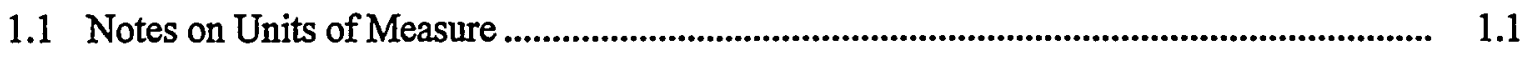

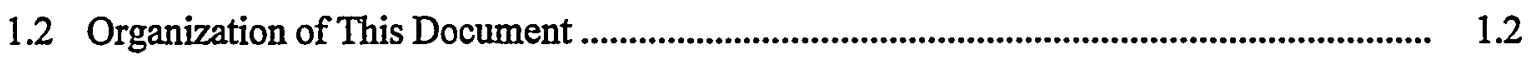

2.0 Facility Descriptions and Previous Monitoring .......................................................... 2.1

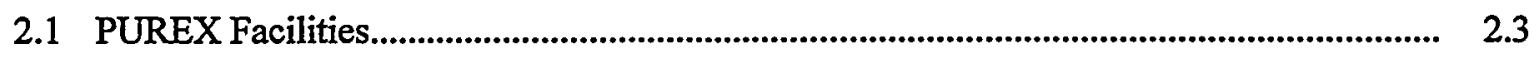

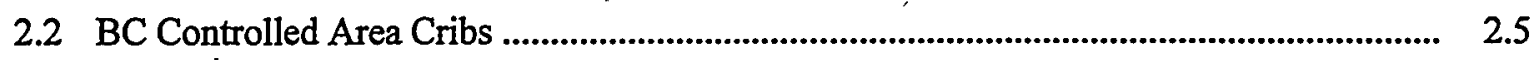

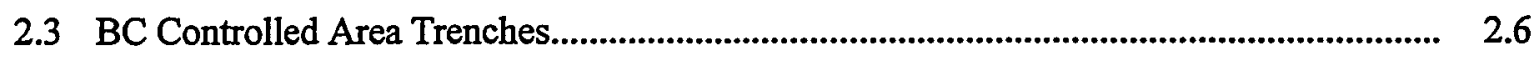

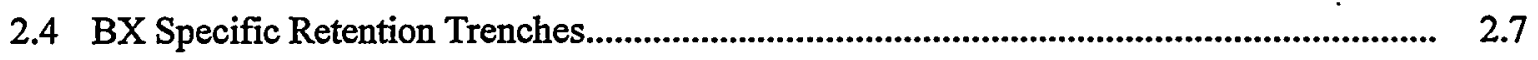

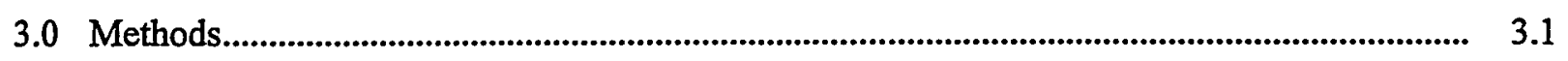

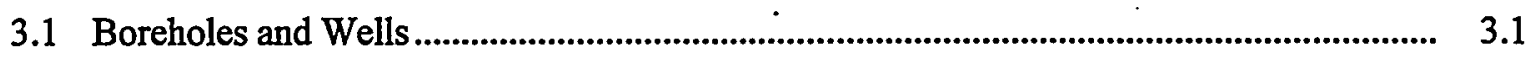

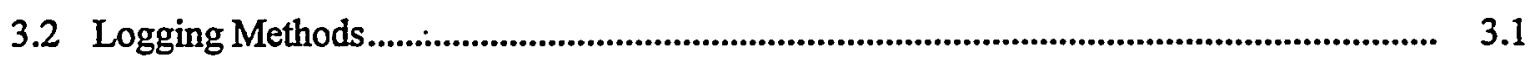

3.2.1 Spectral Gamma-Ray Logging........................................................................... 3.6

3.2.2 Neutron Moisture Logging......................................................................... 3.9

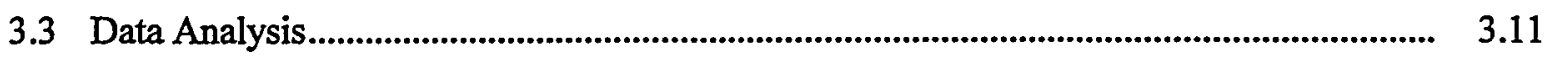

3.3.1 Time Lapse Comparison of Spectral Log Data .................................................. 3.11

3.3.2 Comparison of Gross Gamma Logs ....................................................................... 3.13

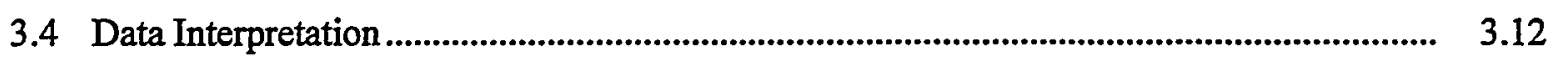

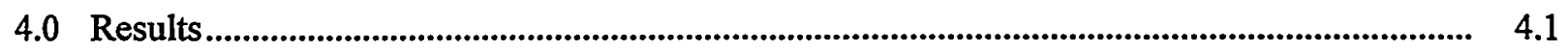

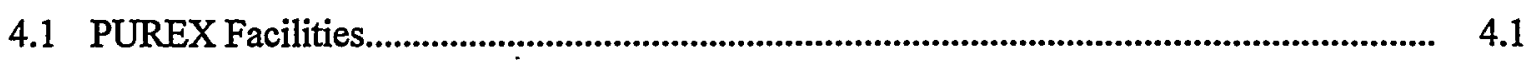

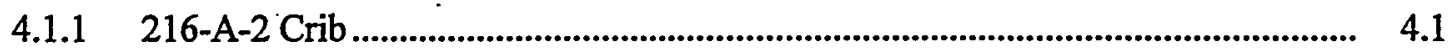

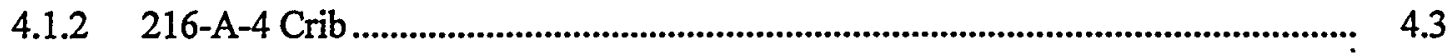

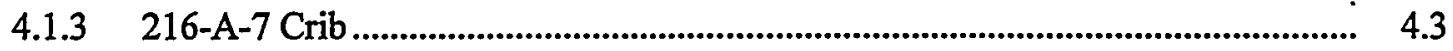

4.1.4 216-A-18 Trench..................................................................................... 4.6 
4.2 BC Controlled Area Cribs ……….................................................................................. 4.7

4.2.1 216-B-14 Crib ..................................................................................... 4.7

4.2.2 216-B-15 Crib ...................................................................................... 4.10

4.2.3 216-B-16 Crib ................................................................................. 4.12

4.2.4 216-B-17 Crib ........................................................................................ 4.15

4.2.5 216-B-18 Crib ...................................................................................... 4.18

4.2.6 216-B-19 Crib .................................................................................... 4.22

4.3 BC Controlled Area Specific Retention Trenches .......................................................... 4.22

4.3.1 216-B-23 Specific Retention Trench.............................................................. 4.22

4.3.2 216-B-25 Specific Retention Trench............................................................... 4.23

4.3.3 216-B-26 Specific Retention Trench................................................................ 4.23

4.3.4 216-B-27 Specific Retention Trench.................................................................... 4.25

4.3.5 216-B-30 Specific Retention Trench............................................................... 4.25

4.3.6 216-B-31 Specific Retention Trench................................................................ 4.27

4.3.7 216-B-32 Specific Retention Trench................................................................. 4.27

4.3.8 216-B-33 Specific Retention Trench............................................................ 4.28

4.3.9 216-B-52 Specific Retention Trench.................................................................. 4.28

4.3.10 216-B-53A Specific Retention Trench.................................................................. 4.29

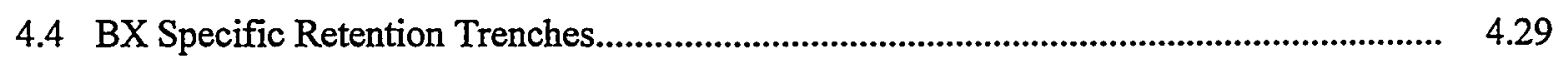

4.4.1 216-B-35 Specific Retention Trench.................................................................... 4.29

4.4.2 216-B-37 Specific Retention Trench............................................................... 4.30

4.4.3 216-B-38 Specific Retention Trench................................................................ 4.32

4.4.4 216-B-41 Specific Retention Trench................................................................ 4.34

4.4.5 216-B-42 Specific Retention Trench................................................................. 4.36

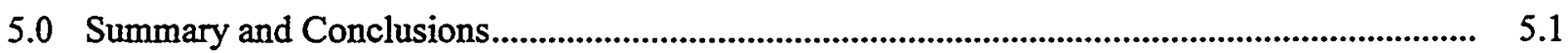

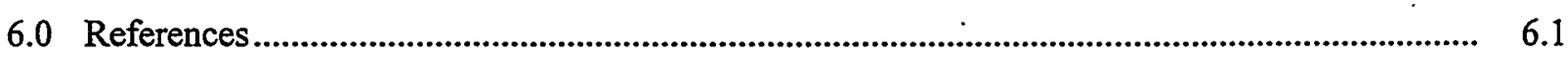

Appendix A - Enhanced Spectral Processing for Low Intensity Photo Peaks ................................... A.1

Appendix B - Borehole Logging Data.................................................................................................... B.1 


\section{Figures}

2.1 Map of the 200 East Area Showing the Location of the Facilities Monitored During FY 1999

3.1 Map of the 216-A-2 and 216-A-4 Cribs Showing the Locations of Boreholes Monitored in 1999

3.2 Map of the 216-A-7 Crib and the 216-A-18 Trench Showing the Locations of Boreholes Monitored in 1999

3.3 Map of the 216-B-14 Through -19 Cribs in the BC Controlled Area Showing Locations of Boreholes Monitored in 1999.

3.4 Map of the 216-B-20 Through -34, -53A, and -58 Specific Retention Trenches in the BC Controlled Area Showing the Locations of Boreholes Logged in 1999.

3.5 Map of the 216-B-35 Through -42 Specific Retention Trenches West of the 241-BX Tank Farm Showing the Locations of Boreholes Logged in 1999 .

4.1 Spectral Gamma-Ray and Neutron Moisture Logs from Borehole 299-E24-53 at the 216-A-2 Crib.

4.2 Comparison of 1999 and 1976 Gross Gamma-Ray Logs from Borehole 299-E24-53.

4.3 Spectral Gamma-Ray and Neutron Moisture Logs from Borehole 299-E24-54 at the 216-A-4 Crib.

4.4 Spectral Gamma-Ray and Neutron Moisture Logs from Well 299-E13-1 at the 216-B-14 Crib.

4.5 Comparison of 1992 and 1999 Spectral Gamma-Ray Logs from Well 299-E13-1

4.6 Comparison of the 1999 and 1976 Gross Gamma-Ray Logs from Well 299-E13-2 at the 216-B-15 Crib

4.7 Comparison of the 1999 and 1992 Spectral Gamma Log Results for ${ }^{137} \mathrm{Cs}$ at Well 299-E13-3 at Two Different Scales

4.8 Comparison of the 1999 and 1992 Spectral Gamma Logs for ${ }^{60} \mathrm{Cs}$ and ${ }^{154} \mathrm{Eu}$ in Well 299-E13-3 at the 216-B-16 Crib . 
4.9 Spectral Gamma-Ray and Neutron Moisture Logs from Well 299-E13-21 at the

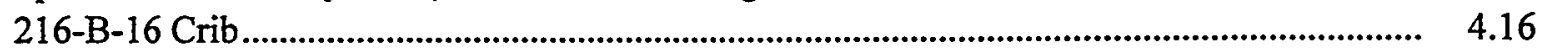

4.10 Comparison of the 1999 and 1976 Gross Gamma-Ray Logs for Well 299-E13-4 at the 216-B-17 Crib

4.11 Spectral Gamma-Ray and Neutron Moisture Logs from Well 299-E13-5 at the 216-B-18 Crib

4.12 Comparison of the 1999 and 1992 Spectral Gamma Log Results for ${ }^{137} \mathrm{Cs}$ at Well 299-E13-5 at Two Different Scales

4.13 Comparison of the 1999 and 1992 Spectral Gamma Log Results for ${ }^{60} \mathrm{Co}$ and ${ }^{125} \mathrm{Sb}$ at Well 299-E13-5

4.14 Spectral Gamma-Ray and Neutron Moisture Logs from Well 299-E13-56 at the 216-B-25 Specific Retention Trench

4.15 Spectral Gamma-Ray and Neutron Moisture Logs from Well 299-E13-52 at the 216-B-30 Specific Retention Trench

4.16 Spectral Gamma-Ray and Neutron Moisture Logs from Boreholes 299-E33-287 and 299-E33-288 at the 216-B-37 Specific Retention Trench

4.17 Comparison of the 1999 and 1984 Gross Gamma-Ray Logs for Well 299-E33-289 at the 216-B-38 Trench.

4.18 Comparison of the 1999 and 1992 Gross Gamma Log and Spectral Gamma Log Results for ${ }^{137} \mathrm{Cs}$ at Well 299-E33-290 at the 216-B-38 Specific Retention Trench

\section{Tables}

2.1 Liquid Disposal Facilities and Associated Boreholes and Wells that were Monitored in Fiscal Year 1999

2.2 Inventory of Contaminants Disposed to the 216-A-2, 216-A-4 and 216-A-7 Cribs, and the 216-A-18 Trench

2.3 Operating Periods and Effluent Volumes for the BC Controlled Area Cribs that were Monitored in 1999 
2.4 Contaminant Inventory for the Cribs in the BC Controlled Area that were Monitored in 1999

2.5 Operating Periods and Effluent Volumes for the BC Controlled Area Specific Retention Trenches Monitored in 1999

2.6 Contaminant Inventory for the Specific Retention Trenches in the BC Controlled Area that were Monitored in 1999.

2.7 Operating Periods and Effluent Volumes for the BX Trenches Monitored in 1999...

2.8 Contaminant Inventory for the Specific Retention Trenches West of the 241-BX Tank Farm Monitored in 1999

3.1 Boreholes and Logged in 1999

3.2 Boreholes with Pre-1999 Spectral Gamma Logs.

4.1 Man-Made Isotopes Identified in Borehole 299-E24-53 


\subsection{Introduction}

This document describes the results of fiscal year (FY) 1999 vadose zone monitoring of 25 inactive liquid waste disposal facilities in the 200 East Area, Hanford Site, Washington. The facilities monitored were 6 cribs and 19 specific retention facilities. Monitoring consisted of spectral gamma-ray and neutron moisture logging of 28 wells and boreholes. This work was performed by the Hanford Groundwater Monitoring Project within the Pacific Northwest National Laboratory in conjunction with Three Rivers Scientific and Waste Management Federal Services, Inc. Northwest Operations.

Specific retention facilities were chosen for monitoring because they are among the highest priority sites as determined by an evaluation of past-practice, liquid waste disposal facilities (Horton et al. 1999). Specific retention facilities are liquid waste disposal sites designed to use the moisture-retention capability of the soils to retain contaminants. Ideally, liquid disposed to specific retention facilities was to be limited to $6 \%$ to $10 \%$ of the soil volume between the facility and the groundwater so that the liquid would be retained in the soils and not reach the groundwater (Waite 1991). The relatively small volume of liquid discharged to the facilities was probably insufficient to flush contaminants through the vadose zone to groundwater. Therefore, the discharged contaminants remain in the soil column and these sites represent potential sources for future contamination of groundwater at the Hanford Site.

The six cribs were monitored because they received the same kind of waste that was disposed to some specific retention facilities, they are in the same area as some of the specific retention facilities, and the results of past monitoring indicated that breakthrough of contaminants to groundwater either had occurred or might possibly occur in the (then) future. The six monitored cribs were not operated as specific retention cribs because they received amounts of effluent in excess of $6 \%$ to $10 \%$ of the soil pore volume.

The FY 1999 monitoring was designed to address the question "What is the configuration of subsurface contamination beneath the facilities and has the contaminant distribution changed since it was last measured?" The results of previous borehole logging, where available, provided the baseline data to help answer this question.

\subsection{Notes on Units of Measure}

This document uses metric units except in discussions of boreholes and the logging results from boreholes where English units are used. The decision to use English units was based on several factors. First, most historical information concerning the drilling and logging of boreholes is in English units. Second, new logging data were obtained in English units (feet and curies), and the software to process the raw data and the software for interpretation of the data are in English units. Finally, most users of borehole and logging data are familiar with parameters such as casing diameter in English units and with radionuclide activities in English units.

\footnotetext{
${ }^{1}$ Pacific Northwest National Laboratory is operated by Battelle for the U.S. Department of Energy.
} 
The following are some useful conversions between English units and metric equivalents:

$$
\begin{aligned}
& 1 \text { foot }=0.3048 \text { meter } \\
& 1 \text { inch }=2.54 \text { centimeters } \\
& 1 \text { curie }=3.7 \times 10^{10} \text { becquerels } \\
& 1 \mathrm{pCi}=3.7 \times 10^{-2} \text { becquerel. }
\end{aligned}
$$

\subsection{Organization of This Document}

This document is organized into several sections which describe 1) the previous work, 2) background of the facility operations and the local geology, 3) the methods used to obtain and evaluate the data, 4) the results for each borehole logged, and 5) a summary of the results. Appendix A contains a technical description of the method used to identify radionuclides in some logs where the radionuclide was present at the minimum detection level. Appendix B contains all of the borehole logs including header sheets, quality control information, and log summary sheets. 


\subsection{Facility Descriptions and Previous Monitoring}

Twenty-five past-practice, liquid waste disposal facilities were monitored in FY 1999. This section presents brief descriptions of their locations, construction details, and types and volume of effluent disposed at each of the facilities. More detailed descriptions can be found in DOE (1993a, 1993b). As-built diagrams for each facility can be found in Wood (1958).

The monitored facilities can be placed into three groups based on geographic location and the type of effluent received. The three groups are 1) PUREX facilities, 2) BC Controlled Area facilities, and 3) BX trenches. Table 2.1 lists the facilities that were monitored in 1999 in each group. Figure 2.1 shows a map of the location of each monitored facility. Originally, the 216-C-5 crib, near C Plant, was scheduled for monitoring (Horton 1999). However, the geophysical tools could not be lowered into the borehole that monitors the crib because the borehole was bent.

Table 2.1. Liquid Disposal Facilities and Associated Boreholes and Wells that were Logged in Fiscal Year 1999

\begin{tabular}{|c|c|c|c|}
\hline Facility & Borehole & Facility & Borehole \\
\hline \multicolumn{4}{|c|}{ PUREX Facilities } \\
\hline 216-A-2 crib & 299-E24-53 & $216-A-7$ & 299-E25-54 \\
\hline 216-A-4 crib & 299-E24-54 & 216-A-18 trench & 299-E25-10 \\
\hline \multicolumn{4}{|c|}{ BC Controlled Area Facilities } \\
\hline 216-B-14 crib & 299-E13-1 & 216-B-26 trench & 299-E13-12 \\
\hline $216-\mathrm{B}-15 \mathrm{crib}$ & 299-E13-2 & 216-B-27 trench & 299-E13-57 \\
\hline 216-B-16 crib & $\begin{array}{l}299-E 13-3 \\
299-E 13-21\end{array}$ & 216-B-30 trench & 299-E13-52 \\
\hline 216-B-17 crib & 299-E13-4 & 216-B-31 trench & 299-E13-58 \\
\hline $216-\mathrm{B}-18 \mathrm{crib}$ & 299-E13-5 & 216-B-32 trench & 299-E13-59 \\
\hline $216-\mathrm{B}-19 \mathrm{crib}$ & 299-E13-6 & 216-B-33 trench & 299-E13-60 \\
\hline 216-B-23 trench & 299-E13-55 & 216-B-52 trench & 299-E13-54 \\
\hline 216-B-25 trench & 299-E13-56 & 216-B-53A trench & 299-E13-61 \\
\hline \multicolumn{4}{|c|}{ BX Trenches } \\
\hline 216-B-35 trench & 299-E33-286 & 216-B-41 trench & 299-E33-8 \\
\hline 216-B-37 trench & $\begin{array}{l}299-E 33-287 \\
299-E 33-288\end{array}$ & 216-B-42 trench & 299-E33-10 \\
\hline $216-\mathrm{B}-38 \mathrm{crib}$ & $\begin{array}{l}299-E 33-289 \\
299-E 33-290\end{array}$ & . & \\
\hline
\end{tabular}




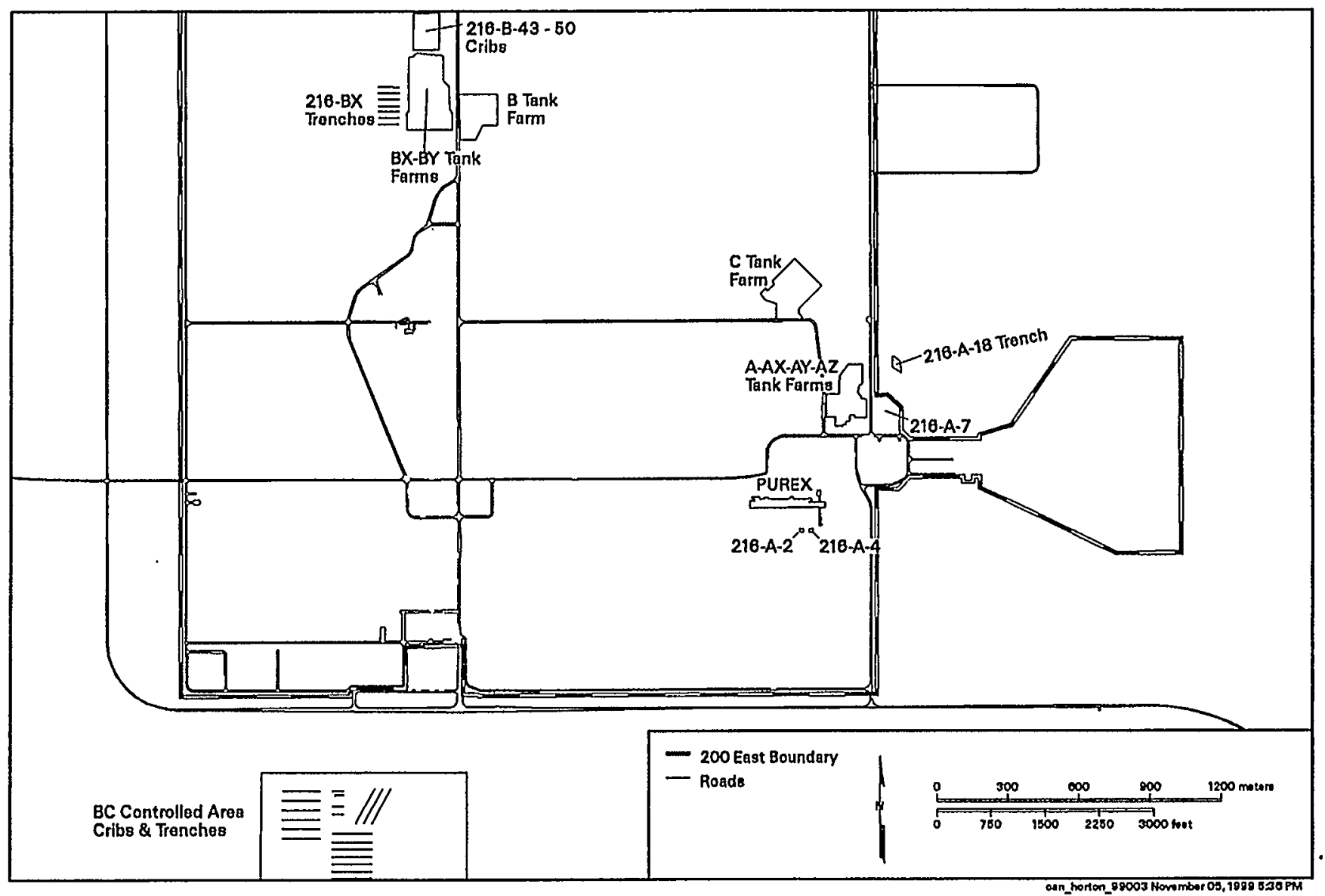

Figure 2.1. Map of the 200 East Area Showing the Location of the Facilities Monitored During FY 1999 


\subsection{PUREX Facilities (216-A-2 Crib, 216-A-4 Crib, 216-A-7 Crib, and 216-A-18 Trench)}

The 216-A-2 and 216-A-4 specific retention cribs are located $80 \mathrm{~m}$ (260 ft) south of the 202-A (PUREX) Building and are about $46 \mathrm{~m}(140 \mathrm{ft}$ ) apart. The 216-A-2 crib was active between January 1956 and January 1963 when it received 230,000 L (61,000 gal) of low salt, neutral/basic waste (Maxfield 1979). The waste was organic waste, containing normal paraffin hydrocarbons and tributyl phosphate from the 202-A Building (DOE 1993a). Table 2.2 is an inventory of the chemical and radionuclide constituents disposed to the crib.

Table 2.2. Inventory of Contaminants Disposed to the 216-A-2, 216-A-4 and 216-A-7 Cribs, and the 216-A-18 Trench $^{(2)}$

\begin{tabular}{|c|c|c|c|c|}
\hline $\begin{array}{l}\text { Radionuclide or } \\
\text { Chemical }\end{array}$ & $\begin{array}{l}216-A-2 \\
\text { Quantity }\end{array}$ & $\begin{array}{l}\text { 216-A-4. } \\
\text { Quantity }\end{array}$ & $\begin{array}{l}\text { 216-A-7 } \\
\text { Quantity }\end{array}$ & $\begin{array}{c}216-A-18 \\
\text { Quantity }\end{array}$ \\
\hline${ }^{60} \mathrm{Co}$ & 0.0297 & 0.0226 & 0.00204 & 0.00179 \\
\hline${ }^{90} \mathrm{Sr}$ & 0.921 & 4.39 & 0.431 & 0.042 \\
\hline${ }^{137} \mathrm{Cs}$ & 1.45 & 6.93 & 2.31 & 0.0444 \\
\hline $\mathrm{Pu}$ (total) $(\mathrm{g})$ & 130 & 140 & 1 & 0.1 \\
\hline${ }^{239} \mathrm{Pu}$ & 7.42 & 7.99 & 0.0571 & 0.00571 \\
\hline${ }^{240} \mathrm{Pu}$ & 2 & 2.16 & 0.0154 & 0.00154 \\
\hline${ }^{99} \mathrm{Tc}$ & 0.000258 & 0.00123 & 0.000411 & 0.00000789 \\
\hline${ }^{106} \mathrm{Ru}$ & 0.0000000782 & 0.0000000438 & 0.00000011 & $2.75 \times 10^{-12}$ \\
\hline $\mathrm{U}$ (total) & 0.026 & 0.133 & 0.00227 & 0.469 \\
\hline${ }^{238} \mathrm{U}$ & 0.0262 & 0.134 & 0.00228 & 0.472 \\
\hline Alpha & 7.98 & 8.6 & 0.0614 & 0.00614 \\
\hline Beta & 4.71 & 2.21 & 5.29 & 0.172 \\
\hline Tributyl phosphate & 70,000 & & 100,000 & \\
\hline $\begin{array}{l}\text { Natural paraffin } \\
\text { hydrocarbons }\end{array}$ & 120,000 & & 180,000 & \\
\hline Sodium & 4,000 & & & \\
\hline Sulfate & 5,000 & & & \\
\hline Sodium dichromate & 110 & & & \\
\hline Nitrate & 300 & & & 730 \\
\hline \multicolumn{5}{|c|}{$\begin{array}{l}\text { (a) Radionuclides are reported in curies unless noted otherwise. }{ }^{238} \mathrm{U} \text { is decay corrected to April 1,1986 } \\
{ }_{99} \mathrm{Tc} \text { is decay corrected to the year } 2050 \text {. All other radionuclides are decay corrected to Decem- } \\
\text { ber } 31,1989 \text {. At the } 216-\mathrm{A}-18 \text { trench only, Pu and beta are decay corrected to April 1, 1986. Chem- } \\
\text { ical quantities are reported in kilograms unless noted otherwise. All data is from DOE (1993a) } \\
\text { except }{ }^{99} \mathrm{Tc} \text { which is from Kincaid et al. (1998). }\end{array}$} \\
\hline
\end{tabular}


The 216-A-4 specific retention crib was active from December 1955 to December 1958. During this time, it received $6,210,000 \mathrm{~L}(1,640,000 \mathrm{gal})$ of low salt, neutral/basic waste: The waste was laboratory cell drainage from the 202-A Building and stack drainage from the 291-A-1 stack. A contaminant inventory of the 216-A-4 crib is given in Table 2.2. Based on the volume of effluent disposed to the crib and on estimates of the pore volume in the sediment beneath the crib (DOE 1993a), the 216-A-4 crib does not appear to have been operated as a specific retention facility. Both the 216-A-2 and 216-A-4 cribs were deactivated by removing a portion of, or by blanking, the effluent pipelines.

The PUREX Source Aggregate Area Management Study Report (DOE 1993a) presents a re-evaluation of available historical gross gamma-ray logs for the 216-A-2 and -4 cribs. The re-evaluation noted significant levels of gamma-ray activity near the cribs. The top of the contamination corresponded to the top of a sand sequence in the Hanford formation and the base of the crib. The lowest depth of the contamination could not be determined because contamination was deeper that the total depth of the boreholes.

The 216-A-7 crib is located inside the 200 East Area perimeter fence extension, $100 \mathrm{~m}(300 \mathrm{ft})$ east of the 241-A tank farm. The 216-A-7 crib was active between November 1955 and November 1966. During this time, it received $326,000 \mathrm{~L}(86,129 \mathrm{gal})$ of low salt neutral/basic waste. Based on the volume of effluent disposed to the crib and on estimates of the pore volume in the sediment beneath the crib (DOE 1993a), the 216-A-7 crib does not appear to have been operated as a specific retention facility. From November 1955 to July 1959, the crib received overflow waste, sump waste, and pump pit drainage from the 241-A-152 diversion box. From July 1959 to November 1966, it received the catch tank overflow waste and pump pit drainage from the same diversion box. In November 1966, the crib received tributyl phosphate-kerosene organic waste from the 202-A Building. A contaminant inventory for the crib is given in Table 2.2. The 216-A-7 crib was deactivated by blanking off the inflow pipeline from the 241-A-152 diversion box (DOE 1993a).

The 216-A-7 crib is monitored by borehole 299-E25-54 (see Section 3.0 for borehole location maps). The latest gross gamma-ray log, obtained in 1986, from that borehole shows contamination beneath the crib between depths of about 3 and $15 \mathrm{ft}$ and between about 28 and $38 \mathrm{ft}$. The base of the upper zone corresponds to the base of the crib and the base of the lower zone corresponds to the base of a sandy gravel unit that overlies the Hanford formation sand sequence.

The 216-A-18 trench is located $150 \mathrm{~m}$ east of 241-AZ tank farm outside of the 200 East perimeter fence. The trench was originally intended to be a crib; however, the crib was never built. The specific retention trench was active from November 1955 to January 1956. During this time, it received $488,000 \mathrm{~L}$ (128,900 gal) of depleted uranium waste from a cold start-up run at 202-A Building (DOE 1993a). An inventory of contaminants disposed to the trench is given in Table 2.2. The 216-A-18 trench was deactivated by removing the aboveground piping and backfilling after specific retention capacity was reached.

The most recent gross gamma-ray log from borehole 299-E25-10, which monitors the 216-A-18 and -19 trenches, shows near background levels of gamma activity throughout the borehole. 


\subsection{BC Controlled Area Cribs (216-B-14 through -19)}

The 216-B-14 through -19 cribs are located in the BC Controlled Area south of the 200 East Area (Figure 2.1). The cribs operated from between January 1956 and December 1957 and each received between 3.4 to 8.7 million liters of effluent. A complete operating history for each crib is given in DOE (1993b); summaries are given in Table 2.3. The cribs received high salt, neutral/basic, scavenged tributyl phosphate waste from the 221-U (U Plant) Building. Table 2.4 gives inventories for each of the cribs. DOE (1993b) and Maxfield (1979) state that the BC Controlled Area cribs were deactivated by valving out the feed pipes to the cribs after specific retention capacity was reached. However, comparing the volume defined by the crib dimensions and the thickness of the vadose zone with the volume of disposed effluent indicates the effluent disposed to the cribs exceeded specific retention capability. As-built diagrams for the 216-B-14 through -19 cribs are given in Wood (1958).

The B Plant Source Aggregate Area Management Study report (DOE 1993b) presents a re-evaluation of available historical gross gamma-ray logs in the area of the $216-\mathrm{B}-14$ through -19 cribs. The report concluded that migration of contaminants had occurred beneath all of the cribs and that breakthrough to the water table may have occurred beneath the 216-B14 and -16 cribs. Gamma contamination was noted in all wells in the BC crib area. There was some evidence that vertical migration was controlled in some wells by a silty layer occurring at a depth of about $95 \mathrm{ft}$. The sparseness of boreholes in the area does not allow good definition of the lateral extent of contamination. However, gamma-ray profiles from two wells taken before their associated cribs were used for liquid disposal showed subsurface contamination that indicated lateral migration had occurred.

Table 2.3. Operating Periods and Effluent Volumes for the BC Controlled Area Cribs that were Monitored in $1999^{(a)}$

\begin{tabular}{|c|l|c|}
\hline Crib & \multicolumn{1}{|c|}{ Operating Period } & Volume (L) \\
\hline \hline $216-\mathrm{B}-14$ & January and February 1956 & $8,710,000$ \\
\hline $216-\mathrm{B}-15$ & April 1956 to December 1957 & $6,320,000$ \\
\hline $216-\mathrm{B}-16$ & April to August 1956 & $5,600,000$ \\
\hline $216-\mathrm{B}-17$ & January 1956 & $3,410,000$ \\
\hline $216-\mathrm{B}-18$ & March and April 1956 & $8,520,000$ \\
\hline $216-\mathrm{B}-19$ & February to October 1957 & $6,400,000$ \\
\hline (a) Data from DOE (1993b). & \\
\hline
\end{tabular}


Table 2.4. Contaminant Inventory for the Cribs in the BC Controlled Area that were Monitored in $1999^{(\mathrm{a})}$

\begin{tabular}{|c|c|c|c|c|c|c|}
\hline $\begin{array}{l}\text { Radionuclide } \\
\text { or Chemical }\end{array}$ & $\begin{array}{l}216-\mathrm{B}-14 \\
\text { Quantity }\end{array}$ & $\begin{array}{l}216-\mathrm{B}-15 \\
\text { Quantity }\end{array}$ & $\begin{array}{l}216-\mathrm{B}-16 \\
\text { Quantity }\end{array}$ & $\begin{array}{l}216-B-17 \\
\text { Quantity }\end{array}$ & $\begin{array}{l}\text { 216-B-18 } \\
\text { Quantity }\end{array}$ & $\begin{array}{l}\text { 216-B-19 } \\
\text { Quantity }\end{array}$ \\
\hline${ }^{106} \mathrm{Ru}$ & 0.0152 & 0.00678 & 0.00334 & 0.0000642 & 0.00488 & 0.0152 \\
\hline${ }^{90} \mathrm{Sr}$ & 172 & 87.3 & 302 & 68.9 & 81.8 & 88.3 \\
\hline${ }^{137} \mathrm{Cs}$ & 114 & 92.4 & 296 & 100 & 114 & 126 \\
\hline${ }^{60} \mathrm{Co}$ & 0.103 & 0.109 & 0.103 & 0.0204 & 0.103 & 0.117 \\
\hline $\mathrm{U}$ (total) & 0.0726 & 0.0348 & 0.107 & 0.118 & 0.0786 & 0.0605 \\
\hline${ }^{238} \mathrm{U}$ & 0.073 & 0.0348 & 0.108 & 0.119 & 0.0791 & 0.0606 \\
\hline $\mathrm{Pu}$ (total) (g) & 25 & 5 & 10 & 10 & 10 & 10 \\
\hline${ }^{239} \mathrm{Pu}$ & 1.43 & 0.285 & 0.571 & 0.571 & 0.571 & 0.571 \\
\hline${ }^{240} \mathrm{Pu}$ & 0.385 & 0.077 & 0.154 & 0.154 & 0.154 & 0.154 \\
\hline${ }^{99} \mathrm{Tc}$ & 6.44 & 5.20 & 16.7 & 5.65 & 6.44 & 7.12 \\
\hline${ }^{3} \mathrm{H}$ & & & 450 & & & \\
\hline Alpha & 1.53 & 0.307 & 0.614 & 0.614 & 0.614 & 0.614 \\
\hline Beta & 567 & 35.7 & 1180 & 330 & 385 & 418 \\
\hline Ferrocyanide & 5,000 & 3,300 & 3,000 & 1,800 & 5,000 & 3,400 \\
\hline Nitrate & $1,500,000$ & 900,000 & $1,100,000$ & $1,100,000$ & $1,000,000$ & $1,500,000$ \\
\hline Sulfate & 50,000 & 60,000 & 110,000 & 90,000 & 70,000 & 90,000 \\
\hline Sodium & 600,000 & 40,000 & 500,000 & 500,000 & 400,000 & 700,000 \\
\hline Phosphate & 40,000 & 50,000 & 70,000 & 60,000 & 50,000 & 100,000 \\
\hline \multicolumn{7}{|c|}{$\begin{array}{l}\text { (a) Radionuclides are reported in curies unless noted otherwise. }{ }^{3} \mathrm{H},{ }^{238} \mathrm{U},{ }^{60} \mathrm{Co} \text {, }{ }^{239} \mathrm{Pu} \text {, and }{ }^{240} \mathrm{Pu} \text { are decay } \\
\text { corrected to April 1, 1986. }{ }^{99} \mathrm{Tc} \text { is decay corrected to the year } 2050 .{ }^{106} \mathrm{Ru} \text { is decay corrected to June } 30 \text {, } \\
\text { 1978. All other radionuclides are decay corrected to December } 31,1989 \text {. Chemical quantities are } \\
\text { reported in kilograms unless otherwise stated. All data is from } \mathrm{DOE} \text { (1993b) except }{ }^{99} \mathrm{Tc} \text { which is from } \\
\text { Kincaid et al. (1998) and }{ }^{106} \mathrm{Ru} \text { which is from Maxfield (1979). }\end{array}$} \\
\hline
\end{tabular}

\subsection{BC Controlled Area Trenches (216-B-23, -25 through -27, -30 through $-33,-52$, and $-53 A$ )}

The 216-B-23, -25 through $-27,-30$ through $-33,-52$, and $-53 \mathrm{~A}$ specific retention trenches are part of the BC Controlled Area trenches located south of the 200 East Area. The 216-B-53A trench was active from October to November 1965. All the other trenches were active for 1 to 3 months between October 1956 and January 1958. A complete operating history for each trench is given in DOE (1993b); summaries are given in Table 2.5. The 216-B-23 through -33 and -52 trenches received high salt, neutral/basic scavenged tributyl phosphate waste from the 221-U building. The 216-B-53A trench received neutral/ basic wastes from the Plutonium Recycle Test Reactor in the 300 Area. Table 2.6 gives inventories for each of the trenches. 
Table 2.5. Operating Periods and Effluent Volumes for the BC Controlled Area Specific Retention Trenches Monitored in $1999^{(\text {a) }}$

\begin{tabular}{|c|l|c|}
\hline Trench & \multicolumn{1}{|c|}{ Operating Period } & Volume (L) \\
\hline $216-\mathrm{B}-23$ & Oct. 1956 & $4,520,000$ \\
\hline $216-\mathrm{B}-25$ & Nov. 1956 to Dec. 1956 & $3,760,000$ \\
\hline $216-\mathrm{B}-26$ & Dec. 1956 to Feb. 1957 & $5,880,000$ \\
\hline $216-\mathrm{B}-27$ & Feb. 1957 to April 1957 & $4,420,000$ \\
\hline $216-\mathrm{B}-30$ & July 1957 & $4,780,000$ \\
\hline $216-\mathrm{B}-31$ & July 1957 to Aug. 1957 & $4,740,000$ \\
\hline $216-\mathrm{B}-32$ & Aug. 1957 to Sept. 1957 & $4,770,000$ \\
\hline $216-\mathrm{B}-33$ & Sept. 1957 to Oct. 1957 & $4,740,000$ \\
\hline $216-\mathrm{B}-52$ & Dec. 1957 to Jan. 1958 & $8,530,000$ \\
\hline $216-\mathrm{B}-53 \mathrm{~A}$ & Oct. 1965 to Nov. 1965 & 549,000 \\
\hline
\end{tabular}

As-built diagrams for the BC Controlled Area specific retention trenches are given in Wood (1958). The trenches were deactivated by removing the above-ground piping connecting each trench to the transfer line. Deactivated trenches were backfilled with the original excavated material. In 1969, the trenches were covered with $15 \mathrm{~cm}$ (6 in.) of gravel (DOE 1993b).

The B Plant Source Aggregate Area Management Study Report (DOE 1993b) presents a re-evaluation of available historical gross gamma-ray logs in the area of the BC Controlled Area specific retention trenches. The re-evaluation showed that elevated gamma activity occurred in most boreholes located between the trenches. However, most boreholes did not extend below the depth of elevated gamma activity, so the vertical extent of contamination could not be defined. Evidence for lateral migration was present in historic gamma-ray logs from most perimeter boreholes, but that activity had decreased to background level in all but one borehole (299-E13-7) by 1993.

\subsection{BX Specific Retention Trenches (216-B-35, -37, -38, -41, and -42)}

The 216-B-35, -37, -38, -41 , and -42 trenches are part of the BX specific retention trenches located about $60 \mathrm{~m}$ (200 ft) west of the 241-BX tank farm. The trenches operated for 1 to 2 months each between February 1954 and February 1955. A complete operating history for each trench is given in DOE (1993b); summaries are given in Table 2.7.

The 216-B-37 trench received first cycle bottoms from the 242-B waste evaporator. The 216-B-42 trench received high salt, neutral/basic scavenged tributyl phosphate supernatant waste from the 221-U building. All other BX trenches received high salt, neutral/basic, first cycle supernatant waste from the 221-B building. Table 2.8 gives inventories for each of the trenches. The trenches were deactivated by removing above-ground piping after reaching specific retention capacity (DOE 1993b). 
Table 2.6. Contaminant Inventory for the Specific Retention Trenches in the BC Controlled Area that were Monitored in $1999^{(a)}$

\begin{tabular}{|c|c|c|c|c|c|c|c|c|c|}
\hline $\begin{array}{l}\text { Radionuclide } \\
\text { or Chemical }\end{array}$ & $\begin{array}{l}\text { 216-B-23 } \\
\text { Quantity }\end{array}$ & $\begin{array}{l}\text { 216-B-25 } \\
\text { Quantity }\end{array}$ & $\begin{array}{l}\text { 216-B-26 } \\
\text { Quantity }\end{array}$ & $\begin{array}{l}\text { 216-B-27 } \\
\text { Quantity }\end{array}$ & $\begin{array}{l}\text { 216-B-30 } \\
\text { Quantity }\end{array}$ & $\begin{array}{c}216-\mathrm{B}-32 \\
\text { Quantity }\end{array}$ & $\begin{array}{l}\text { 216-B-33 } \\
\text { Quantity }\end{array}$ & $\begin{array}{c}216-\mathrm{B}-52 \\
\text { Quantity }\end{array}$ & $\begin{array}{c}\text { 216-B-53A } \\
\text { Quantity }\end{array}$ \\
\hline${ }^{90} \mathrm{Sr}$ & 62.5 & 88.3 & 475 & 263 & 265 & 113 & 18.1 & 4.92 & 0.0538 \\
\hline${ }^{137} \mathrm{Cs}$ & 50.9 & 25.2 & 438 & 15.8 & 1570 & 58.6 & 127 & 160 & 0.0559 \\
\hline${ }^{60} \mathrm{Co}$ & 0.137 & 0.141 & 0.223 & 0.177 & 0.0397 & 0.0397 & 0.0327 & 0.113 & 0.0335 \\
\hline $\mathrm{U}$ (total) & 0.052 & 0.0051 & 0.196 & 0.114 & 0.0293 & 0.00367 & 0.00667 & 0.00998 & 0.00756 \\
\hline${ }^{238} \mathrm{U}$ & 0.0523 & 0.513 & 0.197 & 0.115 & 0.0295 & 0.00368 & 0.0067 & 0.01 & 0.076 \\
\hline $\mathrm{Pu}$ (total) (g) & 1.8 & 2.0 & 2.5 & 0.7 & 2.1 & 2.6 & 11.8 & 19 & 100 \\
\hline${ }^{239} \mathrm{Pu}$ & 0.102 & 0.114 & 0.143 & 0.04 & 0.12 & 0.148 & 0.674 & 1.08 & 5.71 \\
\hline${ }^{240} \mathrm{Pu}$ & 0.0277 & 0.301 & 0.385 & 0.0108 & 0.0323 & 0.04 & 0.182 & 0.293 & 1.54 \\
\hline${ }^{99} \mathrm{Tc}$ & 2.88 & 1.47 & 24.8 & 0.904 & 88.7 & 3.33 & 7.18 & 9.04 & 0.00000993 \\
\hline Alpha & 0.111 & 0.123 & 0.0153 & 0.043 & 0.129 & 0.16 & 0.724 & 1.17 & 6.14 \\
\hline Beta & 226 & 229 & 1800 & 560 & 3540 & 339 & 281 & 317 & 0.246 \\
\hline$\overline{\mathrm{FeCN}}$ & 2,400 & 2,000 & 3,100 & 2,300 & 2,500 & 2,500 & 2,500 & 5,000 & \\
\hline Nitrate & $1,000,000$ & 500,000 & 800,000 & 600,000 & $1,100,000$ & $1,000,000$ & $1,700,000$ & $2,100,000$ & 1 \\
\hline Sulfate & 60,000 & 40,000 & 60,000 & 50,000 & 110,000 & 90,000 & 90,000 & 80,000 & \\
\hline Sodium & 400,000 & 220,000 & 350,000 & 260,000 & 500,000 & 500,000 & 700,000 & 860,000 & \\
\hline Phosphate & $60 ; 000$ & 27,000 & 40,000 & 32,000 & 70,000 & 60,000 & 80,000 & 80,000 & \\
\hline \multicolumn{10}{|c|}{$\begin{array}{l}\text { (a) Radionuclides are reported in curies unless noted otherwise. }{ }^{60} \mathrm{Co},{ }^{239} \mathrm{Pu} \text {, }{ }^{240} \mathrm{Pu} \text {, and }{ }^{238} \mathrm{U} \text { are decay corrected to April } 1,1986 .{ }^{99} \mathrm{Tc} \text { is decay } \\
\text { corrected to the year } 2050 \text {. }{ }^{106} \mathrm{Ru} \text { is decay corrected to June } 30,1978 \text {. All other radionuclides are decay corrected to December } 31,1989 \text {. } \\
\text { Chemical quantities are reported in kilograms unless noted otherwise. All data is from DOE (1993b) except }{ }^{99} \mathrm{Tc} \text { which is from Kincaid et al. } \\
\text { (1998) and total } \mathrm{Pu} \text { from Maxfield (1979). }\end{array}$} \\
\hline
\end{tabular}


Table 2.7. Operating Periods and Effluent Volumes for the BX Trenches Monitored in $1999^{(a)}$

\begin{tabular}{|c|l|c|}
\hline \multicolumn{1}{|c|}{ Trench } & \multicolumn{1}{|c|}{ Operating Period } & Effluent Volume (L) \\
\hline \hline $216-\mathrm{B}-35$ & February 1954 to March 1954 & $1,060,000$ \\
\hline $216-\mathrm{B}-37$ & August 1954 & $4,320,000$ \\
\hline $216-\mathrm{B}-38$ & December 1953 to November 1954 & $1,640,000$ \\
\hline $216-\mathrm{B}-41$ & November 1954 & $1,440,000$ \\
\hline 216-B-42 & January 1955 to February 1955 & $1,500,000$ \\
\hline (a) Data from DOE (1993b).
\end{tabular}

Table 2.8. Contaminant Inventory for the Specific Retention Trenches West of the 241-BX Tank Farm Monitored in $1999^{(2)}$

\begin{tabular}{|c|c|c|c|c|c|}
\hline $\begin{array}{l}\text { Radionuclide or } \\
\text { Chemical }\end{array}$ & $\begin{array}{l}\text { 216-B-35 } \\
\text { Quantity }\end{array}$ & $\begin{array}{l}216-B-37 \\
\text { Quantity }\end{array}$ & $\begin{array}{c}216-\mathrm{B}-38 \\
\text { Quantity }\end{array}$ & $\begin{array}{l}\text { 216-B-41 } \\
\text { Quantity }\end{array}$ & $\begin{array}{c}216-\mathrm{B}-42 \\
\text { Quantity }\end{array}$ \\
\hline$\overline{{ }^{106} \mathrm{Ru}}$ & 0.0000148 & 0.0000323 & 0.0000362 & 0.00000847 & 0.000193 \\
\hline${ }^{90} \mathrm{Sr}$ & 96.4 & 6.56 & 759 & 19.3 & 463 \\
\hline${ }^{137} \mathrm{Cs}$ & 185 & 1350 & 221 & 386 & 42.7 \\
\hline${ }^{60} \mathrm{Co}$ & 0.00047 & 0.0157 & 0.00094 & 0.000160 & 0.179 \\
\hline $\mathrm{U}$ (total) & 0.00557 & 0.00121 & 0.0141 & 0.00250 & 0.227 \\
\hline${ }^{238} \mathrm{U}$ & 0.00559 & 0.00121 & 0.0142 & 0.00251 & 0.228 \\
\hline $\mathrm{Pu}$ (total) $(\mathrm{g})$ & 1.2 & 2 & 1.2 & 0.3 & 10 \\
\hline${ }^{239} \mathrm{Pu}$ & 0.0685 & 0.114 & 0.0685 & 0.0171 & 0.0571 \\
\hline${ }^{240} \mathrm{Pu}$ & 0.0185 & .0308 & 0.0185 & 0.00462 & 0.154 \\
\hline${ }^{99} \mathrm{Tc}$ & 10.5 & 76.3 & 12.5 & 21.8 & 2.43 \\
\hline Alpha & 0.0737 & 0.123 & 0.0737 & 0.0184 & 0.614 \\
\hline Beta & 549 & 2600 & 1,940 & 780 & 1010 \\
\hline Fluoride & 2,600 & 50,000 & 4,000 & 4,000 & \\
\hline $\begin{array}{l}\text { Sodium } \\
\text { Aluminate }\end{array}$ & 10,000 & 250,000 & 18,000 & 18,000 & \\
\hline Nitrate & 90,000 & $1,700,000$ & 120,000 & 120,000 & 210,000 \\
\hline Sulfate & 4,000 & . 90,000 & 6,000 & 6,000 & 150,000 \\
\hline Sodium & 60,000 & $1,300,000$ & 90,000 & 90,000 & 90,000 \\
\hline Nitrite & 10,000 & 200,000 & 13,000 & 13,000 & \\
\hline Phosphate & 20,000 & 400,000 & 27,000 & 27,000 & 11,000 \\
\hline Ferrocyanide & & & & & 800 \\
\hline \multicolumn{6}{|c|}{$\begin{array}{l}\text { (a) Radionuclides are reported in curies unless noted otherwise }{ }^{60}{ }^{60},{ }^{239} \mathrm{Pu},{ }^{240} \mathrm{Pu} \text {, and }{ }^{238} \mathrm{U} \text { are decay corrected } \\
\text { to April } 1,1986 .{ }^{99} \mathrm{Tc} \text { is decay corrected to the year } 2050 .{ }^{106} \mathrm{Ru} \text { is decay corrected to June } 30,1978 \text {. All } \\
\text { other radionuclides are decay corrected to December } 31,1989 \text {. Chemical quantities are reported in kilo- } \\
\text { grams unless noted otherwise. All data is from DOE (1993b) except }{ }^{99} \mathrm{Tc} \text { which is from Kincaid et al. } \\
\text { (1998) and }{ }^{106} \mathrm{Ru} \text { from Maxfield (1979). }\end{array}$} \\
\hline
\end{tabular}




\subsection{Methods}

\subsection{Boreholes and Wells}

Fifty-four boreholes and wells at forty-five past-practice liquid waste disposal facilities in 200 East Area were evaluated for use in vadose zone monitoring. The boreholes were chosen based on

- their locations relative to the facilities

- their locations relative to existing subsurface contamination

- the availability of historical gamma-ray spectra for baseline purposes

- borehole construction information.

The boreholes were then evaluated for logging quality by reviewing information found in driller's logs, borehole construction reports, as-builts diagrams, and documentation of alterations made to the boreholes after their original construction. Based on the results of these evaluations, 29 boreholes were selected for logging (Table 3.1). Most of the boreholes that were not selected were rejected due to the presence of an annular seal that prohibited the use of the neutron moisture tool. During field logging operations, it was discovered that the casing at borehole 299-E24-8, at the 216-C-5 crib, was bent and the logging tools could not be lowered in the hole. Consequently, that borehole was not logged. The location of the logged boreholes relative to the facilities are shown in Figures 3.1 through 3.5. Available well construction and summary reports (as-built diagrams) for the boreholes that were logged are given in Appendix C of Horton (1999).

With a few exceptions, all logged boreholes have 8-in.-diameter, carbon steel casing. Boreholes listed in Table 3.1 as being double cased and grout sealed have an outer 8-in.-diameter casing extending the full depth of the borehole and an inner 6-in.-diameter casing extending over the grouted depths. Boreholes 299-E13-21 and 299-E13-52 have a single 6-in.-diameter, carbon steel casing. Several of the boreholes had not been entered for several years and were swabbed to check for internal contamination. None of the boreholes was internally contaminated.

\subsection{Logging Methods}

High-resolution gamma spectroscopy instrumentation and a neutron moisture tool were used to log the boreholes. The instruments were lowered by an automated hoist controlled by the data acquisition computer system housed in the logging truck. The tool was centered in the borehole by a centralizer. The data collection procedures are described in WMNW (1998).

The logging engineer measured the casing stickup at each borehole prior to logging. Thus, the 1999 observed stickup may be different from documented stickup on previous logs due to changes to the borehole or around the borehole site. Corrections to adjust for different stickup are discussed in Section 3.3.1. 
Table 3.1. Boreholes and Logged in 1999

\begin{tabular}{|c|c|c|c|c|c|}
\hline Facility & Borehole & $\begin{array}{l}\text { Drill } \\
\text { Date }\end{array}$ & $\begin{array}{l}\text { Completion } \\
\text { Depth (ft) }\end{array}$ & $\begin{array}{l}\text { Depth Logged (ft) } \\
\text { Spectral Gamma / } \\
\text { Moisture }\end{array}$ & Comments \\
\hline \multicolumn{6}{|l|}{ PUREX Facilities } \\
\hline $216-A-2$ crib & 299-E24-53 & 1955 & 50 & $0-50 / 0-51$ & Borehole is within the PUREX security fence \\
\hline $216-\mathrm{A}-4 \mathrm{crib}$ & 299-E24-54 & $\begin{array}{l}1955 \\
1982^{(\mathrm{a})}\end{array}$ & 100 & $0-97 / 0-98$ & $\begin{array}{l}\text { Borehole is within the PUREX security fence; double } \\
\text { cased and grout seal } 0-50 \text { and } 100-102 \mathrm{ft}\end{array}$ \\
\hline 216-A-7 crib & 299-E25-54 & 1955 & 152 & $1.5-151.5 / 1.5-151.5$ & \\
\hline 216-A-18 trench & 299-E25-10 & 1958 & 280 & $0-278 / 0-254$ & Pump in well \\
\hline \multicolumn{6}{|c|}{ BC Controlled Area Facilities } \\
\hline 216-B-14 crib & 299-E13-1 & 1955 & 365 & $0-273 / 0-299$ & Double cased and grout seal $0-100 \mathrm{ft}$ \\
\hline 216-B-15 crib & 299-E13-2 & 1956 & 346 & $0-199 / 2-248$ & \\
\hline \multirow[t]{2}{*}{$216-\mathrm{B}-16 \mathrm{crib}$} & 299-E13-3 & 1955 & 353 & $0-336 / 0-238$ & $\begin{array}{l}\text { Double cased and grout seal } 0-100 \mathrm{ft} \text {. Field inspec- } \\
\text { tion report indicates that this well is mislabeled as } \\
299-\mathrm{E} 13-21 \text {. }\end{array}$ \\
\hline & 299-E13-21 & 1965 & 335 & $0-148 / 0-148$ & $\begin{array}{l}\text { Pump in well. Well is mislabeled in the field as } \\
\text { 299-E13-3. }\end{array}$ \\
\hline 216-B-17 crib & 299-E13-4 & 1955 & 362 & $0-148 / 0-157$ & Double cased and grout seal $0-100 \mathrm{ft}$ \\
\hline $216-\mathrm{B}-18 \mathrm{crib}$ & 299-E13-5 & 1955 & 366 & $0-149 / 0-158$ & Double cased and grout seal $0-100 \mathrm{ft}$ \\
\hline $216-\mathrm{B}-19 \mathrm{crib}$ & 299-E13-6 & 1955 & 363 & $1-359 / 1-343$ & Double cased and grout seal $0-100 \mathrm{ft}$ \\
\hline 216-B-23 trench & 299-E13-55 & 1982 & 50 & $0-42 / 0-45$ & Grout seal $0-20 \mathrm{ft}$ \\
\hline 216-B-25 trench & 299-E13-56 & 1982 & 50 & $1-46 / 1-48$ & Grout seal $0-20 \mathrm{ft}$ \\
\hline 216-B-26 trench & 299-E13-12 & 1956 & 342 & $248-340 / 248-331$ & Double cased and grout seal $0-98 \mathrm{ft}$ \\
\hline 216-B-27 trench & 299-E13-57 & 1982 & 50 & $1-45 / 1-48$ & Grout seal $0-20 \mathrm{ft}$ \\
\hline 216-B-30 trench & 299-E13-52 & 1965 & 94 & $0-91 / 0-93$ & \\
\hline 216-B-31 trench & 299-E13-58 & 1982 & 50 & $0-47 / 0-48$ & Grout seal $0-20 \mathrm{ft}$ \\
\hline 216-B-32 trench & 299-E13-59 & 1982 & 50 & $1-45 / 0-45$ & Grout seal $0-20 \mathrm{ft}$ \\
\hline
\end{tabular}


Table 3.1. (contd)

\begin{tabular}{|c|c|c|c|c|c|c|}
\hline Facility & Borehole & $\begin{array}{l}\text { Drill } \\
\text { Date }\end{array}$ & $\begin{array}{l}\text { Completion } \\
\text { Depth (ft) }\end{array}$ & $\begin{array}{l}\text { Depth Logged (ft) } \\
\text { Spectral Gamma / } \\
\text { Moisture }\end{array}$ & \multicolumn{2}{|l|}{ Comments } \\
\hline 216-B-33 trench & 299-E13-60 & 1982 & 50 & $1-46 / 0-48$ & Grout seal $0-20 \mathrm{ft}$ & \\
\hline 216-B-52 trench & 299-E13-54 & 1982 . & 50 & $1-46 / 0-48$ & Grout seal $0-20 \mathrm{ft}$ & \\
\hline 216-B-53A trench & 299-E13-61 & 1982 & 50 & $0-45 / 0-47$ & Grout seal $0-20 \mathrm{ft}$ & \\
\hline \multicolumn{7}{|l|}{ BX Trenches } \\
\hline 216-B-35 trench & 299-E33-286 & 1982 & 50 & $0-51 / 0-50$ & Grout seal $0-20 \mathrm{ft}$ & $\ldots$ \\
\hline \multirow[t]{2}{*}{ 216-B-37 trench } & 299-E33-287 & 1982 & 50 & $0-50 / 0-50$ & Grout seal $0-20 \mathrm{ft}$ & \\
\hline & 299-E33-288 & 1982 & 49 & $1-50 / 1-50$ & Grout seal $0-20 \mathrm{ft}$ & \\
\hline \multirow[t]{2}{*}{ 216-B-38 trench } & 299-E33-289 & 1982 & 49 & $0-49 / 0-49$ & Grout seal $0-20 \mathrm{ft}$ & - \\
\hline & 299-E33-290 & 1982 & 50 & $0-48 / 0-48$ & Grout seal $0-20 \mathrm{ft}$ & - \\
\hline 216-B-41 trench & 299-E33-8 & 1953 & 256 & $0-253 / 0-246$ & Pump in well. & \\
\hline 216-B-42 trench & 299-E33-10 & 1955 & 290 & $3-281 / 117-253$ & Double cased and grout seal $0-122 \mathrm{ft}$ & \\
\hline
\end{tabular}




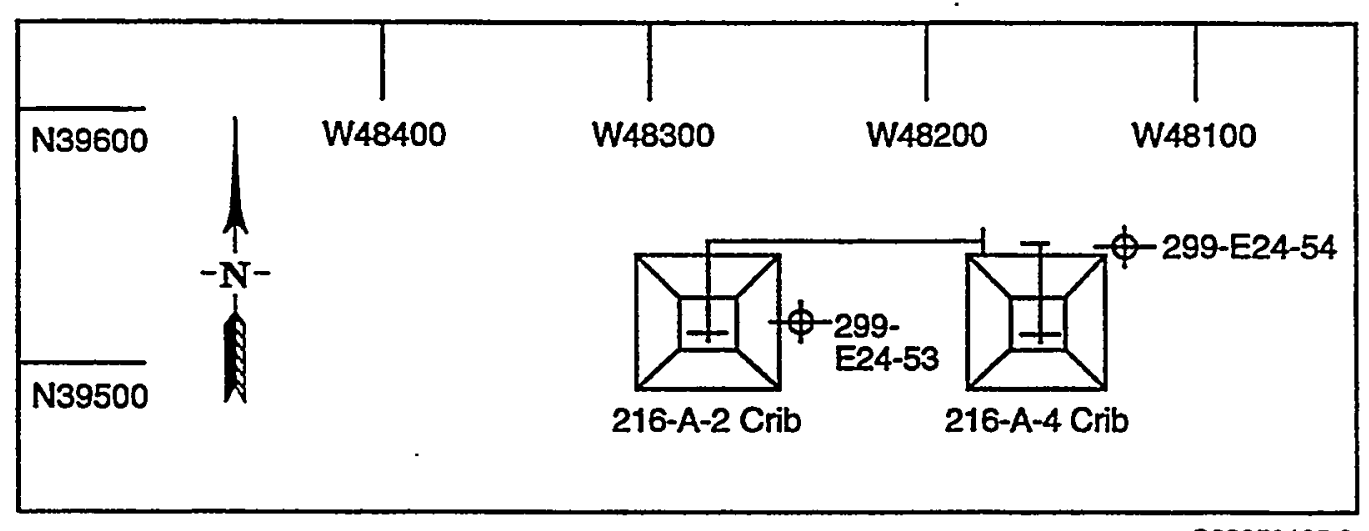

G99050125.6

Figure 3.1. Map of the 216-A-2 and 216-A-4 Cribs Showing the Locations of Boreholes Monitored in 1999 (modified from Fecht et al. 1977)

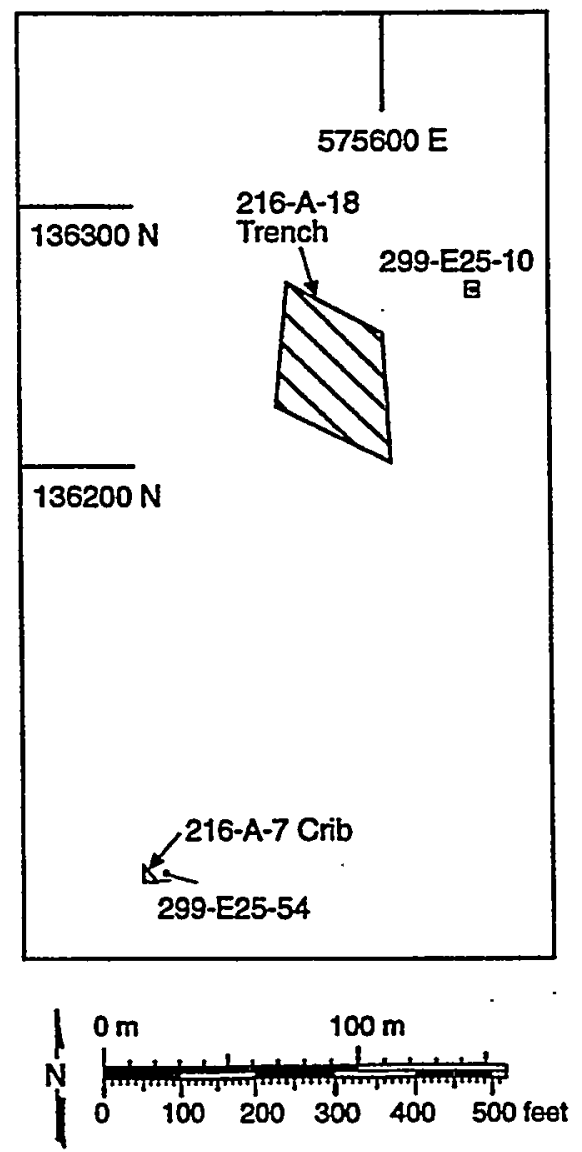

G99050125.1

Figure 3.2. Map of the 216-A-7 Crib and the 216-A-18 Trench Showing the Locations of Boreholes Monitored in 1999 

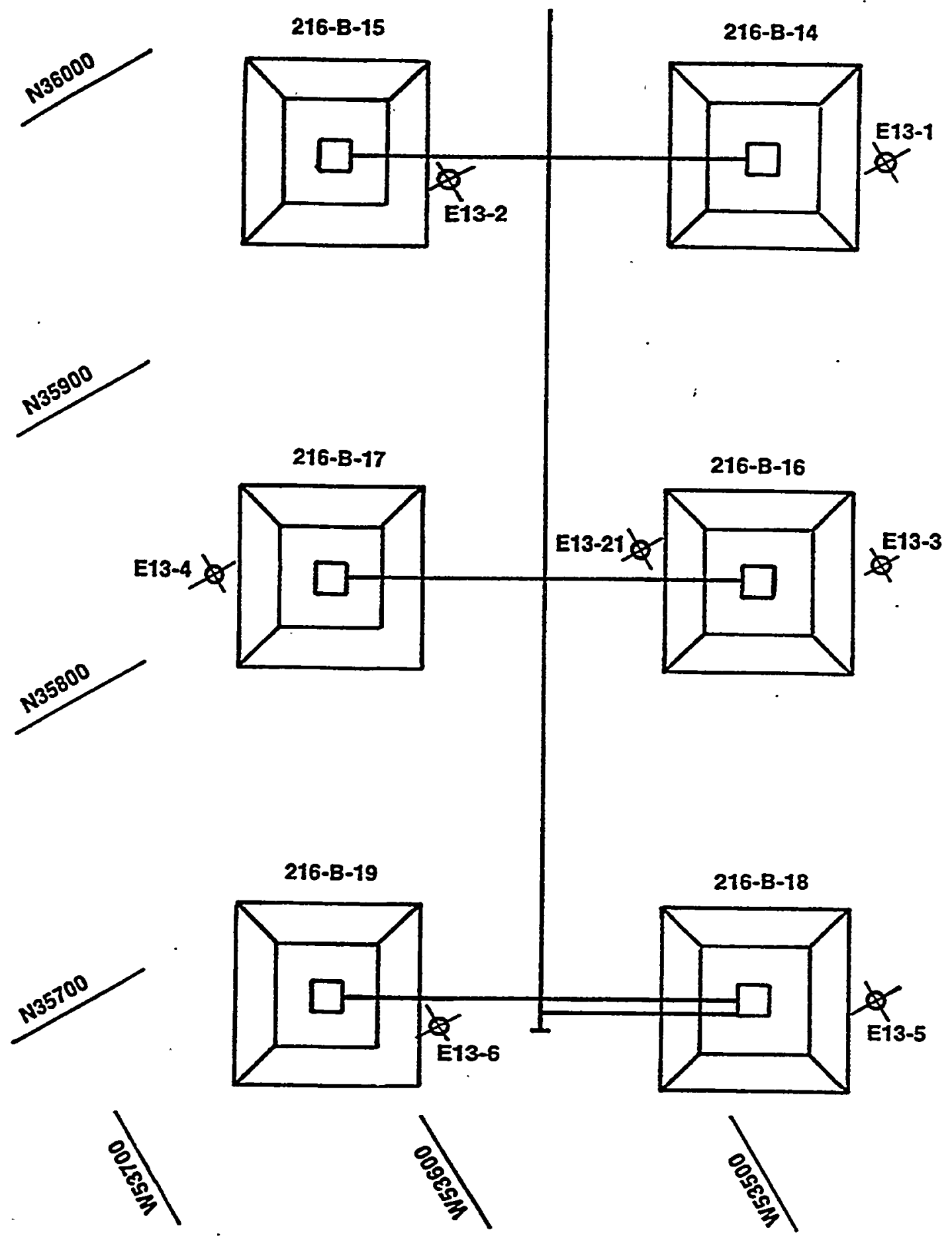

Figure 3.3. Map of the 216-B-14 Through -19 Cribs in the BC Controlled Area Showing Locations of Boreholes Monitored in 1999 (From Fecht et al. 1977). All borehole numbers are prefixed with 299-. 


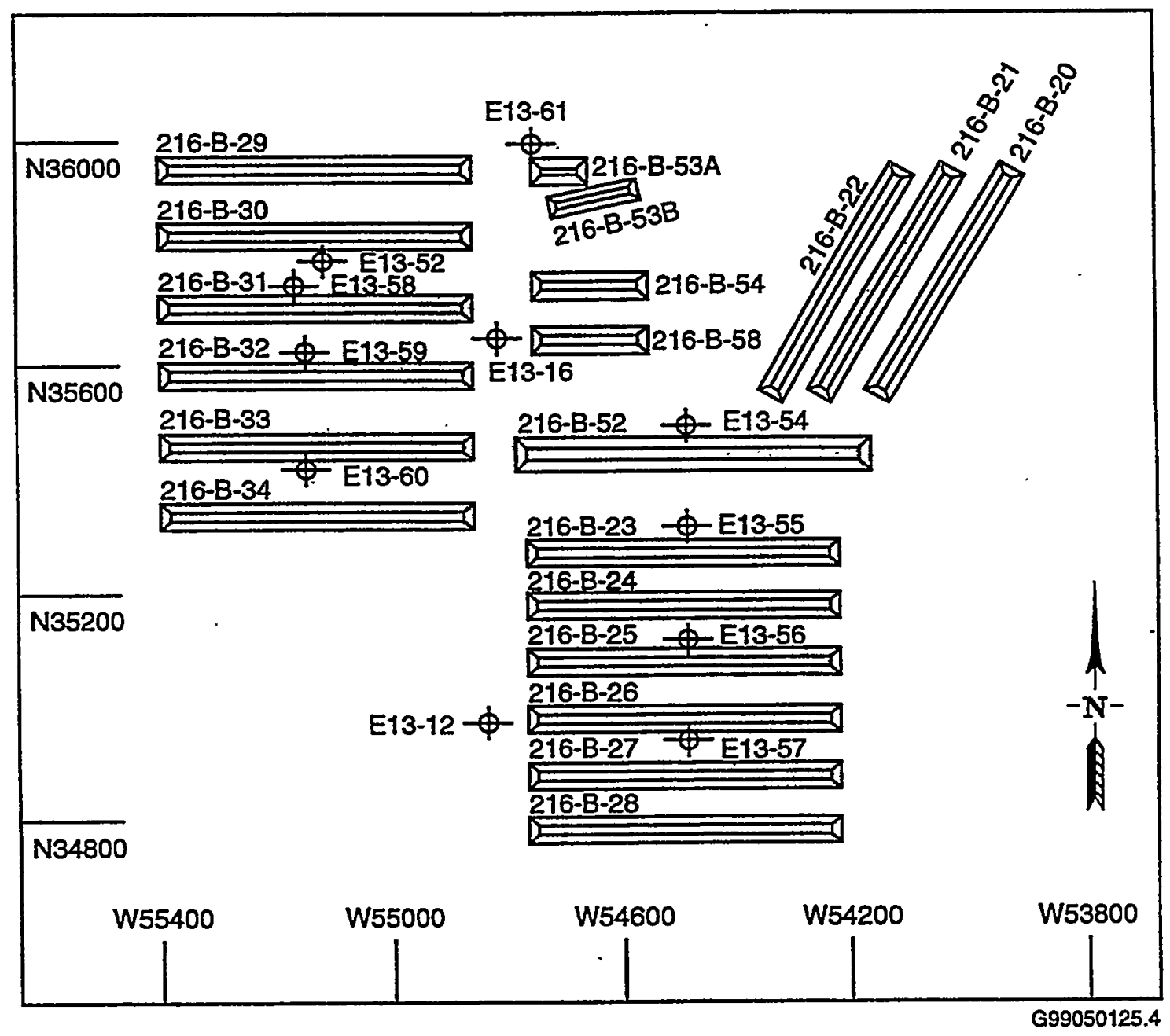

Figure 3.4. Map of the 216-B-20 Through -34, -53A, and -58 Specific Retention Trenches in the BC Controlled Area Showing the Locations of Boreholes Logged in 1999. All borehole numbers are prefixed with 299-.

\subsubsection{Spectral Gamma-Ray Logging}

Data were acquired with a 35\% high-purity germanium (HPGe) detector except for boreholes 299-E13-1, -2, -3, -21, -52, and 299-E33-286 through -290 for which a $10 \%$ HPGe detector was used. The lower efficiency, $10 \%$ tool was used in boreholes for which previous data suggested that the $35 \%$ detector would saturate or exceed dead time correction. The detectors were liquid nitrogen cooled, and the gaseous nitrogen was vented through a tube in the logging cable. Signals from the detector were amplified in the logging tool and transmitted by cable to the data acquisition computer in the logging truck. A multichannel $(4,096)$ analyzer accepted signals from the detectors within the energy range 0 to $3 \mathrm{MeV}$. Dead-time corrections adjusted counting times for losses in high count-rate conditions (Koizumi et al. 1994). 


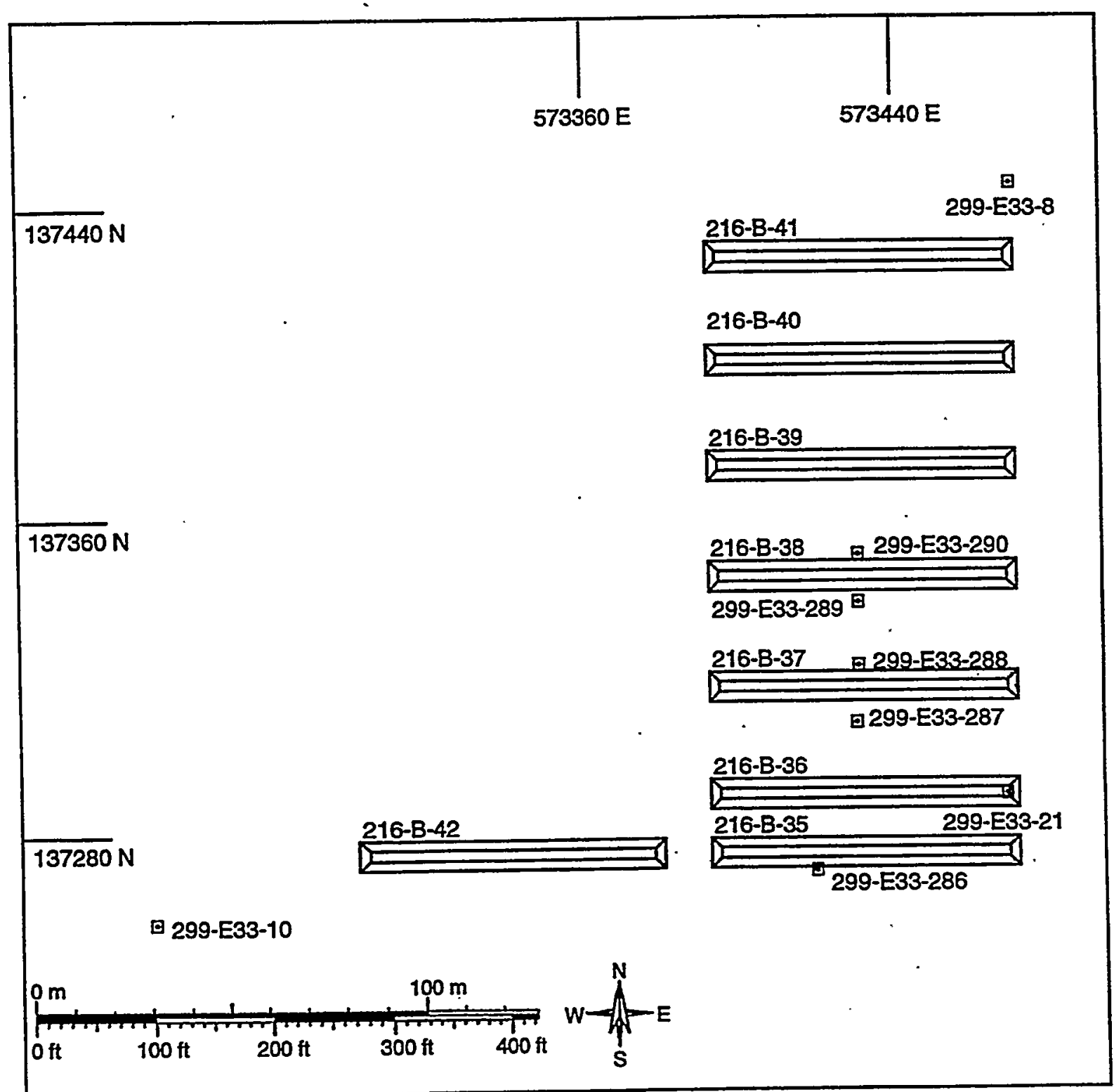

G99050125.2

Figure 3.5. Map of the 216-B-35 Through -42 Specific Retention Trenches West of the 241-BX Tank Farm Showing the Locations of Boreholes Logged in 1999

Spectral gamma-ray logs acquired with the $35 \%$ HPGe detector were obtained at a logging speed of $0.6 \mathrm{ft} / \mathrm{min}$. Logs acquired with the $10 \% \mathrm{HPGe}$ detector were obtained at $0.7 \mathrm{ft} / \mathrm{min}$. Logging speeds were controlled by the data acquisition computer.

Data analysis methods have been described by Stromswold (1994a), who performed a technical review of the software. Briefly, the analysis software reads the spectral data and 1) analyzes the spectrum to locate peak centroids, 2) performs a background subtraction, 3) determines a peak count rate, and 
4) calculates a statistical uncertainty in the count rate. Absolute photo-peak intensities are transformed into radionuclide activities by application of calibration coefficients. In cases where daughter products are used to identify the parent, branching ratios are applied to the calibration coefficient during the analysis process. Radionuclides are then identified based on peak energy and the peak areas are corrected for attenuation of gamma rays by steel casing (Koizumi et al. 1991). Casing thicknesses were measured in the field by caliper. Finally, activities are calculated using peak areas and gamma-ray emission properties. For radionuclides with multiple peaks, the "best result" was determined from the statistical uncertainty of each peak (Stromswold 1994a). The log analysis procedure is given in WMNW (1998). In addition, all channels (energies) were summed to obtained a gross gamma-ray spectrum.

\subsubsection{System Calibration}

The collection of the spectral data required the calibration of the instrumentation. Two calibrations are applicable: 1) a depth calibration of the cable and cable hoist system and 2) a calibration of the detector and associated electronics.

Depth calibration of the logging system cable hoist was performed by the equipment manufacturer (Greenspan, Inc., Houston, Texas) as part of the system assembly and checkout. The depth encoding sheave wheel generates 2,500 pulses per revolution and has a 14-in. diameter. This results in a depth precision of $0.0073 \mathrm{ft}$ per pulse (Section 17.0, Attachment B in WMNW 1998). The accuracy is a function of the weight of the logging probe, the amount of cable in the borehole, and the logging medium (air or water). A depth recalibration is required after system components are subjected to major repairs or alterations. The depth calibration in effect at the time of this logging was performed by Three Rivers Scientific, West Richland, Washington, in March 1998. The depth variance at that time was 0.6-in. root mean square error over $250 \mathrm{ft}$ down and back to the surface for an air-filled borehole.

Calibration of the HPGe logging system is required once each year. The calibration in effect at the time these data were taken was done in January 1999 for the $35 \%$ HPGe detector and in June 1999 for the $10 \% \mathrm{HPGe}$ detector. Calibration measurements are made in the calibration facilities at the Hanford Site. The Hanford Site calibration models were built and assayed by the U.S. Department of Energy's Grand Junction Projects Office (Heistand and Novak 1984) and are traceable to the gamma-ray counting standards certified by the U.S. Department of Energy's New Brunswick Laboratory, Argonne, Illinois. The calibration standards and their construction are described by Stromswold (1994b). The analysis of the calibration data and the resulting calibration factors are described by Randall (1994).

\subsubsection{Pre-Log and Post-Log Energy Calibration/Verification}

Energy calibration was performed on location at each borehole site prior to log data collection. The linear energy conversion from channels was established using two characteristic gamma rays from $\mathrm{a}^{232} \mathrm{Th}$ source, placed directly over the detector section of the logging instrument. The measurement was made with either a Coleman ${ }^{\circledR}$ mantle assembly or a potassium-uranium-thorium assembly from Amersham International PLC (Amersham, United Kingdom). 
Instrument verification was also performed prior to and after each logging event. Because there is no photo peak interference at the $583 \mathrm{keV}$ gamma ray from the ${ }^{232} \mathrm{Th}$ source, that photo peak was used to perform both the pre-log and the post-log instrument verification. The instrument verification was established by measurement of the full width at half maximum of this characteristic gamma ray emitted from the ${ }^{232} \mathrm{Th}$ and observed in the collected spectra. The same spectra collected to perform the photo-peak energy calibration were used to analyze the full width at half maximum of the $583 \mathrm{keV}$ photo peak. The acceptance criteria for the pre- and post-logging energy resolution as determined by the full width at half maximum was 1.5 times the value established during maintenance ( $3 \mathrm{keV}$ ) (Section 17.0, Attachment D in WMNW 1998). For all logging passes, the pre- and post-logging instrument verification was within specifications.

\subsubsection{Repeat Logs}

A quality assurance/quality control requirement for spectral gamma-ray logging is collection of a repeat log section. The logging procedures dictate that the repeat log interval shall be $10 \mathrm{ft}$ or $10 \%$ of total borehole depth, whichever is smaller. The repeat log was collected after the borehole was logged over the entire depth open to the instrument. A gross gamma-ray calculation was generated for the main pass $\log$ data and, from this signature, the repeat depth interval was selected. A high gross gamma-ray response (but not saturated) that indicated the presence of high concentrations of man-made radionuclides was used to select the repeat intervals. Good agreement was obtained between the main log and the repeat log in every case.

Deviations in the log data between the main log and repeat log were within standard statistical limits. Each analysis package for each borehole contains plots of the repeat sections, with the statistical error displayed as error bars. Those plots are included in Appendix B.

\subsubsection{Neutron Moisture Logging}

The moisture tool employed a $50 \mathrm{mCi}$ americium-beryllium ( $\mathrm{AmBe}$ ) neutron source and a ${ }^{3} \mathrm{He}$ detector. The tool is attached to and controlled by the logging system in the same manner as described for the HPGe logging tool. Emitted neutrons from the AmBe source scatter on the surrounding nuclei of the formation and borehole casing. The source neutrons slow down to thermal energies after a sufficient number of collisions. Hydrogen is the dominant element affecting the neutron slow-down process to thermalization. Thus, the spatial extent of the thermal neutron cloud is a function of the hydrogen concentration surrounding the instrument. The thermal neutron detector then measures the intensity of the thermal neutrons and the observed count rates correspond to the moisture content.

The moisture tool was operated at a logging speed of $1.0 \mathrm{ft} / \mathrm{min}$ at a data sampling interval of $0.25 \mathrm{ft}$. All the boreholes were logged throughout their lengths unless multiple casing strings were present or if grout seals had been placed around the casing. However, in several instances, double cased and grouted intervals were logged with the moisture tool due to miscommunication between the logging contractor's project lead and the field personnel. Whereas the effectiveness of the grout seal can be investigated with 
the moisture tool, a vadose zone moisture measurement is not possible when the borehole is grouted. Log data from these latter intervals will not be used for interpretations of subsurface lithology or subsurface moisture or contaminant distribution.

The gross counts for the neutron spectra were derived using the software titled "Field" and were used to prepare the log plots. The software 1) reads the spectra in vendor proprietary format, 2) reads log header information, 3) distinguishes live time from real time, 4) sums gamma-ray counts from all channels, 5) calculates dead time corrected activities, and 6) makes a depth versus count rate file for plotting. A transform that was derived during the moisture tool calibration was used to convert the gross counts to moisture percent by volume. Moisture data were plotted with suitable scales to produce the log plot. Each plot was produced with standard commercial software.

\subsubsection{Detector Calibrations}

The calibration of the neutron moisture tool in effect at the time these data were taken was done in May 1999. Calibration measurements were made in the moisture calibration tanks located at Neil F. Lampson, Inc., Pasco, Washington. The construction of these models is documented in Engleman et al. (1995). The models contain moisture contents (percent by volume) of $5 \%, 12 \%$, and $20 \%$ and are constructed with casing configurations for both 6- and 8-in.-diameter casings. The calibration procedures are documented in Meisner (1995) and Meisner et al. (1996). Casing thickness corrections applied to the log data are documented in Meisner et al. (1996).

Calibration of the logging system cable and cable hoist system was as described above.

\subsubsection{Detector Verification}

Pre- and post-logging verification was performed for each logging event. The verification measurements were made in the shield that carries the source/detector. The field verification results were analyzed to confirm that the moisture logging tool was performing within specifications.

\subsubsection{Replicate Logging}

A quality assurance/quality control requirement for neutron moisture logging is collection of a repeat log section. The logging procedures dictate that the repeat log interval shall be $10 \mathrm{ft}$ or $10 \%$ of total borehole depth, whichever is smaller. The repeat log was collected after the borehole was logged over the entire depth open to the instrument. The repeat interval was chosen near the first part of the borehole logged to represent the longest time interval over which to guarantee instrument stability. Good agreement was obtained between the main $\log$ and the repeat log in every case.

Deviations in the log data between the main log and repeat log were within standard statistical limits. The repeat section from each borehole is plotted on the main log. Those plots are included in Appendix B. 


\subsection{Data Analysis}

\subsubsection{Time Lapse Comparison of Spectral Log Data}

Four of the wells logged in 1999 were previously logged with the high resolution spectral gamma logging instrument. The well numbers and the dates logged are listed in Table 3.2.

Table 3.2. Boreholes with Pre-1999 Spectral Gamma Logs

\begin{tabular}{|c|c|c|}
\hline Well Number & Pre-1999 HPGe Log Date & 1999 HPGe Log Date \\
\hline \hline 299-E13-01 & September 1992 & July 1999 \\
\hline 299-E13-03 & September 1992 & July 1999 \\
\hline 299-E13-05 & September 1992 & July 1999 \\
\hline 299-E33-290 & August 1992 & August 1999 \\
\hline
\end{tabular}

Several adjustments were performed to the data in order to make quantitative comparison of the radionuclide activities from the two separate logging data sets. First, the $1992 \log$ results were decay corrected (according to the specific isotope) to the date of the $1999 \mathrm{log}$. Second, the casing correction methods have changed since the original analysis of the 1992 log data. Therefore, the 1992 raw spectral data were reprocessed so that both data sets were subjected to the same casing correction procedure.

Finally, the 1999 log data were collected with a depth reference of top of casing, but during analysis the depths were shifted to ground surface. The four wells logged in 1992 used a depth reference of ground surface. A depth shift was applied to the 1992 log data to match the 1999 radionuclide activity verses depth profiles. The difference between the resulting depth shift to match radionuclide profiles and the casing stickup ranged between 2 and 6 in. This difference is reasonable considering the possible changes that may have occurred to the ground surface around the boreholes between 1992 and 1999. Also, there may be some small error associated with the logging engineer's pick of ground surface from the surrounding contour. It is possible, but unlikely, that the depth shift would mask vertical movement of contaminants because, for that to happen, the entire contaminant profile would have to migrate a single, fixed distance down the borehole.

All four wells with both 1992 and 1999 data have depth intervals where the 1992 and 1999 logging instruments exceeded the high count-rate limits for accurate activity values. These intervals are specified for each of the wells. Clearly, no radionuclide comparison can be performed over such depth intervals.

Several computations and corrections were necessary to make comparisons between current log data and previously collected log data. These include the following:

1. Depth shift - The depth reference was ground surface for log data collected in the past. The 1999 log data were collected using the top of the casing as the zero depth reference. Additionally, modifications made to the top of the casings and contamination stabilization may have altered the top of the 
casing or ground elevation since the last logging event. To place both spectra relative to the same elevation datum, the gross gamma spectra from the older logging events were depth adjusted to get the best fit with the 1999 data.

2 Dead-time correction limitations - Previous spectral-gamma data were recorded using an earlier version of electronic signal processing. The $1992 \mathrm{log}$ data had a limit for dead-time correction at $20 \%$ dead time and below. The $1999 \log$ data have a limit of $32 \%$ and below for dead-time corrections.

3. Raw data reanalysis - To make rigorous comparisons of old and current data, the raw spectral data of the previous logs were re-analyzed with the exact casing corrections and radionuclides as the current (1999) log data analysis.

4. Gross gamma-ray comparisons - Different amounts of radon from atmospheric pumping occur during different days of log data collection. The changes in radon levels within the borehole cause the gross gamma-ray count rate to change. This was not observed during the 1999 logging.

5. Statistical precision - Apparent but not real changes in radionuclide abundances are possible for very low gamma-ray intensities because of the statistical precision of both the current and past log data sets. In depth intervals with high concentrations of one radionuclide, other radionuclide that may be present will exhibit higher statistical deviations due to interference in the Compton background subtraction.

6. Depth coefficients - Different logging units can have slight systematic errors in absolute depth. At extended depth intervals, the systematic depth errors can be significant. A depth stretch, or shrinkage, can be used to correct for this type of difference and make log-to-log comparisons. Given that possible depth changes in a contaminant can also be viewed as a depth stretch, no such corrections were applied during analysis.

7. Natural decay - Any given radionuclide has an inherent decay with a specific decay rate. ${ }^{137} \mathrm{Cs}$ is the dominant radionuclide detected during 1999 logging but ${ }^{60} \mathrm{Co},{ }^{125} \mathrm{Sb}$, and ${ }^{154} \mathrm{Eu}$ also were detected. All radionuclide activities required a decay correction before comparing the 1999 data with older data.

8. Depth sampling - Different sample points for different logging runs can result in apparent but not real differences in observed maximum readings from thin zones or thinly bedded sediments.

\subsubsection{Comparison of Gross Gamma Logs}

Historical gross gamma logs were compared with the gross gamma logs collected by the spectral instrument in 1999. The older logs were obtained with instruments that were operated only in the gross gamma mode. The detectors were typically scintallator crystal detectors, which have poor energy resolution compared to the high purity germanium detectors used in the 1999 logging. 
Differences in the detector composition and size result in different efficiencies for the gross gamma response. A given activity of ${ }^{137} \mathrm{Cs}$, for example, will yield different observed count rates for the two gross gamma results. In order to rigorously compare the 1999 and the historic gross gamma data, a scaling factor for the different efficiencies for each isotope must be used. This was not done to the historic logs used in this work because the scaling factors are not known. However, the comparison of older gross gamma log results with the 1999 gross gamma response was done qualitatively by plotting each $\log$ on a different scale in the same plot.

Decay correction should also be applied to the older gross gamma data in order to compare with the 1999 data. However, this would require the complex adjustment of the older log on an isotope by isotope basis. Consider the simple case of only one contaminant, ${ }^{137} \mathrm{Cs}$. A single scaling factor is required for each of the different detectors and a decay correction for only the ${ }^{137} \mathrm{Cs}$ contribution to the gross gamma response of the older detector. Because the relative contribution of ${ }^{137} \mathrm{Cs}$ to the gross gamma signal is different for each detector type, the amount of ${ }^{137} \mathrm{Cs}$ contributing to the old gross gamma logs is not known so that a decay correction is not possible. Multiple contaminants further complicate a decay correction. Therefore, no decay corrections were attempted for any comparisons of older gross gamma logs with 1999 gross gamma logs.

The older gross gamma log results were only available on chart paper. Copies of the charts were digitized to facilitate the graphical comparison. Because the quantitative comparison of older gross gamma logs with the 1999 gross gamma response is not possible without extensive calibration efforts, the comparison can only yield indications and not rigorous conclusions. However, changes in the depth distribution of contaminants can sometimes be discounted using the gross gamma time lapse comparison performed.

\subsection{Data Interpretation}

Spectral gamma-ray neutron moisture data were plotted versus depth for each spectrum. These plots were compared to lithologic columns drawn to the same scale to idealize geologic control over contaminant distribution. Lithologic information was taken from geologist's logs, if available, driller's logs, well construction and completion summaries (if no logs were available), and from published stratigraphy (Fecht et al. 1979a, 1979b; DOE 1993a, 1993b). Inconsistencies among sources of lithologic information were common, and data from the geologist's logs were used, if available, in those instances.

One of the major difficulties in comparing the log data with lithology was ensuring that the drilling depths and the depths recorded by the logging systems were all relative to a common datum. Logging data were corrected to surface elevation before making any comparisons. In several cases, discrepancies in top-of-casing elevation exist. In addition, modifications such as shortening the top of the casing may have been made to some of the boreholes since they were drilled. Also, the modifications to the surface around some of the boreholes, such as gravel covers, may have been made since the borehole was drilled. These changes, along with inconsistencies in geologist's and driller's logs, make some depth comparisons difficult. 
Some lithologic information can be obtained from the moisture logging results. Moisture changes with depth are typically caused by changes in the soil characteristics that result in different moisture retention. A significant parameter affecting the moisture log response is formation density.

As described above, comparison of the 1999 logs were made to pre-1999 spectral gamma logs and gross gamma logs if pre-1999 logs existed. These comparisons were the basis for interpretation as to whether the distribution of subsurface contamination had changed between logging events. Comparisons of the $1990 \mathrm{log}$ with older gross gamma logs are qualitative. 


\subsection{Results}

This section contains descriptions of the spectral gamma ray and neutron moisture logging results for each borehole and well logged in 1999. Comparisons are made with past log data where such data exist and where such comparisons are meaningful. The log headers, activity-versus-depth profiles, acceptance quality assurance processing spectra, and log analysis summaries with minimum detection limits for each borehole logged are given in Appendix B of this report. It should be noted that although the reference depth for each $\log$ is top of casing, the narratives and $\log$ plots in Appendix B are referenced to ground surface to ease comparison with historic logs. Also, all depth references in this section are relative to ground surface. Raw spectral data and processed data for all gamma-ray spectra and moisture logs are available in a Pacific Northwest National Laboratory library.

\subsection{PUREX Facilities}

\subsubsection{6-A-2 Crib (Borehole 299-E24-53)}

This borehole is located 10 to $20 \mathrm{ft}$ east of the $216-\mathrm{A}-2$ crib. The borehole was drilled in 1955 to a depth of $50 \mathrm{ft}$. The distributor pipes for the crib are at a depth of $21 \mathrm{ft}$, and the bottom of the crib is at $26 \mathrm{ft}$.

${ }^{137} \mathrm{Cs},{ }^{60} \mathrm{Co},{ }^{235} \mathrm{U},{ }^{238} \mathrm{U}$, and ${ }^{154} \mathrm{Eu}$ were identified between $26 \mathrm{ft}$ and the bottom of the borehole (50 $\mathrm{ft}$ ). The system count-rate limits were exceeded between 31 and $36 \mathrm{ft}$ so that true activities are greater than those recorded over this interval. The identification of ${ }^{154} \mathrm{Eu}$ was made on the basis of only one photo peak $(1274 \mathrm{keV})$ due to interferences from other gamma emitting isotopes. Table 4.1 lists the isotopes, depths identified, maximum activity and depth of maximum activity.

Table 4.1. Man-Made Isotopes Identified in Borehole 299-E24-53

\begin{tabular}{|l|c|c|c|}
\hline \multicolumn{1}{|c|}{ Isotope } & $\begin{array}{c}\text { Depths of Occurrence } \\
\text { (ft) }\end{array}$ & $\begin{array}{c}\text { Maximum Activity } \\
\text { (pCi/g) }\end{array}$ & $\begin{array}{c}\text { Depth of Maximum } \\
\text { Activity (ft) }\end{array}$ \\
\hline \hline${ }^{137} \mathrm{Cs}$ & 26 to 50 & $>4190$ & 33 \\
\hline${ }^{60} \mathrm{Co}$ & 26 to 49 & $>8$ & 40 \\
\hline${ }^{238} \mathrm{U}$ & 37 to 50 & 730 & 44 \\
\hline${ }^{235} \mathrm{U}$ & 38 to 49 & 34 & 40 \\
\hline${ }^{154} \mathrm{Eu}$ & 31 to 40 & 8 & 37 \\
\hline
\end{tabular}

All isotopes are found in a Hanford formation sand layer beneath crib backfill (Figure 4.1 ). ${ }^{137} \mathrm{Cs}$ is concentrated higher in the section than are the other isotopes. The activity of ${ }^{238} \mathrm{U}$, and possibly ${ }^{235} \mathrm{U}$, may be increasing slightly with depth at the bottom of the borehole. The most recent previous log from this borehole is a gross gamma-ray log obtained in 1982. That log shows contamination extending from about 


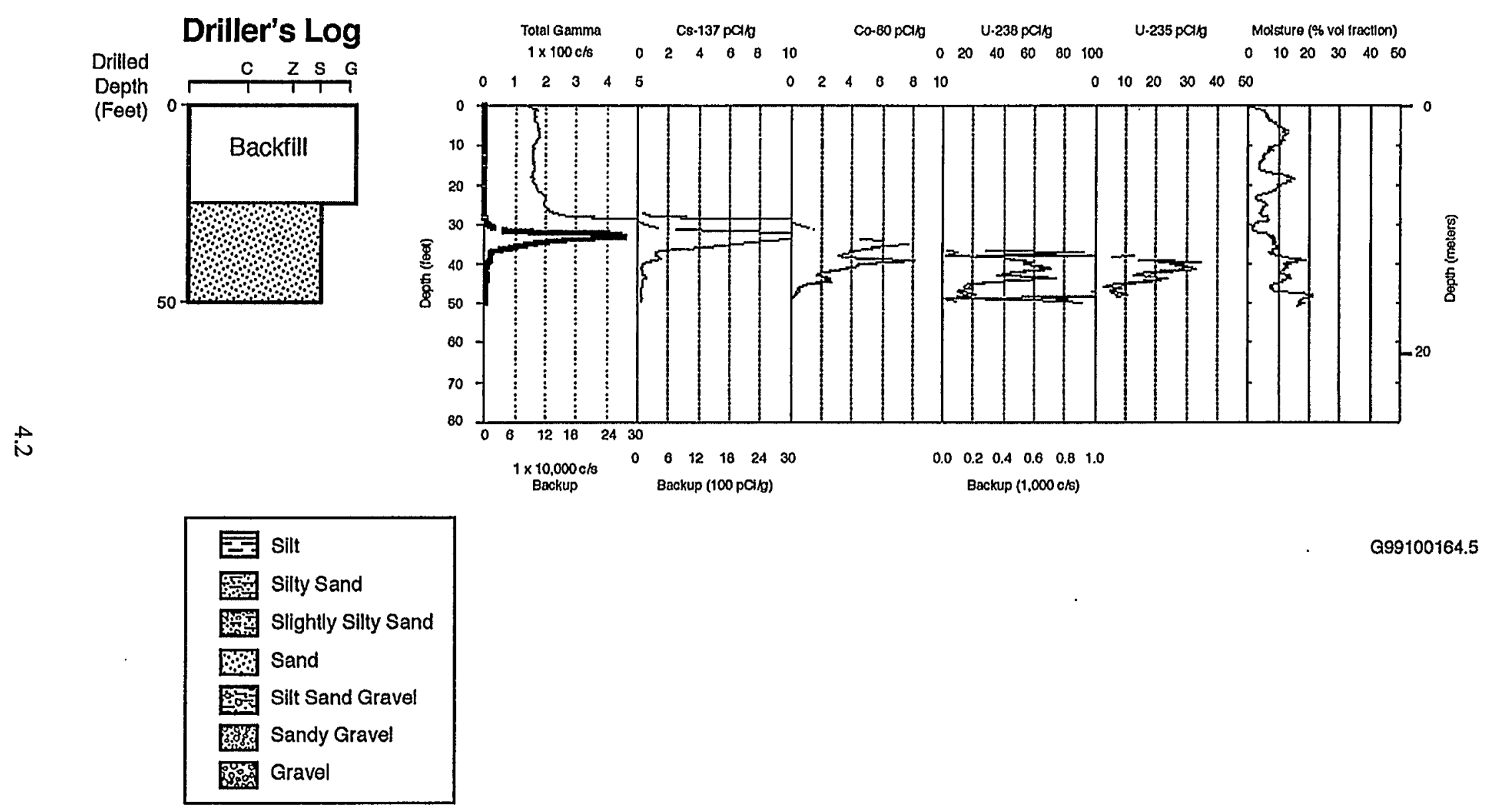

Figure 4.1. Spectral Gamma-Ray and Neutron Moisture Logs from Borehole 299-E24-53 at the 216-A-2 Crib 
$24 \mathrm{ft}$ to the bottom of the borehole with a maximum activity at a depth of about $34 \mathrm{ft}$, corresponding to the depth of the ${ }^{137} \mathrm{Cs}$ maximum in the $1999 \mathrm{log}$. A second, smaller.maximum on the $1982 \mathrm{log}$ corresponds to the ${ }^{238} \mathrm{U}$ maximum on the $1999 \mathrm{log}$. The similarities between the two logs suggest that there has been little to no vertical contaminant movement around borehole 299-E24-53 between 1982 and 1999.

Figure 4.2 shows a comparison between the 1976 gross gamma log and the 1999 gross gamma log. The two gross gamma logs are plotted on different scales to adjust for the different efficiency of each logging instrument. No decay correction was performed. Comparison of the logs shows that, in general, the increases and decreases in intensity from 25 to $50 \mathrm{ft}$ match, indicating no vertical contaminant movement. Lateral movement as well as slight changes in detector efficiency among the different detectors used for the different logs in this interval, could result in the absolute differences observed.

The moisture log from 299-E24-53 shows several zones of high and low moisture content throughout the entire borehole (see Figure 4.1) but the fine structure in the log cannot be related in detail with contaminant distribution or lithology using the available data. Below the backfill material at about $22 \mathrm{ft}$, the moisture content of the sand tends to increase with depth with a maximum moisture content of about $20 \%$ near the bottom of the borehole. Use of the crib ceased in 1963, so much of this moisture must be residual from the effluent disposed to the crib.

\subsubsection{6-A-4 Crib (Borehole 299-E24-54)}

Borehole 299-E24-54 is located approximately $20 \mathrm{ft}$ northeast of the northeast corner of the 216-A-4 crib. The borehole was drilled in 1955 to a depth of $50 \mathrm{ft}$. In 1982, the borehole was deepened to $100 \mathrm{ft}$ and the annulus between the 6 -in. and 8-in. casings was grouted between depths of 0 and $50 \mathrm{ft}$. The distributor pipes for the crib are at a depth of $18 \mathrm{ft}$ and the bottom of the crib is at $26 \mathrm{ft}$.

${ }^{137} \mathrm{Cs}$ and ${ }^{60} \mathrm{Co}$ were identified from the spectral gamma-ray $\log$ of this borehole. ${ }^{137} \mathrm{Cs}$ was found from depths of 26 to $33 \mathrm{ft}$ and from 54 to $89 \mathrm{ft}$ (also a small amount of ${ }^{137} \mathrm{Cs}$ occurs between 0 and $3 \mathrm{ft}$ ). The maximum ${ }^{137} \mathrm{Cs}$ activity was $80 \mathrm{pCi} / \mathrm{g}$ at $65 \mathrm{ft}$. ${ }^{60} \mathrm{Co}$ was found between depths of 26 and $68 \mathrm{ft}$ with a maximum activity of $3.6 \mathrm{pCi} / \mathrm{g}$ at $44 \mathrm{ft}$ (Figure 4.3 ).

Documentation for borehole 299-E24-54 states that a grout seal was placed from a depth of 0 to $50 \mathrm{ft}$ around the annulus. The moisture log suggests that, if such a seal is in place, it must be very thin (approximately $1 \mathrm{in}$.). The relatively high moisture content at about $50 \mathrm{ft}$ may represent an interval with thicker grout.

\subsubsection{6-A-7 Crib (Borehole 299-E25-54)}

Borehole 299-E25-54 is located about $20 \mathrm{ft}$ east of the 216-A-7 crib. The borehole was drilled in 1955 to a depth of $150 \mathrm{ft}$. The distributor pipes for the crib are at a depth of $10 \mathrm{ft}$. 


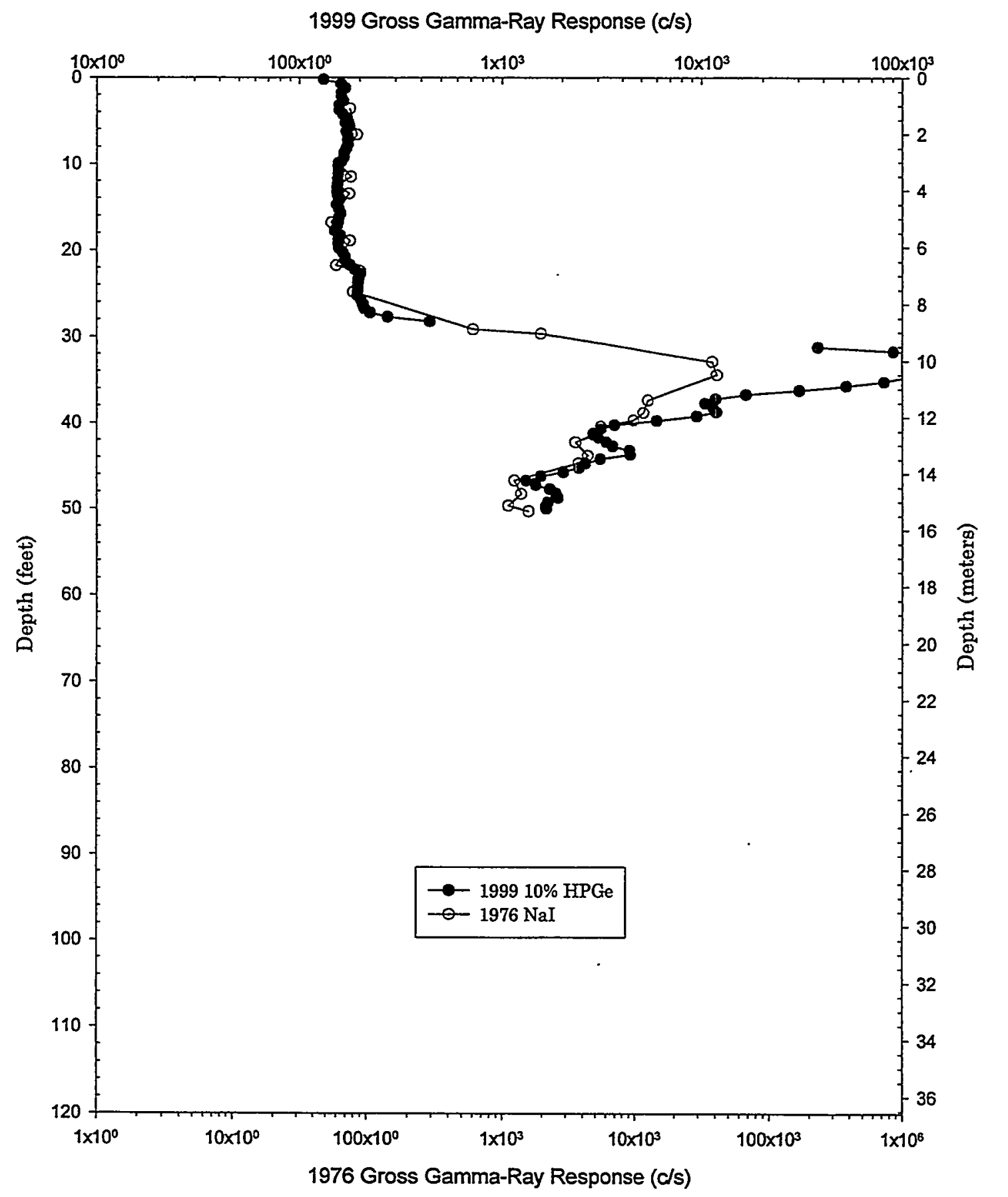

Figure 4.2. Comparison of 1999 and 1976 Gross Gamma-Ray Logs from Borehole 299-E24-53. The 1976 data is digitized from Fecht et al. (1977). 


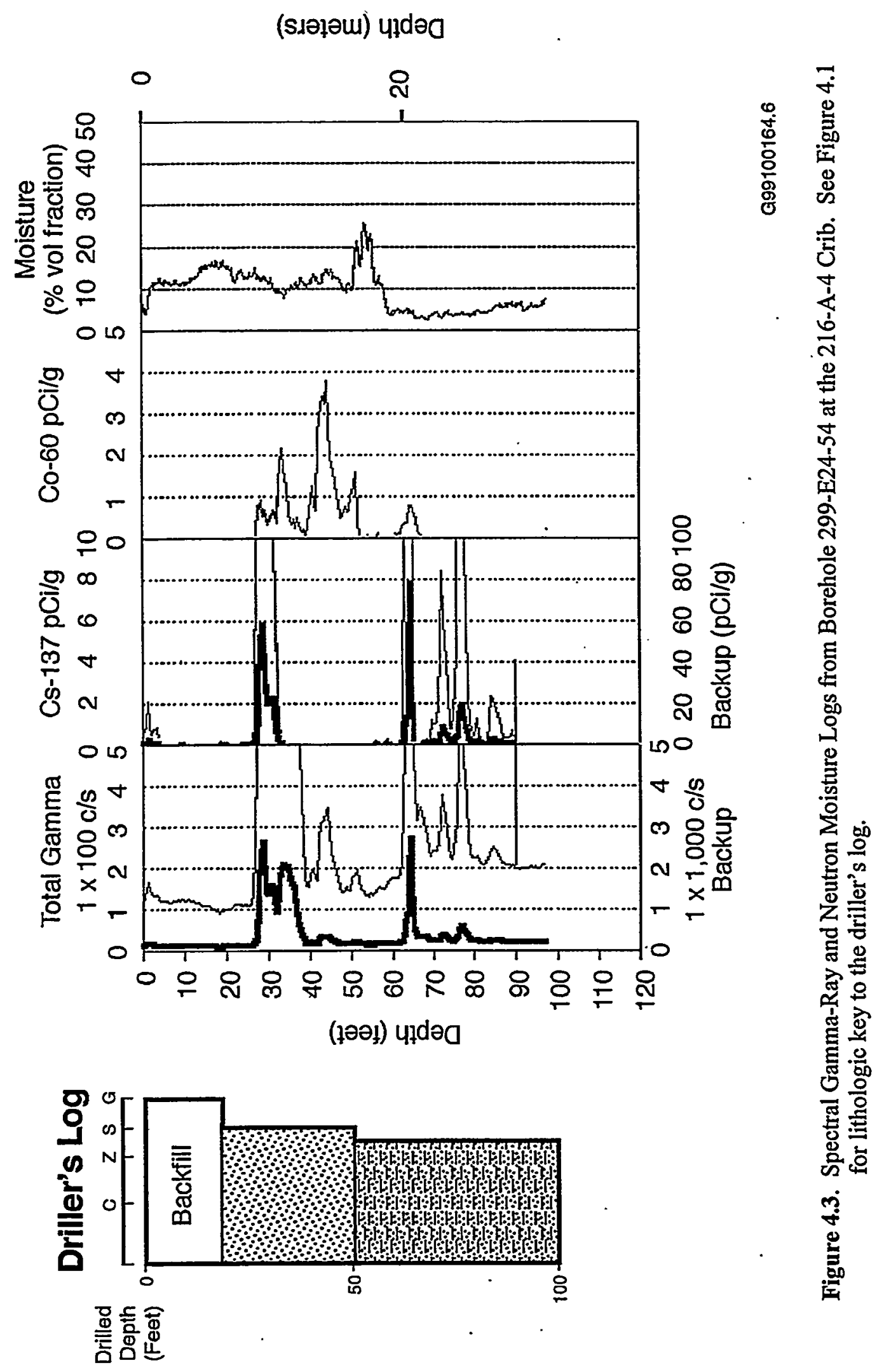


${ }^{137} \mathrm{Cs},{ }^{60} \mathrm{Co},{ }^{238} \mathrm{U}$, and ${ }^{154} \mathrm{Eu}$ were identified from the spectral gamma-ray log of this borehole. The detection of ${ }^{60} \mathrm{Co},{ }^{238} \mathrm{U}$, and ${ }^{154} \mathrm{Eu}$ was verified by the summing technique described in Appendix $\mathrm{A}$. The identification of ${ }^{154} \mathrm{Eu}$ relies on only the $1274 \mathrm{keV}$ gamma-ray due to interferences from other gamma emitting isotopes.

${ }^{137} \mathrm{Cs}$ was identified between depths of about 6 and $10 \mathrm{ft}$. The maximum activity of ${ }^{137} \mathrm{Cs}$ was $880 \mathrm{pCi} / \mathrm{g}$ at $9 \mathrm{ft}$. This corresponds to the depth of the distributor pipes in the crib. The gross gamma-ray $\log$ is higher than expected for the amount of ${ }^{137} \mathrm{Cs}$ present between 5 and $10 \mathrm{ft}$. Because all other identified radionuclides are at very low levels, the high gross gamma response indicates either a strong remote source (most likely ${ }^{137} \mathrm{Cs}$ ) or the presence of a strong beta emitter such as ${ }^{90} \mathrm{Sr}$ probably contributing to the gross gamma-ray intensity. A strong remote source of ${ }^{137} \mathrm{Cs}$ can yield many down scattered gamma rays that produce a gross response, but do not generate many ${ }^{137} \mathrm{Cs}$-specific gamma rays at $661 \mathrm{keV}$ due to earth shielding.

${ }^{60} \mathrm{Co}$ was identified between depths of 24 and $39 \mathrm{ft}$ with a maximum activity of $0.3 \mathrm{pCi} / \mathrm{g}$ at $31 \mathrm{ft}$ (the minimum detection level [MDL] is $0.2 \mathrm{pCi} / \mathrm{g}$ ). ${ }^{238} \mathrm{U}$ was found between 25 and $37 \mathrm{ft}$ at the detection threshold (MDL $25 \mathrm{pCi} / \mathrm{g}$ ) and its presence is verified by the summing technique. Likewise, ${ }^{154} \mathrm{Eu}$ was found at detection levels (MDL $2.5 \mathrm{pCi} / \mathrm{g}$ ) between depths of 8 and $10 \mathrm{ft} .{ }^{154} \mathrm{Eu}$ was identified only on the repeat $\log$ and not on the main log.

Previous gross gamma-ray logs from this borehole, obtained in 1976 and 1986, show a maximum activity at depths of about 8 to $9 \mathrm{ft}$ corresponding to the ${ }^{137} \mathrm{Cs}$ maximum in the $1999 \mathrm{log}$. Both older logs show a second, but smaller, maximum activity between about 28 and $40 \mathrm{ft}$. This second maximum activity corresponds to the depth at which ${ }^{60} \mathrm{Co}$ and ${ }^{238} \mathrm{U}$ are found on the $1999 \mathrm{log}$. The decrease in the relative intensity of the 30 to $40 \mathrm{ft}$ deep maximum relative to the intensity of the 9 to $10 \mathrm{ft}$ deep maximum reflects the decay of ${ }^{60} \mathrm{Co}$ between 1976 and 1999 in the deeper zone.

The moisture log from borehole 299-E25-54 shows several maxima throughout the borehole. There does not appear to be any correlation between the moisture values and the gross gamma values. The largest moisture values are near $32 \%$ by volume and are between depths of 110 and $135 \mathrm{ft}$. Such moisture values are high for the Hanford formation and almost certainly reflect the influx of liquid effluent. The two zones with the highest moisture content are near the upper and lower contacts of a sand, silt, and gravel unit between two finer grained sand units as noted on the driller's log.

\subsubsection{6-A-18 Trench (Well 299-E25-10)}

Well 299-E25-10 is located about $120 \mathrm{ft}$ northeast of the $216-\mathrm{A}-18$ trench. The well is actually closer to the 216-A-19 trench being about $60 \mathrm{ft}$ west of the latter. The well was drilled in 1958 to a depth of $293 \mathrm{ft}$. The trench is $15 \mathrm{ft}$ deep.

No man-made radionuclides were identified from the spectral gamma-ray log from this well. Both the gross gamma-ray log and the moisture log reflect the lithologies surrounding the well. 


\subsection{BC Controlled Area Cribs}

\subsubsection{6-B-14 Crib (Well 299-E13-1)}

Well 299-E13-1 is located at the southeast edge of the 216-B-14 crib. The well was drilled in 1955 to a depth of $355 \mathrm{ft}$. In 1985, a 6 -in. casing and grout annular seal were added between depths of 0 and $95 \mathrm{ft}$. The distribution pipe for the crib is about $6 \mathrm{ft}$ below grade.

${ }^{137} \mathrm{Cs}$ and ${ }^{60} \mathrm{Co}$ were identified from the spectral gamma-ray log of this well (Figure 4.4). High count rates over the depth interval 12 to $49 \mathrm{ft}$, where the major contaminant is ${ }^{137} \mathrm{Cs}$, caused inaccurate deadtime corrections. Activities of radionuclides in this zone are under reported.

${ }^{137} \mathrm{Cs}$ was identified between depths of 10 and $100 \mathrm{ft}$. The maximum activity of ${ }^{137} \mathrm{Cs}$ is greater than $100,000 \mathrm{pCi} / \mathrm{g}$ at some depth between 33 and $47 \mathrm{ft} .{ }^{60} \mathrm{Co}$ was found between about 110 and $180 \mathrm{ft}$ and between 193 and $203 \mathrm{ft}$. The maximum activity of ${ }^{60} \mathrm{Co}$ is $28 \mathrm{pCi} / \mathrm{g}$ at $111 \mathrm{ft} .{ }^{60} \mathrm{Co}$ was also noted between depths of about 70 and $90 \mathrm{ft}$ and between 252 and $256 \mathrm{ft}$ at activities near the detection level (MDL is $2 \mathrm{pCi} / \mathrm{g}$ ).

This well was logged previously several times with a gross gamma-ray system. Fecht et al. (1977) interpreted the logs and concluded that breakthrough to the groundwater from the crib was possible. The well was also logged in 1992 with spectral gamma methods (Brodeur et al. 1993). That log showed ${ }^{137} \mathrm{Cs}$ between the surface and $99 \mathrm{ft},{ }^{60} \mathrm{Co}$ between 56 and $274 \mathrm{ft}$ with a maximum of $70 \mathrm{pCi} / \mathrm{g}$ at $111 \mathrm{ft}$, and ${ }^{125} \mathrm{Sb}$ between depths of 59 and $90 \mathrm{ft}$ with a maximum of $60 \mathrm{pCi} / \mathrm{g}$ at $64 \mathrm{ft}$.

In order to compare the $1992 \log$ data to the 1999 data, the 1992 data were depth shifted $0.8 \mathrm{ft}$. Both data sets contain depth intervals over which the count-rate limits were exceeded. The count-rate limits were exceeded over the depth range of 14 to $52 \mathrm{ft}$ in the 1999 data set and from 11 to $64 \mathrm{ft}$ in the 1992 data set. Thus, no comparisons are possible from 11 to $64 \mathrm{ft}$.

Figure 4.5 compares the 1992 and 1999 spectral gamma-ray logs for ${ }^{137} \mathrm{Cs}$ and ${ }^{60} \mathrm{Co}$. The $1999 \mathrm{log}$ shows a $20 \%$ increase in ${ }^{137} \mathrm{Cs}$ activity between 67 and $88 \mathrm{ft}$ when compared to the $1992 \log$ whereas the thin zone at $98 \mathrm{ft}$ remains constant within depth sampling and statistical differences. An interesting feature of the 67 to 88 .ft zone is that the same $20 \%$ increase is observed throughout the entire depth range, where the ${ }^{137} \mathrm{Cs}$ activity varies from 10 to $70 \mathrm{pCi} / \mathrm{g}$. One possible cause for this constant fraction increase is leaching of a very small percentage of the ${ }^{137} \mathrm{Cs}$ from the highly contaminated zone just above into.this zone. Although this portion of the well has an annular grout seal, contamination could have moved down the casing. The moisture log indicates a variable thickness for the grout seal between 3 and $90 \mathrm{ft}$; there is a large thin zone from 19 to $27 \mathrm{ft}$ with a thicker seal between 70 to $90 \mathrm{ft}$.

${ }^{60} \mathrm{Co}$ shows no change between 1992 and 1999, with the possible exception of a zone from 191 to $201 \mathrm{ft}$ where an influx ${ }^{60} \mathrm{Co}$ is suggested. The moisture content for the depth interval 191 to $201 \mathrm{ft}$ is greater than in the zones just above or below. 


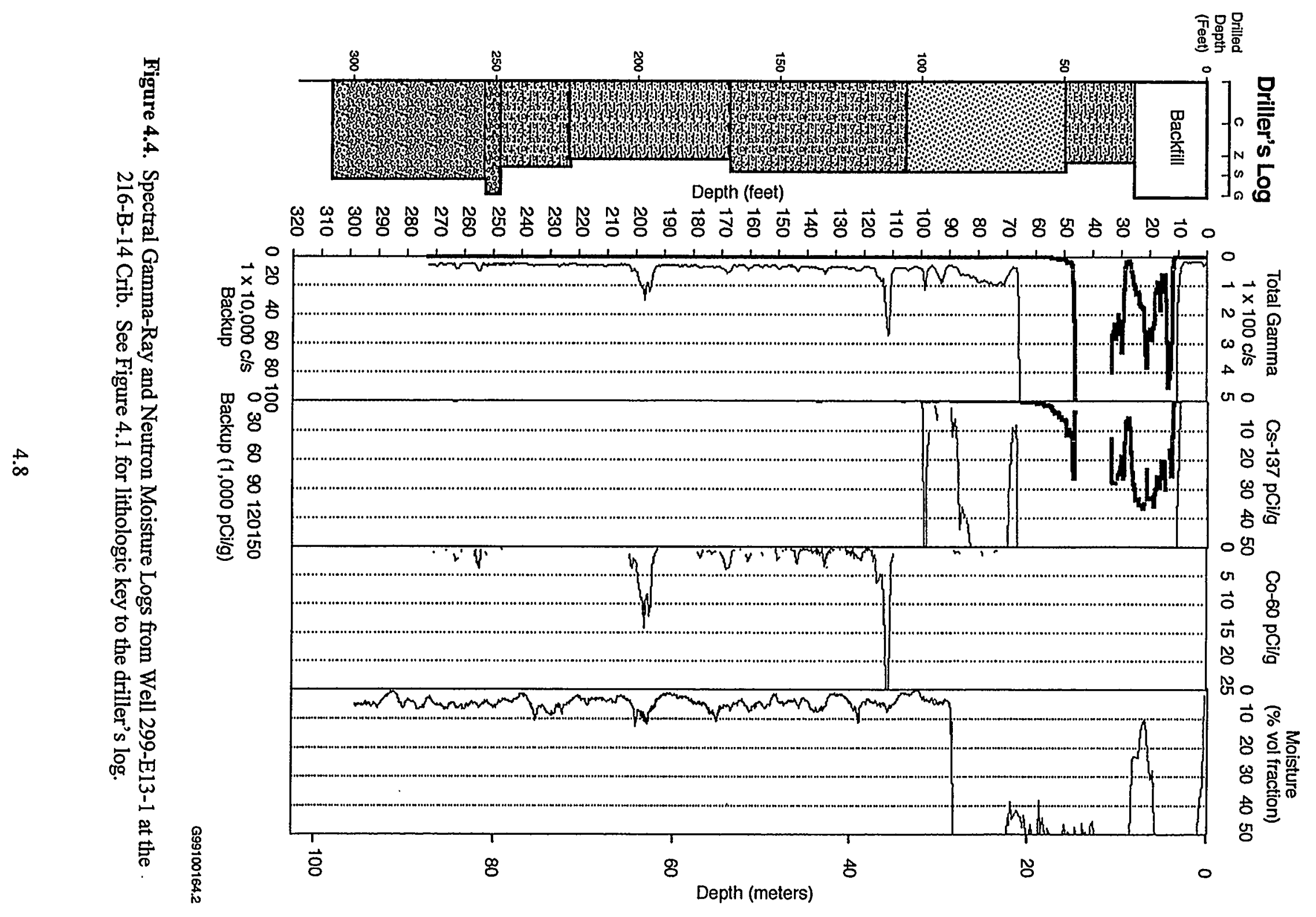



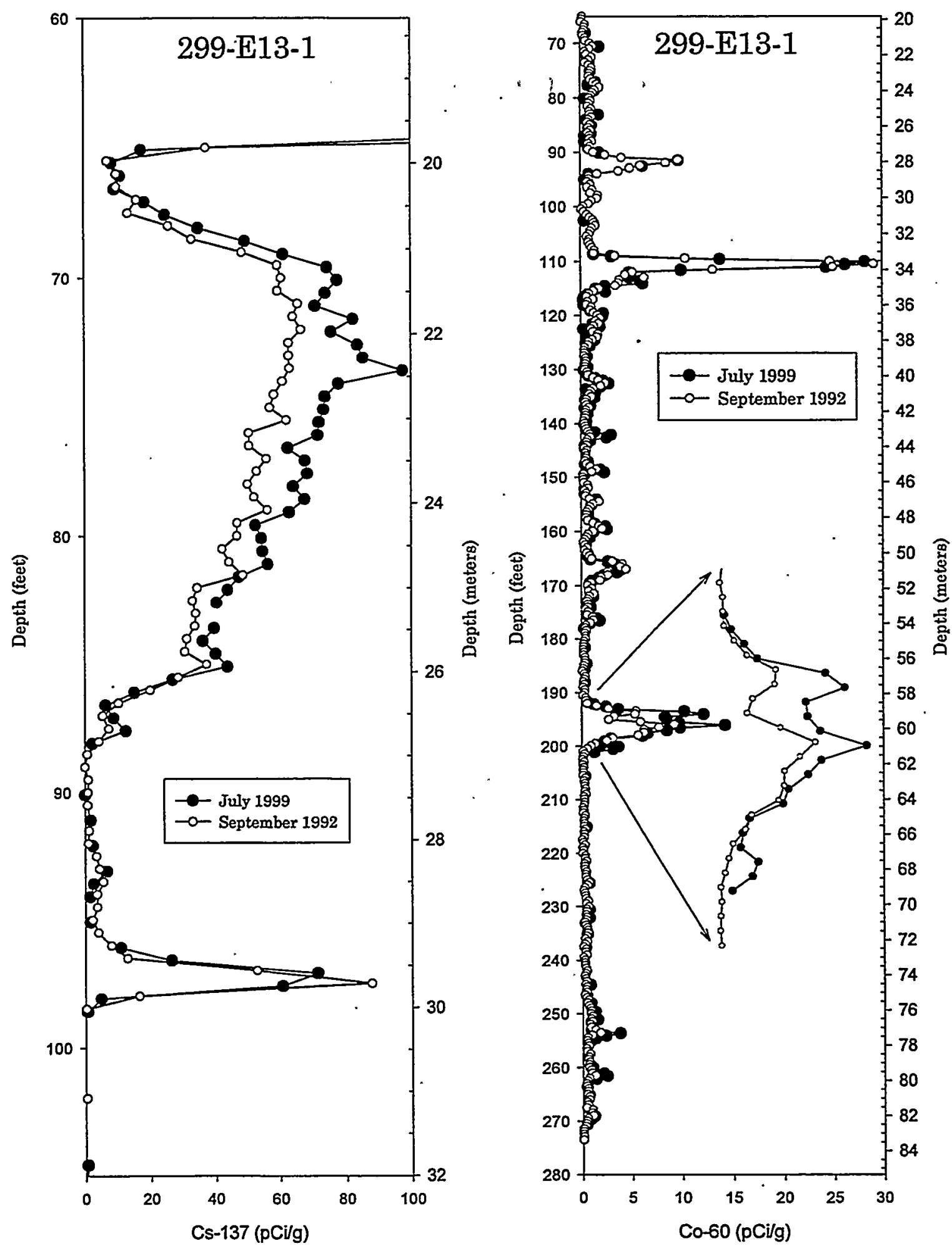

Figure 4.5. Comparison of 1992 and 1999 Spectral Gamma-Ray Logs from Well 299-E13-1 
Comparison of ${ }^{125} \mathrm{Sb}$ data suffers from the use of the $10 \% \mathrm{HPGe}$ tool in 1999, the high MDL for ${ }^{125} \mathrm{Sb}$, and the short half-life of 2.77 years. No ${ }^{125} \mathrm{Sb}$ was detected in 1999 . The non-detect in 1999 indirectly indicates no major influx of ${ }^{125} \mathrm{Sb}$. The maximum observed in 1992 is approximately $50 \mathrm{pCi} / \mathrm{g}$ of ${ }^{125} \mathrm{Sb}$ which reduces to $9 \mathrm{pCi} / \mathrm{g}$ after decay correction to 1999 levels. The MDL value for the $1999 \mathrm{log}$ data is near $9 \mathrm{pCi} / \mathrm{g}$ for ${ }^{125} \mathrm{Sb}$, and thus the non-detect result.

Comparison of the 1999 gross gamma-ray log to older gross gamma-ray logs is complex due to multiple isotopes present. Older gross gamma-ray logs run in 1956,1958, 1959, 1963, 1968, and 1976 (Fecht et al. 1977) show very intense and rapid decay through time from depths of about 60 to $228 \mathrm{ft}$. Less rapid decay occurred above that zone and was still very intense in 1976.

The moisture log from well 299-E13-1 reflects the annular seal between the surface and $90 \mathrm{ft}$ and shows that the thickness of the seal is variable. Below about $90 \mathrm{ft}$, the $\log$ shows several zones with varying moisture content (see Figure 4.4). There is some correlation between high moisture zones and the occurrence of contamination, but the correlation is far from perfect. The relatively high moisture zone between depths of 195 and $200 \mathrm{ft}$ corresponds to the high ${ }^{60} \mathrm{Co}$ interval at the same depth.

\subsubsection{6-B-15 Crib (Well 299-E13-2)}

Well 299-E13-2 is located along the southeast side of the 216-B-15 crib. The well was drilled in 1956 to a depth of $365 \mathrm{ft}$. The distributor pipes for the crib are at a depth of about $6 \mathrm{ft}$.

${ }^{137} \mathrm{Cs}$ was the only man-made radionuclide identified on the spectral gamma-ray log from this well. The maximum activity of ${ }^{137} \mathrm{Cs}$ is greater than $100,000 \mathrm{pCi} / \mathrm{g}$ at $22 \mathrm{ft}$ where the instrument saturated. The activity of ${ }^{60} \mathrm{Co}$ is near detection level for the normal logging pass, and the presence is verified by the summing technique described in Appendix A. The MDL is $1.5 \mathrm{pCi} / \mathrm{g}$ for ${ }^{60} \mathrm{Co}$. The normal log analysis does not detect ${ }^{154} \mathrm{Eu}$ at any depth, but the summing technique definitely identifies ${ }^{154} \mathrm{Eu}$. The MDL for ${ }^{154} \mathrm{Eu}$ by the summing technique is $3.5 \mathrm{pCi} / \mathrm{g}$ and projected to be $7 \mathrm{pCi} / \mathrm{g}$ in the standard logging pass and analysis.

The well was last logged in 1976 (Fecht et al. 1977) by gross gamma-ray methods. That log shows gamma contamination between depths of about 8 and $85 \mathrm{ft}$. Figure 4.6 shows a comparison between the 1976 and the 1999 gross gamma logs. The older log shows detector saturation between about 16 and $40 \mathrm{ft}$. The bottom edge of the interval where the 1976 detector saturated ( $40 \mathrm{ft}$ ) coincides with the bottom of the high count rate interval in the $1999 \log$. From 40 to $85 \mathrm{ft}$, the overall character of the two logs is similar and the small differences between the two are probably due to decay of short lived radionuclides. Fecht et al. (1977) report that a 1956 gross gamma-ray log was obtained prior to use of the crib and that $\log$ showed contamination from near the surface to about $131 \mathrm{ft}$. They interpret the contamination as resulting from lateral spreading from adjacent 216-B-14 and/or 216-B-17 cribs.

The moisture content in the sediments at well 299-E13-2 ranges from 2 to $23 \%$ with the higher values at depths less than $40 \mathrm{ft}$ corresponding to the highest contaminated interval. DOE (1993b) interpreted the 


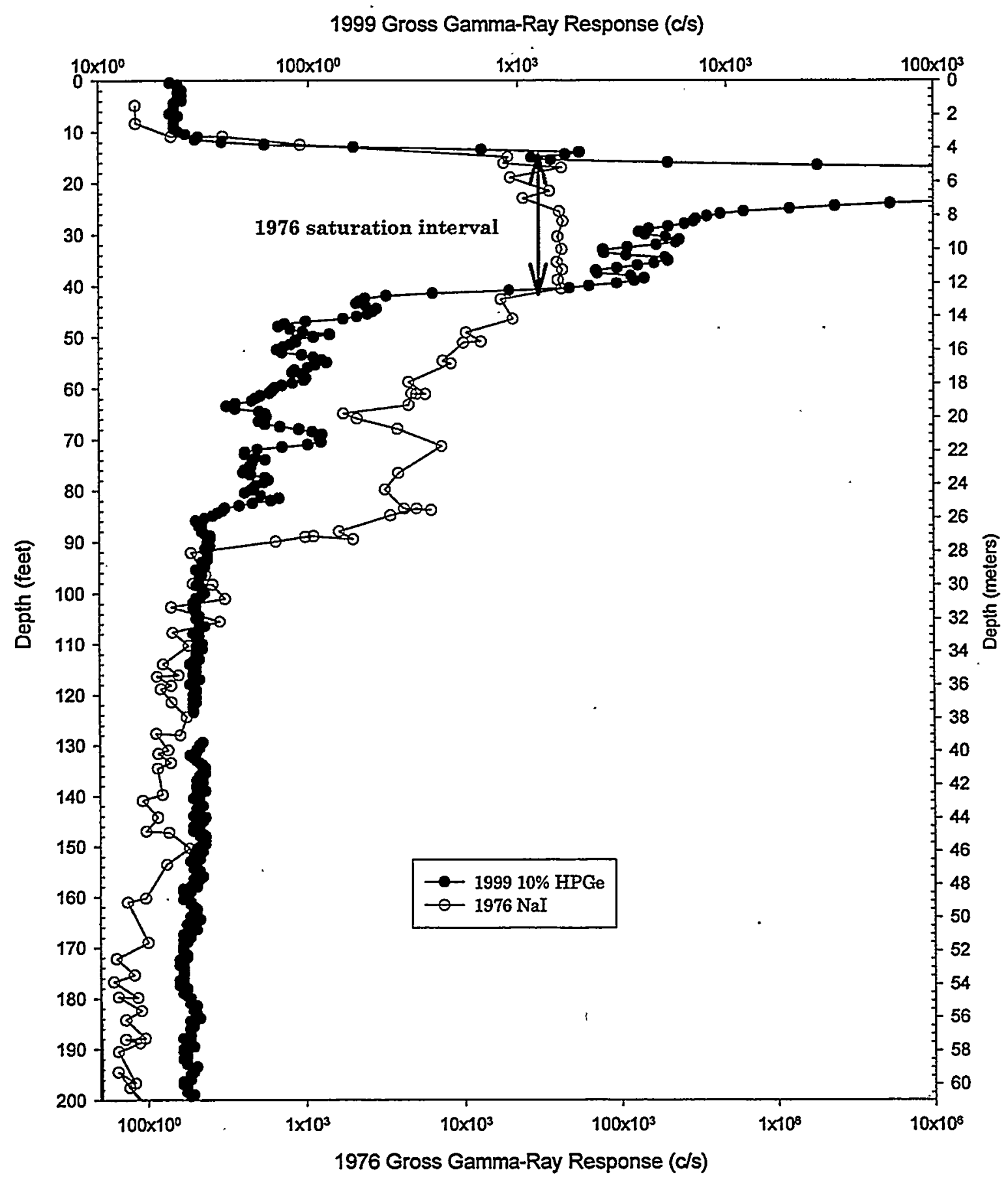

Figure 4.6. Comparison of the 1999 and 1976 Gross Gamma-Ray Logs from Well 299-E13-2 at the 216-B-15 Crib. The 1976 data is digitized from Fecht et al. (1977). 
distribution of contamination beneath the $\mathrm{BC}$ cribs to be controlled, in part, by a fine silty layer at about $95 \mathrm{ft}$. Neither the moisture log nor the gross gamma log show evidence for such a layer at that depth in well 299-E13-2.

\subsubsection{6-B-16 Crib (Wells 299-E13-3 and 299-E13-21)}

Wells 299-E13-3 and 299-E13-21 monitor the 216-B-16 crib. Well 299-E13-3 is located near the southeast edge of the crib and well 299-E13-21 is at the northwest edge of the crib. During analysis of the $1999 \mathrm{log}$ data, it was discovered that the wells are mislabeled in the field. The locations of the wells are correctly shown on Figure 3.3. The well identifications have been corrected on the 1999 logs. A request has been submitted to correctly label the wells in the field.

Well 299-E13-3 was drilled in 1955 to a depth of $365 \mathrm{ft}$. In 1985, a 6-in. casing and cement grout annular seal was added from 0 to $140 \mathrm{ft} .{ }^{137} \mathrm{Cs}$ was identified from the spectral gamma-ray log of this well between depths of 10 and $51 \mathrm{ft}$. High count rates between 14 and $15 \mathrm{ft}$ caused dead-time correction inaccuracy resulting in activities in this interval being greater than reported. The maximum ${ }^{137} \mathrm{Cs}$ activity is greater than $18,000 \mathrm{pCi} / \mathrm{g}$ at $15 \mathrm{ft} .{ }^{60} \mathrm{Co}$ and ${ }^{154} \mathrm{Eu}$ were also identified in the well; ${ }^{60} \mathrm{Co}$ exists between 42 and $49 \mathrm{ft}$ and between 66 and $71 \mathrm{ft}$ and ${ }^{154}$ Eu between 19 and $24 \mathrm{ft}$. Both ${ }^{60} \mathrm{Co}$ and ${ }^{154} \mathrm{Eu}$ are present at detection levels and their existence was confirmed using the summing technique described in Appen$\operatorname{dix} \mathrm{A}$. The MDL for ${ }^{60} \mathrm{Co}$ is $1 \mathrm{pCi} / \mathrm{g}$ and the $\mathrm{MDL}$ for ${ }^{154} \mathrm{Eu}$ is $3 \mathrm{pCi} / \mathrm{g}$ in this well.

Well 299-E13-3 was previously logged with the spectral gamma-ray system in 1992 (Brodeur et al. 1993). That $\log$ showed the presence of ${ }^{137} \mathrm{Cs},{ }^{60} \mathrm{Co},{ }^{125} \mathrm{Sb}$, and ${ }^{154} \mathrm{Eu}$. ${ }^{137} \mathrm{Cs}$ existed between 6 and $55 \mathrm{ft}$ with maximum activity greater than $5000 \mathrm{pCi} / \mathrm{g} ;{ }^{60} \mathrm{Co}$ was found between 22 and $122 \mathrm{ft}$ at less than $4 \mathrm{pCi} / \mathrm{g} ;{ }^{125} \mathrm{Sb}$ was between depths of 23 and $47 \mathrm{ft}$ with maximum activity of $40 \mathrm{pCi} / \mathrm{g}$ at $28 \mathrm{ft}$; and ${ }^{154} \mathrm{Eu}$ was between 16 and $26 \mathrm{ft}$ at less than $10 \mathrm{pCi} / \mathrm{g}$.

In order to compare the $1992 \log$ data with the $1999 \log$ data, the 1992 data were depth shifted $2.2 \mathrm{ft}$. The interval between 12 and $22 \mathrm{ft}$ was not logged in 1992 because of excessively high count rates. Therefore, no comparison can be made over the depth interval from 12 to $22 \mathrm{ft}$.

Figure 4.7 shows a comparison of the 1992 and $1999 \log$ results for ${ }^{137} \mathrm{Cs}$ at two different scales. ${ }^{137} \mathrm{Cs}$ activity has remained unchanged between 28 and $50 \mathrm{ft}$. There is an apparent increase in ${ }^{137} \mathrm{Cs}$ activity, however, between 24 and $28 \mathrm{ft}$. The increase is outside of statistical precision and the cause of the increase is not clear. ${ }^{137} \mathrm{Cs}$ may have migrated into this depth interval from the high activity interval above. However, the rapid change in ${ }^{137} \mathrm{Cs}$ activity from greater than $2000 \mathrm{pCi} / \mathrm{g}$ at about $25 \mathrm{ft}$ to near background at about $30 \mathrm{ft}$ can affect the sampling results. A fraction of a foot difference in placement of the detector while counting in 1999 from the position of the detector in 1992 would mean that the detector would see a different activity in 1999 than in 1992 across the steep activity gradient. Thus, depth sampling may contribute to the apparent increase in activity of ${ }^{137} \mathrm{Cs}$ in this interval.

Figure 4.8 shows comparisons of the 1992 and 1999 logging results for ${ }^{60} \mathrm{Co}$ and ${ }^{154} \mathrm{Eu}$. Both ${ }^{60} \mathrm{Co}$ and ${ }^{154} \mathrm{Eu}$ have high MDLs in the 1999 data because the $10 \% \mathrm{HPGe}$ detector was used to log this well. Neither isotope appears to have changed with respect to depth since 1992 . The appearance of ${ }^{154} \mathrm{Eu}$ 

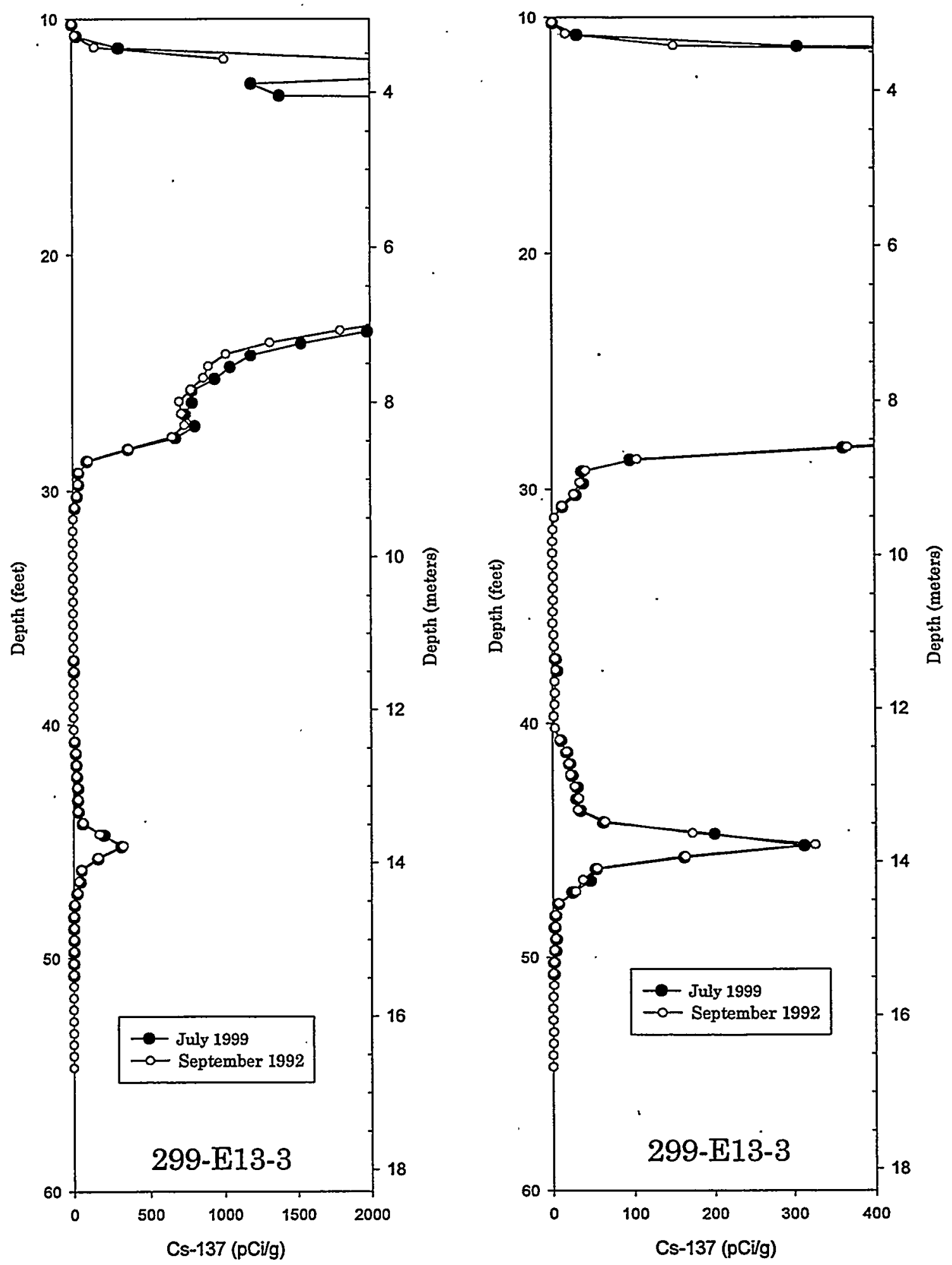

Figure 4.7. Comparison of the 1999 and 1992 Spectral Gamma Log Results for ${ }^{137} \mathrm{Cs}$ at Well 299-E13-3 at Two Different Scales 

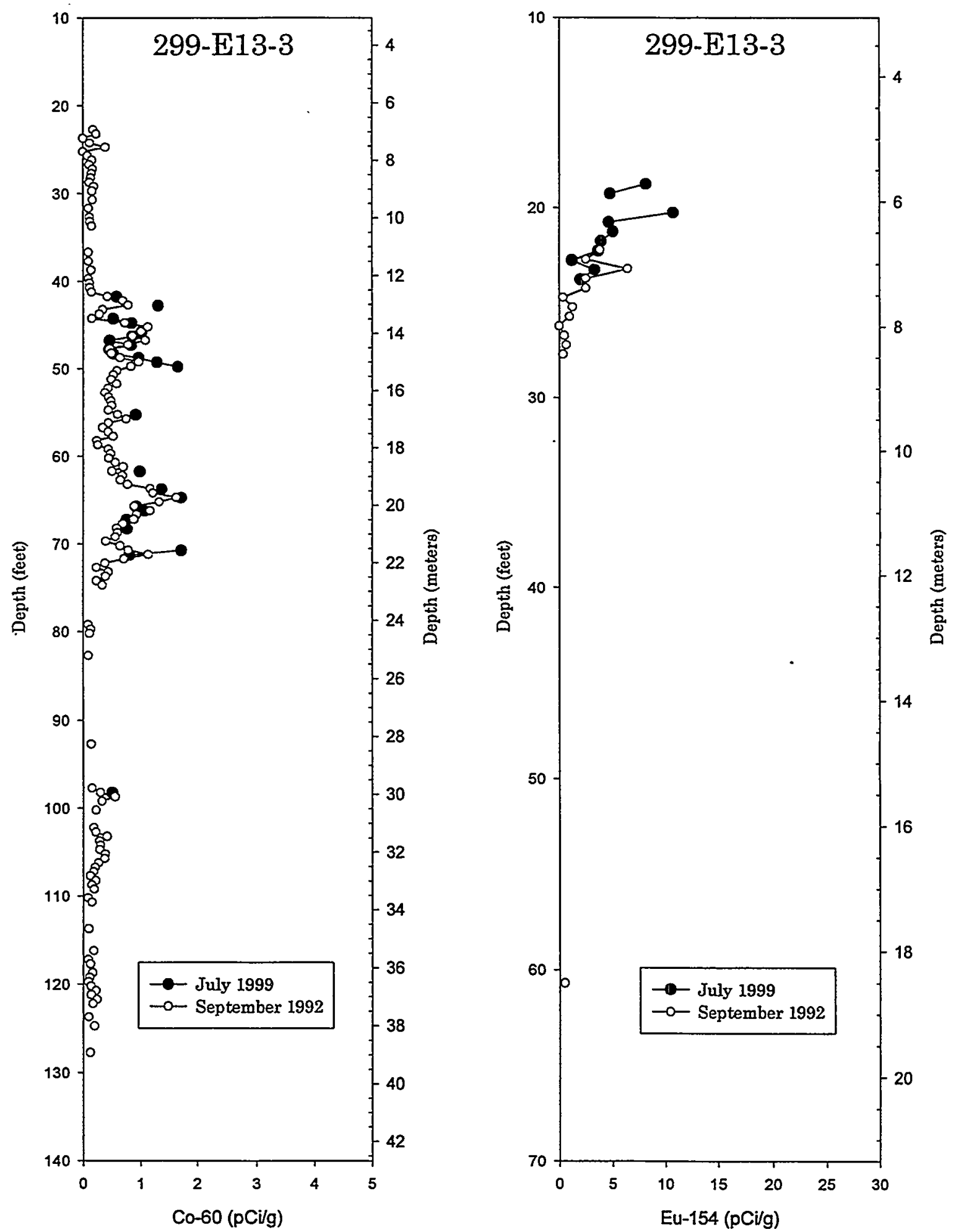

Figure 4.8. Comparison of the 1999 and 1992 Spectral Gamma Logs for ${ }^{60} \mathrm{Co}$ and ${ }^{154} \mathrm{Eu}$ in Well 299-E13-3 at the 216-B-16 Crib 
between 18 and $22 \mathrm{ft}$ in the $1999 \log$ and not in the $1992 \mathrm{log}$ is probably due to the difference in the detectors used in the two logging events and not to movement of ${ }^{154} \mathrm{Eu}$. The $10 \% \mathrm{HPGe}$ detector with a lower sensitivity was used in 1999 and an unshielded 18\% detector was used in 1992. Over the interval from 18 to $22 \mathrm{ft}$, the high activity of ${ }^{137} \mathrm{Cs}$ swamps the more sensitive detector. Conversely, no ${ }^{137} \mathrm{Cs}$ interference occurs from 25 to $28 \mathrm{ft}$ and the more sensitive 1992 detector registers ${ }^{154} \mathrm{Eu}$ where the less sensitive 1999 detector does not.

${ }^{125} \mathrm{Sb}$ was identified at $10 \mathrm{pCi} / \mathrm{g}$ in 1992 but was not detected in 1999. In $1992,10 \mathrm{pCi} / \mathrm{g}$ of ${ }^{125} \mathrm{Sb}$ would have decayed to about $2 \mathrm{pCi} / \mathrm{g}$ today and the $\mathrm{MDL}$ for ${ }^{125} \mathrm{Sb}$ was greater than $2 \mathrm{pCi} / \mathrm{g}$ for the recent log. Thus, the non-detect of ${ }^{125} \mathrm{Sb}$ in 1999 indicates no influx of ${ }^{125} \mathrm{Sb}$ since 1992.

Comparison of the gross gamma-ray logs is complex due to multiple isotopes present. The older gross gamma logs obtained in 1956, 1959, 1963, 1968, and 1976 (Fecht et al. 1977) show very intense radiation and rapid decay through time from about 65 to $112 \mathrm{ft}$. The decay is slower between 10 to $65 \mathrm{ft}$. This probably reflects the deeper distribution of mobile and short lived ${ }^{106} \mathrm{Ru}$ (half-live of 1.02 years) relative to the shallower, less mobile and longer lived ${ }^{137} \mathrm{Cs}$.

The moisture log from well 299-E13-3 reflects the annular seal from 0 to a depth of about $130 \mathrm{ft}$. The high moisture content from 145 to $160 \mathrm{ft}$ may also reflect well construction. There is no correlation with the gross gamma-ray log or no indication of lithology change in the driller's log at this depth. Below this depth, the moisture content is typical of the Hanford formation.

Well 299-E13-21 was drilled in 1965 to a depth of $338 \mathrm{ft} .{ }^{137} \mathrm{Cs}$ was the only contaminant identified from the spectral gamma-ray $\log$ of this well. ${ }^{137} \mathrm{Cs}$ was identified over the entire depths logged ( 2 to $150 \mathrm{ft}$ ) (Figure 4.9). The maximum activity of ${ }^{137} \mathrm{Cs}$ was greater than $90,000 \mathrm{pCi} / \mathrm{g}$. High count rate between 16 and $21 \mathrm{ft}$ and between 25 and $33 \mathrm{ft}$ exceeded the accuracy of the dead-time correction so that actual activities are greater than reported.

Well 299-E13-21 was previously logged with the spectral gamma-ray system in 1992 (Brodeur et al. 1993). The log showed that ${ }^{137} \mathrm{Cs}$ and ${ }^{60} \mathrm{Co}$ were present. ${ }^{137} \mathrm{Cs}$ occurred between 0 and $279 \mathrm{ft}$ depths with a maximum activity exceeding $5000 \mathrm{pCi} / \mathrm{g}$ between 11 and $24 \mathrm{ft} .{ }^{60} \mathrm{Co}$ was found between 188 and $278 \mathrm{ft}$ with activity less than $2 \mathrm{pCi} / \mathrm{g}$. No detailed comparison of the 1992 and $1999 \mathrm{logs}$ was made because the 1992 electronic files could not be located.

There are two zones of relatively high moisture: 1) 5 to $40 \mathrm{ft}$ corresponding to an upper relatively highly contaminated zone and 2) a broad, less moist zone between about 80 and $130 \mathrm{ft}$. The lower zone is slightly deeper than ${ }^{137} \mathrm{Cs}$ (which is at 60 to $100 \mathrm{ft}$ ) and may represent continued infiltration of the moisture which carried the ${ }^{137} \mathrm{Cs}$ to depth.

\subsubsection{6-B-17 Crib (Well 299-E13-4)}

Well 299-E13-4 is adjacent to the northwest edge of the 216-B-17 crib. The well was drilled in 1955 to a depth of $369 \mathrm{ft}$. In 1985, a 6-in. casing and grout annular seal were added between depths of 0 and $95 \mathrm{ft}$ and a sand plug from 95 to $100 \mathrm{ft}$. The distribution pipe for the crib is about $6 \mathrm{ft}$ below grade. 


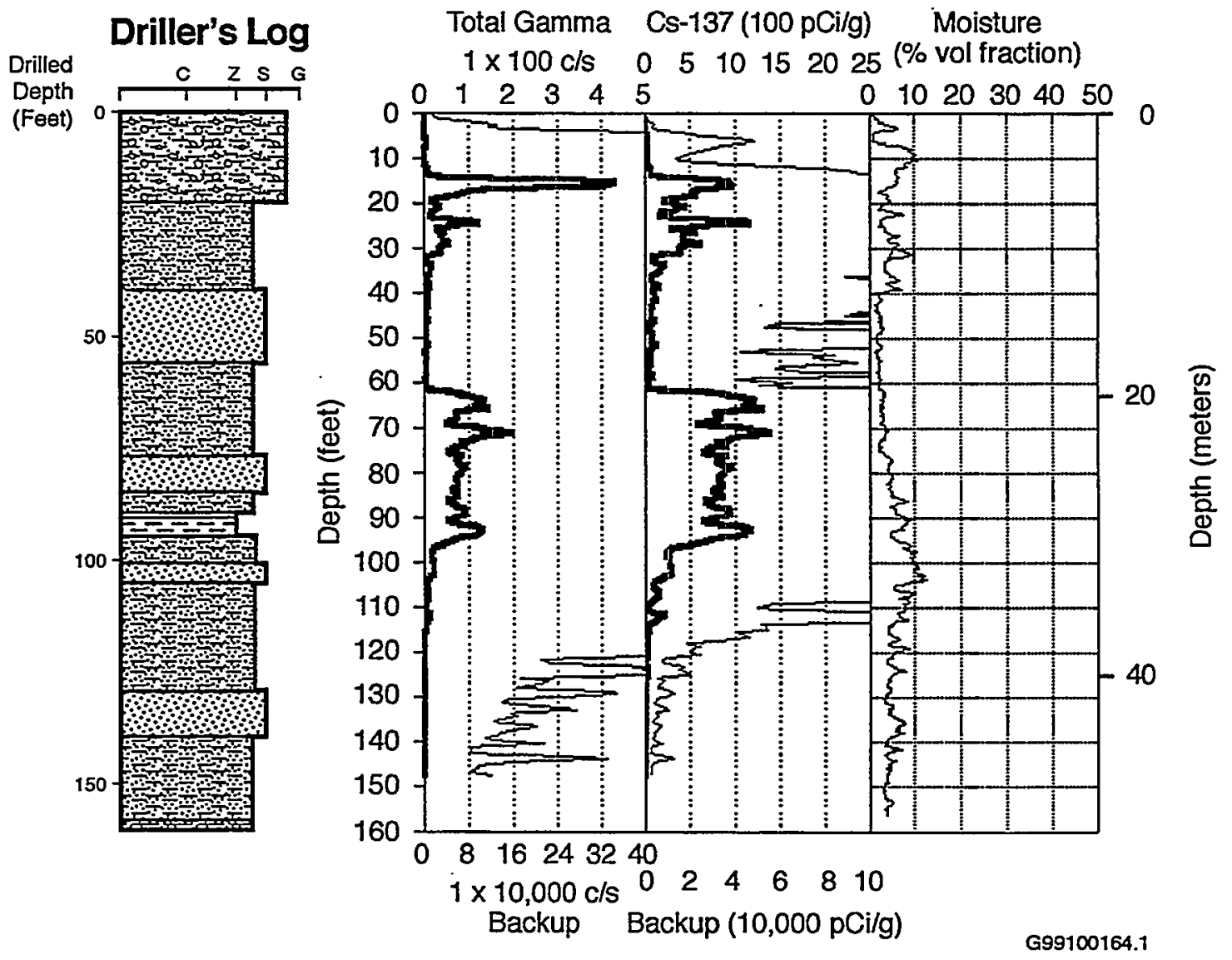

Figure 4.9. Spectral Gamma-Ray and Neutron Moisture Logs from Well 299-E13-21 at the 216-B-16 Crib. See Figure 4.1 for lithologic key to the driller's log.

${ }^{137} \mathrm{Cs}$ and ${ }^{60} \mathrm{Co}$ were identified from the spectral gamma-ray $\log$ of this well. ${ }^{137} \mathrm{Cs}$ was identified between depths of 11 and $63 \mathrm{ft}$ with a maximum activity of $965 \mathrm{pCi} / \mathrm{g}$ at $17 \mathrm{ft}$. ${ }^{60} \mathrm{Co}$ was found between about 19 and $77 \mathrm{ft}$. The maximum activity of ${ }^{60} \mathrm{Co}$ is $1 \mathrm{pCi} / \mathrm{g}$ at $71 \mathrm{ft}\left(\mathrm{MDL}\right.$ is $0.25 \mathrm{pCi} / \mathrm{g}$ in the low ${ }^{137} \mathrm{Cs}$ intervals).

This well was logged previously several times with a gross gamma-ray system. Figure 4.10 shows a comparison of the 1976 and the 1999 gross gamma logs. A logarithmic scale is used in the figures because of a wide range of activities. Comparison of the two logs is complex because of the multiple isotopes present and the high count rates. Between 25 and $70 \mathrm{ft}$ depth, where the older log is saturated, the $1999 \mathrm{log}$ shows much less activity than the $1976 \mathrm{log}$. The difference can be explained by decay of a radionuclide, such as ${ }^{125} \mathrm{Sb}$ or ${ }^{106} \mathrm{Ru}$, with a short half-life. The series of gross gamma logs from 1956 to 1976 in Fecht et al. (1977) shows substantial radionuclide decay during that period. Similar decay of short-lived contaminants can explain the differences between the 1976 and 1999 logs between 80 and $95 \mathrm{ft}$ where contamination existed in 1976 but was not detected in 1999. Note that the increase in intensity in the 1999 gross gamma log at $98 \mathrm{ft}$ is due to a change from two well casings between 0 and $98 \mathrm{ft}$ to one casing from $98 \mathrm{ft}$ to the bottom of the well. 
1999 Gross Gamma-Ray Response (c/s)

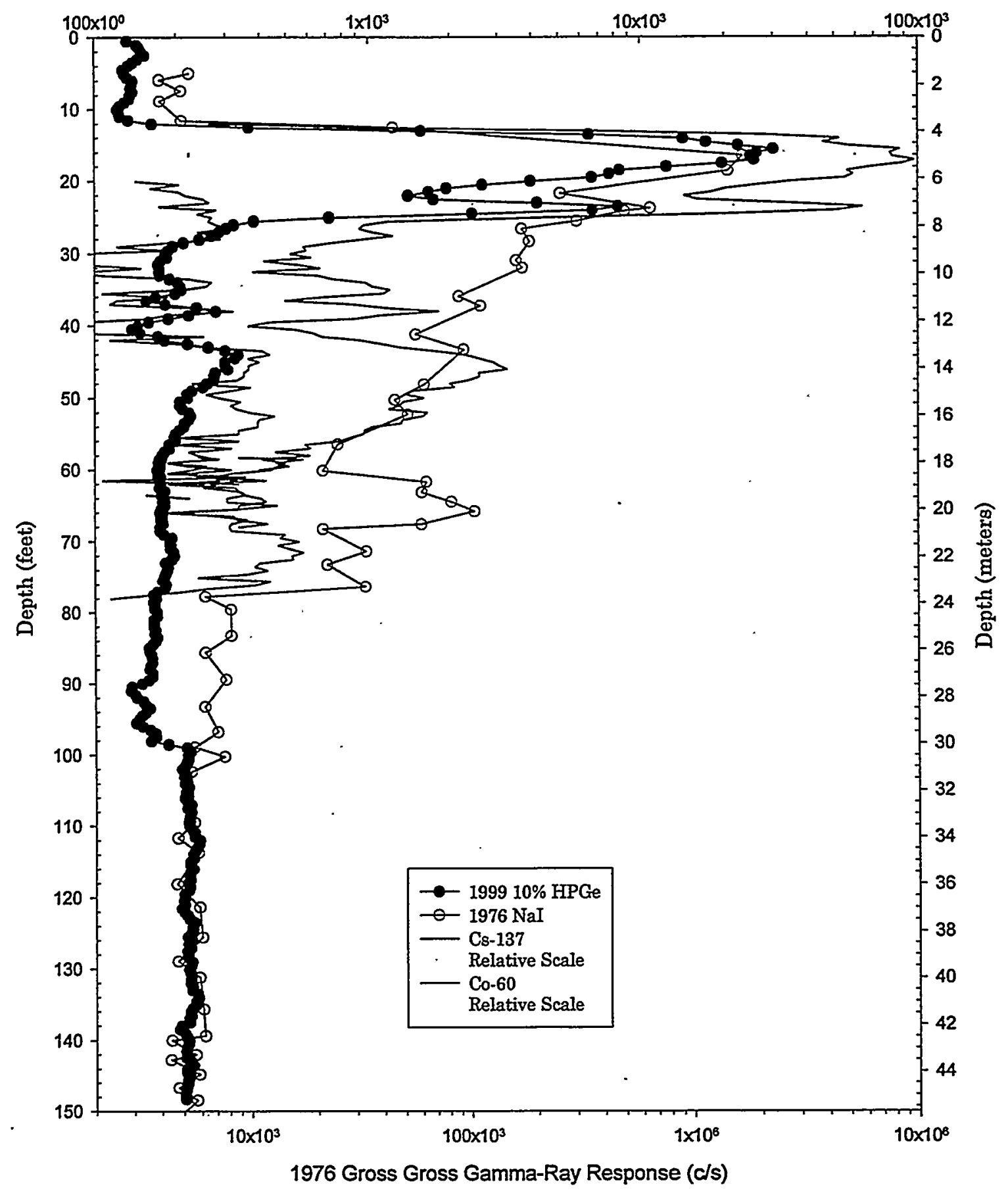

Figure 4.10. Comparison of the 1999 and 1976 Gross Gamma-Ray Logs for Well 299-E13-4 at the 216-B-17 Crib. The 1976 data is digitized from Fecht et al. (1977). 
The moisture log from well 299-E13-4 reflects the annular seal between the surface and $100 \mathrm{ft}$ depth. Below about $100 \mathrm{ft}$, the log shows moisture contents between about 3 and $5 \%$, values typical for the Hanford formation.

\subsubsection{6-B-18 Crib (Well 299-E13-5)}

Well 299-E13-5 is located at the southeast edge of the 216-B-18 crib. The well was drilled in 1955 to a depth of $367 \mathrm{ft}$. In 1985, a 6-in. casing and grout annular seal were added between depths of 0 and $95 \mathrm{ft}$ and a sand plug was placed from depths of 95 to $100 \mathrm{ft}$. The distribution pipe for the crib is about $6 \mathrm{ft}$ below grade.

${ }^{137} \mathrm{Cs},{ }^{60} \mathrm{Co}$, and ${ }^{125} \mathrm{Sb}$ were identified from the spectral gamma-ray log of this well (Figure 4.11). High count rates over the depth interval 14 to $20 \mathrm{ft}$ resulted in inaccurate dead-time corrections. Activities of radionuclides in that zone are under reported.

${ }^{137} \mathrm{Cs}$ was identified between depths of 11 and $100 \mathrm{ft}$. The maximum activity of ${ }^{137} \mathrm{Cs}$ is greater than $3000 \mathrm{pCi} / \mathrm{g}$ at some depth between 14 and $19 \mathrm{ft} .{ }^{60} \mathrm{Co}$ was found between 39 and $94 \mathrm{ft}$ and between 143 and $149 \mathrm{ft}$. The maximum activity of ${ }^{60} \mathrm{Co}$ is $3.5 \mathrm{pCi} / \mathrm{g}$ at $81 \mathrm{ft}$. ${ }^{125} \mathrm{Sb}$ was found between depths of 20 and $60 \mathrm{ft}$ with a maximum activity of $11 \mathrm{pCi} / \mathrm{g}$ at 25 and $31 \mathrm{ft}$. If there is any ${ }^{125} \mathrm{Sb}$ shallower than $20 \mathrm{ft}$, it is masked by the high ${ }^{137} \mathrm{Cs}$ activity.

This well was logged in 1992 using spectral gamma tools (Brodeur et al. 1993). The $1992 \mathrm{log}$ showed ${ }^{137} \mathrm{Cs}$ between depths of 17 and $99 \mathrm{ft},{ }^{60} \mathrm{Co}$ between 41 and $90 \mathrm{ft}$, and ${ }^{125} \mathrm{Sb}$ between 18 and $63 \mathrm{ft}$. Figure 4.12 shows a comparison of the ${ }^{137} \mathrm{Cs}$ activity from the 1992 and the 1999 logs at two different scales. The $1992 \log$ data have been depth shifted $0.8 \mathrm{ft}$. The $1992 \log$ was run from depths of 0 to $100 \mathrm{ft}$ and measurements were taken at selected depths deeper than $100 \mathrm{ft}$. Both logs exceeded the count-rate limit between 12 and $18 \mathrm{ft}$.

The activity of ${ }^{137} \mathrm{Cs}$ at $83 \mathrm{ft}$ has increased by $32 \%$ since 1992 but ${ }^{136} \mathrm{Cs}$ remains unchanged throughout the rest of the well. Interestingly, ${ }^{137} \mathrm{Cs}$ is detected in only the grouted intervals of the well and does not occur below $99 \mathrm{ft}$.

Figure 4.13 shows comparisons of ${ }^{60} \mathrm{Co}$ and ${ }^{125} \mathrm{Sb}$ activities from the 1992 and 1999 logs. There is excellent agreement for ${ }^{60} \mathrm{Co}$ between the 1992 (decay corrected) and the 1999 logs from 18 to $100 \mathrm{ft}$. Stationary samples of 300 seconds count times were acquired at 150,200,250,300, and $362 \mathrm{ft}$ depths in 1992. ${ }^{60} \mathrm{Co}$ was the only man-made isotope detected deeper than $150 \mathrm{ft}$. At the 200 and $250 \mathrm{ft}$ sampling points, ${ }^{60} \mathrm{Co}$ was detected $0.09 \mathrm{pCi} / \mathrm{g}$ which is the MDL for those samples.

${ }^{125} \mathrm{Sb}$ activity on the 1992 and 1999 logs agrees within statistical precision between 18 and $65 \mathrm{ft}$. A thin zone at $83 \mathrm{ft}$ shows an apparent $200 \%$ increase in ${ }^{125} \mathrm{Sb}$ activity that may be due to depth sampling differences. The zone has only one depth reading for both the 1992 and 1999 logs; thus, depth sampling differences can have a large effect. Also, the ${ }^{125} \mathrm{Sb} \mathrm{MDL}$ is high at this depth due to interference from ${ }^{137} \mathrm{Cs}$ on both the 1992 and the 1999 logs. Thus, the conclusion is that there is no significant change in the activity of ${ }^{125} \mathrm{Sb}$. 
(sıәןәu) yұdəa

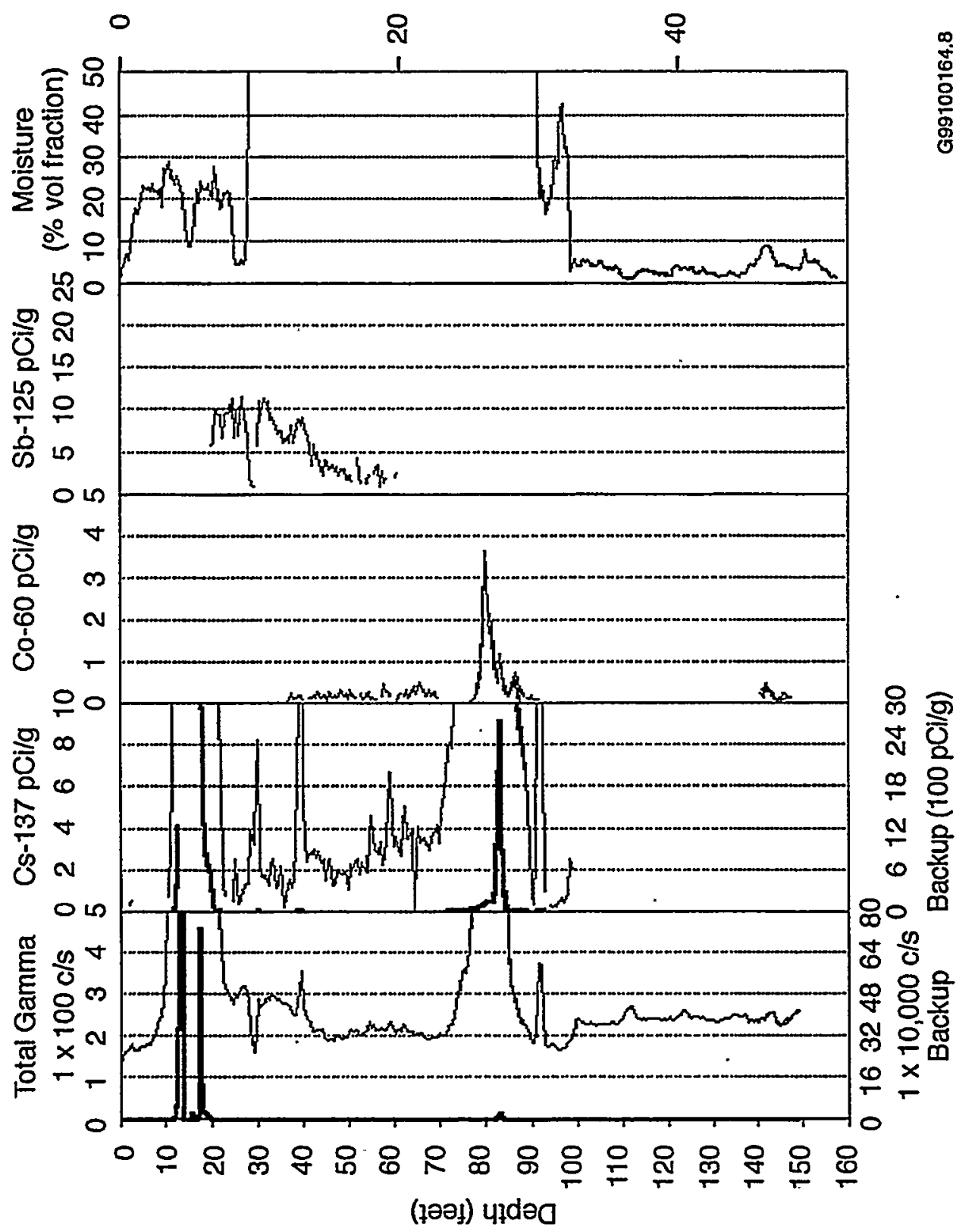

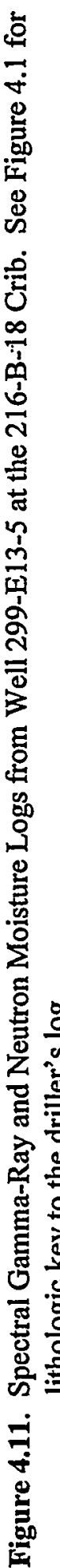
辝言高 

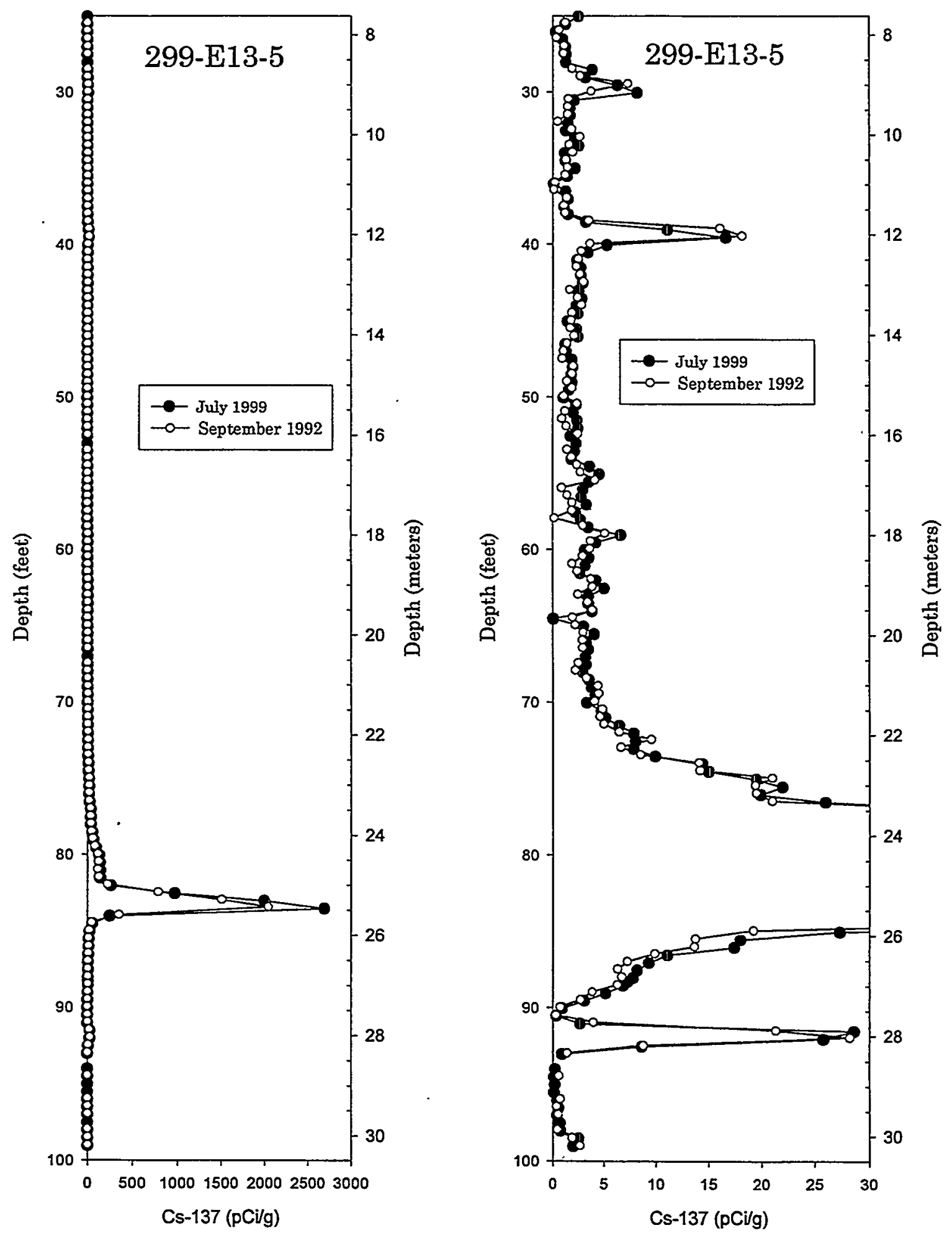

Figure 4.12. Comparison of the 1999 and 1992 Spectral Gamma Log Results for ${ }^{137} \mathrm{Cs}$ at Well 299-E13-5 at Two Different Scales 

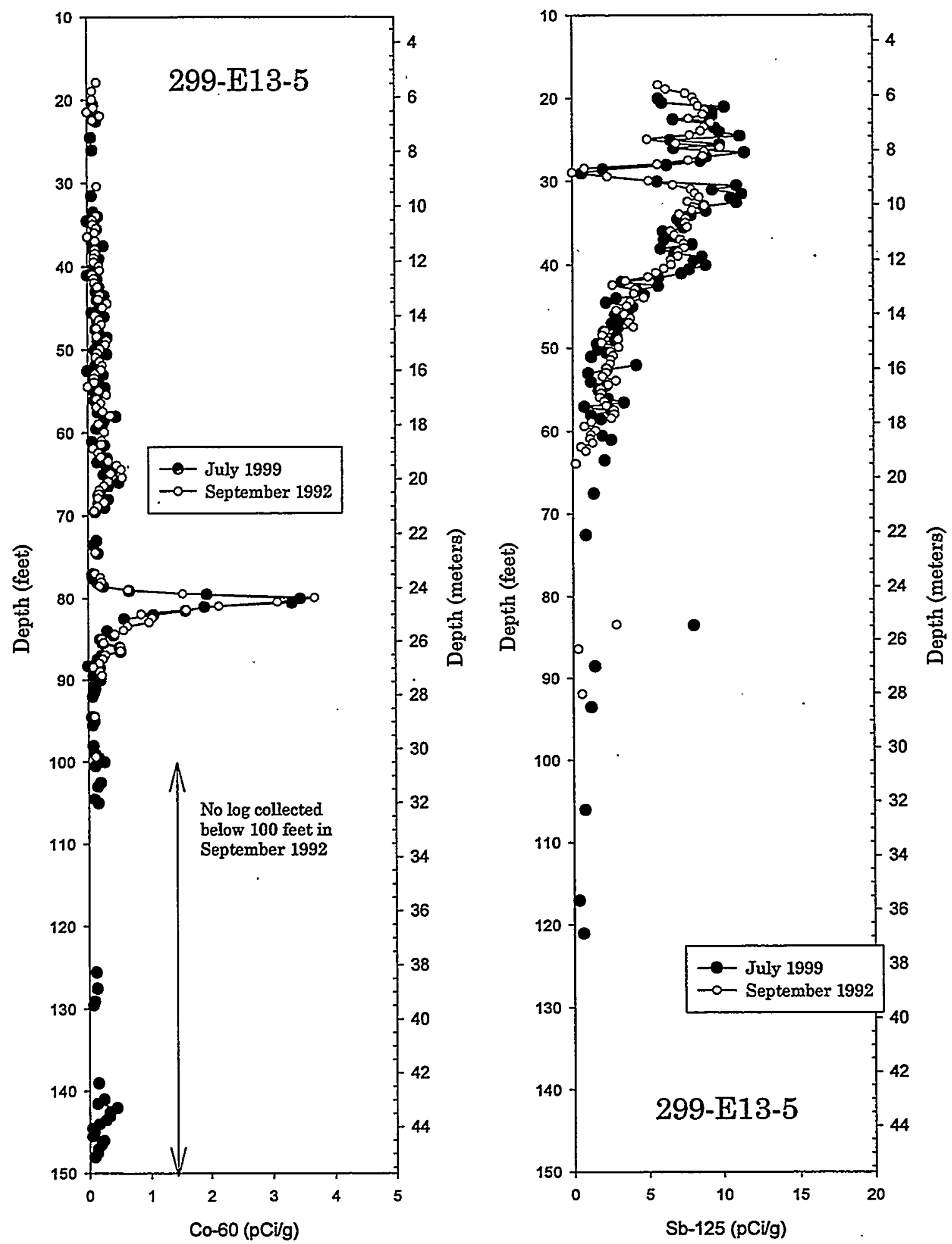

Figure 4.13. Comparison of the 1999 and 1993 Spectral Gamma Log Results for ${ }^{60} \mathrm{Co}$ and ${ }^{125} \mathrm{Sb}$ at Well 299-E13-5 
Well 299-E13-5 also was logged previously several times with a gross gamma-ray system, the latest being in 1976. The $1976 \mathrm{log}$ shows gamma contamination between depths of about 6 and $98 \mathrm{ft}$. The older gross gamma logs run in 1956,1958, 1959, 1963, 1968, and 1976 (Fecht et al. 1977) show very intense and rapid decay with time between about 60 and $122 \mathrm{ft}$ and a zone with less rapid decay between depths of 9 and $76 \mathrm{ft}$. This probably reflects rapid decay of deeper and more mobile, short-lived isotopes, such as ${ }^{106} \mathrm{Ru}$, and less rapid decay of shallower and less mobile ${ }^{137} \mathrm{Cs}$.

The moisture log from well 299-E13-5 reflects the annular seal between the surface and $100 \mathrm{ft}$. Below this depth the moisture content is between 2 and $9 \%$ and the log reflects the Hanford formation sediments.

\subsubsection{6-B-19 Crib (Well 299-E13-6)}

Well 299-E13-6 is located at the southeast edge of the 216-B-19 crib. The well was drilled in 1955 to a depth of $364 \mathrm{ft}$. In 1985, a 6-in. casing and grout annular seal were added between 0 and $95 \mathrm{ft}$ and a sand plug from depths of 95 to $100 \mathrm{ft}$. The distribution pipe for the crib is about $6 \mathrm{ft}$ below grade.

${ }^{137} \mathrm{Cs},{ }^{60} \mathrm{Co}$, and ${ }^{125} \mathrm{Sb}$ were identified from the spectral gamma-ray $\log$ of this well. High count rates over the depth interval 12 to $18 \mathrm{ft}$ resulted in inaccurate dead-time corrections. Activities of radionuclides in that zone are under reported.

${ }^{137} \mathrm{Cs}$ was identified between depths of 10 and $28 \mathrm{ft}$ and near the detection limit between 34 and $48 \mathrm{ft}$. The maximum activity of ${ }^{137} \mathrm{Cs}$ is greater than $1,000 \mathrm{pCi} / \mathrm{g}$ at some depth between 12 and $14 \mathrm{ft}$. ${ }^{60} \mathrm{Co}$ was found from 19 to $60 \mathrm{ft}$ and near detection levels between 60 and $175 \mathrm{ft}$. The maximum activity of ${ }^{60} \mathrm{Co}$ is $1.5 \mathrm{pCi} / \mathrm{g}$ at $47 \mathrm{ft}$ (MDL is $0.2 \mathrm{pCi} / \mathrm{g}$ ). ${ }^{125} \mathrm{Sb}$ was identified from 19 to $32 \mathrm{ft}$ depth with a maximum activity of $11 \mathrm{pCi} / \mathrm{g}$ at $23 \mathrm{ft}$. ${ }^{125} \mathrm{Sb}$ could possibly be present at shallower depths but is masked by ${ }^{137} \mathrm{Cs}$.

This well was logged previously several times with a gross gamma-ray system the latest of which is 1987. That $\log$ shows high activity between about 8 and $40 \mathrm{ft}$ dropping to near background at about $60 \mathrm{ft}$ which is in fairly good agreement with the 1999 gross gamma-ray log.

The moisture log from well 299-E13-6 reflects the annular seal between the surface and $100 \mathrm{ft}$ depth. Below about $100 \mathrm{ft}$, the moisture log probably reflects Hanford formation lithology. However, the driller's log is not detailed enough to make comparisons between the moisture log and lithology except for a gravel and clay unit at about $310 \mathrm{ft}$ depth which shows an increase in moisture content to near $18 \%$ and a corresponding increase in gross gamma intensity.

\subsection{BC Controlled Area Specific Retention Trenches}

\subsubsection{6-B-23 Specific Retention Trench (Borehole 299-E13-55)}

Borehole 299-E13-55 is located at the north of and at the center of the 216-B-23 specific retention trench. The borehole was drilled in 1982 to a depth of $50 \mathrm{ft}$. The borehole has an 8-in. casing throughout and a grouted annular seal from depths of 0 to $20 \mathrm{ft}$. The base of the trench is at a depth of $10 \mathrm{ft}$. 
${ }^{137} \mathrm{Cs},{ }^{60} \mathrm{Co}$, and ${ }^{125} \mathrm{Sb}$ were identified from the spectral gamma-ray $\log .{ }^{137} \mathrm{Cs}$ was found between a depth of 1 and $5 \mathrm{ft}$ with a maximum activity of $1.6 \mathrm{pCi} / \mathrm{g}$ at $4 \mathrm{ft}(\mathrm{MDL}$ is $0.3 \mathrm{pCi} / \mathrm{g}) ;{ }^{60} \mathrm{Co}$ was found between 15 and $41 \mathrm{ft}$ with a maximum activity of $1.2 \mathrm{pCi} / \mathrm{g}$ at $36 \mathrm{ft}$ (MDL is $0.2 \mathrm{pCi} / \mathrm{g}$ ); and ${ }^{125} \mathrm{Sb}$ was found between 19 and $24 \mathrm{ft}$ at the level of detection.

This borehole was logged previously in 1987 with a gross gamma-ray system. The 1987 log showed a maximum of gamma activity at about 20 to $21 \mathrm{ft}$ and a smaller peak at about $37 \mathrm{ft}$. These maxima probably correspond to the ${ }^{125} \mathrm{Sb}$ and ${ }^{60} \mathrm{Co}$ maxima on the $1999 \mathrm{log}$.

The moisture log from borehole 299-E13-55 reflects the annular seal and little can be inferred about the moisture content of the sediments.

\subsubsection{6-B-25 Specific Retention Trench (Borehole 299-E13-56)}

Borehole 299-E13-56 is located at the center of the north end of the 216-B-25 specific retention trench. The borehole was drilled in 1982 to a depth of $50 \mathrm{ft}$. The borehole has an 8-in. casing throughout and a grouted annular seal from depths of 0 to $15 \mathrm{ft}$. The base of the trench is at a depth of $10 \mathrm{ft}$.

${ }^{137} \mathrm{Cs}$ and ${ }^{125} \mathrm{Sb}$ were identified from the spectral gamma-ray log of this borehole (Figure 4.14$) .{ }^{137} \mathrm{Cs}$ is identified between 3 and $45 \mathrm{ft}$ depth with a maximum activity of $150 \mathrm{pCi} / \mathrm{g}$ at $16 \mathrm{ft} .{ }^{137} \mathrm{Cs}$ activity also increases and peaks near the bottom of the borehole. ${ }^{125} \mathrm{Sb}$ is found between 16 and $32 \mathrm{ft}$ with a maximum activity of $9 \mathrm{pCi} / \mathrm{g}$ at $22 \mathrm{ft}$.

This borehole was logged previously in 1987 with a gross gamma-ray system. The 1987 log showed a maximum of gamma activity at about $14 \mathrm{ft}$ corresponding to the ${ }^{137} \mathrm{Cs}$ interval on the $1999 \mathrm{log}$. Also, the $1987 \mathrm{log}$ showed a smaller maximum on the shoulder of the ${ }^{137} \mathrm{Cs}$ peak which may correspond to the ${ }^{125} \mathrm{Sb}$ maximum on the $1999 \log$.

Borehole documentation states that 81 gal $(306 \mathrm{~L})$ of grout were used as a seal around the upper $20 \mathrm{ft}$ of borehole 299-E13-56. The relatively low moisture readings (about 20\%) indicate that the grout seal is very thin (about 0.75 in. thick) (see Figure 4.14). The readings also indicate that the seal most likely reaches a depth of 34 or $40 \mathrm{ft}$. If a seal exists only from 0 to depths of $20 \mathrm{ft}$, then the vadose zone from 20 to $40 \mathrm{ft}$ is very moist with a very dry zone beginning at $42 \mathrm{ft}$. The possible dry zone (or the base of the annular seal) coincides with the deeper ${ }^{137} \mathrm{Cs}$ contamination at $41 \mathrm{ft}$.

\subsubsection{6-B-26 Specific Retention Trench (Well 299-E13-12)}

Well 299-E13-12 is located about $80 \mathrm{ft}$ from the west end of the 216-B-26 specific retention trench. The well was drilled in 1956 to a depth of $366 \mathrm{ft}$. In 1989, a 6-in. casing and a grout annular seal were added between 0 and $98 \mathrm{ft}$. The base of the trench is at a depth of $12 \mathrm{ft}$.

No man-made radionuclides were identified from the 1999 spectral gamma-ray log. This well was logged previously in 1959 and 1976 with gross gamma-ray tools. Both logs show near background levels 


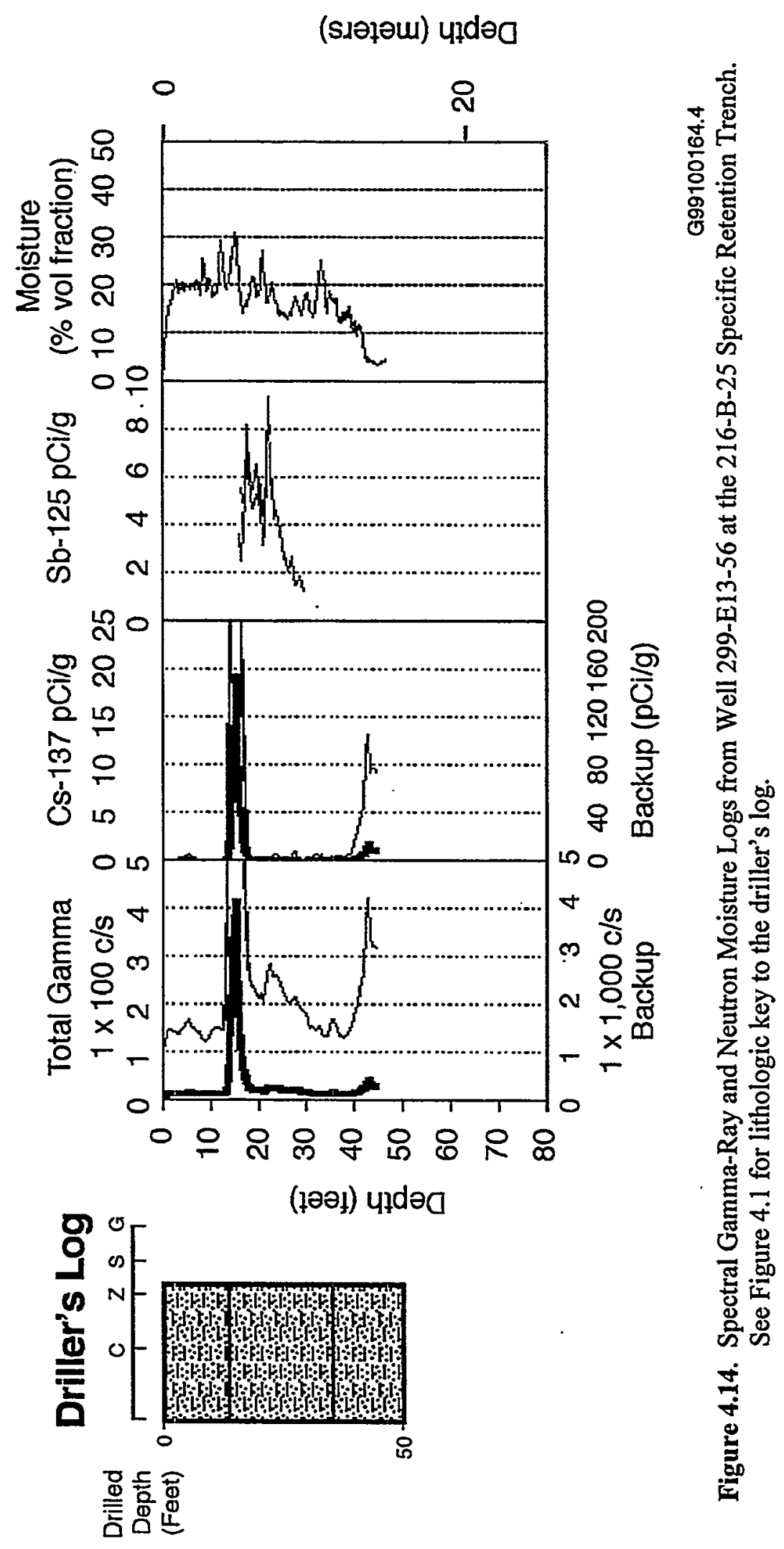


of radioactivity. The neutron moisture log was run from about $250 \mathrm{ft}$ to the water table at about $335 \mathrm{ft}$. The moisture log reflects Hanford formation lithology with moisture content between about 1 and $7 \%$ by volume.

\subsubsection{6-B-27 Specific Retention Trench (Borehole 299-E13-57)}

Borehole 299-E13-57 is located at the north of and at the center of the 216-B-27 specific retention trench. The borehole was drilled in 1982 to a depth of $50 \mathrm{ft}$. The borehole has an 8-in. casing throughout and a grouted annular seal from 0 to depths of $20 \mathrm{ft}$. The base of the trench is at a depth of $10 \mathrm{ft}$.

${ }^{137} \mathrm{Cs},{ }^{60} \mathrm{Co}$, and ${ }^{125} \mathrm{Sb}$ were identified from the spectral gamma-ray log of this borehole. From 5 to $7 \mathrm{ft}$, high count rates exceeded the accuracy limit for the dead-time correction so that activities are under reported in that depth interval.

${ }^{137} \mathrm{Cs}$ is present throughout the entire depth of the borehole. The maximum ${ }^{137} \mathrm{Cs}$ activity is greater than $4,800 \mathrm{pCi} / \mathrm{g}$ at $6 \mathrm{ft}$. Deeper in the borehole, there may be some correlation between ${ }^{137} \mathrm{Cs}$ and lithology. The driller's log states that silt lenses were encountered at depths of about 36 and $39 \mathrm{ft}$, and these depths correspond to increases in the activity of ${ }^{137} \mathrm{Cs}$.

${ }^{125} \mathrm{Sb}$ is found between 12 and $20 \mathrm{ft}$ with a maximum activity of $3.4 \mathrm{pCi} / \mathrm{g}$ at $16 \mathrm{ft} .{ }^{60} \mathrm{Co}$ is present at depths from 28 to $40 \mathrm{ft}$ with activities at the detection limit (MDL is $0.2 \mathrm{pCi} / \mathrm{g}$ ). The occurrence of ${ }^{60} \mathrm{Co}$ was verified with the summing technique.described in Appendix A.

This borehole was logged previously in 1987 with a gross gamma-ray system. The 1987 log shows gamma activity between about 4 and $26 \mathrm{ft}$ with a maximum near $6 \mathrm{ft}$. This corresponds to the ${ }^{137} \mathrm{Cs}$ maximum on the $1999 \mathrm{log}$. The $1987 \mathrm{log}$ also shows a second zone of lesser activity from $31 \mathrm{ft}$ to the maximum depth logged $(46 \mathrm{ft})$.

Borehole documentation indicates there is grout annular seal around the upper $20 \mathrm{ft}$ of borehole 299-E13-57. The relatively low moisture readings (about 20\%) could only be from a thin grout seal. If the readings are the result of a thin annular seal, then the seal may extend to about $30 \mathrm{ft}$. If the seal extends to only $20 \mathrm{ft}$ then the $10 \mathrm{ft}$ interval below the seal is very moist sediment.

\subsubsection{6-B-30 Specific Retention Trench (Borehole 299-E13-52)}

Borehole 299-E13-52 is immediately adjacent to the south-center of the 216-B-30 specific retention trench. The borehole was drilled in 1965 to a depth of $94 \mathrm{ft}$. Contamination levels up to 70,000 counts per minute were encountered during drilling. The base of the trench is at a depth of $10 \mathrm{ft}$.

${ }^{137} \mathrm{Cs},{ }^{60} \mathrm{Co}$, and ${ }^{154} \mathrm{Eu}$ were identified from the spectral gamma-ray log of this borehole (Figure 4.15). The detector count rate exceeded the dead-time accuracy at depths from 11 to $17 \mathrm{ft}$, so actual activities are greater than reported in that interval. 

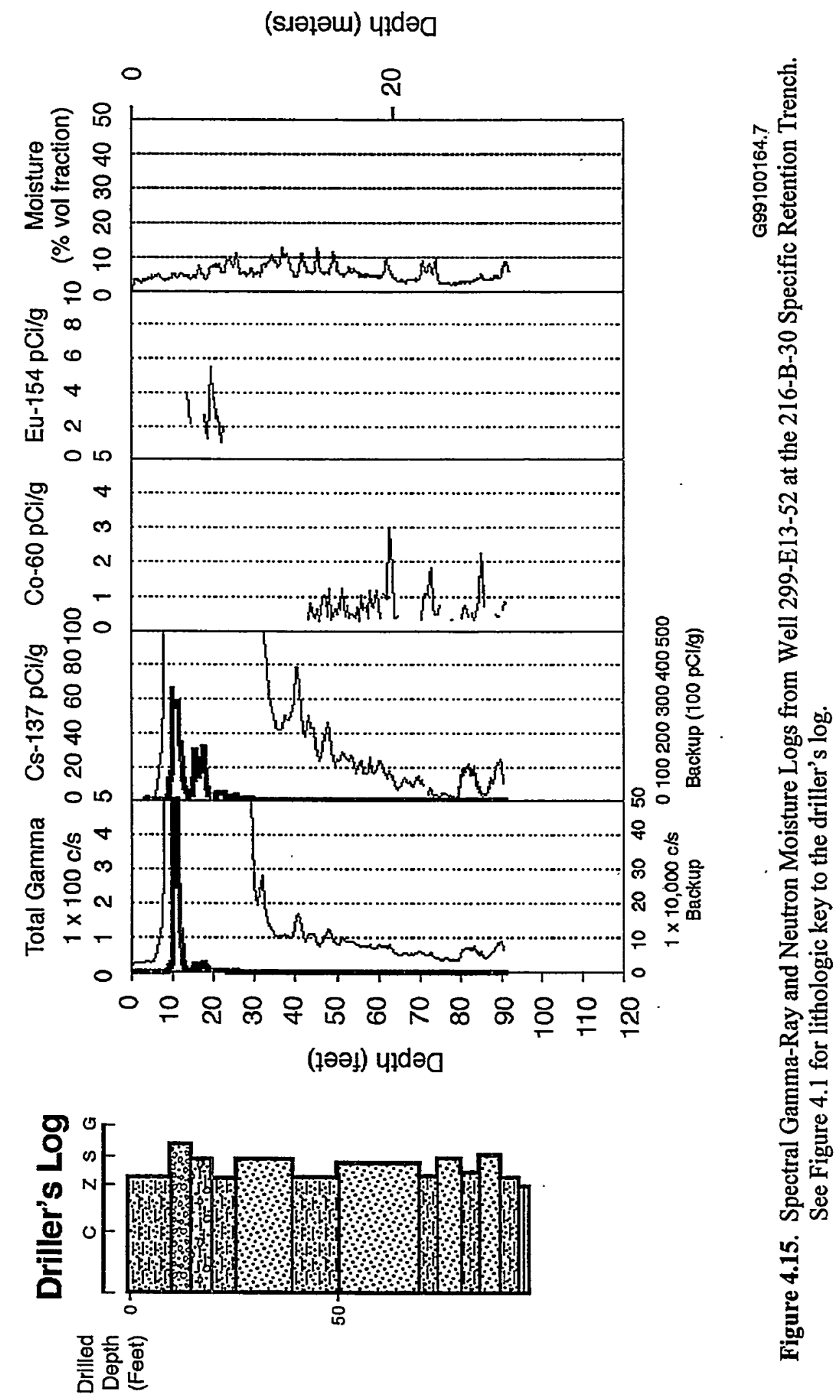
${ }^{137} \mathrm{Cs}$ occurs between depths of 5 and $91 \mathrm{ft}$ and may exist below the bottom of the borehole. The maximum ${ }^{137} \mathrm{Cs}$ activity is greater than $30,000 \mathrm{pCi} / \mathrm{g}$ at $11.2 \mathrm{ft} .{ }^{60} \mathrm{Co}$ is found between 44 and $91 \mathrm{ft}$ with a maximum of $3 \mathrm{pCi} / \mathrm{g}$ at $62 \mathrm{ft}$. ${ }^{154} \mathrm{Eu}$ exists between 14 and $22 \mathrm{ft}$ with a maximum activity of $5.5 \mathrm{pCi} / \mathrm{g}$ at $20 \mathrm{ft}$.

The moisture log from borehole 299-E13-52 shows several relatively high moisture zones throughout the borehole. Some correlation between moisture content and contaminant distribution is evident, especially below depths of about $40 \mathrm{ft}$. Unfortunately, the driller's log is not sufficiently detailed to allow much correlation between moisture content or contaminant distribution with lithology.

\subsubsection{6-B-31 Specific Retention Trench (Borehole 299-E13-58)}

Borehole 299-E13-58 is immediately adjacent to the north-center of the 216-B-31 specific retention trench. The borehole was drilled in 1982 to a depth of $50 \mathrm{ft}$. The borehole has a grouted annular seal from 0 to depths of $20 \mathrm{ft}$. The base of the trench is at a depth of $10 \mathrm{ft}$.

${ }^{137} \mathrm{Cs}$ and ${ }^{60} \mathrm{Co}$ were identified from the spectral gamma-ray log of this borehole. ${ }^{137} \mathrm{Cs}$ was identified between depths of 2 and $10 \mathrm{ft}$ and between 40 and $45 \mathrm{ft}$. The maximum ${ }^{137} \mathrm{Cs}$ activity is $2.6 \mathrm{pCi} / \mathrm{g}$ at $4 \mathrm{ft}$. ${ }^{60} \mathrm{Co}$ was identified between depths of 30 and $45 \mathrm{ft}$ with a maximum activity of $0.5 \mathrm{pCi} / \mathrm{g}$ at $37 \mathrm{ft}$ (MDL is $0.15 \mathrm{pCi} / \mathrm{g})$.

This borehole was logged previously in 1987 with a gross gamma-ray system. That log shows that maximum activity was at a depth of about $37 \mathrm{ft}$, which corresponds with the depth of maximum ${ }^{60} \mathrm{Co}$ on the 1999 log. DOE (1993b) shows an isopach map of gamma radiation at the BC Controlled Area trenches. That map shows a 90-ft-thick zone of gamma activity beneath the 216-B-31 trench. The 1999 and the 1987 logs (as well as pre-1977 logs in Fecht et al. [1977]) do not corroborate the map.

The moisture log from borehole 299-E13-58 reflects the annular seal around this borehole from 0 to depths of $20 \mathrm{ft}$. However, the readings are relatively low suggesting that the seal is probably very thin. Below $20 \mathrm{ft}$, the moisture log reflects Hanford formation lithology with values between about 4 and $9.5 \mathrm{wt} . \%$ by volume.

\subsubsection{6-B-32 Specific Retention Trench (Borehole 299-E13-59)}

Borehole 299-E13-59 is immediately adjacent to the center of the north side of the 216-B-32 specific retention trench. The borehole was drilled in 1982 to a depth of $50 \mathrm{ft}$. The borehole has a grouted annular seal from 0 to depths of $15 \mathrm{ft}$. The base of the trench is at a depth of $10 \mathrm{ft}$.

${ }^{137} \mathrm{Cs},{ }^{60} \mathrm{Co}$, and ${ }^{125} \mathrm{Sb}$ were identified from the spectral gamma-ray log of this borehole. ${ }^{137} \mathrm{Cs}$ occurs at a depth of 4 to $9 \mathrm{ft}$ depth with a maximum activity of $3.2 \mathrm{pCi} / \mathrm{g}$ at $5 \mathrm{ft}$. ${ }^{60} \mathrm{Co}$ occurs from 26 to $42 \mathrm{ft}$ with a maximum of $0.4 \mathrm{pCi} / \mathrm{g}$ at $41 \mathrm{ft}$. ${ }^{125} \mathrm{Sb}$ exists from depths of 19 to $22 \mathrm{ft}$ with activities near detection limit (MDL is $0.7 \mathrm{pCi} / \mathrm{g}$ ). The existence of ${ }^{125} \mathrm{Sb}$ was confirmed using the summing technique described in Appendix A. 
This borehole was logged previously in 1987 with a gross gamma-ray system. That log shows a thin zone of contamination at a depth of $21 \mathrm{ft}$. That zone may represent ${ }^{125} \mathrm{Sb}$, which has decayed since 1987 to today's levels. As with the data from boreholes at 216-B-31 trench, data from borehole 299-E13-59 does not corroborate the gamma radiation isopach map in DOE (1993b).

The moisture log from borehole 299-E13-59 reflects a thin annular seal from 0 to about a depth of $17 \mathrm{ft}$. Below that depth, both the moisture log and the gross gamma log reflect the sediments in the Hanford formation.

\subsubsection{6-B-33 Specific Retention Trench (Borehole 299-E13-60)}

Borehole 299-E13-60 is immediately adjacent to the center of the south side of the 216-B-33 specific retention trench. The borehole was drilled in 1982 to a depth of $50 \mathrm{ft}$. The borehole has a grouted annular seal from 0 to a depth of $20 \mathrm{ft}$. The base of the trench is at a depth of $10 \mathrm{ft}$.

${ }^{137} \mathrm{Cs},{ }^{60} \mathrm{Co}$, and ${ }^{125} \mathrm{Sb}$ were identified from the spectral gamma-ray $\log$ of this borehole. ${ }^{137} \mathrm{Cs}$ occurs from 3 to $5 \mathrm{ft}$ and from 18 to $32 \mathrm{ft}$. The maximum ${ }^{137} \mathrm{Cs}$ activity is $3 \mathrm{pCi} / \mathrm{g}$ at $4 \mathrm{ft}$. ${ }^{60} \mathrm{Co}$ occurs from depths of 18 to $20 \mathrm{ft}$ with a maximum of $2.5 \mathrm{pCi} / \mathrm{g}$ at $19 \mathrm{ft}$. ${ }^{125} \mathrm{Sb}$ exists from depths of 18 to $45 \mathrm{ft}$ with activities near detection limit (MDL is $0.2 \mathrm{pCi} / \mathrm{g}$ ). The existence of ${ }^{125} \mathrm{Sb}$ was confirmed using the summing technique described in Appendix A.

This borehole was logged previously in 1987 with a gross gamma-ray system. That log shows a thin zone of contamination at $20 \mathrm{ft}$. That zone corresponds to the depth of the ${ }^{60} \mathrm{Co}$ zone identified on the $1999 \log$.

Borehole documentation states that a grout annular seal is around the upper $20 \mathrm{ft}$ of borehole 299-E13-60. The readings from the moisture log are low for a grout seal suggesting that it must be relatively thin (less than about $1 \mathrm{in}$.). Also the seal may thin and reach depths below $20 \mathrm{ft}$. Finally, the log shows that the annular seal has a variable thickness and is essentially not present at about $10 \mathrm{ft}$.

\subsubsection{6-B-52 Specific Retention Trench (Borehole 299-E13-54)}

Borehole 299-E13-54 is located north of the midpoint of the 216-B-52 specific retention trench. The borehole was drilled in 1982 to a depth of $50 \mathrm{ft}$. The borehole has a grouted annular seal from 0 to depths of $20 \mathrm{ft}$. The base of the trench is at a depth of $8 \mathrm{ft}$.

${ }^{137} \mathrm{Cs},{ }^{60} \mathrm{Co}$, and ${ }^{125} \mathrm{Sb}$ were identified from the spectral gamma-ray log of this borehole. The accuracy of the dead-time correction was exceeded between 21 and $22.5 \mathrm{ft}$ due to high count rates. Activities in this zone are greater than reported.

${ }^{137} \mathrm{Cs}$ occurs throughout the borehole except from 13 to $19 \mathrm{ft}$. The maximum activity of ${ }^{137} \mathrm{Cs}$ is greater than $2,000 \mathrm{pCi} / \mathrm{g}$ at $21 \mathrm{ft} .{ }^{137} \mathrm{Cs}$ activity is increases from about $30 \mathrm{ft}$ to the bottom of the borehole (48ft). ${ }^{60} \mathrm{Co}$ occurs from depths of 35 to $43 \mathrm{ft}$ and ${ }^{125} \mathrm{Sb}$ occurs at $25 \mathrm{ft}$. Both ${ }^{60} \mathrm{Co}$ and ${ }^{125} \mathrm{Sb}$ exist at 
detection limit levels and their presence was confirmed with the summing technique described in Appendix A. The minimum detection limits for ${ }^{60} \mathrm{Co}$ and ${ }^{125} \mathrm{Sb}$ in this borehole are 0.25 and $1.5 \mathrm{pCi} / \mathrm{g}$ in the low ${ }^{137}$ Cs zones, respectively.

This borehole was logged previously in 1987 with a gross gamma-ray system. That log shows a maximum in gamma radiation at a depth of $21 \mathrm{ft}$ which corresponds to the depth of ${ }^{137} \mathrm{Cs}$ maximum in the $1999 \log$.

The moisture log from borehole 299-E13-54 reflects a thin annular seal from 0 to about a depth of $20 \mathrm{ft}$ below which the moisture reading vary from about 3 to $10 \%$, values typical for the Hanford formation.

\subsubsection{6-B-53A Specific Retention Trench (Borehole 299-E13-61)}

Borehole 299-E13-61 is located north of and near the west end of the 216-B-52 specific retention trench. The borehole was drilled in 1982 to a depth of $50 \mathrm{ft}$. The borehole has a grouted annular seal from 0 to $20 \mathrm{ft}$. The base of the trench is at a depth of $10 \mathrm{ft}$.

${ }^{137} \mathrm{Cs}$ and ${ }^{60} \mathrm{Co}$ were identified from the spectral gamma-ray $\log$ of this borehole. ${ }^{137} \mathrm{Cs}$ occurs between depths of 3 and $4 \mathrm{ft}$ and between 17 and $30 \mathrm{ft}$. The maximum activity of ${ }^{137} \mathrm{Cs}$ is $1.5 \mathrm{pCi} / \mathrm{g}$ at $18 \mathrm{ft} .{ }^{60} \mathrm{Co}$ occurs from depths of 17 to $22 \mathrm{ft}$ and from 25 to $33 \mathrm{ft}$. The maximum activity of ${ }^{60} \mathrm{Co}$ is $0.5 \mathrm{pCi} / \mathrm{g}$ at $21 \mathrm{ft}(\mathrm{MDL}$ is $0.15 \mathrm{pCi} / \mathrm{g})$.

Borehole 299-E13-61 was logged previously in 1987 with a gross gamma-ray system. That log shows a zone of gamma activity between about 14 and $22 \mathrm{ft}$ with a maximum at $18 \mathrm{ft}$.

The moisture log from borehole 299-E13-61 reflects a thin, annular seal from 0 to depths of about $16 \mathrm{ft}$ and reflects the sediments of the Hanford formation with values from about 3 to $10 \%$ below the seal.

\subsection{BX Specific Retention Trenches}

\subsubsection{6-B-35 Specific Retention Trench (Borehole 299-E33-286)}

Borehole 299-E33-286 is located about $20 \mathrm{ft}$ south of the 216-B-35 specific retention trench. The borehole was drilled in 1982 to a depth of $50 \mathrm{ft}$. Contamination up to 60,000 counts per minute was encountered between 17 and $26 \mathrm{ft}$ during drilling. The borehole has a grouted annular seal from 0 to depths of $20 \mathrm{ft}$. The base of the trench is at a depth of $10 \mathrm{ft}$.

${ }^{137} \mathrm{Cs}$ was the only man-made radionuclide identified from the spectral gamma-ray log of this borehole. ${ }^{137} \mathrm{Cs}$ occurs between the depths of 20 and $50 \mathrm{ft}$. The maximum activity of ${ }^{137} \mathrm{Cs}$ is greater than $47,000 \mathrm{pCi} / \mathrm{g}$ at $36 \mathrm{ft}$. The count rate limits were exceeded from 35 to $37.5 \mathrm{ft}$ so that the actual activity of

${ }^{137} \mathrm{Cs}$ is greater than reported.

Borehole 299-E33-286 was logged previously in 1984 and 1987 with a gross gamma-ray system. The latest log shows a zone of gamma contamination from about $20 \mathrm{ft}$ to total depth of the borehole $(50 \mathrm{ft})$. 
. The moisture log from borehole 299-E33-286 reflects the annular seal from 0 to depths of about $20 \mathrm{ft}$. The high moisture value just below the seal at 20 to $22 \mathrm{ft}$ may be an artifact of the well construction such as thicker grout in that area or may reflect a zone with higher moisture in the sediment. Unfortunately, the lithology between 10 and $24 \mathrm{ft}$ was not described by the driller. Moisture values below about $22 \mathrm{ft}$ are typical of Hanford formation sediments.

\subsubsection{6-B-37 Specific Retention Trench (Boreholes 299-E33-287 and 299-E33-288)}

Borehole 299-E33-287 is located about $30 \mathrm{ft}$ south of the middle of the 216-B-37 specific retention trench. The borehole was drilled in 1982 to a depth of $50 \mathrm{ft}$. Contamination up to 80,000 counts per minute was encountered between 22 and $38 \mathrm{ft}$ during drilling. The driller's log states that the borehole has a grouted annular seal from 0 to depths of $20 \mathrm{ft}$. The base of the trench is at a depth of $10 \mathrm{ft}$.

${ }^{137} \mathrm{Cs}$ was the only man-made radionuclide identified from the spectral gamma-ray log of this borehole (Figure 4.16). ${ }^{137} \mathrm{Cs}$ occurs between 2 and $5 \mathrm{ft}$ and between 22 and $49 \mathrm{ft}$. The maximum activity of ${ }^{137} \mathrm{Cs}$ is greater than $55,000 \mathrm{pCi} / \mathrm{g}$ at $35 \mathrm{ft}$. The count rate limits were exceeded from 26 to $37.5 \mathrm{ft}$ so that the actual activity of ${ }^{137} \mathrm{Cs}$ is greater than reported. The driller's log for this borehole notes a change in lithology from sandy gravel to underlying fine-grained sand at about $37 \mathrm{ft}$, which corresponds to the bottom of the high ${ }^{137} \mathrm{Cs}$ zone (see Figure 4.16). This depth also corresponds to a slight decrease in the moisture readings on the neutron log.

Borehole 299-E33-287 was logged previously in 1984 and 1987 with a gross gamma-ray system. The latest log shows a narrow zone of gamma contamination at depths of about 4 to $8 \mathrm{ft}$ and a deeper, higher activity zone between $26 \mathrm{ft}$ and the bottom of the borehole at $50 \mathrm{ft}$.

Borehole documentation states that a grout annular seal is around the upper $20 \mathrm{ft}$ of borehole 299-E33-287. However, the neutron log shows that a seal is essentially absent to a depth of about $15 \mathrm{ft}$ and the moisture content between about 5 and $15 \mathrm{ft}$ is typical of Hanford formation sediments. The relatively high moisture zone between 2 and $5 \mathrm{ft}$ corresponds to high ${ }^{137} \mathrm{Cs}$ activity at that depth which is about $5 \mathrm{ft}$ above the base of the trench.

Borehole 299-E33-288 is located about $20 \mathrm{ft}$ north of the middle of the 216-B-37 specific retention trench. The borehole was drilled in 1982 to a depth of $50 \mathrm{ft}$. Contamination up to 20,000 counts per minute was encountered at $35 \mathrm{ft}$ during drilling. The driller's log states that the borehole has a grouted annular seal from 0 to $20 \mathrm{ft}$.

${ }^{137} \mathrm{Cs}$ was the only man-made radionuclide identified from the spectral gamma-ray log of this borehole (see Figure 4.16). ${ }^{137} \mathrm{Cs}$ occurs between the depths of 2 to $8 \mathrm{ft}$ and 16 to $49 \mathrm{ft}$. The maximum activity of ${ }^{137} \mathrm{Cs}$ is greater than $8,500 \mathrm{pCi} / \mathrm{g}$ at $31 \mathrm{ft}$. The count rate limits were exceeded from 18 to $36 \mathrm{ft}$ so that the actual activity of ${ }^{137} \mathrm{Cs}$ is greater than reported. As in borehole $299-\mathrm{E} 33-288$, most of the ${ }^{137} \mathrm{Cs}$ appears to be in the overlying sandy gravel unit and the activity of ${ }^{137} \mathrm{Cs}$ drops off drastically at the contact with the underlying fine-grained sand. 
299-33-287

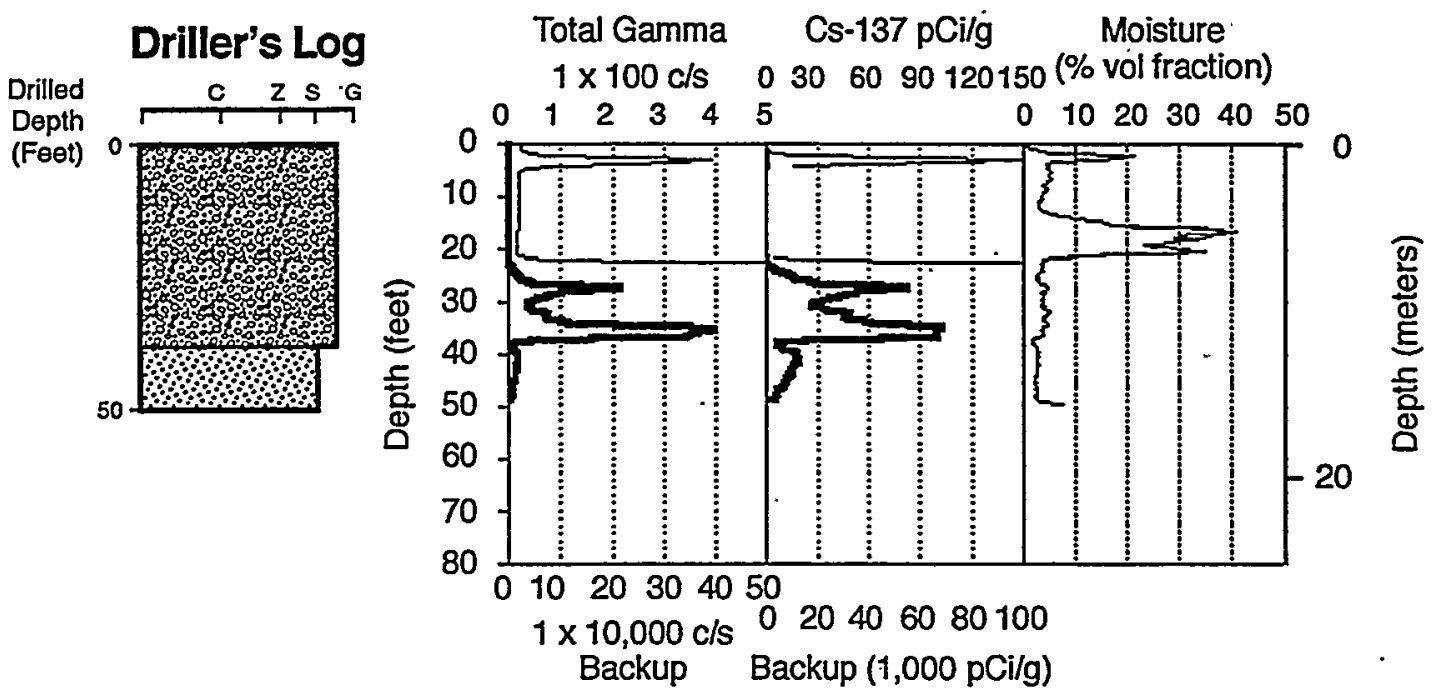

299-33-288

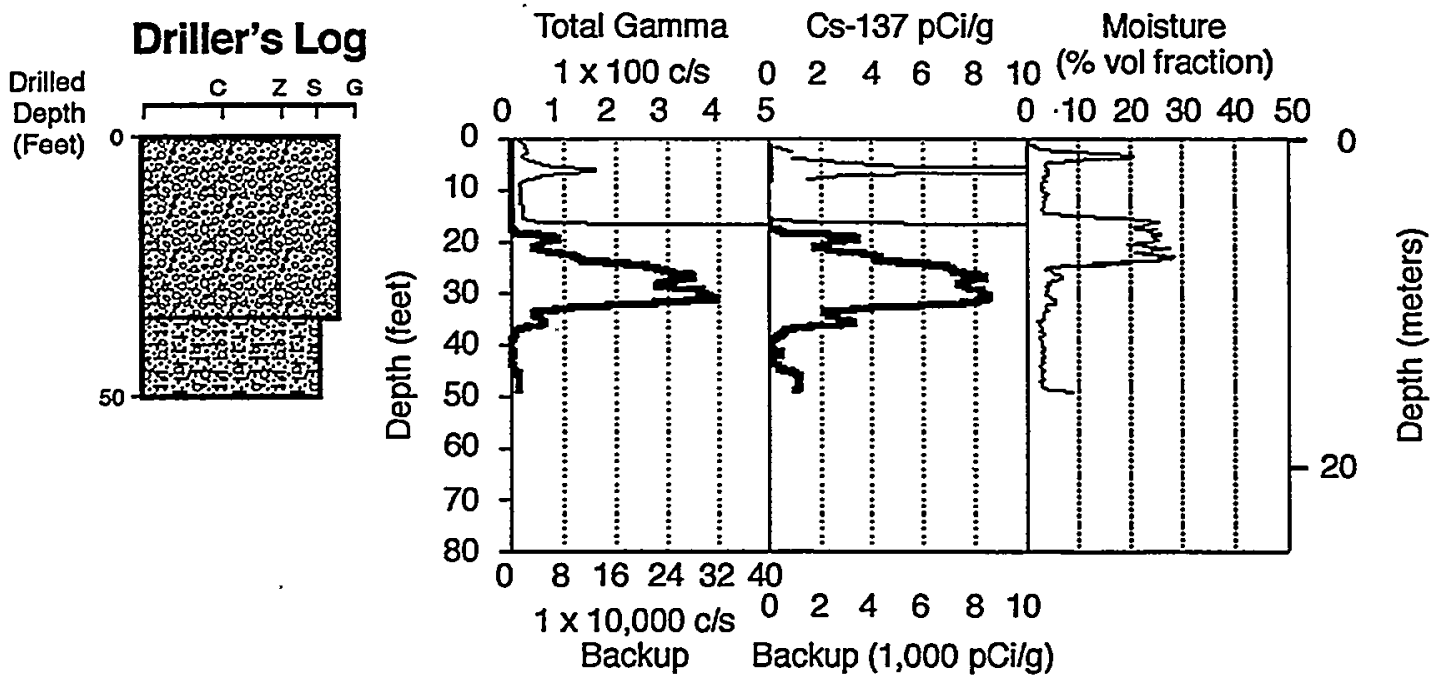

G99100164.3

Figure 4.16. Spectral Gamma-Ray and Neutron Moisture Logs from Boreholes 299-E33-287 and 299-E33-288 at the 216-B-37 Specific Retention Trench. See Figure 4.1 for lithologic key to the driller's log. 
Borehole 299-E33-288.was logged previously in 1984 and 1987 with a gross gamma-ray system. The latest $\log$ shows three zones of gamma contamination at about centered at $22 \mathrm{ft}, 36 \mathrm{ft}$, and just above the bottom of the borehole ( $50 \mathrm{ft}$ ). The $1984 \mathrm{log}$ shows the zone at the bottom of the borehole but the detector saturated between 38 and $21 \mathrm{ft}$. The deep contamination at $50 \mathrm{ft}$ does not show up on the $1999 \log$, possibly because decay of short-lived isotopes.

The moisture log from this borehole is similar in character to that of borehole 299-E33-287 suggesting that the annular seal is between only about 15 and $25 \mathrm{ft}$. The relatively high moisture zone at a depth of about $5 \mathrm{ft}$ corresponds to high ${ }^{137} \mathrm{Cs}$ activity at that depth.

\subsubsection{6-B-38 Specific Retention Trench (Boreholes 299-E33-289 and 299-E33-290)}

Borehole 299-E33-289 is located 20 to $30 \mathrm{ft}$ south of the middle of the 216-B-38 specific retention trench. The borehole was drilled in 1982 to a depth of $50 \mathrm{ft}$. During drilling, contamination was encountered from 14 to $21 \mathrm{ft}$ and from 27 to $33 \mathrm{ft}$. The driller's log states that the borehole has a grouted annular seal from 0 to $14 \mathrm{ft}$. The base of the trench is at a depth of $10 \mathrm{ft}$.

${ }^{137} \mathrm{Cs}$ was the only man-made radionuclide identified from the spectral gamma-ray log of this borehole. ${ }^{137} \mathrm{Cs}$ occurs between 2 and $5 \mathrm{ft}$ and between depths of 15 and $49 \mathrm{ft}$. The maximum activity of ${ }^{137} \mathrm{Cs}$ is greater than $55,000 \mathrm{pCi} / \mathrm{g}$ at $17 \mathrm{ft}$. The count rate limits were exceeded from 16 to $19 \mathrm{ft}$ so that the actual activity of ${ }^{137} \mathrm{Cs}$ is greater than reported.

Borehole 299-E33-289 was logged previously in 1984 with a gross gamma-ray system. Figure 4.17 shows a comparison between the 1999 and the 1984 gross gamma logs. The depth profiles of the 1984 log data and the 1999 gross gamma response match throughout the intervals logged except between depths of 16 and $19 \mathrm{ft}$. The 1984 gross gamma log shows a decrease in intensity in this depth interval, whereas the 1999 gross gamma log shows an increase. It is possible that the detector used in 1984 saturated in this interval. The detector used in 1999 exceeded high count-rate limits between depths of 16 and $19 \mathrm{ft}$ but did not saturate.

The shallow contamination at $4 \mathrm{ft}$ in the $1999 \log$ appears at $6 \mathrm{ft}$ in the $1984 \mathrm{log}$ data. Also, contamination near the bottom of the borehole begins to increase at $45 \mathrm{ft}$ in the 1999 log data whereas this same feature begins at $43 \mathrm{ft}$ in the 1984 data. These differences could be caused by contaminant movement in the subsurface, or by poor depth control with the 1984 logging system hoist and depth encoder. Because the character of the depth profiles matches so well, it is more likely that the apparent differences are caused by inaccurate depth control rather than contaminant movement. However, since the absolute efficiencies of the two different detectors are not established, no rigorous statement can be made concerning the possibility of lateral contaminant movement. .

Borehole documentation indicates that a annular seal of grout was placed around the upper $20 \mathrm{ft}$ of the casing at borehole 299-E33-289. The moisture log from the borehole shows a large variation in the thickness of the seal and that the seal is probably absent between depths of about 5 and $20 \mathrm{ft}$ and probably extends from depths of 20 to $25 \mathrm{ft}$. 


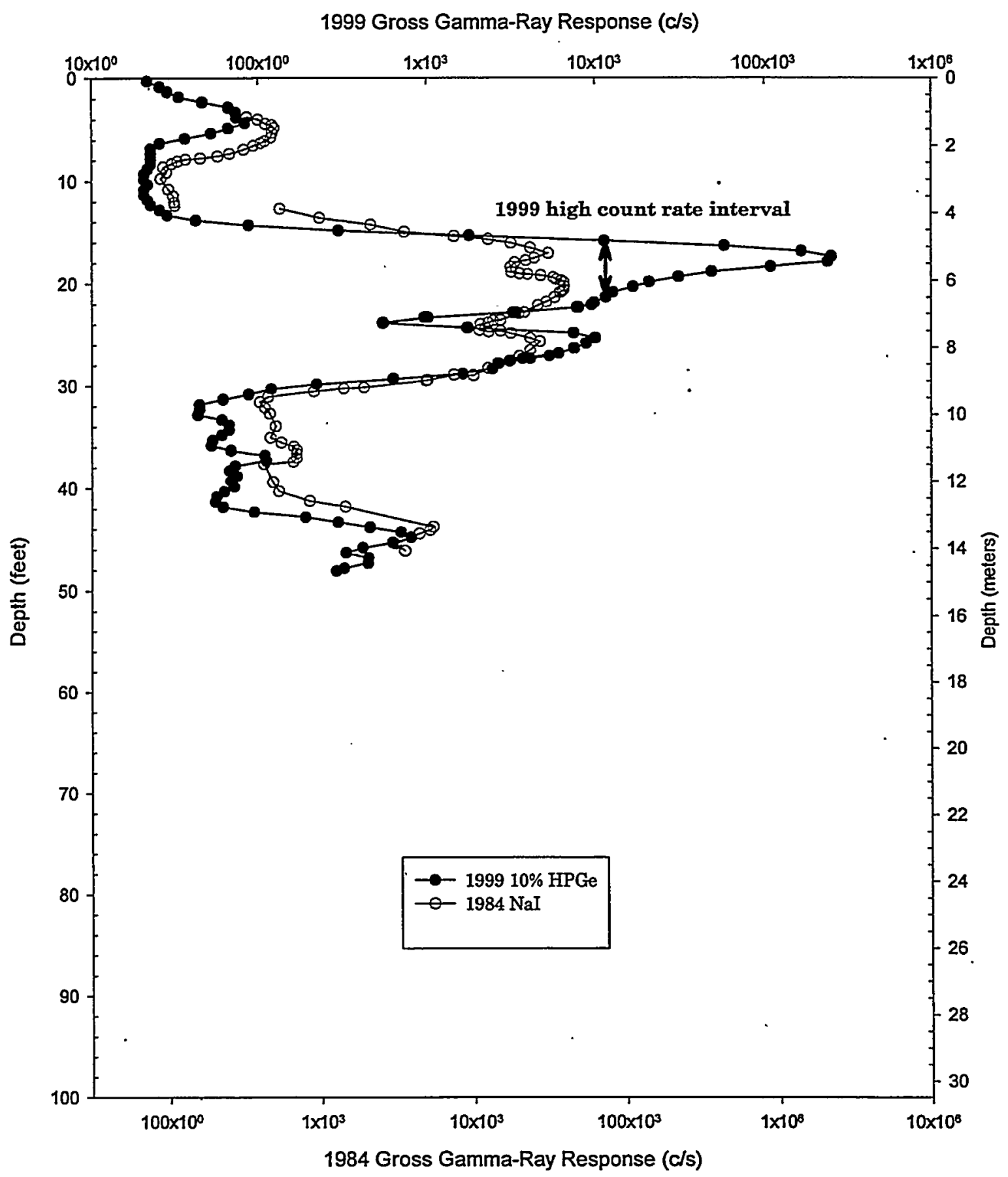

Figure 4.17. Comparison of the 1999 and 1984 Gross Gamma-Ray Logs for Well 299-E33-289 at the 216-B-38 Trench 
Borehole 299-E33-290 is located about $20 \mathrm{ft}$ north of the middle of the 216-B-38 specific retention trench. The borehole was drilled in 1982 to a depth of $50 \mathrm{ft}$. Contamination was encountered between about 25 and $40 \mathrm{ft}$ during drilling. The driller's $\log$ states that the borehole has a grouted annular seal from 0 to $20 \mathrm{ft}$.

${ }^{137} \mathrm{Cs}$ was the only man-made radionuclide identified from the spectral gamma-ray log of this borehole. ${ }^{137} \mathrm{Cs}$ occurs between depths of 19 and $49 \mathrm{ft}$. The maximum activity of ${ }^{137} \mathrm{Cs}$ is greater than $60,000 \mathrm{pCi} / \mathrm{g}$ at $25 \mathrm{ft}$. The count rate limits were exceeded from 21 to $30 \mathrm{ft}$ so that the actual activity of ${ }^{137} \mathrm{Cs}$ is greater than reported.

Borehole 299-E33-290 was logged previously in 1984 and 1987 with a gross gamma-ray system and in 1992 with the spectral gamma-ray system. The $1992 \mathrm{log}$ (Brodeur et al. 1993) identified ${ }^{137} \mathrm{Cs}$ between 2 and $7 \mathrm{ft}$ and between 16 and $45 \mathrm{ft}$ (maximum depth logged). ${ }^{60} \mathrm{Co}$ was identified between depths of 31 and $41 \mathrm{ft}$. The detector saturated from 22 to $29 \mathrm{ft}$.

Figure 4.18 shows a comparison of the 1992 and 1999 gross gamma logs and the spectral gamma log for ${ }^{137} \mathrm{Cs}$. The $1992 \mathrm{log}$ has been depth shifted $4.0 \mathrm{ft}$ for the gross gamma comparison and shifted $3.8 \mathrm{ft}$ for the ${ }^{137} \mathrm{Cs}$ comparison. The 1999 casing stick up is $3.6 \mathrm{ft}$.

The 1999 data exceeded the count rate limits over the depth interval from 21 to $32 \mathrm{ft}$, and the 1992 log data exceeds high count-rate limits from 21 to 32 and from 44.5 to $49 \mathrm{ft}$. ${ }^{137} \mathrm{Cs}$ concentrations from the 1992 data are severely affected by high count rate and good readings exist only for the low concentration zone from 2 to $6 \mathrm{fh}$, where there is good agreement in ${ }^{137} \mathrm{Cs}$.

Because ${ }^{137} \mathrm{Cs}$ is the only significant radionuclide in the borehole, comparison of the two gross gamma logs is relatively straight foreword. The concentration levels are sufficiently high that no background subtraction of natural potassium, uranium, and thorium is required. The high count-rate limits occur at 70,000 c/s for the 1999 instrumentation and at 20,000 c/s for the 1992 instrumentation after applying the scale factor of 3.5. A single scaling factor of 3.5 was found for a good comparison over the depths from 32 to $44 \mathrm{ft}$. Basically, the scale factor allows comparison of two data sets collected with two tools of different counting efficiency. It is possible, but highly unlikely that changes in ${ }^{137} \mathrm{Cs}$ concentrations occurred, but it would have had to change equally for all depth samples between 32 to $44 \mathrm{ft}$ (see Figure 4.18).

The moisture log from borehole 299-E33-290 is similar in character to the logs from the 216-B-37 trench and indicate that the annular seal is absent between 5 and $20 \mathrm{ft}$. There is an increase in the moisture content around the borehole between about 40 and $45 \mathrm{ft}$ but the values are within the expected range of Hanford formation sediments.

\subsubsection{4-B-41 Specific Retention Trench (Well 299-E33-8)}

Well 299-E33-8 is located about $50 \mathrm{ft}$ north of the east end of the 216-B-41 specific retention trench. The well was drilled in 1953 to a depth of $257 \mathrm{ft}$. The base of the trench is at a depth of $10 \mathrm{ft}$. 

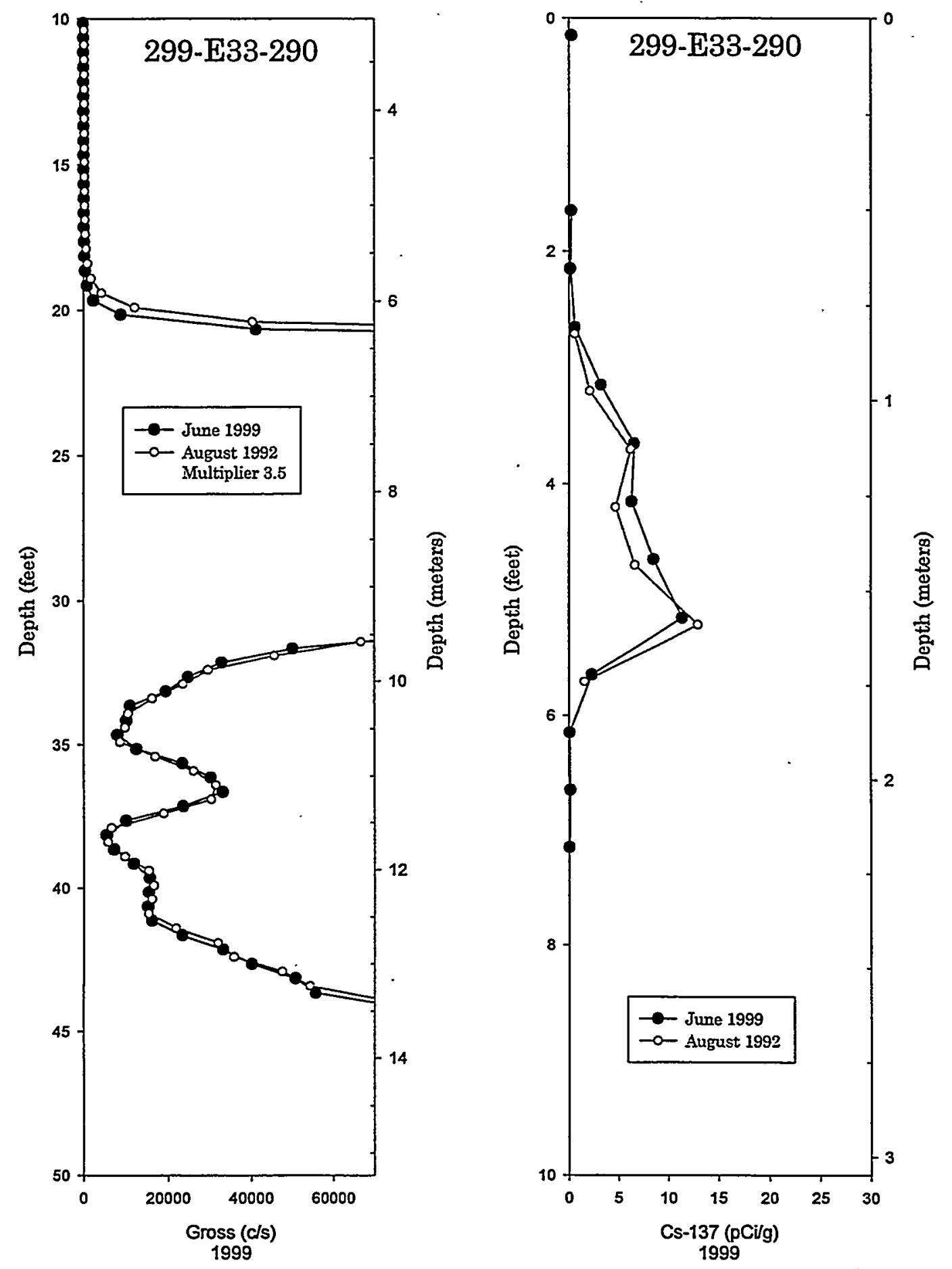

Figure 4.18. Comparison of the 1999 and 1992 Gross Gamma Log and Spectral Gamma Log Results for ${ }^{137} \mathrm{Cs}$ at Well 299-E33-290 at the 216-B-38 Specific Retention Trench 
${ }^{137} \mathrm{Cs},{ }^{60} \mathrm{Co}$, and ${ }^{125} \mathrm{Sb}$ were identified from the spectral gamma-ray log of this well. ${ }^{137} \mathrm{Cs}$ occurs between the depths of 26 and $41 \mathrm{ft}$ and between 224 and $244 \mathrm{ft}$. The maximum activity of ${ }^{137} \mathrm{Cs}$ is $6 \mathrm{pCi} / \mathrm{g}$ at $27 \mathrm{ft}$. ${ }^{60} \mathrm{Co}$ occurs from 26 to $61 \mathrm{ft}$ and from depths of 248 to $252 \mathrm{ft}$ with a maximum activity of $1 \mathrm{pCi} / \mathrm{g}$ at $30 \mathrm{ft}$. ${ }^{125} \mathrm{Sb}$ occurs at a depth of $30 \mathrm{ft}$. Both the ${ }^{125} \mathrm{Sb}$ at $30 \mathrm{ft}$ and the ${ }^{60} \mathrm{Co}$ in the depth range of 248 to $252 \mathrm{ft}$ exist at detection limit levels and their presence was confirmed with the summing technique described in Appendix A. The minimum detection limits for ${ }^{60} \mathrm{Co}$ and ${ }^{125} \mathrm{Sb}$ in this borehole are 0.2 and $2.5 \mathrm{pCi} / \mathrm{g}$, respectively.

Borehole 299-E33-8 was logged previously in 1976 (Fecht et al. 1977) with a gross gamma-ray system. That log shows a zone of gamma contamination from depths of about 26 to $62 \mathrm{ft}$.

The moisture log from well 299-E33-8 shows several zones of relatively high moisture between 0 and $75 \mathrm{ft}$. There is some correlation between the moisture log and the gross gamma-ray log throughout this interval.

\subsubsection{4-B-42 Specific Retention Trench (Borehole 299-E33-10)}

Well 299-E33-10 is located about $180 \mathrm{ft}$ southwest of the west end of the $216-\mathrm{B}-42$ specific retention trench. The well was drilled in 1955 to a depth of $290 \mathrm{ft}$. In 1984, 6-in. casing and a grout annular seal were added to the well from 0 to $122 \mathrm{ft}$. The base of the trench is at a depth of $10 \mathrm{ft}$.

${ }^{137} \mathrm{Cs}$ and ${ }^{60} \mathrm{Co}$ were identified from the spectral gamma-ray log of this borehole. ${ }^{137} \mathrm{Cs}$ exists from 0 to $2 \mathrm{ft}$ and from 21 to $23 \mathrm{ft}$ with a maximum activity of $0.6 \mathrm{pCi} / \mathrm{g}$ at $21 \mathrm{ft}$. The response on the gross gamma log between 21 and $23 \mathrm{ft}$ is higher than expected for the small level of ${ }^{137} \mathrm{Cs}$ and the lack of a significant KUT signal. Because all other identified radionuclides are at very low levels, this indicates either 1) a strong remote source (most likely ${ }^{137} \mathrm{Cs}$ ) or 2) the presence of a strong beta emitter such as ${ }^{90} \mathrm{Sr}$ is probably contributing to the gross gamma-ray intensity. A strong remote source of ${ }^{137} \mathrm{Cs}$ can yield many down scattered gamma rays that produce a gross response, but does not generate many photo peak gamma rays at $661 \mathrm{keV}$ due to earth shielding.

${ }^{60} \mathrm{Co}$ was identified between depths of 277 and $281 \mathrm{ft}$ at or below the detection limit. The existence of ${ }^{60} \mathrm{Co}$ was verified using the summing technique described in Appendix A. The MDL for ${ }^{60} \mathrm{Co}$ in this well is $0.2 \mathrm{pCi} / \mathrm{g}$.

Well 299-E33-10 was logged previously in 1976 (Fecht et al. 1977) with a gross gamma-ray system. That log shows a zone of gamma contamination from depths of about 16 to $40 \mathrm{ft}$.

The moisture log from well 299-E33-10 shows moisture contents typical of the Hanford formation. There is some correlation with the gross gamma response indicative of variations in lithology but the available driller's log is not detailed enough to pick specific relationships. 


\subsection{Summary and Conclusions}

The isotopes ${ }^{137} \mathrm{Cs},{ }^{60} \mathrm{Co},{ }^{235} \mathrm{U},{ }^{238} \mathrm{U}$, and ${ }^{154} \mathrm{Eu}$ were identified on the spectral gamma logs from boreholes monitoring the PUREX specific retention facilities. No previous spectral gamma logs are available for comparison to the 1999 logs, but several older gross gamma logs exist. One gross gamma log obtained in 1976 was digitized for comparison with the $1999 \log$ (borehole 299-E24-53 at the 216-A-2 crib). The presence of several man-made, gamma-emitting radionuclides made the comparison very difficult. However, the two logs showed the same general character suggesting no vertical movement of radionuclides. Lateral movement cannot be ruled out by the comparison. Qualitative, visual (not digitized) comparison of the other 1999 gross gamma logs with historical gross gamma logs suggest that no vertical movement of radionuclides has occurred since the previous logging events. Most differences between historical logs and the 1999 logs can be explained by decay of relatively short-lived radionuclides.

The isotopes ${ }^{137} \mathrm{Cs},{ }^{60} \mathrm{Co},{ }^{125} \mathrm{Sb}$, and ${ }^{154} \mathrm{Eu}$ were identified on the spectral gamma logs from boreholes monitoring the BC Controlled Area cribs and trenches. Three of the boreholes in this area had been previously logged in 1992 with a spectral gamma tool. The 1992 logs were compared with the 1999 logs. In two of the three boreholes with both 1992 and 1999 logs, zones were identified where ${ }^{137} \mathrm{Cs}$ activity has increased since 1992. ${ }^{137} \mathrm{Cs}$ activity increased by about $20 \%$ between 67 and $88 \mathrm{ft}$ in well 299-E13-1 (at the $216-\mathrm{B}-14 \mathrm{crib}$ ) and by about $32 \%$ at $83 \mathrm{ft}$ in well 299-E13-5 (at the 216-B-18 crib). The movement of ${ }^{137} \mathrm{Cs}$ in well 299-E13-5 is interpreted to be lateral because there is no change in ${ }^{137} \mathrm{Cs}$ activity above and below the zone of increase. The increase in ${ }^{137} \mathrm{Cs}$ activity in well 299-E13-1 could result from vertical movement, but more information is needed to make a definite interpretation.

There is an apparent increase in ${ }^{137} \mathrm{Cs}$ activity between 24 and $28 \mathrm{ft}$ in well 299-E13-3 (at the 216-B-16 crib). The increase may be the result of differences in the depths at which the 1992 and 1999 measurements were taken. Well 299-E13-1 also showed a small increase in ${ }^{60} \mathrm{Co}$ activity at 191 to $201 \mathrm{ft}$ depth. All three wells with 1992 data showed a decrease in ${ }^{125} \mathrm{Sb}$ activity that can be explained by natural decay.

Historic gross gamma logs from two wells, 299-E13-2 and 299-E13-4 were digitized to allow comparison with 1999 gross gamma logs. Differences between the 1992 and 1999 logs can be explained by natural decay of relatively short-lived radionuclides; the comparison, however, is qualitative. Similarly, most of the differences between the 1999 logs and the other historical logs in Fecht et al. (1977) reflect the decay of relatively deeper, short-lived isotopes and the much slower decay of the shallower and longer-lived isotopes.

The isotopes ${ }^{137} \mathrm{Cs},{ }^{60} \mathrm{Co}$, and ${ }^{125} \mathrm{Sb}$ were identified on the spectral gamma logs from boreholes at the $\mathrm{BX}$ specific retention trenches. The ${ }^{60} \mathrm{Co}$ and ${ }^{125} \mathrm{Sb}$ were identified only at or near detection limits by the summing technique described in Appendix A.

A 1984 gross gamma log from borehole 299-E33-289 was digitized and compared to the 1999 gross gamma results. The different instrument efficiencies allow only qualitative comparison. The depth 
profile of the contaminants match very well, but possible depth control errors in the 1984 data make any conclusions regarding vertical changes in contaminant distribution uncertain. However, it is believed that no vertical migration of contaminants has occurred in the borehole since 1984.

One borehole at the BX trenches, 299-E33-290 (at the 216-B-38 trench) had been previously logged with a spectral gamma tool in $1992 .{ }^{137} \mathrm{Cs}$ was the only man-made radioisotope noted in both logs. Comparison of the 1992 and 1999 gross gamma logs indicated that a change in the distribution of ${ }^{137} \mathrm{Cs}$ was highly unlikely. Most of the qualitative differences between the 1999 logs and the historical logs from the BX trenches in Fecht et al. (1977) reflect the decay of short-lived isotopes primarily ${ }^{106} \mathrm{Ru}$.

Only four of the boreholes logged in 1999 had previous spectral gamma logs for comparison. Two of those logs showed that changes in the subsurface distribution of man-made radioisotopes had occurred since 1992. Although the changes are not great, they do point to continued movement of contaminants in the vadose zone. The logs obtained in 1999 create a larger baseline for comparison with future logs.

None of the facilities monitored in 1999 have been used for at least 30 years and some for 40 years. Thus, the driving force for the changes is not known for certain but must be either natural recharge, residual moisture from facility operations, or moisture from adjacent facilities. There are several facilities, including cribs and tank farms near the BX trenches, that may contribute moisture to the subsurface under the trenches. There are no nearby liquid waste disposal facilities near the cribs and trenches in the $\mathrm{BC}$ Controlled Area. Therefore, the driving force there must be residual moisture from past operations or natural recharge.

The radionuclides that were observed to have moved since 1992 are ${ }^{137} \mathrm{Cs}$ and ${ }^{60} \mathrm{Co}$. Given the amount of movement and the half-lives of the isotopes, it is expected that they will decay to insignificant amounts before reaching groundwater. Although not seen to have moved in 1999, the same is expected for all of the other detected isotopes except those of uranium.

Unfortunately, gamma-ray logging cannot detect many of the contaminants of interest such as ${ }^{99} \mathrm{Tc}$, nitrate, or ${ }^{129} \mathrm{I}$, all of which have long half-lives and can be highly mobile in the vadose zone. The time series of gross gamma logs given in Fecht et al. (1977) for many of the specific retention facilities show large decreases in gamma intensity between the late 1950 s and 1976. The maximum intensity is generally between depths of 33 to $65 \mathrm{ft}$. The rapid decay is probably due to ${ }^{106} \mathrm{Ru}$ (half life $1.02 \mathrm{yr}$ ) and the ${ }^{106} \mathrm{Ru}$ probably reached a maximum depth of 33 to $65 \mathrm{ft}$ with the original slug of water disposed in the short (generally about 1 month) time the facilities operated. Depending on the chemical characteristics of the waste stream, the mobility of ${ }^{99} \mathrm{Tc}$ and ${ }^{129} \mathrm{I}$, as gauged by experimentally determined distribution coefficients, is either near that of or greater than that of ${ }^{106} \mathrm{Ru}$. Thus, the minimum depth that ${ }^{99} \mathrm{Tc}$, ${ }^{129} \mathrm{I}$, and nitrate probably reached during facility operation is indicated by the depth of rapid ${ }^{106} \mathrm{Ru}$ decay. Subsequent movement of the long-lived and mobile constituents cannot be measured with the available geophysical logging tools. 


\subsection{References}

Brodeur, J. R., R. K. Price, R. D. Wilson, and C. J. Koizumi. 1993. Results of Spectral Gamma-Ray Logging of Select Boreholes for the Aggregate Area Management Study. WHC-SD-EN-TI-021, Westinghouse Hanford Company, Richland, Washington.

DOE/RL-92-04. 1993a. PUREX Source Aggregate Area Management Study Report. U.S. Department of Energy, Richland Operations Office, Richland, Washington.

DOE/RL-92-05. 1993b. B-Plant Source Aggregate Area Management Study Report. U.S. Department of Energy, Richland Operations Office, Richland, Washington.

Engleman, R. E., R. E. Lewis, D. C. Stromswold, and J. R. Hearst. 1995. Calibration Models for Measuring Moisture in Unsaturated formations by Neutron Logging. PNL-10801, Pacific Northwest Laboratory, Richland, Washington.

Fecht, K. R., G. V. Last, and K. R. Price. 1977. Evaluation of Scintillation Probe Profiles From 200 Area Crib Monitoring Wells. ARH-ST-156, Atlantic Richfield Hanford Company, Richland, Washington.

Fecht, K. R., G. V. Last, and M. C. Marratt. 1979a. Stratigraphy of the Late Cenozoic Sediments Beneath the 216-A Crib Facilities. RHO-LD-71, Rockwell Hanford Operations, Richland, Washington.

Fecht, K. R., G. V. Last, and M. C. Marratt. 1979b. Stratigraphy of the Late Cenozoic Sediments Beneath the 216-B \&C Crib Facilities. RHO-LD-72, Rockwell Hanford Operations, Richland, Washington.

Heistand, B. E., and E. F. Novak. 1984. Parameter Assignments for Spectral Gamma-Ray Borehole Calibration Models. GJBX-2(84), Bendix Field Engineering Corporation, Grand Junction, Colorado.

Horton, D. G. 1999. Monitoring Plan for Fiscal Year 1999 Borehole Logging at 200 East Area Specific Retention Facilities. PNNL-12222, Pacific Northwest National Laboratory, Richland, Washington.

Horton, D. G., S. P. Reidel, and G. V. Last. 1999. Monitoring Guidance for Vadose Zone Monitoring of Liquid Waste Disposal Facilities for the Hanford Groundwater Project. PNNL-11958, Rev. 2, Pacific Northwest National Laboratory, Richland, Washington.

Kincaid, C. T., M. P. Bergeron, C. R. Cole, M. D. Freshley, N. L. Hassig, V. G. Johnson, D. I. Kaplan, R. J. Serne, G. P. Streile, D. L. Strenge, P. D. Thorne, L. W. Vail, G. A. Whyatt, and S. K. Wurstner. 1998. Composite Analysis for Low-Level Waste Disposal in the 200 Area Plateau of the Hanford Site. PNNL-11800, Pacific Northwest National Laboratory, Richland, Washington. 
Koizumi, C. J., J. R. Brodeur, W. H. Ulbricht, and R. K. Price. 1991. Calibration of the RLS HPGe Spectral Gamma Ray Logging System. WHC-EP-0464, Westinghouse Hanford Company, Richland, Washington.

Koizumi, C. J., J. R. Brodeur, R. K. Price, J. E. Meisner, and D. C. Stromswold. 1994. "High-Resolution Gamma-Ray Spectrometry Logging for Contamination Assessment.” Nucl. Geophys. 8:149-164.

Maxfield, H. L. 1979. Handbook 200 Areas Waste Sites. Vols. 1 and 3. RHO-CD-673. Rockwell Hanford Operations, Richland, Washington.

Meisner, J. E. 1995. Vadose Zone Moisture Measurement Through Steel Casing Evaluation. .WHC-SDEN-TI-304, Westinghouse Hanford Company, Richland, Washington.

Meisner, J. E., R. K. Price, and R. R. Randall. 1996. Radionuclide Logging System In-Situ Vadose Zone Moisture Measurement Calibration. WHC-SD-EN-TI-306, Westinghouse Hanford Company, Richland, Washington.

Randall, R. R. 1994. Calibration of the Radionuclide Logging System Germanium Detector. WHC-SDEN-TI-292, Westinghouse Hanford Company, Richland, Washington.

Stromswold, D. C. 1994a. Technical Evaluation of Software for Gamma-Ray Logging System. PNL-9807, Pacific Northwest Laboratory, Richland, Washington.

Stromswold, D. C. 1994b. Calibration Facilities at Hanford for Gamma-Ray and Fission-Neutron Well Logging. PNL-9958, Pacific Northwest Laboratory, Richland, Washington.

Waite, J. L. 1991. Tank Wastes Discharged Directly to the Soil at the Hanford Site. WHC-MR-0227, Westinghouse Hanford Company, Richland, Washington.

Wood, V. W. 1958. Index of CPD Crib Building Numbers - Designs of CPD Radioactive Liquid Wastes Disposal Sites, Parts I and VI. HW-55176, General Electric Hanford Atomic Products Operation, Richland, Washington.

Waste Management Federal Services, Inc. Northwest Operations (WMNW). 1998. "Section 17.0, Geophysical Logging" and "Section 18.0, Geophysical Long Data Analysis." In Operational Environmental Monitoring, WMNW-CM-004, Richland, Washington. 


\section{Appendix A}

\section{Enhanced Spectral Processing for Low Intensity Photo Peaks}




\section{Appendix A}

\section{Enhanced Spectral Processing for Low Intensity Photo Peaks}

\section{A.1 Background}

High resolution spectral gamma-ray data are collected in wells at the Hanford Site. The analysis of the spectral data involves the stripping of the photo peaks from the Compton background in order to obtain the concentration of radionuclides in the earth formations as a function of depth. Even in the presence of man-made radionuclides, the naturally occurring potassium, uranium, and thorium, (KUT) can be identified with spectral processing of the appropriate photo peaks. The KUT logging signature can be used for identification of lithologic features.

The logging speed dictates the spectral sample time, which is a major factor in the determination of the minimum detection level (MDL) for any radionuclide. Low KUT concentrations and the steel casing that is used for most wells at Hanford result in low.KUT photo peak intensities. An enhanced method of spectral data processing has been developed that improves the KUT signal effectively comparable to a factor of 1/4 logging speed, (or factor of 4 longer sample times for the same logging speed). Using this enhanced processing allows selection from a range of faster logging speed or reduction in statistical error for the same logging speed.

Application of this method of spectral data processing enhances other high resolution photo peak analysis in addition to KUT. Any photo peak at or near MDL will be increased in signal, resulting in a lower MDL for the enhanced data.

\section{A.2 Method}

The developed enhancement in log analysis is a simple stacking of spectra prior to the normal photo peak stripping. The most common depth sampling is 6-in.-depth increments, and a stack of 4 contiguous sample spectral are summed as the recommended configuration. Stacking spectra over too long a depth interval destroys vertical resolution and any possible real variations due to the changes in the formation KUT signals, or vertical depositional variation of contaminates. The inherent detector response is a view of gamma rays emanating from the formation $18 \mathrm{in}$. above and below the center of the crystal. Therefore, this inherent vertical depth response of the logging instrument is easily $2 \mathrm{ft}$, and thus the choice of $2 \mathrm{ft}$ for the stacking or summing. The choice of four, 6-in. samples is a trade-off between statistical precision improvement and loss of depth resolution. Some spectral processing applications may use either more depth sample stacking or less, depending on the specific project goals.

A "running" stack of four spectra conserves the log appearance for review to determine lithologic signatures. The first running stack is a sum of the first four spectra and the next running stack is the sum 
of the second through fifth spectra. These summed spectra are then written to disk as a stacked spectrum for later log analysis processing. The live and real-time values for the stack spectra have been added, and the depth of the stacked spectra is computed as the mid point between the start and end of the 4 spectra.

There is one major difference between this technique and a simple post filter of the log analysis results. The pre photo peak stripping summation actually reduces the MDL values because the signal is enhanced. If a signal were at MDL then half the time there would be no response to filter. However, adding the spectra produces more signal, and, thus, lowers the MDL that can be obtained using this technique.

A significant use of the enhanced processing is the lithologic information from better KUT values, but other applications exist. HPGe analysis for man-made radionuclides is improved for the recognition of any radionuclides. Analysis can be targeted for specific radionuclides, but if other radionuclides are present, they may be missed. Analyzing stacked spectra brings out photo peaks so that recognition of their presence is enhanced and less likely to be overlooked.

Another application of this type of processing is the use of low signals for interpretation. The neutron gamma capture spectroscopy logging system uses a neutron source housed with a HPGe detector. The Al capture can be indicative of mineral content of the soils surrounding the borehole; however, this signal is very low. Figure A.1 is an example of two spectra, one the raw spectrum, and the other a stack of four spectra over this same interval. The energy scale is expanded to closely view the Al photo peak at $7724 \mathrm{keV}$. In the unstacked spectra, the $\mathrm{Al}$ photo peak is not visible and at MDL value. The stacked spectra clearly improves the photo peak signal to the Compton background.

\section{A.3 Confirmation Data and Analysis}

The statistical precision of the stacking technique in the proposed configuration will be improved the equivalent of a 4-times-longer sample time. This condition can rigorously be demonstrated for spectra that are pure repeats of the same gamma ray flux. The logging instrument was set up with the Coleman Mantle verification source and 236 spectra were recorded at 30-second sample time. This produced 236 spectra of a constant source of gamma rays, and these data can then be analyzed for the variations observed.

These 236 repeated spectra were log analyzed for $\mathrm{K}-40$, Th (583 keV peak), and Th ( $2614 \mathrm{keV}$ peak) in both the conventional log analysis and the enhanced $\log$ analysis. (Note that the $\mathrm{K}-40$ signal is from the cement flooring of the lab.) Figure A.2 contains a plot of these data analyzed in both processes. All variations shown in this figure are due to the statistical variations and no changes in $\mathrm{K}$ or $\mathrm{Th}$.

The results of statistical analysis for these data are shown in Table A.1. From the collection of repeat values for the unstacked results, an observed root mean square produces the measure of the standard deviation. Similar results are also listed for the stacked processing results. The last row contains the observed ratio between these two methods of processing. Since the stack is by 4 and the effective time is 4 times longer, the statistical precision should be reduced by the square root of 4 , which is 2 . The observed ratio is 2 within measurement errors. 


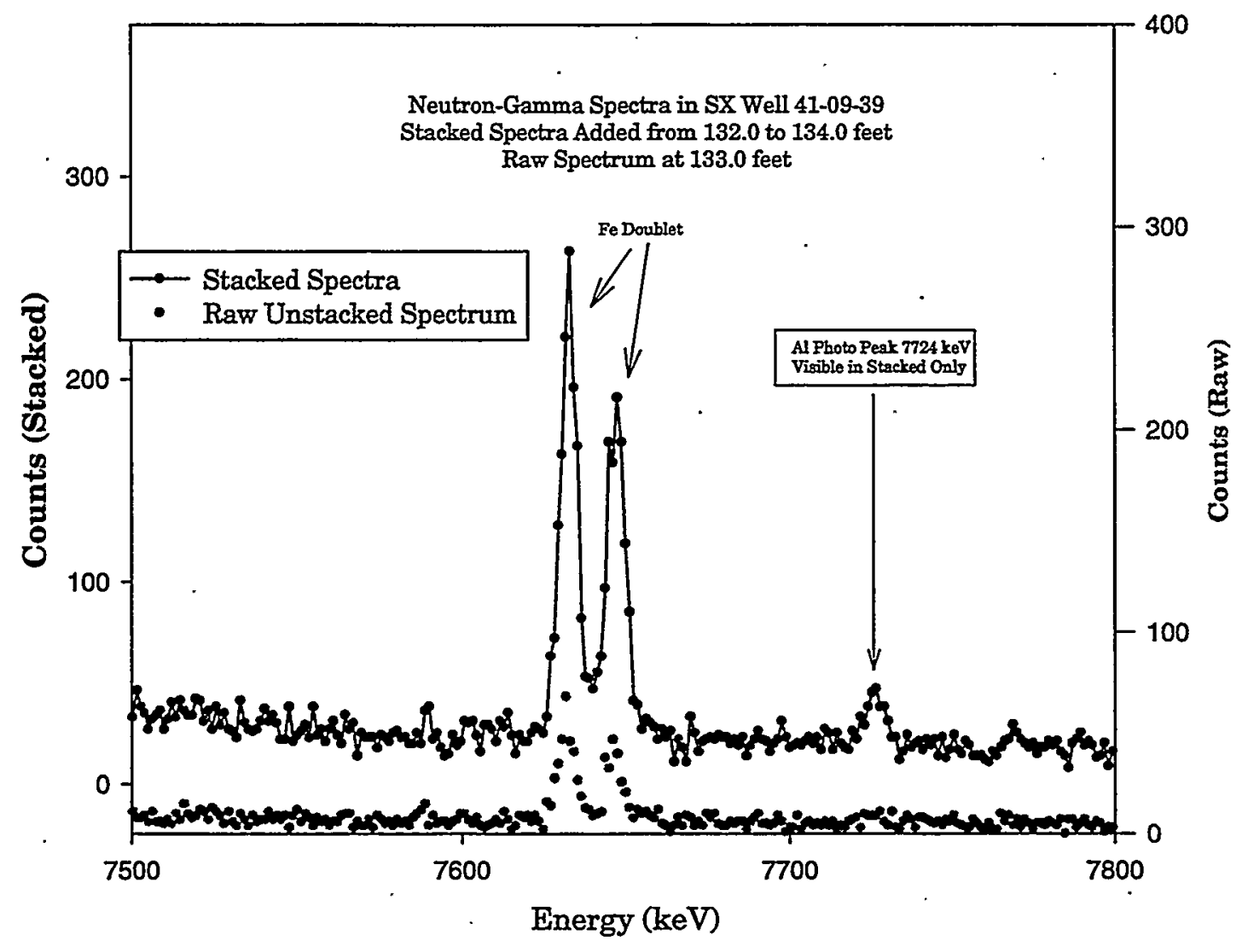

Figure A.1. Spectral Example of the Photo Peak Enhancement as a Result of Spectral Stacking

\section{A.4 Application To Log Data}

Well 299-E14-14 was logged with the RLS high resolution spectral system on October 29 and November 7, 1998. These logging data were collected with two different logging speeds. Some regions of the well were logged at 30-second samples every 6 in., and the entire well was logged at 100-second samples every 6 in.

Figure A. 3 contains a plot of the normal processing compared to the enhanced processing between the depths of 0 and $130 \mathrm{ft}$, for the slower logging speed data. There are both real KUT produced variations with depth as well as inherent statistical variations in the values shown. These two variations can be mistaken for each other; i.e., statistical variations can be thought to be changes in KUT.

There is a small change in $\mathrm{U}$ from 31 to $38 \mathrm{ft}$ over the values both above and below this depth interval. This small change could not be accurately recognized by using only the normal processing because the statistical variations hide the change. However, the enhanced processing does allow for this signature recognition. Likewise, there is a small, but noticeable (with the stacked result) change in the Th response 
RLS Spectral KUT Processed Data

Waste Management Federal Services inc., Northwest Operations

Project: Repeat Testing Log Date : January 13, 1999

Borehole: 427 Bldg (Coleman2) Sample Time: 30 s stations

Enhanced Processing \& Normal

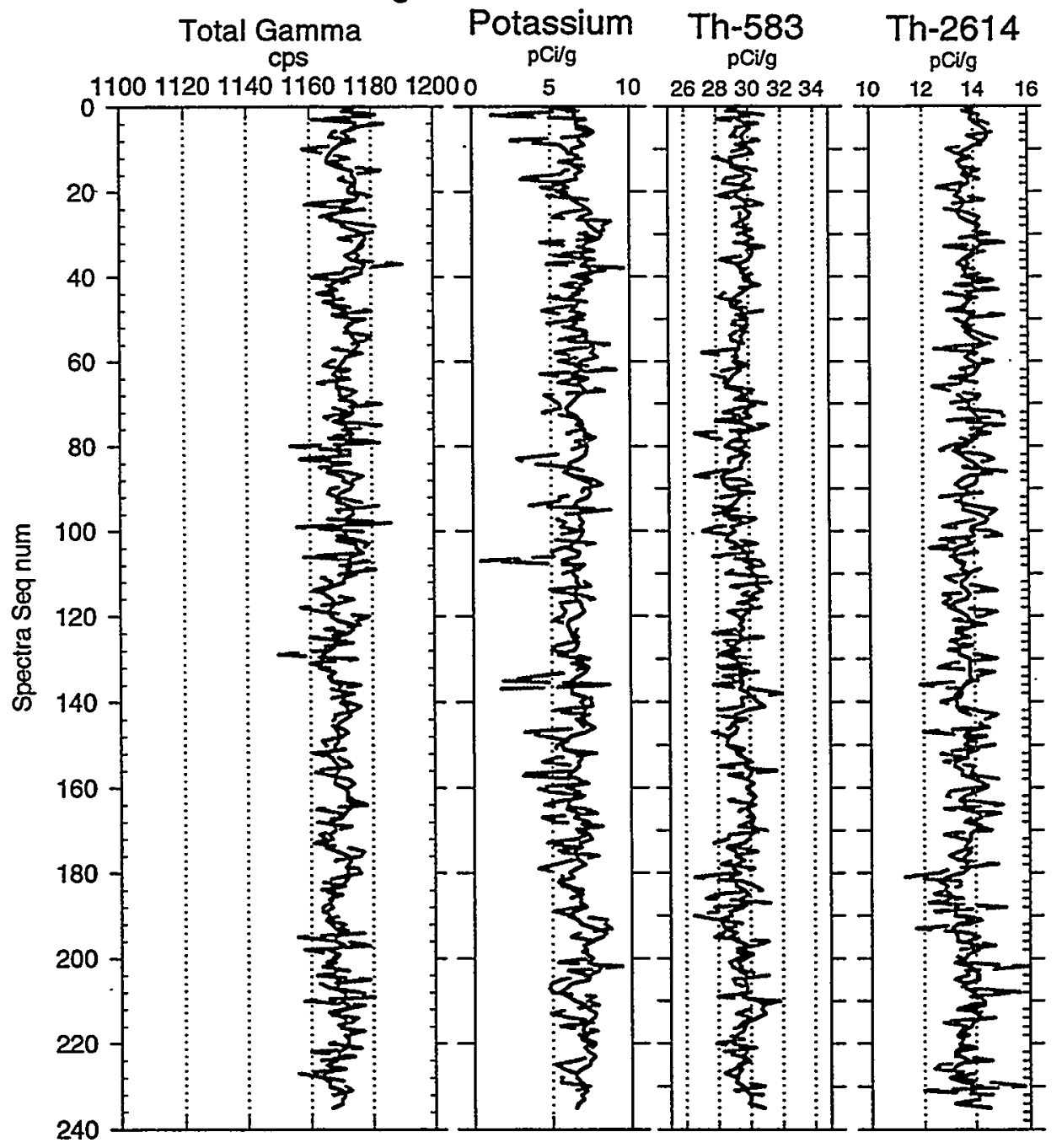

Figure A.2. Inherent Statistical Variations for the RLSG3.2 for Laboratory Collected Data

Table A.1. Statistical Parameters for Analysis of Test Data

\begin{tabular}{|c|c|c|c|c|}
\hline$\sigma$ & Gross (\%) & $\mathrm{K}(\%)$ & Th-583 (\%) & Th-2614 (\%) \\
\hline \hline Normal & 0.55 & 22.8 & 3.5 & 5.7 \\
\hline Stacked & 0.29 & 8.1 & 1.9 & 2.6 \\
\hline Ratio & 2.0 & 2.8 & 2.5 & 2.2 \\
\hline
\end{tabular}




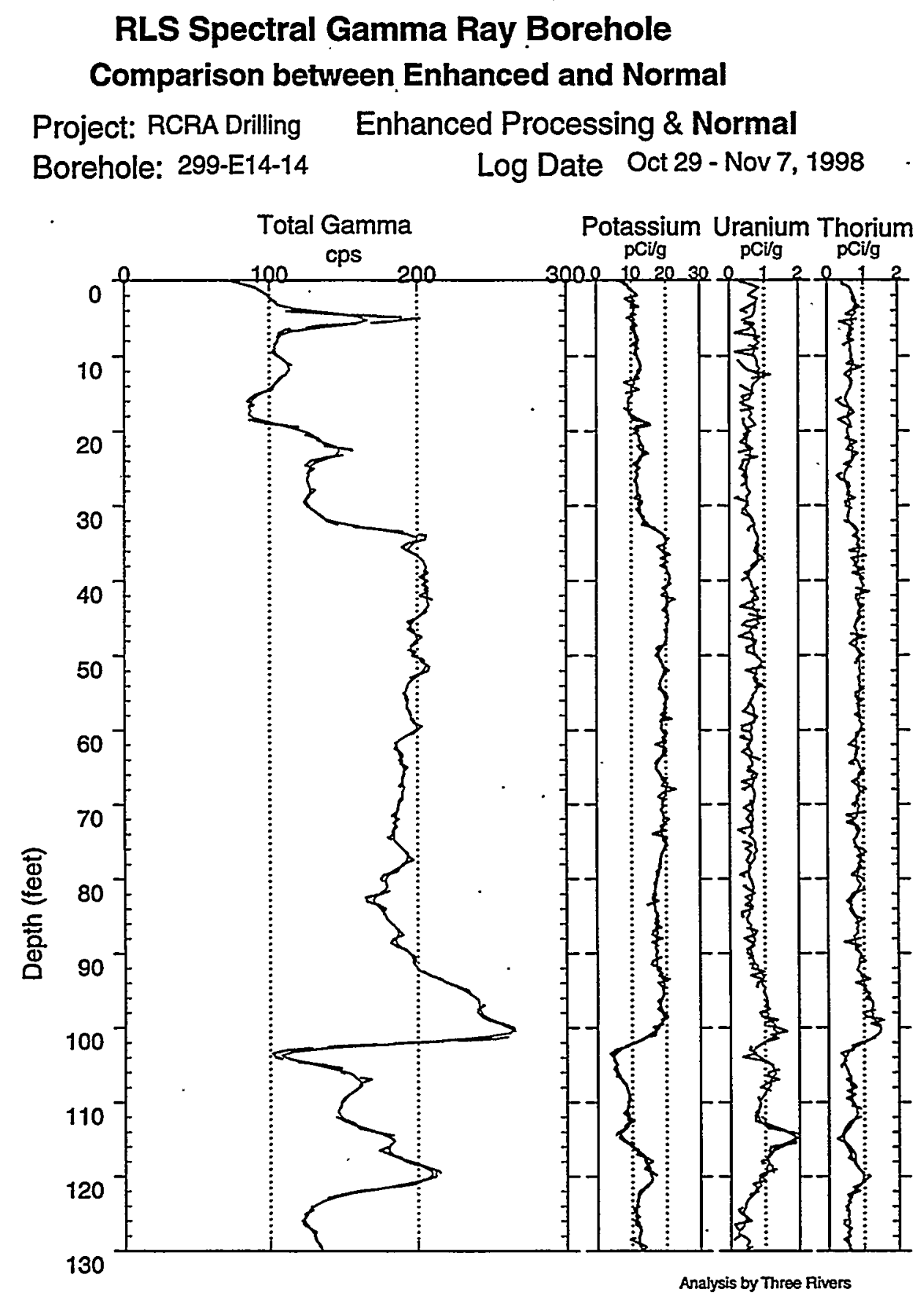

Figure A.3. Log Data Processing Comparison of Normal and Enhanced Analysis 
at $32 \mathrm{ft}$. This change would not be identifiable using normal processing. Note that the $\mathrm{K}$ signal in this interval is clear for either method of processing. The end result of the enhanced KUT processing is more information regarding lithologic features.

There are large changes in KUT as a result of lithologic changes between depths of 90 and $130 \mathrm{ft}$ that are clearly visible in both methods of processing. However, the changes are more easily viewed using the enhanced processing.

A thin zone at $5 \mathrm{ft}$ in the gross gamma response is not caused by any KUT changes. This flags the contaminant ${ }^{137} \mathrm{Cs}$ that was identified by the high resolution spectral processing. Very thin beds will be vertically degraded to some extent with the enhanced processing. Figure A.4 contains plots of the ${ }^{137} \mathrm{Cs}$ results for both the normal processing and the enhanced processing. The plot on the left is at normal depth scaling for reference, and the plot on the right is an expanded scale for close inspection.

Very thin beds are also vertically degraded to some degree by the inherent instrument response, since the detector views gamma rays from up to $18 \mathrm{in}$. above and below the center of the crystal. This effect is represented in Figure A.4 by the bar, which represents the true thin zone. The true zone is thin and of higher concentration than the maximum reading with the normal processing, and the enhanced processing further degrades this thin bed response into a thicker bed of lower concentration.

Extrapolation of this thin bed effect for any of the KUT possible signatures is possible. A thin bed change in $U$ for example, would be masked by the statistical nature of the signal for the normal processing. Thus, either technique can miss a thin bed if the change is not large. A sufficiently large change can be observed with normal techniques, but the enhanced processing will reduce the level required for observing changes.

\section{A.5 Conclusion}

The method of enhanced statistical variations has been described. The results of these processes have been demonstrated for purely repeat variations in laboratory conditions. Examples from field data have also been presented and discussed. The following points result:

- Lowered MDL values can result from stacking, but not from filtering of the results.

- The statistical precision for a given log at given logging speed is reduced to the equivalent of a logging speed of a factor of 4 slower, with optimal depth resolution. This factor of 4 can be used to generate more statistical precision as normal logging speeds, or reduce logging speeds.

- Very thin zones are somewhat degraded by the enhanced processing, but at low signal levels, such zones are also not viewable with normal processing.

- There is absolutely no loss of data because both views (normal and enhanced) are possible. There is no reason to replace one method of analysis for the other method. 


\section{RLS Spectral Gamma Ray Borehole Survey . Enhanced Processing Thin Bed Response}

Project: RCRA Drilling - FY1999

Borehole: 299-W14-14 (B8547)

Cs-137 (pCi/g)

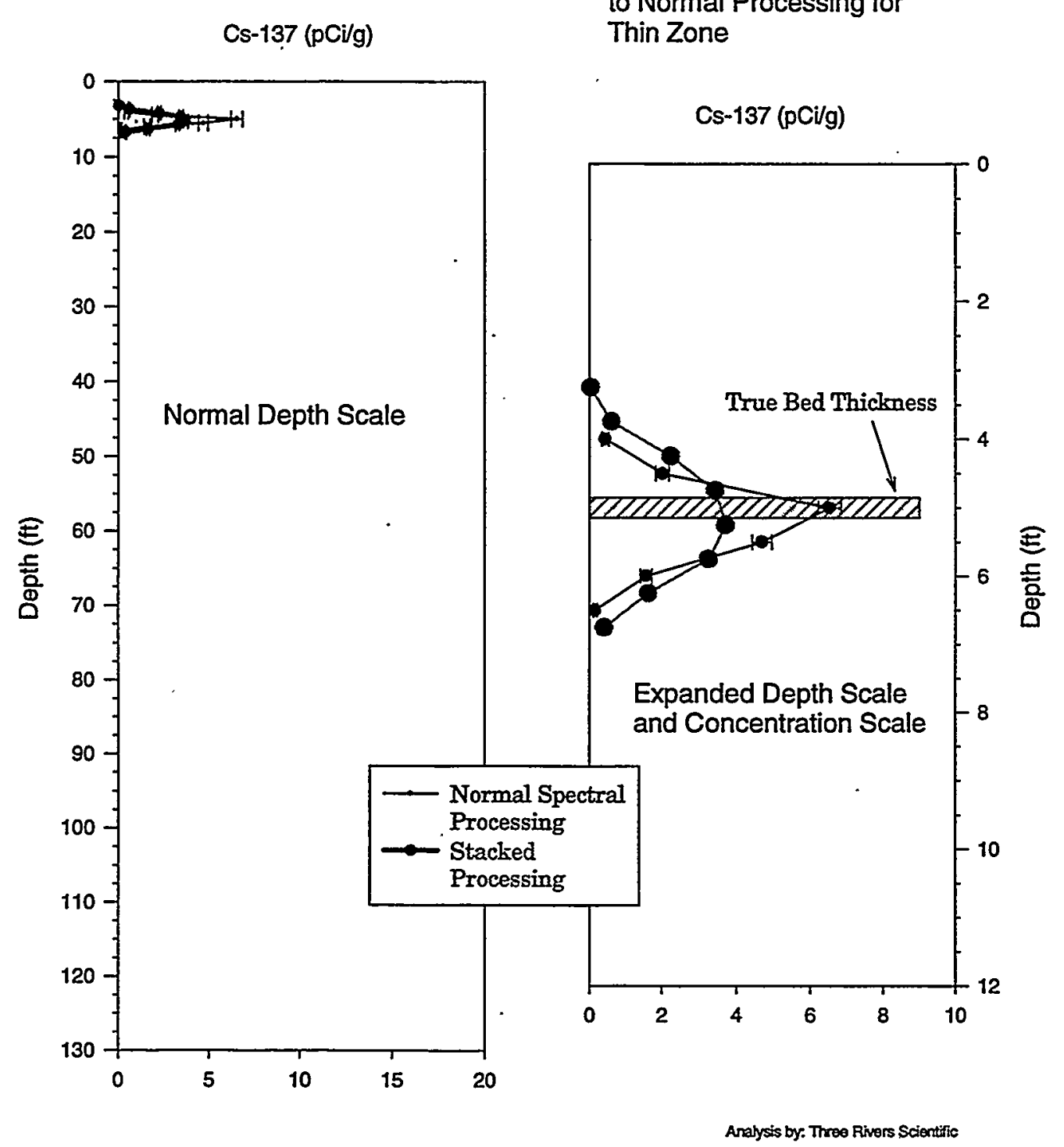

Analysis by: Three Rivers Scientific
Log Date: Oct 29 \& Nov 7, 1998 Compare Enhanced Processing to Normal Processing for Thin Zone

Figure A.4. A Comparison of the Thin Bed Response for the Two Analytical Techniques 


\section{Appendix B}

\section{Borehole Logging Data}




\section{Appendix B}

\section{Borehole Logging Data}

This appendix contains log header sheets, depth-versus-activity plots, acceptance quality assurance processing plots, and log analysis summaries for each borehole logged at the 200 East Area specific retention facilities. All logging data were collected by Waste Management Federal Services, Inc., Northwest Operations according to procedures in WMNW (1998a). Log data analysis was completed by Three Rivers Scientific according to procedures in WMNW (1998b). The log data were collected with a depth reference of top of casing as noted on the log header sheets. During analysis, however, depths were shifted to a ground surface reference so that the depth reference for all plots and log analysis summary discussions in this appendix is ground surface.

\section{B.1 References}

WHC-SD-EN-TI-292. 1994. Calibration of the Radionuclide Logging System Germanium Detector. R. R. Randall, Westinghouse Hanford Company, Richland, Washington.

WHC-SD-EN-TI-306. 1996. Radionuclide Logging System In Situ vadose Zone Moisture Measurement Calibration. J. E. Meisner, R. K. Price, and R. R. Randall, Westinghouse Hanford Company, Richland, Washington.

WMNW (Waste Management Federal Services, Inc., Northwest Operations). 1998a. "Section 17.0, Geophysical Logging." In Operational Environmental Monitoring, WMNW-CM-004, Richland, Washington.

WMNW (Waste Management Federal Services, Inc., Northwest Operations). 1998b. "Section 18.0, Geophysical Log Data Analysis." In Operational Environmental Monitoring, WMNW-CM-004, Richland, Washington. 


\section{RLS Spectral Gamma Ray Borehole Survey \\ Waste Management Federal Services NW}

\section{Log Header}

Project: PNNL Vadose Zone Monitoring Well: 299-E13-1

Log Type: $\quad$ HPGe Spectral Gamma Ray

Borehole Information

\begin{tabular}{|c|c|c|}
\hline Well \# unk & Water Depth unk & Total Depth $364 \mathrm{ft}$ \\
\hline Elevation Reference $\underline{\mathrm{n} / \mathrm{a}}$ & Elevation $\quad \mathrm{n} / \mathrm{a}$ & \\
\hline Depth Reference Top Casing & Casing Stickup 1.33 & \\
\hline Casing Diameter $\underline{6}$ in & Depth Interval 0 to $100 \mathrm{ft}$ & Thickness \\
\hline Casing Diameter $\underline{8}$ in & Depth Interval 0 to 364 & Thickness \\
\hline
\end{tabular}

Logging Information

Log Type:

Company

Date/Archive File Name

Logging Engineers

Instrument Series

Logging Unit

Depth Interval

Instrument Calibration Date

Calibration Report
10\% HPGe Spectral Gamma Ray

Waste Management NW

July 27, 1999 H2E13001

S. Kos

RLSG01000H00.0

RLS-1

1 to $150 \mathrm{ft}$

145 to $274 \mathrm{ft}$

Prefix AP25

AP26

Jan 19, 1999

WHC-SD-EN-TI-292

Analysis Information

$\begin{array}{ll}\text { Company } & \text { Three Rivers Scientific } \\ \text { Analyst } & \text { Russ Rañdall } \\ \text { Date } & \text { August } 1,-1999 \\ \text { Depth Reference } & \text { Ground Surface (plots depth shifted) }\end{array}$

Notes Cs-137 and Co-60 are the only man made radionuclides detected. High count rate over the depth interval from 12 to 17 feet result in inaccurate dead time correction, and radionuclide concentrations are under reported. 


\section{RLS Spectral Gamma Ray Borehole Survey Waste Management Federal Services NW}

Project: PNNL Vadose Zone Monitoring Log Date: July 26\&27, 1999 Borehole: 299-E13-1

Naturally Occurring Radionuclides

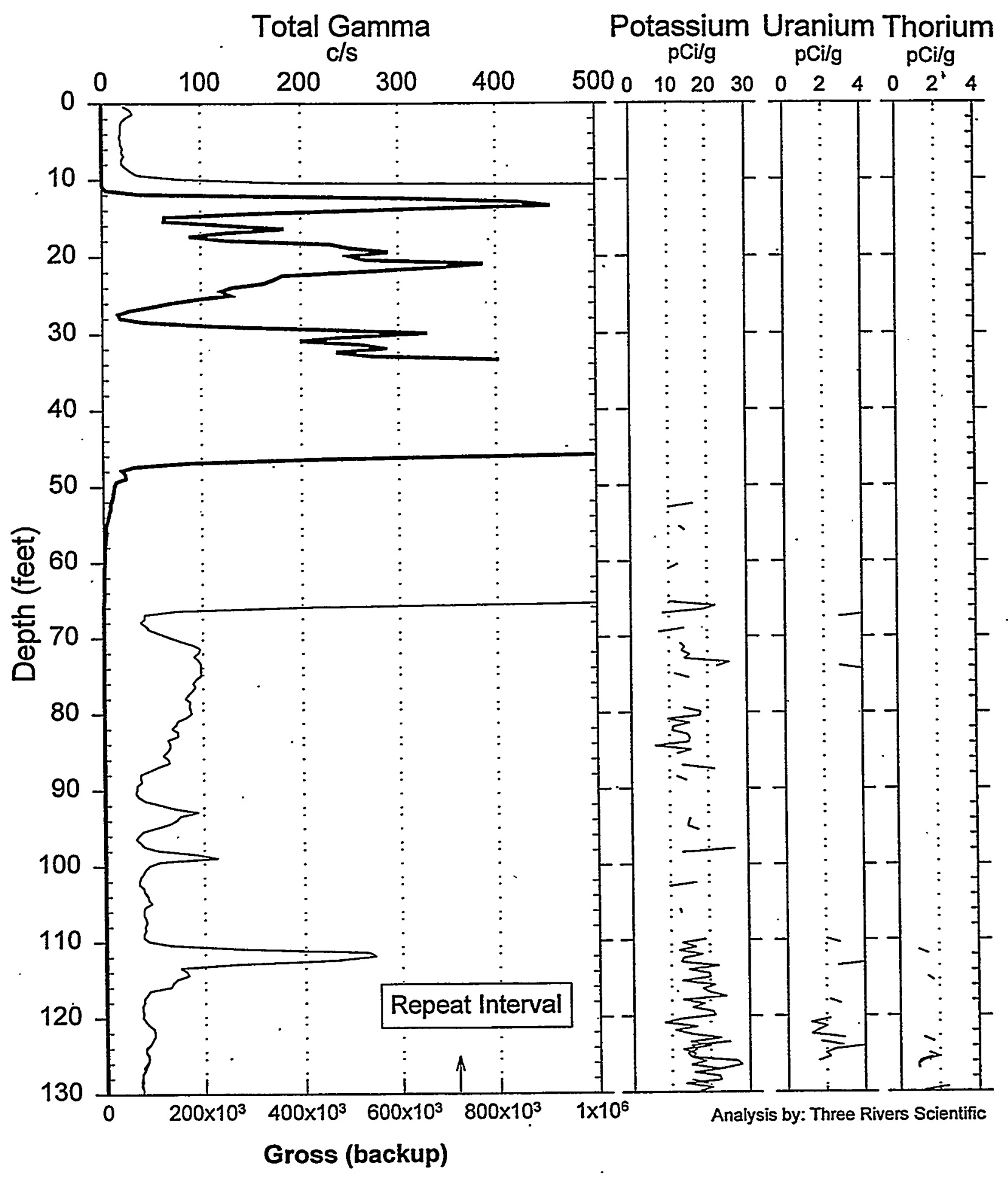




\section{RLS Spectral Gamma Ray Borehole Survey Waste Management Federal Services NW}

Project: PNNL Vadose Zone Monitoring Log Date: July 26\&27, 1999 Borehole: 299-E13-1

Naturally Occurring Radionuclides

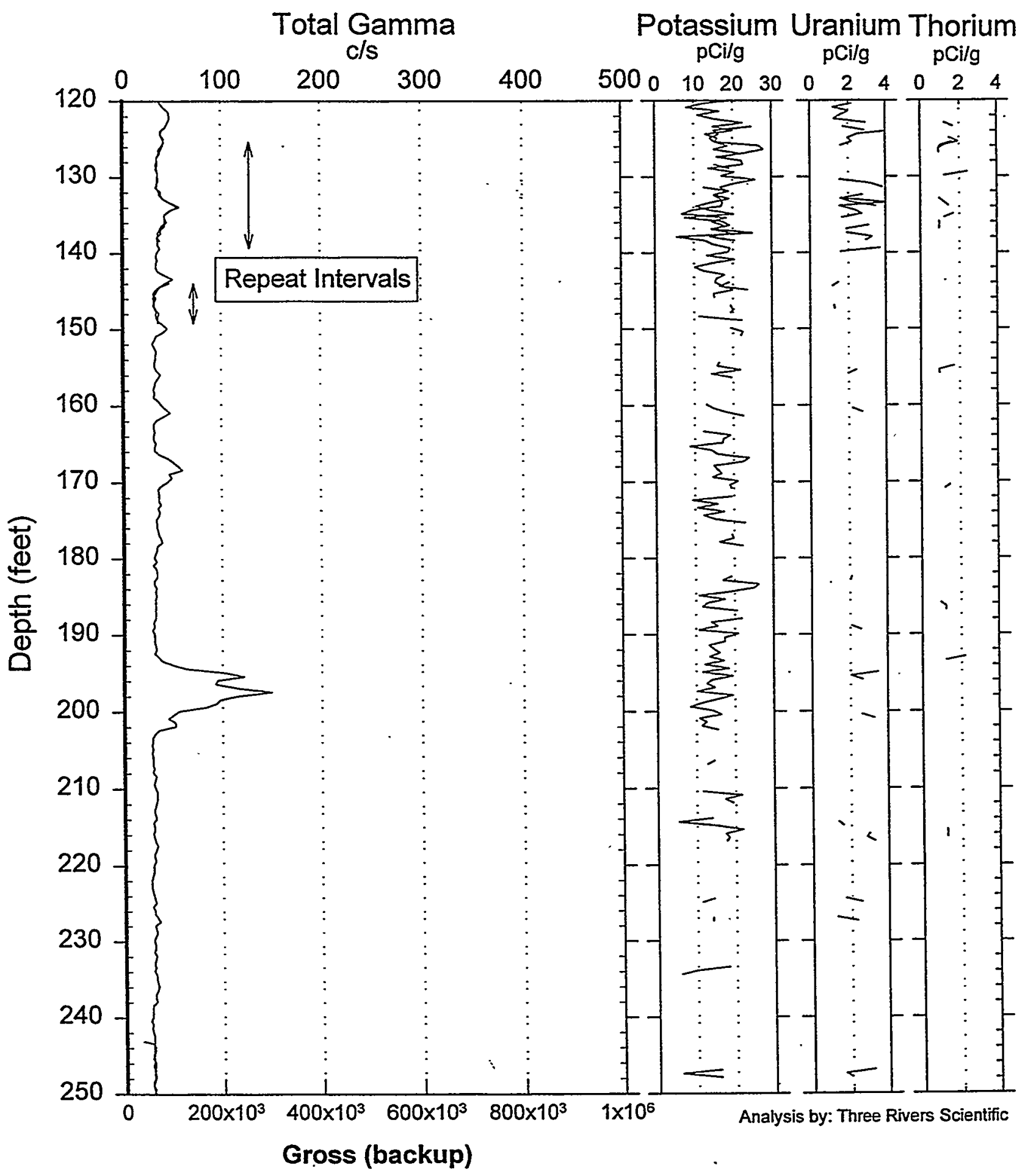




\section{RLS Spectral Gamma Ray Borehole Survey \\ Waste Management Federal Services NW}

Project: PNNL Vadose Zone Monitoring Log Date: July 26\&27, 1999 Borehole: 299-E13-1

Naturally Occurring Radionuclides

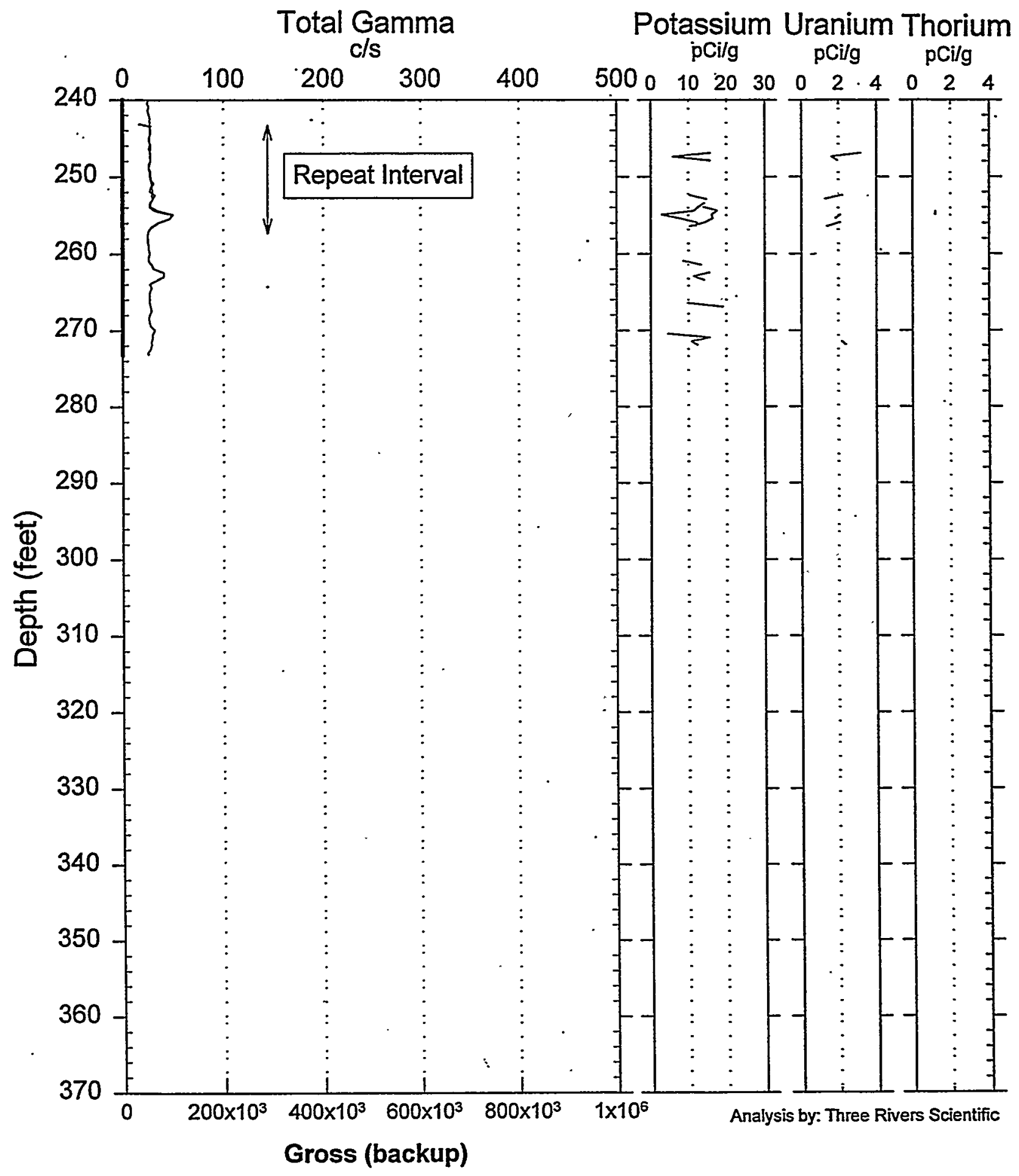




\section{RLS Spectral Gamma-Ray Borehole Survey Waste Management Federal Services NW}

Project: PNNL Vadose Zone Monitoring Log Date: July 26\&27, 1999 Borehole: 299-E13-1

Man-Made Radio-Nuclides

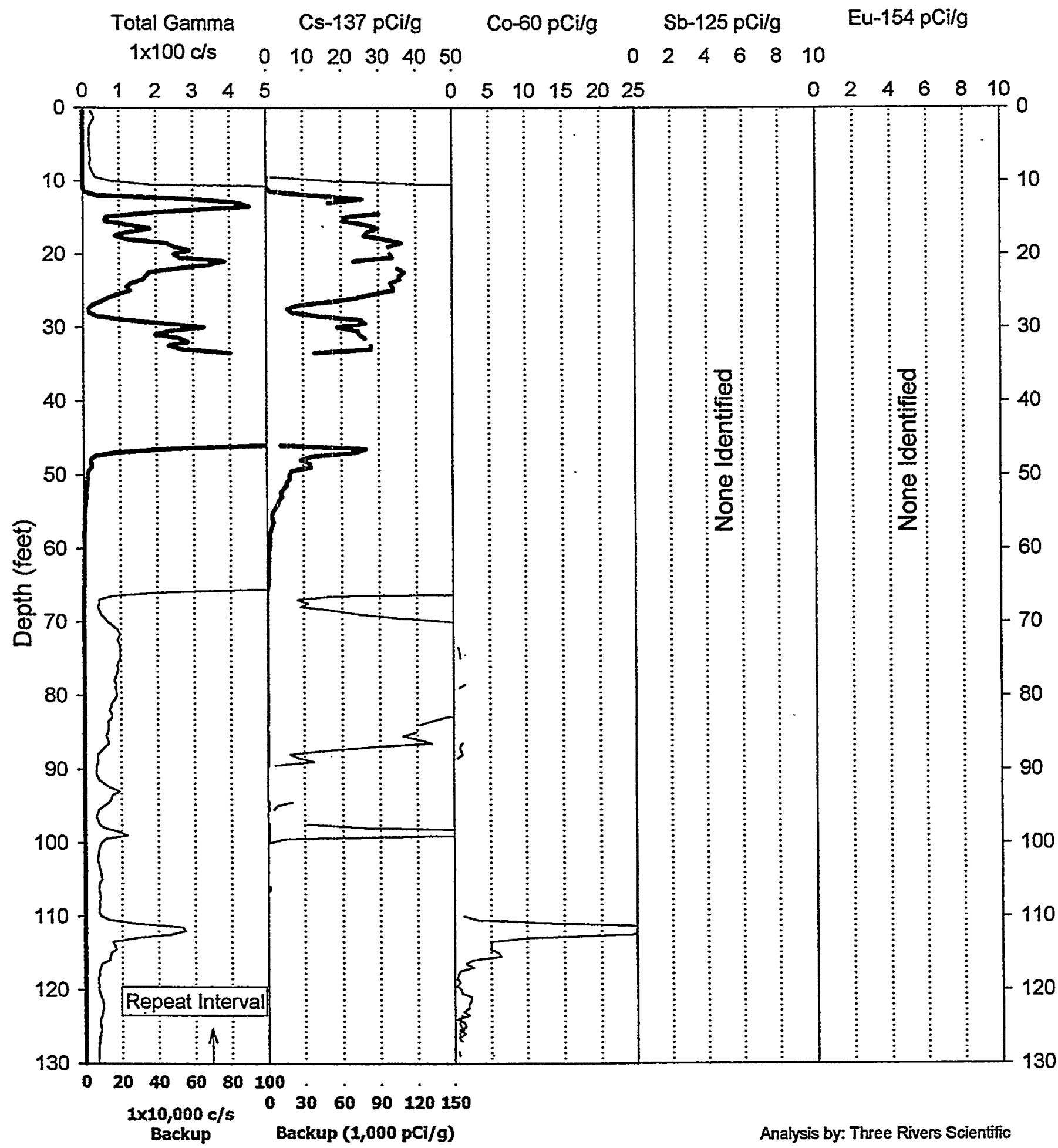


RLS Spectral Gamma-Ray Borehole Survey

\section{Waste Management Federal Services NW}

Project: PNNL Vadose Zone Monitoring Log Date: July 26\&27, 1999 Borehole: 299-E13-1 Man-Made Radio-Nuclides

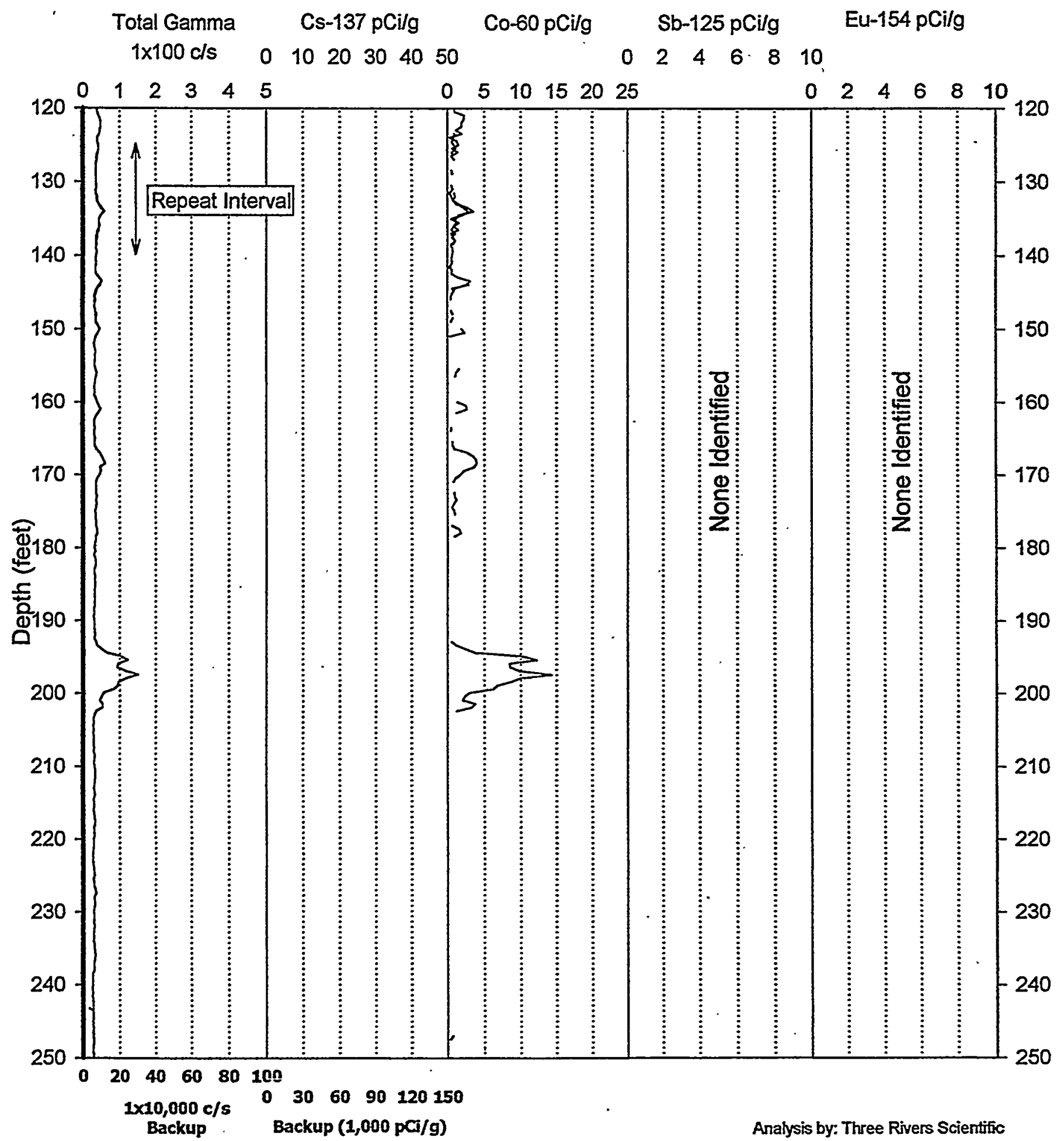

B.7 


\section{RLS Spectral Gamma-Ray Borehole Survey Waste Management Federal Services NW}

Project: PNNL Vadose Zone Monitoring Log Date: July 26\&27, 1999 Borehole: 299-E13-1

Man-Made Radio-Nuclides

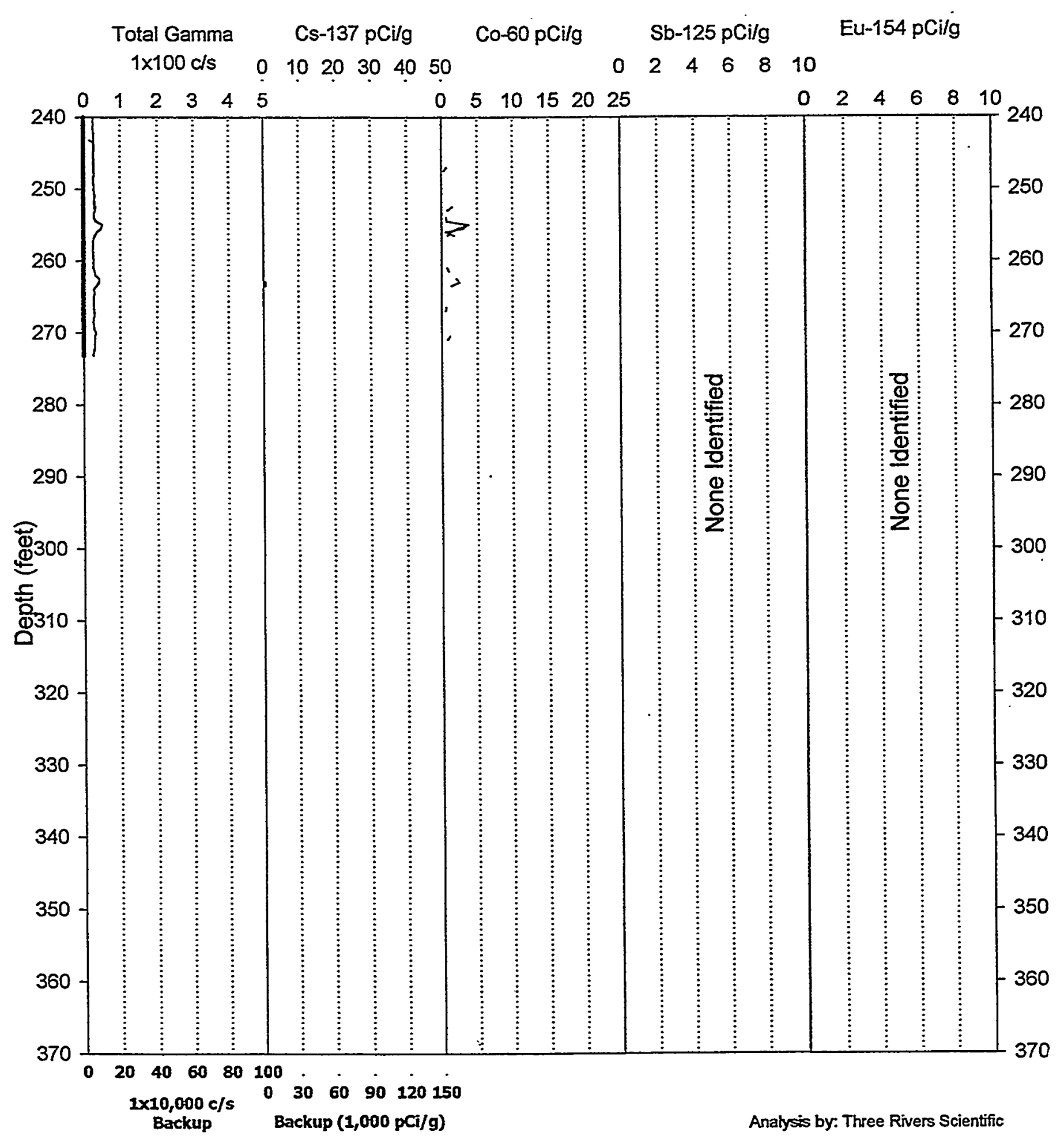




\section{RLS Spectral Gamma Ray Borehole Survey Acceptance QA Processing}

Project: PNNL Vadose Zone Monitoring Borehole: 299-E13-1

Log Date: July. 26\&27, 1999 Compare Main Log \& Repeat

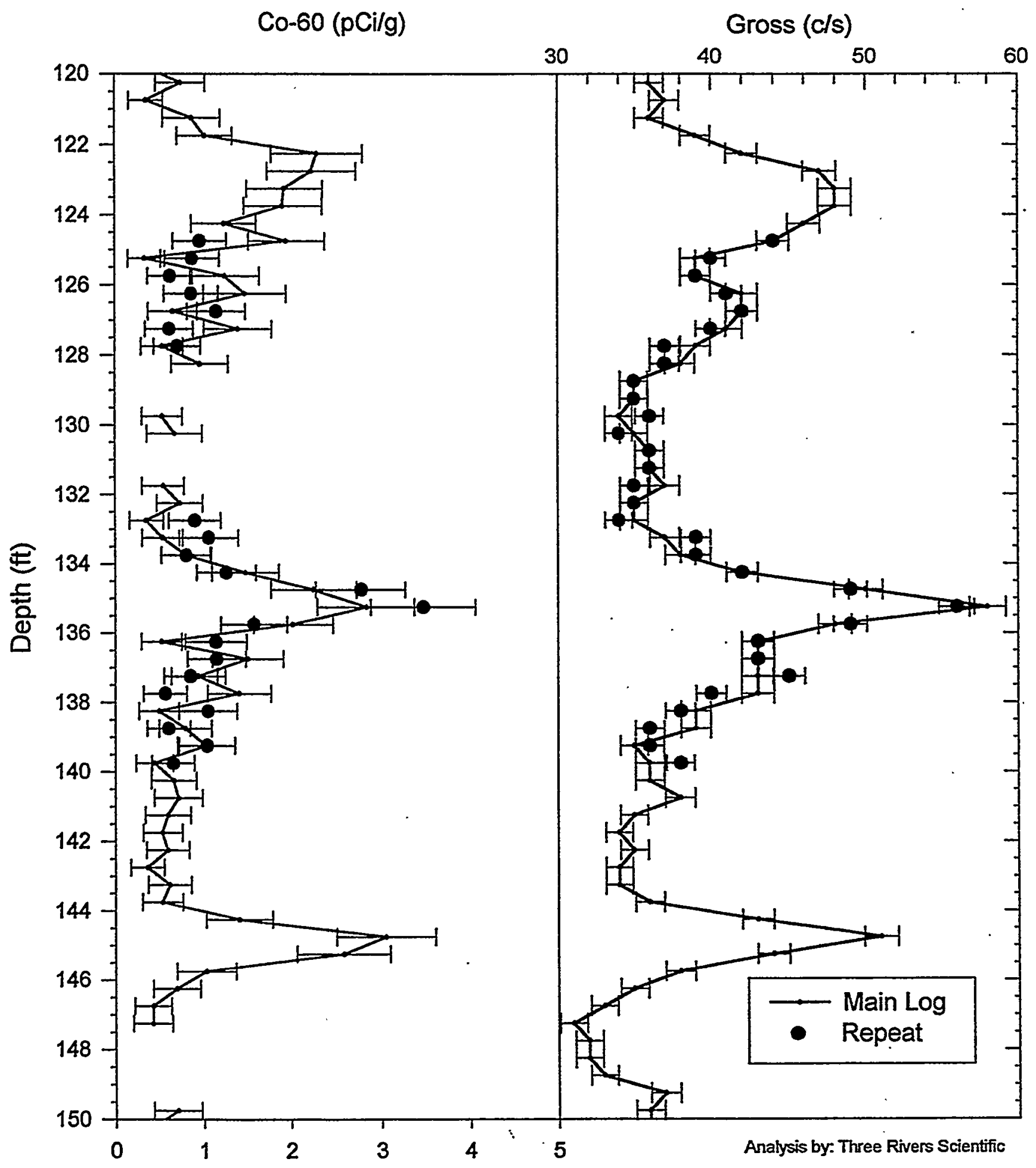




\section{RLS Spectral Gamma Ray Borehole Survey \\ Waste Management Federal Services NW}

\section{Log Analysis Summary Report}

Project: $\quad$ PNNL Vadose Zone Monitoring

Log Type: $\quad$ HPGe Spectral Gamma Ray
Well:

299-E13-1

Log Dates: July 26\&27, 1999

\section{General Notes:}

Total gamma is mostly a response to gamma emitting contaminants and no lithologic information is possible from the gross gamma response.

Log data collected with a depth reference of top of casing, and during analysis the depths were shifted to ground surface reference for all plots.

System Performance Verify: The pre- and post-log verification passed performance standards.

Repeat Interval: Based on the repeat interval, the logging system performed as per specifications. The error bars are calculated for 1 standard deviation of the net photo peak count rate statistical variance. Thus, the repeat should fall within these error bars $67 \%$ of the time.

Environmental Corrections: All radionuclide concentrations have been corrected for casing attenuation (entire well). Water level is below depths logged. No casing correction was applied to the total gamma due to Compton downscatter interference.

High count rates over the depth interval from 12 to 17 feet result in inaccurate dead time correction, and all radionuclides are under reported in this interval.

\section{Radionuclides:}

Cs-137 was identified over the depths from 10-100 feet. The maximum concentration of Cs-137 occurs somewhere between 33 and 47 feet, with a value greater than $100,000 \mathrm{pCi} / \mathrm{g}$. The Cs-137 MDL value for these log data is near $4 \mathrm{pCi} / \mathrm{g}$.

Co-60 was identified over the depths from 73-202 feet, and from 252-256 feet. (Note, the Co-60 from 252-256 feet is at detection threshold, but a summing by 4 technique confirms its presence.) The maximum concentration of Co-60 occurs at a depth of 111 feet, with a reading of $28 \mathrm{pCi} / \mathrm{g}$. The Co-60 MDL value for these log data is 2 $\mathrm{pCi} / \mathrm{g}$. 


\section{Moisture Logging Service \\ Log Header}

Project: $\quad$ PNNL Vadose Zone Monitoring

Well: 299-E13-1

Log Type: Moisture Gauge

Borehole Information

\begin{tabular}{|c|c|c|}
\hline Well \# $\underline{\mathrm{n} / \mathrm{a}}$. & Water Depth $\quad \underline{n} / \mathrm{a}$ & Total Depth $364 \mathrm{ft}$ \\
\hline Elevation Reference $\mathrm{n} / \mathrm{a}$ & Elevation & \\
\hline Depth Reference Top Casing & Casing Stickup 1.33 & $\cdot$ \\
\hline Casing Diameter $\underline{6}$ in & Depth Interval 0 to 100 & Thickness .25 \\
\hline Casing Diameter 8 & Depth Interval 0 to 364 & Thickness .32 \\
\hline
\end{tabular}

Logging Information

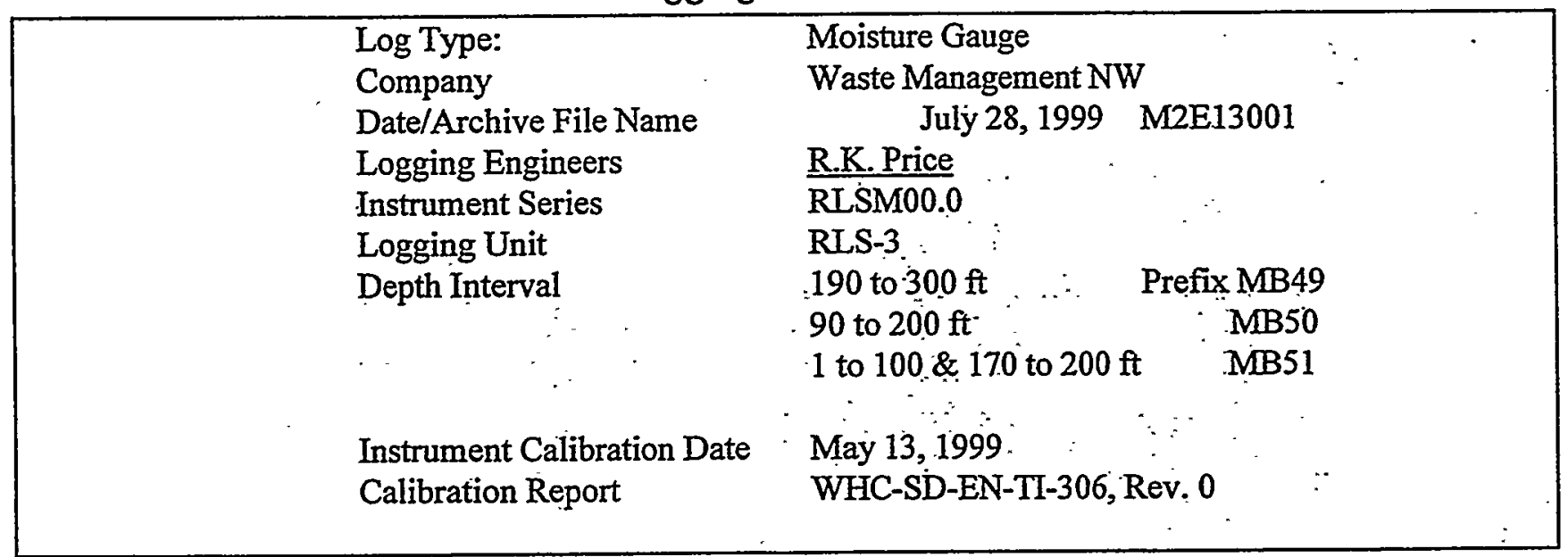

Analysis Information

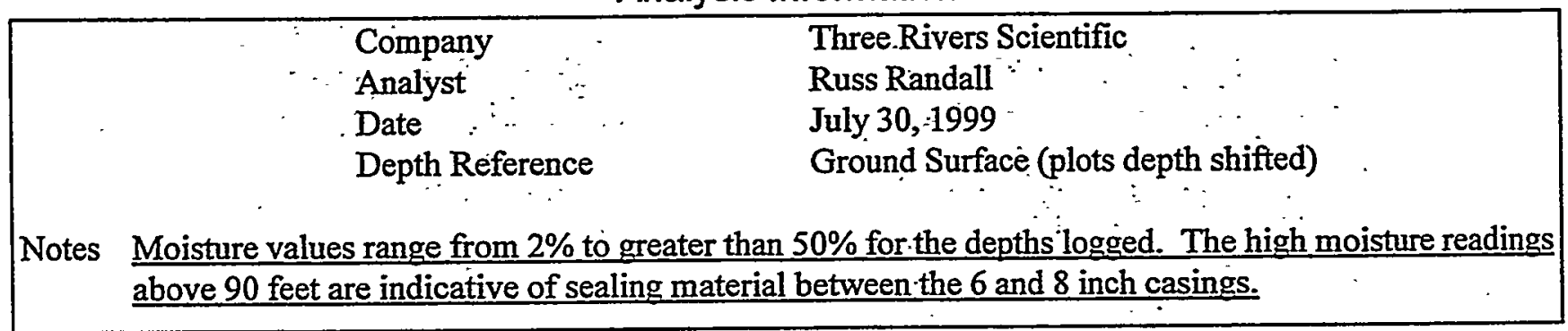




\section{RLS Moisture Processed Log Data}

\section{Waste Management Federal Services NW}

Project: Vadose Zone Monitoring Borehole: 299-E13-1

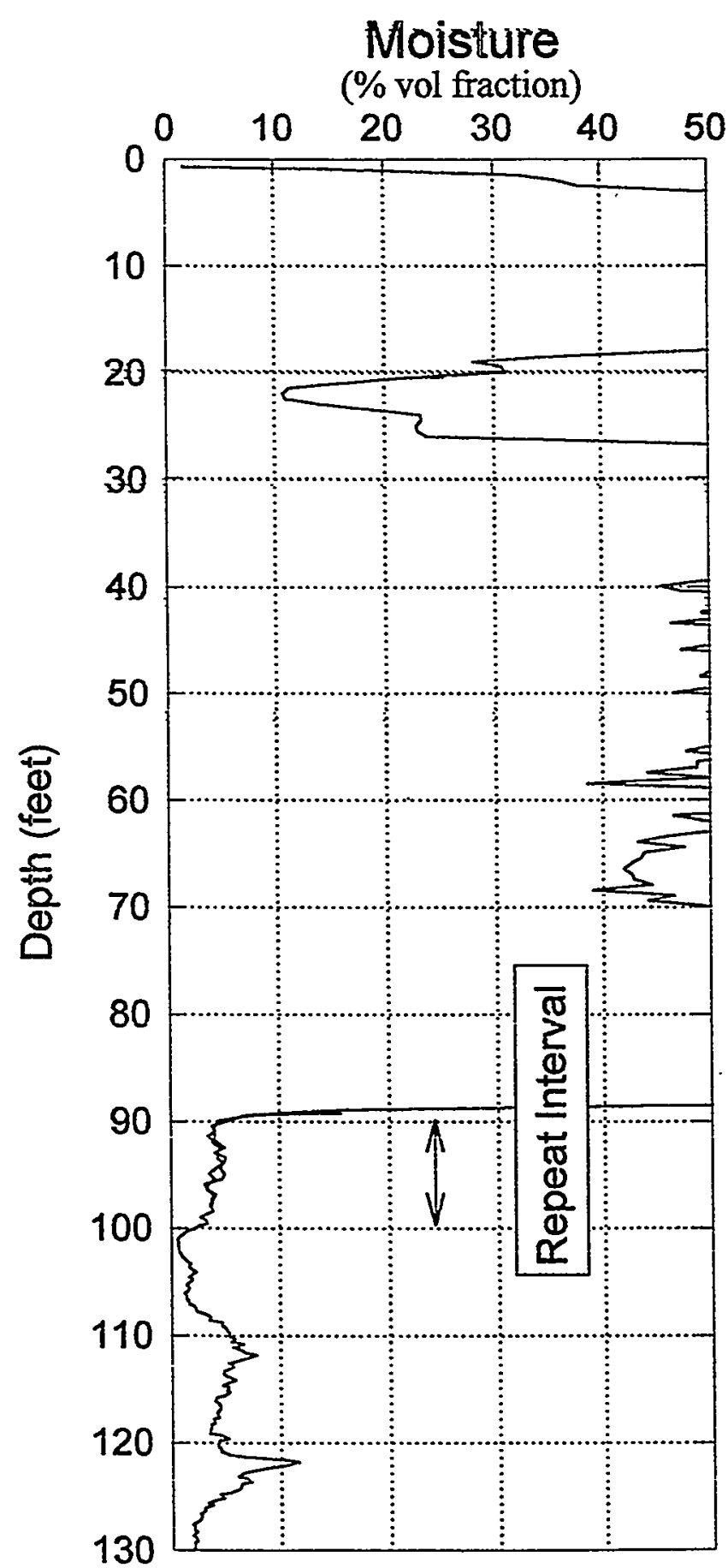

8" Casing Calibration Log Date July 27\&28, 1999

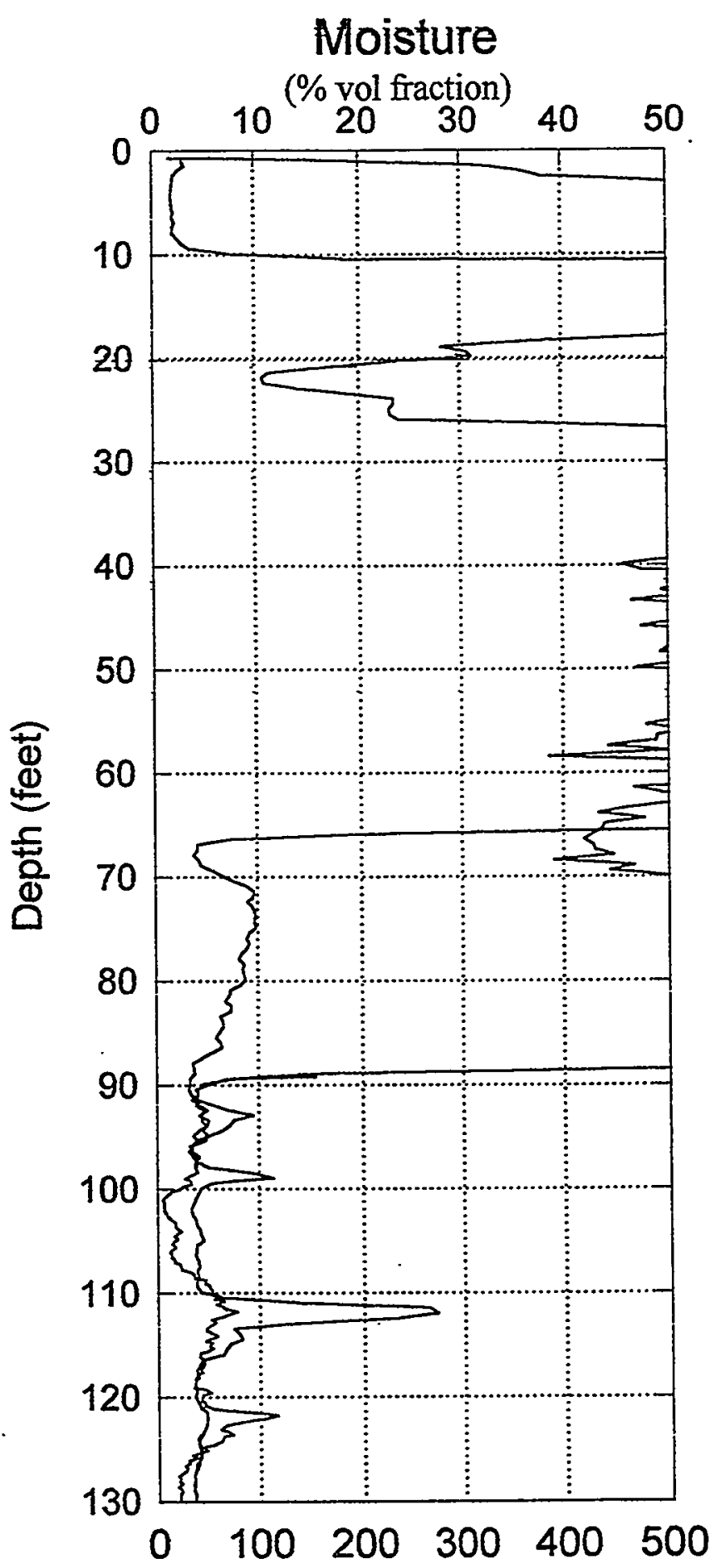

B. 12 


\section{RLS Moisture Processed Log Data}

Waste Management Federal Services NW

Project: Vadose Zone Monitoring Borehole: 299-E13-1

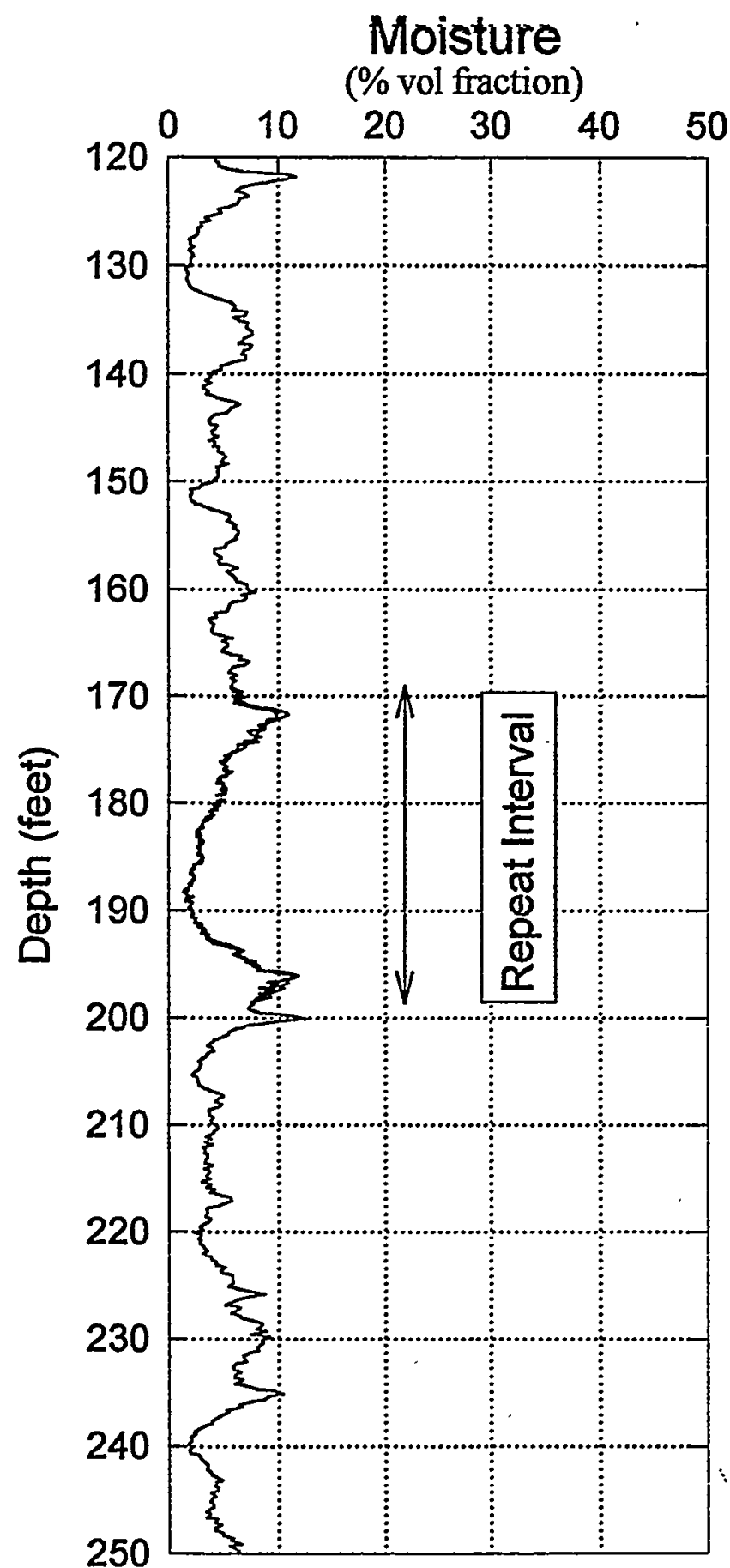

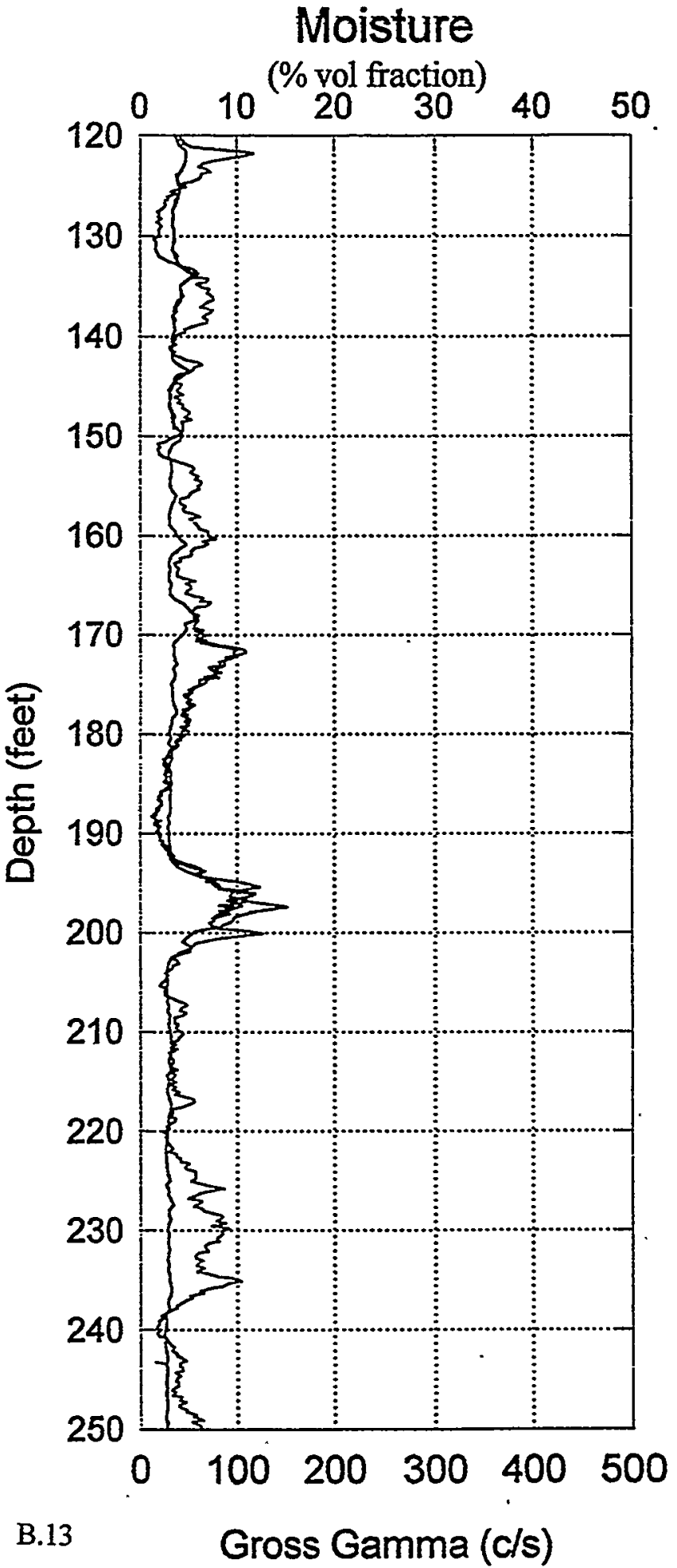




\section{RLS Moisture Processed Log Data}

\section{Waste Management Federal Services NW}

Project: Vadose Zone Monitoring Borehole: 299-E13-1

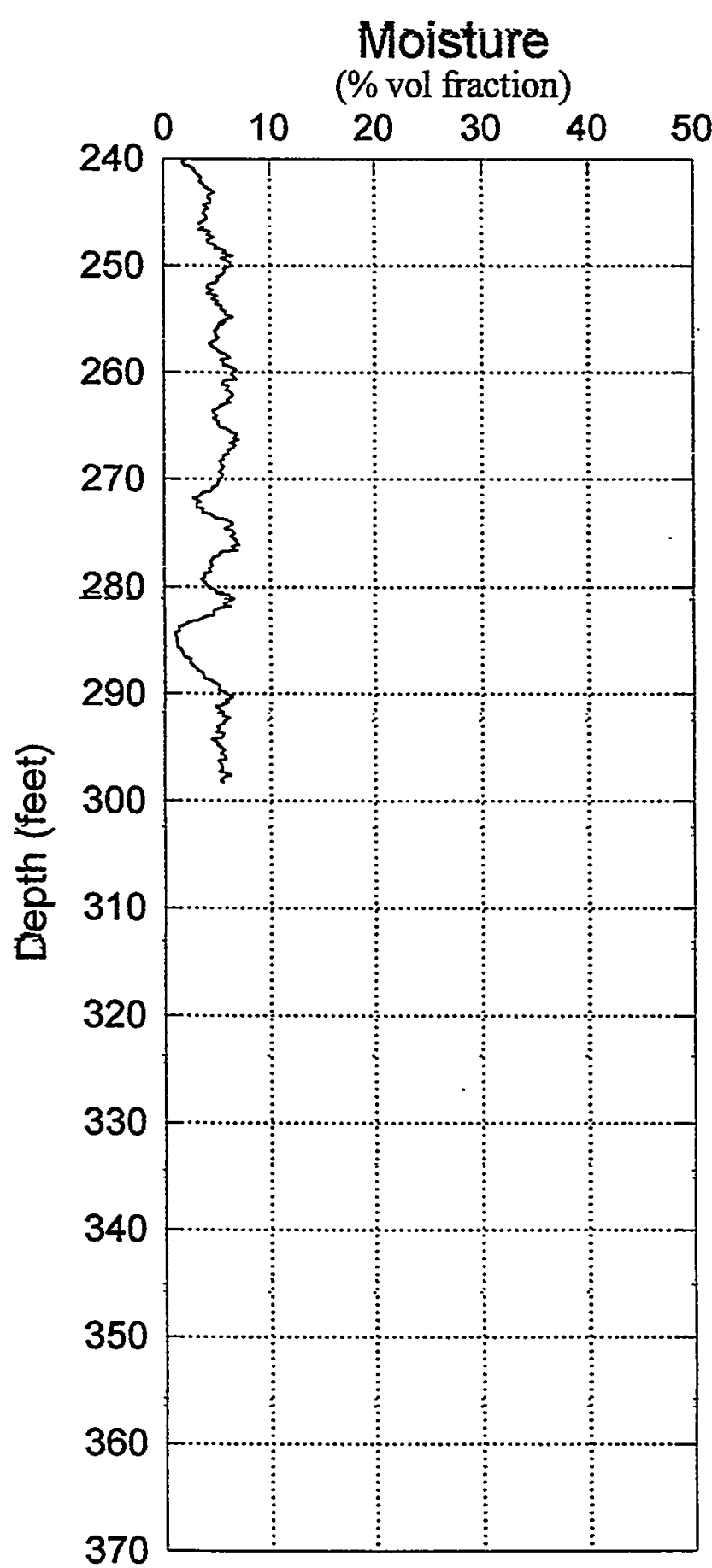

8" Casing Calibration Log Date July 27\&28, 1999.

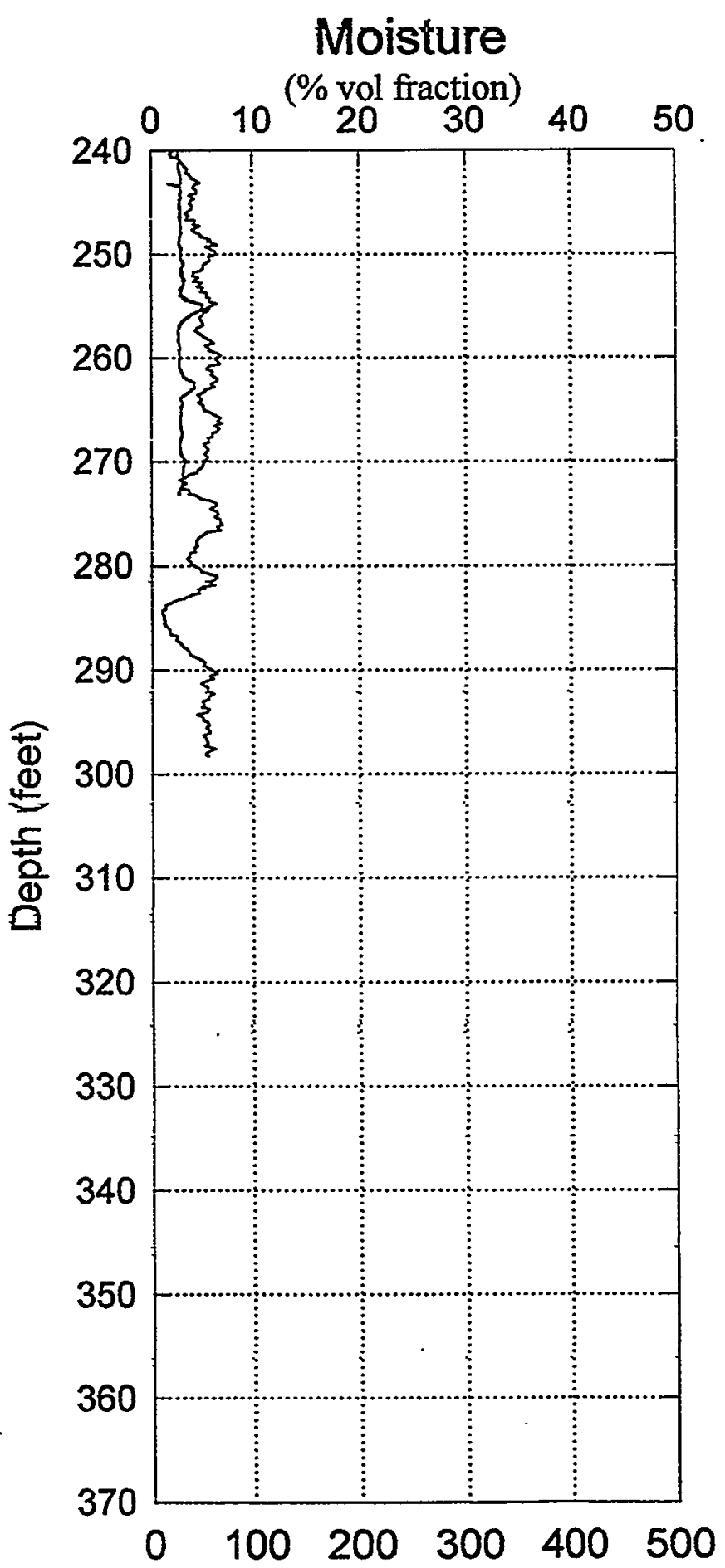

B. 14

Gross Gamma (c/s) 


\section{RLS \\ Log Analysis \& Summary .}

$\begin{array}{lllr}\text { Project: } & \text { PNNL Vadose Zone Monitoring } & \text { Well ID: } & \text { 299-E13-1 } \\ \text { Log Type: } & \text { Moisture Gauge } & \text { Log Dates: July 27 \& 28, 1999 }\end{array}$

\section{General Notes:}

The low reading from 0 feet to 2 feet is due to surface effects and not necessarily the moisture content of the sediments surrounding the borehole.

Log data collected with a depth reference of top of casing, and during analysis the depths were shifted to ground surface reference for all plots.

System Performance Verify: The pre- and post-log verification passed performance standards, $+1.9 \%$ day one and $-0.1 \%$ day two in the shield verify.

Repeat Interval: Based on the repeat interval from 90 to 100 feet and from 169 to 199 feet, the logging system performed according to specifications.

Environmental Corrections: The moisture levels have been corrected for casing attenuation (entire well). Dual casing thickness corrections are applied to depths below 90 feet.

\section{Observations:}

The moisture levels shows values ranging from 32 to greater than $50 \%$ for depth interval from 2 feet to 299 feet. The abnormally high readings above 90 feet are indicative of the sealing material between the casings, and are not indicative of the vadose zone moisture content. 


\section{RLS Spectral Gamma Ray Borehole Survey \\ Waste Management Federal Services NW}

\section{Log Header}

Project: PNNL Vadose Zone Monitoring Well: 299-E13-2

Log Type: $\quad H P G e$ Spectral Gamma Ray

Borehole Information

\begin{tabular}{|c|c|c|c|}
\hline Well \# unk & Water Depth & $\mathrm{ft}$ & Total Depth $365 \mathrm{ft}$ \\
\hline Elevation Reference $\mathrm{n} / \mathrm{a}$ & Elevation $\mathrm{n} / \mathrm{a}$ & $\mathrm{ft}$ & \\
\hline Depth Reference Top Casing & Casing Stickup 0.8 & $\mathrm{ft}$ & \\
\hline Casing Diameter $\underline{8}$ in & Depth Interval 0 to 365 & ft & Thickness $\quad 0.3125$ in \\
\hline
\end{tabular}

\section{Logging Information}

\begin{tabular}{lll}
$\begin{array}{l}\text { Log Type: } \\
\text { Company }\end{array}$ & $\begin{array}{l}10 \% \text { HPGe Spectral Gamma Ray } \\
\text { Date/Archive File Name }\end{array}$ & \multicolumn{2}{c}{$\begin{array}{c}\text { July 26, 1999 } \\
\text { Logging Engineers }\end{array}$} & R.K. Price & \\
Instrument Series & RLSG01000H00.0 & \\
Logging Unit & RLS-1 & \\
Depth Interval & 1 to $137 \mathrm{ft}$ & Prefix AP23 \\
& 130 to $200 \mathrm{ft}$ & Prefix AP24
\end{tabular}

Instrument Calibration Date Jan 19, 1999

Calibration Report WHC-SD-EN-TI-292

Analysis Information

$\begin{array}{ll}\text { Company } & \text { Three Rivers Scientific } \\ \text { Analyst } & \text { Russ Randall } \\ \text { Date } & \text { August 1, 1999 } \\ \text { Depth Reference } & \text { Ground Surface (plots depth shifted) }\end{array}$

Notes Cs-137. Co-60, and Eu-154 are the only man made radionuclides detected. Detection of Co-60 occurs at normal analysis methods, but summing technique confirms the presence. Detection of Eu-154 does not occur with standard analysis, but its presence is definite using the summing technique. 


\section{RLS Spectral Gamma Ray Borehole Survey \\ Waste Management Federal Services NW}

Project: PNNL Vadose Zone Monitoring Log Date: July 22\&26, 1999 Borehole: 299-E13-2

Naturally Occurring Radionuclides

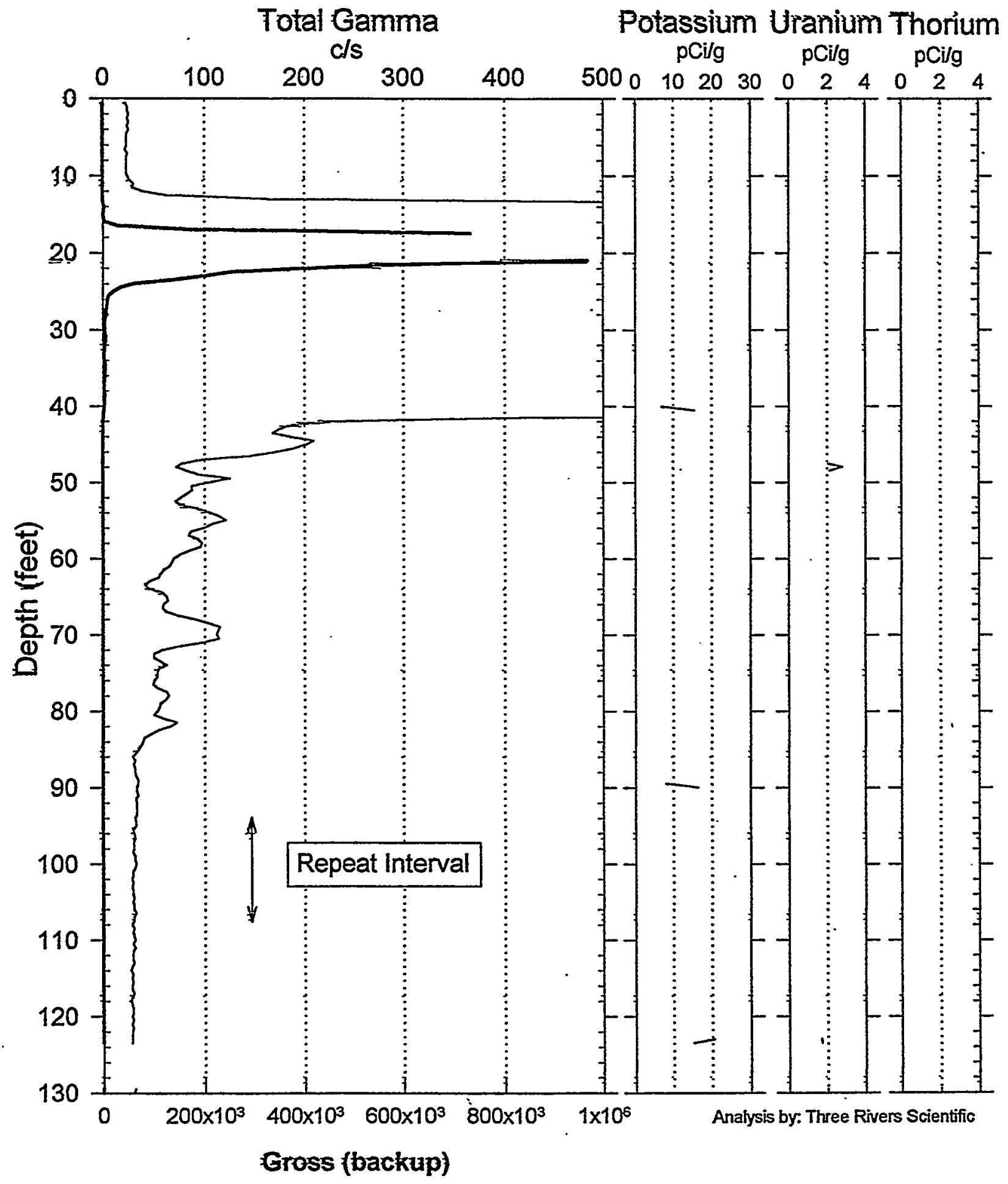




\section{RLS Spectral Gamma Ray Borehole Survey Waste Management Federal Services NW}

Project: PNNL Vadose Zone Monitoring Log Date: July 22\&26, 1999 Borehole: 299-E13-2

Naturally Occurring Radionuclides

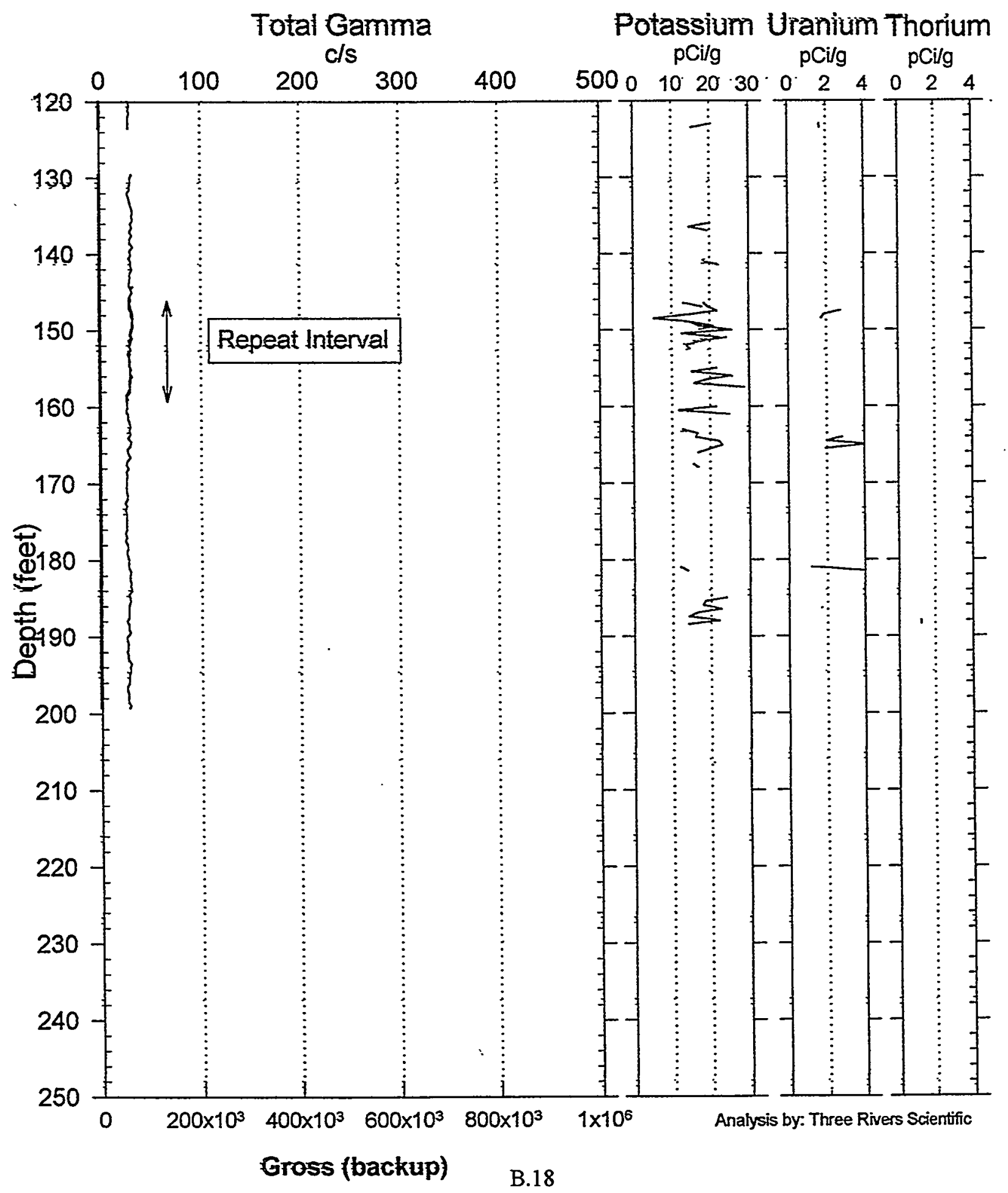


RLS Spectral Gamma-Ray Borehole Survey

\section{Waste Management Federal Services NW}

Project: PNNL Vadose Zone Monitoring Log Date: July 22\&26, 1999 Borehole: 299-E13-2 Man-Made Radio-Nuclides

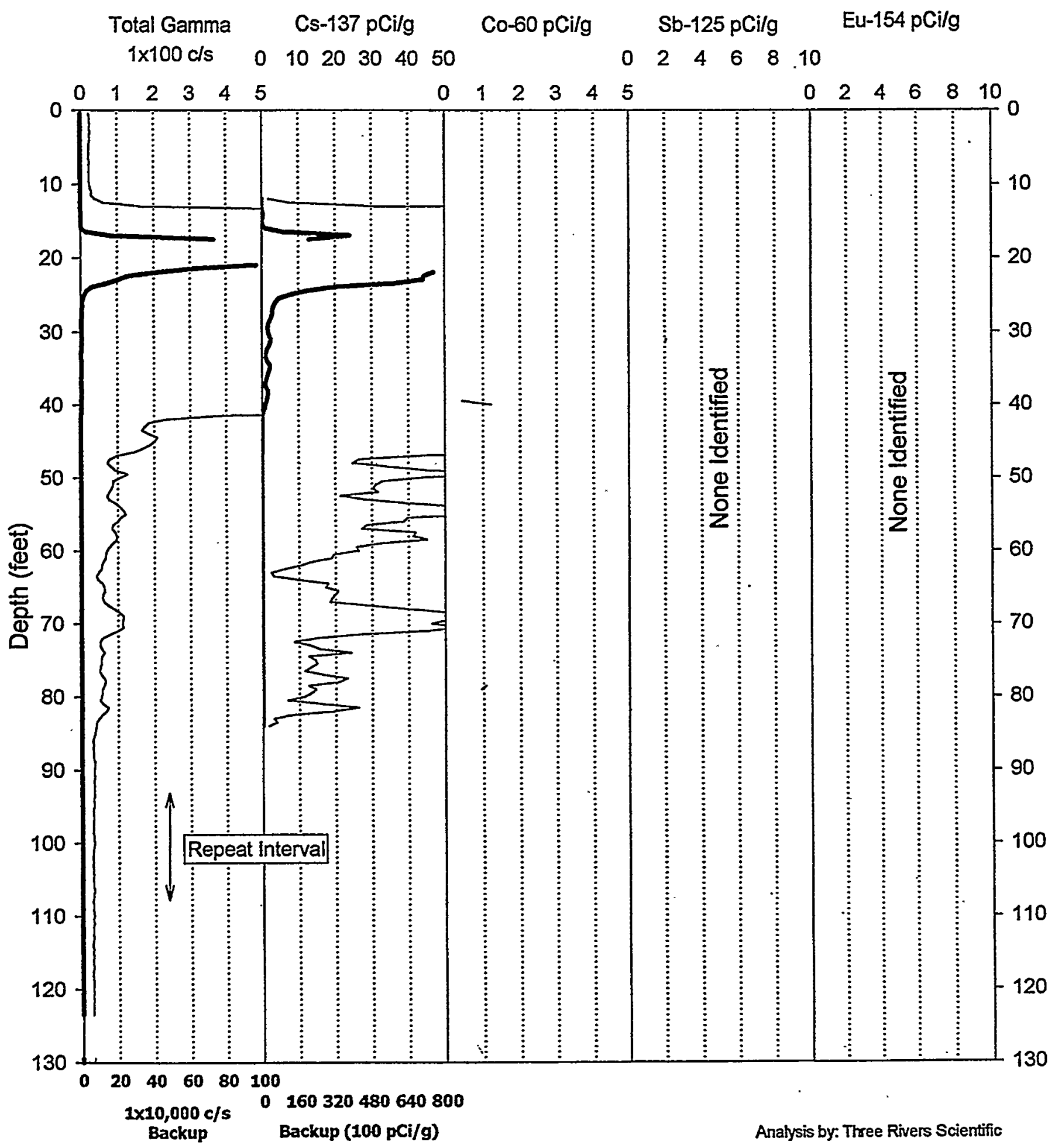

B.19 


\section{RLS Spectral Gamma-Ray Borehole Survey \\ Waste Management Federal Services NW}

Project: PNNL Vadose Zone Monitoring Log Date: July 22\&26, 1999 Borehole: 299-E13-2

Man-Made Radio-Nuclides

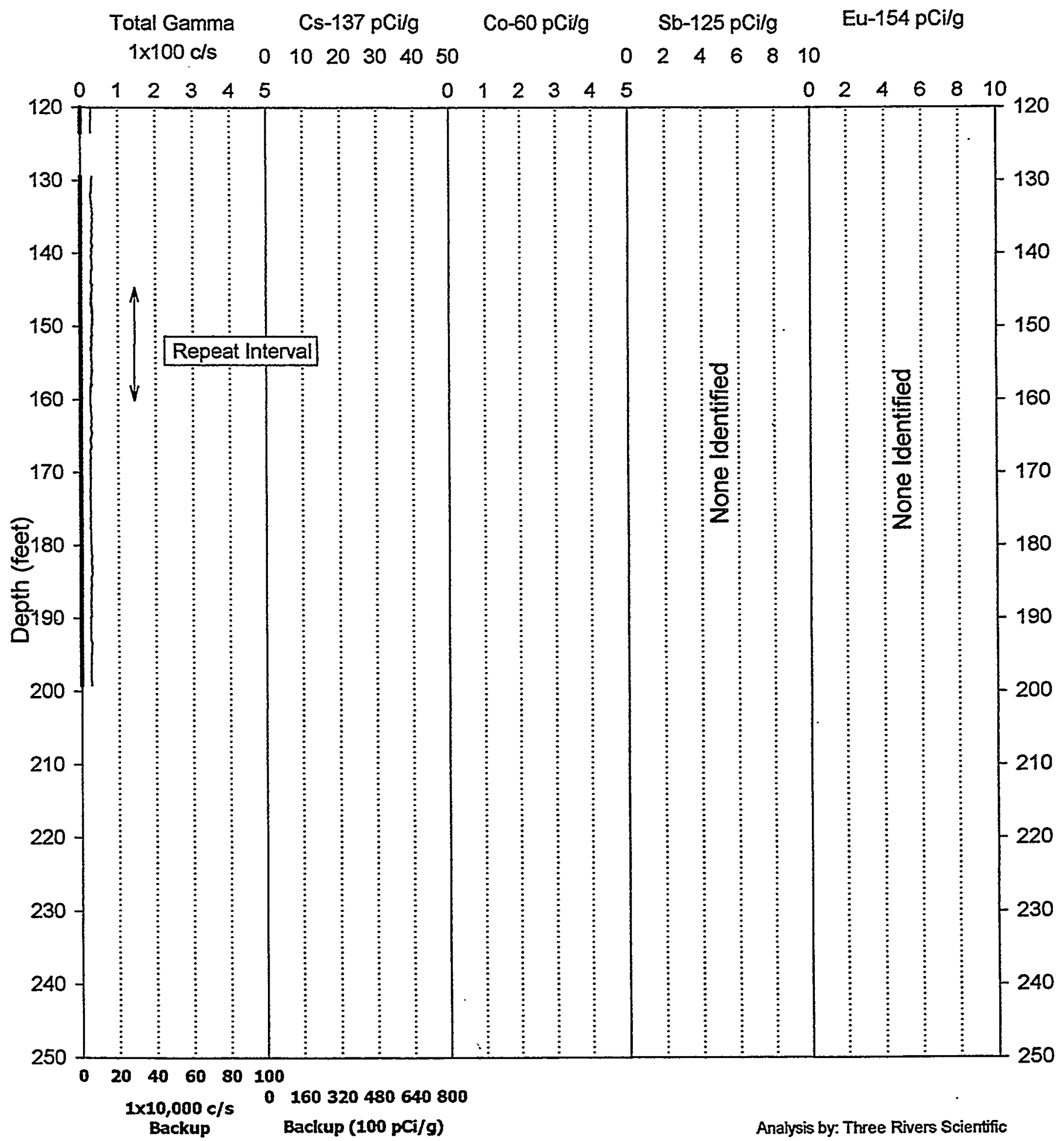




\section{RLS Spectral Gamma Ray Borehole Survey Acceptance QA Processing}

Project: PNN Vadose Zone Monitoring Borehole: , 299-E13-2
Log Date: July 22\&26, 1999

Compare Main Log \& Repeat

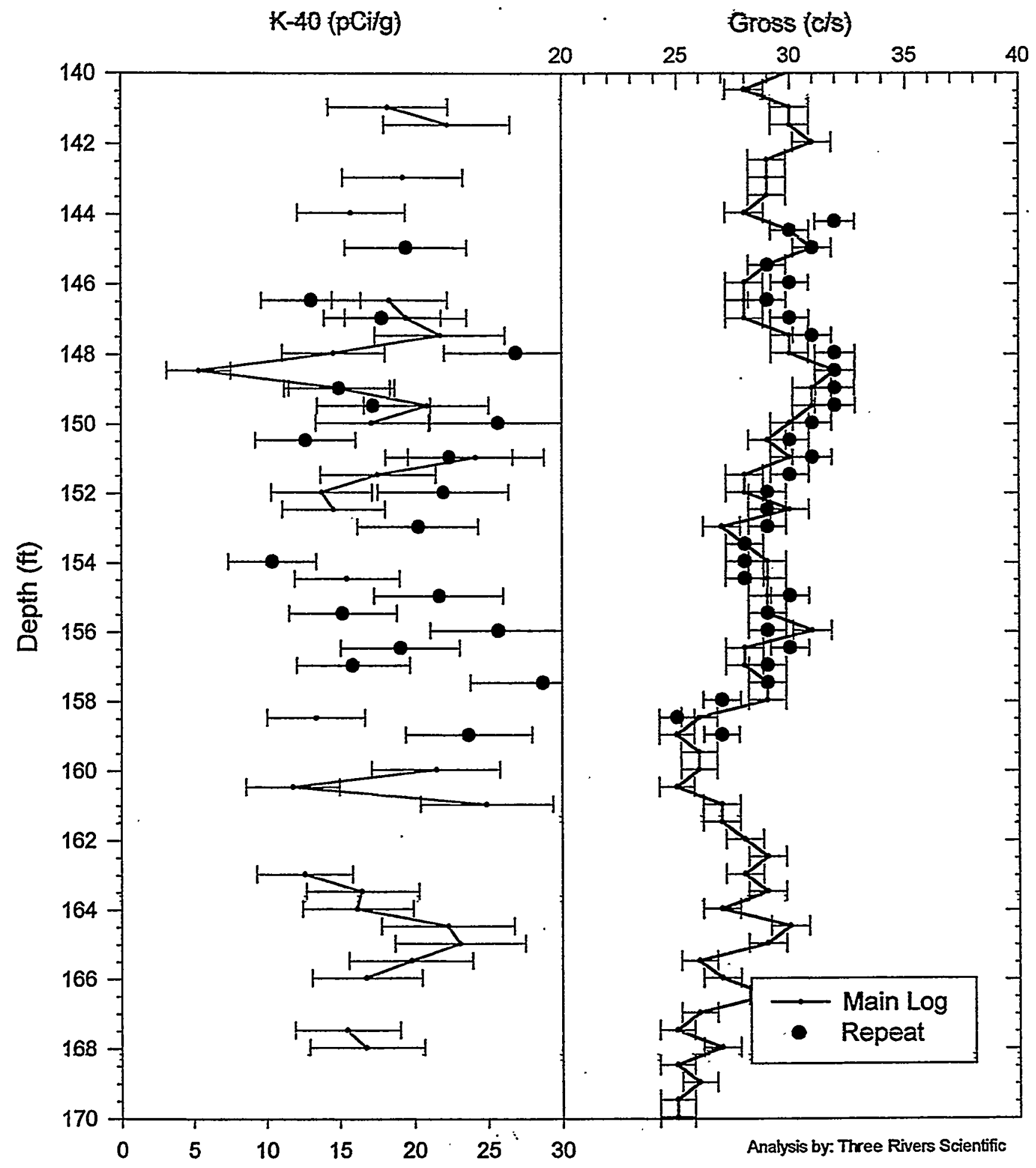




\title{
RLS Spectral Gamma Ray Borehole Survey \\ Waste Management Federal Services NW
}

\section{Log Analysis Summary Report}

\author{
Project: $\quad$ PNNL Vadose Zone Monitoring \\ Well: \\ 299-E13-2 \\ Log Type: HPGe Spectral Gamma Ray \\ Log Dates: July 22\&26, 1999
}

\section{General Notes:}

Total gamma is a response to geologic concentrations of natural radionuclides except for the depth interval from 11-82 feet.

Log data collected with a depth reference of top of casing, and during analysis the depths were shifted to ground surface reference for all plots.

Log data over the depths from 124 to 130 were lost due to computer malfunction.

System Performance Verify: The pre- and post-log verification passed performance standards.

Repeat Interval: Based on the repeat interval, the logging system performed as per specifications. The error bars are calculated for 1 standard deviation of the net photo peak count rate statistical variance. Thus, the repeat should fall within these error bars $67 \%$ of the time. The low sensitivity of the instrumentation results in loss of KUT signals in clean sections of the well.

Environmental Corrections: All radionuclide concentrations have been corrected for casing attenuation (entire well). Water level is below depths logged. No casing correction was applied to the total gamma due to Compton downscatter interference.

\section{Radionuclides:}

Cs-137 was identified over the depths from 11-83 feet. The maximum concentration of Cs-137 occurs at a depth of 22 feet, where the instrument saturates. Since the instrument saturated the maximum value is over $100,000 \mathrm{pCi} / \mathrm{g}$. The Cs-137 MDL value for these $\log$ data is $2 \mathrm{pCi} / \mathrm{g}$.

Co-60 was identified over the depths from 35-80 feet. (Note, the Co-60 is at detection threshold, but a summing by 4 technique confirms its presence.) The maximum concentration of $\mathrm{Co}-60$ occurs at a depth of 41 feet, with a reading of $1 \mathrm{pCi} / \mathrm{g}$, which is statistically in-significant since the Co-60 MDL value for these log data is $1.5 \mathrm{pCi} / \mathrm{g}$.

Eu-154 was only identified using a summing by 4 technique. The normal analysis does not identify the presence of Eu-154. 


\section{Moisture Logging Service Log Header}

Project: $\quad$ PNNL Vadose Zone Monitoring

Well: 299-E13-2

Log Type: $\quad$ Moisture Gauge

Borehole Information

\begin{tabular}{|c|c|c|c|}
\hline Well \# unk & Water Depth & $250 \quad \mathrm{ft}$ & Total Depth $365 \mathrm{ft}$ \\
\hline Elevation Reference $\mathrm{n} / \mathrm{a}$ & Elevation & $\mathrm{n} / \mathrm{a}$ & \\
\hline Depth Reference Iop Casing & Casing Stickup & 0.8 & \\
\hline Casing Diameter 8 in & Depth Interval & 365 & Thickness _.3125 in \\
\hline
\end{tabular}

Logging Information

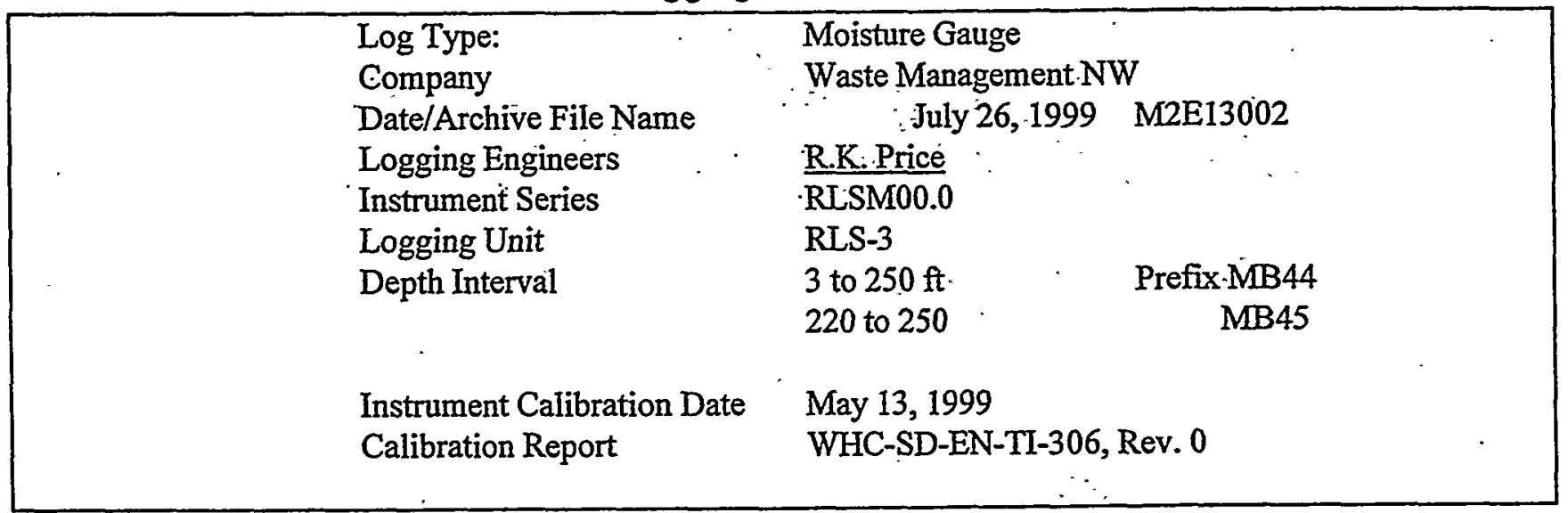

Analysis Information

\begin{tabular}{|c|c|c|}
\hline & $\begin{array}{l}\text { Company } \\
\text { Analyst } \\
\text { Date } \\
\text { Depth Reference }\end{array}$ & $\begin{array}{l}\text { Three Rivers Scientific } \\
\text { Russ Raridall } \\
\text { August 1, 1999 } \\
\text { Ground Surface (plots depth shifted) }\end{array}$ \\
\hline Notes & $\begin{array}{l}\text { Moisture values range from } 2 \% \text { to } \\
\text { due to water level in the borehole. }\end{array}$ & lepths logged. The high moisture reading at 250 feet is \\
\hline
\end{tabular}




\section{RLS Moisture Processed Log Data Waste Management Federal Services NW}

Project: Vadose Zone Monitoring

Borehole: 299-E13-2

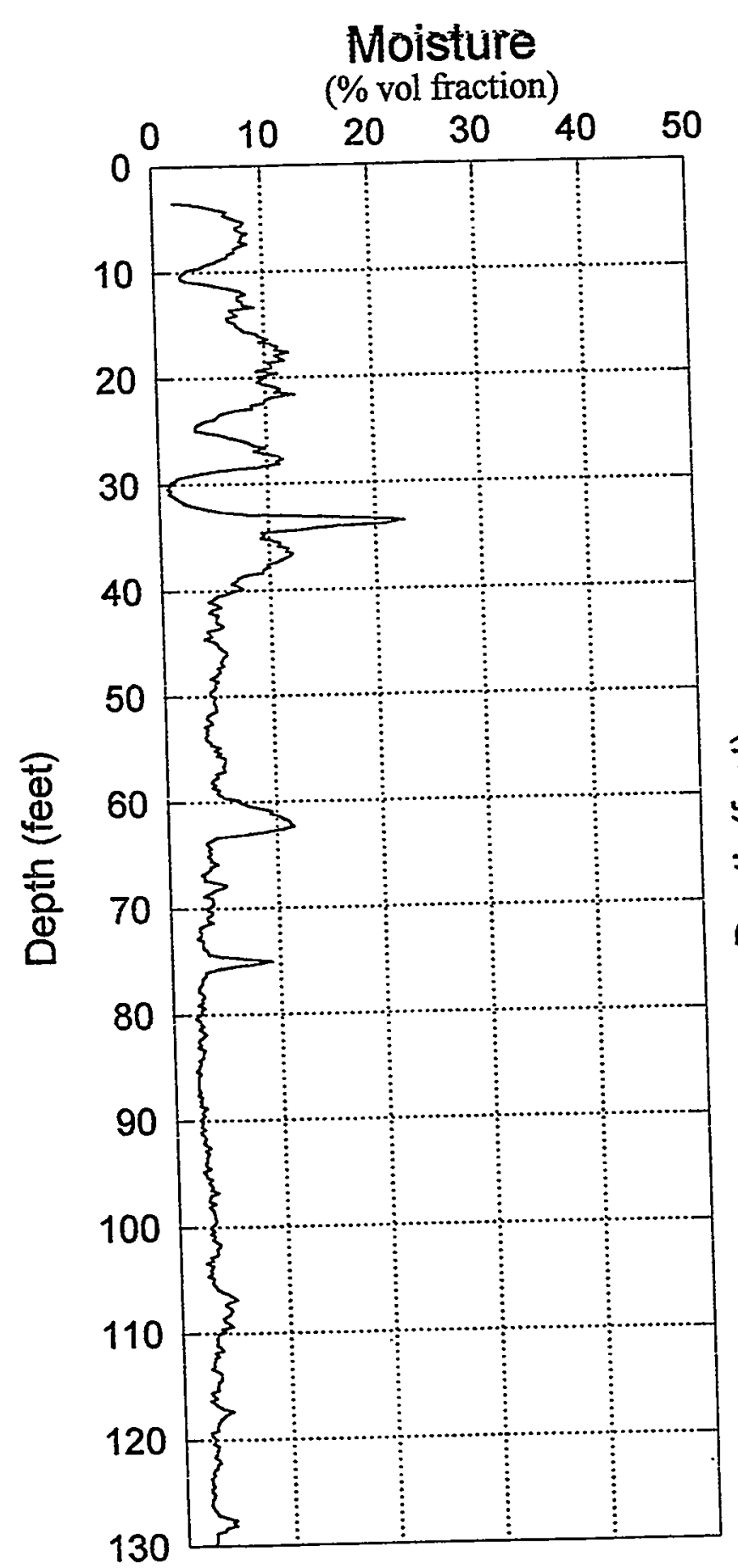

8" Casing Calibration

Log Date July 26, 1999

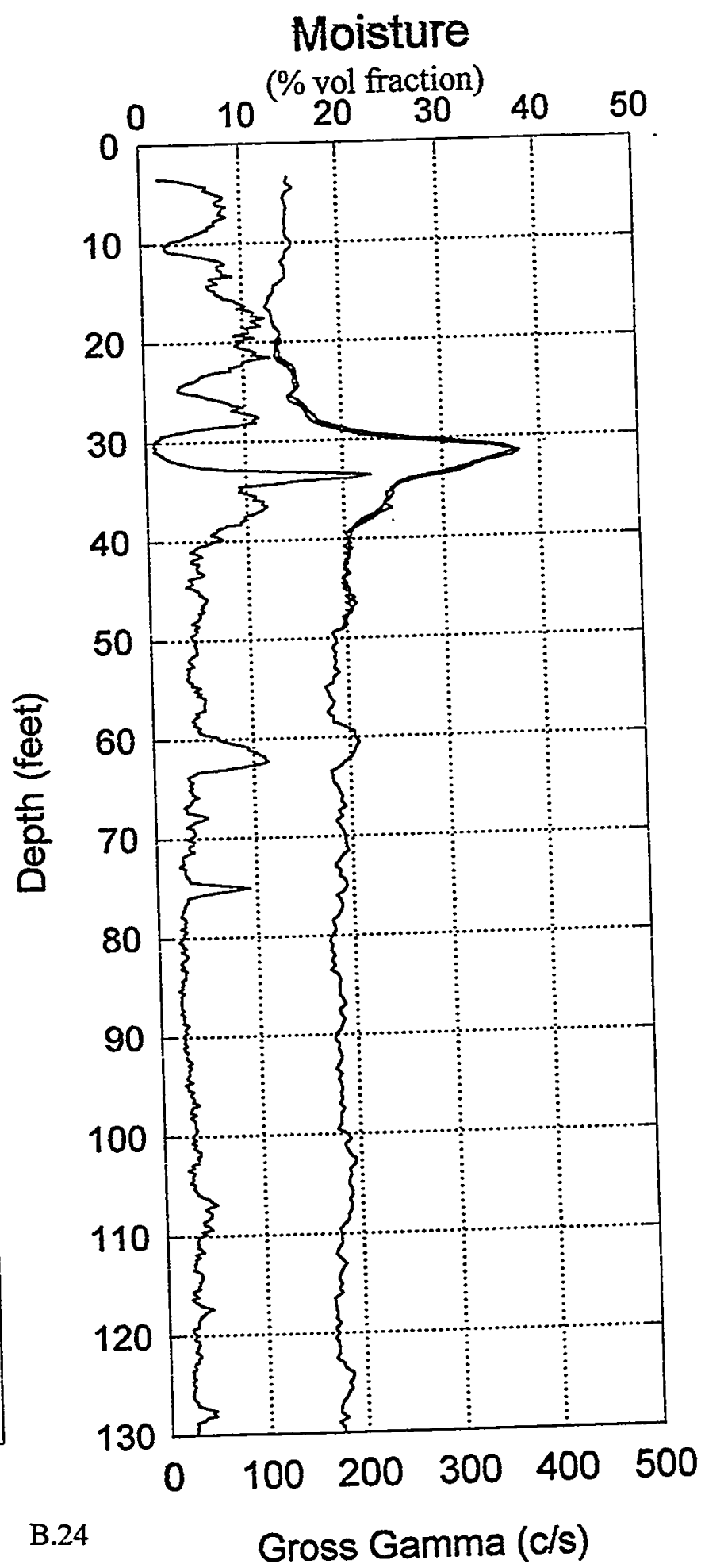




\section{RLS Moisture Processed Log Data}

\section{Waste Management Federal Services NW}

Project: Vadose Zone Monitoring Borehole: 299-E13-2

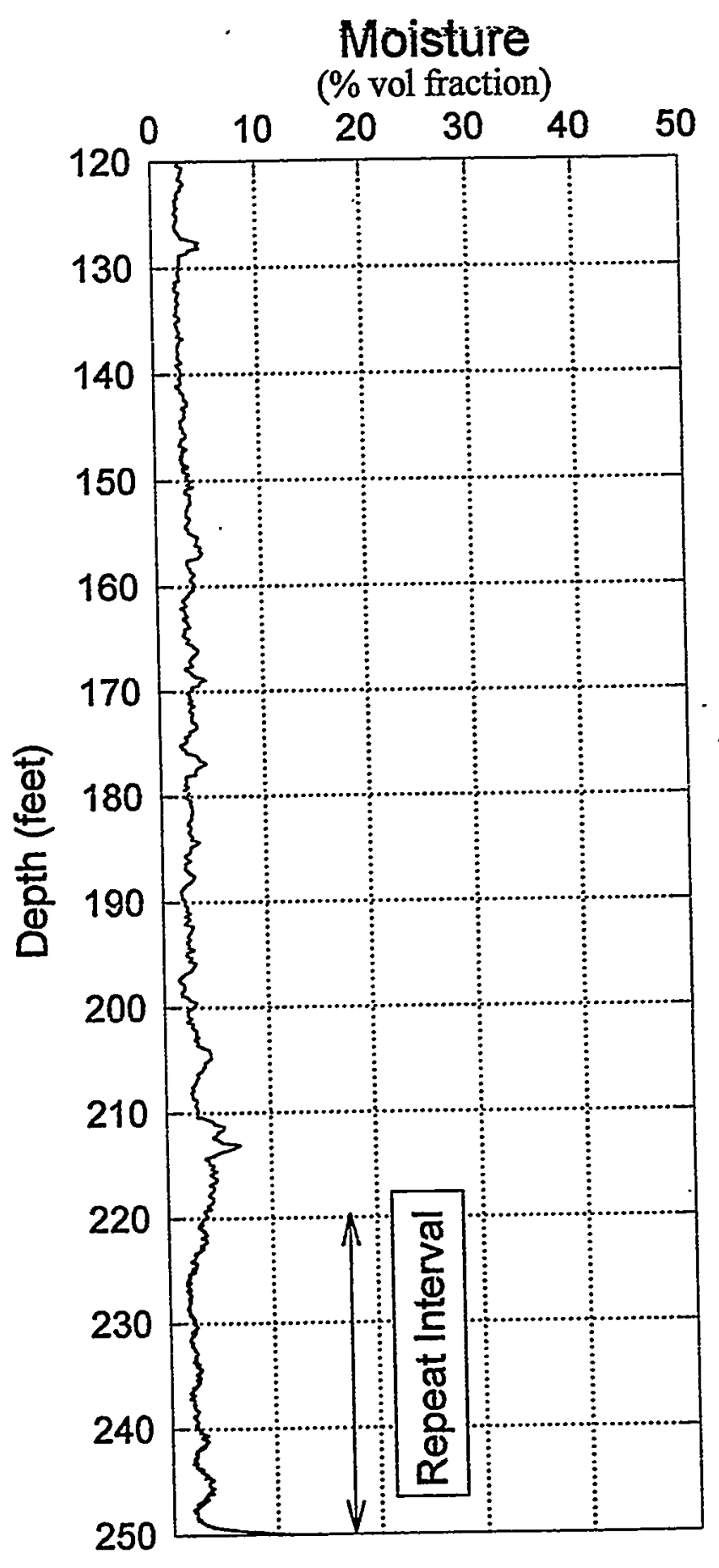

8" Casing Calibration Log Date July 26, 1999

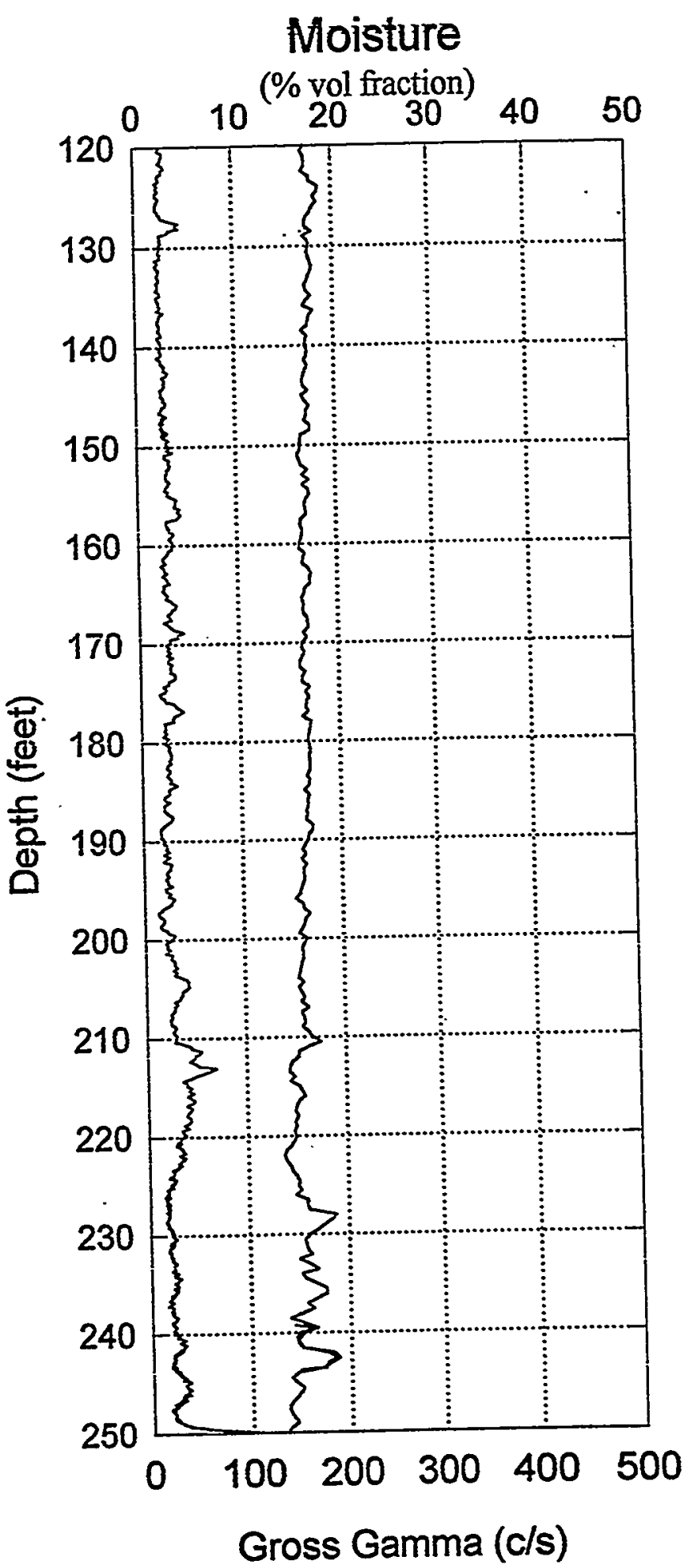




\section{RLS Moisture Processed Log Data}

\section{Waste Management Federal Services NW}

Project: Vadose Zone Monitoring

Borehole: 299-E13-2

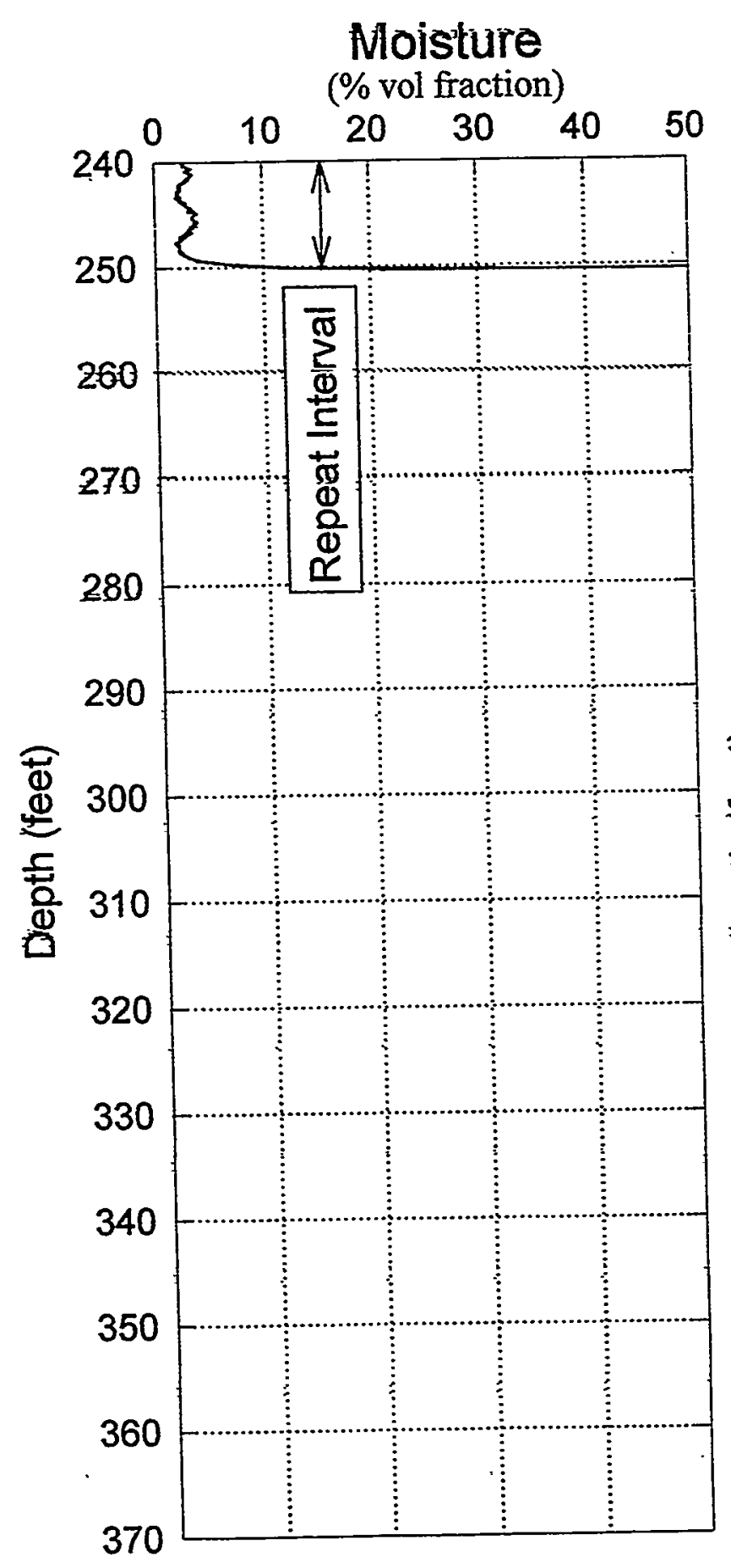

8" Casing Calibration

Log Date July 26, 1999

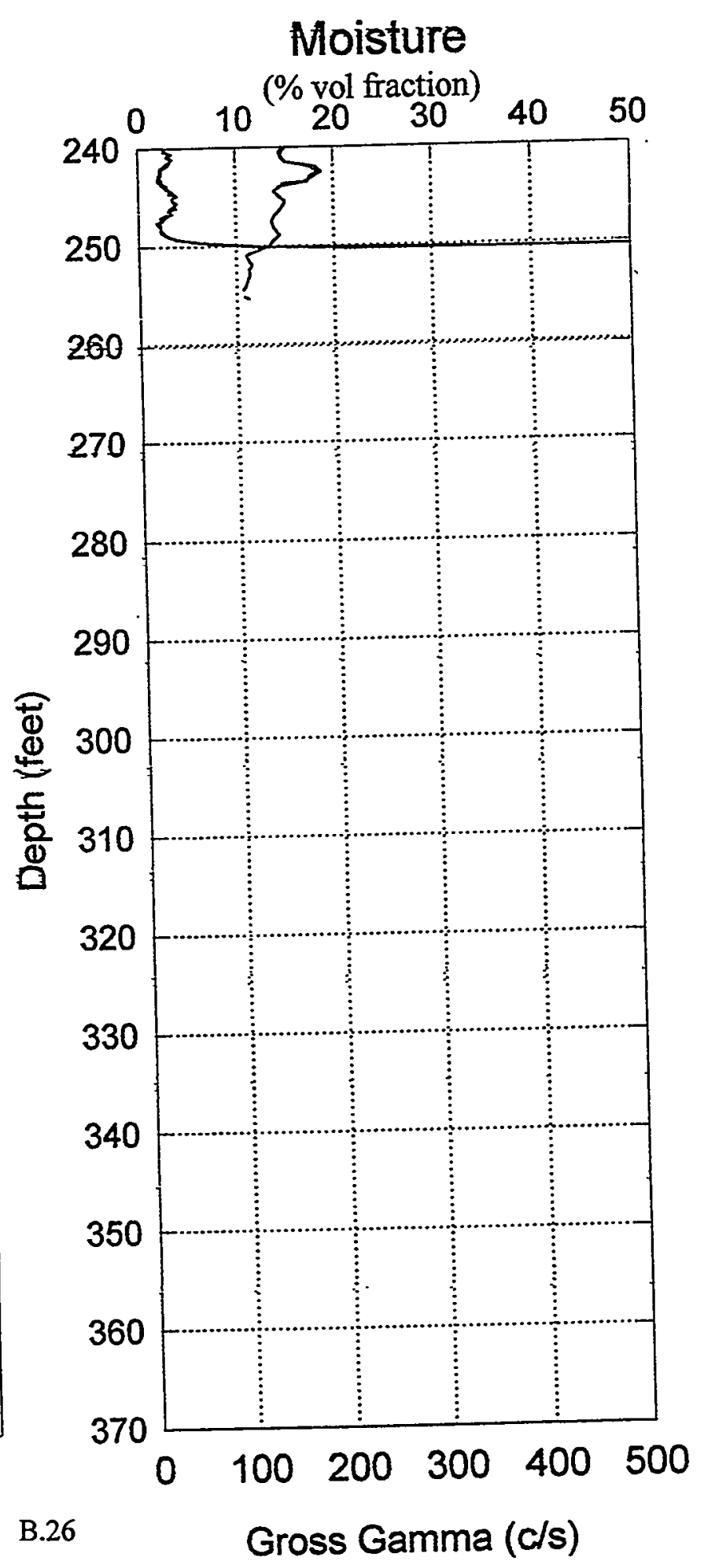




\section{RLS \\ Log Analysis \& Summary}

$\begin{array}{lllr}\text { Project: } & \text { PNNL Vadose Zone Monitoring } & \text { Well ID: } & \text { 299-E13-2 } \\ \text { Log Type: } & \text { Moisture Gauge } & \text { Log Date: } & \text { July 26, 1999 }\end{array}$

\section{General Notes:}

Log data collected with a depth reference of top of casing, and during analysis the depths were shifted to ground surface reference for all plots.

System Performance Verify: The pre- and post-log verification passed performance standards, $+1.5 \%$ in the shield verify.

Repeat Interval: Based on the repeat interval from 220 to 250 feet, the logging system performed according to specifications.

Environmental Corrections: The moisture levels have been corrected for casing attenuation (entire well).

\section{Observations:}

The moisture levels show values ranging from $2 \%$ to $23 \%$ for depth interval from 3 feet to 250 feet. The highest moisture occurs at a depth of 34 feet, with a maximum reading of $23 \%$ by volume. Just above this high moisture zone at 34 feet there is a very low moisture zone at 30 feet. The extremely low reading at 30 feet is indicative of voids outside of the casing. The majority of contaminants in this well occurs between 30 to 40 feet.

The abnormally high reading at 250 feet is due to water level in the borehole. 


\section{RLS Spectral Gamma Ray Borehole Survey \\ Waste Management Federal Services NW}

\section{Log Header}

Project: PNNL Vadose Zone Monitoring Well: 299-E13-3

Log Type: $\quad$ HPGe Spectral Gamma Ray

Borehole information

\begin{tabular}{|c|c|c|c|}
\hline Well \# unk & Water Depth unk & Total Deptl & $338 \mathrm{ft}$ \\
\hline Elevation Reference $\underline{\mathrm{n} / \mathrm{a}}$ & Elevation & $\mathrm{ft}$ & \\
\hline Depth Reference Top Casing & Casing Stickup 2.0 & $\mathrm{ft}$ & \\
\hline $\begin{array}{l}\text { Casing Diameter } \underline{6} \text { in } \\
8 \text { inch casing is present at ground s }\end{array}$ & $\begin{array}{l}\text { Depth Interval } 0 \text { to } 338 \\
\text { ut is not identified on the as-buil }\end{array}$ & $\begin{array}{l}\mathrm{ft} \\
\text { illt drawing for this well. }\end{array}$ & 0.250 in \\
\hline
\end{tabular}

Logging Information

\begin{tabular}{|llr|}
\hline Log Type: & 10\% HPGe Spectral Gamma Ray \\
Company & Waste Management NW \\
Date/Archive File Name & July 28, 1999 H2E13003 \\
Logging Engineers & S. Kos & \\
Instrument Series & RLSG01000H00.0 & \\
Logging Unit & RLS-1 Prefix AP27 & AP28 \\
Depth Interval & 2 to $100 \mathrm{ft}$ & AP29 \\
& 95 to $300 \mathrm{ft}$ & \\
& 300 to 336 ft & \\
& & \\
Instrument Calibration Date & Jan 19, 1999 & \\
Calibration Report & WHC-SD-EN-TI-292 & \\
\hline
\end{tabular}

Analysis Information

$\begin{array}{lll}\text { Company } & \text { Three Rivers Scientific } \\ \text { Analyst } & \text { Russ Randall } \\ \text { Date } & \text { August 1, 1999 } \\ \text { Depth Reference } & . & \text { Ground Surface (plots depth shifted) }\end{array}$

Notes Cs-137, Co-60, and Eu-154 are the only man made radionuclides detected. Detection of Eu-154 required a summing technique since the levels are at detection threshold. High count rates over the depth interval from 14 to 15 feet result in under reported radionuclide concentrations due to dead time correction inaccuracy. 


\section{RLS Spectral Gamma Ray Borehole Survey Waste Management Federal Services NW}

Project: PNNL Vadose Zone Monitoring Log Date: July 28, 1999 Borehole: 299-E13-3

Naturally Occurring Radionuclides

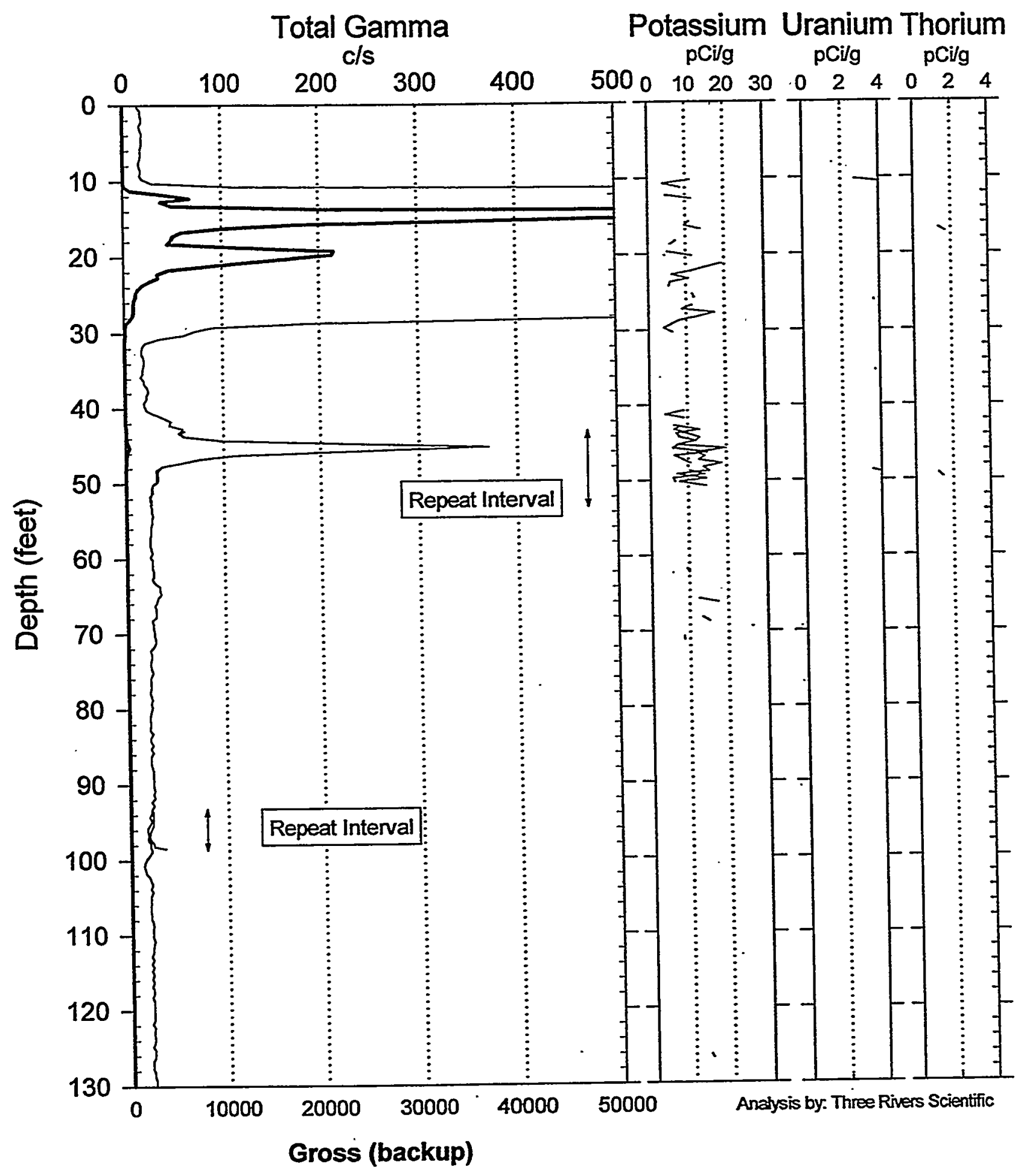




\section{RLS Spectral Gamma Ray Borehole Survey Waste Management Federal Services NW}

Project: PNNL Vadose Zone Monitoring Log Date: July 28, 1999 Borehole: 299-E13-3

Naturally Occurring Radionuclides

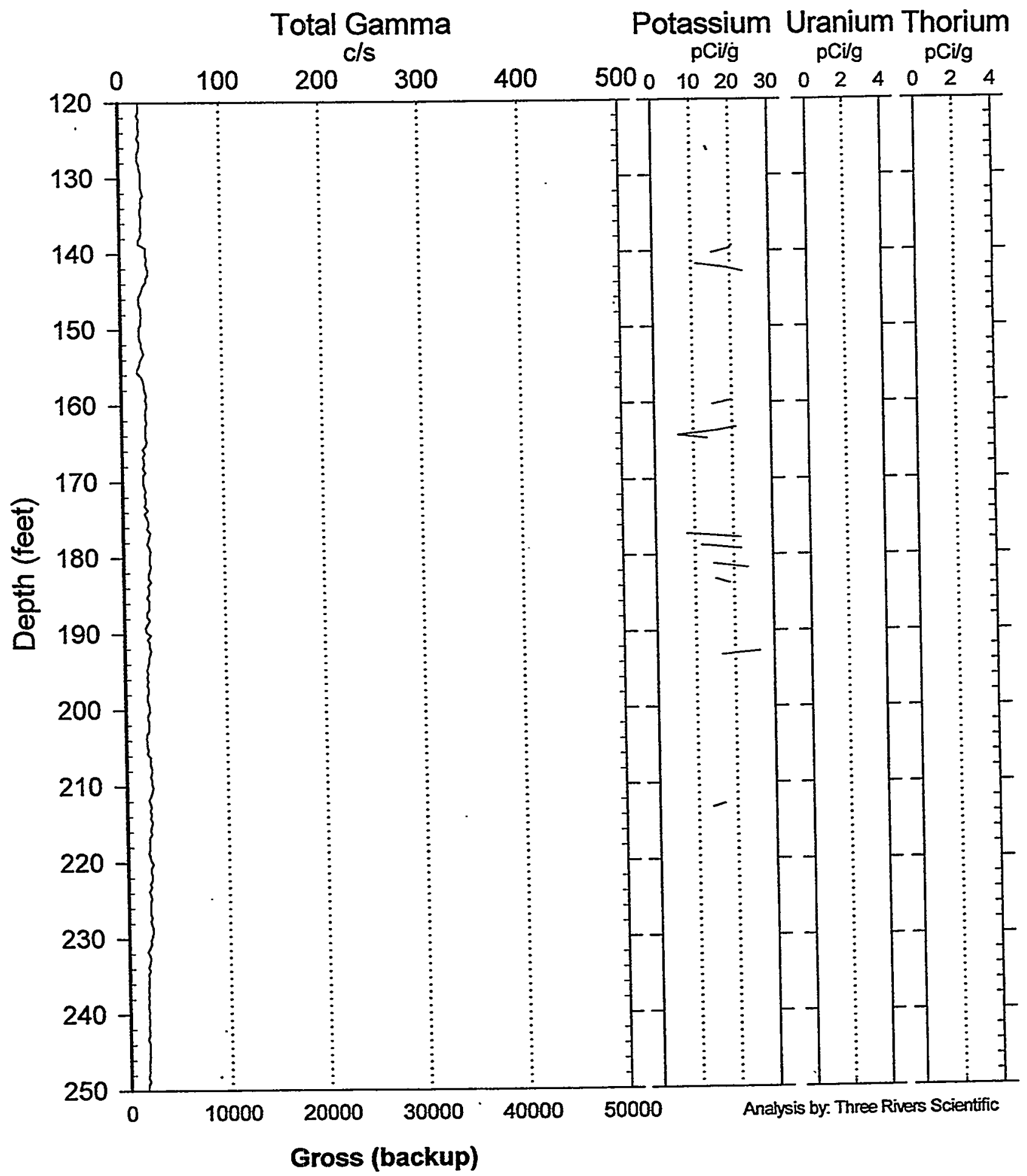




\section{RLS Spectral Gamma Ray Borehole Survey Waste Management Federal Services NW}

Project: PNNL Vadose Zone Monitoring Log Date: July 28, 1999 Borehole: 299-E13-3

Naturally Occurring Radionuclides

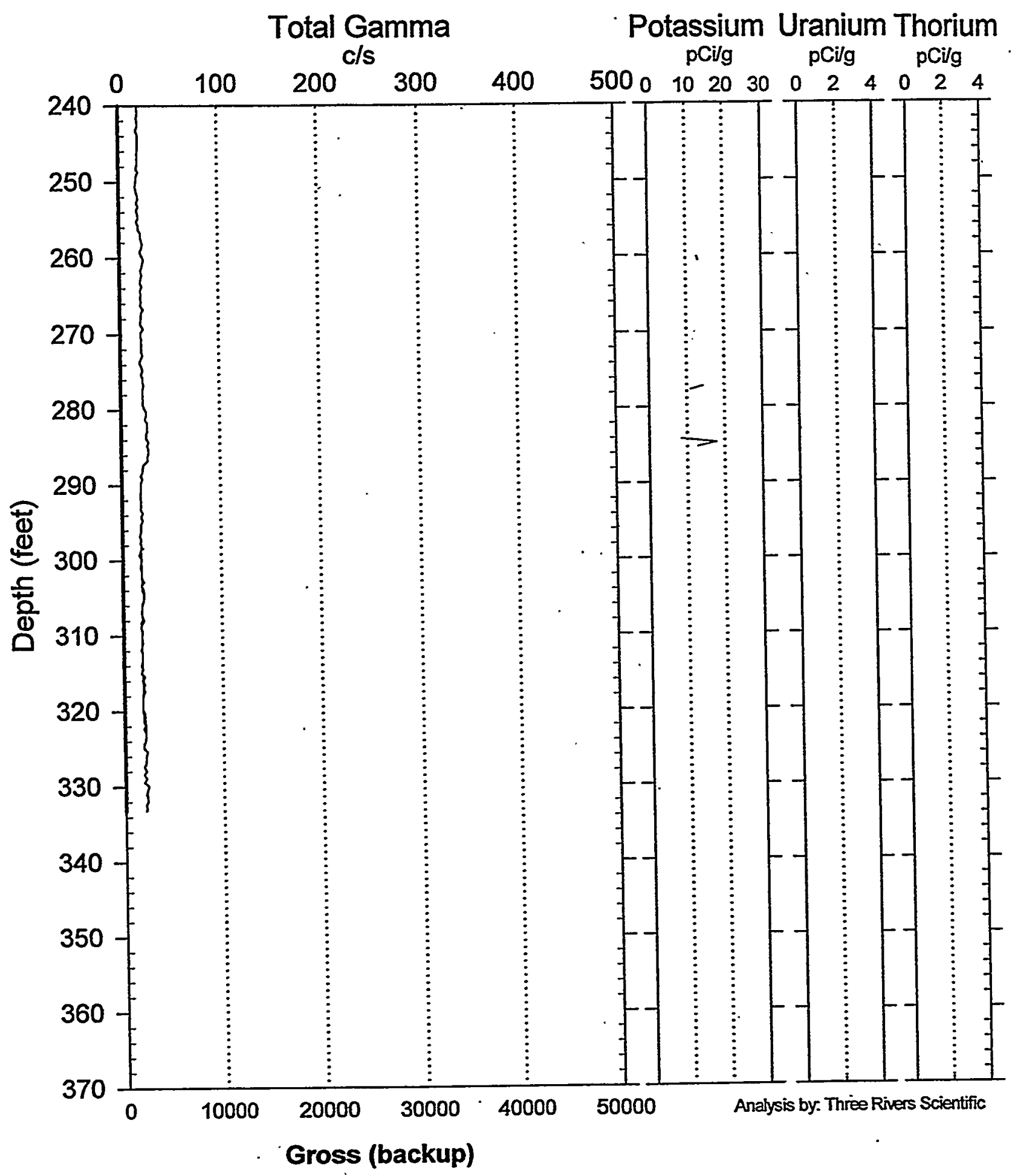




\section{RLS Spectral Gamma-Ray Borehole Survey Waste Management Federal Services NW}

Project: PNNL Vadose Zone Monitoring Log Date: July 28, 1999
Borehole: 299-E13-3

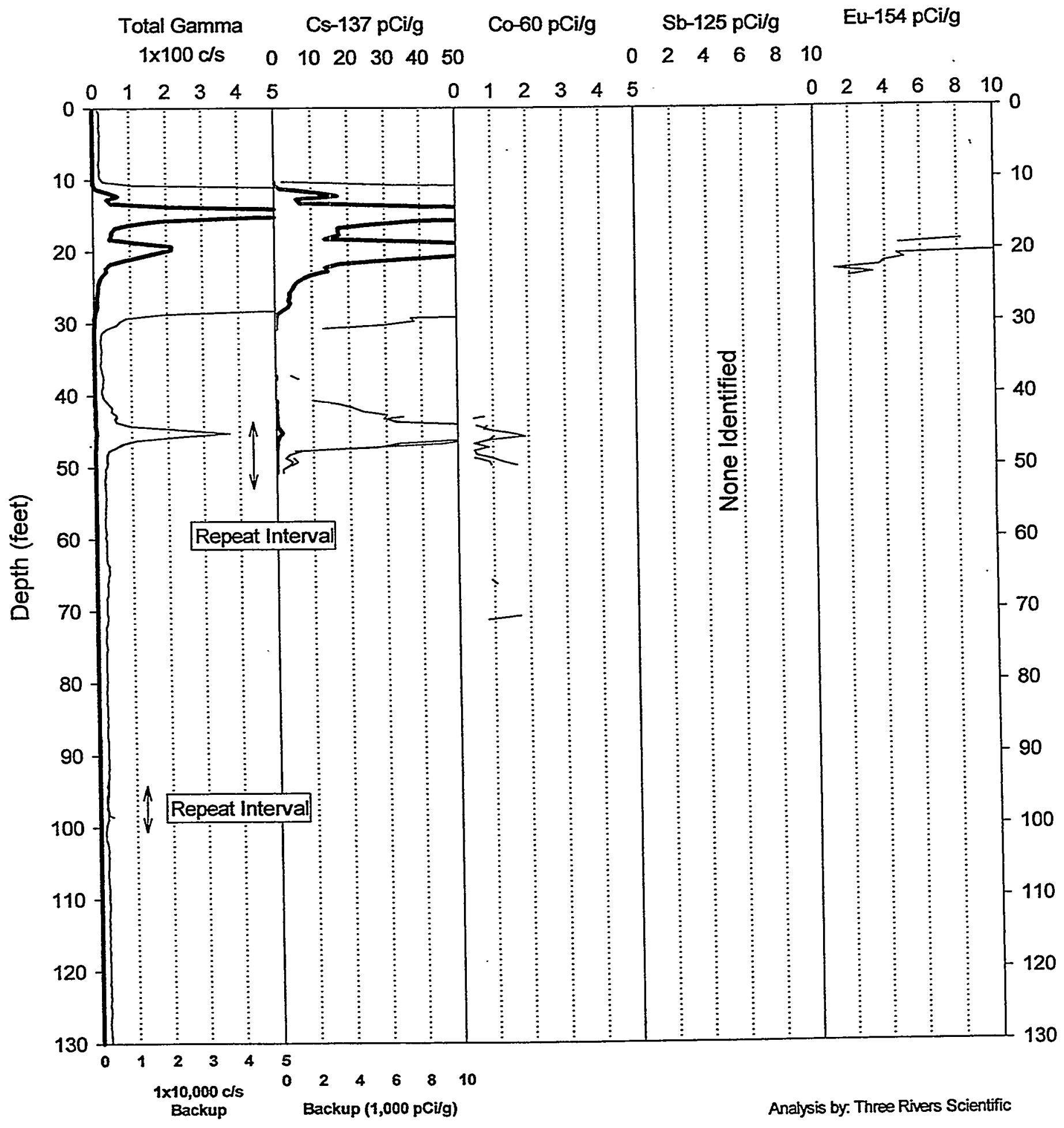




\section{RLS Spectral Gamma-Ray Borehole Survey}

\section{Waste Management Federal Services NW}

Project: PNNL Vadose Zone Monitoring Log Date: July 28, 1999 Borehole: 299-E13-3

\section{Man-Made Radionuclides}

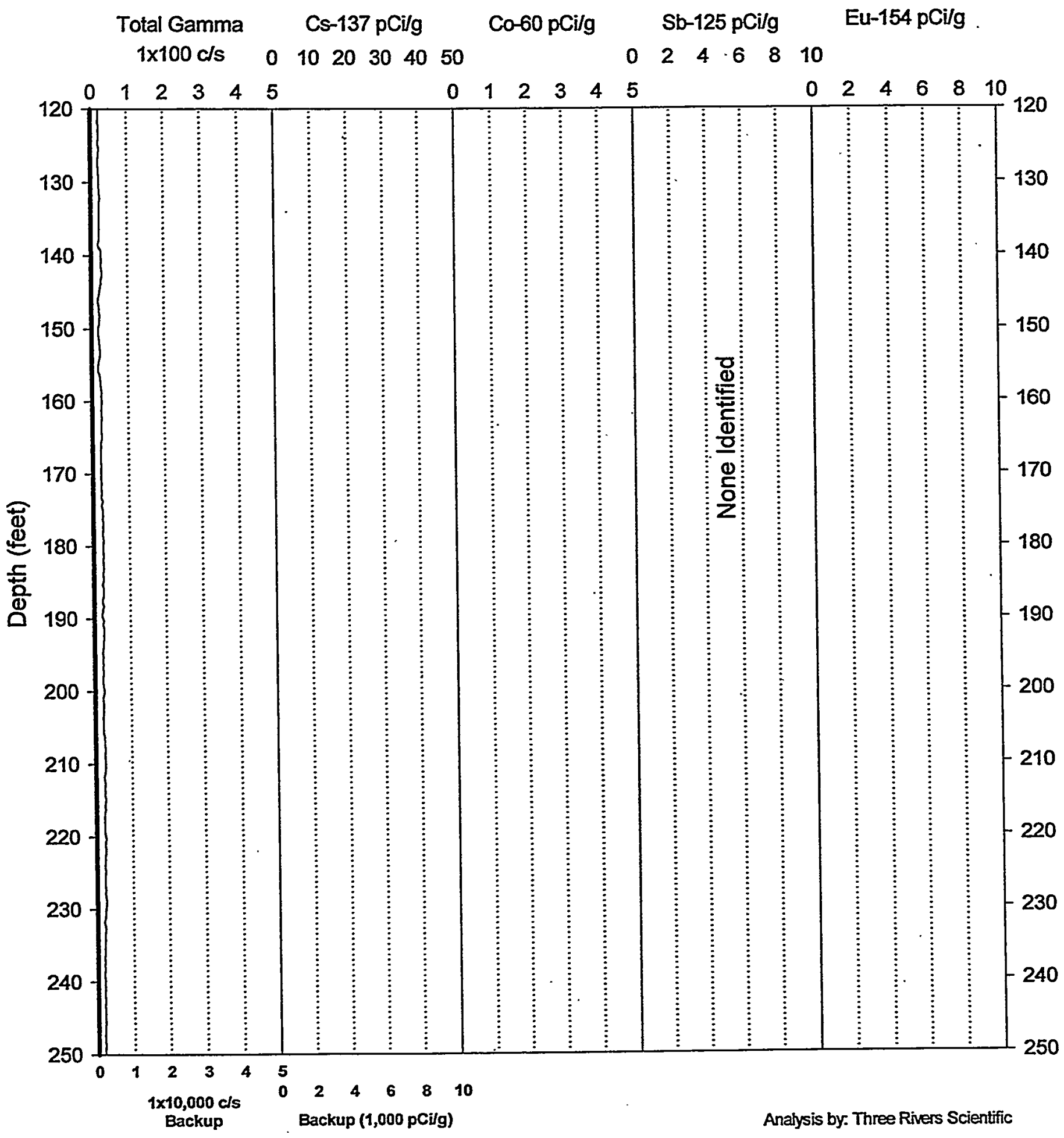




\section{RLS Spectral Gamma-Ray Borehole Survey Waste Management Federal Services NW}

Project: PNNL Vadose Zone Monitoring Log Date: July 28, 1999 Borehole: 299-E13-3 Man-Made Radionuclides

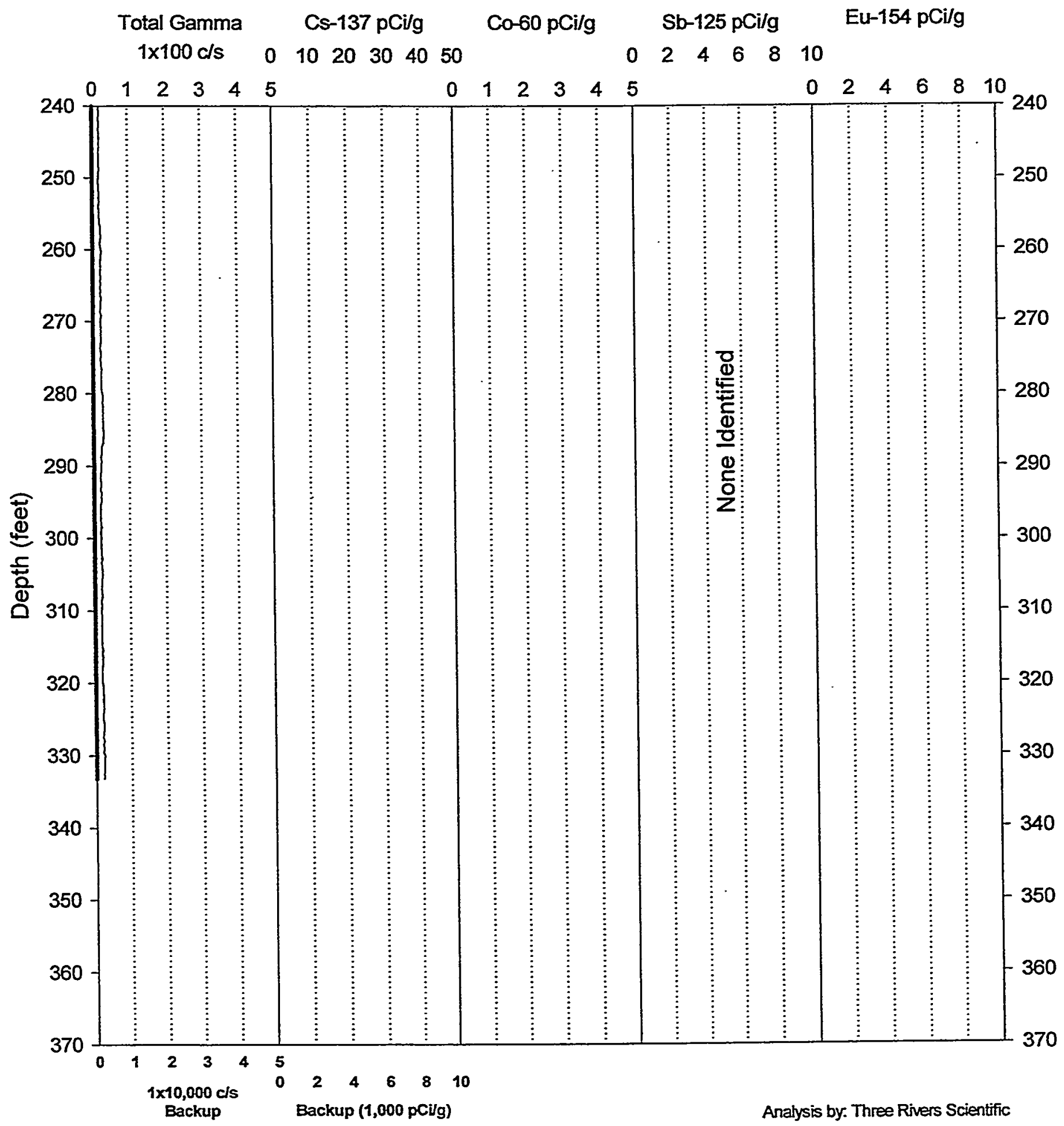




\section{RLS Spectral Gamma Ray Borehole Survey Acceptance QA Processing}

Project: PNNL Vadose Zone Monitoring Log Date: July 28, 1999 Borehole: 299-E13-3

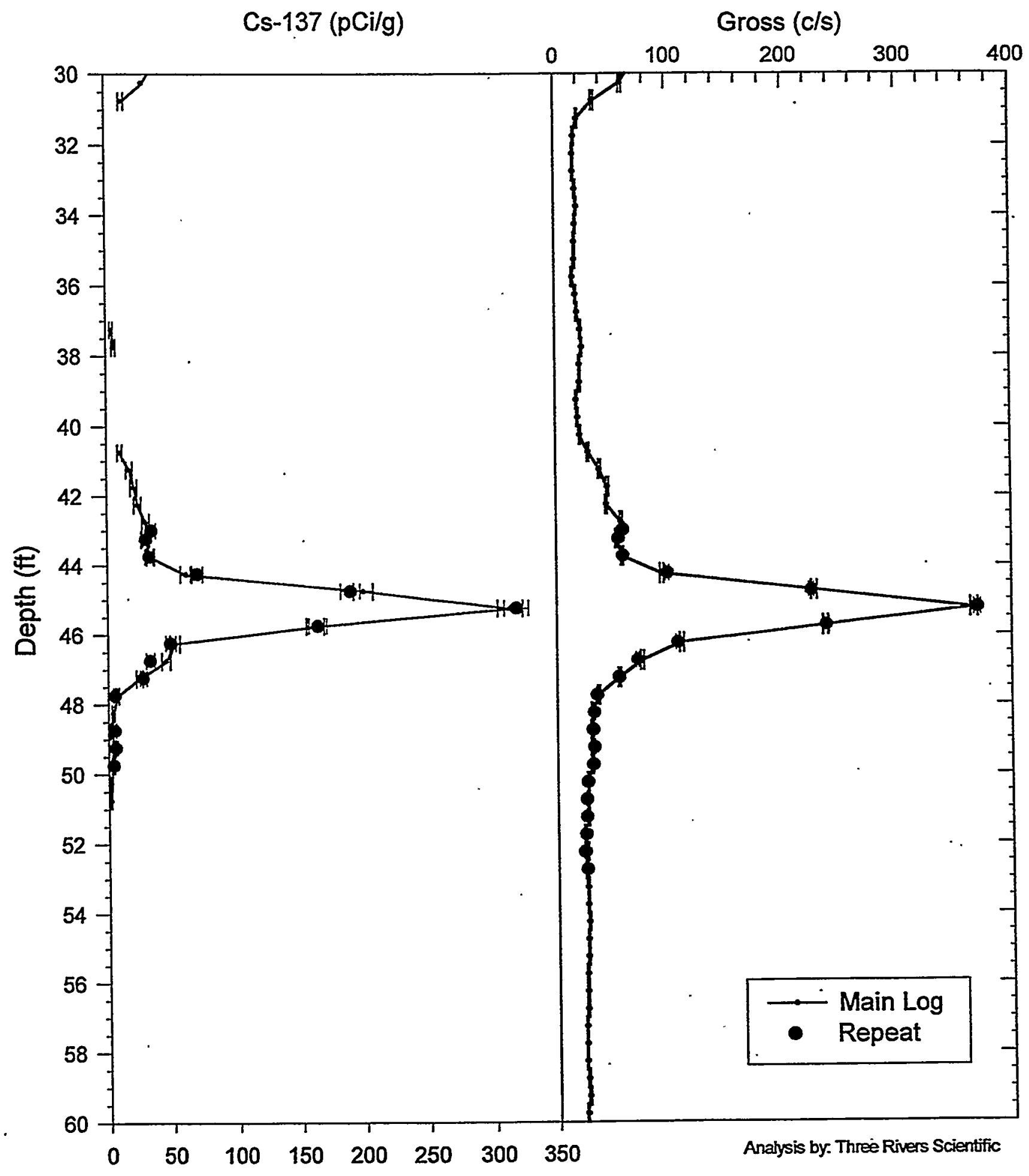




\title{
RLS Spectral Gamma Ray Borehole Survey
}

\author{
Waste Management Federal Services NW
}

\section{Log Analysis Summary Report}

$\begin{array}{lllr}\text { Project: } & \text { PNNL Vadose Zone Monitoring } & \text { Well: } & 299-E 13-3 \\ \text { Log Type: } & \text { HPGe Spectral Gamma Ray } & \text { Log Dates: } & \text { July 27\&28, 1999 }\end{array}$

\section{General Notes:}

Total gamma is a response to geologic concentrations of natural radionuclides except for the depth interval from 10-52 feet.

Log data collected with a depth reference of top of casing, and during analysis the depths were shifted to ground surface reference for all plots.

System Performance Verify: The pre- and post-log verification passed performance standards.

Repeat Interval: Based on the repeat interval, the logging system performed as per specifications. The error bars are calculated for 1 standard deviation of the net photo peak count rate statistical variance. Thus, the repeat should fall within these error bars $67 \%$ of the time.

The low sensitivity of the logging instrument results in many gaps and absences of KUT values; however, the high intensity zones are recorded with more accuracy.

Environmental Corrections: All radionuclide concentrations have been corrected for casing attenuation (entire well). Water level is below depths logged. No casing correction was applied to the total gamma due to Compton downscatter interference. Dual casing attenuation affects the gross gamma over the interval from 130 to 125 feet.

\section{Radionuclides:}

Cs-137 was identified over the depths from 10-51 feet. The maximum concentration of Cs-137 occurs at a depth of 15 feet, with a reading greater than $18,000 \mathrm{pCi} / \mathrm{g}$. The Cs-137 MDL value for these log data is $2 \mathrm{pCi} / \mathrm{g}$.

Co-60 was identified over the depths from 42-49 feet, and from 66-71 feet. (Note, the Co-60 from 66-71 feet is at detection threshold, but a summing by 4 technique confirms its presence.) The maximum concentration of Co- 60 occurs at a depth of 46 feet, with a reading of $1.2 \mathrm{pCi} / \mathrm{g}$. The Co-60 MDL for these log data is $1 \mathrm{pCi} / \mathrm{g}$

Eu-154 was identified over the depths from 19-24 feet. This Eu-154 level of detection is at threshold, but is confirmed using a summing by 4 technique. The maximum concentration of Eu-154 occurs at a depth of 21 feet, with a reading of $3.5 \mathrm{pCi} / \mathrm{g}$. The $\mathrm{Eu}-154 \mathrm{MDL}$ value for these $\log$ data is $3 \mathrm{pCi} / \mathrm{g}$. 


\section{Moisture Logging Service \\ Log Header}

Project: $\quad$ PNNL Vadose Zone Monitoring

Well: 299-E13-3

\section{Log Type: Moisture Gauge}

Borehole Information

\begin{tabular}{|c|c|c|}
\hline Well \# unk & Water Depth unk. f ft & Total Depth $\underline{338 \mathrm{ft}}$ \\
\hline Elevation Reference $\underline{n} / \mathbf{a}$ & Elevation & \\
\hline Depth Reference Top Casing & Casing Stickup 2.0 & \\
\hline Casing Diameter $\underline{6}$ in & Depth Interval 0 to $100^{*} \mathrm{ft}$ & Thickness \\
\hline Casing Diameter $\underline{8}$ & Depth Interval 0 to unk $\mathrm{ft}$ & Thickness \\
\hline
\end{tabular}

*Other completion depths were 100 feet for this project, thus the pick in this well

Logging Information

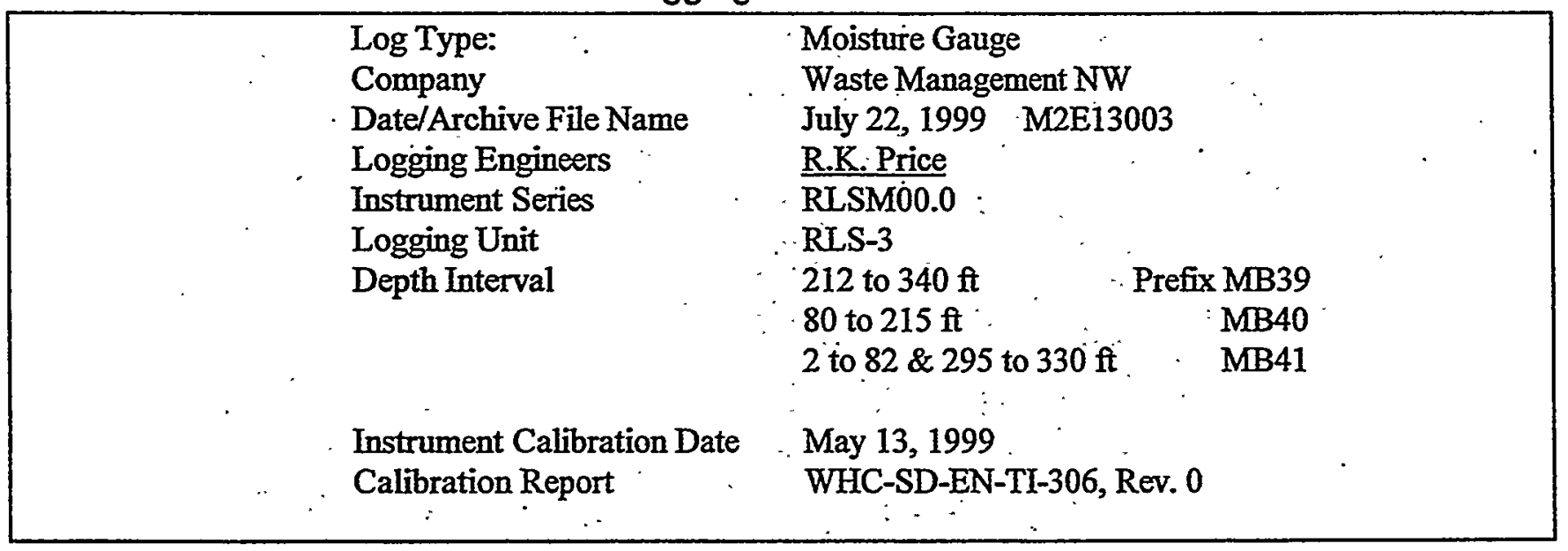

Analysis Information

\begin{tabular}{|c|c|c|}
\hline & $\begin{array}{l}\text { Company } \\
\text { Analyst } \\
\text { Date } \\
\text { Depth Reference }\end{array}$ & $\begin{array}{l}\text { Three Rivers Scientific } \\
\text { Russ Randall } \\
\text { August } 1,1999 \\
\text { Ground Surface (plots depth shifted) }\end{array}$ \\
\hline Notes & $\begin{array}{l}\text { Moisture values range from } 2 \% \text { to } \\
100 \text { feet is indicative of the sealing }\end{array}$ & $\begin{array}{l}50 \% \text { for the depths logged. The high moisture from } 2 \text { to } \\
\text { reen the dual casings. }\end{array}$ \\
\hline
\end{tabular}




\section{RLS Moisture Processed Log Data}

\section{Waste Management Federal Services NW}

Project: Vadose Zone Monitoring

Borehole: 299-E13-3

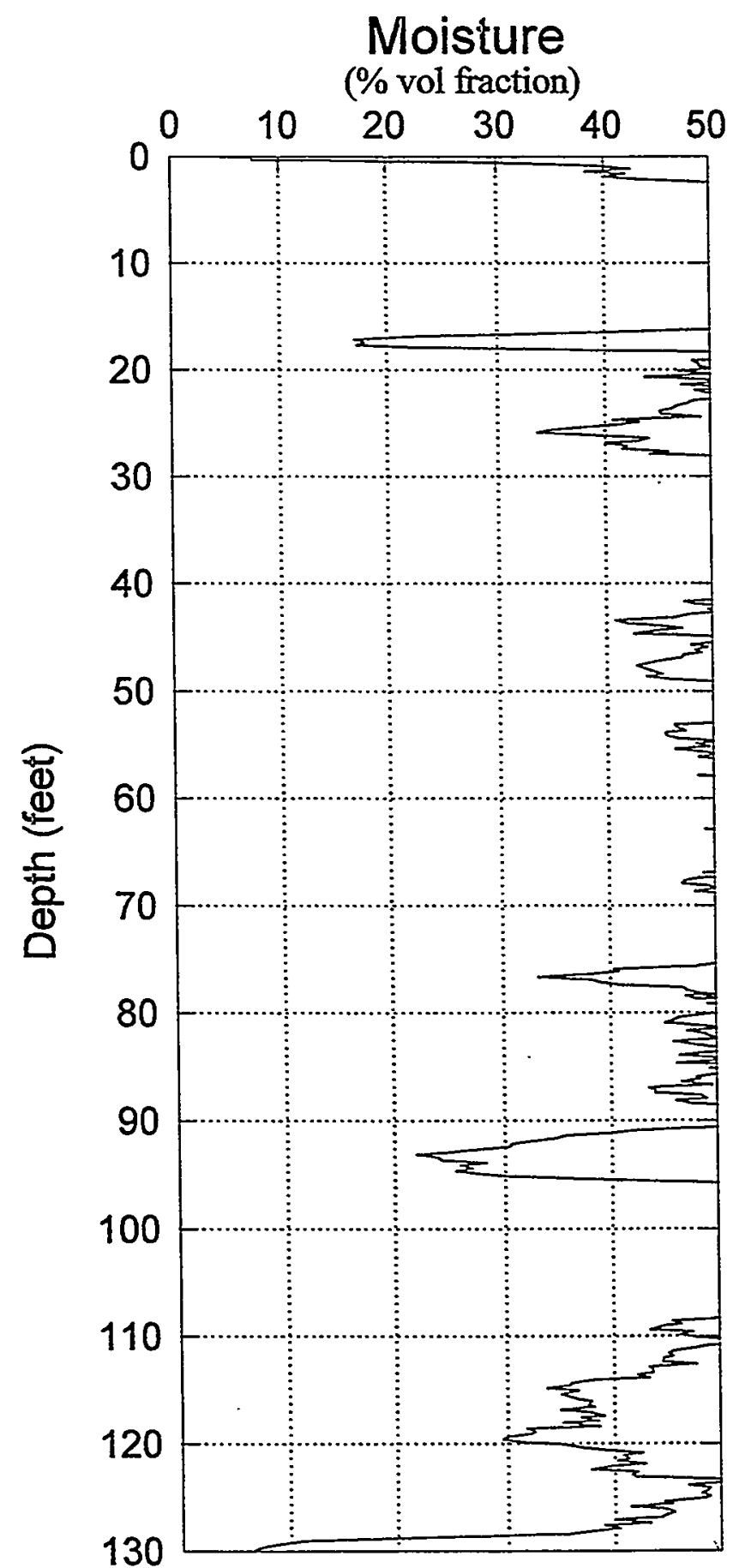

8" Casing Calibration

Log Date July 22, 1999

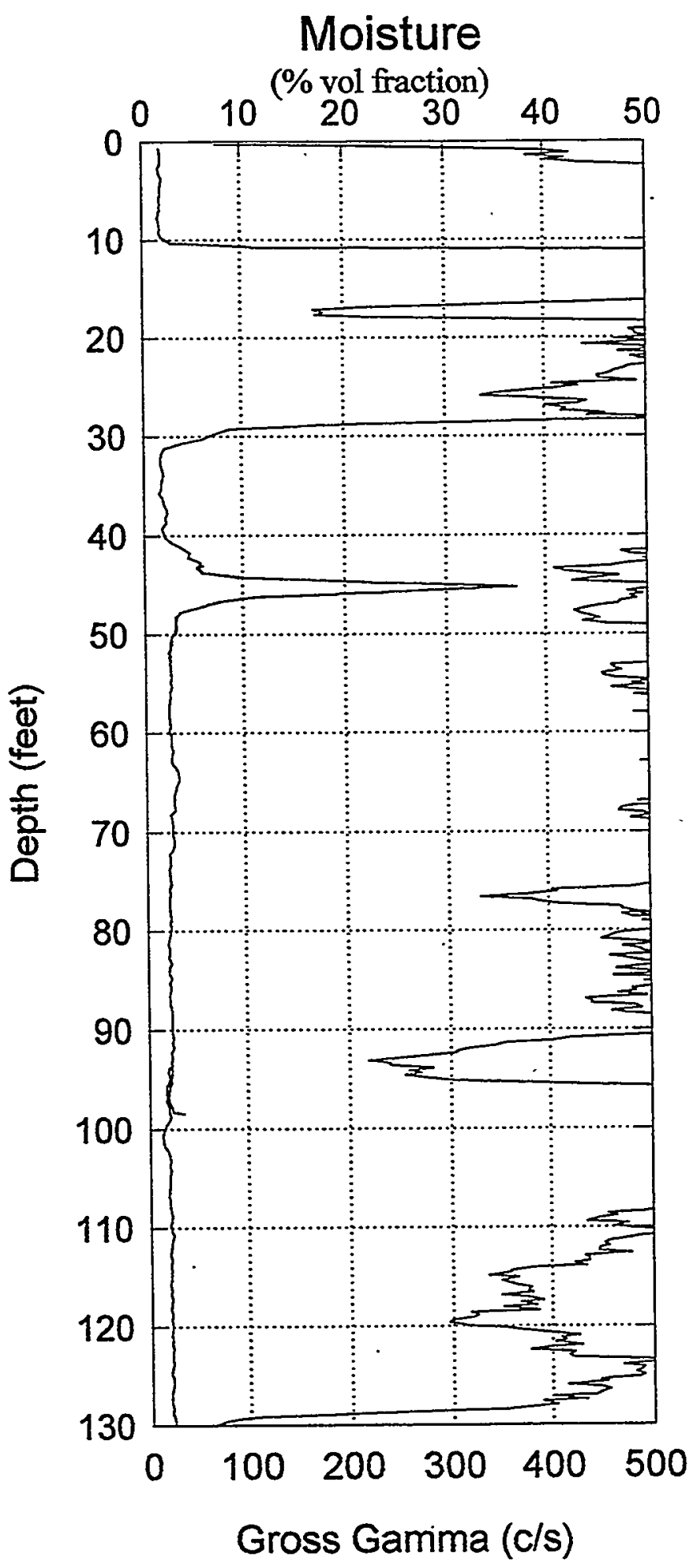




\section{RLS Moisture Processed Log Data}

\section{Waste Management Federal Services NW}

Project: Vadose Żone Monitoring

Borehole: 299-E13-3

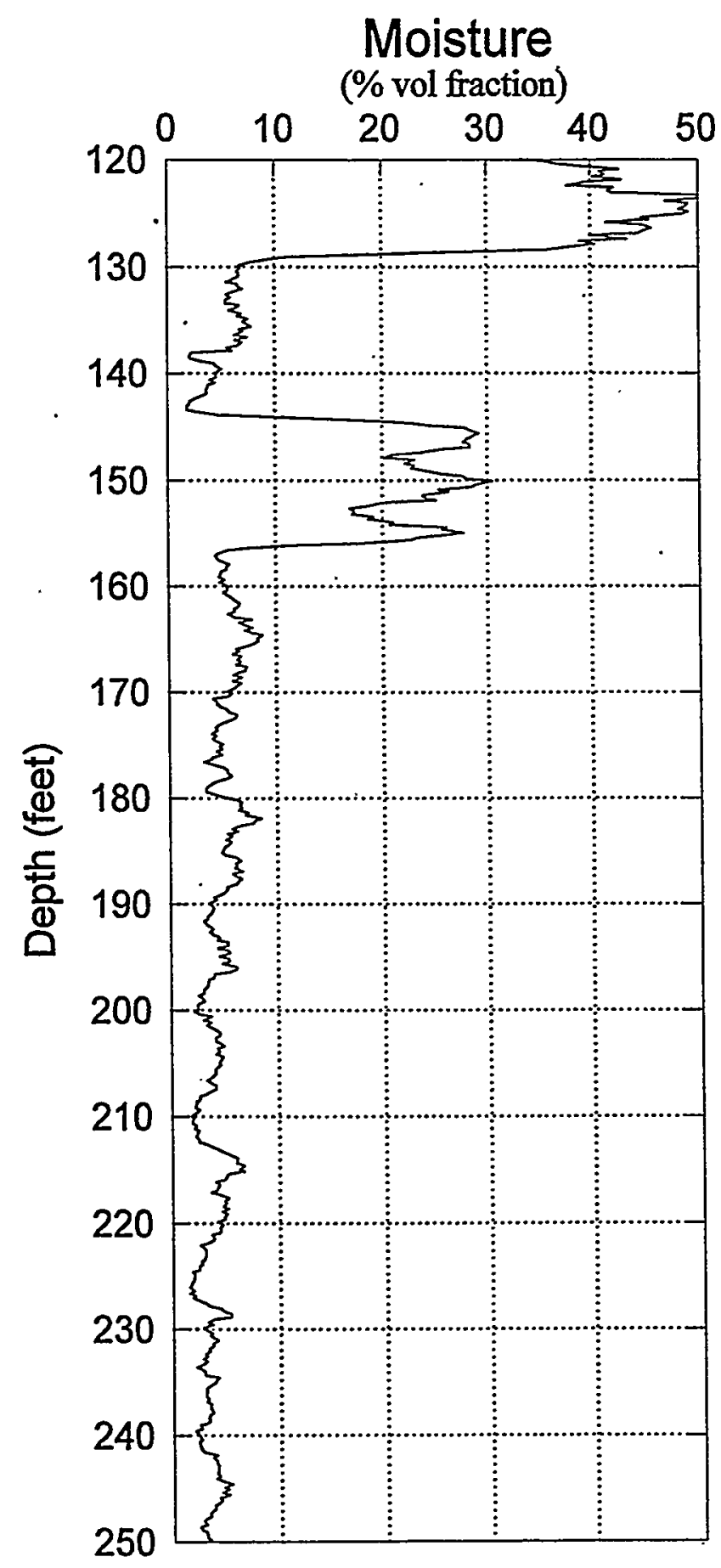

8" Casing Calibration Log Date July 22, 1999

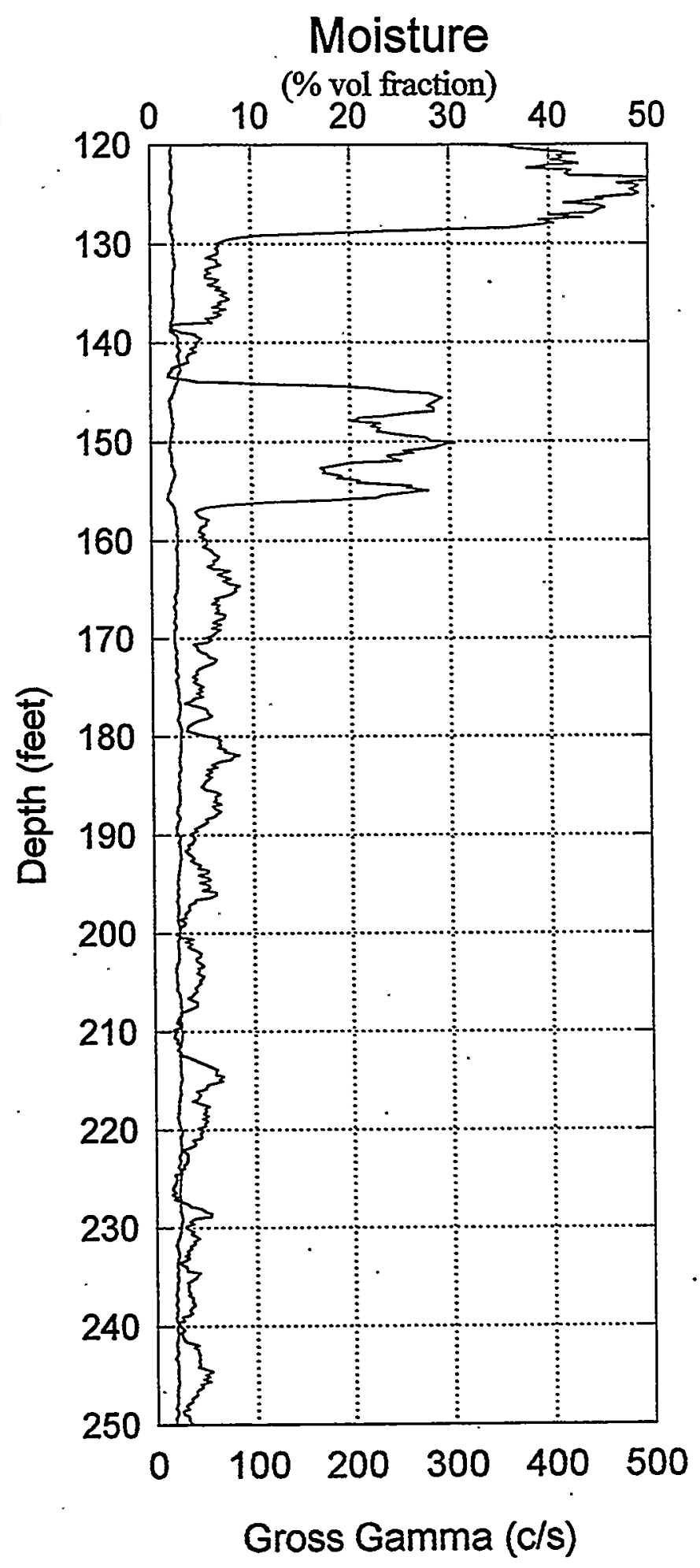




\section{RLS Moisture Processed Log Data}

\section{Waste Management Federal Services NW}

Project: Vadose Zone Monitoring Borehole: 299-E13-3

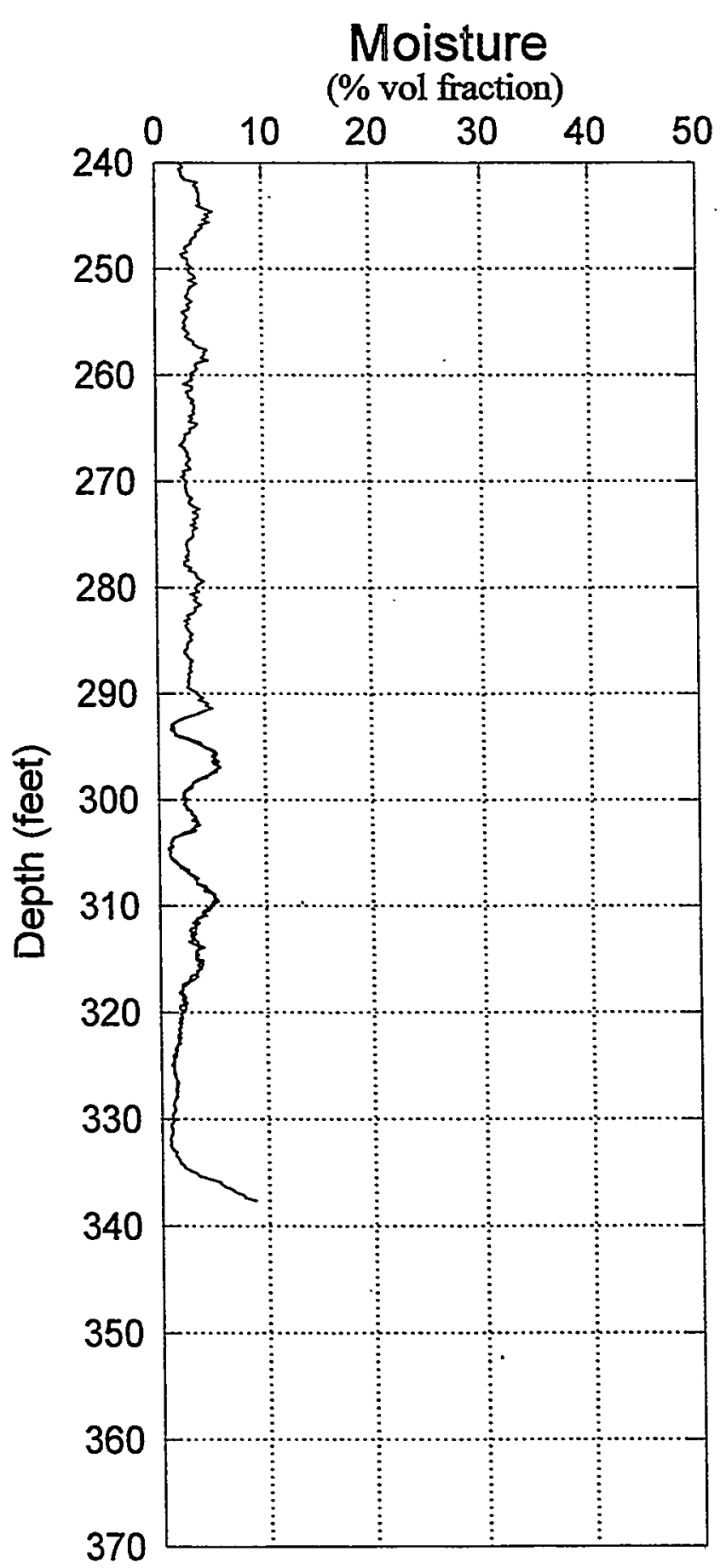

8" Casing Calibration Log Date July 22, 1999

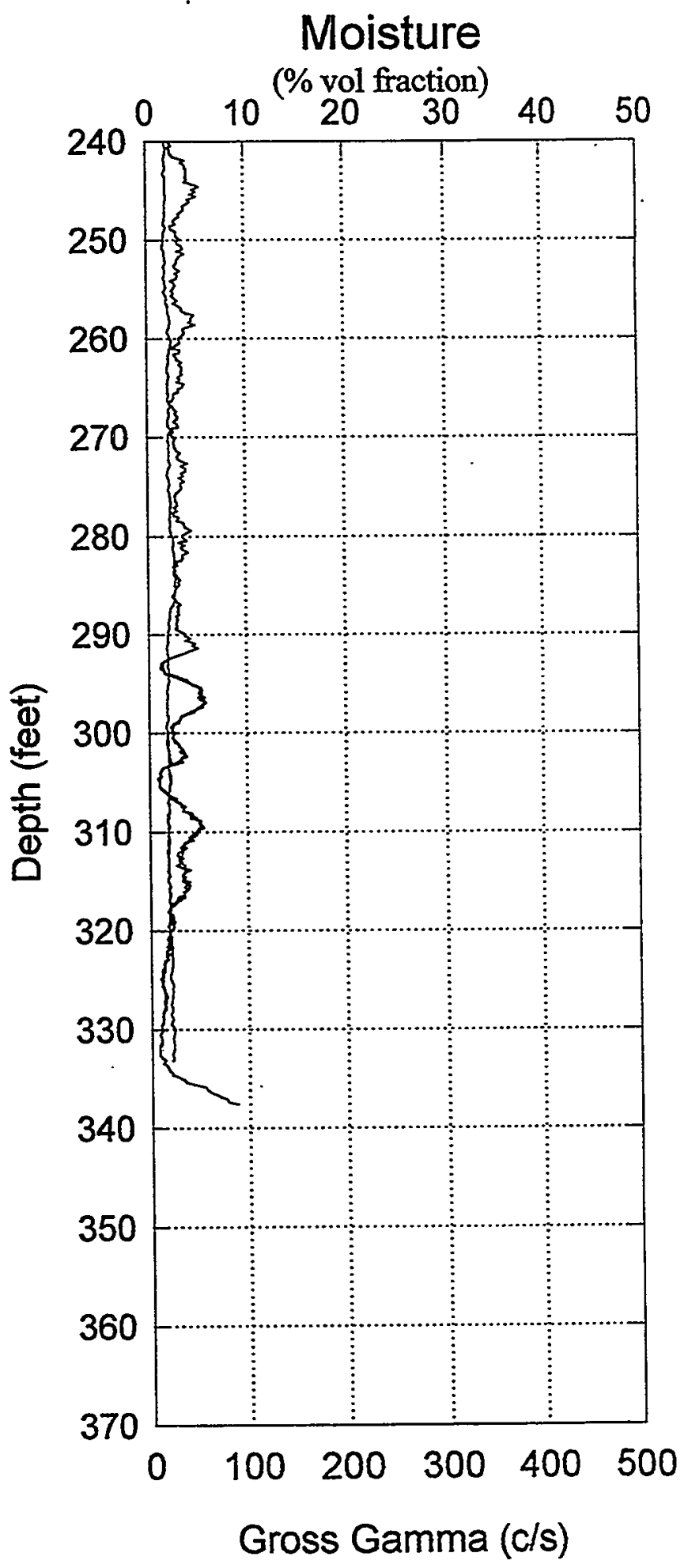




\section{RLS \\ Log Analysis \& Summary}

Project: $\quad$ PNNL Vadose Zone Monitoring

Well ID:

299-E13-3

Log Type: Moisture Gauge

Log Date: July 22, 1999

\section{General Notes:}

The low reading from 0 feet to 2 feet is due to surface effects and not necessarily the moisture content of the earth surrounding the borehole.

Log data collected with a depth reference of top of casing, and during analysis the depths were shifted to ground surface reference for all plots.

System Performance Verify: The pre- and post-log verification passed performance standards, $-0.4 \%$ in the shield verify.

Repeat Interval: Repeat interval from 295 to 330 feet performed according to specifications.

Environmental Corrections: The moisture levels have been corrected for casing attenuation (entire well).

The true depth of the 6 inch casing and thus the grout between casings is unknown. Since other wells in this crib complex had the completion at 100 feet, this depth was used for the casing thickness correction. Neutron raw count rate data would suggest a depth of 161 feet for the bottom of the grout.

\section{Observations:}

The moisture levels show values ranging from $2 \%$ to greater than $50 \%$ for depth interval from 2 feet to 340 feet. The abnormally high moisture values from 2 to 100 feet is indicative of the grout, which the analysis cannot correct. 


\section{RLS Spectral Gamma Ray Borehole Survey \\ Waste Management Federal Services NW}

\section{Log Header}

Project: $\quad$ PNNL Vadose Zone Monitoring

Well: 299-E13-4

\section{Log Type: $\quad$ HPGe Spectral Gamma Ray}

Borehole Information

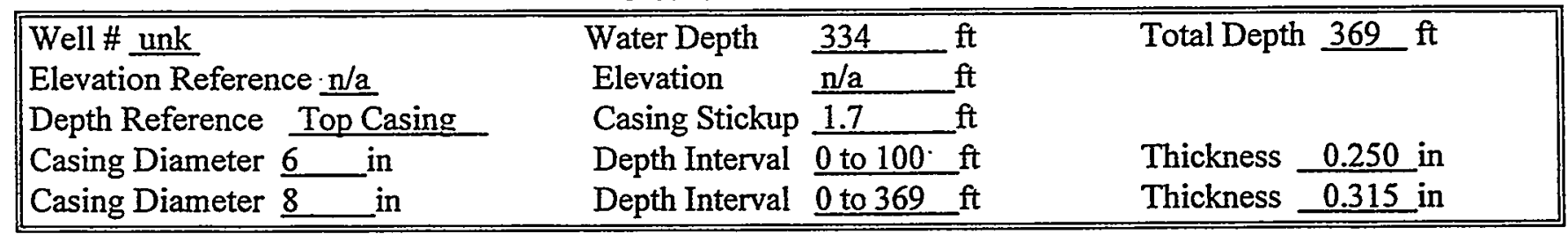

Logging Information

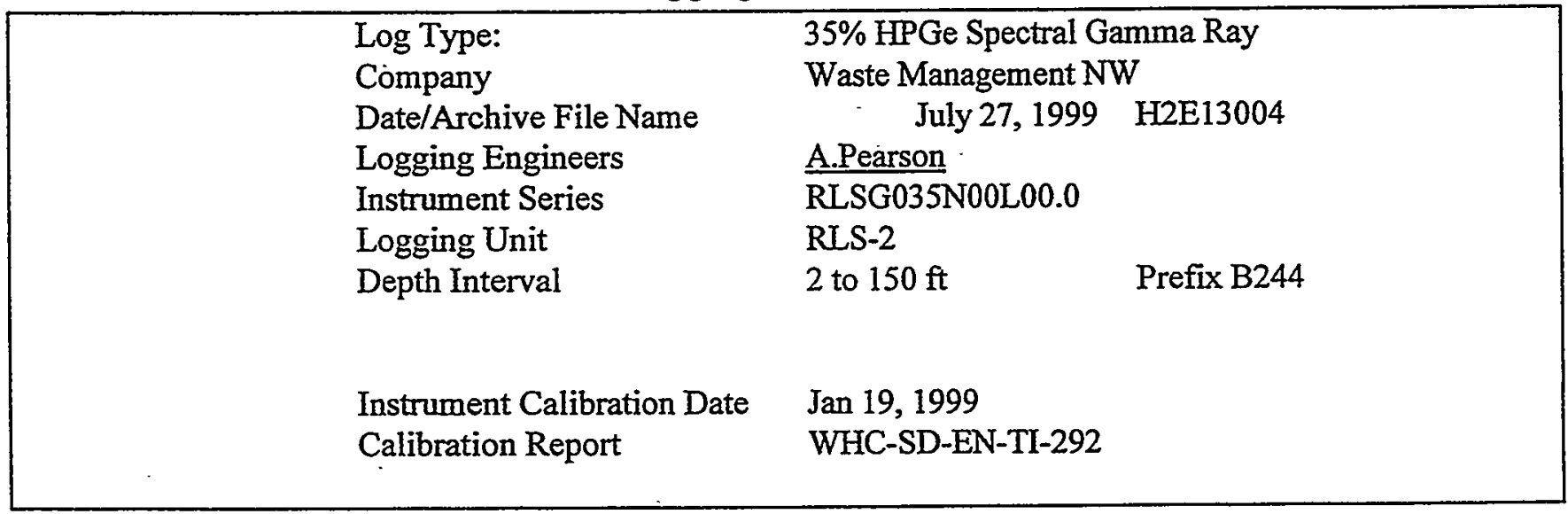

Analysis Information

$\begin{array}{ll}\text { Company } & \text { Three Rivers Scientific } \\ \text { Analyst } & \text { Russ Randall } \\ \text { Date } & \text { August 1, 1999 } \\ \text { Depth Reference } & \text { Ground Surface (plots depth shifted) }\end{array}$

Notes Cs-137 and Co-60 are the only man made radionuclides detected. 


\section{RLS Spectral Gamma Ray Borehole Survey Waste Management Federal Services NW}

Project: PNNL Vadose Zone Monitoring Log Date: July 21, 1999 Borehole: 299-E13-4

Naturally Occurring Radionuclides

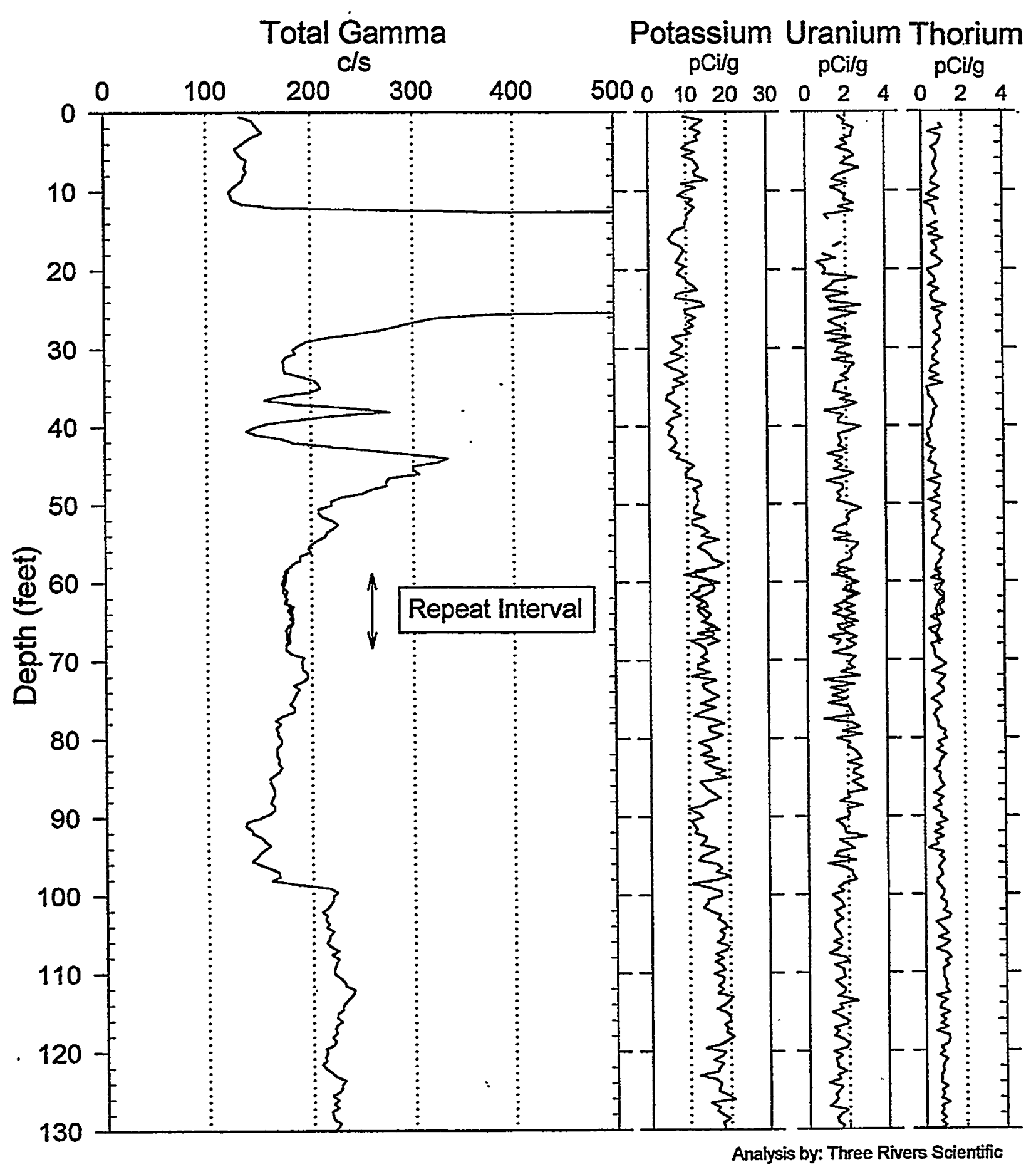




\section{RLS Spectral Gamma Ray Borehole Survey Waste Management Federal Services NW}

Project: PNNL Vadose Zone Monitoring Log Date: July 21, 1999 Borehole: 299-E13-4

Naturally Occurring Radionuclides

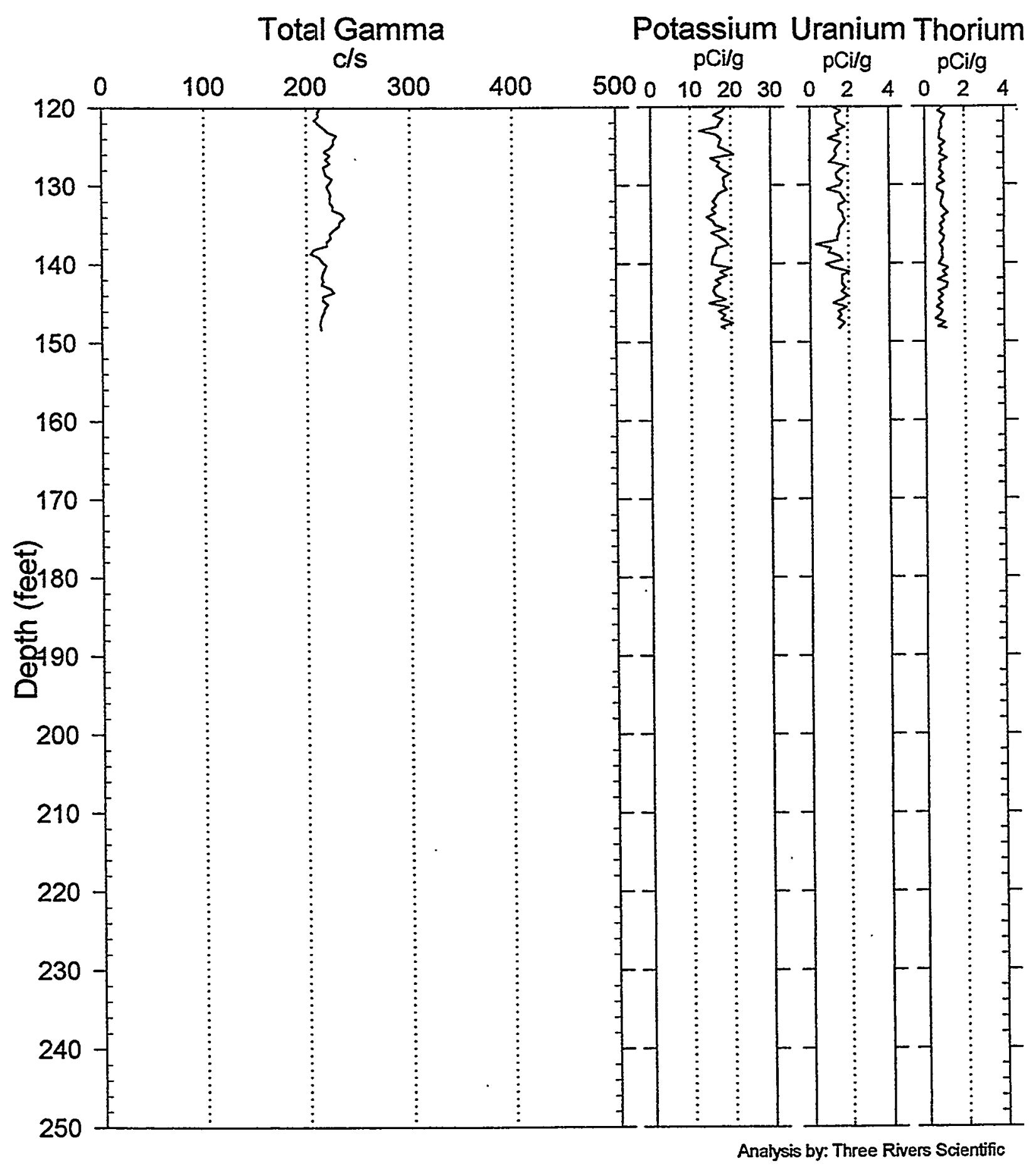




\section{RLS Spectral Gamma-Ray Borehole Survey Waste Management Federal Services NW}

Project: PNNL Vadose Zone Monitoring Log Date: July 27, 1999 Borehole: 299-E13-4 Man-Made Radio-Nuclides

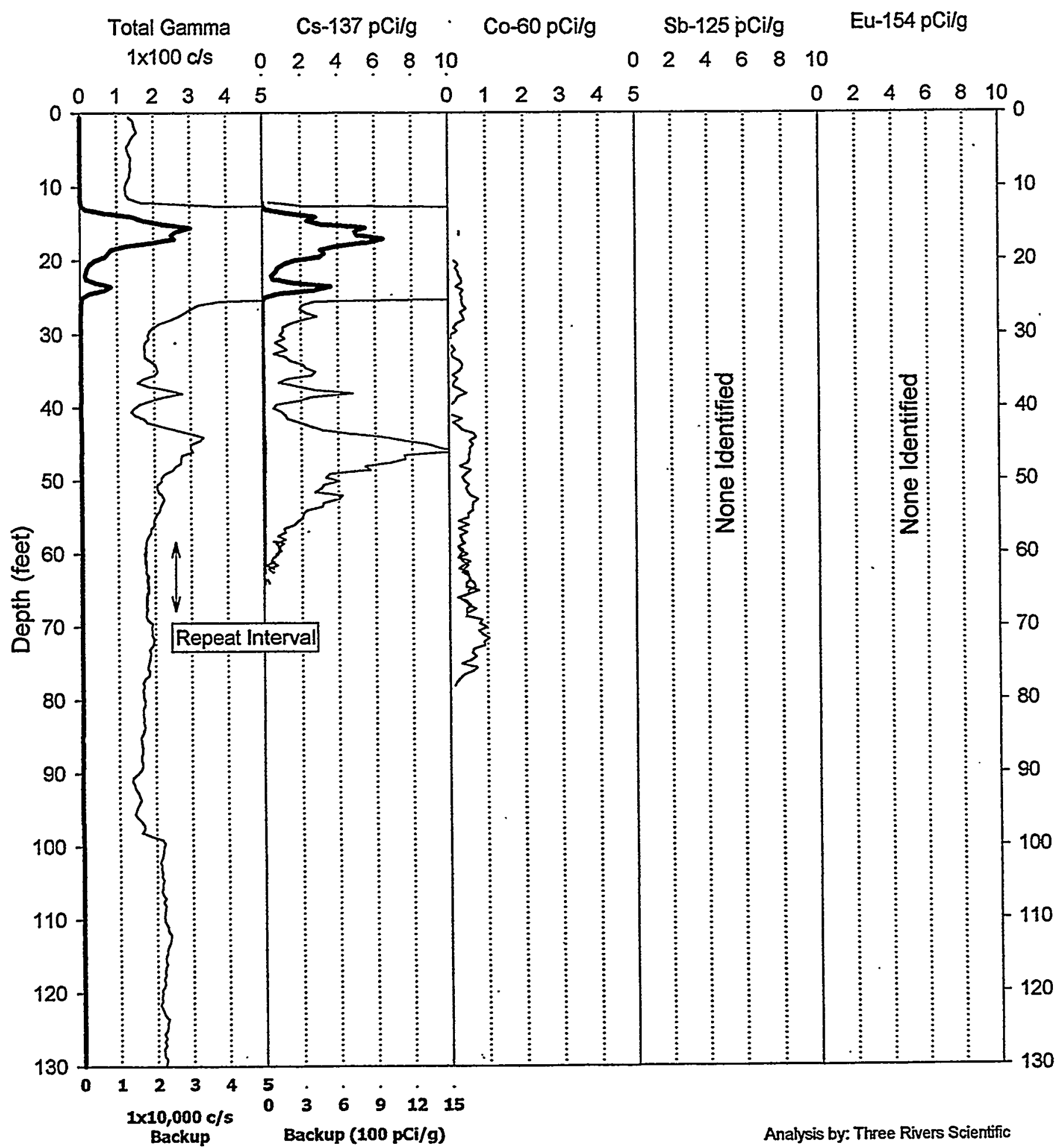


RLS Spectral Gamma-Ray Borehole Survey

Waste Management Federal Services NW

Project: PNNL Vadose Zone Monitoring Log Date: July 27, 1999 Borehole: 299-E13-4

Man-Made Radio-Nuclides

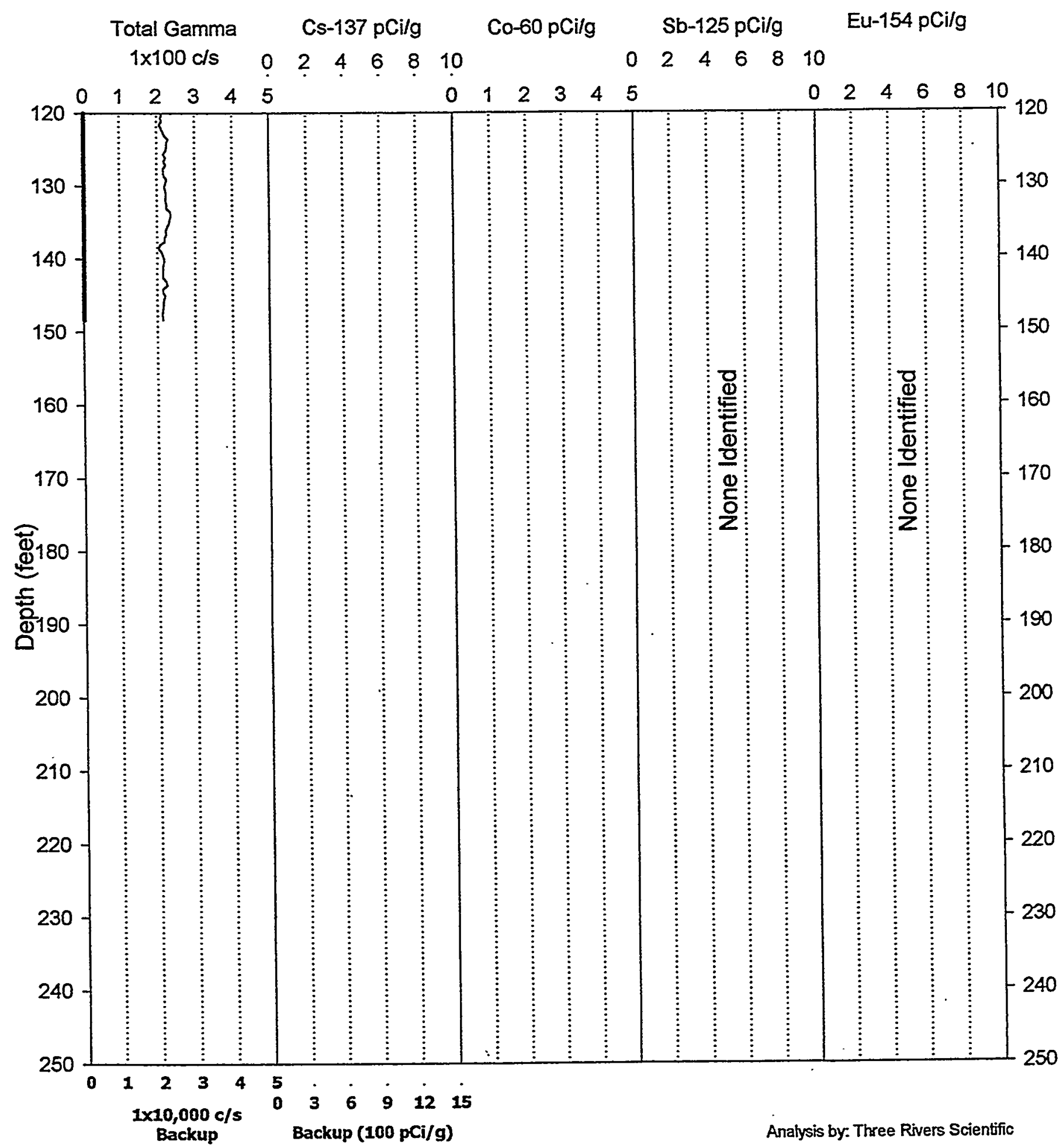




\section{RLS Spectral Gamma Ray Borehole Survey Acceptance QA Processing}

Project: PNNL Vadose Zone Monitoring - Log Date: July 27, 1999 Borehole: 299-E13-4 Compare Main Log \& Repeat

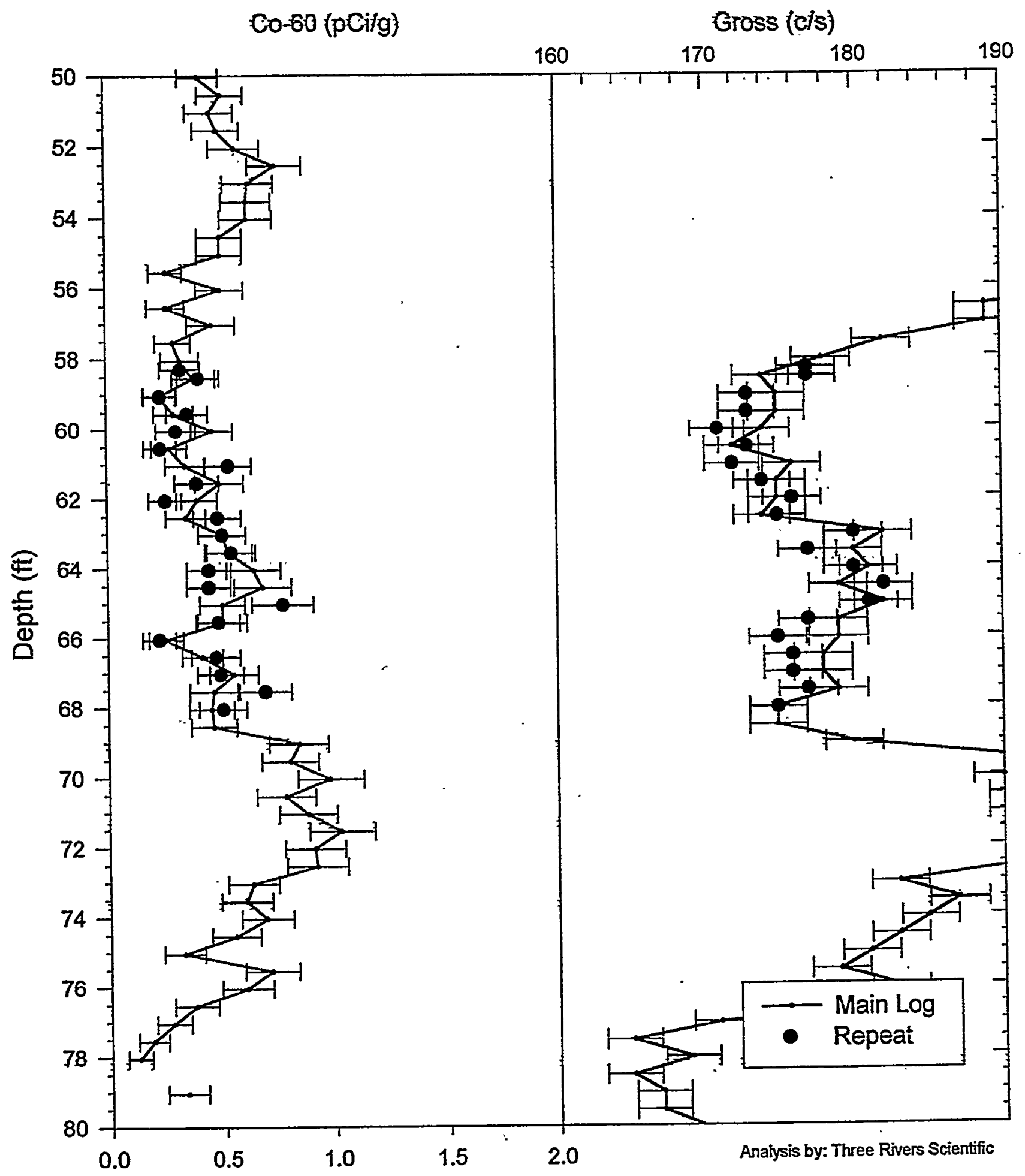




\section{RLS Spectral Gamma Ray Borehole Survey \\ Waste Management Federal Services NW}

\section{Log Analysis Summary Report}

Project: $\quad$ PNNL Vadose Zone Monitoring

Log Type: $\quad$ HPGe Spectral Gamma Ray
Well:

299-E13-4

Log Date:
July 27, 1999

\section{General Notes:}

Total gamma is a response to geologic concentrations of natural radionuclides except for the depth interval from 11-77 feet.

Log data collected with a depth reference of top of casing, and during analysis the depths were shifted to ground surface reference for all plots.

System Performance Verify: The pre- and post-log verification passed performance standards.

Repeat Interval: Based on the repeat interval, the logging system performed as per specifications. The error bars are calculated for 1 standard deviation of the net photo peak count rate statistical variance. Thus, the repeat should fall within these error bars $67 \%$ of the time.

Environmental Corrections: All radionuclide concentrations have been corrected for casing attenuation (entire well). Water level is below depths logged. No casing correction was applied to the total gamma due to Compton downscatter interference.

\section{Radionuclides:}

Cs-137 was identified over the depths from 11-63 feet. The maximum concentration of Cs-137 occurs at 17 feet, with a reading of $965 \mathrm{pCi} / \mathrm{g}$. The Cs- $137 \mathrm{MDL}$ value for these log data is $0.4 \mathrm{pCi} / \mathrm{g}$.

Co-60 was identified over the depths from 19-77 feet. The maximum concentration of Co-60 occurs at a depth of 71 feet, with a reading of $1 \mathrm{pCi} / \mathrm{g}$. The Co-60 MDL value for these $\log$ data is $0.25 \mathrm{pCi} / \mathrm{g}$, in the low Cs-137 intervals. 


\section{Moisture Logging Service \\ Log Header}

Project: $\quad$ PNNL Vadose Zone Monitoring

Well: 299-E13-4

Log Type: $\quad$ Moisture Gauge

Borehole Information

\begin{tabular}{|c|c|c|}
\hline Well \# $\underline{n / a}$ & Water Depth & Total Depth $369 \mathrm{ft}$ \\
\hline Elevation Reference $\underline{n / a}$ & Elevation $\quad \underline{n / a}$ & \\
\hline Depth Reference Top Casing & Casing Stickup $1.7 \quad \mathrm{ft}$ & \\
\hline Casing Diameter 6 in & Depth Interval 0 to $100 \mathrm{ft}$ & Thickness .25 \\
\hline Casing Diameter 8 & Depth Interval 0 to $369 \mathrm{ft}$ & Thickness \\
\hline
\end{tabular}

"Used nominal 8" thickness

Logging Information

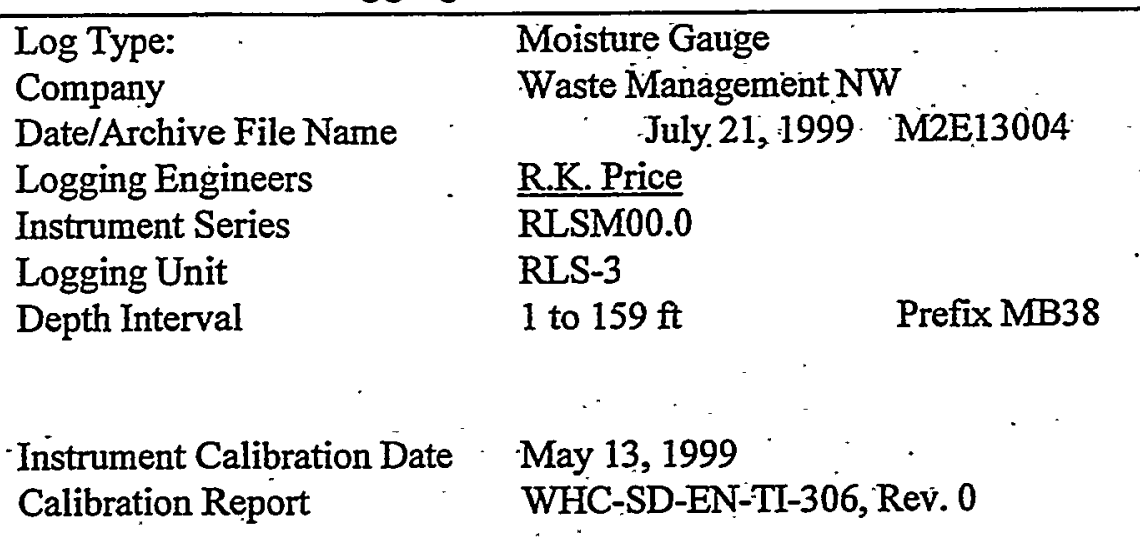

Analysis Information

$\begin{array}{ll}\text { Company } & \text { Three Rivers Scientific } \\ \text { Analyst } & \text { Russ Randall } \\ \text { Date } & \text { July 29, 1999 } \\ \text { Depth Reference } & \text { Ground Surface (plots depth:shifted) }\end{array}$

Notes Moisture values range from $2 \%$ to $50 \%$ for the depths logged. The log results indicate grout or bentonite sealer with correspondingly high moisture readings above $100 \mathrm{feet}$ 


\section{RLS Moisture Processed Log Data}

\section{Waste Management Federal Services NW}

Project: Vadose Zone Monitoring

Borehole: 299-E13-4

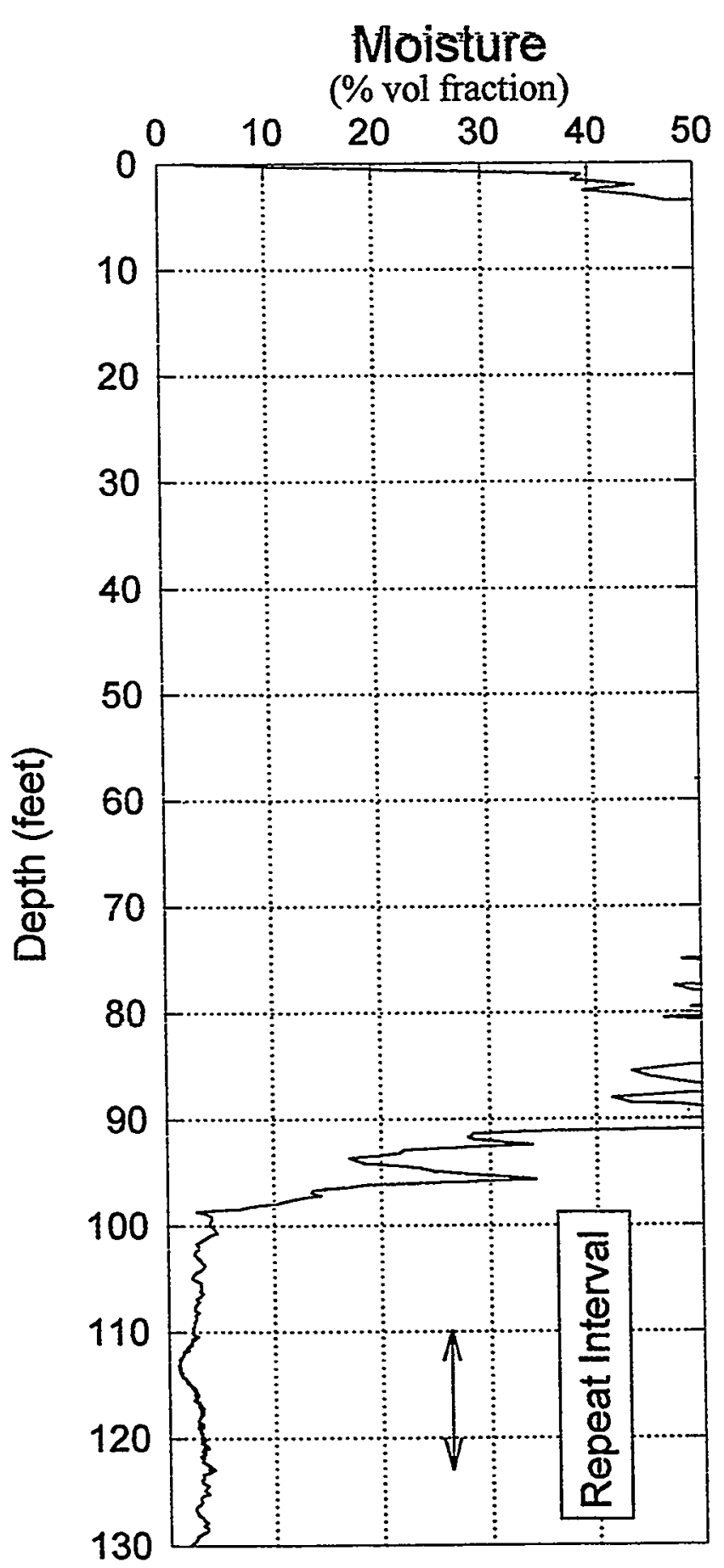

8" Casing Calibration Log Date July 21, 1999

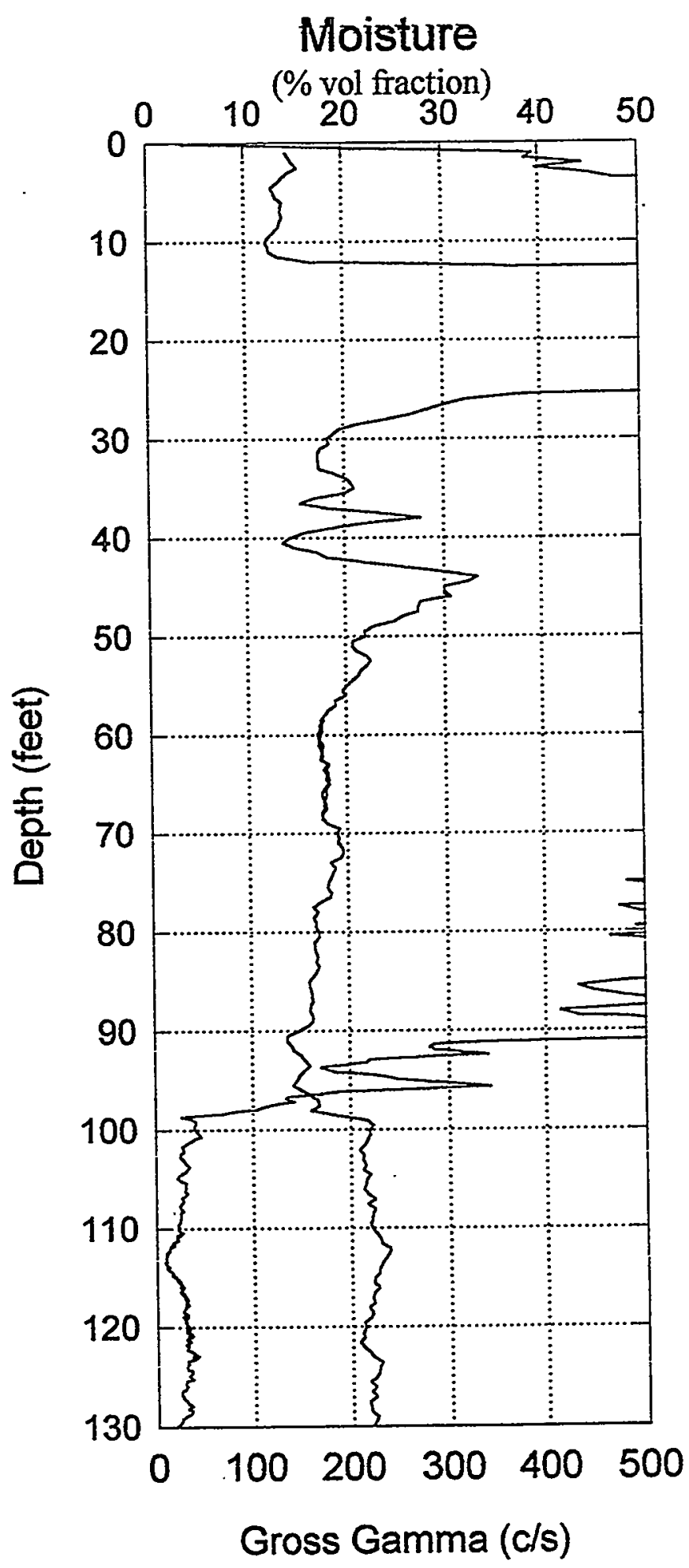




\section{RLS Moisture Processed Log Data}

\section{Waste Management Federal Services NW \\ Project: Vadose Żone Monitoring $\quad 8$ " Casing Calibration Borehole: 299-E13-4 Log Date July 21, 1999}
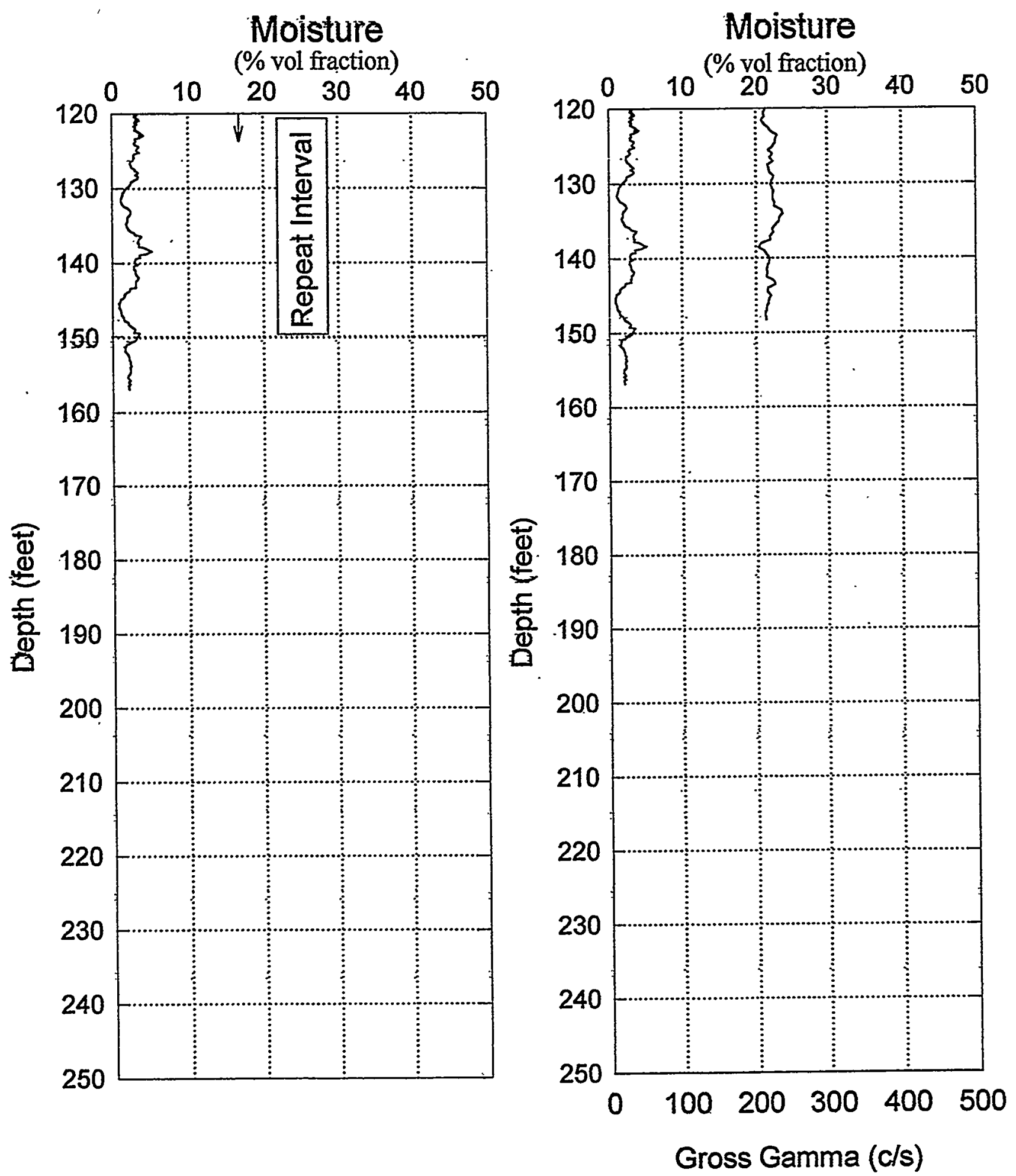


\section{RLS \\ Log Analysis \& Summary}

$\begin{array}{lllr}\text { Project: } & \text { PNNL Vadose Zone Monitoring } & \text { Well ID: } & \text { 299-E13-4 } \\ \text { Log Type: } & \text { Moisture Gauge } & \text { Log Date: } & \text { July 21, 1999 }\end{array}$

\section{General Notes:}

The low reading from 0 feet to 2 feet is due to surface effects and not necessarily the moisture content of the sediments surrounding the borehole.

Log data collected with a depth reference of top of casing, and during analysis the depths were shifted to ground surface reference for all plots.

System Performance Verify: The pre- and post-log verification passed performance standards, $-3.4 \%$ in the shield verify.

Repeat Interval: Based on the repeat interval from 110 to 123 feet, the logging system performed according to specifications.

Environmental Corrections: The moisture levels have been corrected for casing attenuation (entire well). Above 98.5 feet, the 8 " calibration and dual wall thickness corrections were applied, and below 98.5 feet the 6 " and single wall thickness correction were applied.

\section{Observations:}

The moisture levels show values ranging from $3 \%$ to greater than $50 \%$ for depth interval from 2 feet to 158 feet. The high moisture readings from 2 to 98 feet are indicative of sealing material and not soil moisture content. The bottom of the 8 " casing was determined from the KUT and gross gamma signature. 


\section{RLS Spectral Gamma Ray Borehole Survey \\ Waste Management Federal Services NW}

\section{Log Header}

Project: $\quad$ PNNL Vadose Zone Monitoring

Well: 299-E13-5

Log Type: $\quad$ HPGe Spectral Gamma Ray

Borehole Information

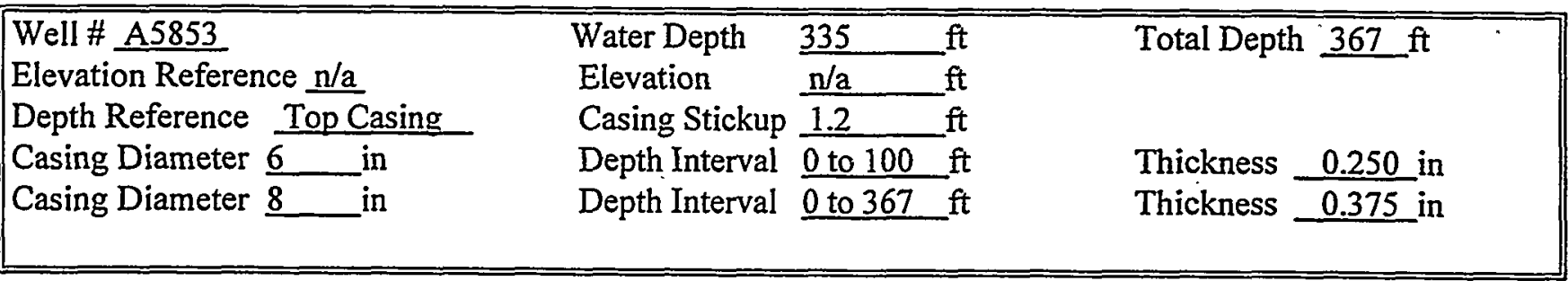

Logging Information

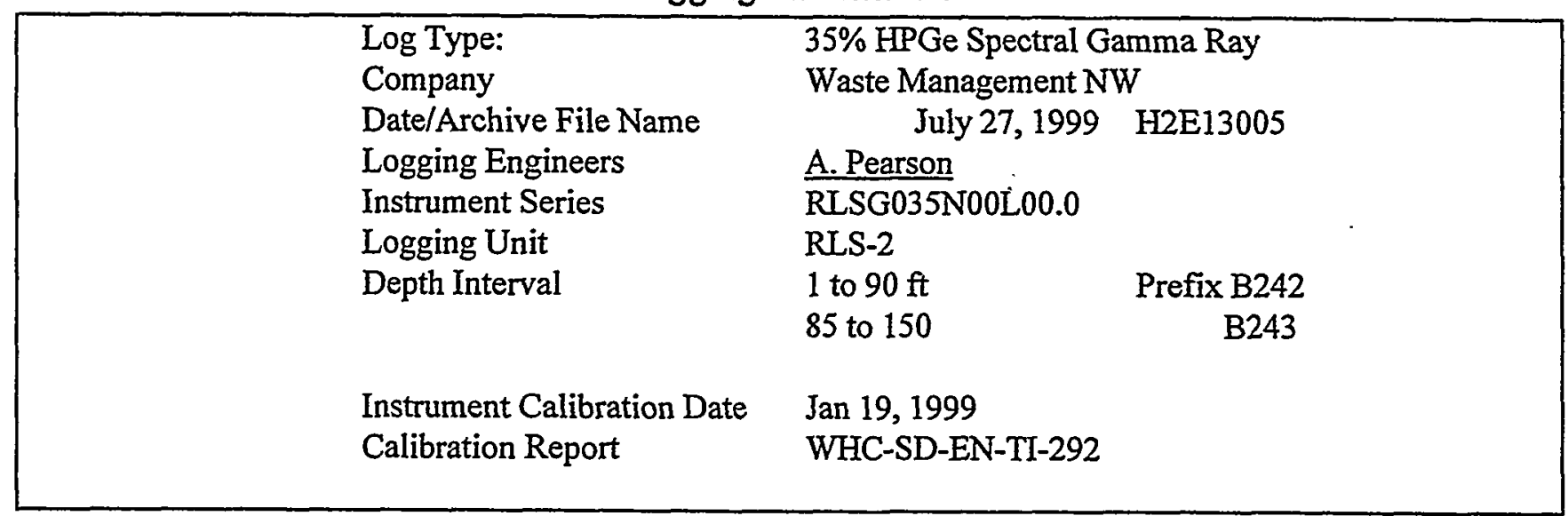

Analysis Information

\begin{tabular}{|c|c|c|}
\hline & $\begin{array}{l}\text { Company } \\
\text { Analyst } \\
\text { Date } \\
\text { Depth Reference }\end{array}$ & $\begin{array}{l}\text { Three Rivers Scientific } \\
\text { Russ Randall } \\
\text { August 1, } 1999 \\
\text { Ground Surface (plots depth shifted) }\end{array}$ \\
\hline Notes & \multicolumn{2}{|c|}{$\begin{array}{l}\text { Cs-137. Co- } 60 \text {, and } \mathrm{Sb}-125 \text { are the only man made radionuclides detected. The dead time correction } \\
\text { accuracy was exceeded from } 14 \text { to } 20 \text { feet due to excessive count rates. }\end{array}$} \\
\hline
\end{tabular}




\section{RLS Spectral Gamma Ray Borehole Survey Waste Management Federal Services NW}

Project: PNNL Vadose Zone Monitoring Log Date: July 26\&27, 1999 Borehole: 299-E13-5

Naturally Occurring Radionuclides

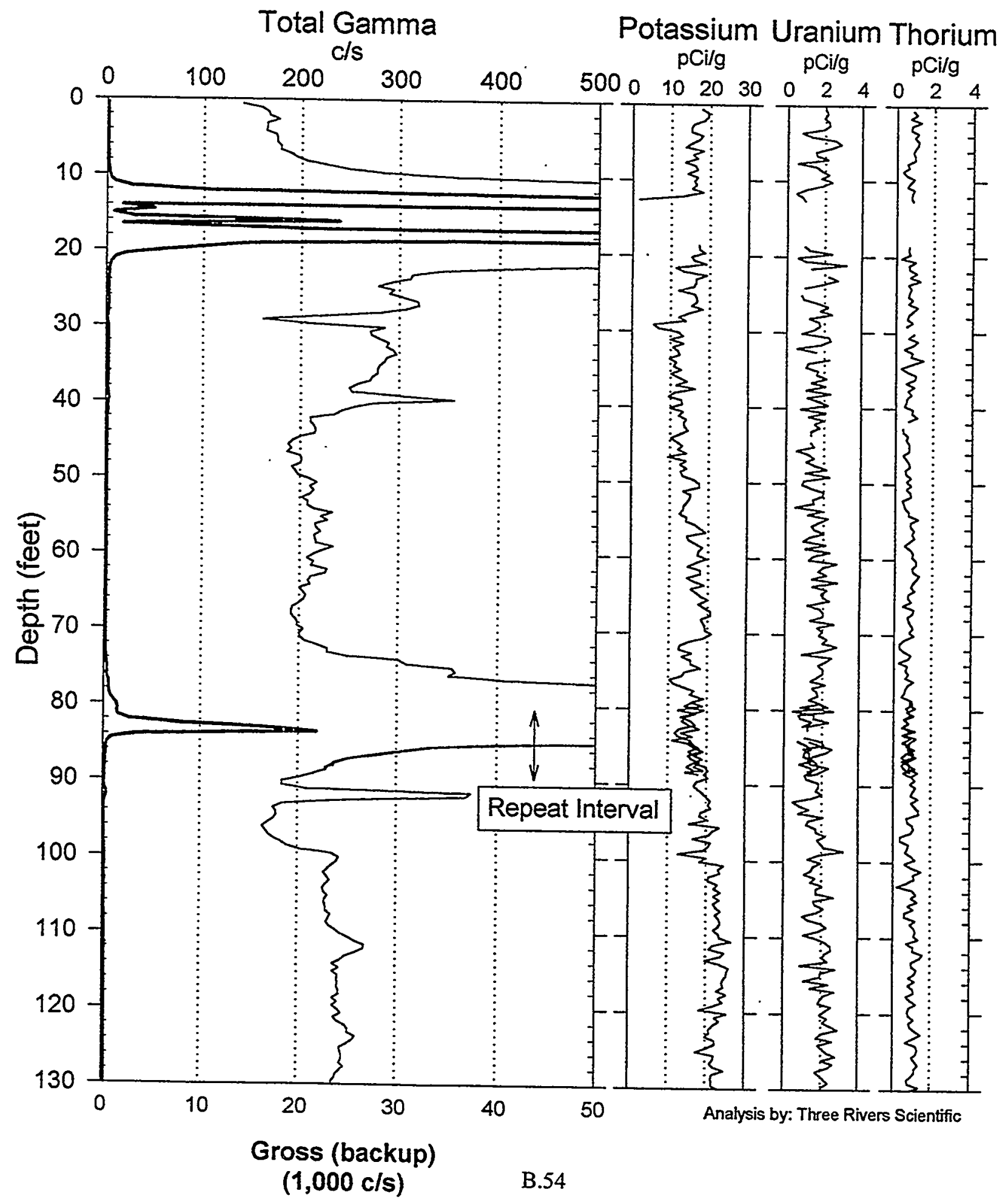




\section{RLS Spectral Gamma Ray Borehole Survey Waste Management Federal Services NW}

Project: PNNL Vadose Zone Monitoring - Log Date: July 26\&27, 1999 Borehole: 299-E13-5

Naturally Occurring Radionuclides

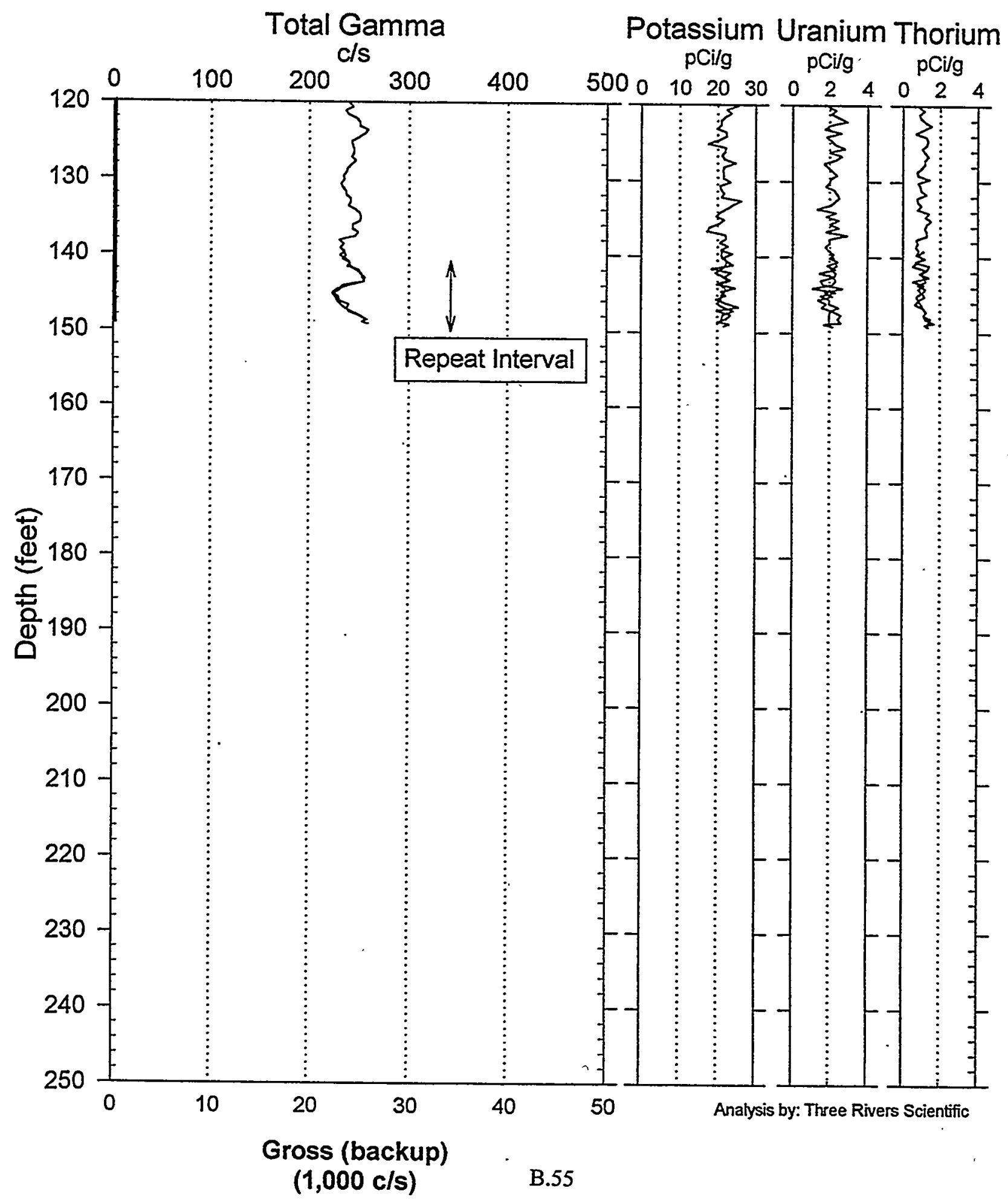




\section{RLS Spectral Gamma-Ray Borehole Survey}

\section{Waste Management Federal Services NW}

Project: PNNL Vadose Zone Monitoring Log Date: July 26\&27, 1999 Borehole: 299-E13-5

Man-Made Radio-Nuclides

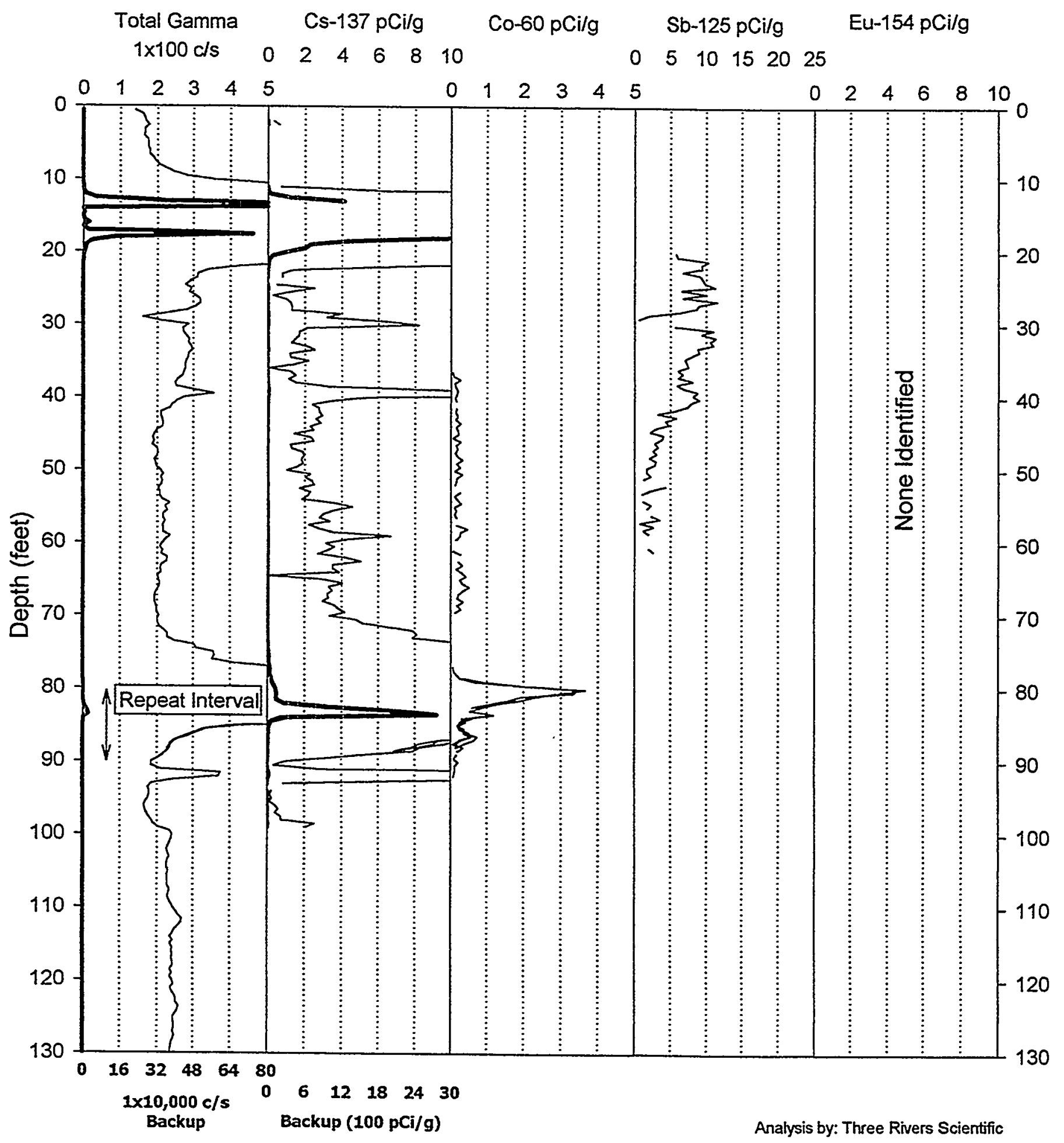


RLS Spectral Gamma-Ray Borehole Survey

\section{Waste Management Federal Services NW}

Project: PNNL Vadose Zone Monitoring Log Date:July 26\&27, 1999 Borehole: 299-E13-5

\section{Man-Made Radio-Nuclides}

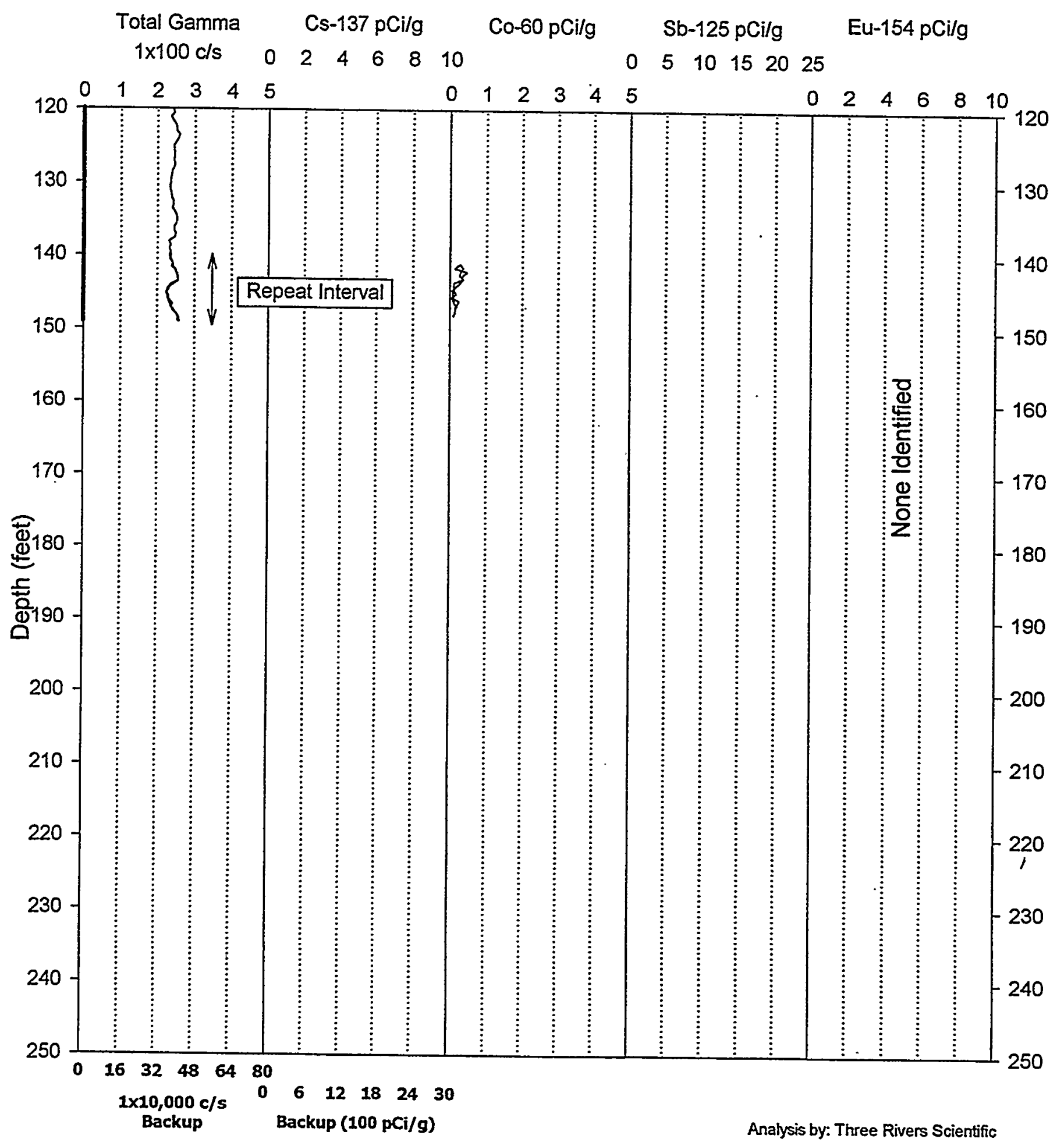


RLS Spectral Gamma Ray Borehole Survey

Acceptance QA Processing

Project: PNNL Vadose Zone Monitoring

Borehole: 299-E13-5
Log Date: July 26\&27, 1999

Compare Main Log \& Repeat

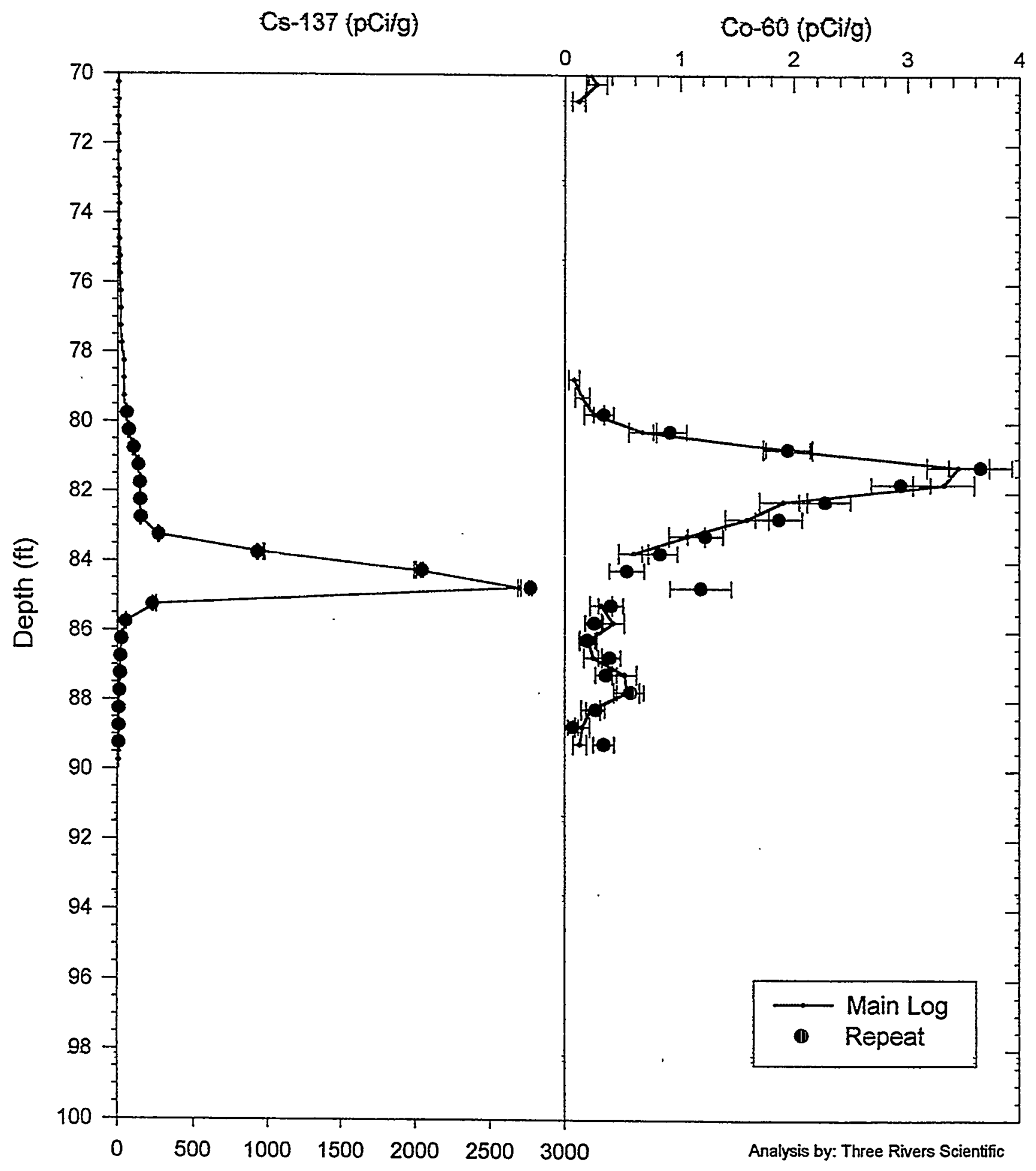




\title{
RLS Spectral Gamma Ray Borehole Survey \\ Waste Management Federal Services NW
}

\section{Log Analysis Summary Report}

\author{
Project: $\quad$ PNNL Vadose Zone Monitoring \\ Well: \\ 299-E13-5 \\ Log Type: $\quad$ HPGe Spectral Gamma Ray \\ Log Dates: July 26\&27, 1999
}

\section{General Notes:}

Total gamma is a response to geologic concentrations of natural radionuclides except for the depth interval from 11-100 feet.

Log data collected with a depth reference of top of casing, and during analysis the depths were shifted to ground surface reference for all plots.

System Performance Verify: The pre- and post-log verification passed performance standards.

Repeat Interval: Based on the repeat interval, the logging system performed as per specifications, refer to repeat plot. The error bars are calculated for 1 standard deviation of the net photo peak count rate statistical variance. Thus, the repeat should fall within these error bars $67 \%$ of the time.

Environmental Corrections: All radionuclide concentrations have been corrected for casing attenuation (entire well). Water level is below depths logged. No casing correction was applied to the total gamma due to Compton downscatter interference. Dual casing attenuation affects the gross gamma over the interval from 130 to 125 feet.

Concentrations of all radionuclides are under reported over the interval from 14 to 20 feet. The high count rates over this interval result in loss of dead time correction accuracy.

\section{Radionuclides:}

Cs-137 was identified over the depths from 11-100 feet. The maximum concentration of Cs-137 occurs somewhere between 14 and 19 feet; the instrument encounters too high a count rate to identify the Cs-137 photo peak. The maximum concentration is greater than $3,000 \mathrm{pCi} / \mathrm{g}$. The Cs- $137 \mathrm{MDL}$ value for these log data is near $0.5 \mathrm{pCi} / \mathrm{g}$.

Co-60 was identified over the depths from 35-94 feet, and from 143-149 feet. The maximum concentration of Co60 occurs at a depth of 81 feet, with a reading of $3.5 \mathrm{pCi} / \mathrm{g}$. The Co-60 MDL value for these $\log$ data is $0.3 \mathrm{pCi} / \mathrm{g}$, in the low Cs-137 intervals.

Sb- 125 was identified at over the depths from 20-60 feet. Any Sb-125 shallower than 20 feet may be masked by the high Cs-137 concentration. The maximum concentration of Sb-125 occurs at depths of 25 and 31 feet, with a reading of $11 \mathrm{pCi} / \mathrm{g}$. The $\mathrm{Sb}-125 \mathrm{MDL}$ value for these $\log$ data is $2 \mathrm{pCi} / \mathrm{g}$ in the low Cs-137 intervals.

Special Note: Cs-137 ends at the dual casing end (100 feet). There is good correlation between presence of Cs137 and grout. 


\section{Moisture Logging Service Log Header}

Project: $\quad$ PNNL Vadose Zone Monitoring

Well: 299-E13-5

Log Type: Moisture Gauge

Borehole Information

\begin{tabular}{|c|c|c|c|}
\hline Well \# A5853 & Water Depth 374 & $\mathrm{ft}$ & Total Depth $367 \mathrm{ft}$ \\
\hline Elevation Reference $\underline{n} / \mathrm{a}$ & Elevation $\quad \mathrm{n} / \mathrm{a}$ & $\mathrm{ft}$ & \\
\hline Depth Reference Top Casing & Casing Stickup 1.17 & $\mathrm{ft}$ & \\
\hline Casing Diameter 6 in & Depth Interval 0 to 100 & $\mathrm{ft}$ & Thickness .25 \\
\hline Casing Diameter $\underline{8}$ in & Depth Interval 0 to 367 & $\mathrm{ft}$ & Thickness \\
\hline
\end{tabular}

Logging Information

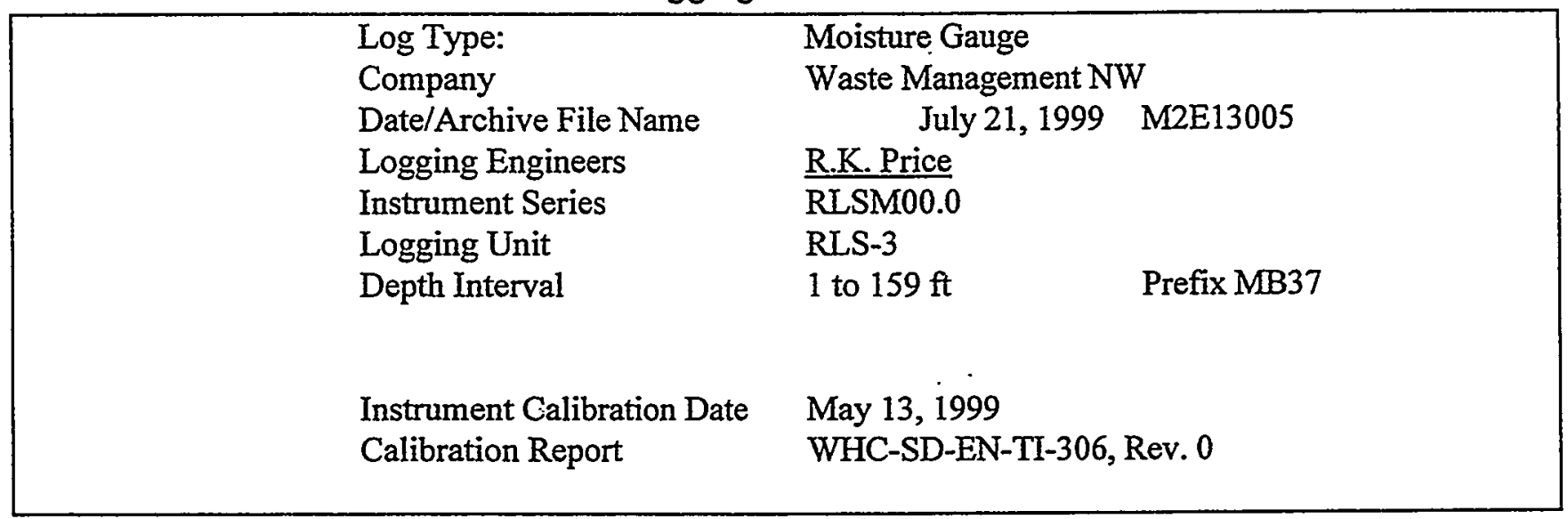

Analysis Information

\begin{tabular}{|c|c|c|}
\hline & $\begin{array}{l}\text { Company } \\
\text { Analyst } \\
\text { Date } \\
\text { Depth Reference }\end{array}$ & $\begin{array}{l}\text { Three Rivers Scientific } \\
\text { Russ Randall } \\
\text { July } 30,1999 \\
\text { Ground Surface (plots depth shifted) }\end{array}$ \\
\hline Notes & \multicolumn{2}{|c|}{$\begin{array}{l}\text { Moisture values range from } 2 \% \text { to greater } 50 \% \text { for the depths logged. The log results indicate grout or } \\
\text { bentonite sealer with correspondingly high moisture readings above } 99 \text { feet. }\end{array}$} \\
\hline
\end{tabular}




\section{RLS Moisture Processed Log Data}

\section{Waste Management Federal Services NW}

Project: Vadose Zone Monitoring

Borehole: 299-E13-5

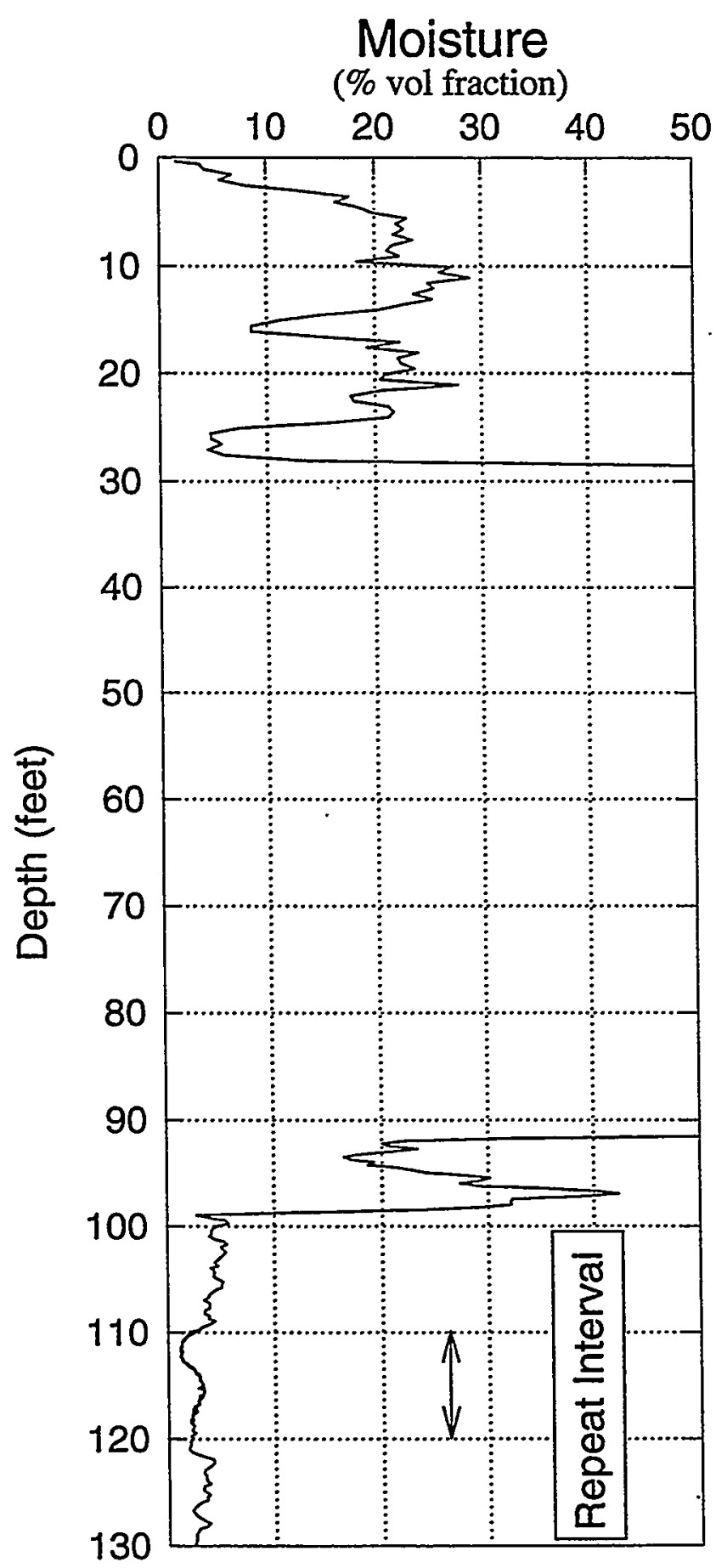

6" Casing Calibration Log Date July 21, 1999

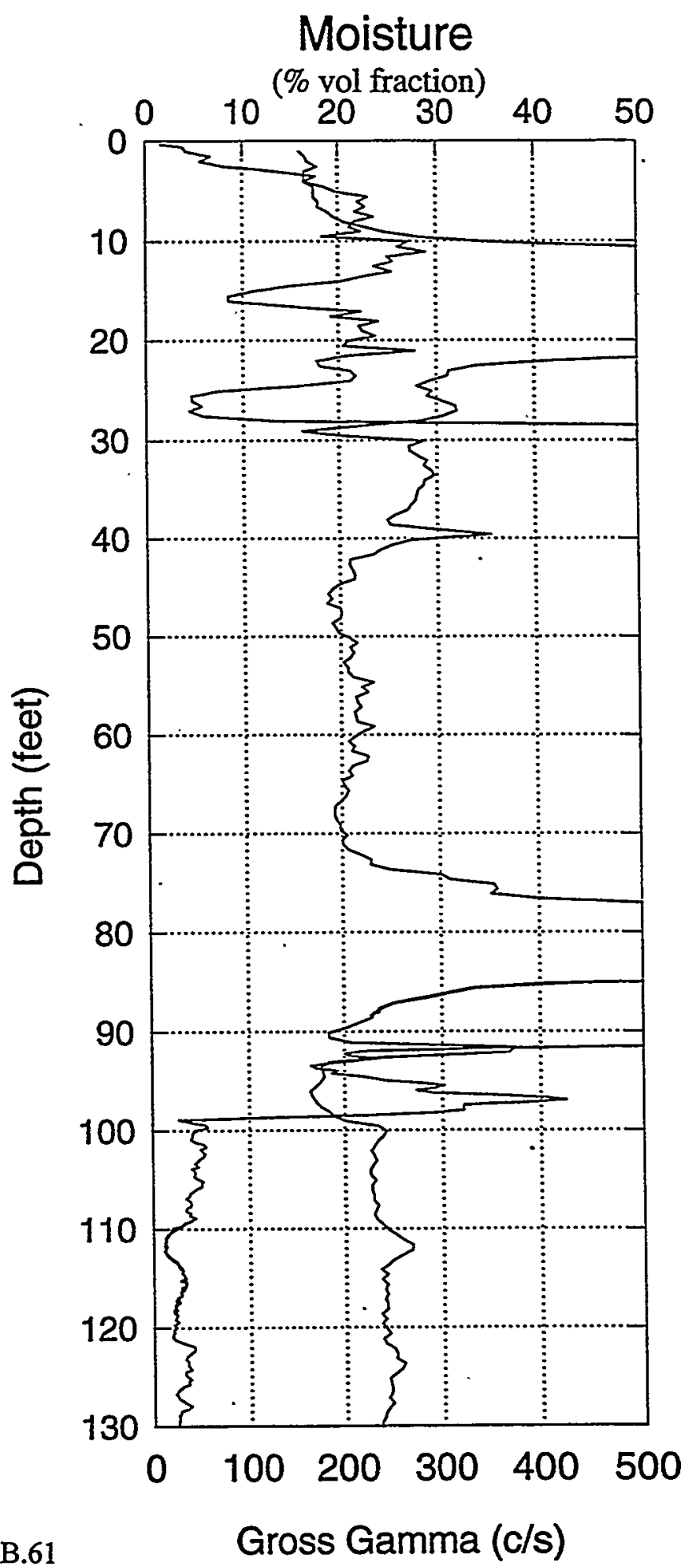




\section{RLS Moisture Processed Log Data}

\section{Waste Management Federal Services NW}

Project: Vadose Zone Monitoring

Borehole: 299-E13-5

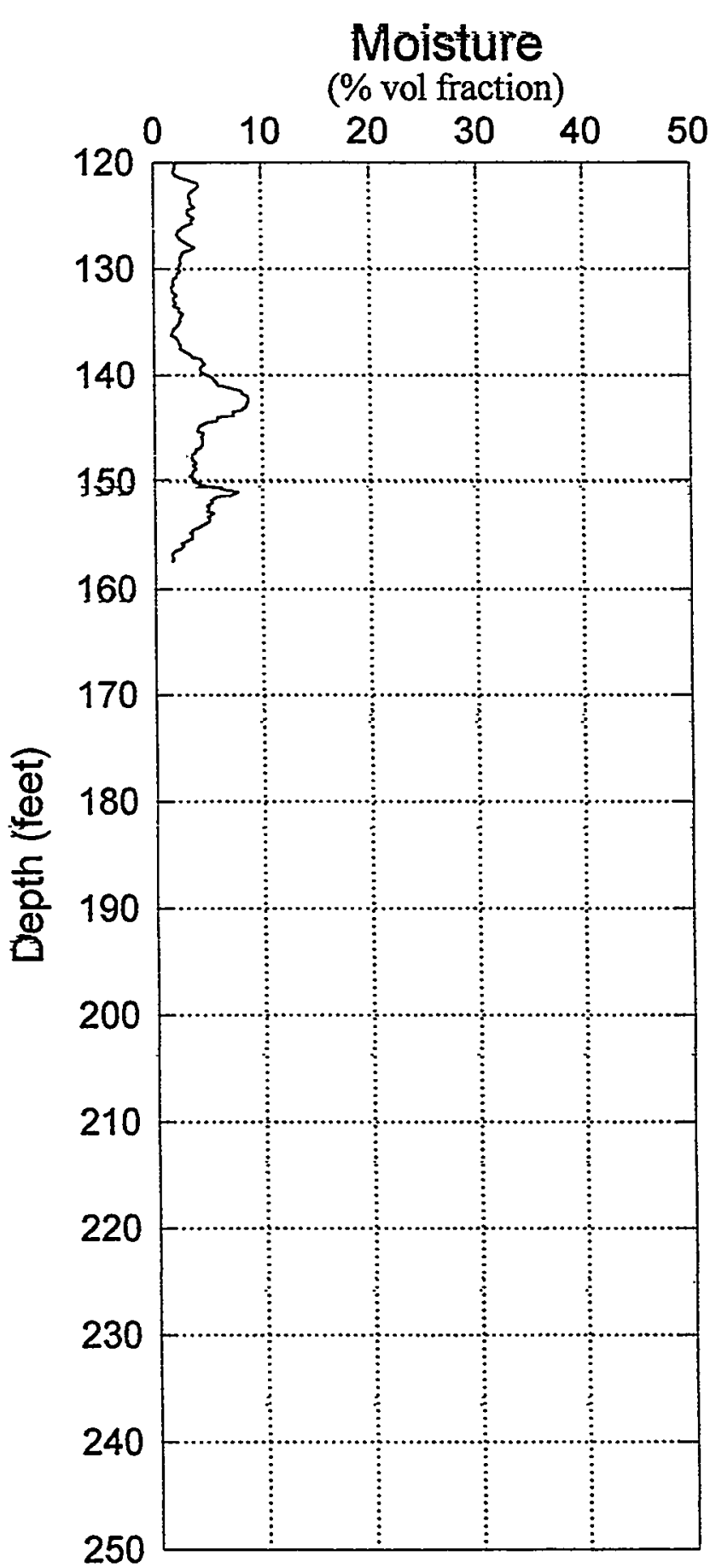

6" Casing Calibration Log Date July 21, 1999

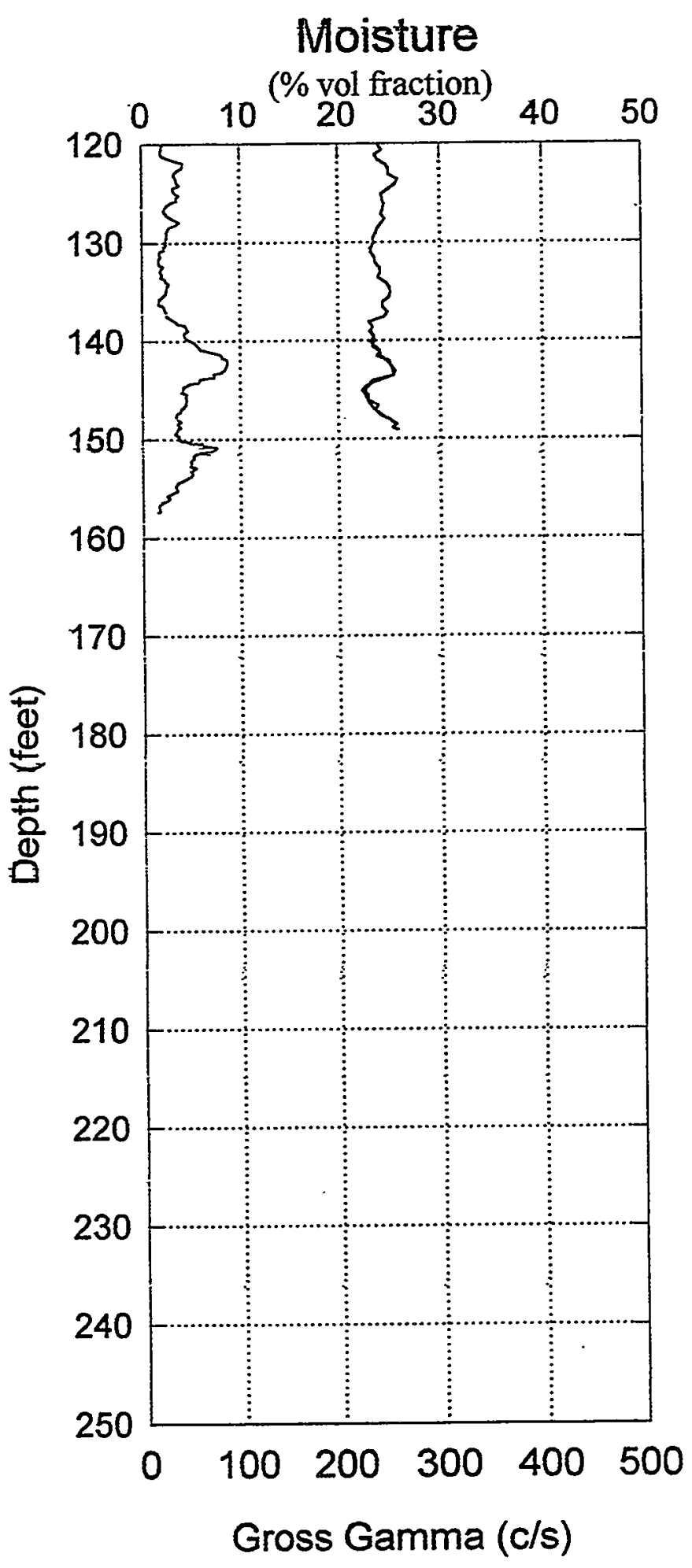




\section{RLS \\ Log Analysis \& Summary}

Project: $\quad$ PNNL Vadose Zone Monitoring

Well ID:

299-E13-5

Log Type: Moisture Gauge

Log Date:

July 21,1999

\section{General Notes:}

The low reading from 0 feet to 2 feet is due to surface effects and not necessarily the moisture content of the sediments surrounding the borehole.

Log data collected with a depth reference of top of casing, and during analysis the depths were shifted to ground surface reference for all plots.

System Performance Verify: The pre- and post-log verification passed performance standards, $-2.1 \%$ in the shield verify.

Repeat Interval: Based on the repeat interval from 110 to 120 feet, the logging system performed according to specifications.

Environmental Corrections: The moisture levels have been corrected for casing attenuation (entire well). Above 99 feet, the $8^{\prime \prime}$ calibration and dual wall thickness corrections were applied, and below 99 feet the $6^{\prime \prime}$ and single wall thickness correction were applied.

\section{Observations:}

The moisture levels show values ranging from 3\% to greater than $50 \%$ for depth interval from 2 feet to 158 feet. The high moisture readings from 2 to 99 feet are indicative of sealing material and are not indicative of soil moisture content. The bottom of the 6 inch diameter casing was determined from the KUT and gross gamma signature. 


\section{RLS Spectral Gamma Ray Borehole Survey \\ Waste Management Federal Services NW}

\section{Log Header}

Project: $\quad$ PNNL Vadose Zone Monitoring

Well: 299-E13-6

Log Type: $\quad$ HPGe Spectral Gamma Ray

Borehole Information

\begin{tabular}{|c|c|c|}
\hline Well \# $\mathrm{A} 6025$ & Water Depth 343 & Total Depth $364 \mathrm{ft}$ \\
\hline Elevation Reference $\underline{\mathrm{n} / \mathrm{a}}$ & Elevation & \\
\hline Depth Reference Top Casing & Casing Stickup $1.4 \quad \mathrm{ft}$ & \\
\hline Casing Diameter $\underline{6 \quad \text { in }}$ & Depth Interval 0 to $100 \mathrm{ft}$ & Thickness \\
\hline Casing Diameter $\underline{8}$ & Depth Interval 0 to $364 \mathrm{ft}$ & Thickness \\
\hline
\end{tabular}

"Water level identified from KUT data

Logging Information

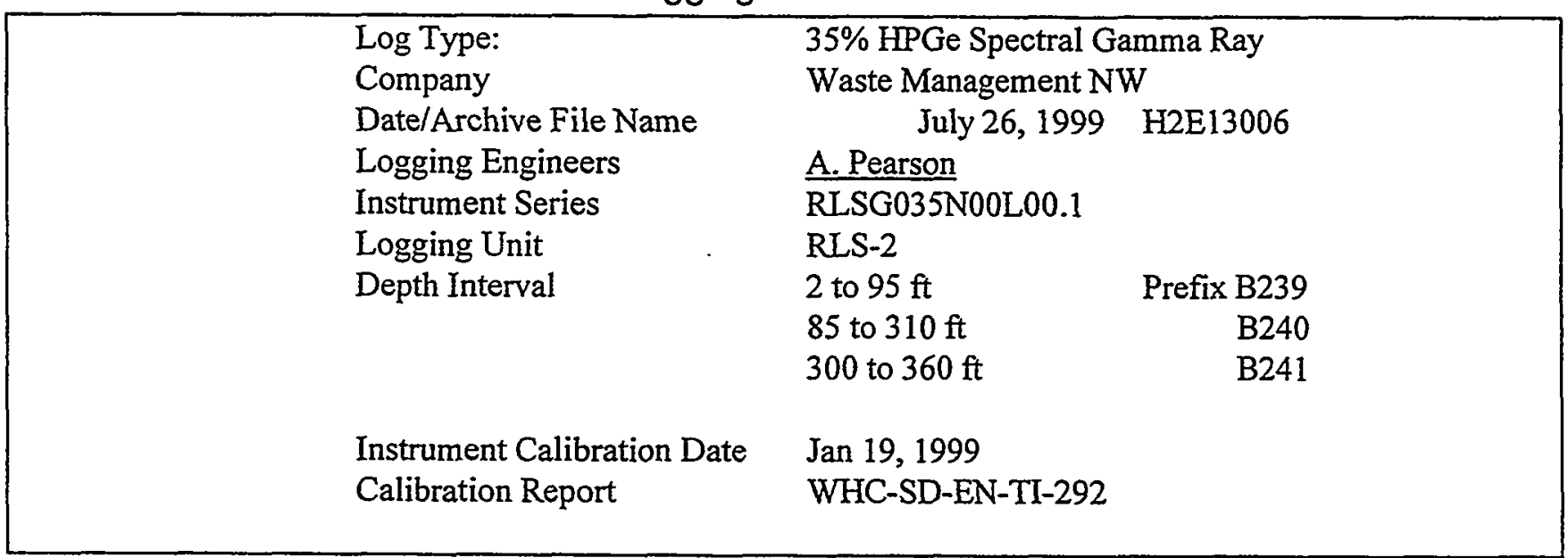

Analysis Information

\begin{tabular}{|c|c|c|}
\hline & $\begin{array}{l}\text { Company } \\
\text { Analyst } \\
\text { Date } \\
\text { Depth Reference }\end{array}$ & $\begin{array}{l}\text { Three Rivers Scientific } \\
\text { Russ Randall } \\
\text { August 1,1999 } \\
\text { Ground Surface (plots depth shifted) }\end{array}$ \\
\hline Notes & \multicolumn{2}{|c|}{$\begin{array}{l}\mathrm{Cs}-137 . \mathrm{Co}-60 \text {, and } \mathrm{Sb}-125 \text { are the only man made radionuclides detected. The high count rate over } \\
\text { the interval from } 12 \text { to } 18 \text { feet results in under reported radionuclide concentrations due to inaccurate } \\
\text { dead time correction.. }\end{array}$} \\
\hline
\end{tabular}




\section{RLS Spectral Gamma Ray Borehole Survey Waste Management Federal Services NW}

Project: PNNL Vadose Zone Monitoring Log Date: July 21,22\&26, 1999 Borehole: 299-E13-6

Naturally Occurring Radionuclides

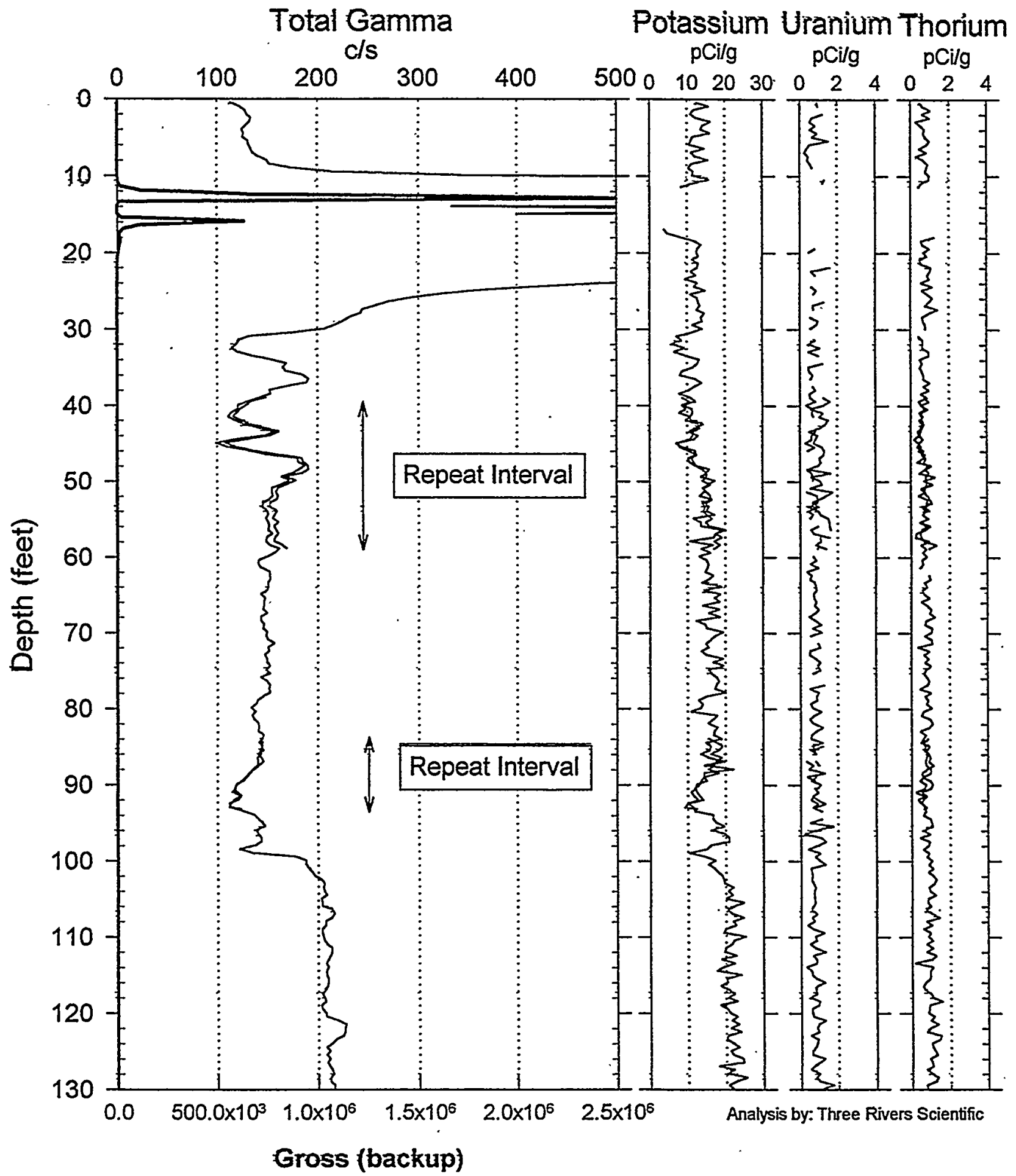




\section{RLS Spectral Gamma Ray Borehole Survey Waste Management Federal Services NW}

Project: PNNL Vadose Zone Monitoring Log Date: July 21,22\&26, 1999 Borehole: 299-E13-6

Naturally Occurring Radionuclides

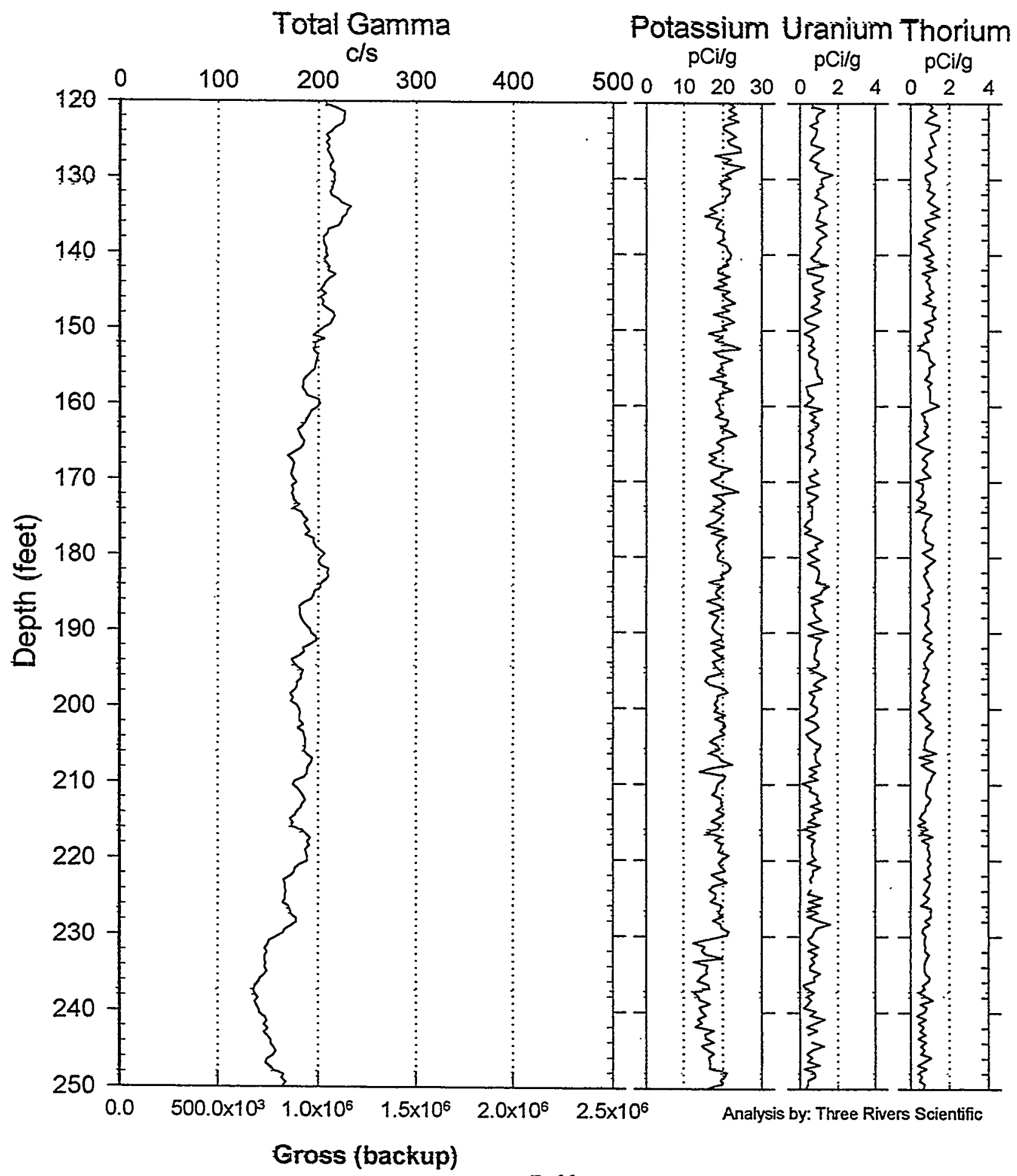




\section{RLS Spectral Gamma Ray Borehole Survey Waste Management Federal Services NW}

Project: PNNL Vadose Zone Monitoring Log Date: July 21,22\&26, 1999 Borehole: 299-E13-6

Naturally Occurring Radionuclides

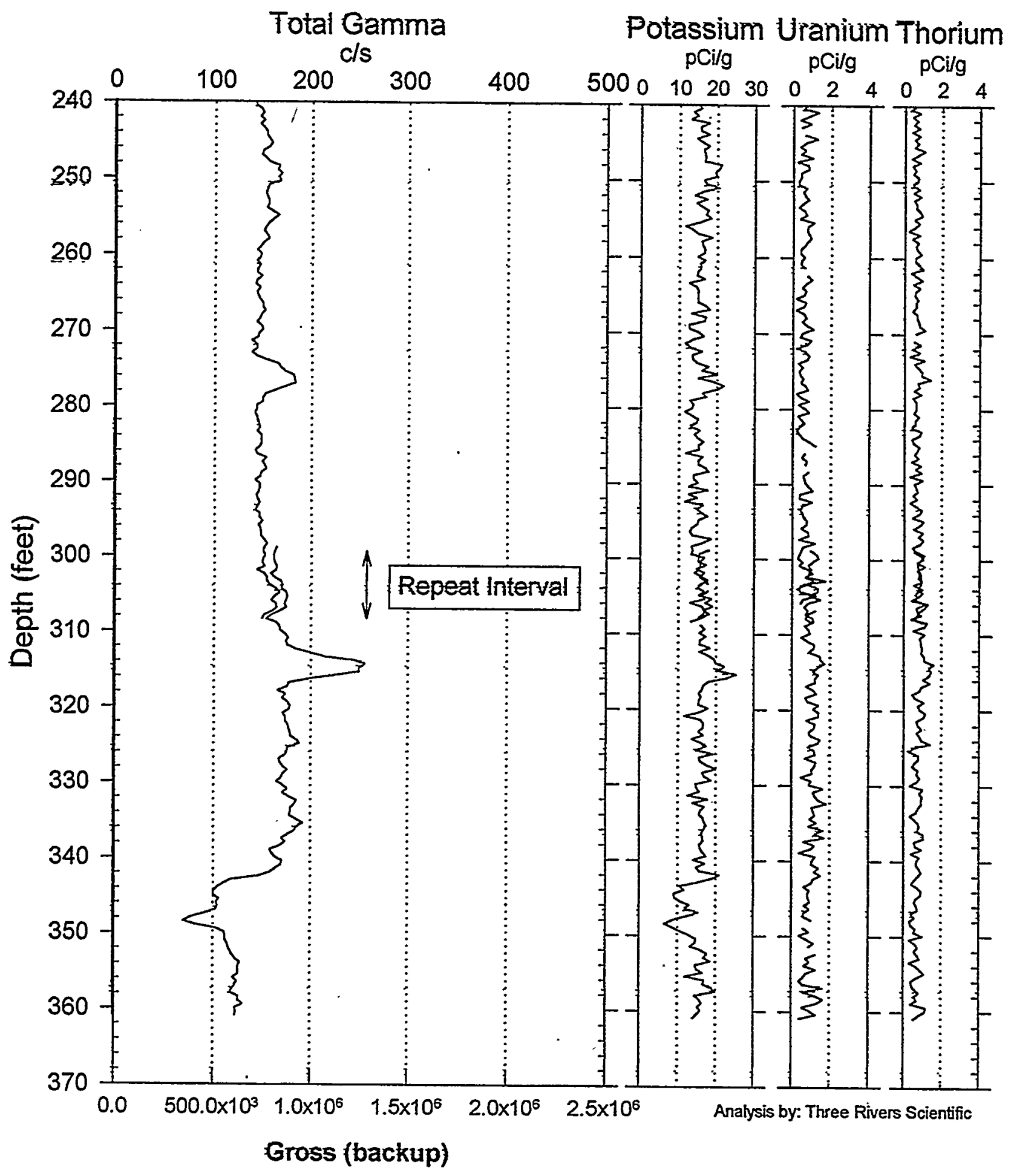




\section{RLS Spectral Gamma-Ray Borehole Survey \\ Waste Management Federal Services NW}

Project: PNNL Vadose Zone Monitoring Log Date: July 21,22\&26, 1999 Borehole: 299-E13-6

Man-Made Radio-Nuclides

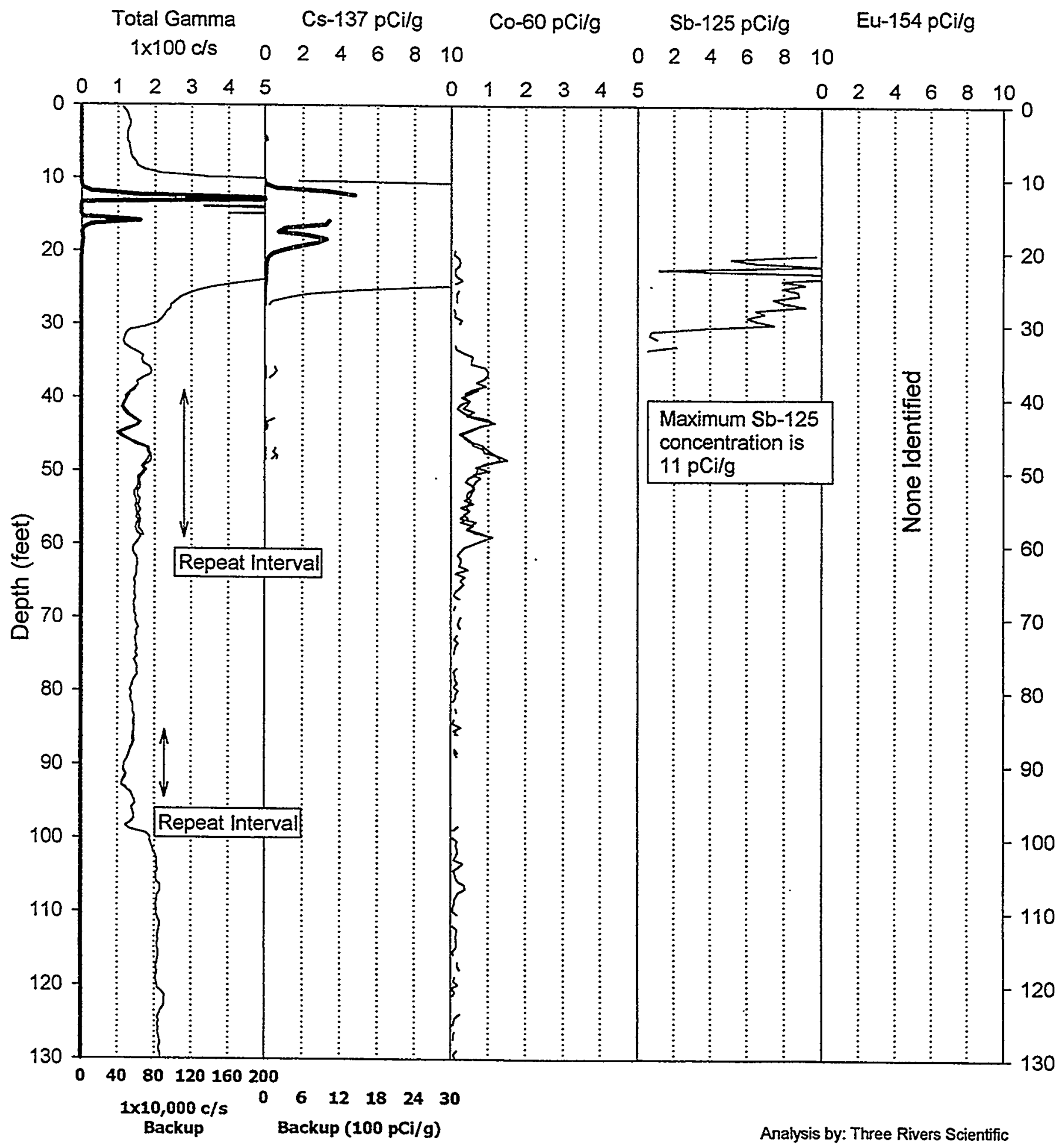




\section{RLS Spectral Gamma-Ray Borehole Survey Waste Management Federal Services NW}

Project: PNNL Vadose Zone Monitoring Log Date: July 21,22\&26, 1999 Borehole: 299-E13-6

\section{Man-Made Radio-Nuclides}

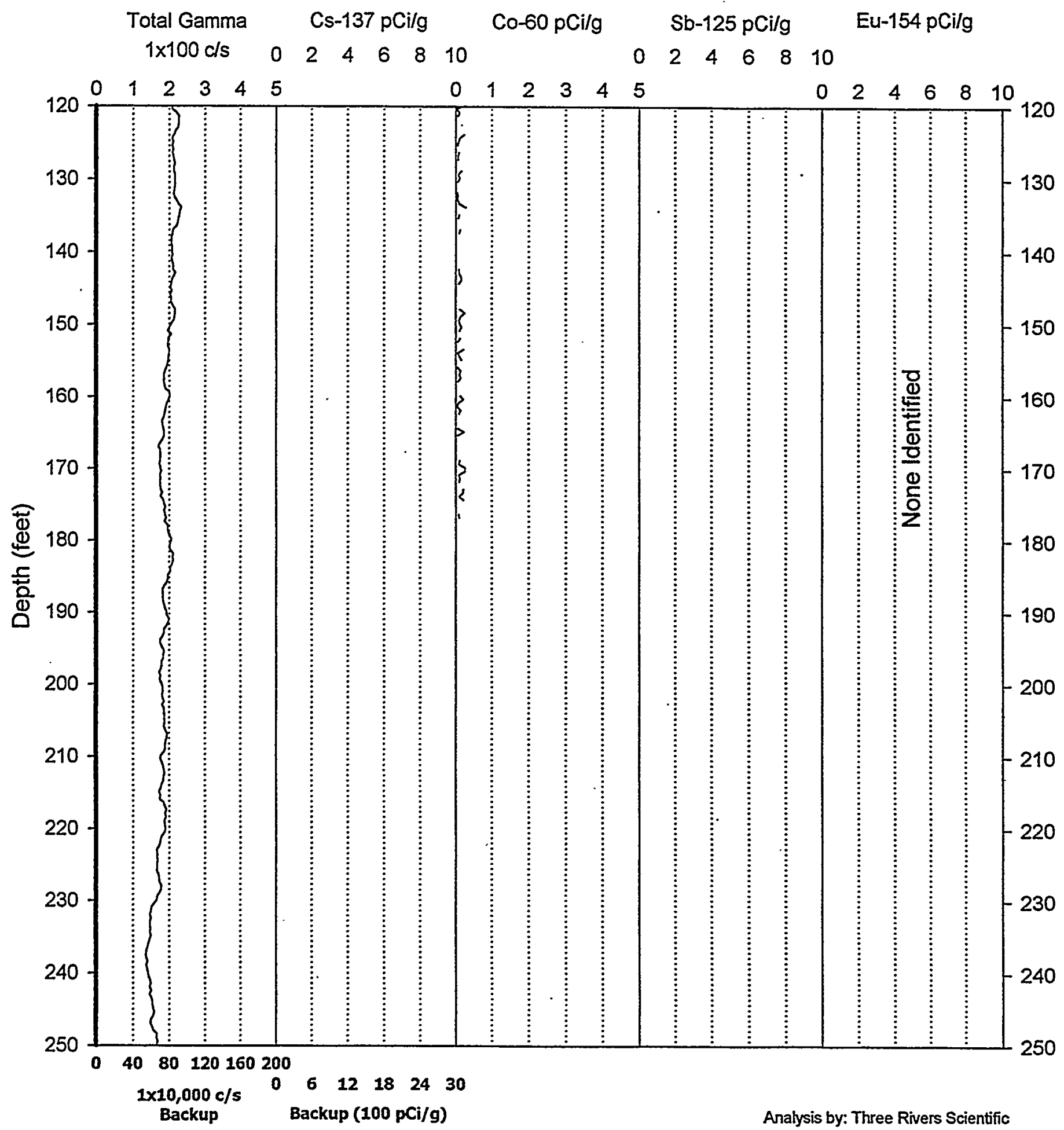




\section{RLS Spectral Gamma-Ray Borehole Survey}

Waste Management Federal Services NW

Project: PNNL Vadose Zone Monitoring Log Date: July 21,22\&26, 1999 Borehole: 299-E13-6 Man-Made Radio-Nuclides

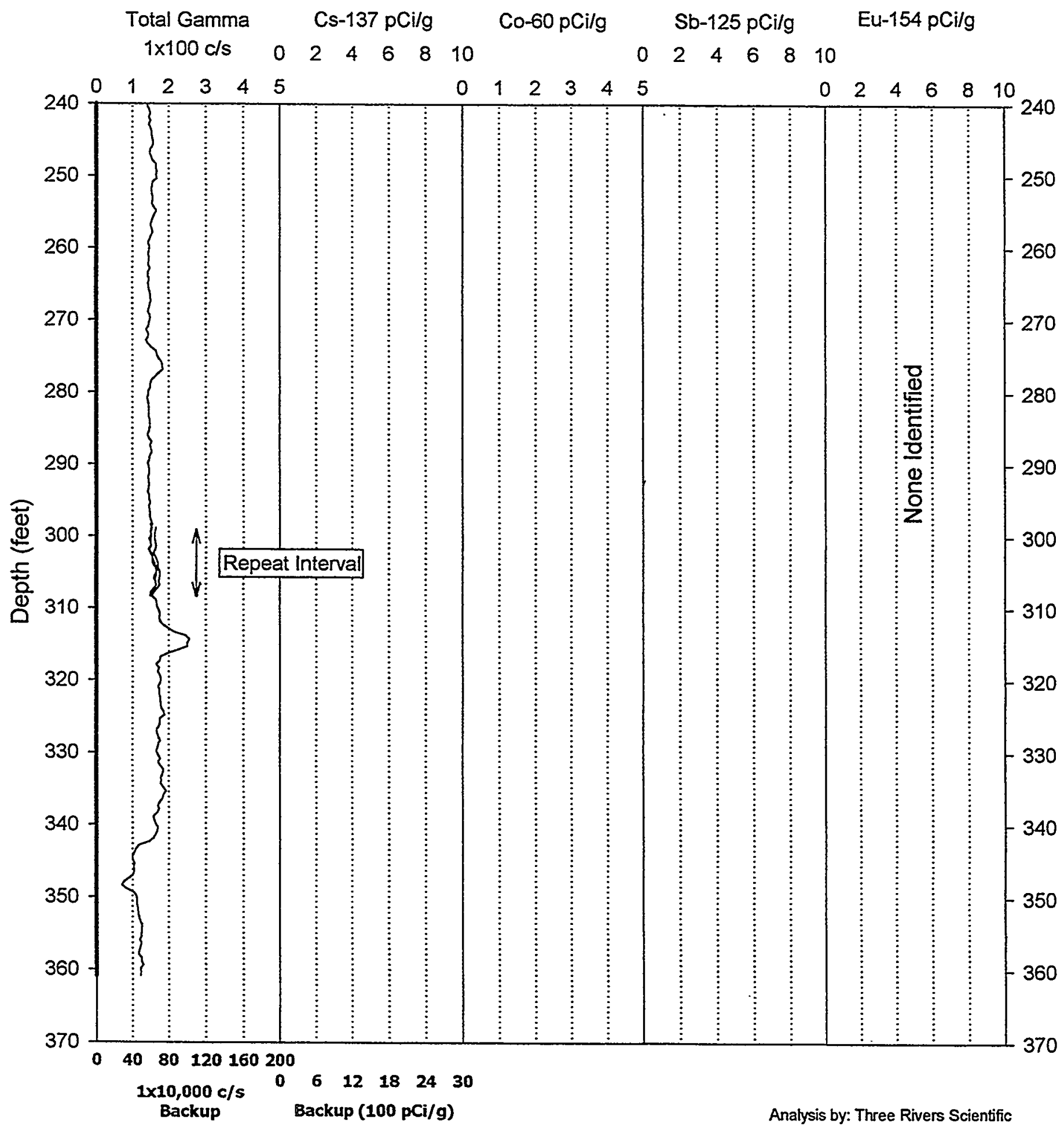




\section{RLS Spectral Gamma Ray Borehole Survey Acceptance QA Processing}

Project: PNNL Vadose Zone Monitoring Borehole: 299-E13-6
Log Date: July 21,22\&26, 1999 Compare Main Log \& Repeat

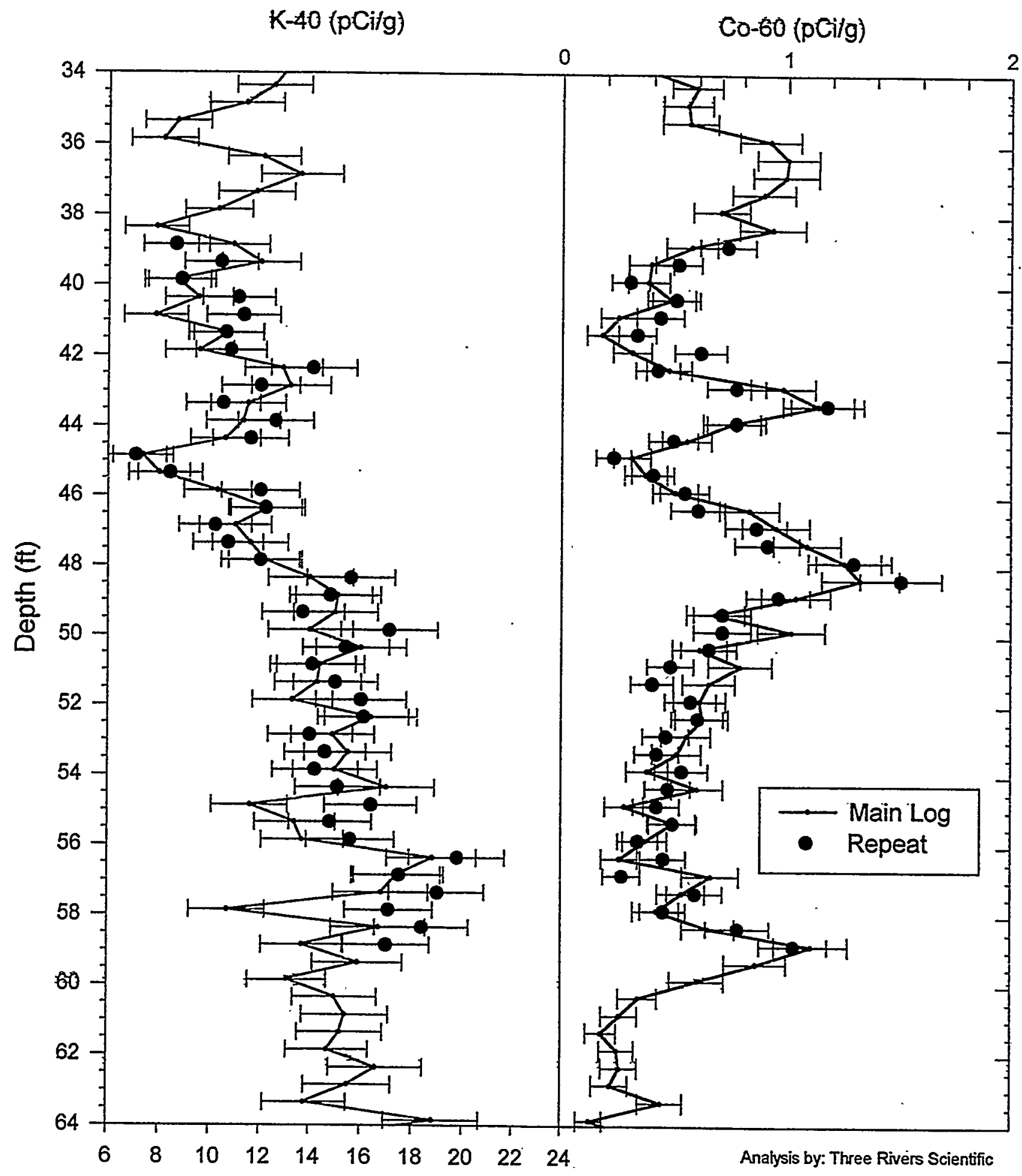




\title{
RLS Spectral Gamma Ray Borehole Survey
}

Waste Management Federal Services NW

\section{Log Analysis Summary Report}

\author{
Project: $\quad$ PNNL Vadose Zone Monitoring \\ Well: \\ 299-E13-6 \\ Log Type: HPGe Spectral Gamma Ray \\ Log Dates: July 21,22\&26, 1999
}

\section{General Notes:}

Total gamma is a response to geologic concentrations of natural radionuclides except for the depth interval from $10-65$ feet.

Log data collected with a depth reference of top of casing, and during analysis the depths were shifted to ground surface reference for all plots.

System Performance Verify: The pre- and post-log verification passed performance standards.

Repeat Interval: Based on the repeat interval, the logging system performed as per specifications. The error bars are calculated for 1 standard deviation of the net photo peak count rate statistical variance. Thus, the repeat should fall within these error bars $67 \%$ of the time. The gross gamma is observed to differ on different logging days due to radon pumping. For this reason, the $\mathrm{K}-40$ and $\mathrm{Co}-60$ results were repeat analyzed.

Environmental Corrections: All radionuclide concentrations have been corrected for casing attenuation (entire well). Water level was picked on the basis of the KUT and gross signature before water correcting. The water level used is 342 feet. No casing correction was applied to the total gamma due to Compton downscatter interference.

From 12 to 18 feet, the high count rates experienced result in in-accurate dead time corrections, and the true radionuclide concentrations are larger than reported.

\section{Radionuclides:}

Cs-137 was identified over the depths from 10-28 feet, and near detection threshold from 34-48 feet. The maximum concentration of Cs-137 occurs somewhere between 12 and 14 feet, with a reading greater than 1,000 $\mathrm{pCi} / \mathrm{g}$. The true value is larger due to high count rate limits exceeding the accuracy of the dead time correction. The Cs-137 MDL value for these log data is $0.3 \mathrm{pCi} / \mathrm{g}$

Co-60 was identified over the depths from 19-60. Very low levels are observed from 60 to 175 feet, but many of these occur near threshold. The maximum concentration of Co-60 occurs at a depth of 47 feet, with a reading of $1.5 \mathrm{pCi} / \mathrm{g}$. The Co-60 MDL value for these $\log$ data is $0.2 \mathrm{pCi} / \mathrm{g}$.

$\mathrm{Sb}-125$ was identified over the depths from 19-32 feet. The maximum concentration of Sb-125 occurs at a depth of 23 feet, with a reading of $11 \mathrm{pCi} / \mathrm{g}$. The possible presence of Sb-125 above 19 feet is masked by the strong Cs-137 signal above 19 feet. The Sb-125 MDL value for these log data is $1.7 \mathrm{pCi} / \mathrm{g}$. 


\section{Moisture Logging Service \\ Log Header}

Project: $\quad$ PNNL Vadose Zone Monitoring

Well: 299-E13-6

Log Type: $\quad$ Moisture Gauge

Borehole Information

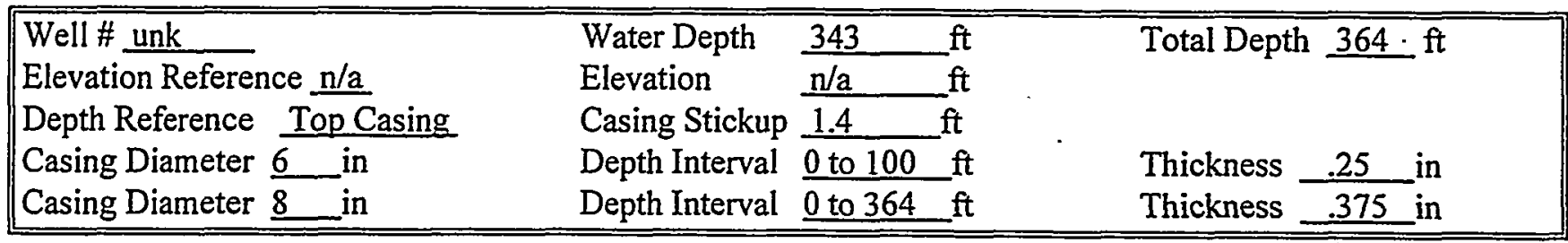

Logging Information

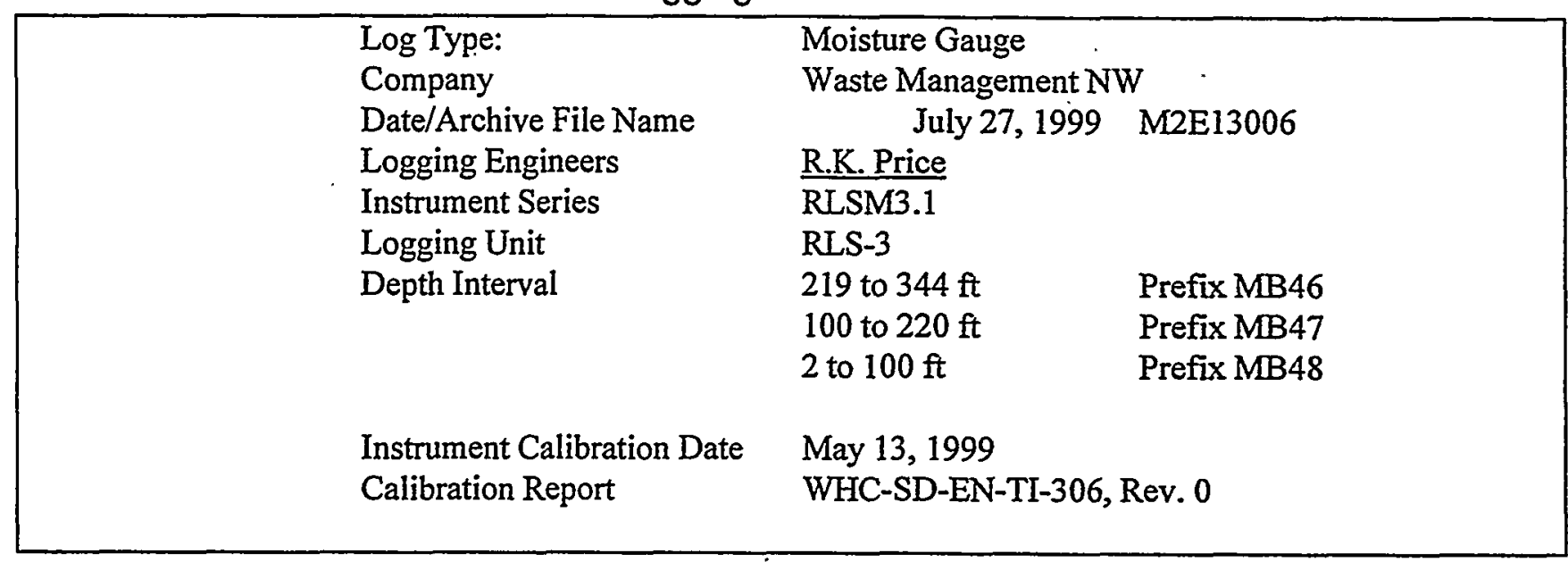

Analysis Information

\begin{tabular}{|c|c|c|}
\hline & $\begin{array}{l}\text { Company } \\
\text { Analyst } \\
\text { Date } \\
\text { Depth Reference }\end{array}$ & $\begin{array}{l}\text { Three Rivers Scientific } \\
\text { Russ Randall } \\
\text { July } 30,1999 \\
\text { Ground Surface (plots depth shifted) }\end{array}$ \\
\hline Notes & \multicolumn{2}{|c|}{$\begin{array}{l}\text { Moisture values range from } 2 \% \text { to greater than } 50 \% \text { for the depths logged. The high moisture reading } \\
\text { above } 93 \text { feet are indicative of the sealer material between the dual casing configurations. }\end{array}$} \\
\hline
\end{tabular}




\section{RLS Moisture Processed Log Data}

\section{Waste Management Federal Services NW}

Project: Vadose Zone Monitoring

Borehole: 299-E13-6
8" Casing Calibration

Log Date July 27, 1999
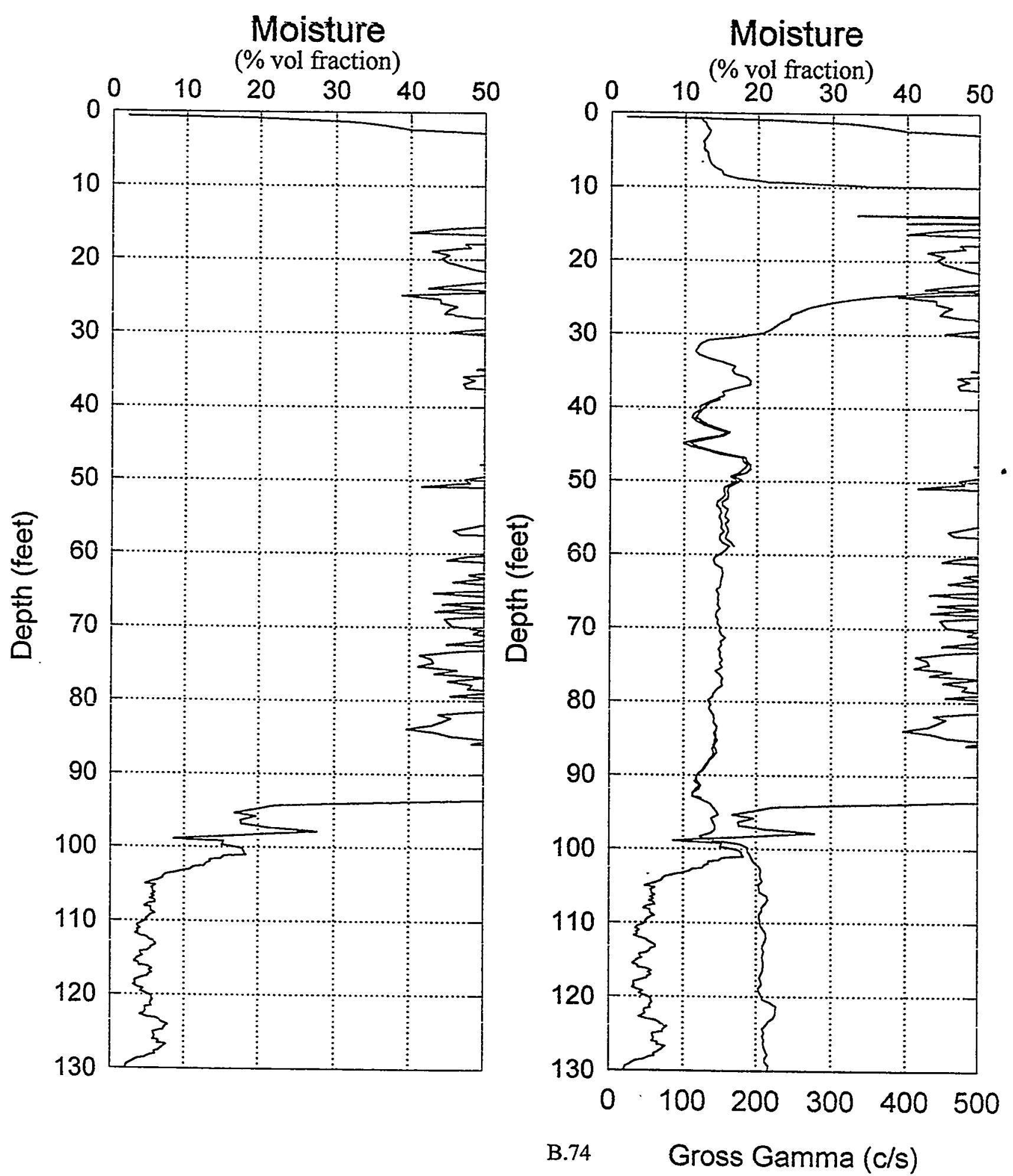
RLS Moisture Processed Log Data Waste Management Federal Services NW

Project: Vadose Zone Monitoring Borehole: 299-E13-6

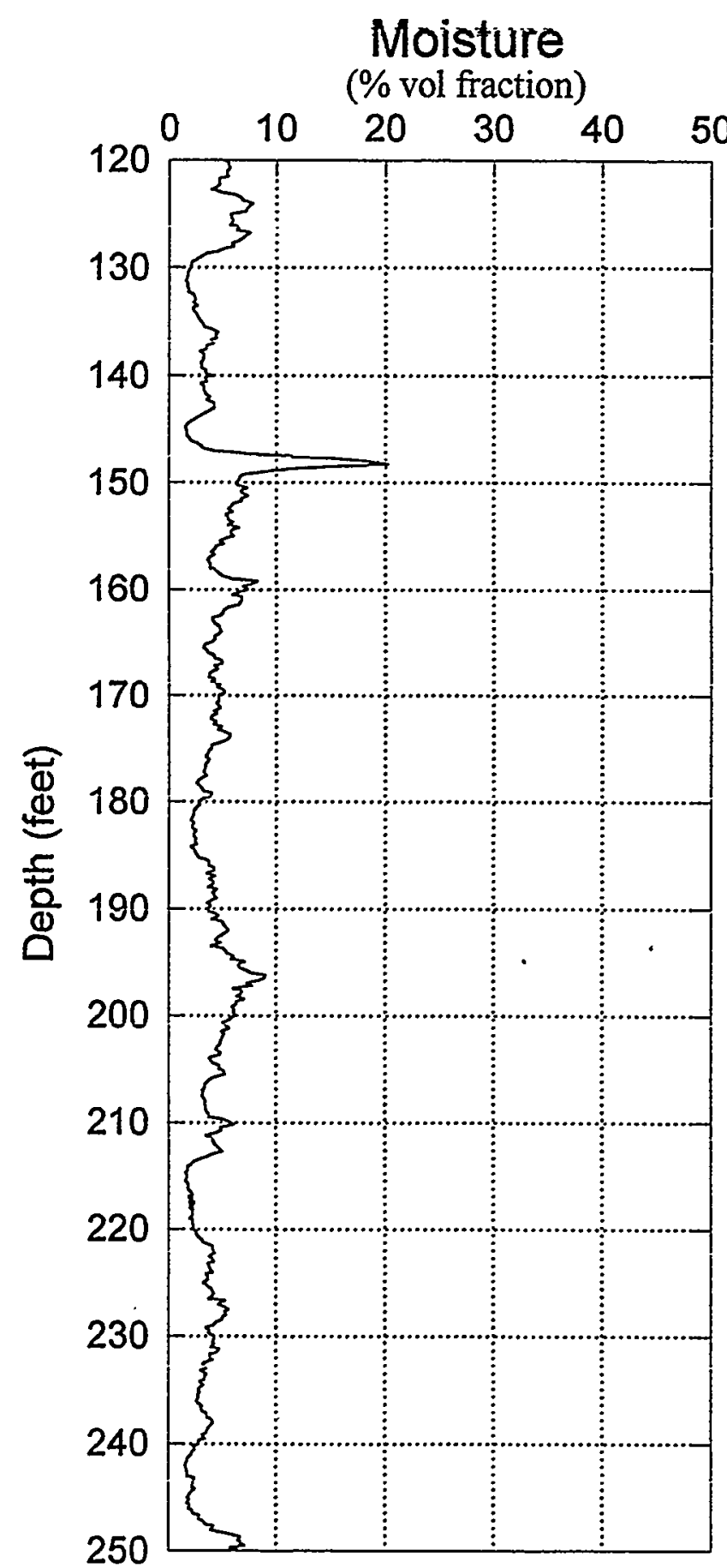

8" Casing Calibration Log Date July 27, 1999

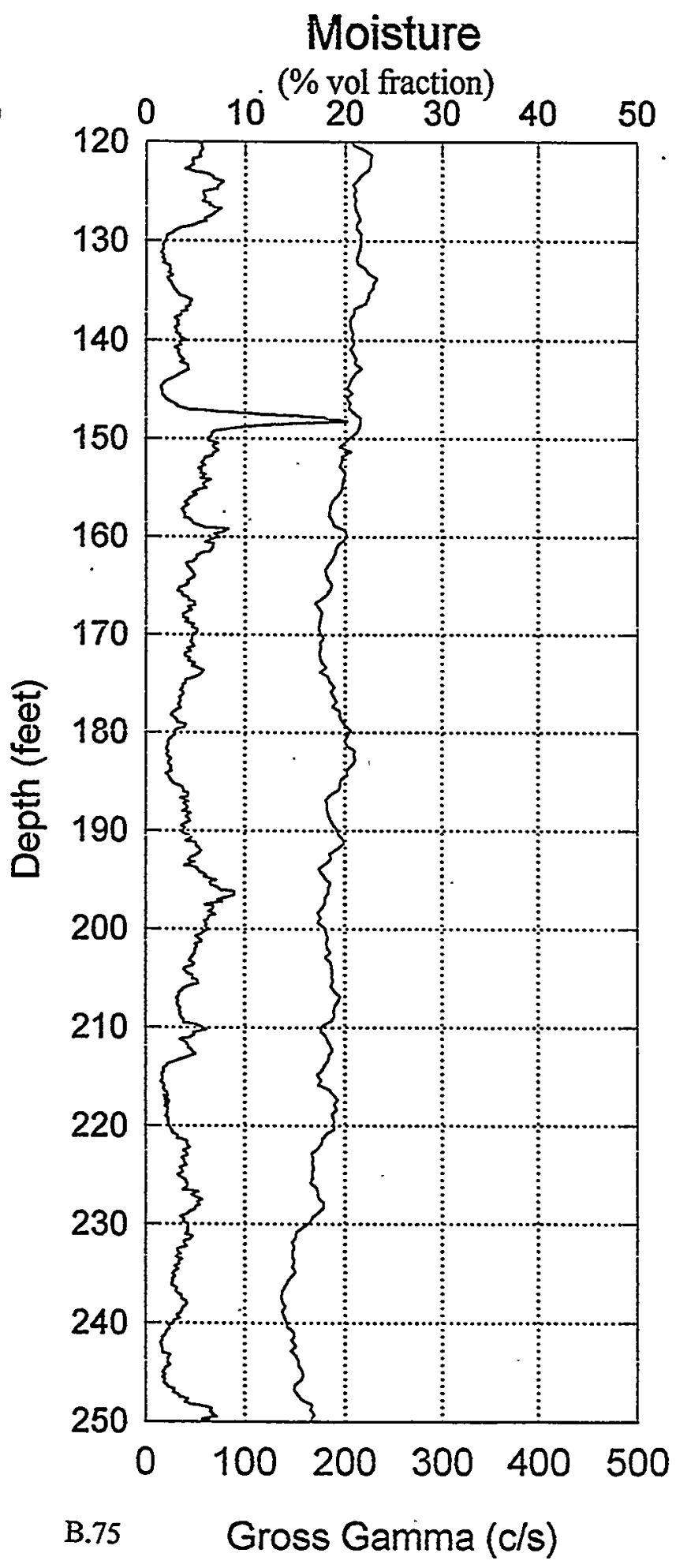




\section{RLS Moisture Processed Log Data}

\section{Waste Management Federal Services NW}

Project: Vadose Zone Monitoring Borehole: 299-E13-6
8" Casing Calibration Log Date July 27, 1999
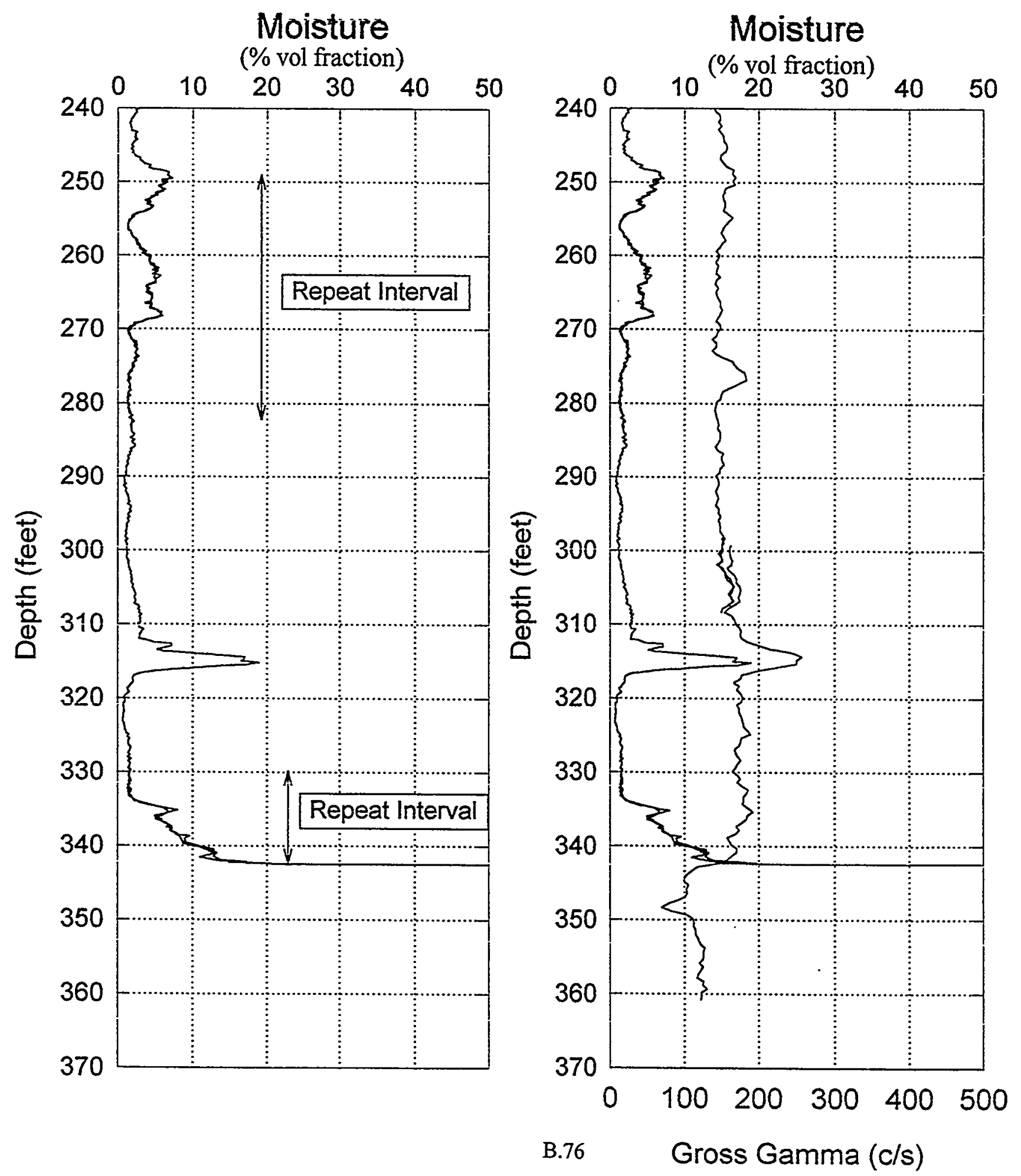


\section{RLS \\ Log Analysis \& Summary}

$\begin{array}{ll}\text { Project: } & \text { PNNL Vadose Zone Monitoring } \\ \text { Log Type: } & \text { Moisture Gauge }\end{array}$

Well ID:

299-E13-6

Log Date:

July 27,1999

\section{General Notes:}

The low reading from 0 feet to 2 feet is due to surface effects and not necessarily the moisture content of the earth surrounding the borehole.

Log data collected with a depth reference of top of casing, and during analysis the depths were shifted to ground surface reference for all plots.

System Performance Verify: The pre- and post-log verification passed performance standards, $+0.3 \%$ in the shield verify.

Repeat Interval: Based on the repeat intervals from 249 to 283 feet and from 330 to 343 feet, the logging system performed according to specifications.

Environmental Corrections: The moisture levels have been corrected for casing attenuation (entire well). Above 100 feet dual casing thickness is used and below 100 feet only the 8 " casing thickness is used.

\section{Observations:}

The moisture levels show values ranging from $2 \%$ to greater than $50 \%$ for the depth interval from 2 feet to 343 feet. The abnormally high readings from 2 to 93 feet are indicative of the sealer material between the casing and are not indicative of vadose zone moisture content. At 315 feet there is a high moisture zone that correlates to a high gross gamma zone, and the gross increase in this zone is due to changes in the natural KUT concentrations. 


\section{RLS Spectral Gamma Ray Borehole Survey \\ Waste Management Federal Services NW}

\section{Log Header}

Project: $\quad$ PNNL Vadose Zone Monitoring

Well: 299-E13-12

Log Type: $\quad$ HPGe Spectral Gamma Ray

Borehole Information

\begin{tabular}{|c|c|c|c|c|}
\hline Well \# $\mathrm{A} 4725$ & Water Depth & 333 & Total Dept & $366 \mathrm{ft}$ \\
\hline Elevation Reference $\underline{\mathrm{n} / \mathrm{a}}$ & Elevation & $\mathrm{ft}$ & & \\
\hline Depth Reference Top Casing & Casing Stickup & $1.9 \quad \mathrm{ft}$ & & \\
\hline Casing Diameter $\underline{6}$ in & Depth Interval & 0 to $100 \mathrm{ft}$ & Thickness & 0.250 in \\
\hline Casing Diameter $\underline{8}$ & Depth Interval & 0 to $366 \mathrm{ft}$ & Thickness & 0.3125 in \\
\hline
\end{tabular}

Logging Information

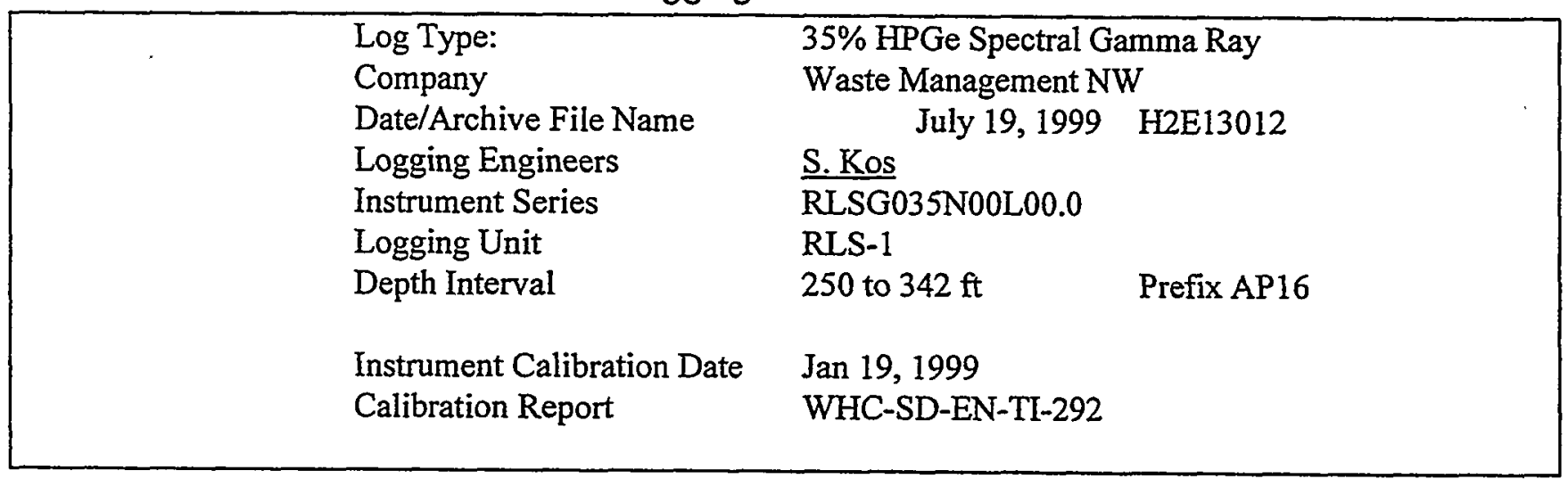

Analysis Information

$\begin{array}{ll}\text { Company } & \text { Three Rivers Scientific } \\ \text { Analyst } & \text { Russ Randall } \\ \text { Date } & \text { July 19, 1999 } \\ \text { Depth Reference } & \text { Ground Surface (plots depth shifted) }\end{array}$

Notes No man-made radionuclides were detected over the interval logged. 


\section{RLS Spectral Gamma Ray Borehole Survey \\ Waste Management Federal Services NW}

Project: PNNL Vadose Zone Monitoring Log Date: July 19, 1999 Borehole: 299-E13-12

Naturally Occurring Radionuclides

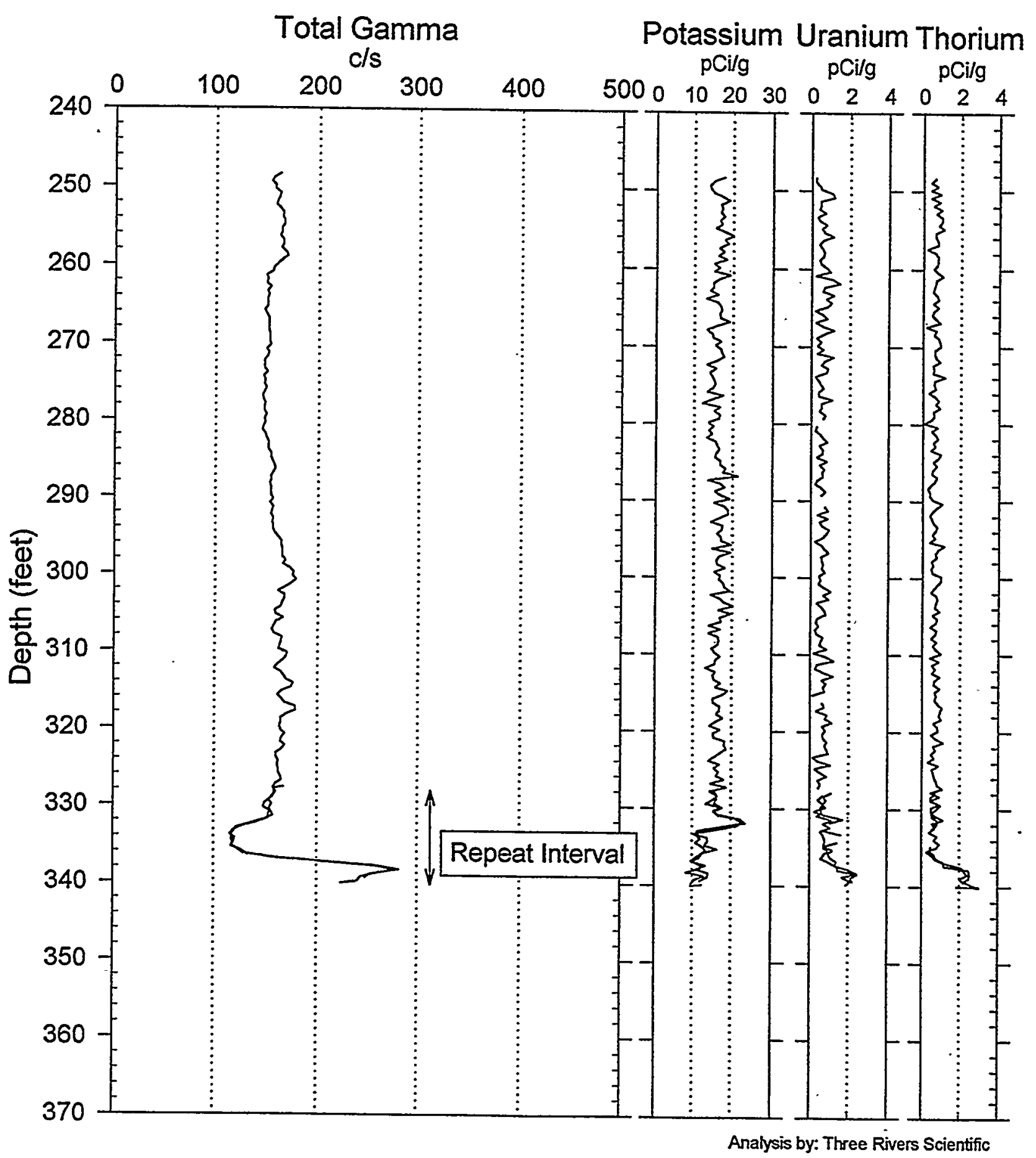




\section{RLS Spectral Gamma Ray Borehole Survey Acceptance QA Processing}

Project: PNNL Vadose Zone Monitoring Borehole: 299-E13-12
Log Date: July 19, 1999 Compare Main Log \& Repeat

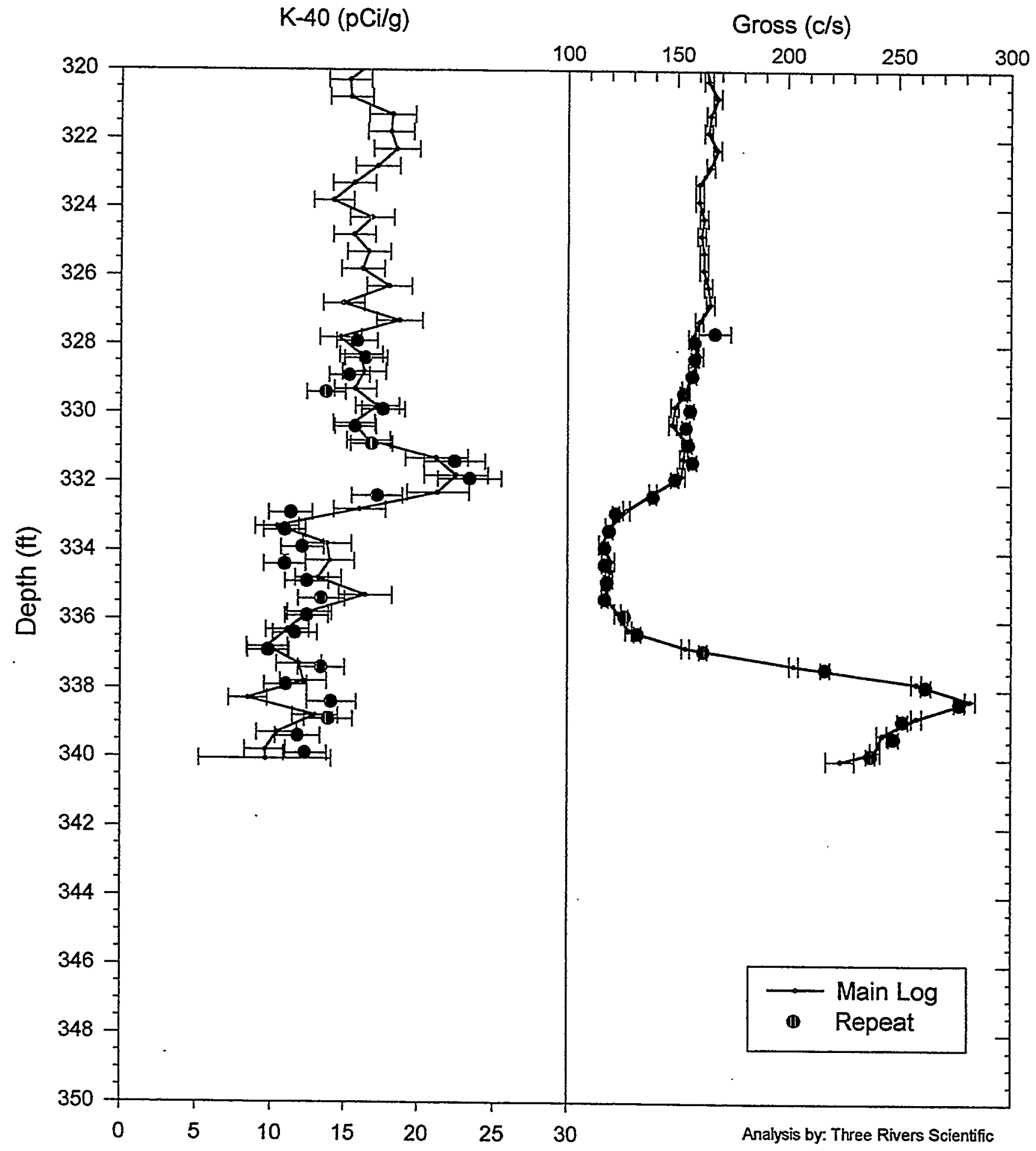




\section{RLS Spectral Gamma Ray Borehole Survey \\ Waste Management Federal Services NW \\ Log Analysis Summary Report}

$\begin{array}{ll}\text { Project: } & \text { PNNL Vadose Zone Monitoring } \\ \text { Log Type: } & \text { HPGe Spectral Gamma.Ray }\end{array}$
Well:

299-E13-12

Log Date:

July 19,1999

\section{General Notes:}

Total gamma is a response to geologic concentrations of natural radionuclides for the depth intervals logged.

Log data collected with a depth reference of top of casing, and during analysis the depths were shifted to ground surface reference for all plots.

System Performance Verify: The pre- and post-log verification passed performance standards.

Repeat Interval: Based on the repeat interval, the logging system performed as per specifications. The error bars are calculated for 1 standard deviation of the net photo peak count rate statistical variance. Thus, the repeat should fall within these error bars $67 \%$ of the time.

Environmental Corrections: All radionuclide concentrations have been corrected for casing attenuation (entire depths logged). Water level is 331 feet, and water correction has been applied below this depth. No casing correction was applied to the total gamma due to Compton downscatter interference.

\section{Radionuclides:}

No man-made radionuclides were detected over the depth interval logged.

Cement grouting is documented over 305 to 358 feet. The gross and KUT signatures do not display the presence of grout over 305 to 358 feet. A possible cement grout annulus starting at 336 feet is indicated by the gross and KUT. 


\section{Moisture Logging Service \\ Log Header}

Project: $\quad$ PNNL Vadose Zone Monitoring

Well: 299-E13-12

Log Type: $\quad$ Moisture Gauge

Borehole Information

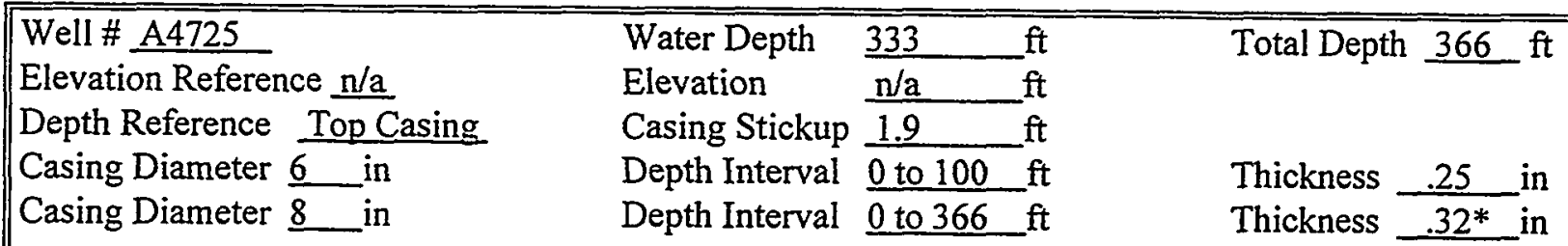

${ }^{\star}$ Casing thickness unknown, used nominal

Logging Information

\begin{tabular}{|llll|}
\hline $\begin{array}{l}\text { Log Type: } \\
\text { Company } \\
\text { Date/Archive File Name } \\
\text { Logging Engineers }\end{array}$ & $\begin{array}{l}\text { Moisture Gauge } \\
\text { Waste Management NW }\end{array}$ & \multicolumn{1}{c|}{ July 20\&21, 1999 } & M2E13012 \\
Instrument Series & $\frac{\text { R.K. Price }}{\text { RLSM00.0 }}$ & & \\
Logging Unit & RLS-3 & Prefix MB34 \\
Depth Interval & 302 to 333 ft & Prefix MB35 \\
& 250 to 333 & \\
& & & \\
& May 13, 1999 & \\
Instrument Calibration Date & WHC-SD-EN-TI-306, Rev. 0 & \\
\hline
\end{tabular}

Analysis Information

$\begin{array}{ll}\text { Company } & \text { Three Rivers Scientific } \\ \text { Analyst } & \text { Russ Randall } \\ \text { Date } & \text { July 23, 1999 } \\ \text { Depth Reference } & \text { Ground Surface (plots depth shifted) }\end{array}$

Notes Moisture values range from $2 \%$ to $7 \%$ for the depths logged. The high observed at 33 feet is a result of entering the water level in the borehole, and the calibration does not apply. 


\section{RLS Moisture Processed Log Data}

\section{Waste Management Federal Services NW}

Project: Vadose Zone Monitoring Borehole: 299-E13-12

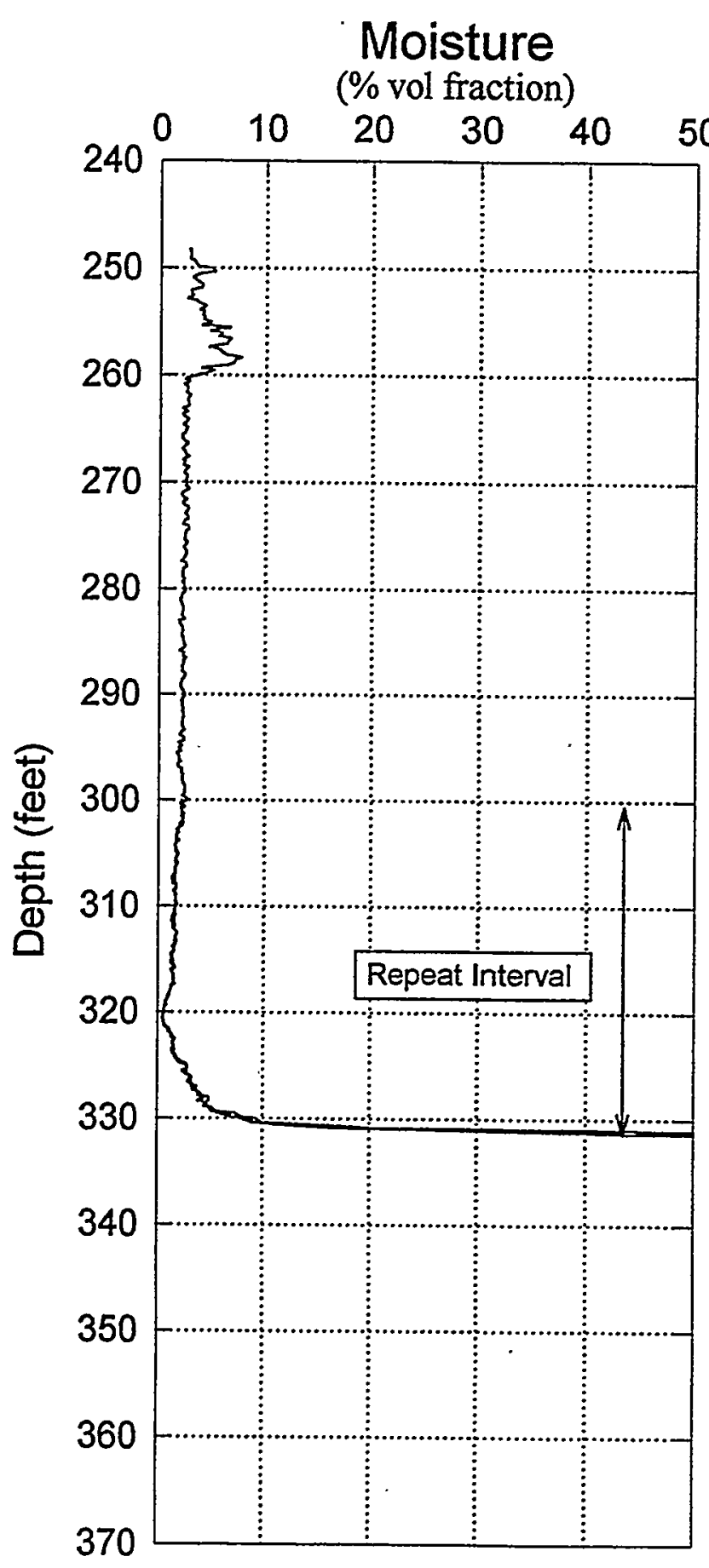

8" Casing Calibration Log Date July 20\&21, 1999

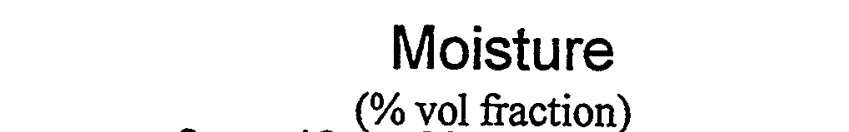

$240 \stackrel{0}{0} 10^{(\% \text { vol fraction })} 40 \quad 50$

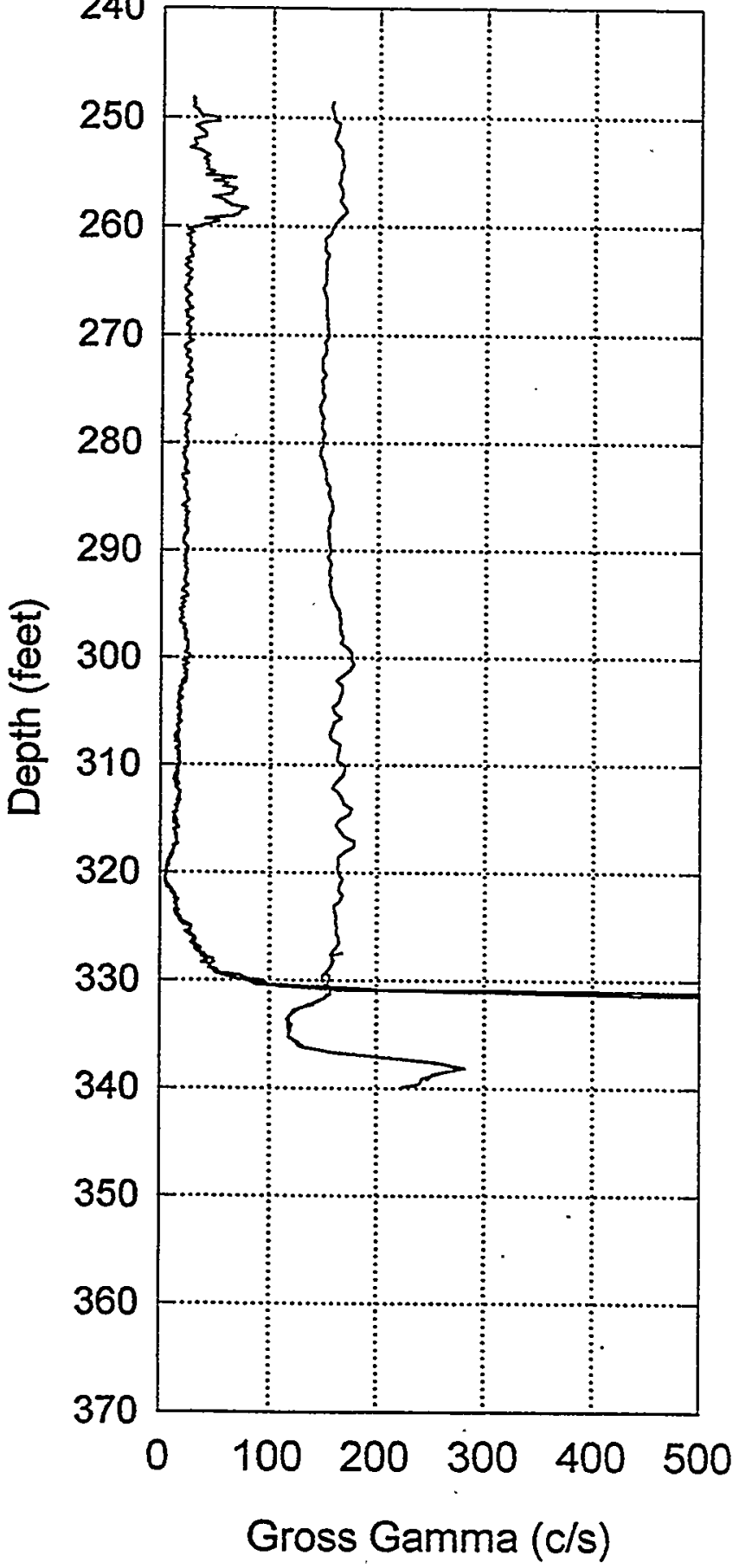

B.83 


\section{RLS \\ Log Analysis \& Summary}

$\begin{array}{lllr}\text { Project: } & \text { PNNL Vadose Zone Monitoring } & \text { Well D: } & 299-E 13-12 \\ \text { Log Type: } & \text { Moisture Gauge } & \text { Log Date: } & \text { July 20\&21, 1999 }\end{array}$

\section{General Notes:}

The high reading at 331 feet is due to the instrument entering the water level. Vadose zone moisture calibration does not apply in the water filled borehole.

Log data collected with a depth reference of top of casing, and during analysis the depths were shifted to ground surface reference for all plots.

System Performance Verify: The pre- and post-log verification passed performance standards, $+0.7 \%$ and $+1.2 \%$ in the shield verify.

Repeat Interval: Based on the repeat interval from 300 to 331 feet, the logging system performed according to specifications.

Environmental Corrections: The moisture levels have been corrected for casing attenuation (entire logged intervals). Cement grouting occurs at depths not logged, thus no correction need or applied.

\section{Observations:}

The moisture levels show values ranging from $2 \%$ to $7 \%$ for depth interval from 248 feet to 301 feet. The highest moisture interval is in a series of thin zones from 250 to 260 feet, with a maximum reading of $7 \%$ by volume. 


\section{RLS Spectral Gamma Ray Borehole Survey \\ Waste Management Federal Services NW}

\section{Log Header}

Project: $\quad$ PNNL Vadose Zone Monitoring

Well: 299-E13-21

Log Type: HPGe Spectral Gamma Ray

Borehole Information

\begin{tabular}{|c|c|c|}
\hline Well \# n/a & Water Depth $\underline{\mathrm{n} / \mathrm{a}}$ & Total Depth $\underline{365 \mathrm{ft}}$ \\
\hline Elevation Reference $\underline{\mathrm{n} / \mathrm{a}}$ & Elevation & \\
\hline Depth Reference Top Casing & Casing Stickup 2.4 & \\
\hline Casing Diameter $\underline{6 \quad \text { in }}$ & Depth Interval $\underline{0 \text { to } 140 \mathrm{ft}}$ & Thickness \\
\hline Casing Diameter $\underline{8}$ & Depth Interval & Thickness $0.3125 *$ in \\
\hline
\end{tabular}

"Used nominal 8" casing thickness since value unknown

Logging Information

\begin{tabular}{|llr|}
\hline Log Type: & HPGe Spectral Gamma Ray \\
Company & Waste Management NW \\
Date/Archive File Name & July 22, 1999 H2E13021 \\
Logging Engineers & S. Kos & \\
Instrument Series & RLSG01000H00.0 & Prefix AP21 \\
Logging Unit & RLS-1 & AP22 \\
Depth Interval & 2 to $50 \mathrm{ft}$ & \\
& 45 to 150 & \\
& & \\
Instrument Calibration Date & Jan 19,1999 & \\
Calibration Report & WHC-SD-EN-TI-292 & \\
\hline
\end{tabular}

Analysis Information

\begin{tabular}{|c|c|c|}
\hline & $\begin{array}{l}\text { Company } \\
\text { Analyst } \\
\text { Date } \\
\text { Depth Reference }\end{array}$ & $\begin{array}{l}\text { Three Rivers Scientific } \\
\text { Russ Randall } \\
\text { August 1, } 1999 \\
\text { Ground Surface (plots depth shifted) }\end{array}$ \\
\hline Notes & \multicolumn{2}{|c|}{$\begin{array}{l}\text { Cs- } 137 \text { is the only man made radionuclide detected. Due to high count rate, dead time accuracy was } \\
\text { exceeded from } 16 \text { to } 21 \text { feet and from } 25 \text { to } 33 \text { feet. where all concentrations are under reported. }\end{array}$} \\
\hline
\end{tabular}




\section{RLS Spectral Gamma Ray Borehole Survey Waste Management Federal Services NW}

Project: PNNL Vadose Zone Monitoring Log Date: July 21\&22, 1999 Borehole: 299-E13-21

Naturally Occurring Radionuclides

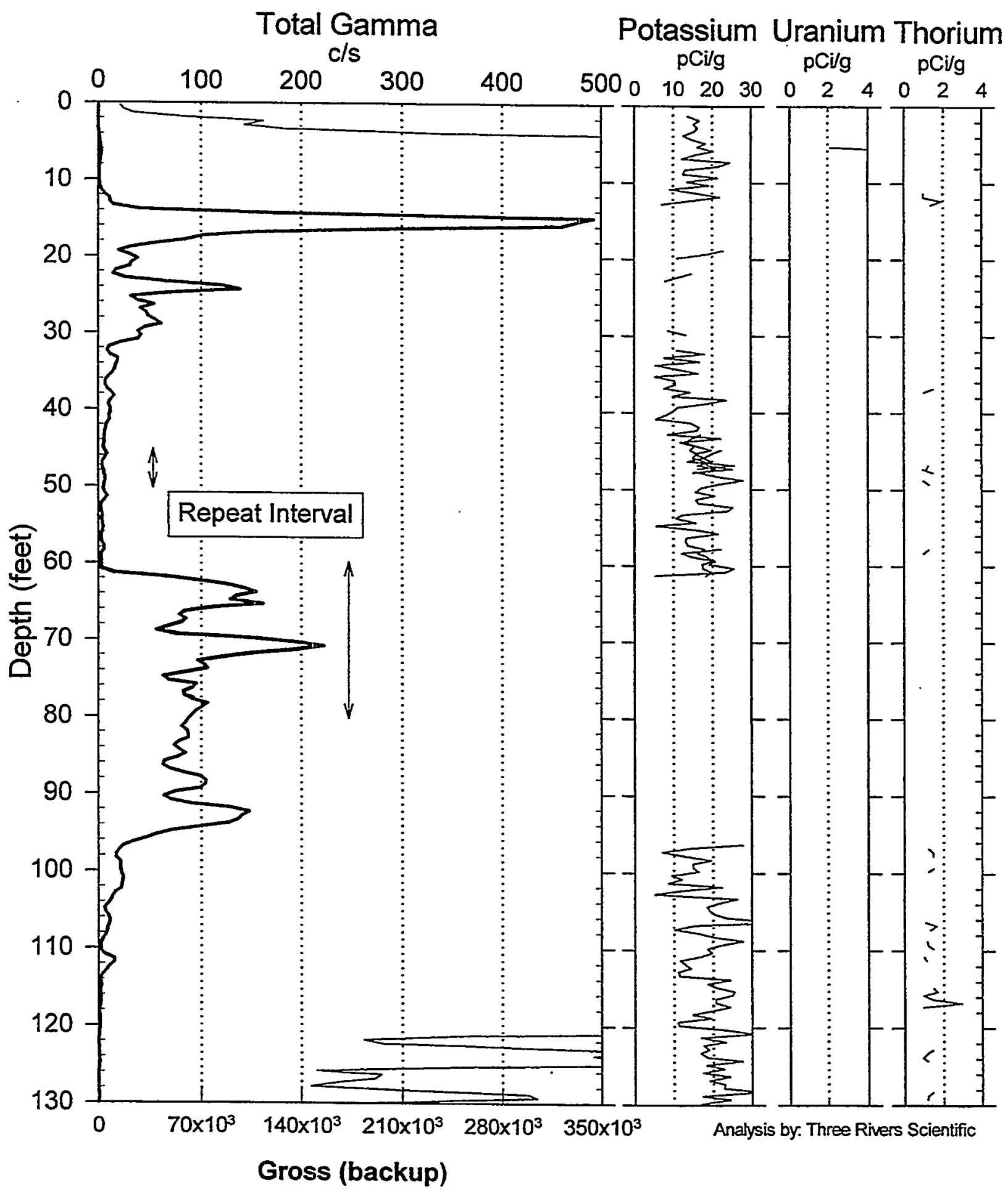




\section{RLS Spectral Gamma Ray Borehole Survey Waste Management Federal Services NW}

Project: PNNL Vadose Zone Monitoring Log Date: July 21\&22, 1999 Borehole: 299-E13-21

Naturally Occurring Radionuclides

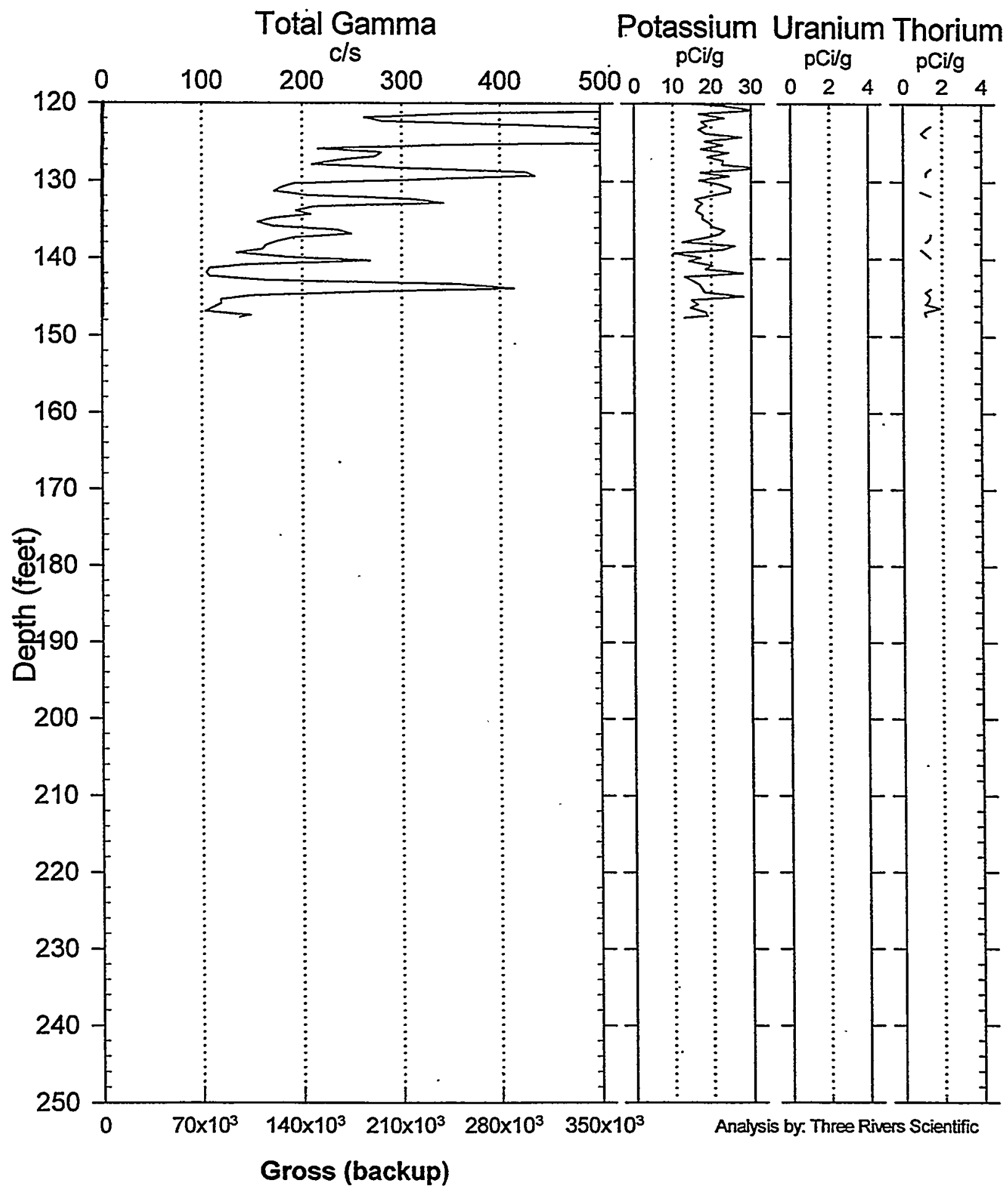




\section{RLS Spectral Gamma-Ray Borehole Survey Waste Management Federal Services NW}

Project: PNNL Vadose Zone Monitoring Log Date: July 21\&22, 1999 Borehole: 299-E13-21

Man-Made Radio-Nuclides

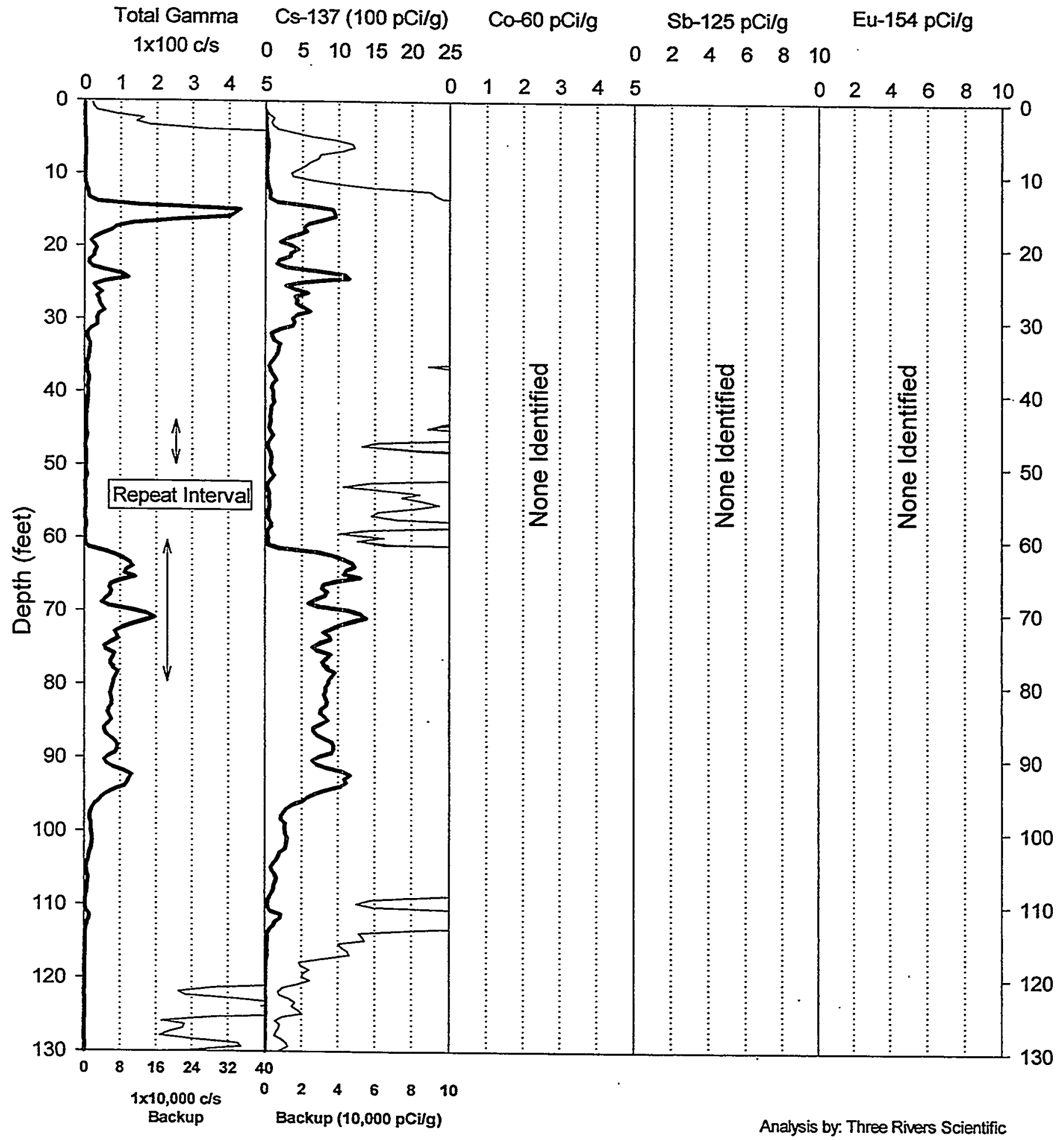


RLS Spectral Gamma-Ray Borehole Survey Waste Management Federal Services NW

Project: PNNL Vadose Zone Monitoring Log Date: July 21\&22, 1999 Borehole: 299-E13-21

Man-Made Radio-Nuclides

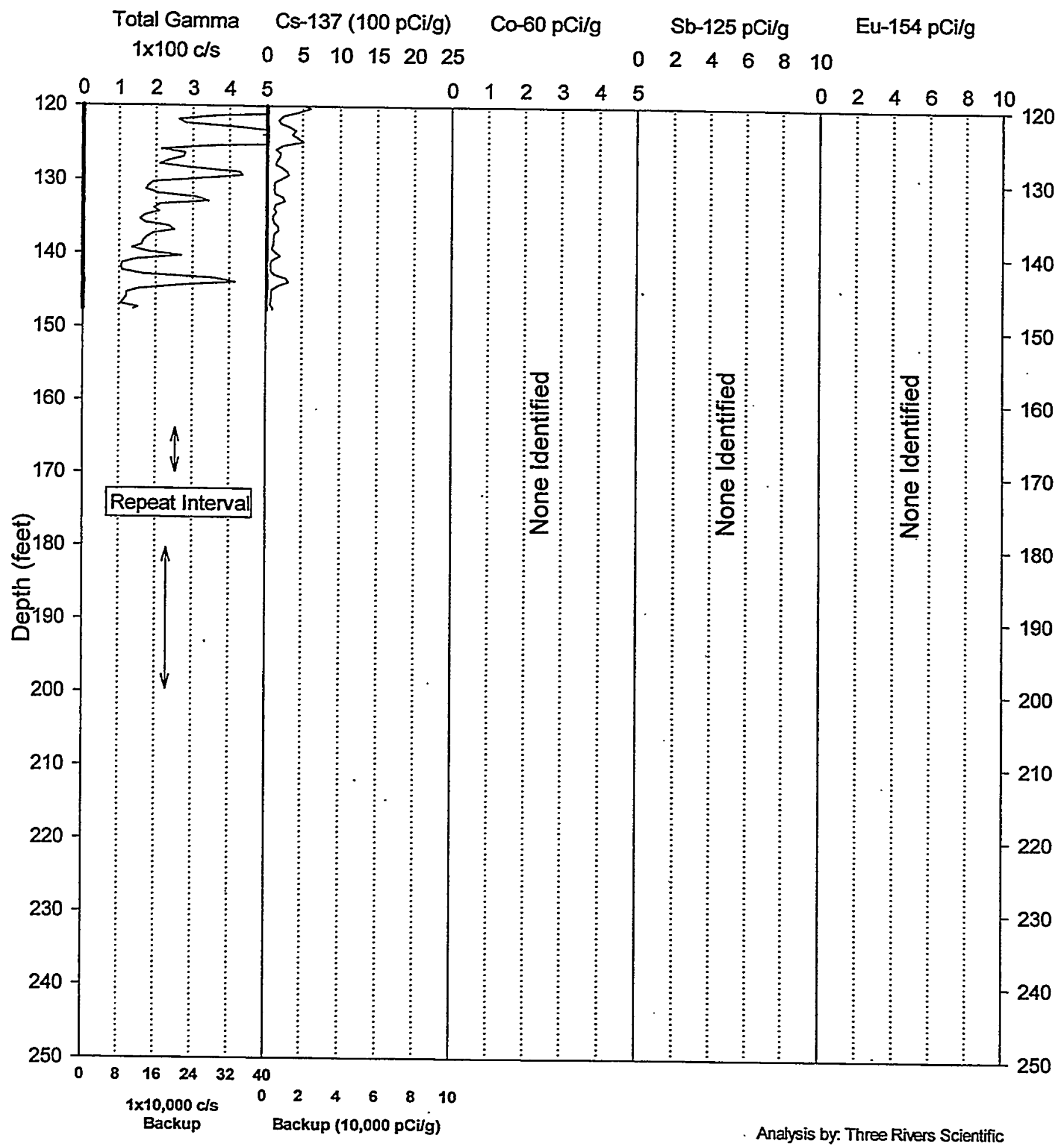




\section{RLS Spectral Gamma Ray Borehole Survey Acceptance QA Processing}

Project: PNNL Vadose Zone Monitoring Borehole: 299-E13-21
Log Date: July 21\&22, 1999 Compare Main Log \& Repeat

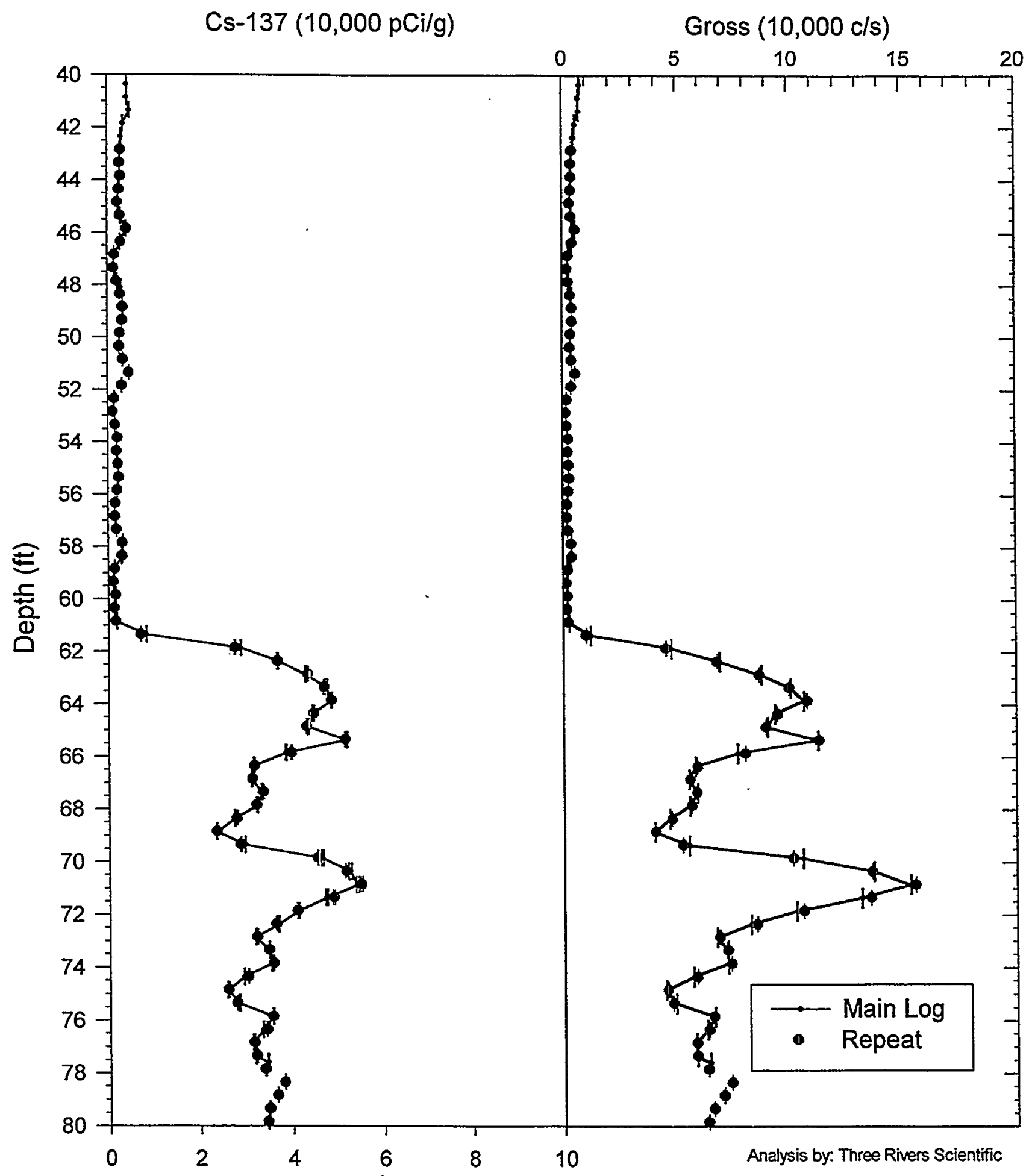




\section{RLS Spectral Gamma Ray Borehole Survey \\ Waste Management Federal Services NW}

\section{Log Analysis Summary Report}

Project: PNNL Vadose Zone Monitoring Well: 299-E13-21

Log Type: HPGe Spectral Gamma Ray L Log Dates: July 21\&21, 1999

\section{General Notes:}

Total gamma is a response to contaminants for the entire depths logged, and no lithologic information is possible from the gross gamma.

Log data collected with a depth reference of top of casing, and during analysis the depths were shifted to ground surface reference for all plots.

System Performance Verify: The pre- and post-log verification passed performance standards.

Repeat Interval: Based on the repeat interval, the logging system performed as per specifications. The error bars are calculated for 1 standard deviation of the net photo peak count rate statistical variance. Thus, the repeat should fall within these error bars $67 \%$ of the time.

Environmental Corrections: All radionuclide concentrations have been corrected for casing attenuation (entire well). Water level is below depths logged. No casing correction was applied to the total gamma due to Compton downscatter interference. Dual casing attenuation affects the gross gamma over the interval from 130 to 125 feet.

High count rates causes under reporting of all radionuclide concentrations over the depth intervals from 16 to 21 feet and from 25 to 33 feet. The accuracy of the dead time correction has been exceeded over these intervals.

\section{Radionuclides:}

Cs-137 was identified over the entire depths logged. The maximum concentration of Cs-137 is greater than $90,000 \mathrm{pCi} / \mathrm{g}$. The ratio of Cs-137 to gross count rate is relatively constant except for the one zone centered at 16 feet, where the gross count rate is proportionally much higher than the amount of $\mathrm{Cs}-137$ in this interval. The most likely cause for this loss of relationship between gross count rate and Cs- 137 concentrations is the dead time in-accuracy, and not the possibility of a beta emitter. 


\section{Moisture Logging Service Log Header}

Project: $\quad$ PNNL Vadose Zone Monitoring

Well: 299-E13-21

Log Type: Moisture Gauge

Borehole Information

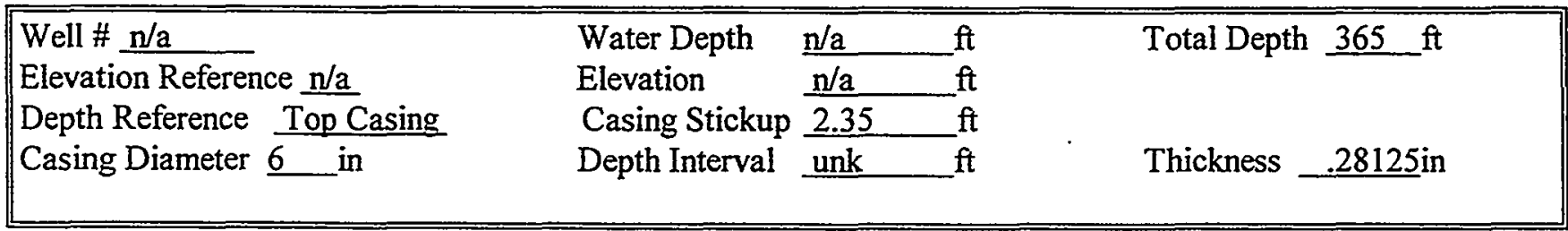

Logging Information

\begin{tabular}{|c|c|c|}
\hline Log Type: & Moisture Gauge & \\
\hline Company & Waste Management NW & \\
\hline Date/Archive File Name & July $26,1999 \quad$ M2E13021 & \\
\hline Logging Engineers & R.K. Price & \\
\hline Instrument Series & RLSM00.0 & \\
\hline Logging Unit & RLS-3 & \\
\hline Depth Interval & $\begin{array}{l}32 \text { to } 156 \mathrm{ft} \\
0 \text { to } 35 \& 13 \text { to } 150\end{array}$ & $\begin{array}{l}\text { MB42 } \\
\text { MB43 }\end{array}$ \\
\hline Instrument Calibration Date & May 13, 1999 & \\
\hline Calibration Report & WHC-SD-EN-TI-306, Rev. 0 & \\
\hline
\end{tabular}

Analysis Information

$\begin{array}{ll}\text { Company } & \text { Three Rivers Scientific } \\ \text { Analyst } & \text { Russ Randall } \\ \text { Date } & \text { July 30, 1999 } \\ \text { Depth Reference } & \text { Ground Surface (plots depth shifted) }\end{array}$

Notes Moisture values range from $3 \%$ to $12 \%$ for the depths logged. The highest observed moisture zone occurs at the depth of 103 feet with a reading of $12 \%$ by volume. 


\section{RLS Moisture Processed Log Data}

\section{Waste Management Federal Services NW}

Project: Vadose Zone Monitoring

Borehole: 299-E13-21
6" Casing Calibration Log Date July 26, 1999
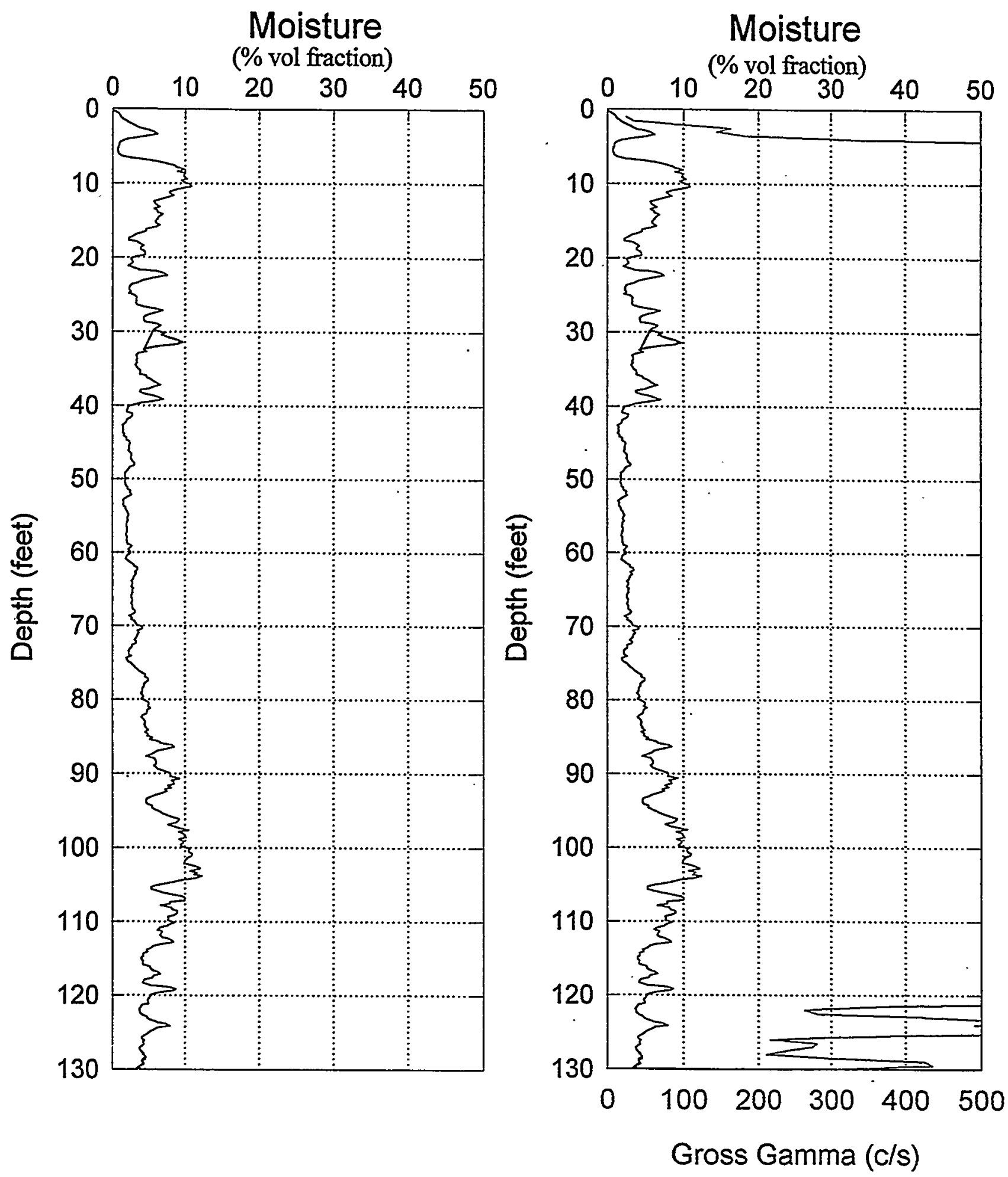


\section{RLS Moisture Processed Log Data}

\section{Waste Management Federal Services NW}

Project: Vadose Zone Monitoring Borehole: 299-E13-21
6" Casing Calibration

Log Date July 26, 1999
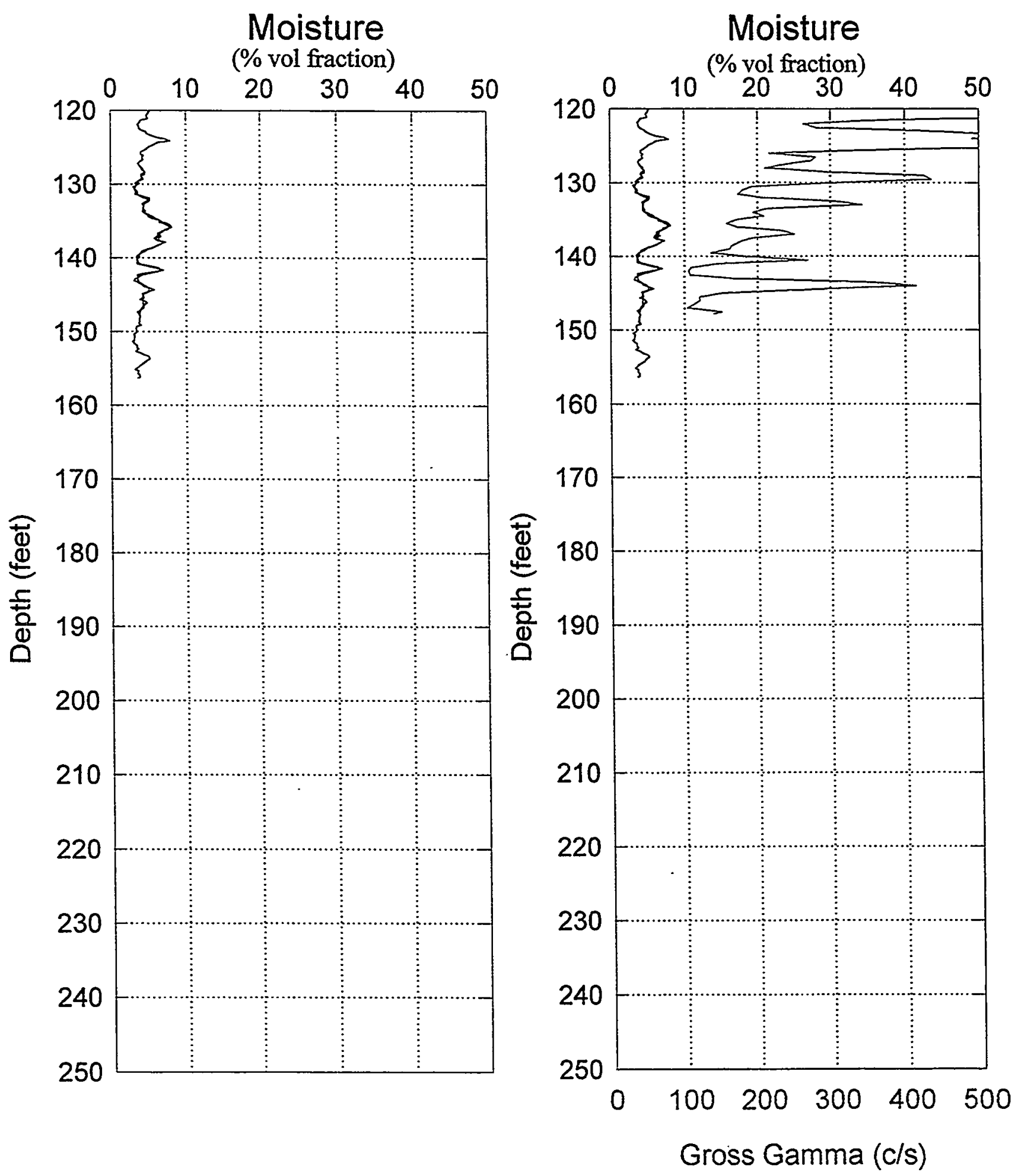


\section{RLS \\ Log Analysis \& Summary}

$\begin{array}{lllr}\text { Project: } & \text { PNNL Vadose Zone Monitoring } & \text { Well ID: } & \text { 299-E13-21 } \\ \text { Log Type: } & \text { Moisture Gauge } & \text { Log Date: } & \text { July 26, 1999 }\end{array}$

\section{General Notes:}

The low reading from 0 feet to 2 feet is due to surface effects and not necessarily the moisture content of the sediments surrounding the borehole.

Log data collected with a depth reference of top of casing, and during analysis the depths were shifted to ground surface reference for all plots.

System Performance Verify: The pre- and post-log verification passed performance standards, $-3.0 \%$ in the shield verify.

Repeat Interval: Based on the repeat interval from 129 to 149 feet, the logging system performed according to specifications.

Environmental Corrections: The moisture levels have been corrected for casing attenuation (entire well).

\section{Observations:}

The moisture levels show values ranging from $3 \%$ to $12 \%$ for depth interval from 2 feet to 156 feet. The highest moisture occurs at a depth of 103 feet, with a maximum reading of $12 \%$ by volume. 


\section{RLS Spectral Gamma Ray Borehole Survey \\ Waste Management Federal Services NW}

\section{Log Header}

Project: $\quad$ PNNL Vadose Zone Monitoring

Well: 299-E13-52

\section{Log Type: $\quad$ HPGe Spectral Gamma Ray}

\section{Borehole Information}

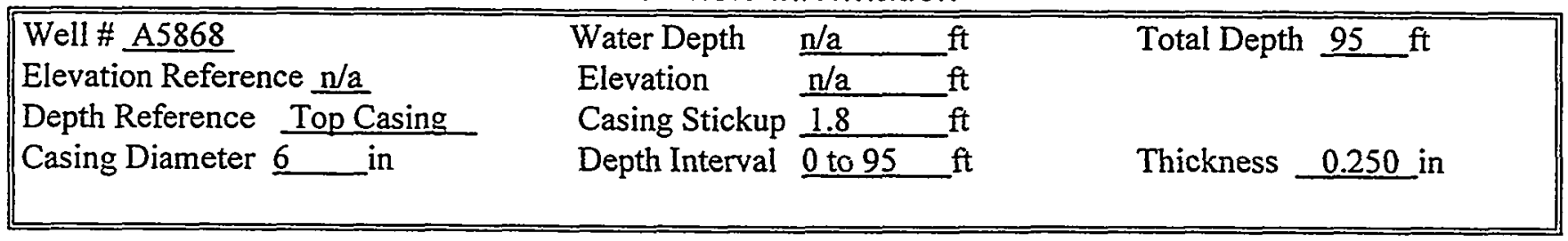

Logging Information

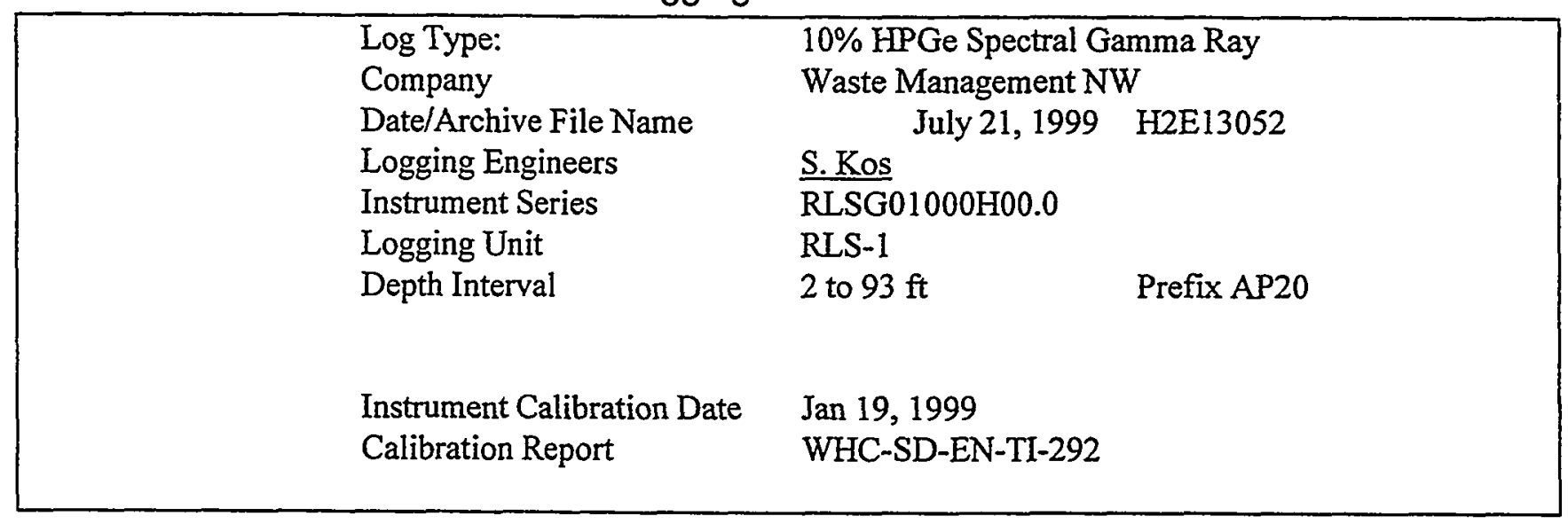

Analysis Information

$\begin{array}{ll}\text { Company } & \text { Three Rivers Scientific } \\ \text { Analyst } & \text { Russ Randall } \\ \text { Date } & \text { July 26, 1999 } \\ \text { Depth Reference } & \text { Ground Surface (plots depth shifted) }\end{array}$

Notes Cs-137, Co-60, and Eu-154 are the only man made radionuclides detected. Detection of Eu-154 required a summing technique since the levels are near detection threshold. Count rates exceeding dead time correction accuracy occurred from 9 to 15 feet. Over this interval, all concentrations are under reported. 


\section{RLS Spectral Gamma Ray Borehole Survey Waste Management Federal Services NW}

Project: PNNL Vadose Zone Monitoring Log Date: ' July 21, 1999 Borehole: 299-E13-52

Naturally Occurring Radionuclides

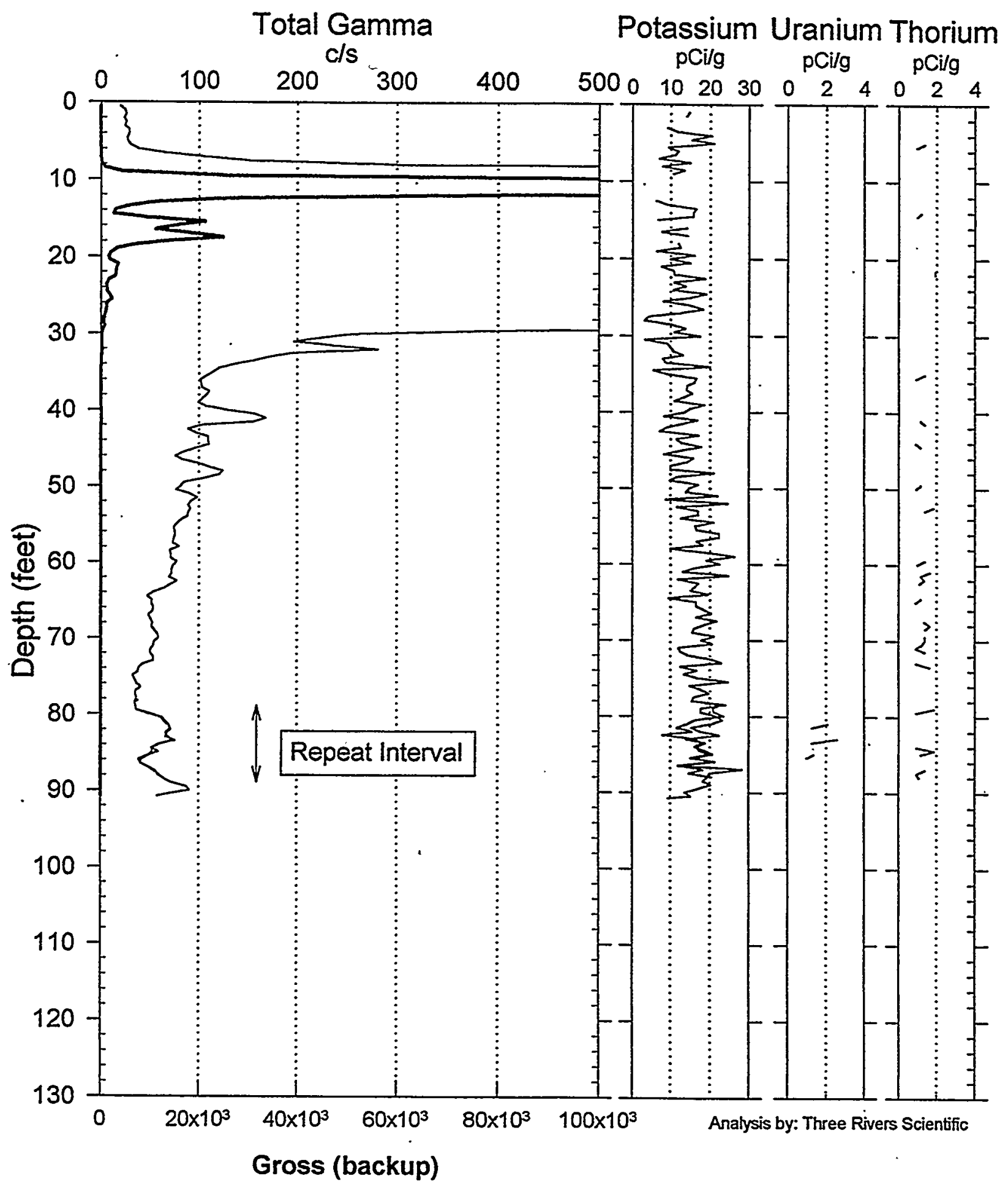




\section{RLS Spectral Gamma-Ray Borehole Survey Waste Management Federal Services NW}

Project: PNNL Vadose Zone Monitoring Log Date: July 21, 1999 Borehole: 299-E13-52

Man-Made Radionuclides

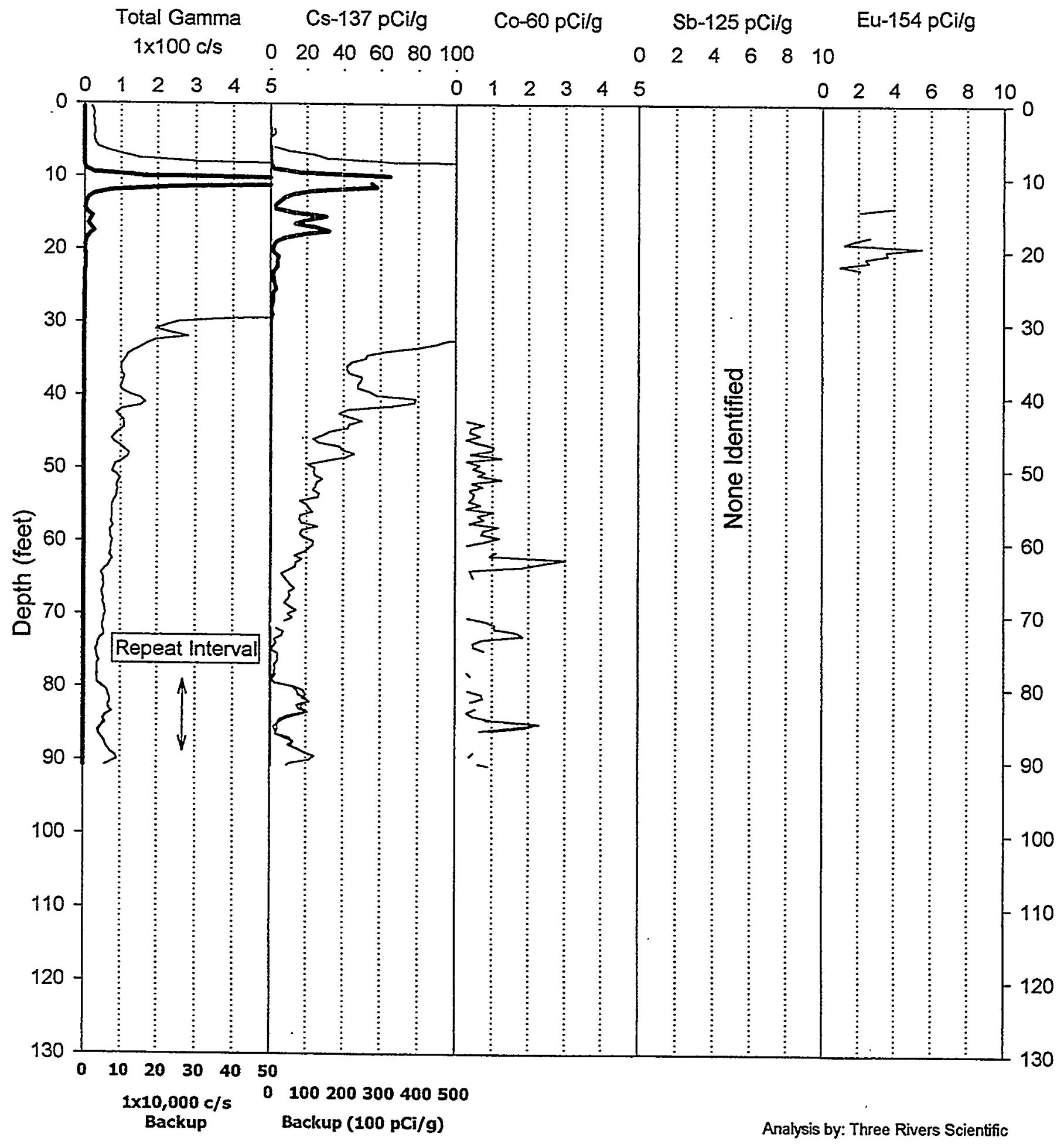




\section{RLS Spectral Gamma Ray Borehole Survey Acceptance QA Processing}

Project: PNNL Vadose Zone Monitoring Log Date: July 21, 1999 Borehole: 299-E13-52.

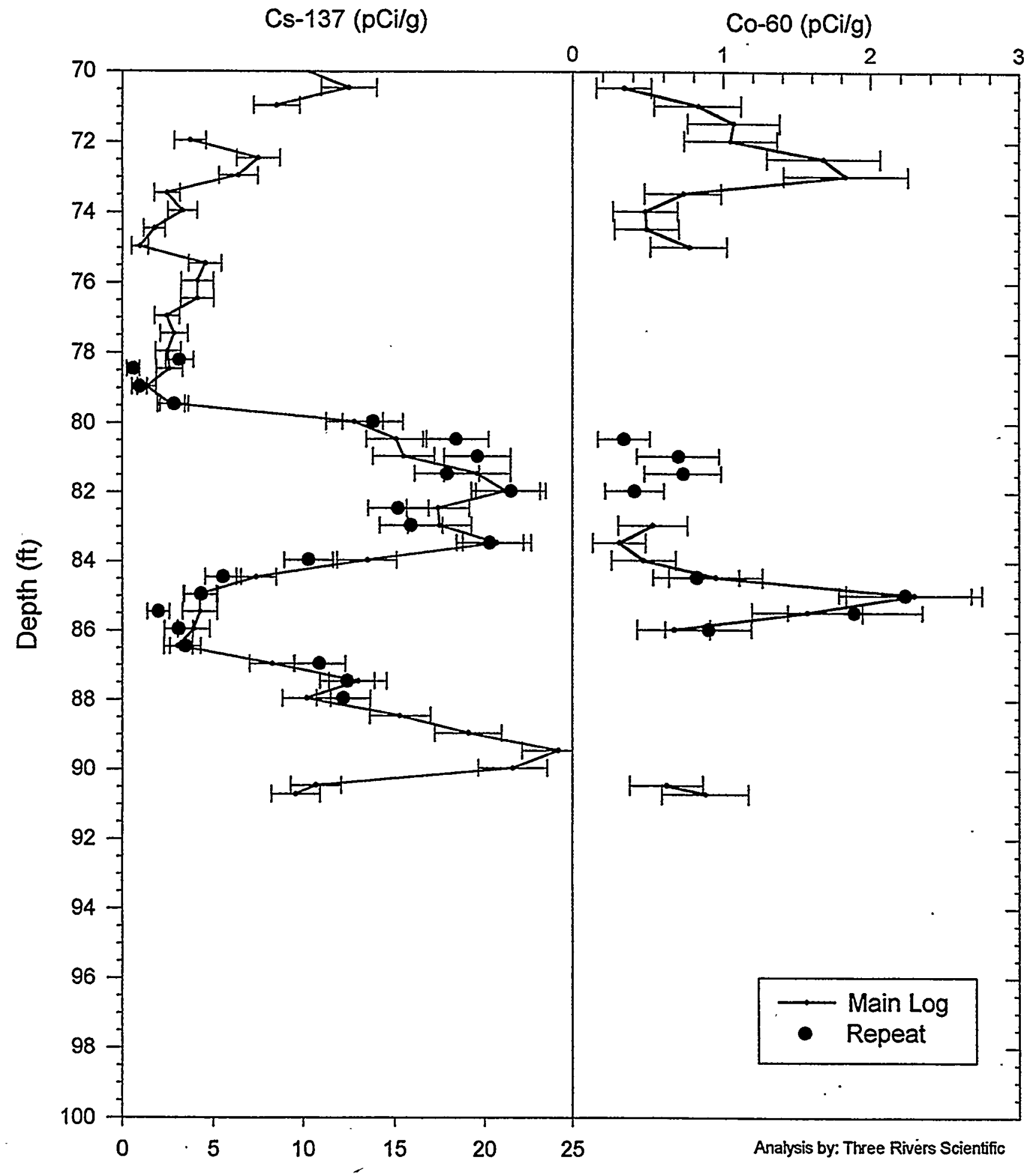




\section{RLS Spectral Gamma Ray Borehole Survey \\ Waste Management Federal Services NW}

\section{Log Analysis Summary Report}

$\begin{array}{lllr}\text { Project: } & \text { PNNL Vadose Zone Monitoring } & \text { Well: } & \text { 299-E13-52 } \\ \text { Log Type: } & \text { HPGe Spectral Gamma Ray } & \text { Log Date: } & \text { July 21, 1999 }\end{array}$

\section{General Notes:}

Total gamma is a response to man-made radionuclides, and cannot be used for lithologic information.

Log data collected with a depth reference of top of casing, and during analysis the depths were shifted to ground surface reference for all plots.

System Performance Verify: The pre- and post-log verification passed performance standards.

Repeat Interval: Based on the repeat interval, the logging system performed as per specifications, refer to repeat plot. The error bars are calculated for 1 standard deviation of the net photo peak count rate statistical variance. Thus, the repeat should fall within these error bars $67 \%$ of the time.

Environmental Corrections: All radionuclide concentrations have been corrected for casing attenuation (entire well). Water level is below depths logged. No casing correction was applied to the total gamma due to Compton downscatter interference.

\section{Radionuclides:}

From 11 to 17 feet, the detector count rate exceeds the dead time accuracy. All radionuclide concentrations are under reported in these high count rate conditions. At 11.2 feet the instrument saturated for this single depth sample.

Cs-137 was identified over the depths from 5-91 feet. The Cs-137 may exist below the bottom of the well. The maximum concentration of Cs-137 occurs at a depth of 11.2 feet, with a reading greater than $30,000 \mathrm{pCi} / \mathrm{g}$. The Cs- $137 \mathrm{MDL}$ value for these $\log$ data is $2 \mathrm{pCi} / \mathrm{g}$.

Co-60 was identified over the depths from $44-91$ feet. The maximum concentration of Co-60 occurs at a depth of 62 feet, with a reading of $3 \mathrm{pCi} / \mathrm{g}$. The Co-60 MDL value for these $\log$ data is $1 \mathrm{pCi} / \mathrm{g}$, for the depths where the Cs- 137 concentration is below $80 \mathrm{pCi} / \mathrm{g}$.

Eu-154 was identified over the depths from 14-22 feet. The maximum concentration of Eu-154 occurs at a depth of 20 feet, with a reading of $5.5 \mathrm{pCi} / \mathrm{g}$. The Eu- $154 \mathrm{MDL}$ value for these log data is $2 \mathrm{pCi} / \mathrm{g}$, for the depths where the Cs- 137 concentration is below $80 \mathrm{pCi} / \mathrm{g}$. 


\section{Moisture Logging Service \\ Log Header}

Project: $\quad$ PNNL Vadose Zone Monitoring

Well: 299-E13-52

Log Type: $\quad$ Moisture Gauge

Borehole Information

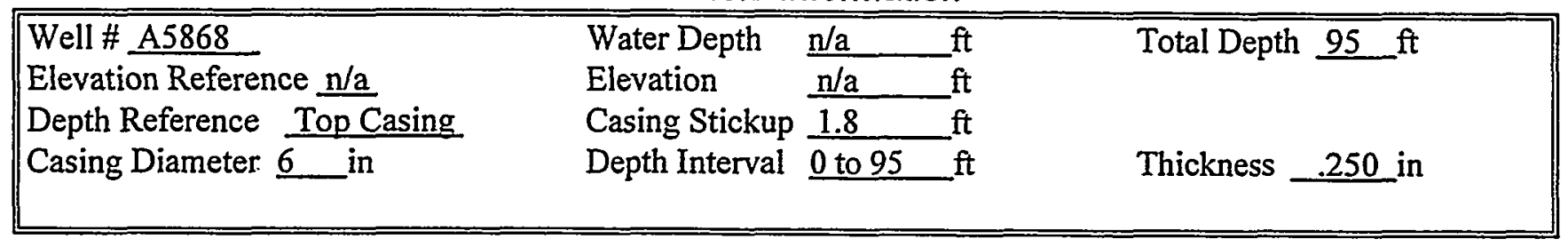

Logging Information

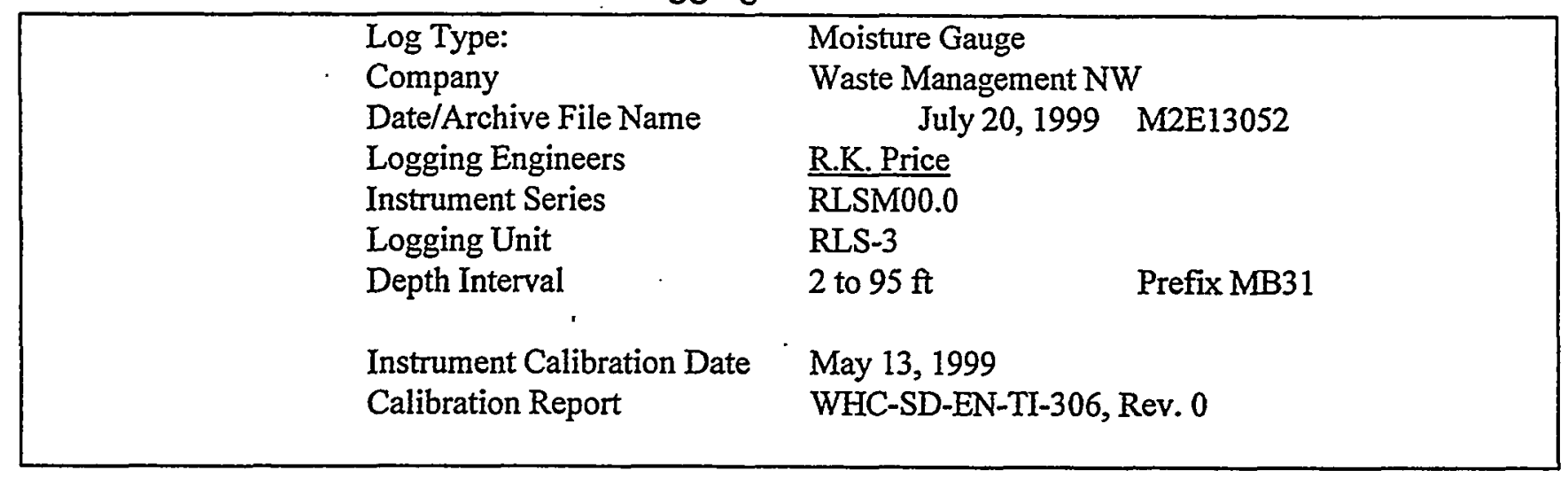

Analysis Information

$\begin{array}{ll}\text { Company } & \text { Three Rivers Scientific } \\ \text { Analyst } & \text { Russ Randall } \\ \text { Date } & \text { July 23, 1999 } \\ \text { Depth Reference } & \text { Ground Surface (plots depth shifted) }\end{array}$

Notes Moisture values range from $3 \%$ to $12 \%$ for the depths logged. Several thin zones reach moisture levels just above $10 \%$ by volume. 


\section{RLS Moisture Processed Log Data}

Waste Management Federal Services NW

Project: Vadose Zone Monitoring

Borehole: 299-E13-52
6" Casing Calibration

Log Date July 20, 1999
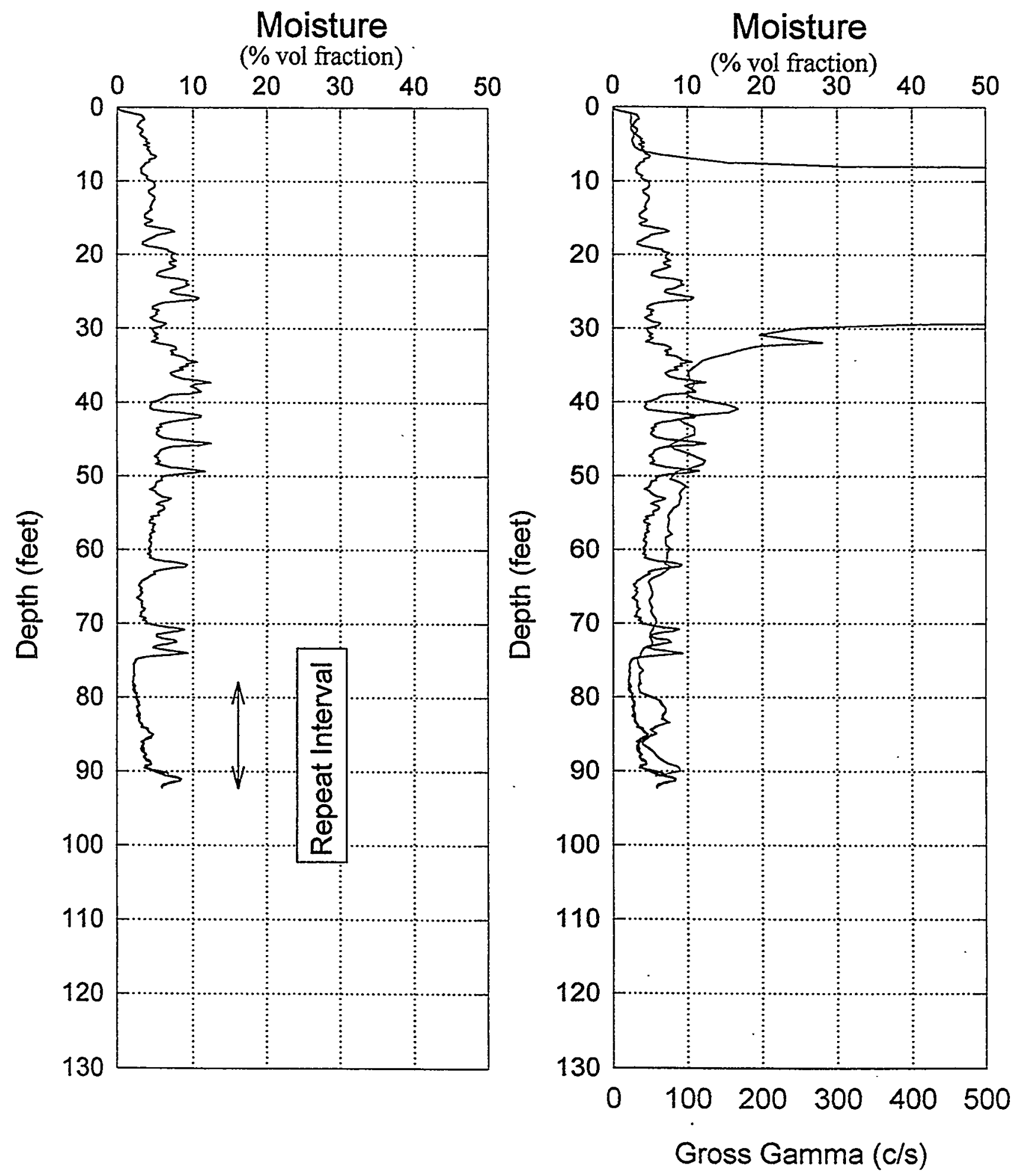

B.102 


\section{RLS \\ Log Analysis \& Summary}

Project: $\quad$ PNNL Vadose Zone Monitoring

Log Type: Moisture Gauge

Well ID:

299-E13-52

Log Date: July 20,1999

\section{General Notes:}

The low reading from 0 feet to 2 feet is due to surface effects and not necessarily the moisture content of the earth surrounding the borehole.

Log data collected with a depth reference of top of casing, and during analysis the depths were shifted to ground surface reference for all plots.

System Performance Verify: The pre- and post-log verification passed performance standards, $+0.4 \%$ in the shield verify.

Repeat Interval: Based on the repeat interval from 79 to 92 feet, the logging system performed according to specifications.

Environmental Corrections: The moisture levels have been corrected for casing attenuation (entire well).

\section{Observations:}

The moisture levels show values ranging from $3 \%$ to $12 \%$ for depth interval from 2 feet to 92 feet. The highest moisture interval is in a series of thin zones from 20 to 76 feet, with a maximum reading of $12 \%$ by volume. From 37 to 50 feet several interbeded moisture zones record high moisture values when the gross gamma records low count rates, indicative of lithology effects. 


\section{RLS Spectral Gamma Ray Borehole Survey \\ Waste Management Federal Services NW}

\section{Log Header}

Project: $\quad$ PNNL Vadose Zone Monitoring

Well: 299-E13-54

Log Type: HPGe Spectral Gamma Ray

Borehole Information

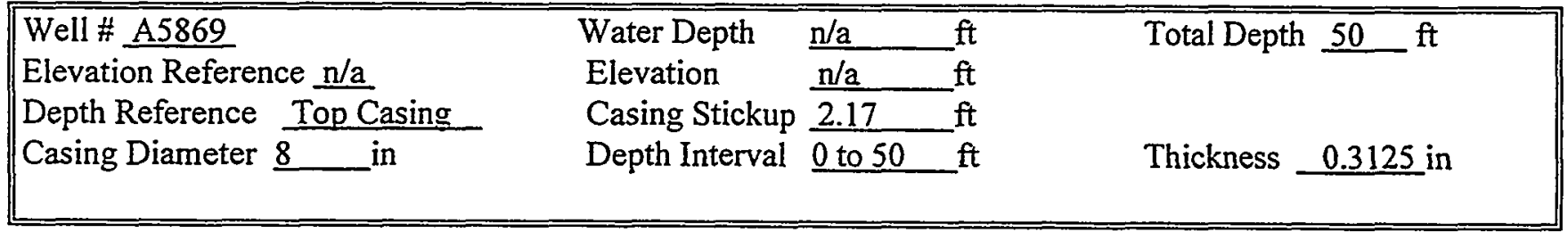

Logging Information

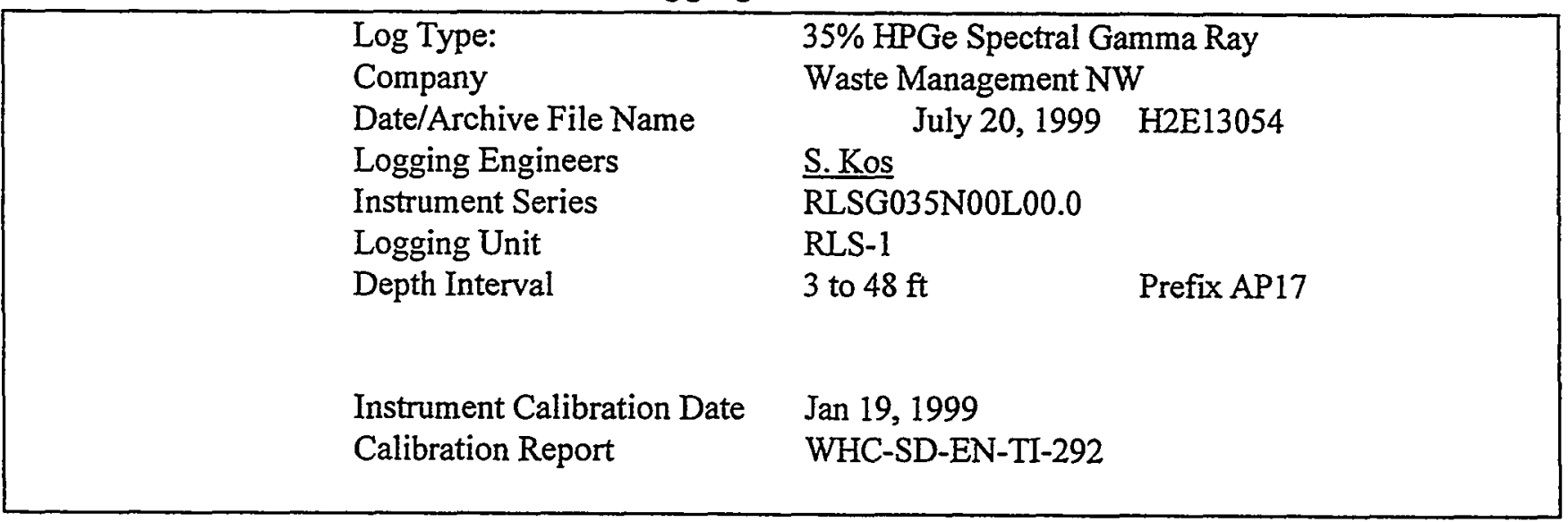

Analysis Information

\begin{tabular}{|c|c|c|}
\hline & $\begin{array}{l}\text { Company } \\
\text { Analyst } \\
\text { Date } \\
\text { Depth Reference }\end{array}$ & $\begin{array}{l}\text { Three Rivers Scientific } \\
\text { Russ Randall } \\
\text { July } 27,1999 \\
\text { Ground Surface (plots depth shifted) }\end{array}$ \\
\hline Notes & \multicolumn{2}{|c|}{$\begin{array}{l}\text { Cs-137, Co- } 60 \text {, and Sb-125 are the only man made radionuclides detected. Detection of Sb-125 } \\
\text { required a summing technique since the levels are at detection threshold. The detector exceeded high } \\
\text { count rate limits of dead time correction accuracy over the depth interval from } 21 \text { to } 22 \text { feet, even } \\
\text { though the detector did not saturate. }\end{array}$} \\
\hline
\end{tabular}




\section{RLS Spectral Gamma Ray Borehole Survey Waste Management Federal Services NW}

Project: PNNL Vadose Zone Monitoring Log Date: July 20, 1999 Borehole: 299-E13-54

Naturally Occurring Radionuclides

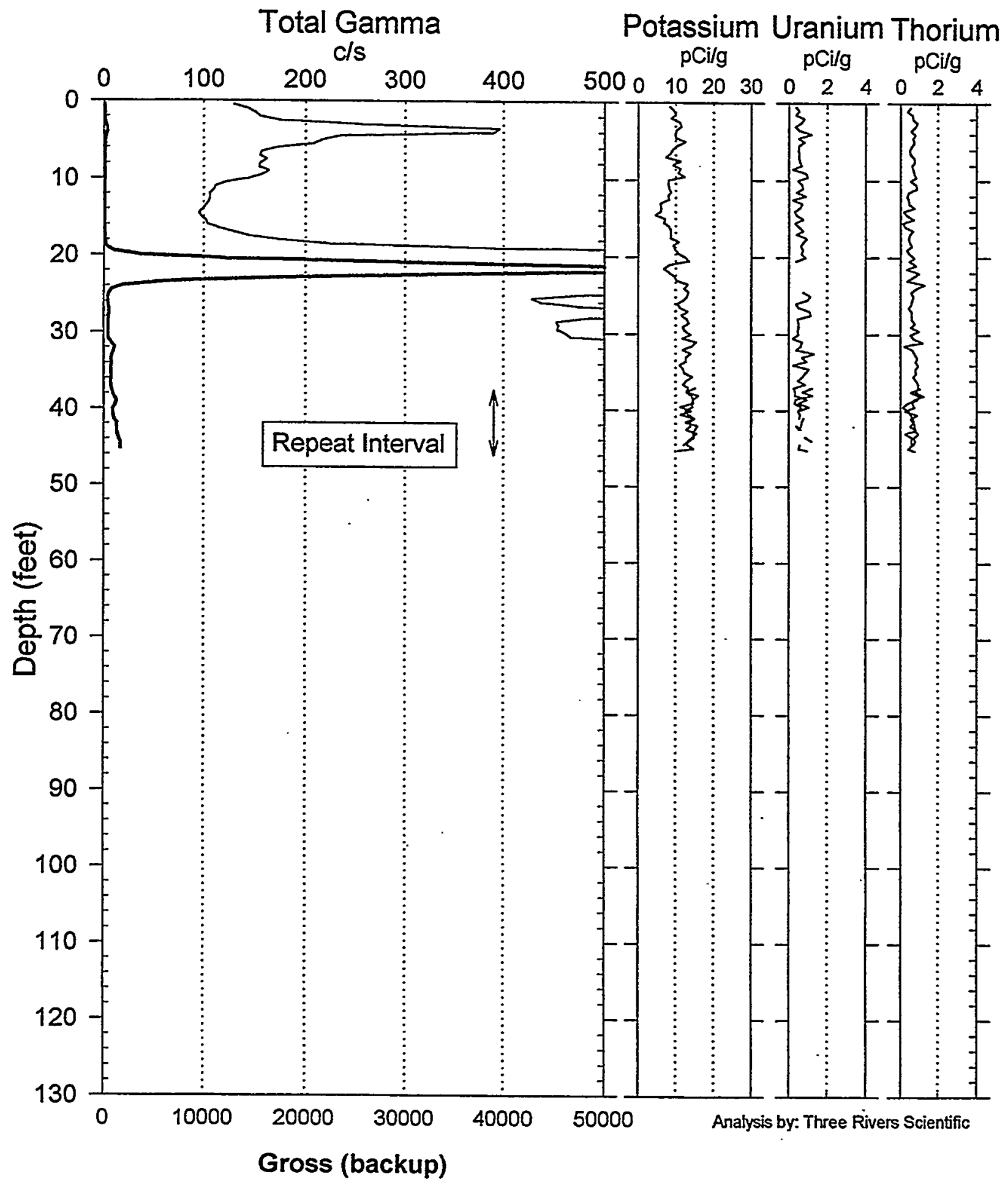




\section{RLS Spectral Gamma-Ray Borehole Survey Waste Management Federal Services NW}

Project: PNNL Vadose Zone Monitoring Log Date: July 20, 1999 Borehole: 299-E13-54

Man-Made Radionuclides

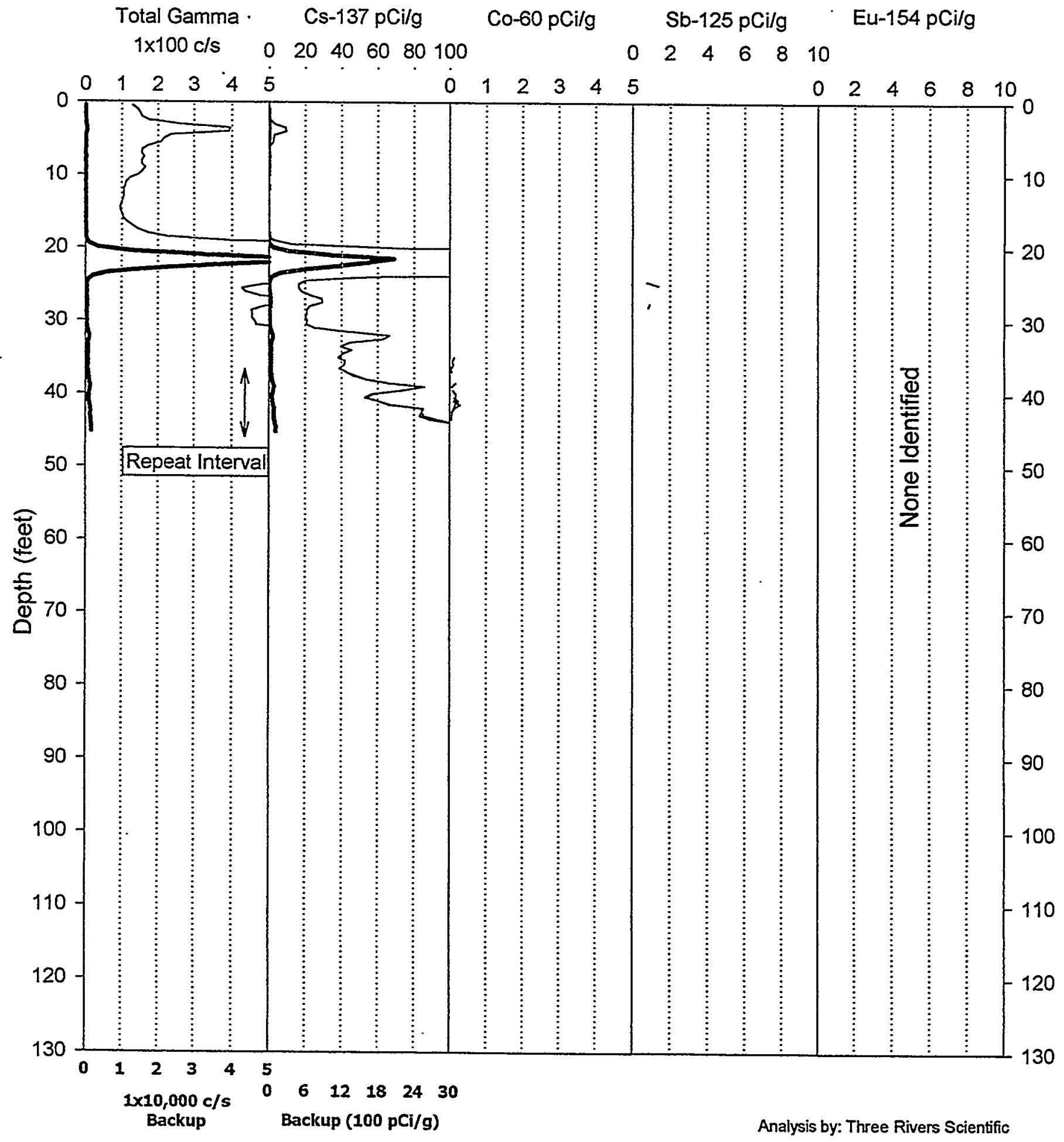




\section{RLS Spectral Gamma Ray Borehole Survey \\ Acceptance QA Processing}

Project: PNNL Vadose Zone Monitoring Log Date: July 20, 1999 Borehole: 299-E13-54 · Compare Main Log \& Repeat

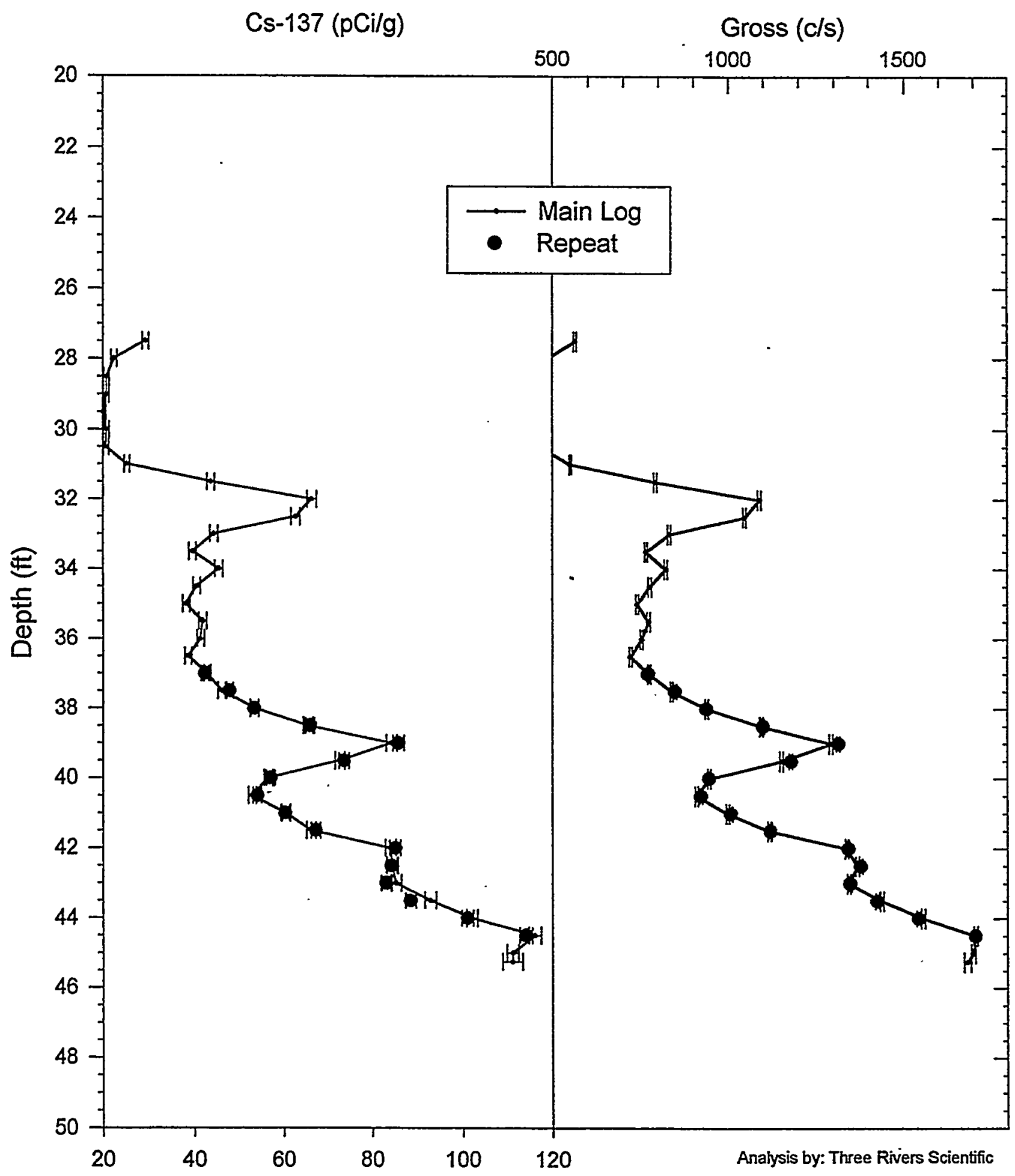




\title{
RLS Spectral Gamma Ray Borehole Survey \\ Waste Management Federal Services NW
}

\section{Log Analysis Summary Report}

\author{
Project: $\quad$ PNNL Vadose Zone Monitoring \\ Well: \\ 299-E13-54 \\ Log Type: $\quad$ HPGe Spectral Gamma Ray \\ Log Date: \\ July 20, 1999
}

\section{General Notes:}

Total gamma is mostly a response to Cs-137 contamination and cannot be used for lithologic information.

Log data collected with a depth reference of top of casing, and during analysis the depths were shifted to ground surface reference for all plots.

System Performance Verify: The pre- and post-log verification passed performance standards.

Repeat Interval: Based on repeat interval, the logging system performed as per specifications, refer to repeat plot. The error bars are calculated for 1 standard deviation of the net photo peak count rate statistical variance. Thus, the repeat should fall within these error bars $67 \%$ of the time.

Environmental Corrections: All radionuclide concentrations have been corrected for casing attenuation (entire well). Water level is below depths logged. No casing correction was applied to the total gamma due to Compton downscatter interference.

The instrument experienced dead time correction in-accuracy due to high count rates over the depth interval from 21.0 to 22.5 feet. In this interval, all concentrations are under reported.

\section{Radionuclides:}

Cs-137 was identified over the depths logged, except for the depth interval from 13 to 19 feet. The maximum concentration of Cs-137 occurs at a depth of 21 feet, with a reading greater than $2,000 \mathrm{pCi} / \mathrm{g}$. The Cs-137 MDL value for these log data is $0.25 \mathrm{pCi} / \mathrm{g}$.

Co-60 was identified over the depths from $35-43$ feet. (Note, the Co-60 is at detection threshold, but a summing by 4 technique confirms its presence.) The maximum concentration of Co-60 occurs at a depth of 42 feet, with a reading of $0.25 \mathrm{pCi} / \mathrm{g}$. The Co-60 MDL value for these log data is $0.25 \mathrm{pCi} / \mathrm{g}$, in the low Cs-137 depth intervals.

Sb-125 was identified at the depth of 25 feet. This Sb-125 level of detection is at threshold, but confirmed using a summing by 4 technique. The maximum concentration of Sb-125 occurs at a depth of 25 feet, with a reading of 1.5 $\mathrm{pCi} / \mathrm{g}$. The Sb-125 MDL value for these log data is $1.5 \mathrm{pCi} / \mathrm{g}$, in the low Cs-137 depth intervals. 


\section{Moisture Logging Service Log Header}

Project: $\quad$ PNNL Vadose Zone Monitoring

Well: 299-E13-54

Log Type: Moisture Gauge

Borehole Information

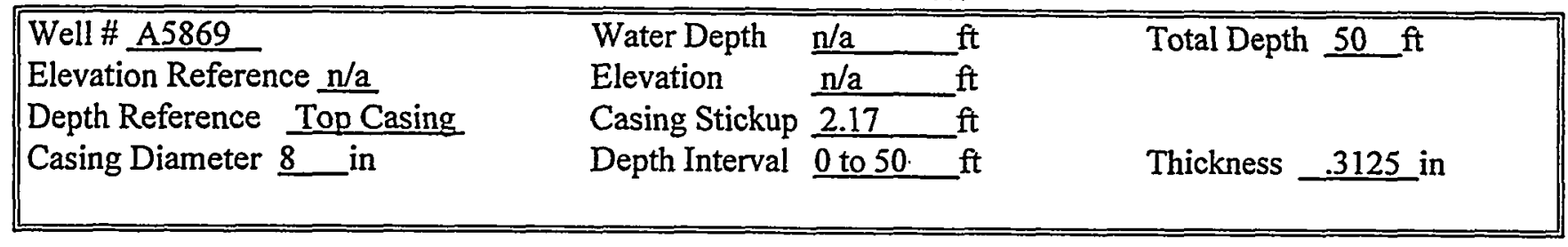

Logging Information

\begin{tabular}{|c|c|c|}
\hline Log Type: & Moisture Gauge & \\
\hline Company & Waste Management NV & \\
\hline Date/Archive File Name & July 19, 1999 & M2E13054 \\
\hline Logging Engineers & R.K. Price & \\
\hline Instrument Series & $\overline{\text { RLSM00.0 }}$ & \\
\hline Logging Unit & RLS-3 & \\
\hline Depth Interval & 2 to $50 \mathrm{ft}$ & Prefix MB28 \\
\hline & & . \\
\hline Instrument Calibration Date & \multirow{2}{*}{\multicolumn{2}{|c|}{$\begin{array}{l}\text { May 13, } 1999 \\
\text { WHC-SD-EN-TI-306, Rev. } 0\end{array}$}} \\
\hline Calibration Report & & \\
\hline
\end{tabular}

Analysis Information

$\begin{array}{ll}\text { Company } & \text { Three Rivers Scientific } \\ \text { Analyst } & \text { Russ Randall } \\ \text { Date } & \text { July 24, 1999 } \\ \text { Depth Reference } & \text { Ground Surface (plots depth shifted) - }\end{array}$

Notes Moisture values range from $3 \%$ to $34 \%$ for the depths logged. The bottom of the highest observed moisture zone occurs at the depth of 17 feet with a reading of $34 \%$ by volume. This highest moisture zone occurs just above the contaminated interval from 20 to 47 feet. 


\section{RLS Moisture Processed Log Data}

\section{Waste Management Federal Services NW}

Project: Vadose Zone Monitoring

Borehole: 299-E13-54
8" Casing Calibration

Log Date July 19, 1999
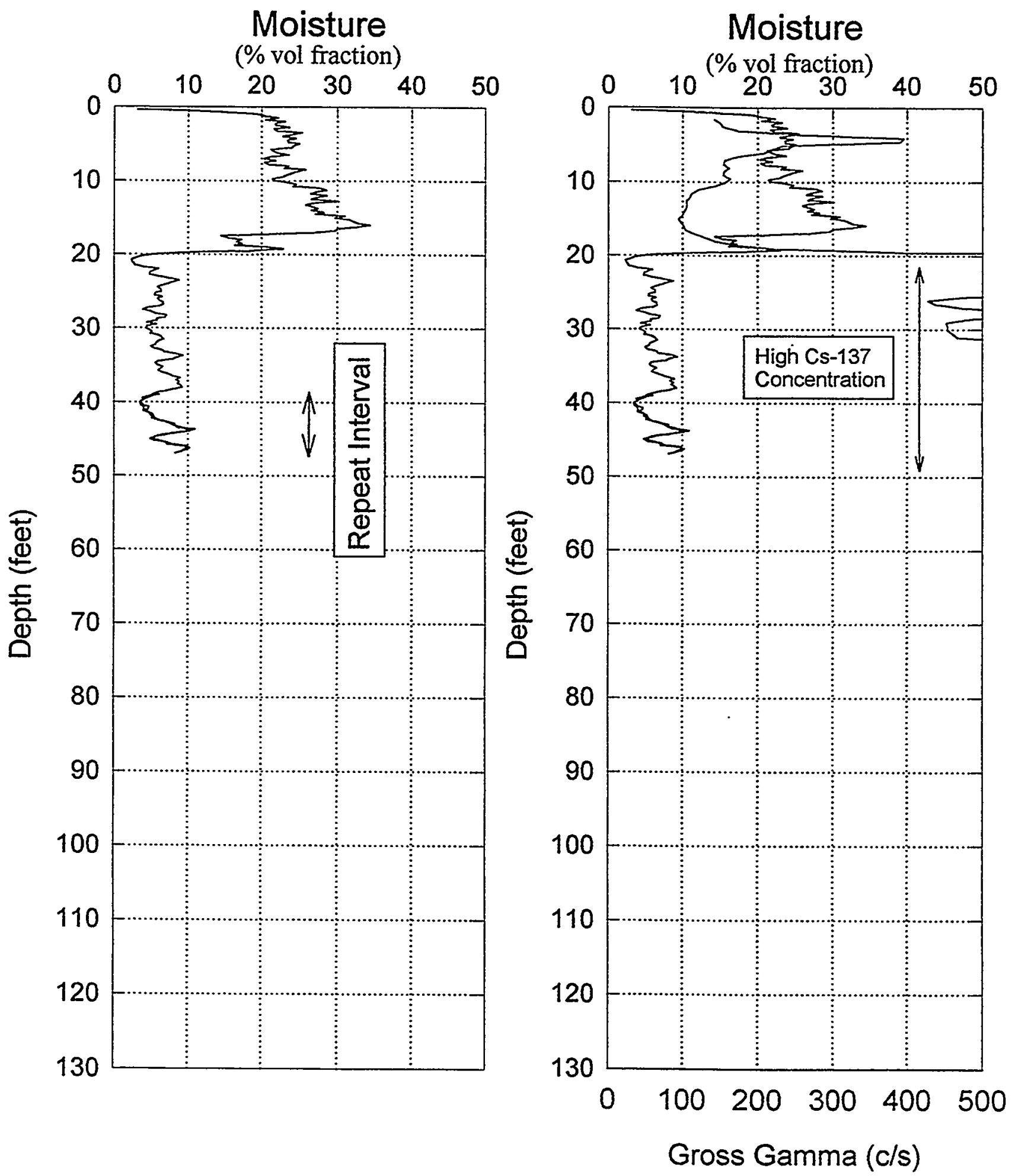

B.110 


\section{RLS \\ Log Analysis \& Summary}

Project: $\quad$ PNNL Vadose Zone Monitoring

Log Type: Moisture Gauge

Well ID:

299-E13-54

Log Date: July 19, 1999

\section{General Notes:}

The low reading from 0 feet to 2 feet is due to surface effects and not necessarily the moisture content of the sediments surrounding the borehole.

Log data collected with a depth reference of top of casing, and during analysis the depths were shifted to ground surface reference for all plots.

System Performance Verify: The pre- and post-log verification passed performance standards, $-1.2 \%$ in the shield verify.

Repeat Interval: Based on the repeat interval from 39 to 47 feet, the logging system performed according to specifications.

Environmental Corrections: The mọisture levels have been corrected for casing attenuation (entire well).

\section{Observations:}

The moisture levels show values ranging from $3 \%$ to $34 \%$ for the depth interval from 2 feet to 47 feet. The bottom of the highest moisture interval occurs at a depth of 17 feet, with a reading of $34 \%$ by volume. Below this depth the moisture levels fall to readings between $3 \%$ and $10 \%$ by volume and the highest concentration of Cs- 137 contaminant occurs below 20 feet. 


\section{RLS Spectral Gamma Ray Borehole Survey \\ Waste Management Federal Services NW}

\section{Log Header}

Project: PNNL Vadose Zone Monitoring Well: 299-E13-55

Log Type: $\quad$ HPGe Spectral Gamma Ray

Borehole Information

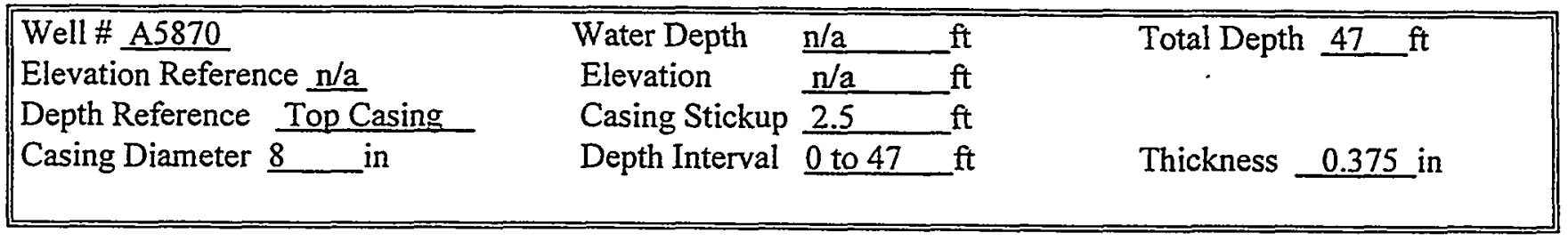

Logging Information

Log Type:

Company

Date/Archive File Name

Logging Engineers

Instrument Series

Logging Unit

Depth Interval

Instrument Calibration Date

Calibration Report
$35 \%$ HPGe Spectral Gamma Ray

Waste Management NW

July $15,1999 \quad$ H2E13055

A. Pearson

RLSG035N00L00.0

RLS-1

3 to $45 \mathrm{ft}$

Prefix AP13

Jan 19, 1999

WHC-SD-EN-TI-292

Analysis Information

$\begin{array}{ll}\text { Company } & \text { Three Rivers Scientific } \\ \text { Analyst } & \text { Russ Randall } \\ \text { Date } & \text { July 27, 1999 } \\ \text { Depth Reference } & \text { Ground Surface (plots depth shifted) }\end{array}$

Notes Cs-137. Co-60, and Sb-125 are the only man made radionuclides detected. Detection of Sb-125 required a summing technique since the levels are at detection threshold. 


\section{RLS Spectral Gamma Ray Borehole Survey Waste Management Federal Services NW}

Project: PNNL Vadose Zone Monitoring Log Date: July 15, 1999 Borehole: 299-E13-55

Naturally Occurring Radionuclides

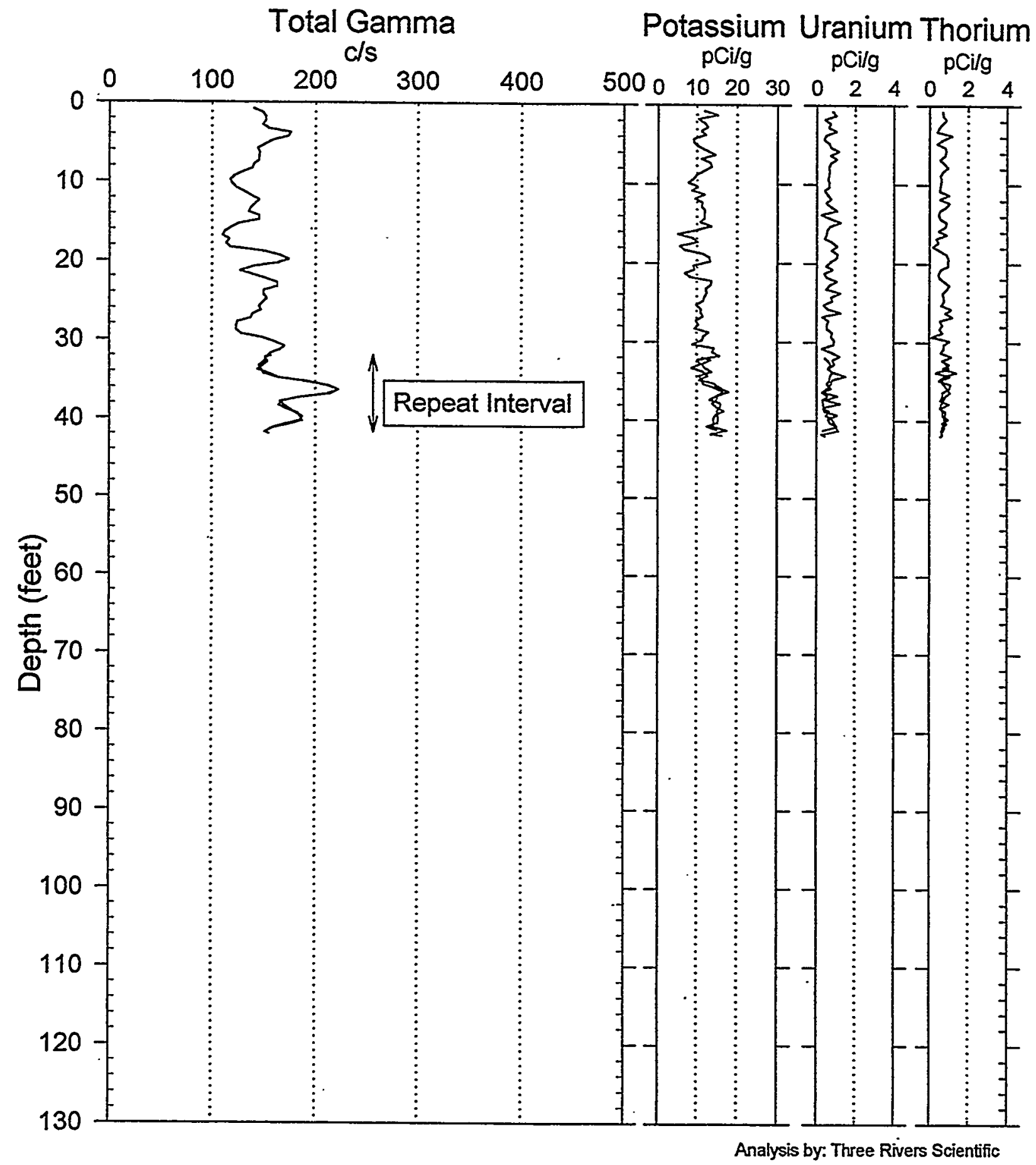




\section{RLS Spectral Gamma-Ray Borehole Survey Waste Management Federal Services NW}

Project: PNNL Vadose Zone Monitoring Log Date: July 15, 1999 Borehole: 299-E13-55 Man-Made Radionuclides

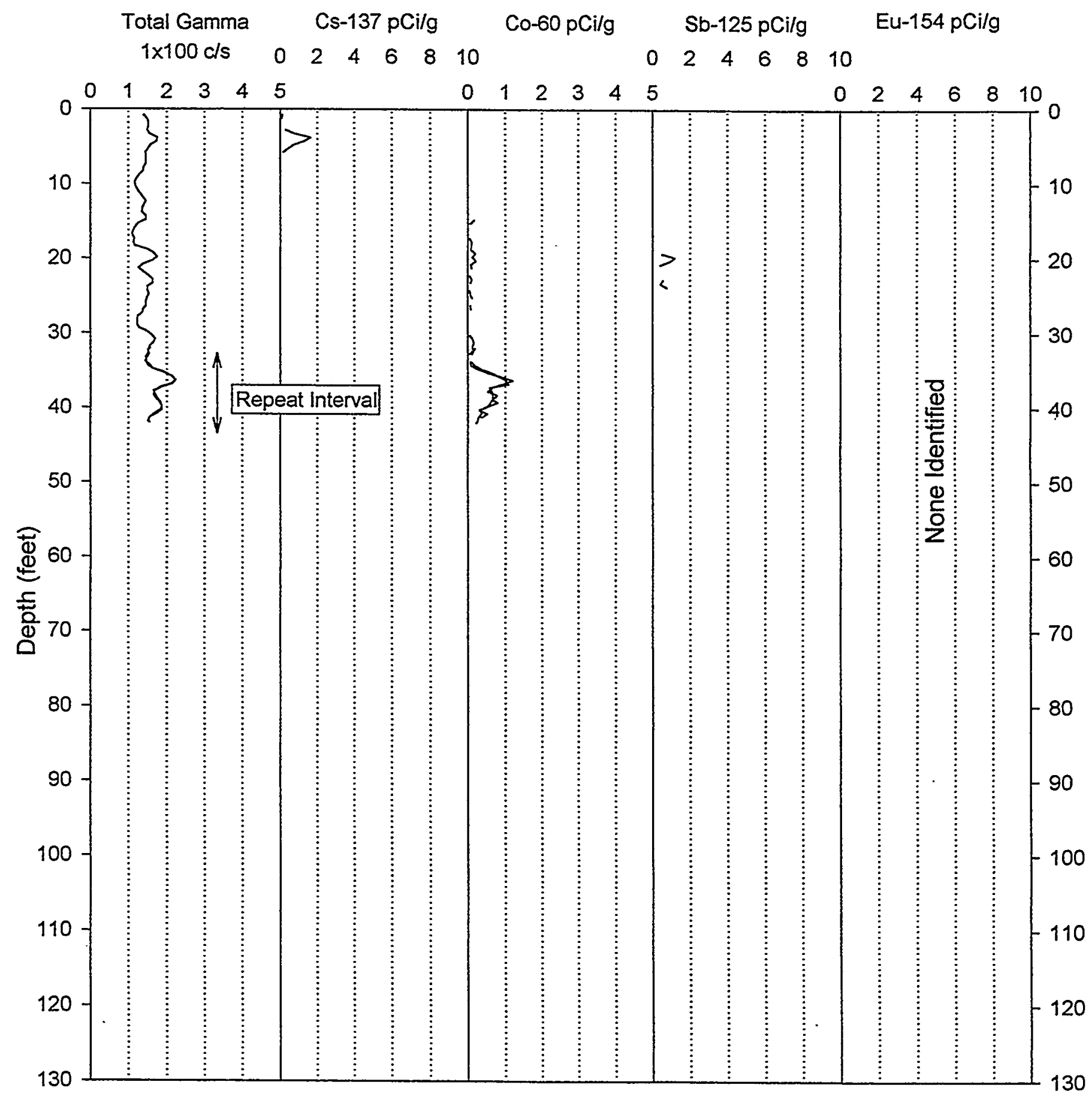




\section{RLS Spectral Gamma Ray Borehole Survey Acceptance QA Processing}

Project: PNNL Vadose Zone Monitoring Log Date: July 15, 1999 Borehole: 299-E13-55 . Compare Main Log \& Repeat

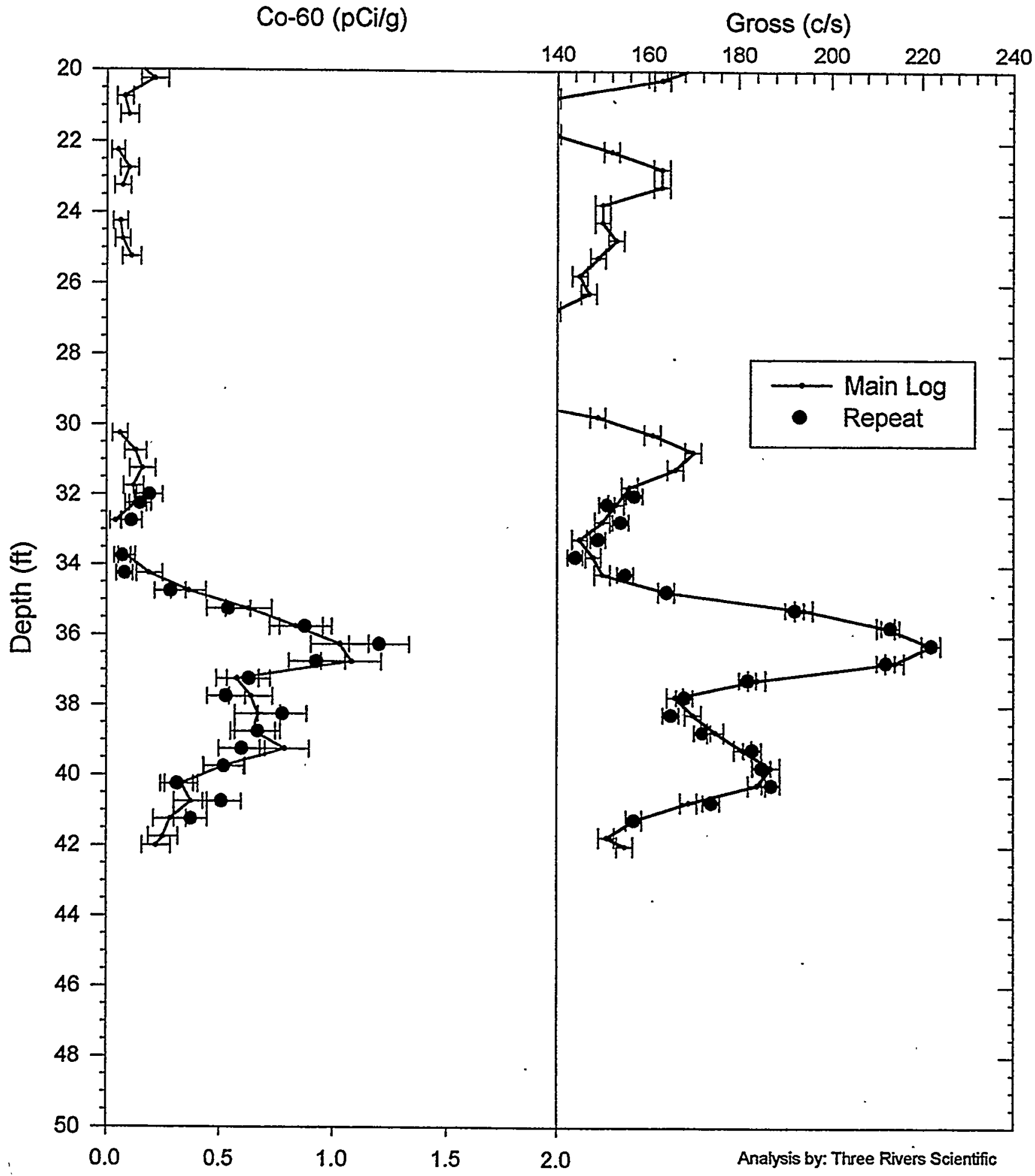




\section{RLS Spectral Gamma Ray Borehole Survey \\ Waste Management Federal Services NW}

\section{Log Analysis Summary Report}

$\begin{array}{lllr}\text { Project: } & \text { PNNL Vadose Zone Monitoring } & \text { Well: } & \text { 299-E13-55 } \\ \text { Log Type: } & \text { HPGe Spectral Gamma Ray } & \text { Log Date: } & \text { July 15, 1999 }\end{array}$

\section{General Notes:}

Total gamma is mostly a response to Cs-137 contamination and cannot be used for lithologic information.

Log data collected with a depth reference of top of casing, and during analysis the depths were shifted to ground surface reference for all plots.

System Performance Verify: The pre- and post-log verification passed performance standards.

Repeat Interval: Based on repeat interval, the logging system performed as per specifications, refer to repeat plot. The error bars are calculated for 1 standard deviation of the net photo peak count rate statistical variance. Thus, the repeat should fall within these error bars $67 \%$ of the time.

Environmental Corrections: All radionuclide concentrations have been corrected for casing attenuation (entire well). Water level is below depths logged. No casing correction was applied to the total gamma due to Compton downscatter interference.

\section{Radionuclides:}

Cs-137 was identified over the depths from 1-5 feet. The maximum concentration of Cs-137 occurs at a depth of 4 feet, with a reading of $1.6 \mathrm{pCi} / \mathrm{g}$. The Cs-137 MDL value for these $\log$ data is $0.3 \mathrm{pCi} / \mathrm{g}$.

Co-60 was identified over the depths from $15-41$ feet. The maximum concentration of Co-60 occurs at a depth of 36 feet, with a reading of $1.2 \mathrm{pCi} / \mathrm{g}$. The Co-60 MDL value for these $\log$ data is $0.2 \mathrm{pCi} / \mathrm{g}$.

Sb-125 was identified over the depths from 19-24 feet. This Sb-125 level of detection is at threshold, but confirmed using a summing by 4 technique. The maximum concentration of Sb-125 occurs at a depth of 20 feet, with a reading of $1.2 \mathrm{pCi} / \mathrm{g}$. The $\mathrm{Sb}-125 \mathrm{MDL}$ value for these $\log$ data is $0.9 \mathrm{pCi} / \mathrm{g}$. 


\title{
Moisture Logging Service Log Header
}

\author{
Project: $\quad$ PNNL Vadose Zone Monitoring \\ Well: 299-E13-55
}

Log Type: $\quad$ Moisture Gauge

Borehole Information

\begin{tabular}{|c|c|c|}
\hline Well \# A5870 & Water Depth $\mathrm{n} / \mathrm{a} \quad \mathrm{ft}$ & Total Depth 47 \\
\hline Elevation Reference $n / a$ & Elevation & \\
\hline Depth Reference Top Casing & Casing Stickup 2.4 & \\
\hline Casing Diameter $\underline{8}$ in & Depth Interval $\underline{0 \text { to } 47} \mathrm{ft}$ & Thickness .375 \\
\hline
\end{tabular}

Logging Information

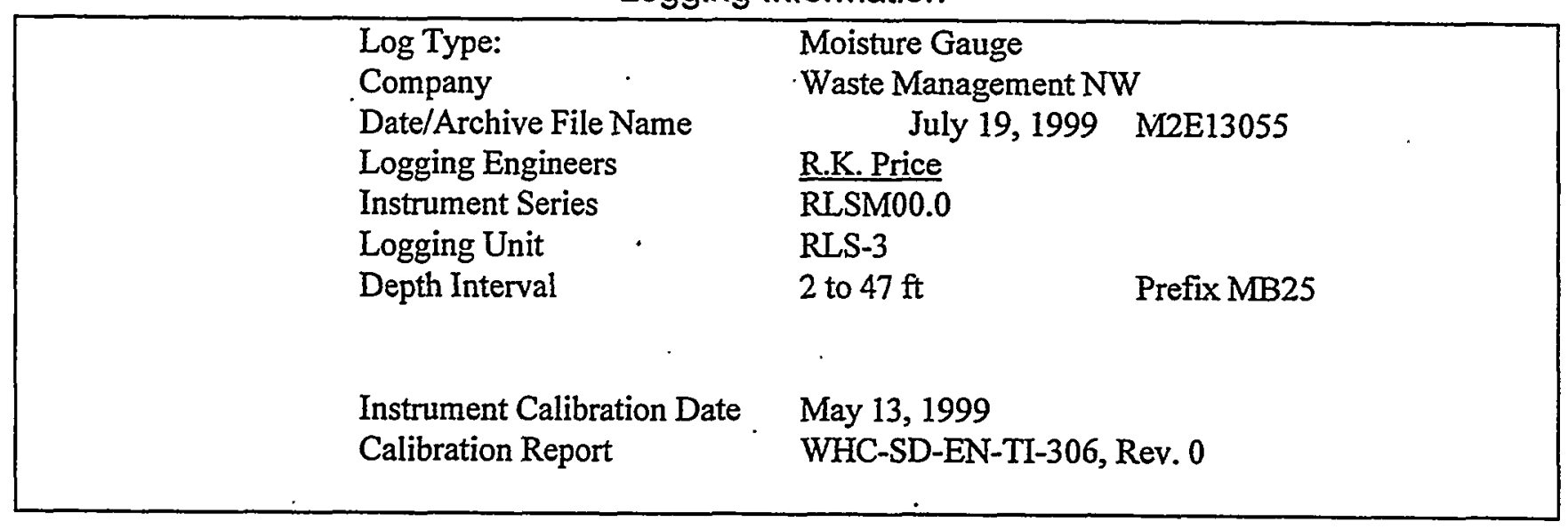

Analysis Information

\begin{tabular}{|c|c|c|}
\hline & $\begin{array}{l}\text { Company } \\
\text { Analyst } \\
\text { Date } \\
\text { Depth Reference }\end{array}$ & $\begin{array}{l}\text { Three Rivers Scientific } \\
\text { Russ Randall } \\
\text { July 24, } 1999 \\
\text { Ground Surface (plots depth shifted) }\end{array}$ \\
\hline Notes & \multicolumn{2}{|c|}{$\begin{array}{l}\text { Moisture values range from } 4 \% \text { to } 32 \% \text { for the depths logged. The highest observed moisture zone } \\
\text { occurs at the depth of } 9 \text { feet with a reading of } 32 \% \text { by volume. }\end{array}$} \\
\hline
\end{tabular}




\section{RLS Moisture Processed Log Data}

Waste Management Federal Services NW

Project: Vadose Zone Monitoring

Borehole: 299-E13-55
8" Casing Calibration

Log Date July 19, 1999
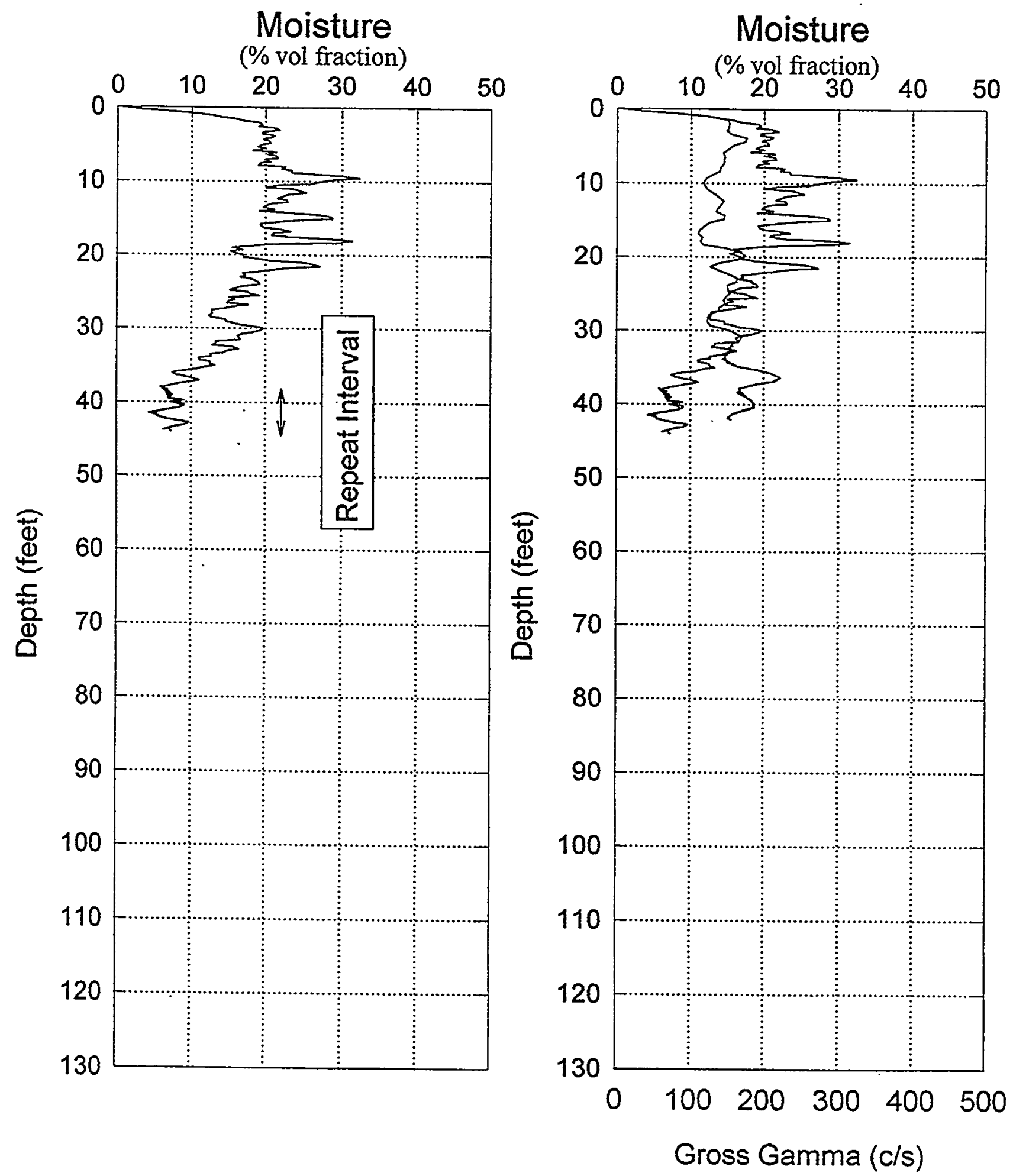

B.118 


\section{RLS \\ Log Analysis \& Summary}

$\begin{array}{lllr}\text { Project: } & \text { PNNL Vadose Zone Monitoring } & \text { Well D: } & \text { 299-E13-55 } \\ \text { Log Type: } & \text { Moisture Gauge } & \text { Log Date: } & \text { July 19, 1999 }\end{array}$

\section{General Notes:}

The low reading from 2 feet to 4 feet is due to surface effects and not necessarily the moisture content of the sediments surrounding the borehole.

Log data collected with a depth reference of top of casing, and during analysis the depths were shifted to ground surface reference for all plots.

System Performance Verify: The pre- and post-log verification passed performance standards, $+0.5 \%$ in the shield verify.

Repeat Interval: Based on the repeat interval from 38 to 44 feet, the logging system performed according to specifications.

Environmental Corrections: The moisture levels have been corrected for casing attenuation (entire well).

\section{Observations:}

The moisture levels show values ranging from 4 to $32 \%$ for the depth interval from 2 feet to 44 feet. The highest moisture interval is in a series of thin zones from 8 to 22 feet, with a maximum reading of $32 \%$ by volume at 9 feet. 


\section{RLS Spectral Gamma Ray Borehole Survey \\ Waste Management Federal Services NW}

\section{Log Header}

Project: $\quad$ PNNL Vadose Zone Monitoring

Well: 299-E13-56

Log Type: $\quad$ HPGe Spectral Gamma Ray

Borehole Information

\begin{tabular}{|c|c|c|}
\hline Well \# A5871 & Water Depth n/a & Total Depth 50 \\
\hline Elevation Reference $\underline{\mathrm{n} / \mathrm{a}}$ & Elevation $\quad \underline{n / a}$ & \\
\hline Depth Reference Top Casing & Casing Stickup $2.3 \quad \mathrm{ft}$ & \\
\hline Casing Diameter $\underline{8 \quad \text { in }}$ & Depth Interval 0 to $50 \mathrm{ft}$ & Thickness \\
\hline
\end{tabular}

Logging Information

Log Type:

Company

Date/Archive File Name

Logging Engineers

Instrument Series

Logging Unit

Depth Interval

Instrument Calibration Date

Calibration Report
35\% HPGe Spectral Gamma Ray

Waste Management NW

July 16, 1999 H2E13056

A. Pearson

RLSG035N00L00.0

RLS-1

3 to $48 \mathrm{ft} \quad$ Prefix AP14

Jan 19, 1999

WHC-SD-EN-TI-292

Analysis Information

$\begin{array}{ll}\text { Company } & \text { Three Rivers Scientific } \\ \text { Analyst } & \text { Russ Randall } \\ \text { Date } & \text { July 27, 1999 } \\ \text { Depth Reference } & \text { Ground Surface (plots depth shifted) }\end{array}$

Notes Cs-137 and Sb-125 are the only man made radionuclides detected. 


\section{RLS Spectral Gamma Ray Borehole Survey \\ Waste Management Federal Services NW}

Project: PNNL Vadose Zone Monitoring Log Date: July 16, 1999 Borehole: 299-E13-56

Naturally Occurring Radionuclides

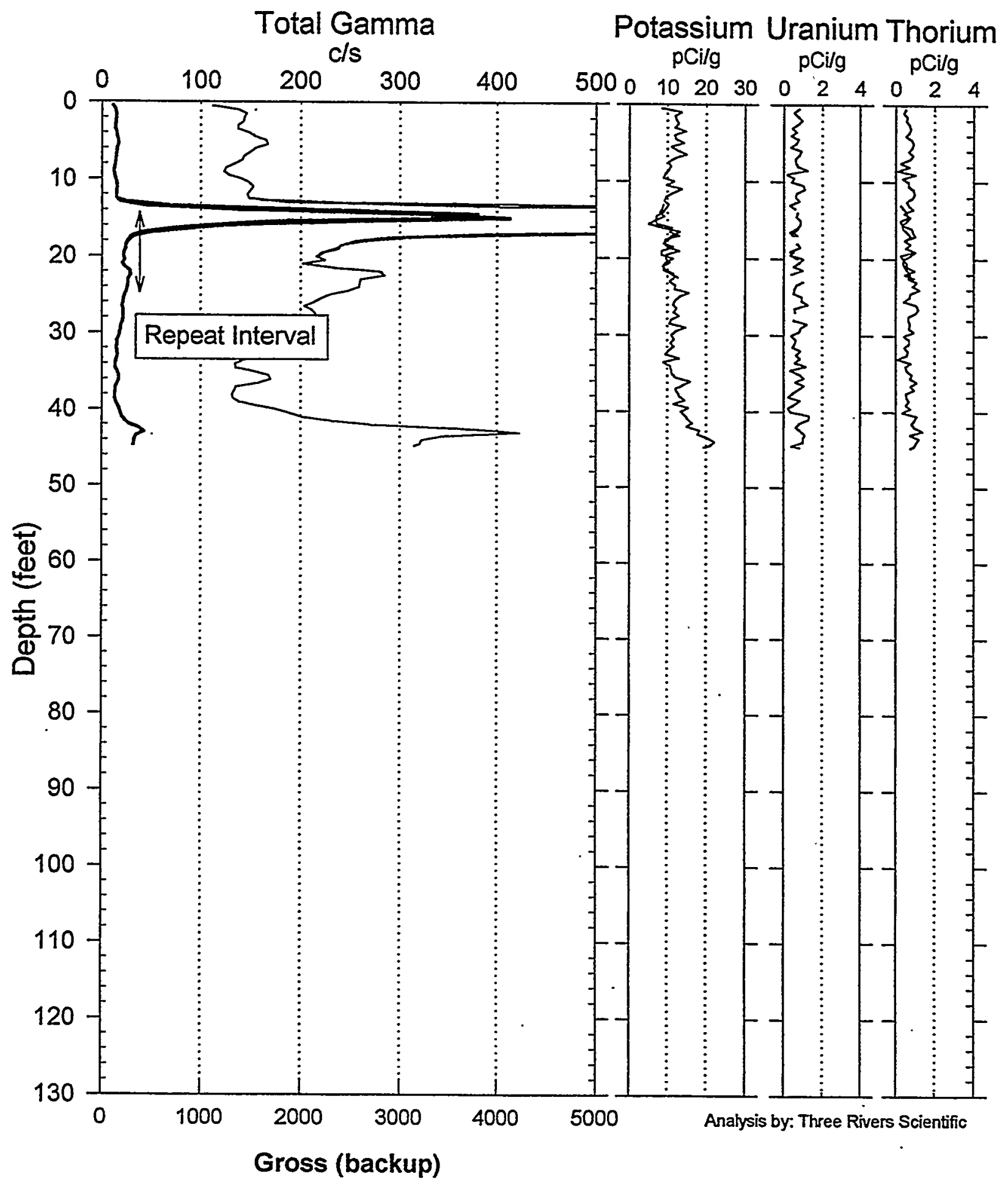




\section{RLS Spectral Gamma-Ray Borehole Survey Waste Management Federal Services NW}

Project: PNNL Vadose Zone Monitoring Log Date: July 16, 1999 Borehole: 299-E13-56

Man-Made Radionuclides

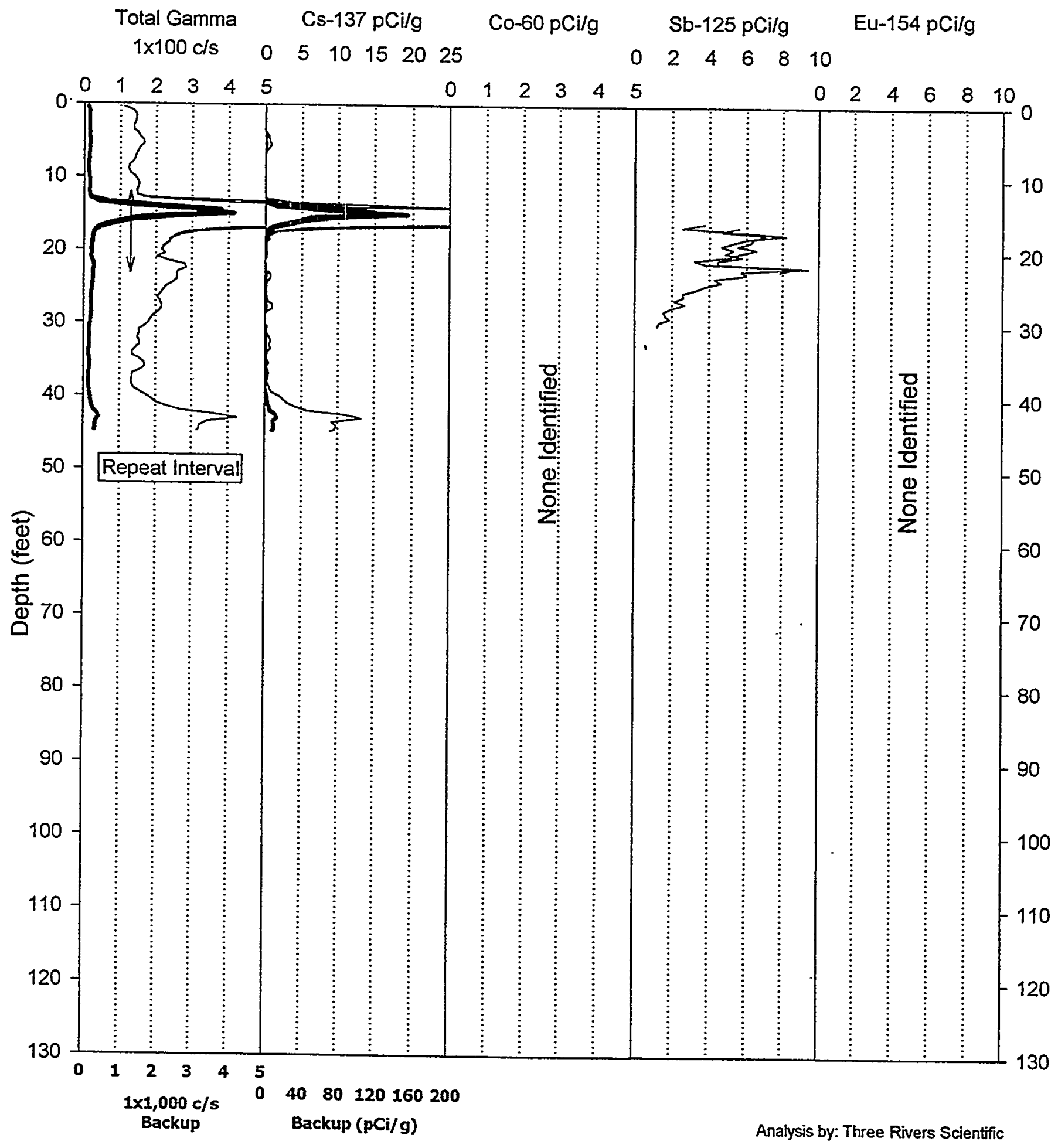




\section{RLS Spectral Gamma Ray Borehole Survey Acceptance QA Processing}

Project: PNNL Vadose Zone Monitoring Log Date: July 16, 1999 Borehole: 299-E13-56 . Compare Main Log \& Repeat

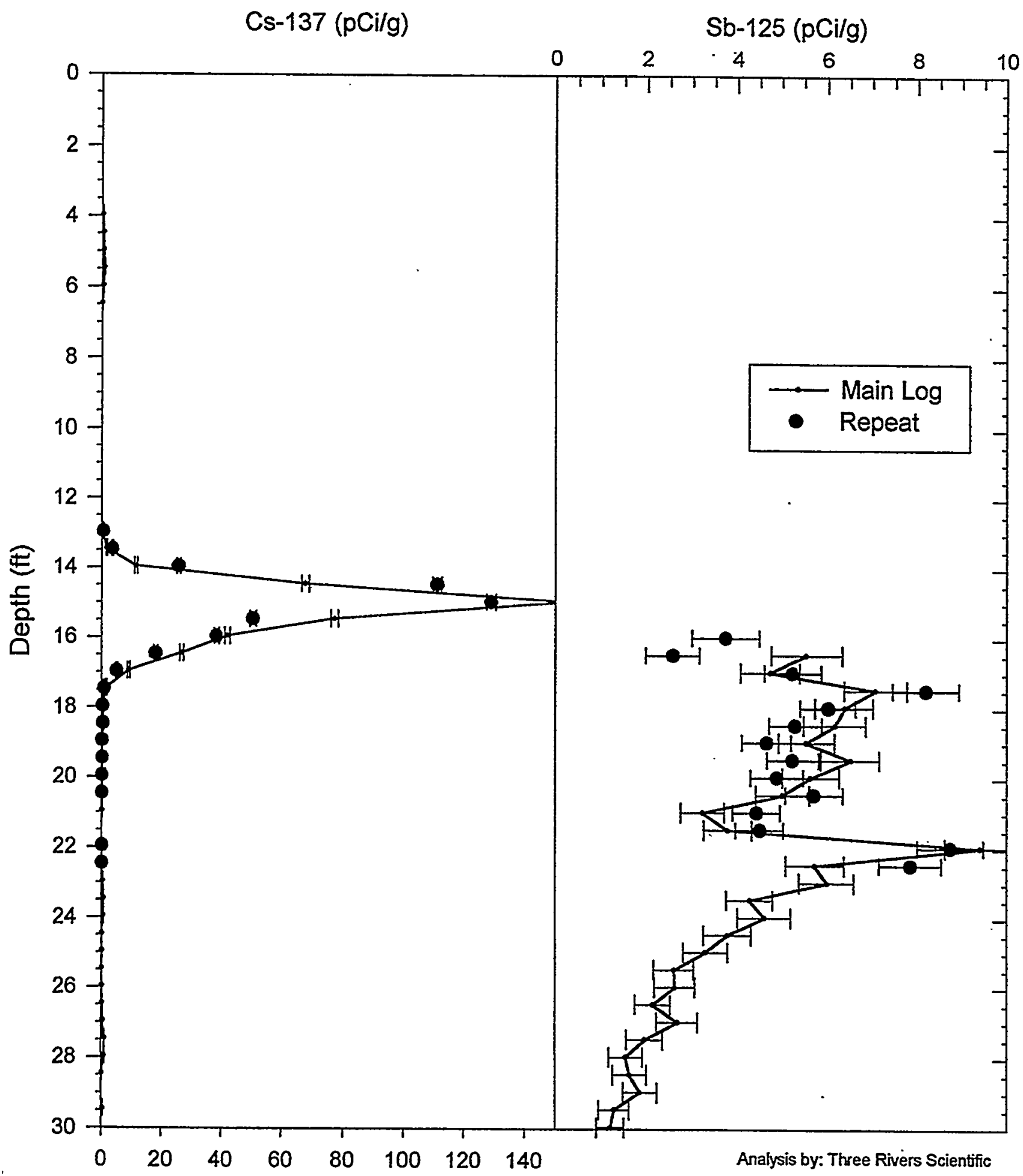




\section{RLS Spectral Gamma Ray Borehole Survey \\ Waste Management Federal Services NW}

\section{Log Analysis Summary Report}

$\begin{array}{lllr}\text { Project: } & \text { PNNL Vadose Zone Monitoring } & \text { Well: } & \text { 299-E13-56 } \\ \text { Log Type: } & \text { HPGe Spectral Gamma Ray } & \text { Log Date: } & \text { July 16, 1999 }\end{array}$

\section{General Notes:}

Total gamma is mostly a response to contaminants and cannot be used for lithologic information.

Log data collected with a depth reference of top of casing, and during analysis the depths were shifted to ground surface reference for all plots.

System Performance Verify: The pre- and post-log verification passed performance standards.

Repeat Interval: Based on repeat interval, the logging system performed as per specifications, refer to repeat plot. The error bars are calculated for 1 standard deviation of the net photo peak count rate statistical variance. Thus, the repeat should fall within these error bars $67 \%$ of the time.

Environmental Corrections: All radionuclide concentrations have been corrected for casing attenuation (entire well). Water level is below depths logged. No casing correction was applied to the total gamma due to Compton downscatter interference.

\section{Radionuclides:}

Cs-137 was identified over the depths from 3-45 feet. The maximum concentration of Cs-137 occurs at a depth of 15 feet, with a reading of $150 \mathrm{pCi} / \mathrm{g}$. The Cs- $137 \mathrm{MDL}$ value for these $\log$ data is $0.2 \mathrm{pCi} / \mathrm{g}$.

$\mathrm{Sb}-125$ was identified over the depths from 16-32 feet. The maximum concentration of Sb-125 occurs at a depth of 22 feet, with a reading of $9 \mathrm{pCi} / \mathrm{g}$. The Sb-125 MDL value for these log data is $1.2 \mathrm{pCi} / \mathrm{g}$. 


\section{Moisture Logging Service \\ Log Header}

Project: $\quad$ PNNL Vadose Zone Monitoring

Well: 299-E13-56

Log Type: Moisture Gauge

Borehole Information

\begin{tabular}{|c|c|c|}
\hline Well \# A5871 & Water Depth $\mathrm{n} / \mathrm{a}$ & Total Depth $\underline{50}$ \\
\hline Elevation Reference $\mathrm{n} / \mathrm{a}$ & Elevation & \\
\hline Depth Reference Top Casing & Casing Stickup 2.3 & \\
\hline Casing Diameter $\underline{8 \text { in }}$ & Depth Interval 0 to 50 & Thickness .375 in \\
\hline
\end{tabular}

Logging Information

Log Type:

Company

Date/Archive File Name

Logging Engineers

Instrument Series

Logging Unit

Depth Interval

Instrument Calibration Date

Calibration Report
Moisture Gauge

Waste Management NW

$\underline{\text { R.K. Price }}$

July 19, 1999 M2E13056

RLSM00.0

RIS-3

2 to $50 \mathrm{ft}$

Prefix MB26

WHC-SD-EN-TI-306, Rev. 0

Analysis Information

$\begin{array}{ll}\text { Company } & \text { Three Rivers Scientific } \\ \text { Analyst } & \text { Russ Randall } \\ \text { Date } & \text { July } 15,1999 \\ \text { Depth Reference } & \text { Ground Surface (plots depth shifted) }\end{array}$

Notes Moisture values range from 3\% to $31 \%$ for the depths logged. The highest observed moisture zone occurs at the depth of 16 feet with a reading of $31 \%$ by volume. 


\section{RLS Moisture Processed Log Data}

\section{Waste Management Federal Services NW}

\section{Project: Vadose Zone Monitoring}

Borehole: 299-E13-56
8" Casing Calibration

Log Date July 19, 1999
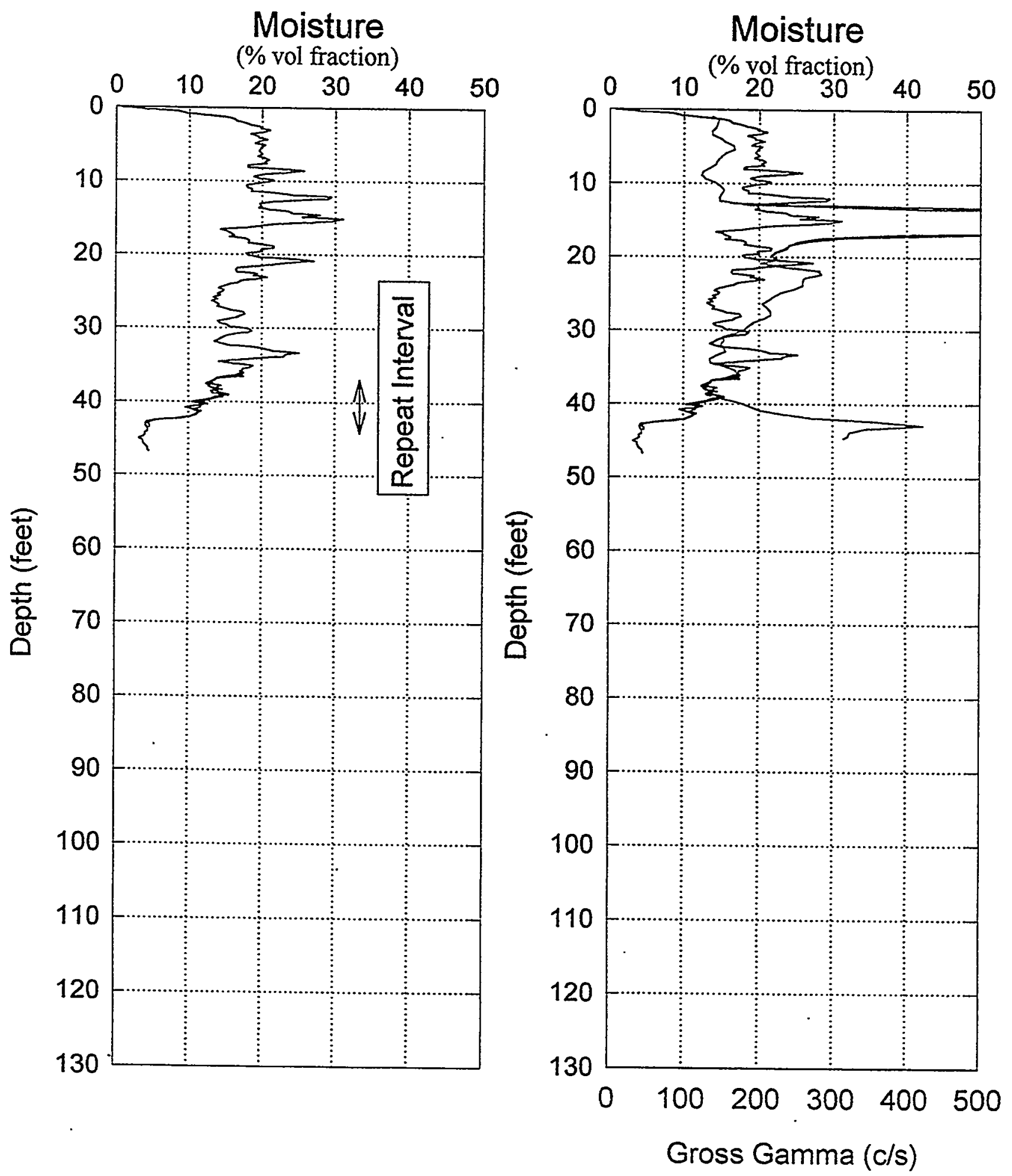

B. 126 


\section{RLS \\ Log Analysis \& Summary}

Project: PNNL Vadose Zone Monitoring

Log Type: $\quad$ Moisture Gauge
Well ID:

Log Date:
299-E13-56

July 19,1999

\section{General Notes:}

The low reading from 2 feet to 4 feet is due to surface effects and not necessarily the moisture content of the sediments surrounding the borehole.

Log data collected with a depth reference of top of casing, and during analysis the depths were shifted to ground surface reference for all plots.

System Performance Verify: The pre- and post-log verification passed performance standards, $-0.1 \%$ in the shield verify.

Repeat Interval: Based on the repeat interval from 37 to 45 feet, the logging system performed according to specifications.

Environmental Corrections: The moisture levels have been corrected for casing attenuation (entire well).

\section{Observations:}

The moisture levels show values ranging from $3 \%$ to $31 \%$ for the depth interval from 2 feet to 47 feet. The highest moisture occurs at a depth of 16 feet, with a reading of $31 \%$ by volume. This is also where the highest level of gamma emitting contamination exists. 


\section{RLS Spectral Gamma Ray Borehole Survey \\ Waste Management Federal Services NW}

\section{Log Header}

Project: PNNL Vadose Zone Monitoring Well: 299-E13-57

Log Type: $\quad$ HPGe Spectral Gamma Ray

Borehole Information

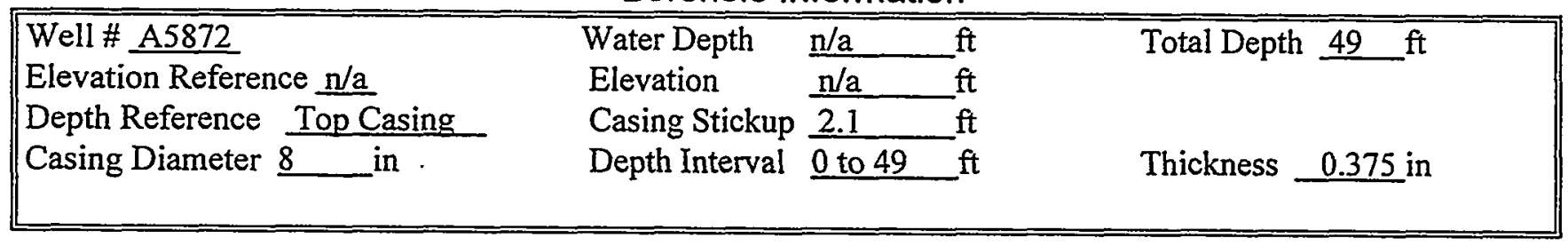

Logging Information

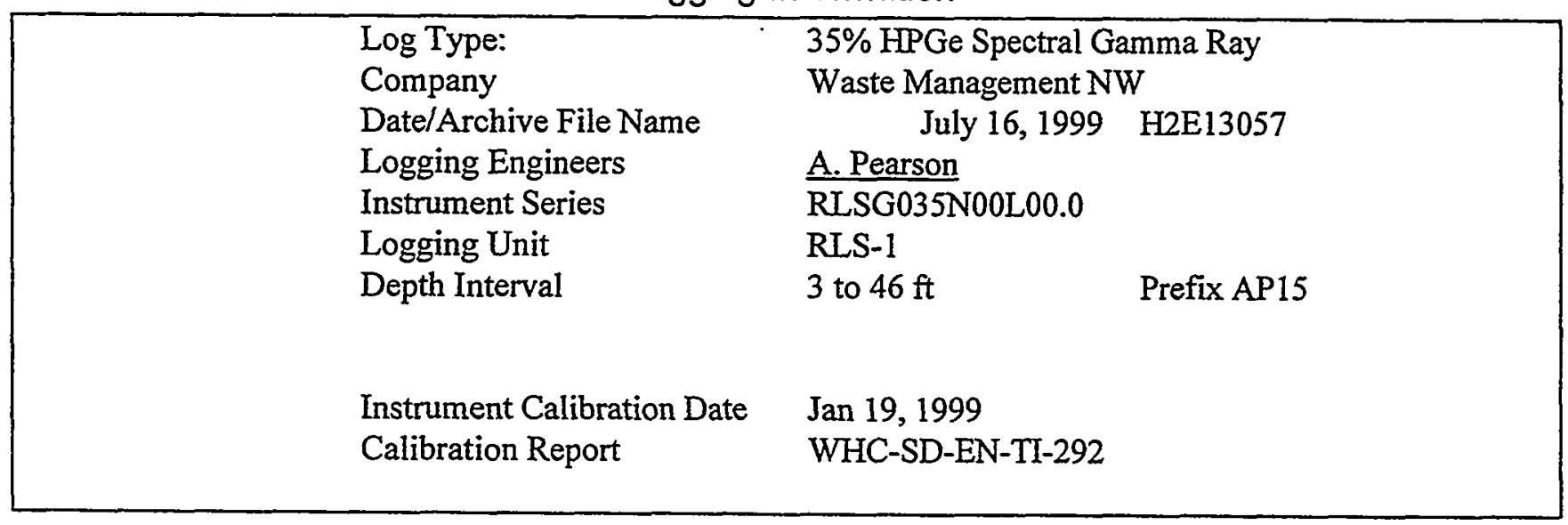

Analysis Information

$\begin{array}{ll}\text { Company } & \text { Three Rivers Scientific } \\ \text { Analyst } & \text { Russ Randall } \\ \text { Date } & \text { July 27, 1999 } \\ \text { Depth Reference } & \text { Ground Surface (plots depth shifted) }\end{array}$

Notes Cs-137. Co-60, and Sb-125 are the only man made radionuclides detected. Detection of Co-60 required a summing technique since the levels are at detection threshold. High count rates over the depth interval from 6 to 8 feet exceed the dead time correction accuracy. 


\section{RLS Spectral Gamma Ray Borehole Survey Waste Management Federal Services NW}

Project: PNNL Vadose Zone Monitoring Log Date: July 16, 1999 Borehole: 299-E13-57

Naturally Occurring Radionuclides

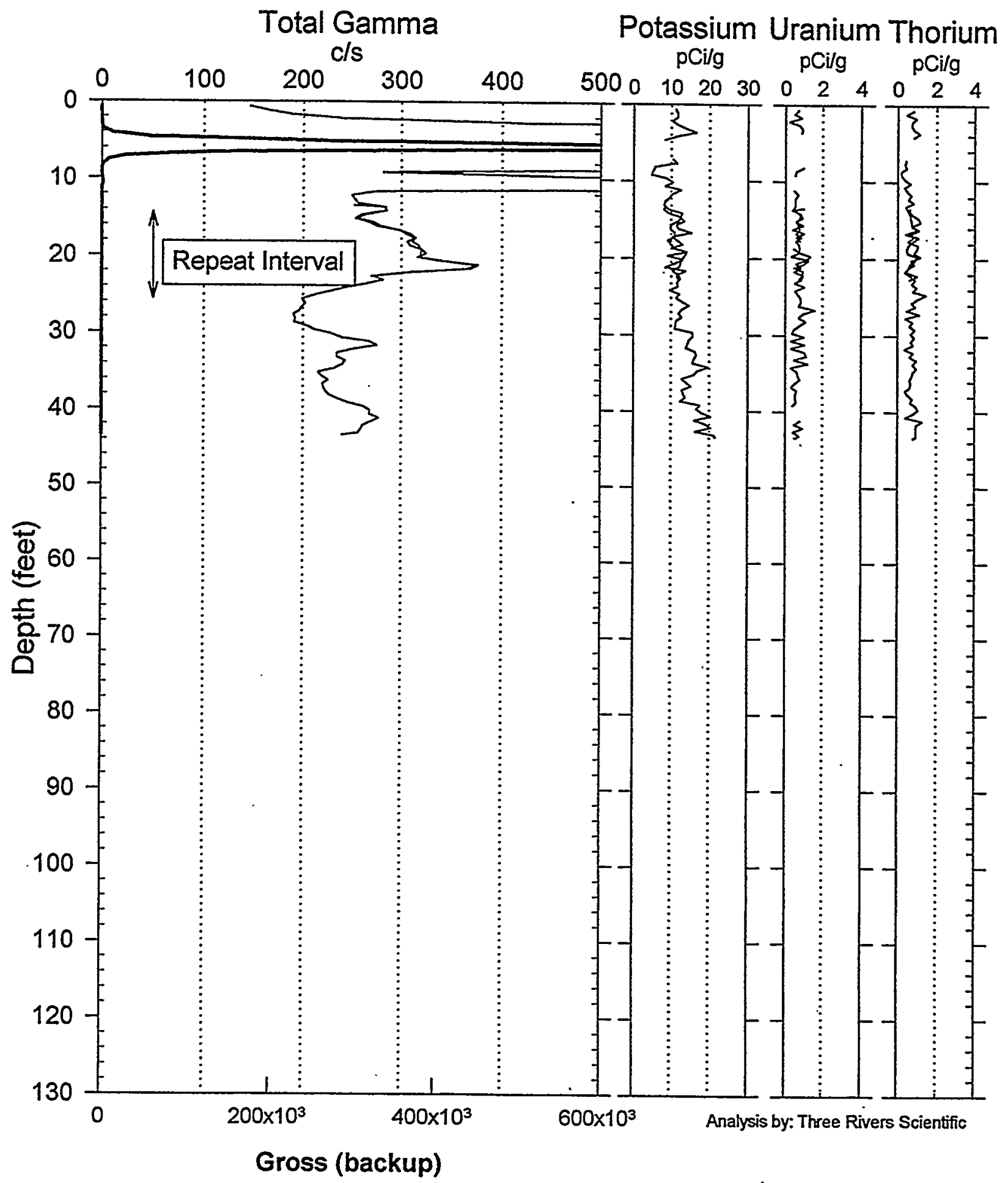




\section{RLS Spectral Gamma-Ray Borehole Survey Waste Management Federal Services NW}

Project: PNNL Vadose Zone Monitoring . Log Date: July 16, 1999 Borehole: 299-E13-57

Man-Made Radionuclides

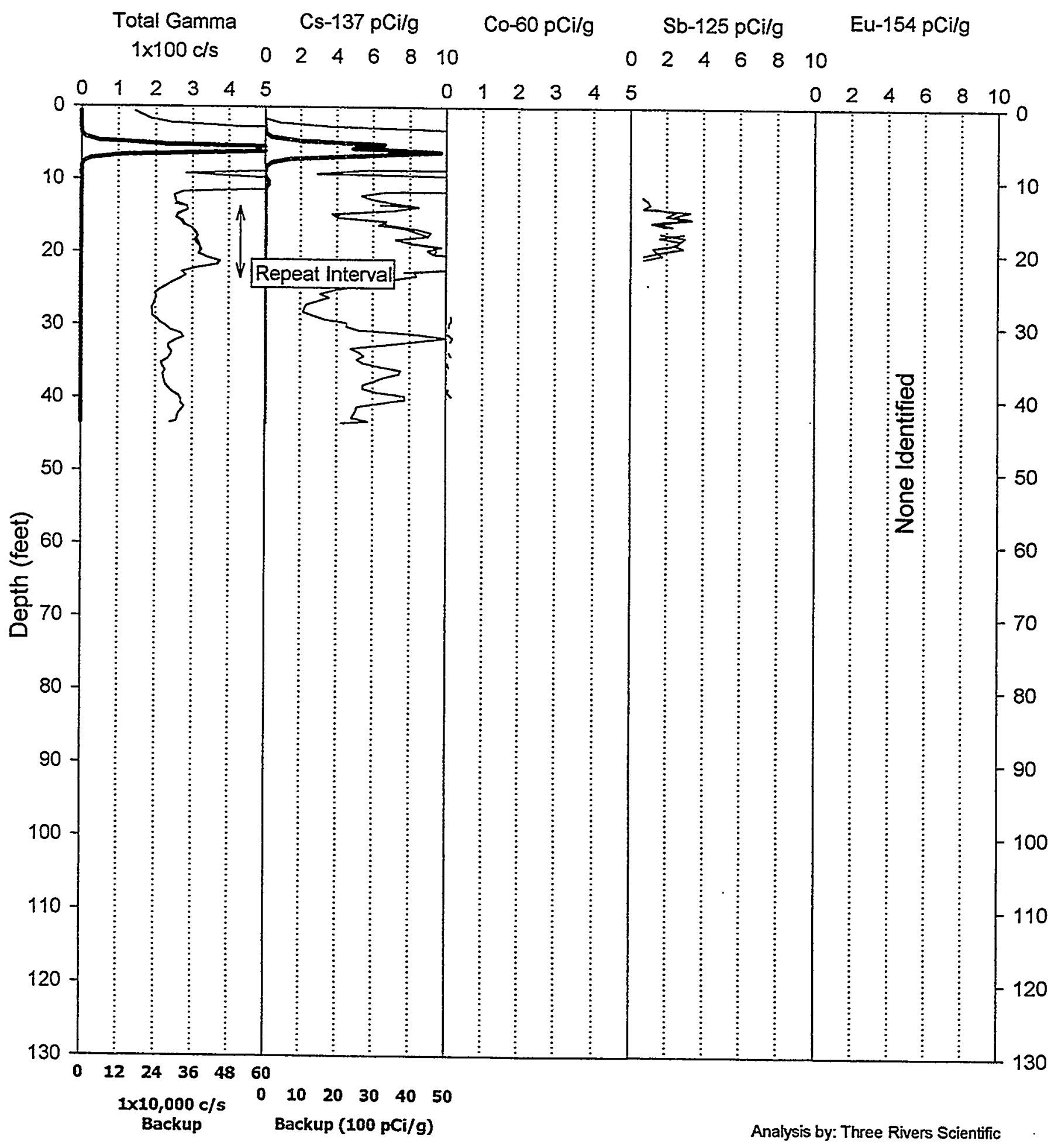




\section{RLS Spectral Gamma Ray Borehole Survey Acceptance QA Processing}

Project: PNNL Vadose Zone Monitoring Borehole: 299-E13-57
Log Date: July 16, 1999

Compare Main Log \& Repeat

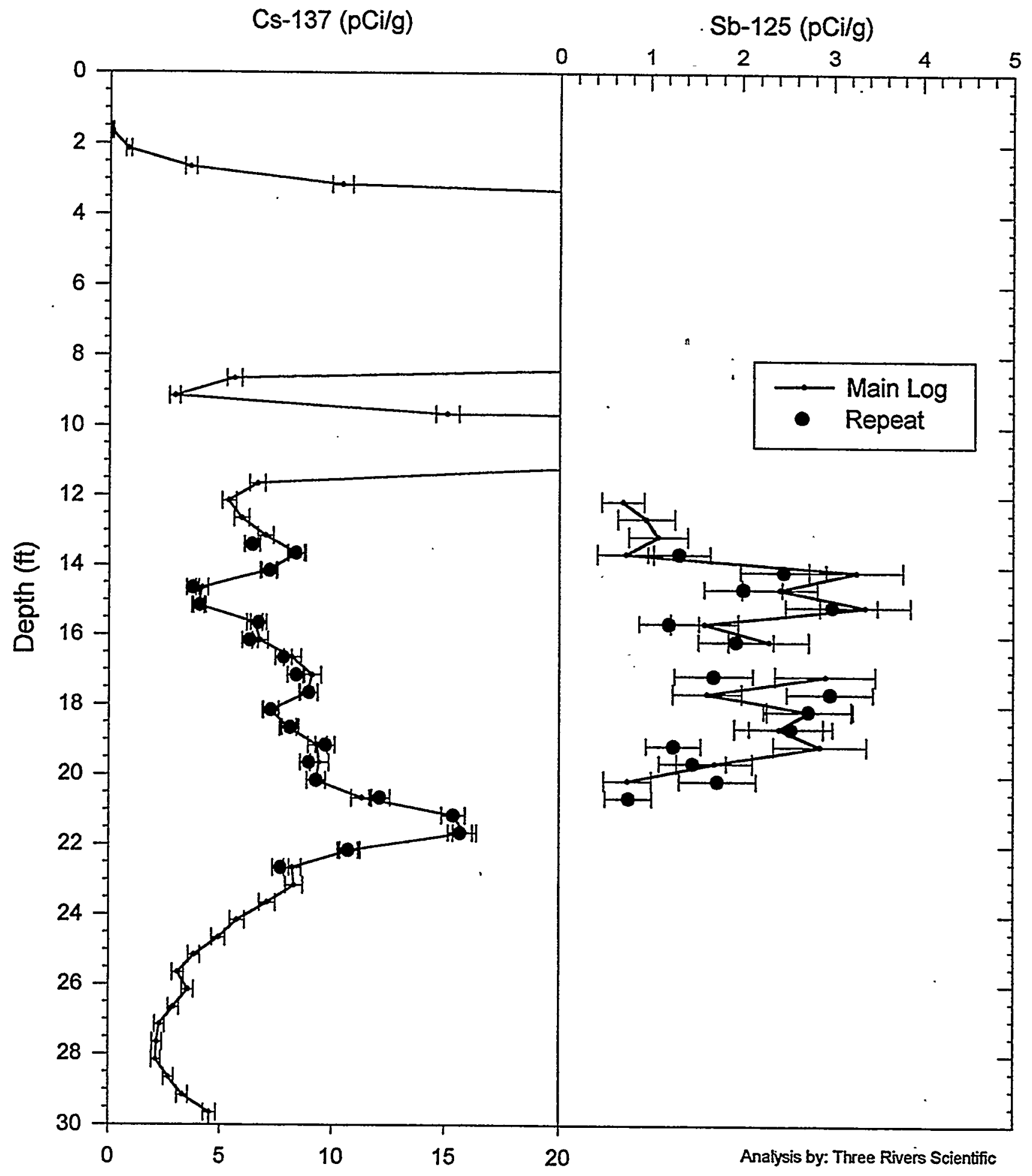




\section{RLS Spectral Gamma Ray Borehole Survey \\ Waste Management Federal Services NW}

\section{Log Analysis Summary Report}

$\begin{array}{lllr}\text { Project: } & \text { PNNL Vadose Zone Monitoring } & \text { Well: } & \text { 299-E13-57 } \\ \text { Log Type: } & \text { HPGe Spectral Gamma Ray } & \text { Log Date: } & \text { July 16, 1999 }\end{array}$

\section{General Notes:}

Total gamma is mostly a response to contaminants, and cannot be used to obtain lithologic information.

Log data collected with a depth reference of top of casing, and during analysis the depths were shifted to ground surface reference for all plots.

System Performance Verify: The pre- and post-log verification passed performance standards.

Repeat Interval: Based on repeat interval, the logging system performed as per specifications, refer to repeat plot. The error bars are calculated for 1 standard deviation of the net photo peak count rate statistical variance. Thus, the repeat should fall within these error bars $67 \%$ of the time.

Environmental Corrections: All radionuclide concentrations have been corrected for casing attenuation (entire well). Water level is below depths logged. No casing correction was applied to the total gamma due to Compton downscatter interference.

From 4.7 to 7.2 feet (inclusive), the high count rates exceed the accuracy limit for dead time correction. The concentrations over this depth interval are under reported for all radionuclides.

\section{Radionuclides:}

Cs-137 was identified over the entire depth of the well. The maximum concentration of Cs-137 occurs at a depth of 6 feet, with a reading greater than $4,800 \mathrm{pCi} / \mathrm{g}$. The Cs-137 MDL value for these $\log$ data is $0.2 \mathrm{pCi} / \mathrm{g}$.

Co-60 was identified over the depths from $28-40$ feet. (Note, the Co-60 is at detection threshold, but a summing by 4 technique confirms its presence.) The maximum concentration of Co-60 occurs at a depth of 31 feet, with a reading of $.2 \mathrm{pCi} / \mathrm{g}$. The $\mathrm{Co}-60 \mathrm{MDL}$ value for these log data is $0.2 \mathrm{pCi} / \mathrm{g}$, for the depth intervals with low Cs-137 concentration.

$\mathrm{Sb}-125$ was identified over the depths from 12-20 feet. The maximum concentration of Sb-125 occurs at a depth of 16 feet, with a reading of $3.4 \mathrm{pCi} / \mathrm{g}$. The Sb-125 MDL value for these log data is $1 \mathrm{pCi} / \mathrm{g}$, for the depth intervals with low Cs-137 concentration. 


\section{Moisture Logging Service \\ Log Header}

Project: $\quad$ PNNL Vadose Zone Monitoring

Well: 299-E13-57

Log Type: $\quad$ Moisture Gauge

Borehole Information

\begin{tabular}{|c|c|c|}
\hline Well \# A5872 & Water Depth n/a & Total Depth $49 \mathrm{ft}$ \\
\hline Elevation Reference n/a & Elevation $\quad \mathrm{n} / \mathrm{a}$ & \\
\hline Depth Reference Top Casing & Casing Stickup 2.1 & \\
\hline Casing Diameter $\underline{8 \quad \text { in }}$ & Depth Interval 0 to $49 \mathrm{ft}$ & Thickness \\
\hline
\end{tabular}

Logging Information

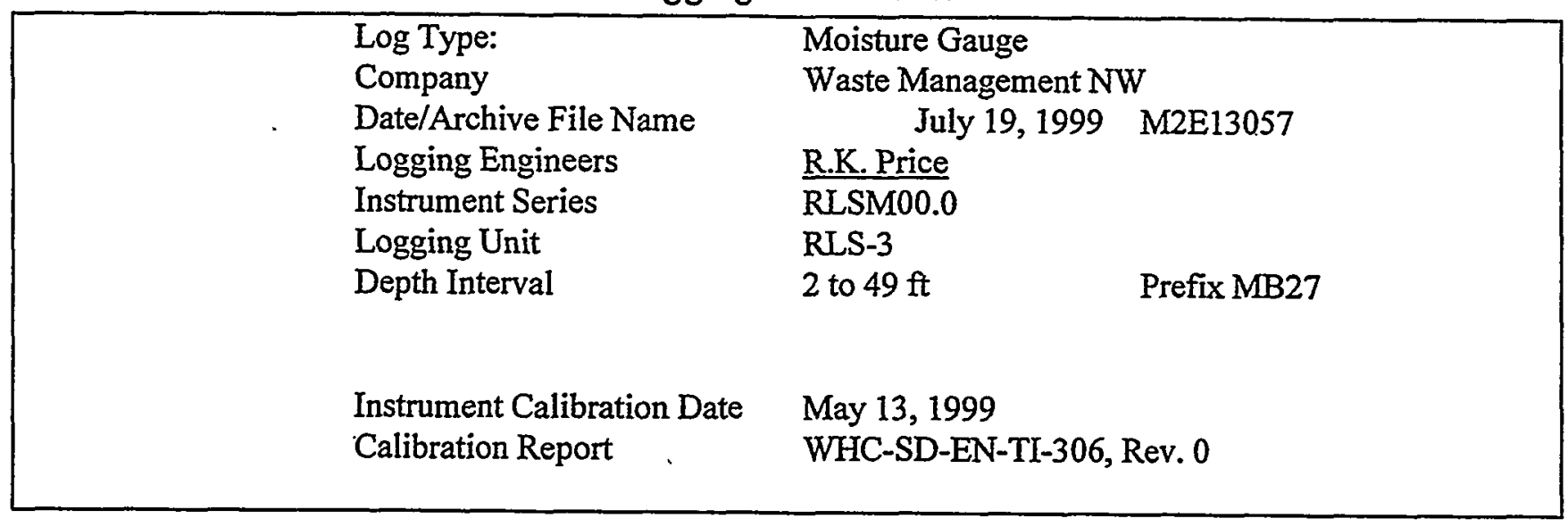

Analysis Information

$\begin{array}{ll}\text { Company } & \text { Three Rivers Scientific } \\ \text { Analyst } & \text { Russ Randall } \\ \text { Date } & \text { July 24, 1999 } \\ \text { Depth Reference } & \text { Ground Surface (plots depth shifted) }\end{array}$

Notes Moisture values range from $4 \%$ to $37 \%$ for the depths logged. The highest observed moisture zone occurs at the depth of 9 feet with a reading of $37 \%$ by volume. 


\section{RLS Moisture Processed Log Data}

\section{Waste Management Federal Services NW}

Project: Vadose Zone Monitoring

Borehole: 299-E13-57
8" Casing Calibration

Log Date July 19, 1999
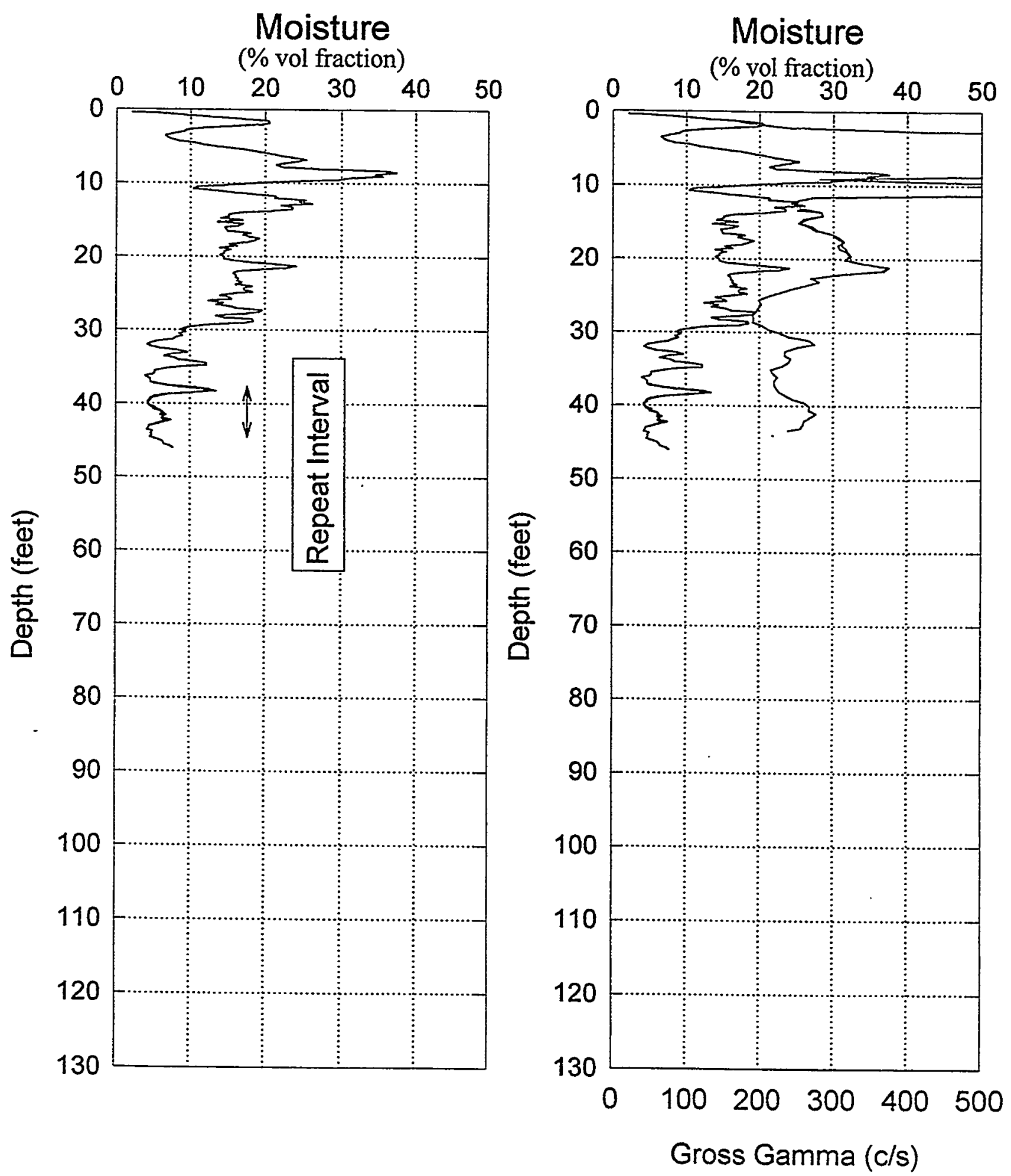

B. 134 


\section{RLS \\ Log Analysis \& Summary}

$\begin{array}{lllr}\text { Project: } & \text { PNNL Vadose Zone Monitoring } & \text { Well ID: } & \text { 299-E13-57 } \\ \text { Log Type: } & \text { Moisture Gauge } & \text { Log Date: } & \text { July 19, 1999 }\end{array}$

\section{General Notes:}

The low reading from 0 feet to 2 feet is due to surface effects and not necessarily the moisture content of the sediments surrounding the borehole.

Log data collected with a depth reference of top of casing, and during analysis the depths were shifted to ground surface reference for all plots.

System Performance Verify: The pre- and post-log verification passed performance standards, $-0.3 \%$ in the shield verify.

Repeat Interval: Based on the repeat interval from 38 to 45 feet, the logging system performed according to specifications.

Environmental Corrections: The moisture levels have been corrected for casing attenuation (entire well).

\section{Observations:}

The moisture levels show values ranging from $4 \%$ to $37 \%$ for the depth interval from 2 feet to 46 feet. The highest moisture occurs at a depth of 9 feet, with a reading of $37 \%$ by volume. 


\section{RLS Spectral Gamma Ray Borehole Survey \\ Waste Management Federal Services NW}

\section{Log Header}

Project: PNNL Vadose Zone Monitoring . Well: 299-E13-58

Log Type: $\quad$ HPGe Spectral Gamma Ray

Borehole Information

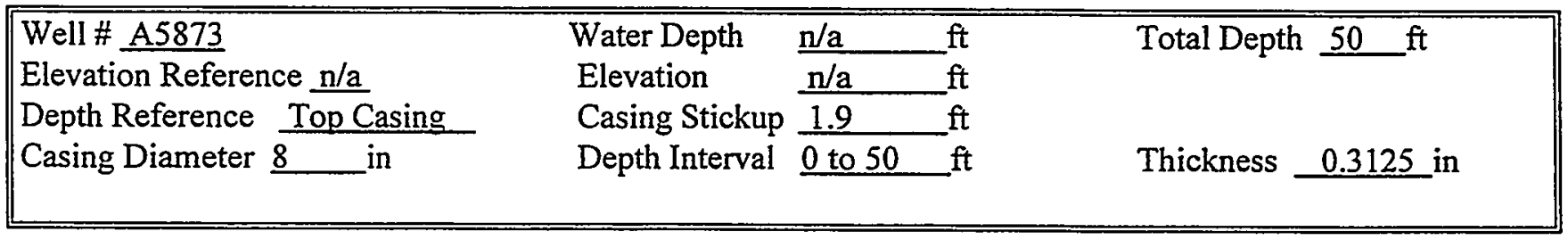

Logging Information

Log Type:

Company

Date/Archive File Name

Logging Engineers

Instrument Series

Logging Unit

Depth Interval

Instrument Calibration Date

Calibration Report
$35 \%$ HPGe Spectral Gamma Ray

Waste Management NW

S. Kos

July 20, 1999 H2E13058

RLSG035N00L00.0

RLS-1

2 to $49 \mathrm{ft} \quad$ Prefix AP18

Jan 19, 1999

WHC-SD-EN-TI-292

Analysis Information

$\begin{array}{ll}\text { Company } & \text { Three Rivers Scientific } \\ \text { Analyst } & \text { Russ Randall } \\ \text { Date } & \text { July 27, 1999 } \\ \text { Depth Reference } & \text { Ground Surface (plots depth shifted) }\end{array}$

Notes Cs-137 and Co-60 are the only man made radionuclides detected. 


\section{RLS Spectral Gamma Ray Borehole Survey Waste Management Federal Services NW}

Project: PNNL Vadose Zone Monitoring' Log Date: · July 20, 1999 Borehole: 299-E13-58

Naturally Occurring Radionuclides

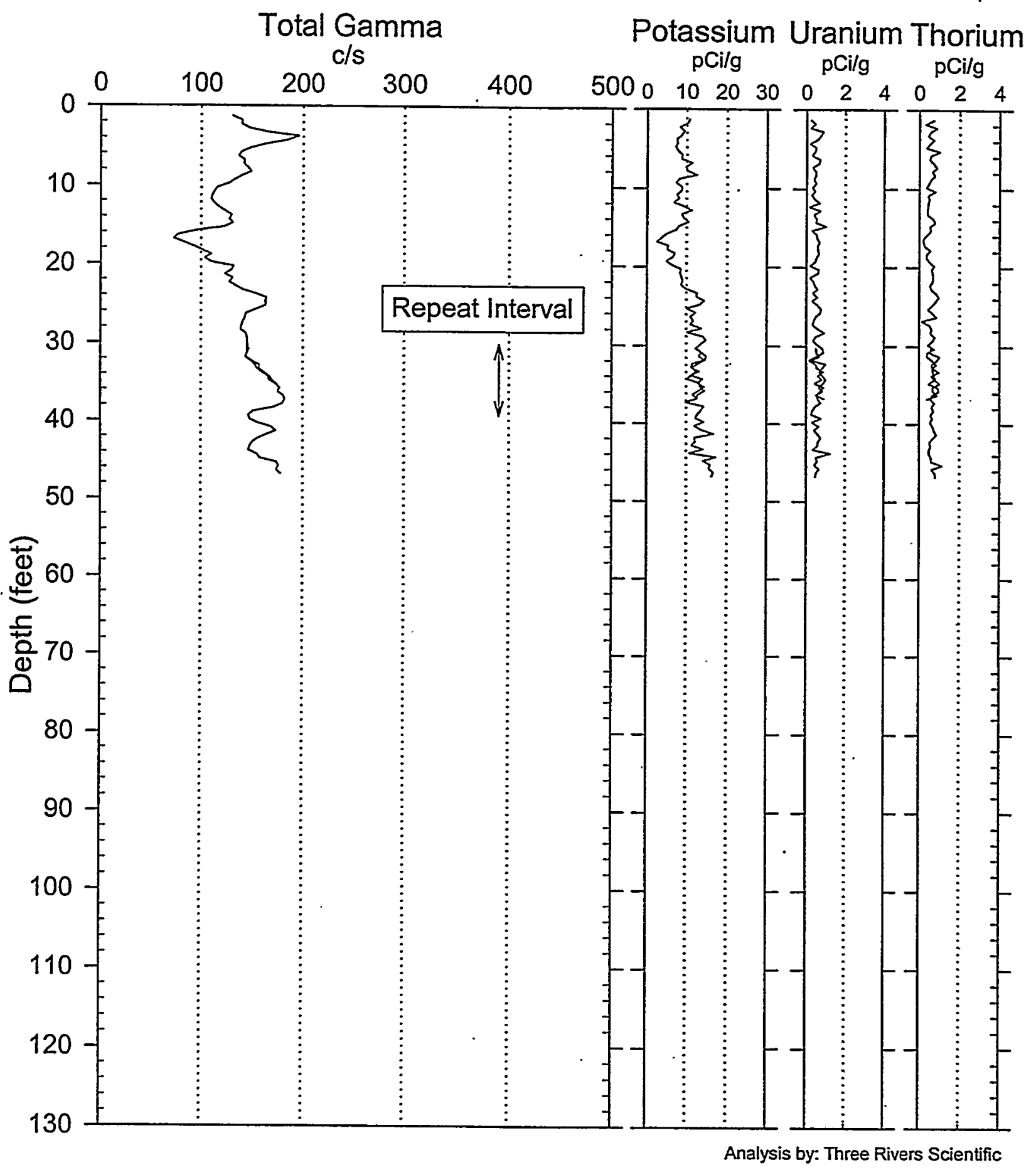




\section{RLS Spectral Gamma-Ray Borehole Survey Waste Management Federal Services NW}

Project: PNNL Vadose Zone Monitoring Log Date: July 20, 1999 Borehole: 299-E13-58

Man-Made Radionuclides

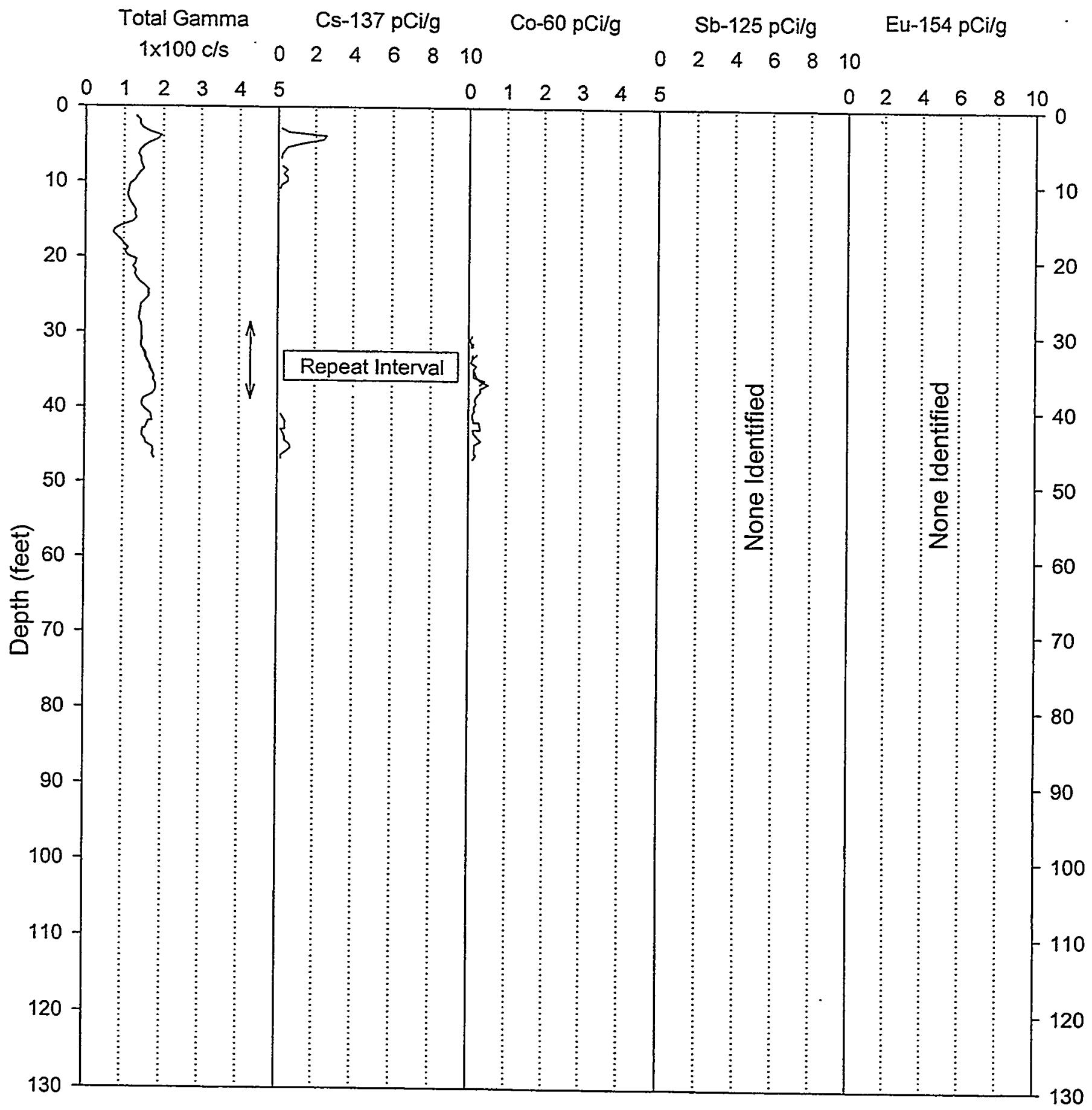




\section{RLS Spectral Gamma Ray Borehole Survey Acceptance QA.Processing}

Project: PNNL Vadose Zone Monitoring Borehole: 299-E13-58
Log Date: July 20, 1999

Compare Main Log \& Repeat

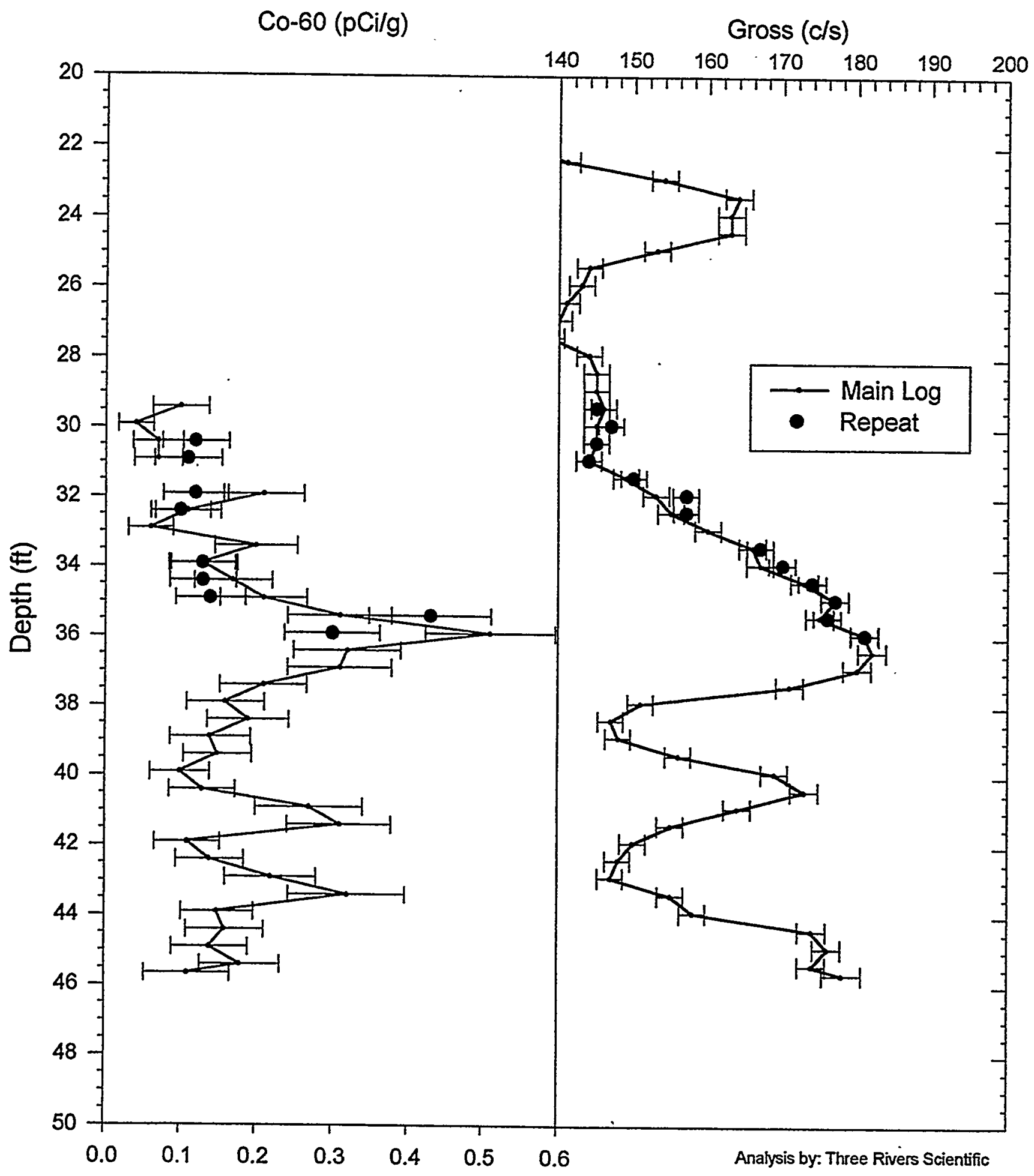




\section{RLS Spectral Gamma Ray Borehole Survey \\ Waste Management Federal Services NW}

\section{Log Analysis Summary Report}

$\begin{array}{lllr}\text { Project: } & \text { PNNL Vadose Zone Monitoring } & \text { Well: } & \text { 299-E13-58 } \\ \text { Log Type: } & \text { HPGe Spectral Gamma Ray } & \text { Log Date: } & \text { July 20, 1999 }\end{array}$

\section{General Notes:}

Total gamma is mostly a response to contaminants and cannot be used for lithologic information.

Log data collected with a depth reference of top of casing, and during analysis the depths were shifted to ground surface reference for all plots.

System Performance Verify: The pre- and post-log verification passed performance standards.

Repeat Interval: Based on the repeat interval, the logging system performed as per specifications, refer to repeat plot. The error bars are calculated for 1 standard deviation of the net photo peak count rate statistical variance. Thus, the repeat should fall within these error bars $67 \%$ of the time.

Environmental Corrections: All radionuclide concentrations have been corrected for casing attenuation (entire well). Water level is below depths logged. No casing correction was applied to the total gamma due to Compton downscatter interference.

\section{Radionuclides:}

Cs-137 was identified over the depths from 2-10 feet, and from 40-45 feet. The maximum concentration of Cs-137 occurs at a depth of 4 feet, with a reading of $2.6 \mathrm{pCi} / \mathrm{g}$. The $\mathrm{Cs}-137 \mathrm{MDL}$ value for these log data is $0.2 \mathrm{pCi} / \mathrm{g}$.

Co-60 was identified over the depths from $30-45$ feet. The maximum concentration of Co-60 occurs at a depth of 37 feet, with a reading of $0.5 \mathrm{pCi} / \mathrm{g}$. The Co-60 MDL value for these $\log$ data is $0.15 \mathrm{pCi} / \mathrm{g}$. 


\section{Moisture Logging Service \\ Log Header}

Project: $\quad$ PNNL Vadose Zone Monitoring

Well: 299-E13-58

Log Type: $\quad$ Moisture Gauge

Borehole Information

\begin{tabular}{|c|c|c|c|}
\hline Well \# A5873 & Water Depth & $\underline{n} / \mathrm{a}$ & Total Depth $\underline{50 \mathrm{ft}}$ \\
\hline Elevation Reference n/a & Elevation & $n / a$ & \\
\hline Depth Reference Top Casing & Casing Stickup & 1.9 & \\
\hline Casing Diameter $\underline{8}$ in & Depth Interval & 0 to 50 & Thickness \\
\hline
\end{tabular}

Logging Information

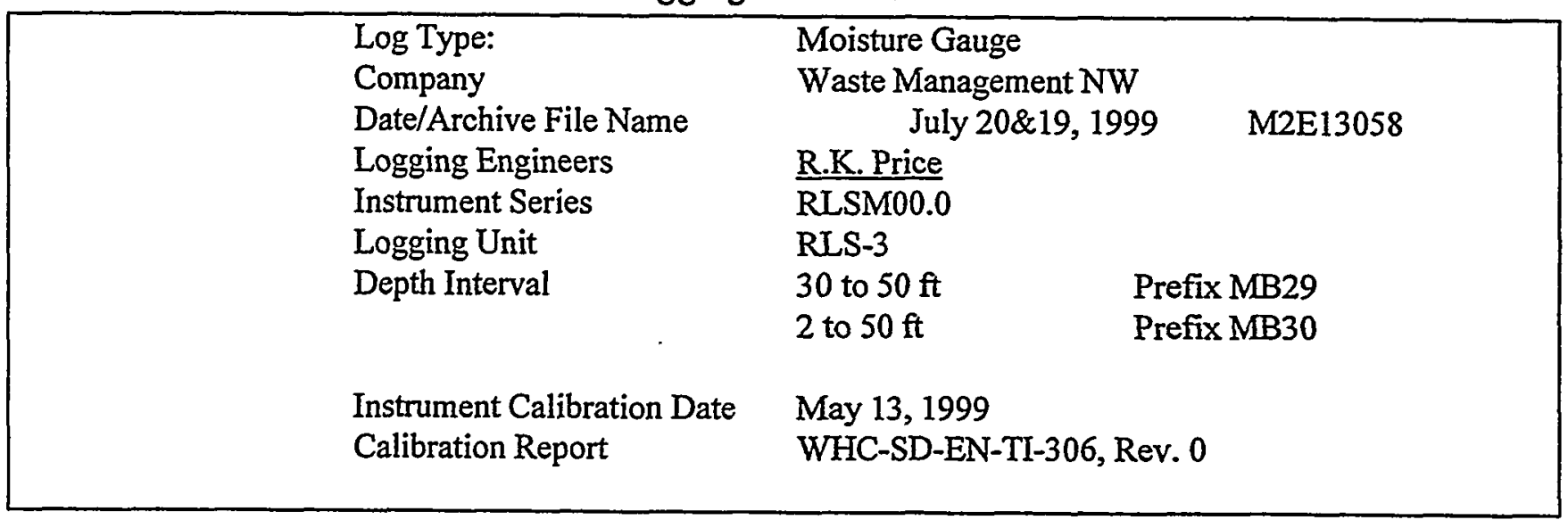

Analysis Information

$\begin{array}{ll}\text { Company } & \text { Three Rivers Scientific } \\ \text { Analyst } & \text { Russ Randall } \\ \text { Date } & \text { July 24, 1999 } \\ \text { Depth Reference } & \text { Ground Surface (plots depth shifted) }\end{array}$

Notes Moisture values range from $3 \%$ to $32 \%$ for the depths logged. The highest observed moisture zone occurs at the depth of 5 feet with a reading of $32 \%$ by volume. 


\section{RLS Moisture Processed Log Data}

\section{Waste Management Federal Services NW}

Project: Vadose Zone Monitoring Borehole: 299-E13-58
8" Casing Calibration

Log Date July 19\&20, 1999
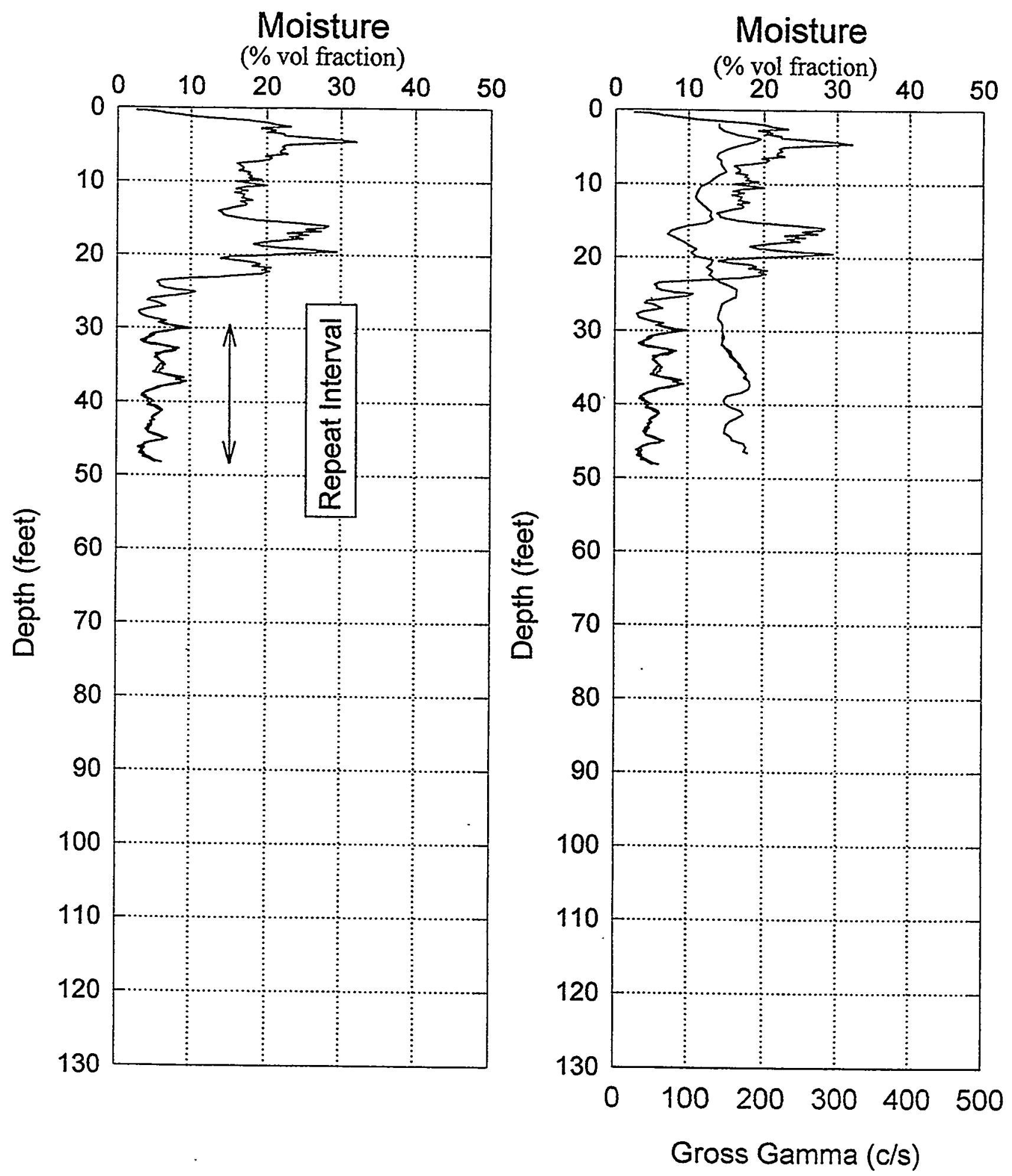

B.142 


\section{RLS \\ Log Analysis \& Summary}

Project: $\quad$ PNNL Vadose Zone Monitoring

Well ID:

299-E13-58

Log Type: Moisture Gauge

Log Date: July 19\&20, 1999

\section{General Notes:}

The low reading from 2 feet to 4 feet is due to surface effects and not necessarily the moisture content of the sediments surrounding the borehole.

Log data collected with a depth reference of top of casing, and during analysis the depths were shifted to ground surface reference for all plots.

System Performance Verify: The pre- and post-log verification passed performance standards, $+2.6 \%$ and $+1.1 \%$ in the shield verify.

Repeat Interval: Based on the repeat interval from 29 to 48 feet, the logging system performed according to specifications.

Environmental Corrections: The moisture levels have been corrected for casing attenuation (entire well).

\section{Observations:}

The moisture levels show values ranging from $3 \%$ to $32 \%$ for the depth interval from 2 feet to 48 feet. The highest moisture interval is in a thin zone at 5 feet, with a maximum reading of $32 \%$ by volume. From 24 feet to bottom of well ( 48 feet) the moisture readings are $3 \%$ to $10 \%$ by volume. 


\section{RLS Spectral Gamma Ray Borehole Survey \\ Waste Management Federal Services NW}

\section{Log Header}

Project: PNNL Vadose Zone Monitoring Well: 299-E13-59

Log Type: $\quad$ HPGe Spectral Gamma Ray

Borehole Information

\begin{tabular}{|c|c|c|}
\hline Well \# A5874 & Water Depth $\quad \mathrm{n} / \mathrm{a} \quad \mathrm{ft}$ & Total Depth $50 \mathrm{ft}$ \\
\hline Elevation Reference $\mathrm{n} / \mathrm{a}$ & Elevation $\quad \mathrm{n} / \mathrm{a}$ & \\
\hline Depth Reference Top Casing & Casing Stickup $2.1 \quad \mathrm{ft}$ & \\
\hline Casing Diameter $\underline{8}$ in & Depth Interval 0 to $50 \mathrm{ft}$ & Thickness \\
\hline
\end{tabular}

Logging Information

Log Type:

Company

Date/Archive File Name

Logging Engineers

Instrument Series

Logging Unit

Depth Interval

Instrument Calibration Date

Calibration Report
35\% HPGe Spectral Gamma Ray

Waste Management NW

S.Kos

RLSG35N00L00.0

RLS-1

3 to $47 \mathrm{ft}$

Prefix AP19

Jan 19, 1999
WHC-SD-EN-TI-292

Analysis Information

$\begin{array}{ll}\text { Company } & \text { Three Rivers Scientific } \\ \text { Analyst } & \text { Russ Randall } \\ \text { Date } & \text { July 27, 1999 } \\ \text { Depth Reference } & \text { Ground Surface (plots depth shifted) }\end{array}$

Notes $\mathrm{Cs}-137, \mathrm{Co}-60$, and $\mathrm{Sb}-125$ are the only man made radionuclides detected. 


\section{RLS Spectral Gamma Ray Borehole Survey \\ Waste Management Federal Services NW}

Project: PNNL Vadose Zone Monitoring Log Date: July 20, 1999 Borehole: 299-E13-59

Naturally Occurring Radionuclides

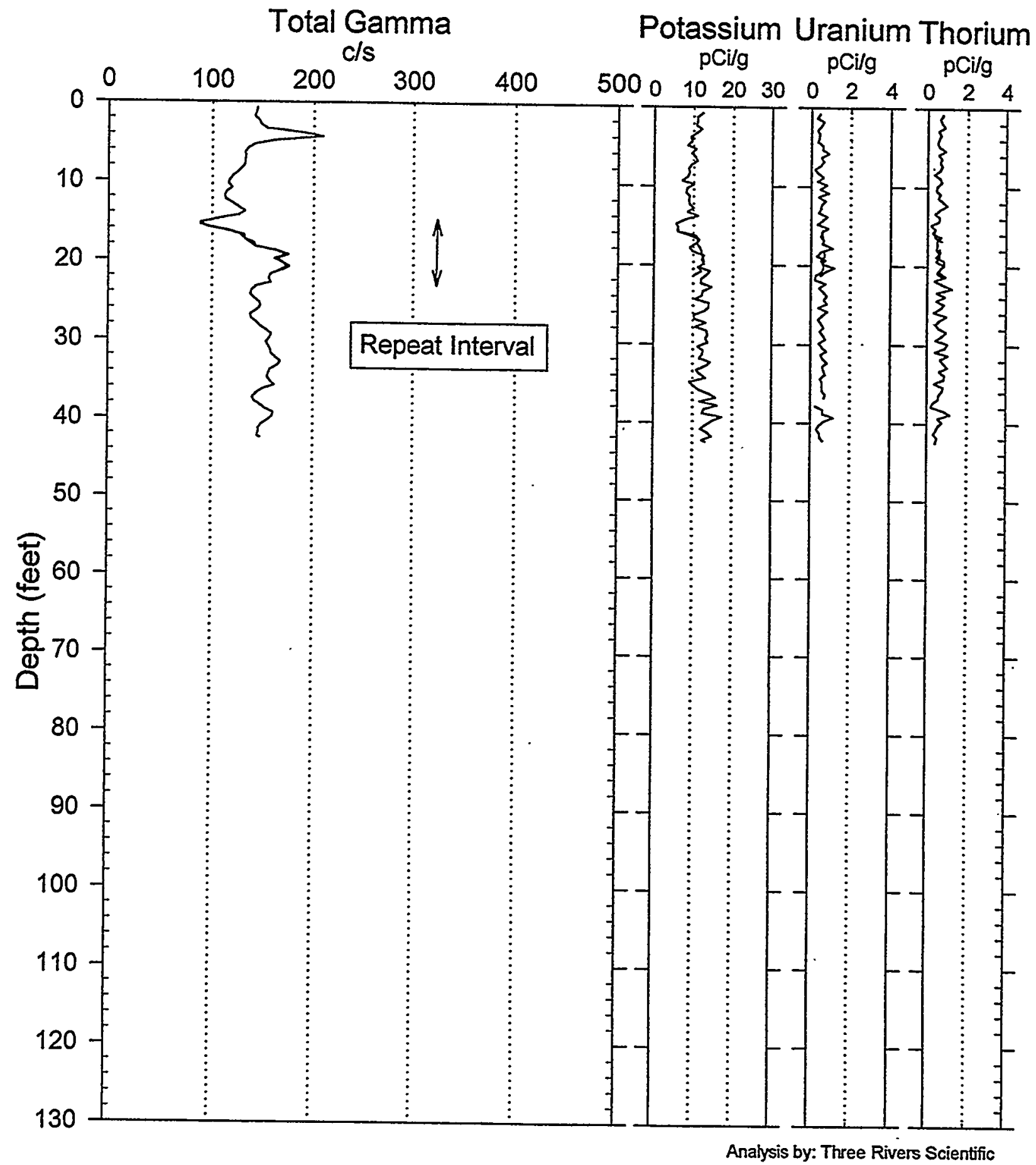




\section{RLS Spectral Gamma-Ray Borehole Survey Waste Management Federal Services NW}

Project: PNNL Vadose Zone Monitoring Log Date: July 20, 1999 Borehole: 299-E13-59

Man-Made Radionuclides

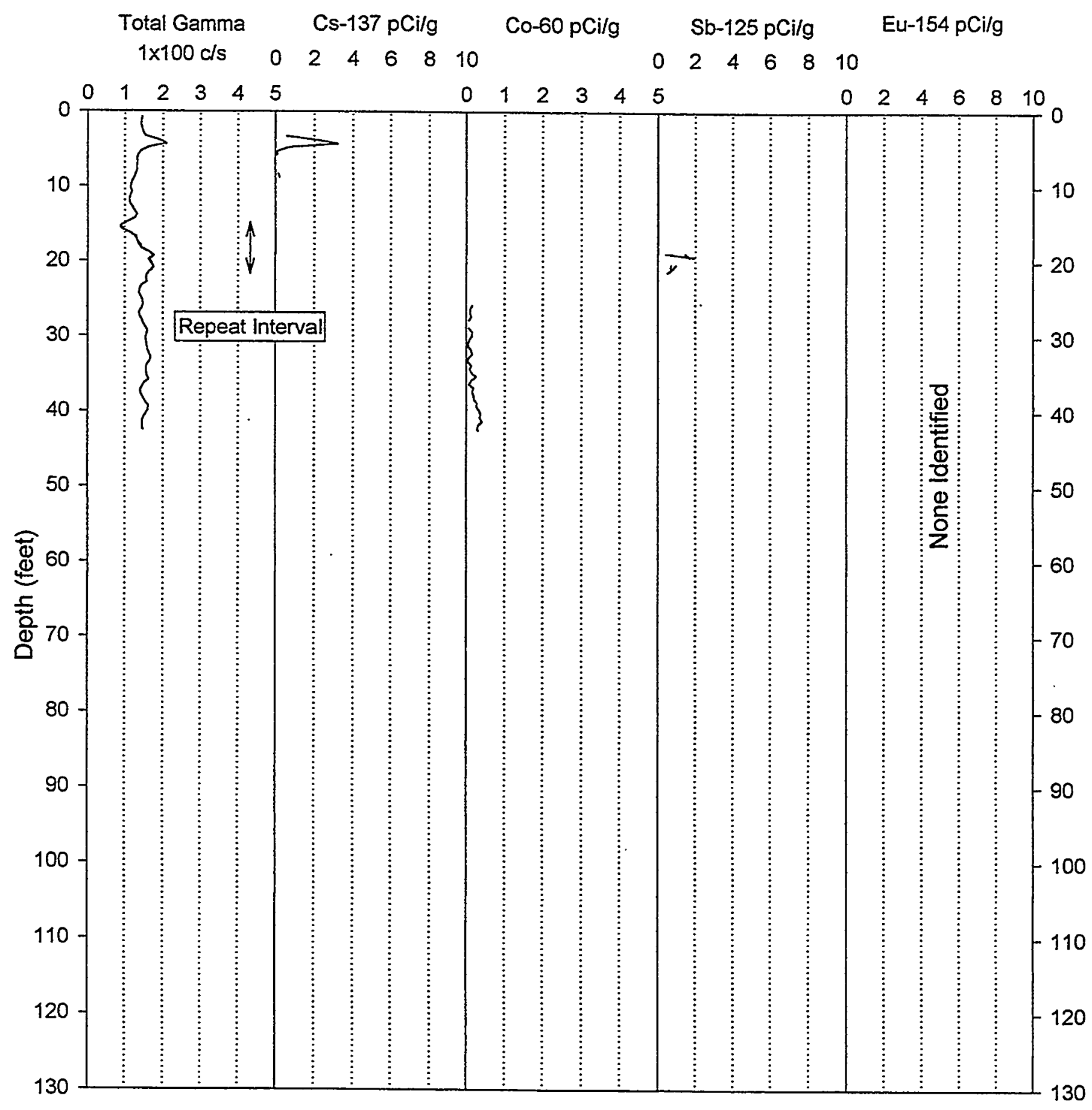

Analysis by: Three Rivers Scientific 


\section{RLS Spectral Gamma Ray Borehole Survey Acceptance QA Processing}

Project: PNNL Vadose Zone Monitoring Borehole: 299-E13-59
Log Date: July 20, 1999 Compare Main Log \& Repeat

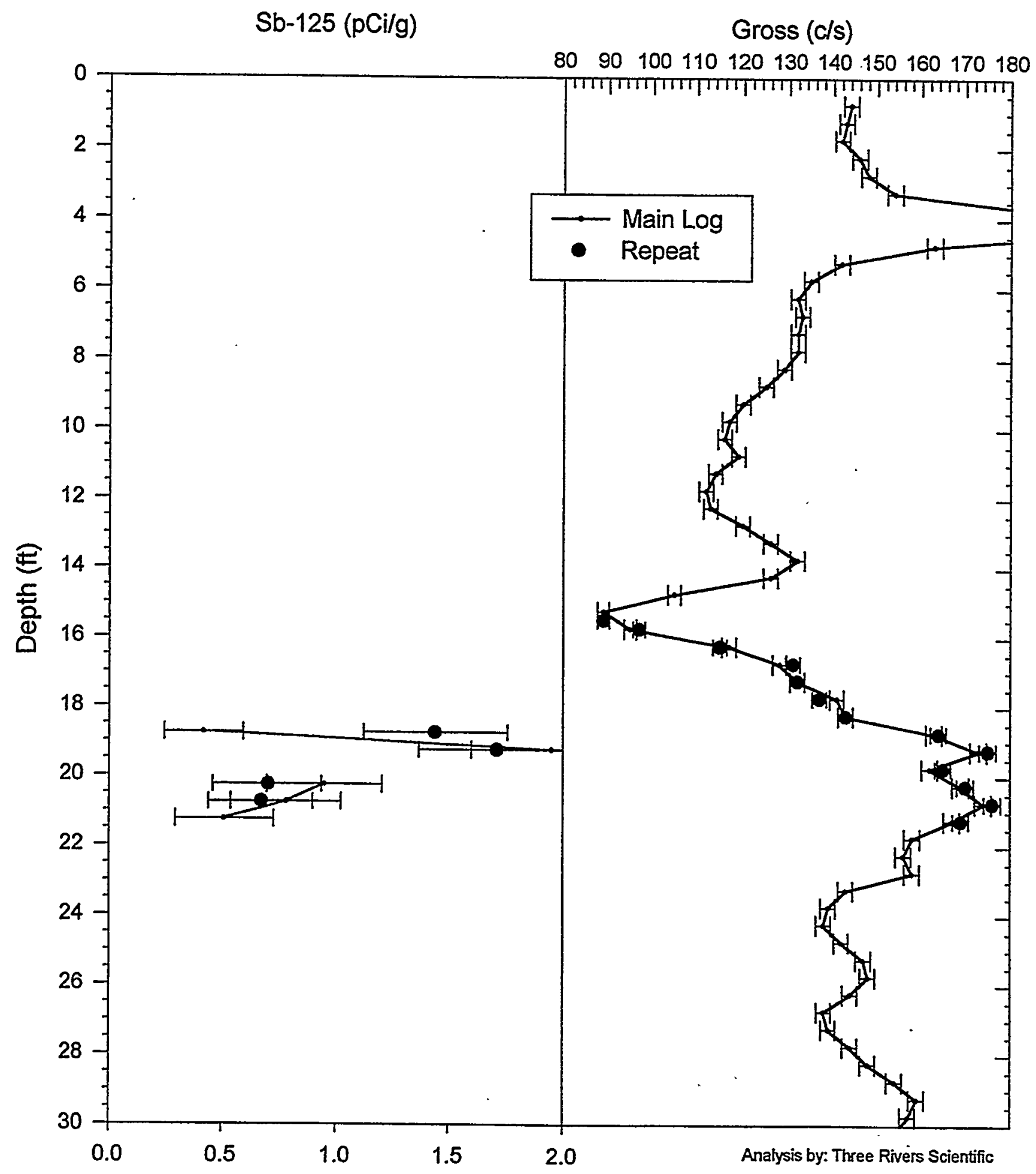




\section{RLS Spectral Gamma Ray Borehole Survey \\ Waste Management Federal Services NW}

\section{Log Analysis Summary Report}

$\begin{array}{lllr}\text { Project: } & \text { PNNL Vadose Zone Monitoring } & \text { Well: } & \text { 299-E13-59 } \\ \text { Log Type: } & \text { HPGe Spectral Gamma Ray } & \text { Log Date: } & \text { July 20, 1999 }\end{array}$

\section{General Notes:}

Total gamma is mostly a response to contaminants and no lithologic information can be obtained from the gross gamma.

Log data collected with a depth reference of top of casing, and during analysis the depths were shifted to ground surface reference for all plots.

System Performance Verify: The pre- and post-log verification passed performance standards.

Repeat Interval: Based on the repeat interval, the logging system performed as per specifications, refer to repeat plot. The error bars are calculated for 1 standard deviation of the net photo peak count rate statistical variance. Thus, the repeat should fall within these error bars $67 \%$ of the time.

Environmental Corrections: All radionuclide concentrations have been corrected for casing attenuation (entire well). Water level is below depths logged. No casing correction was applied to the total gamma due to Compton downscatter interference.

\section{Radionuclides:}

Cs-137 was identified over the depths from 4-9 feet. The maximum concentration of Cs-137 occurs at a depth of 5 feet, with a reading of $3.2 \mathrm{pCi} / \mathrm{g}$. The Cs- $137 \mathrm{MDL}$ value for these $\log$ data is $0.2 \mathrm{pCi} / \mathrm{g}$.

Co-60 was identified over the depths from 26-42 feet. The maximum concentration of Co-60 occurs at a depth of 41 feet, with a reading of $0.4 \mathrm{pCi} / \mathrm{g}$. The Co- $60 \mathrm{MDL}$ value for these log data is $0.15 \mathrm{pCi} / \mathrm{g}$.

Sb-125 was identified over the depth from 19-22 feet. This Sb-125 level of detection is near threshold, but confirmed using a summing by 4 technique. The maximum concentration of Sb-125 occurs at a depth of 20 feet, with a reading of $1.7 \mathrm{pCi} / \mathrm{g}$. The $\mathrm{Sb}-125 \mathrm{MDL}$ value for these $\log$ data is $0.7 \mathrm{pCi} / \mathrm{g}$. 


\section{Moisture Logging Service Log Header}

Project: $\quad$ PNNL Vadose Zone Monitoring

Well: 299-E13-59

Log Type: Moisture Gauge

Borehole Information

\begin{tabular}{|c|c|c|}
\hline Well \# & Water Depth $\mathrm{n} / \mathrm{a} \quad \mathrm{ft}$ & Total Depth $\underline{50}$ \\
\hline Elevation Reference $\mathrm{n} / \mathrm{a}$ & Elevation $\quad \mathrm{n} / \mathrm{a}$ & \\
\hline Depth Reference Top Casing & Casing Stickup $\underline{2.1 \quad \mathrm{ft}}$ & \\
\hline Casing Diameter $\underline{8}$ in & Depth Interval 0 to $50 \mathrm{ft}$ & Thickness \\
\hline
\end{tabular}

\section{Logging Information}

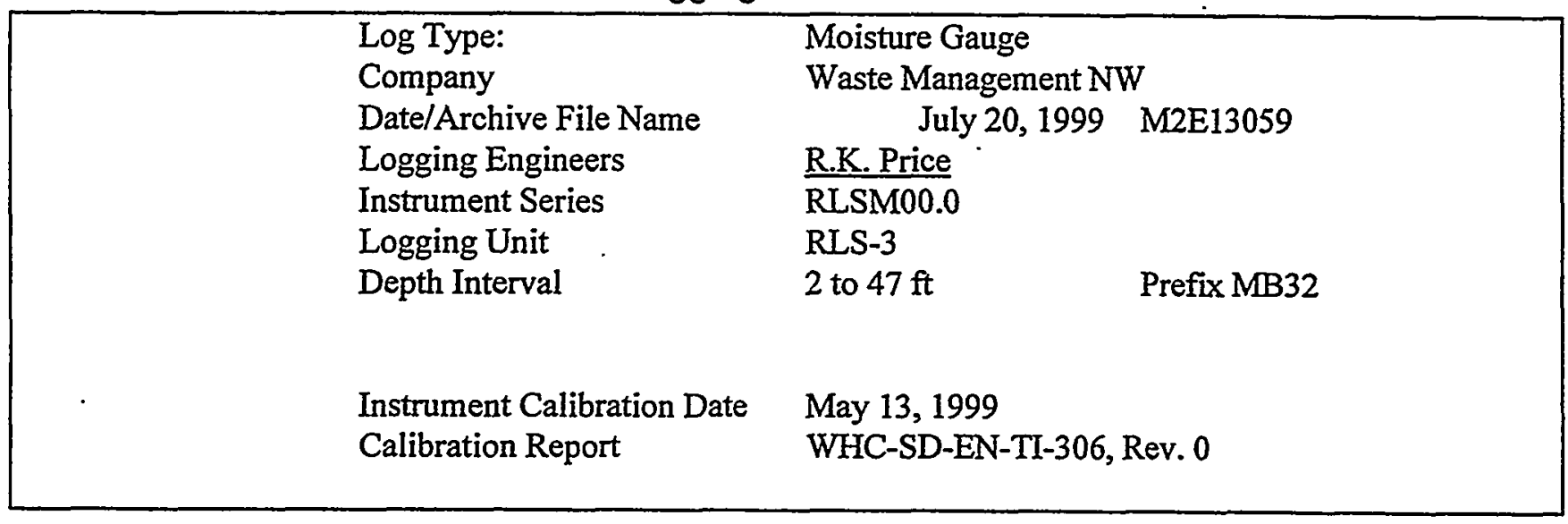

Analysis Information

$\begin{array}{ll}\text { Company } & \text { Three Rivers Scientific } \\ \text { Analyst } & \text { Russ Randall } \\ \text { Date } & \text { July 24, 1999 } \\ \text { Depth Reference } & \text { Ground Surface (plots depth shifted) }\end{array}$

Notes Moisture values range from $3 \%$ to $27 \%$ for the depths logged. The highest observed moisture zone occurs at the depth of 16 feet with a reading of $27 \%$ by volume. 


\section{RLS Moisture Processed Log Data}

\section{Waste Management Federal Services NW}

Project: Vadose Zone Monitoring 8" Casing Calibration Borehole: 299-E13-59

Log Date July 20, 1999
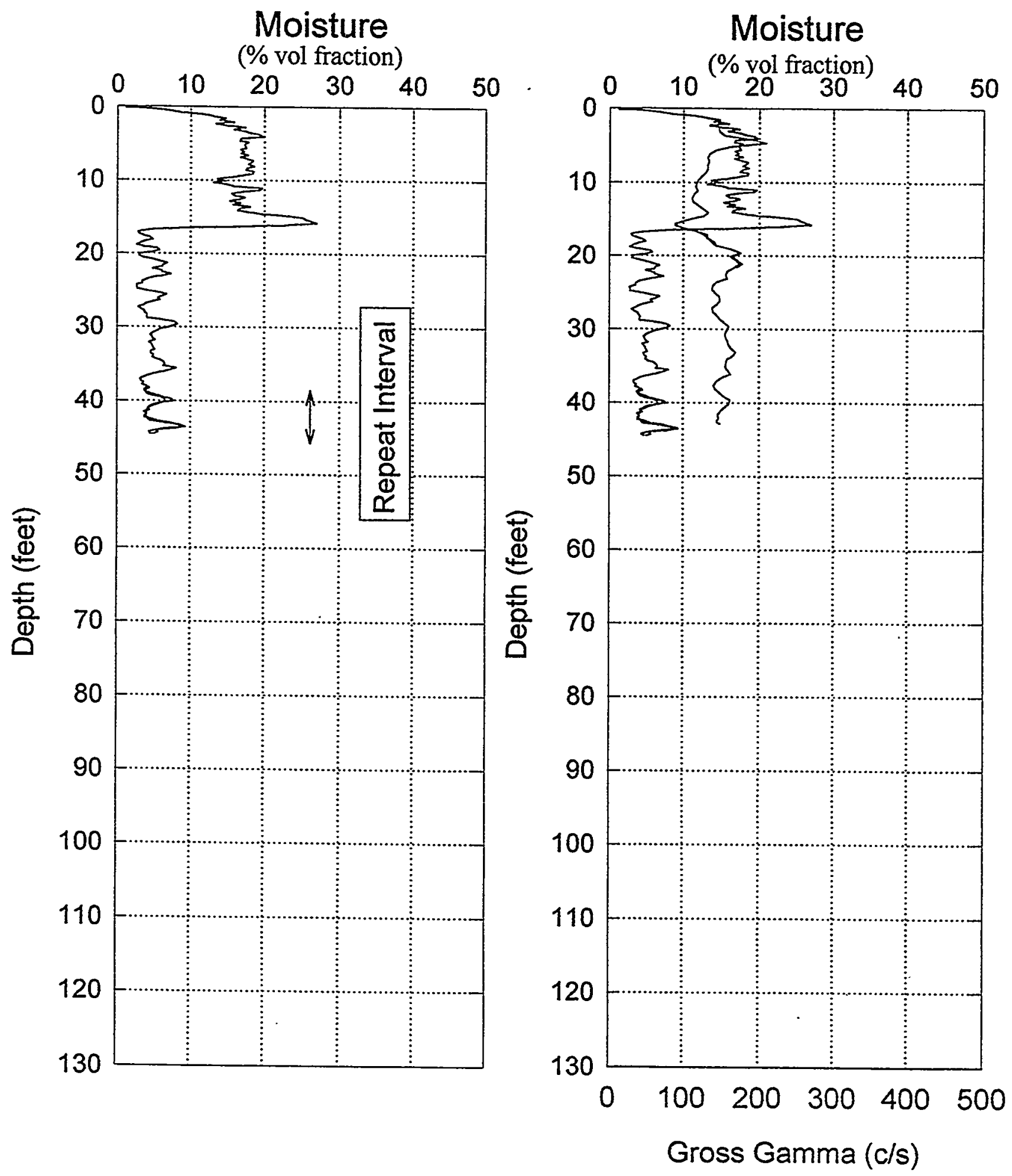

B. 150 


\section{RLS \\ Log Analysis \& Summary}

$\begin{array}{lllr}\text { Project: } & \text { PNNL Vadose Zone Monitoring } & \text { Well ID: } & \text { 299-E13-59 } \\ \text { Log Type: } & \text { Moisture Gauge } & \text { Log Date: } & \text { July 20, } 1999\end{array}$

\section{General Notes:}

The low reading from 0 feet to 0 feet is due to surface effects and not necessarily the moisture content of the sediments surrounding the borehole.

Log data collected with a depth reference of top of casing, and during analysis the depths were shifted to ground surface reference for all plots.

System Performance Verify: The pre- and post-log verification passed performance standards, $-1.4 \%$ in the shield verify.

Repeat Interval: Based on the repeat interval from 38 to 46 feet, the logging system performed according to specifications.

Environmental Corrections: The moisture levels have been corrected for casing attenuation (entire well).

\section{Observations:}

The moisture levels show values ranging from $3 \%$ to $27 \%$ for the depth interval from 2 feet to 45 feet. The highest moisture occurs at a depth of 16 feet, with a reading of $27 \%$ by volume. 


\section{RLS Spectral Gamma Ray Borehole Survey Waste Management Federal Services NW}

\section{Log Header}

Project: PNNL Vadose Zone Monitoring

Well: 299-E13-60

Log Type: HPGe Spectral Gamma Ray

Borehole Information

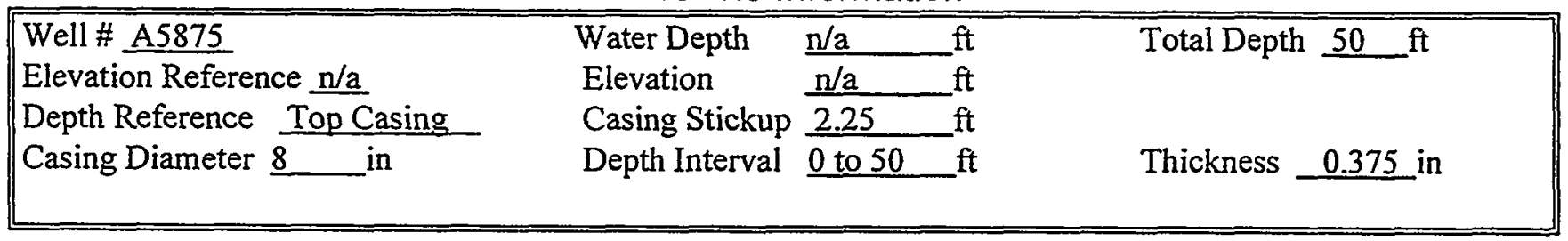

Logging Information

\begin{tabular}{|lll|}
\hline $\begin{array}{l}\text { Log Type: } \\
\text { Company } \\
\text { Date/Archive File Name } \\
\text { Logging Engineers }\end{array}$ & $\begin{array}{l}\text { 35\% HPGe Spectral Gamma Ray } \\
\text { Waste Management NW } \\
\text { July 21, 1999 H2E13060 } \\
\text { Instrument Series }\end{array}$ & $\begin{array}{ll}\text { A. Pearson } \\
\text { RLSG035N00L00.0 }\end{array}$ \\
$\begin{array}{l}\text { Loging Unit } \\
\text { Depth Interval }\end{array}$ & $\begin{array}{l}\text { RLS-2 } \\
\text { to 48 ft }\end{array}$ & Prefix B237 \\
& & \\
& & \\
Instrument Calibration Date & Jan 19, 1999 & \\
Calibration Report & WHC-SD-EN-TI-292 & \\
\hline
\end{tabular}

Analysis Information

\begin{tabular}{|c|c|c|}
\hline & $\begin{array}{l}\text { Company } \\
\text { Analyst } \\
\text { Date } \\
\text { Depth Reference }\end{array}$ & $\begin{array}{l}\text { Three Rivers Scientific } \\
\text { Russ Randall } \\
\text { July 26, } 1999 \\
\text { Ground Surface (plots depth shifted) }\end{array}$ \\
\hline Notes & \multicolumn{2}{|c|}{$\begin{array}{l}\text { Cs-137. Co-60, and } \mathrm{Sb}-125 \text { are the only man made radionuclides detected. Detection of Sb-125 } \\
\text { required a summing technique since the levels are near detection threshold. }\end{array}$} \\
\hline
\end{tabular}




\section{RLS Spectral Gamma Ray Borehole Survey \\ Waste Management Federal Services NW}

Project: PNNL Vadose Zone Monitoring Log Date: July 21, 1999 Borehole: 299-E13-60

Naturally Occurring Radionuclides

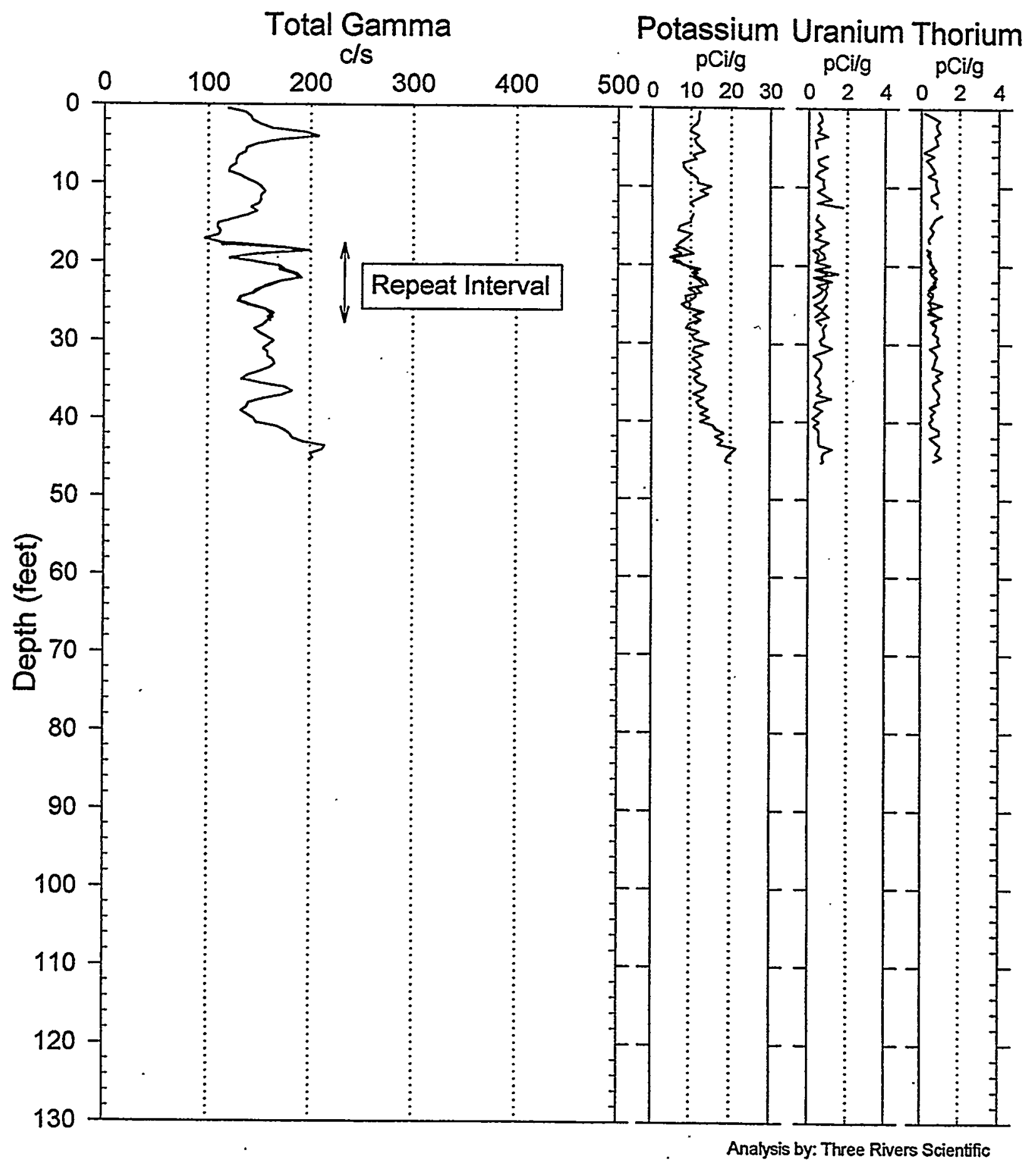




\section{RLS Spectral Gamma-Ray Borehole Survey Waste Management Federal Services NW}

Project: PNNL Vadose Zone Monitoring Log Date: July 21, 1999 Borehole: 299-E13-60 Man-Made Radionuclides

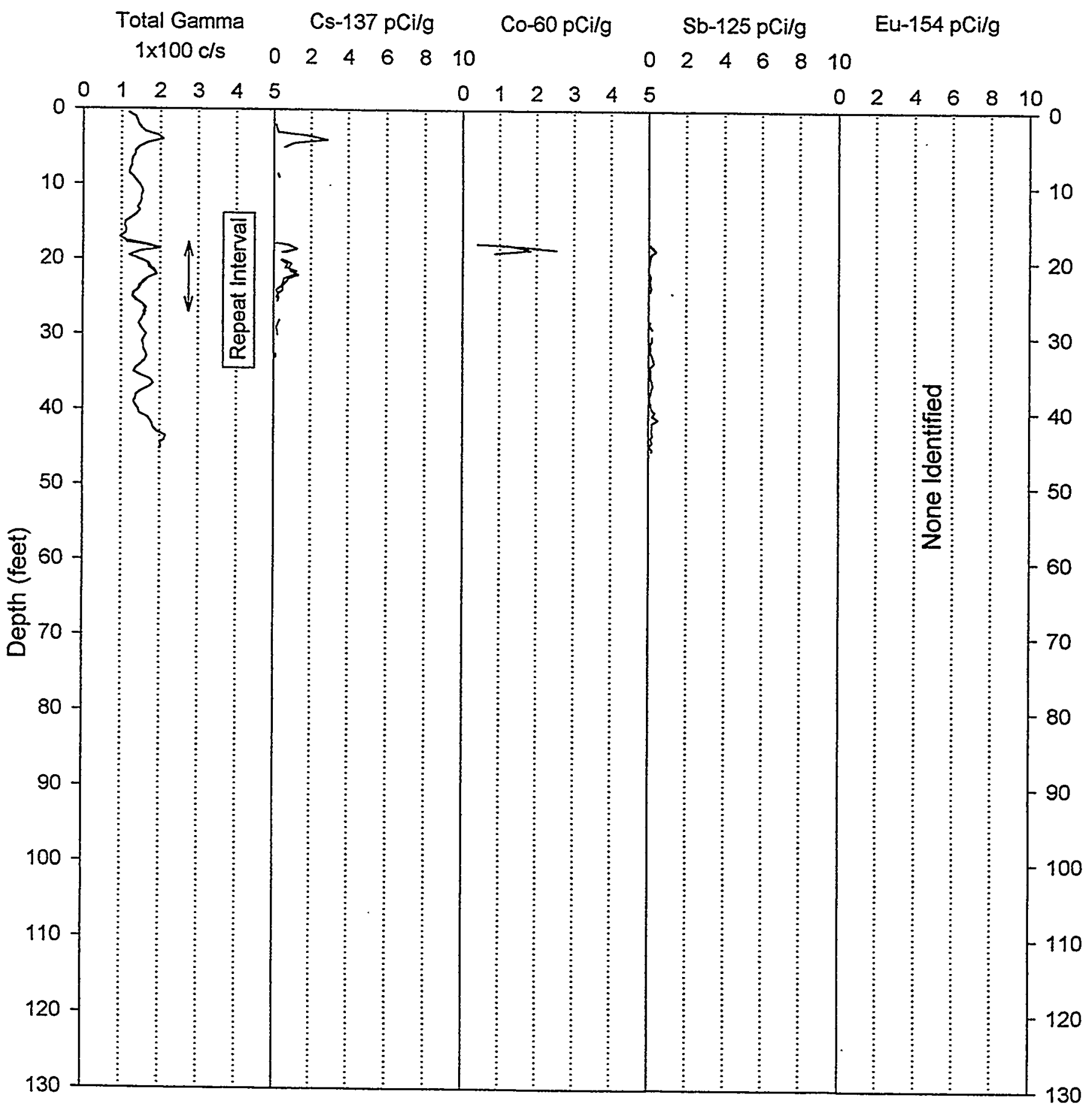




\section{RLS Spectral Gamma Ray Borehole Survey Acceptance QA Processing}

Project: PNNL Vadose Zone Monitoring Borehole: 299-E13-60
Log Date: July 21, 1999

Compare Main Log \& Repeat

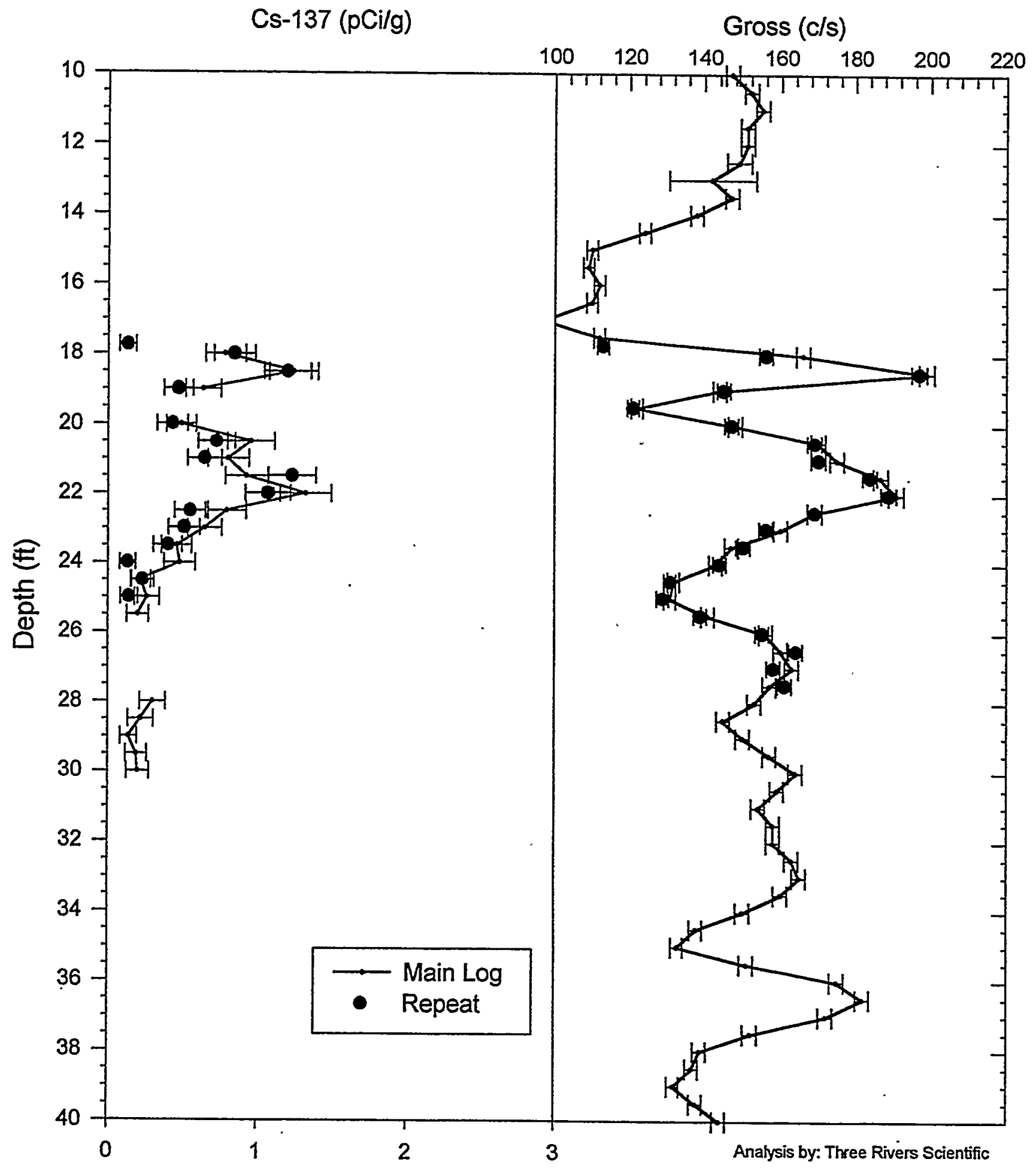




\section{RLS Spectral Gamma Ray Borehole Survey \\ Waste Management Federal Services NW}

\section{Log Analysis Summary Report}

$\begin{array}{ll}\text { Project: } & \text { PNNL Vadose Zone Monitoring } \\ \text { Log Type: } & \text { HPGe Spectral Gamma Ray }\end{array}$
Well:

299-E13-60

Log Date: July 21,1999

\section{General Notes:}

Total gamma is mostly a response to man-made radionuclides, and no lithologic information is possible with only the gross gamma response.

Log data collected with a depth reference of top of casing, and during analysis the depths were shifted to ground surface reference for all plots.

System Performance Verify: The pre- and post-log verification passed performance standards.

Repeat Interval: Based on the repeat interval, the logging system performed as per specifications, refer to repeat plot. The error bars are calculated for 1 standard deviation of the net photo peak count rate statistical variance. Thus, the repeat should fall within these error bars $67 \%$ of the time.

Environmental Corrections: All radionuclide concentrations have been corrected for casing attenuation (entire well). Water level is below depths logged. No casing correction was applied to the total gamma due to Compton downscatter interference.

\section{Radionuclides:}

Cs-137 was identified over the depths from 3-5 feet, and from 18-32 feet. The maximum concentration of Cs-137 occurs at a depth of 4 feet, with a reading of $3 \mathrm{pCi} / \mathrm{g}$. The Cs-137 MDL value for these log data is $0.2 \mathrm{pCi} / \mathrm{g}$.

Co-60 was identified over the depths from 18-20 feet. The maximum concentration of $\mathrm{Co}-60$ occurs at a depth of 19 feet, with a reading of $2.5 \mathrm{pCi} / \mathrm{g}$. The Co-60 MDL value for these log data is $0.15 \mathrm{pCi} / \mathrm{g}$.

Sb-125 was identified over the depths from 18-45 feet. This Sb-125 level of detection is near threshold, but confirmed using a summing by 4 technique. The maximum concentration of $\mathrm{Sb}-125$ occurs at a depth of 41 feet, with a reading of $0.5 \mathrm{pCi} / \mathrm{g}$. The $\mathrm{Sb}-125 \mathrm{MDL}$ value for these $\log$ data is $0.2 \mathrm{pCi} / \mathrm{g}$. 


\section{Moisture Logging Service \\ Log Header}

Project: $\quad$ PNNL Vadose Zone Monitoring

Well: 299-E13-60

Log Type: Moisture Gauge

Borehole Information

\begin{tabular}{|c|c|c|}
\hline Well \# A5875 & Water Depth $\mathrm{n} / \mathrm{a} \quad \mathrm{ft}$ & Total Depth $50 \mathrm{ft}$ \\
\hline Elevation Reference n/a & Elevation $\quad \mathrm{n} / \mathrm{a}$ & \\
\hline Depth Reference Top Casing & Casing Stickup 2.25 & \\
\hline Casing Diameter $\underline{8}$ in & Depth Interval 0 to $50 \mathrm{ft}$ & Thickness .375 in \\
\hline
\end{tabular}

Logging Information .

Log Type:
Company
Date/Archive File Name
Logging Engineers
Instrument Series
Logging Unit
Depth Interval

Instrument Calibration Date
Calibration Report

Log Type:

Company

Date/Archive File Name

Instrument Series

Logging Unit

Depth Interval

Calibration Report
Moisture Gauge
Waste Management NW

R.K. Price

July 20, 1999 M2E13060

RLSM00.0

RLS-3

2 to $50 \mathrm{ft} \quad$ Prefix MB33

May 13, 1999

WHC-SD-EN-TI-306, Rev. 0

Analysis Information

\begin{tabular}{ll}
\hline Company & Three Rivers Scientific \\
Analyst & Russ Randall \\
Date & July 30, 1999 \\
Depth Reference & Ground Surface (plots depth shifted)
\end{tabular}

Notes Moisture values range from $5 \%$ to $30 \%$ for the depths logged. The highest observed moisture zone occurs at the depth of 18 feet with a reading of $30 \%$ by volume. 


\section{RLS Moisture Processed Log Data}

\section{Waste Management Federal Services NW}

Project: Vadose Zone Monitoring Borehole: 299-E13-60
8" Casing Calibration Log Date July 20, 1999
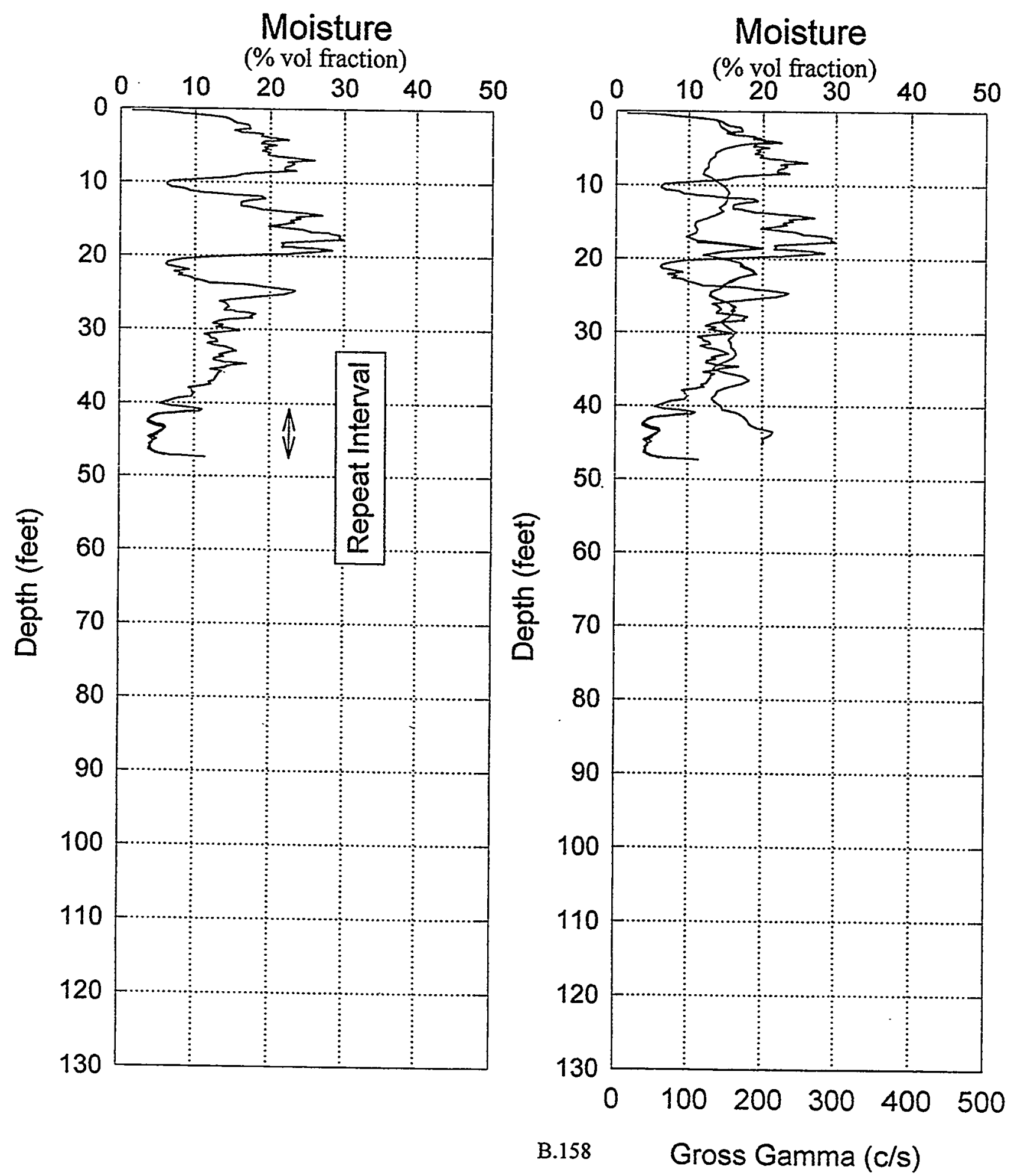


\section{RLS \\ Log Analysis \& Summary}

Project: PNNL Vadose Zone Monitoring

Log Type: Moisture Gauge

Well ID:

299-E13-60

Log Date: July 20, 1999

\section{General Notes:}

The low reading from 0 feet to 2 feet is due to surface effects and not necessarily the moisture content of the sediments surrounding the borehole.

Log data collected with a depth reference of top of casing, and during analysisi the depths were shifted to ground surface reference for all plots.

System Performance Verify: The pre- and post-log verification passed performance standards, $+2.6 \%$ in the shield verify.

Repeat Interval: Based on the repeat interval from 41 to 47 feet, the logging system performed according to specifications.

Environmental Corrections: The moisture levels have been corrected for casing attenuation (entire well).

\section{Observations:}

The moisture levels show values ranging from $5 \%$ to $30 \%$ for depth interval from 2 feet to 47 feet. The highest moisture occurs at a depth of 18 feet, with a maximum reading of $30 \%$ by volume. 


\section{RLS Spectral Gamma Ray Borehole Survey \\ Waste Management Federal Services NW}

\section{Log Header}

Project: $\quad$ PNNL Vadose Zone Monitoring

Well: 299-E13-61

Log Type: HPGe Spectral Gamma Ray

Borehole Information

\begin{tabular}{|c|c|c|}
\hline Well \# A5876 & Water Depth $\quad \mathrm{n} / \mathrm{a}$ & Total Depth 50 \\
\hline Elevation Reference $\underline{n / a}$ & Elevation $\quad \mathrm{n} / \mathrm{a}$ & \\
\hline Depth Reference Top Casing & Casing Stickup 2.0 & \\
\hline Casing Diameter 8 in & Depth Interval 0 to 50 & Thickness 0.375 in \\
\hline
\end{tabular}

Logging Information

\begin{tabular}{|c|c|c|}
\hline Log Type: & $35 \%$ HPGe Spectral G & mma Ray \\
\hline Company & Waste Management $N$ & \\
\hline Date/Archive File Name & July 21,1999 & H2E13061 \\
\hline Logging Engineers & A. Pearson & \\
\hline Instrument Series & RLSG035N00L00.0 & \\
\hline Logging Unit & RLS-2 & \\
\hline Depth Interval & 2 to $47 \mathrm{ft}$ & Prefix B23 \\
\hline
\end{tabular}

Instrument Calibration Date

Calibration Report

Jan 19, 1999

WHC-SD-EN-TI-292

Analysis Information

$\begin{array}{ll}\text { Company } & \text { Three Rivers Scientific } \\ \text { Analyst } & \text { Russ Randall } \\ \text { Date } & \text { July 26, 1999 } \\ \text { Depth Reference } & \text { Ground Surface (plots depth shifted) }\end{array}$

Notes $\mathrm{Cs}_{-}-137$ and $\mathrm{Co}-60$ are the only man made radionuclides detected. 


\section{RLS Spectral Gamma Ray Borehole Survey Waste Management Federal Services NW}

Project: PNNL Vadose Zone Monitoring Log Date: July 21, 1999 Borehole: 299-E13-61

Naturally Occurring Radionuclides

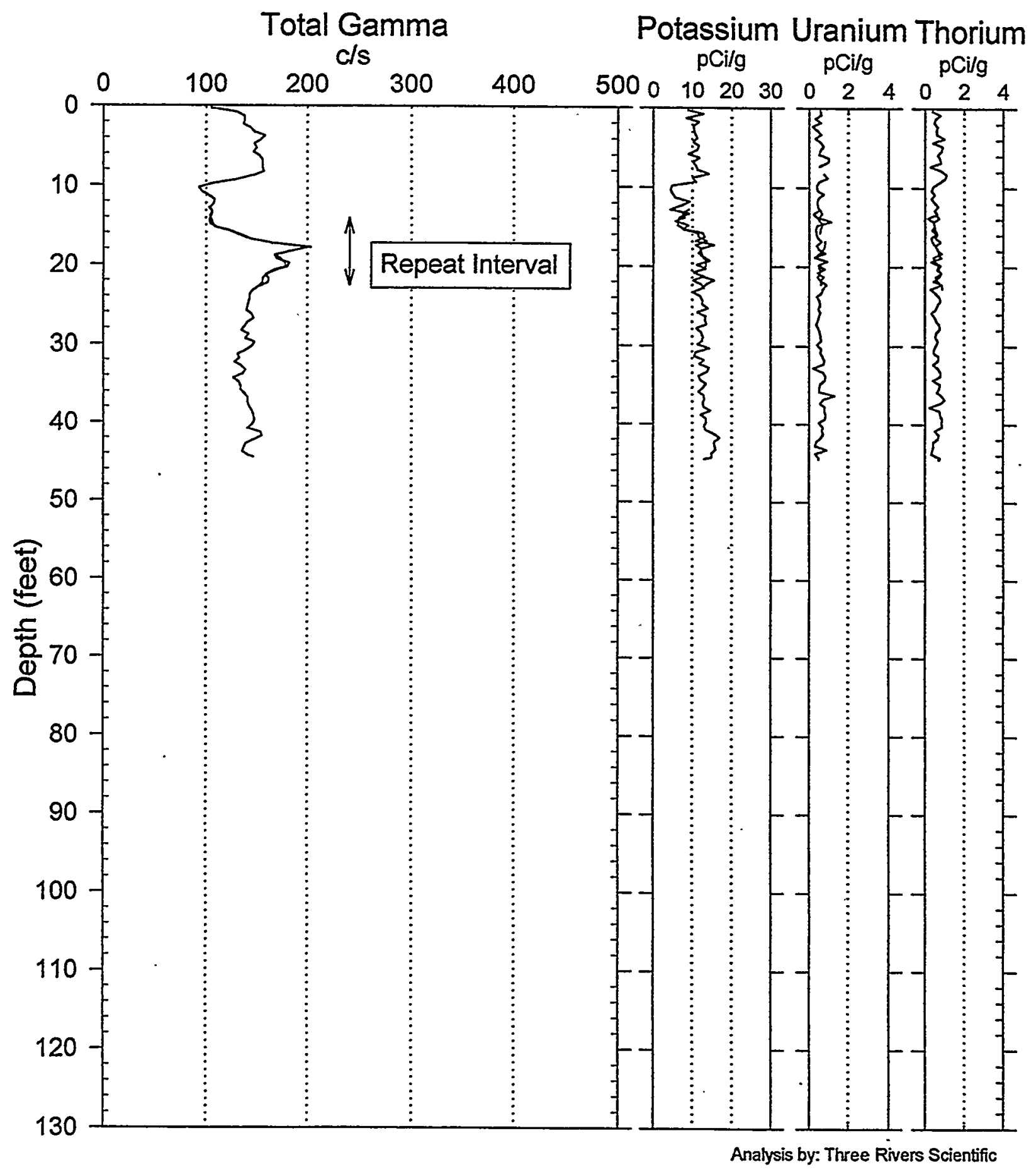


RLS Spectral Gamma-Ray Borehole Survey

\section{Waste Management Federal Services NW}

Project: PNNL Vadose Zone Monitoring Log Date: July 21, 1999 Borehole: 299-E13-61

Man-Made Radionuclides

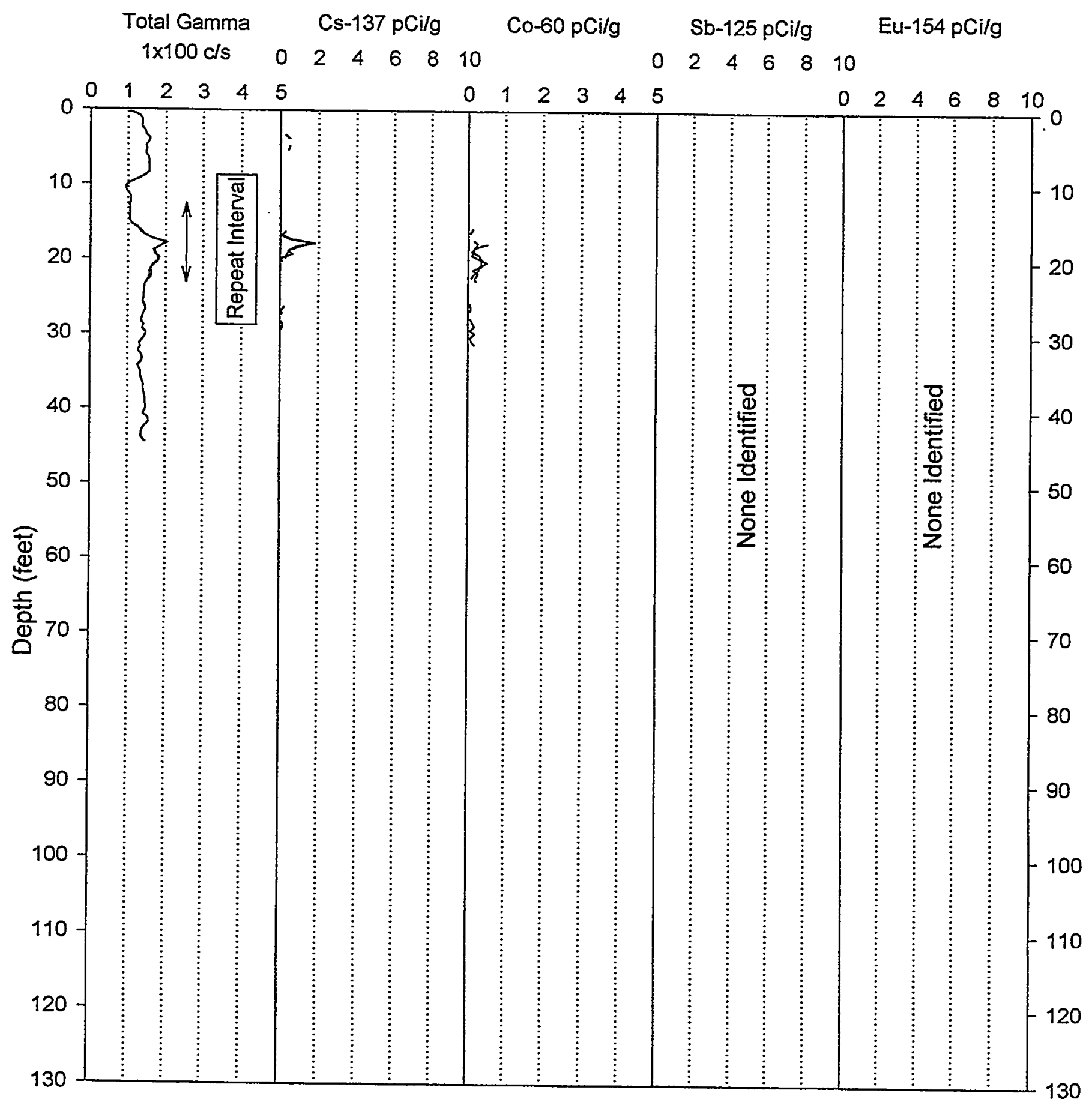




\section{RLS Spectral Gamma Ray Borehole Survey \\ Acceptance QA Processing}

Project: PNNL Vadose Zone Monitoring Log Date: July 21, 1999 Borehole: 299-E13-61 Compare Main Log \& Repeat

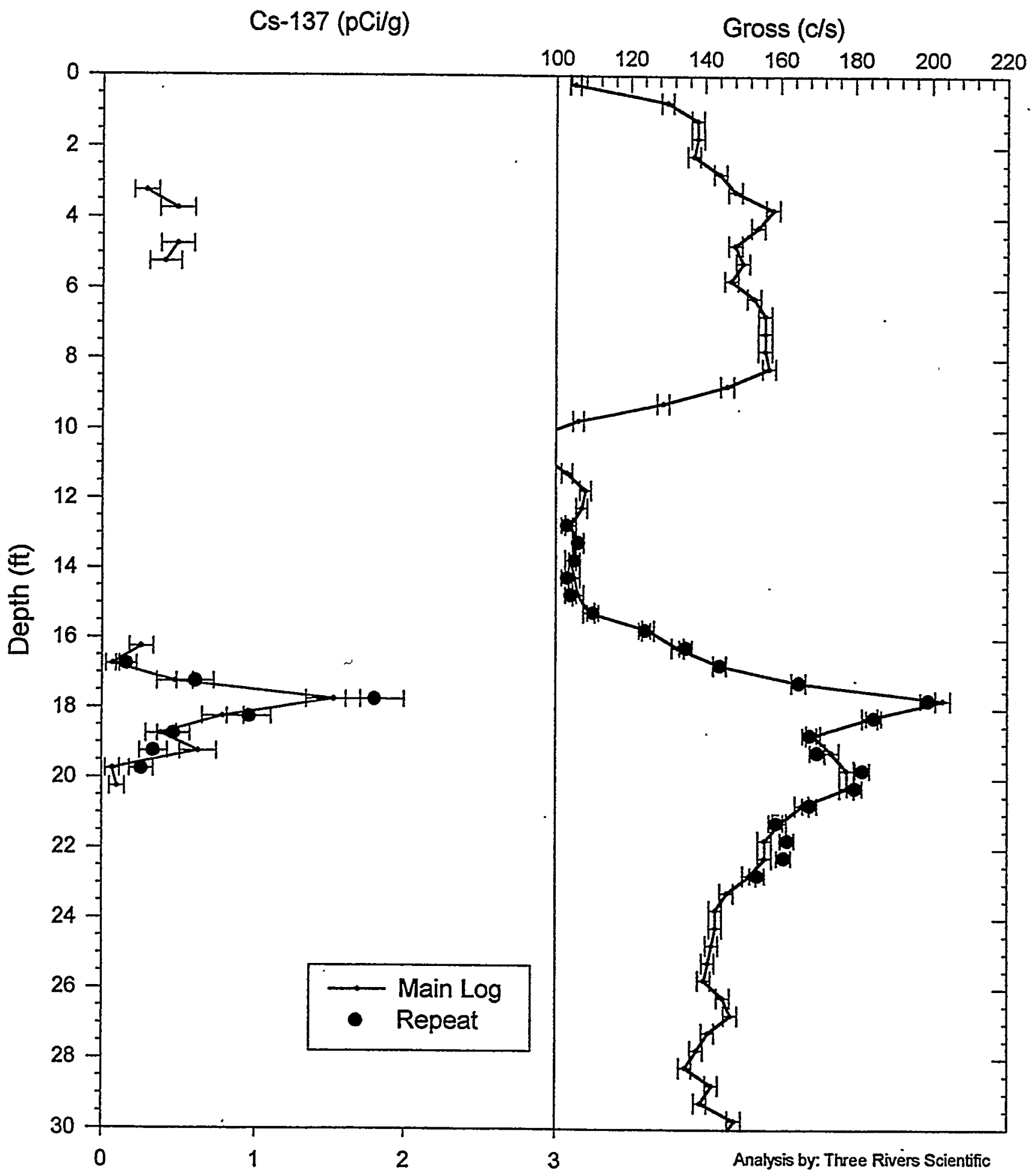




\section{RLS Spectral Gamma Ray Borehole Survey \\ Waste Management Federal Services NW}

\section{Log Analysis Summary Report}

$\begin{array}{lllr}\text { Project: } & \text { PNNL Vadose Zone Monitoring } & \text { Well: } & \text { 299-E13-61 } \\ \text { Log Type: } & \text { HPGe Spectral Gamma Ray } & \text { Log Date: } & \text { July 21, 1999 }\end{array}$

\section{General Notes:}

Total gamma is a response to geologic concentrations of natural radionuclides except for the depth interval from 17-22 feet, where it reflects the presence of $\mathrm{Cs}-137$ and Co-60.

Log data collected with a depth reference of top of casing, and during analysis the depths were shifted to ground surface reference for all plots.

System Performance Verify: The pre- and post-log verification passed performance standards.

Repeat Interval: Based on the repeat interval, the logging system performed as per specifications, refer to repeat plot. The error bars are calculated for 1 standard deviation of the net photo peak count rate statistical variance. Thus, the repeat should fall within these error bars $67 \%$ of the time.

Environmental Corrections: All radionuclide concentrations have been corrected for casing attenuation (entire well). Water level is below depths logged. No casing correction was applied to the total gamma due to Compton downscatter interference.

\section{Radionuclides:}

Cs-137 was identified over the depths from 3-4 feet, and from 17-30 feet. The maximum concentration of Cs-137 occurs at a depth of 18 feet, with a reading of $1.5 \mathrm{pCi} / \mathrm{g}$. The Cs-137 MDL value for these log data is $0.2 \mathrm{pCi} / \mathrm{g}$.

Co-60 was identified over the depths from 17-22 feet, and from 25-33 feet. The maximum concentration of Co-60 occurs at a depth of 21 feet, with a reading of $0.5 \mathrm{pCi} / \mathrm{g}$. The MDL value for these log data is $0.15 \mathrm{pCi} / \mathrm{g}$. 


\section{Moisture Logging Service \\ Log Header}

Project: $\quad$ PNNL Vadose Zone Monitoring

Well: 299-E13-61

Log Type: $\quad$ Moisture Gauge

Borehole Information

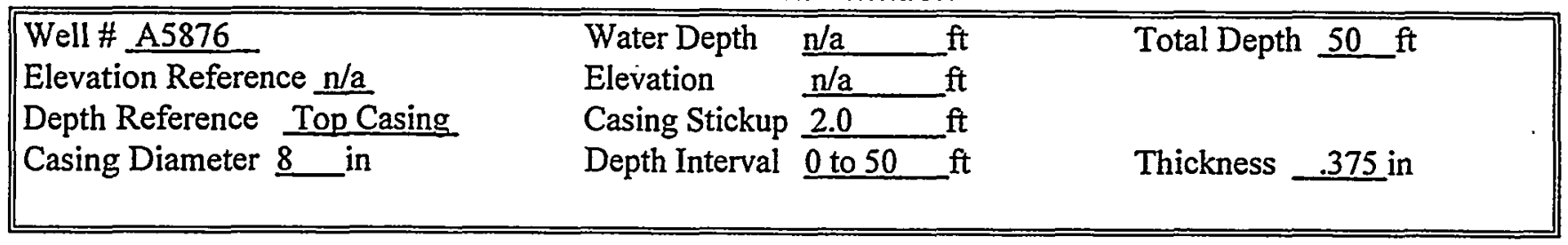

Logging Information

\begin{tabular}{|c|c|c|}
\hline Log Type: & \multicolumn{2}{|l|}{ Moisture Gauge } \\
\hline Company & \multicolumn{2}{|c|}{ Waste Management NW } \\
\hline Date/Archive File Name & July 21, 1999 & M2E13061 \\
\hline Logging Engineers & R.K. Price & \\
\hline Instrument Series & $\overline{\text { RLSM00.0 }}$ & \\
\hline Logging Unit & RLS-3 & \\
\hline Depth Interval & 2 to $49 \mathrm{ft}$ & Prefix MB36 \\
\hline Instrument Calibration Date & May 13, 1999 & \\
\hline Calibration Report & WHC-SD-EN-TI-306, & Rev. 0 \\
\hline
\end{tabular}

Analysis Information

$\begin{array}{ll}\text { Company } & \text { Three Rivers Scientific } \\ \text { Analyst } & \text { Russ Randall } \\ \text { Date } & \text { July 29, 1999 } \\ \text { Depth Reference } & \text { Ground Surface (plots depth shifted) }\end{array}$

Notes Moisture values range from 3\% to $25 \%$ for the depths logged. 


\section{RLS Moisture Processed Log Data}

\section{Waste Management Federal Services NW}

Project: Vadose Zone Monitoring Borehole: 299-E13-61
8" Casing Calibration

Log Date July 21, 1999
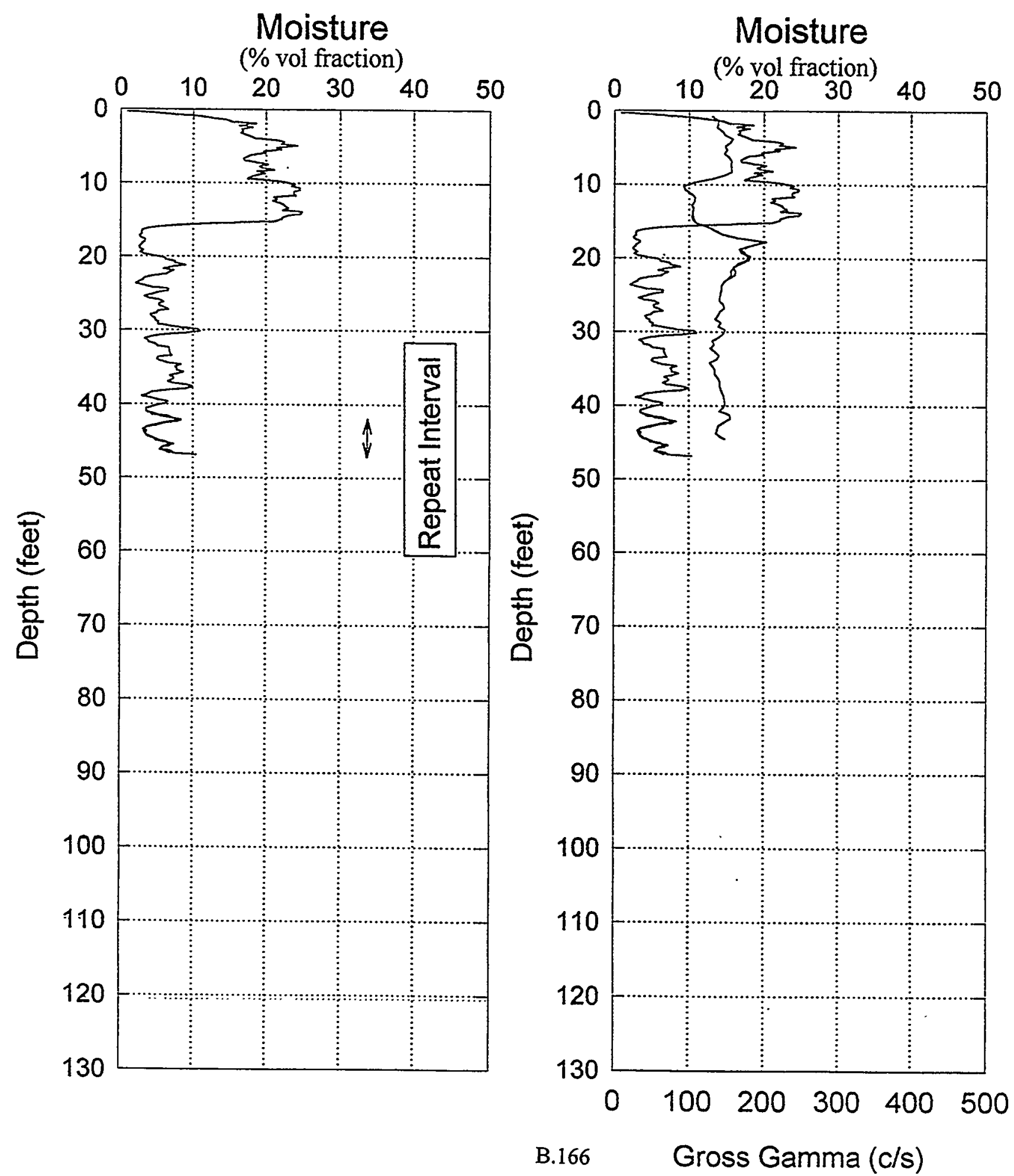


\section{RLS \\ Log Analysis \& Summary}

$\begin{array}{lllr}\text { Project: } & \text { PNNL Vadose Zone Monitoring } & \text { Well D: } & \text { 299-E13-61 } \\ \text { Log Type: } & \text { Moisture Gauge } & \text { Log Date: } & \text { July 21, 1999 }\end{array}$

\section{General Notes:}

The low reading from 0 feet to 2 feet is due to surface effects and not necessarily the moisture content of the sediments surrounding the borehole.

Log data collected with a depth reference of top of casing, and during analysis the depths were shifted to ground surface reference for all plots.

System Performance Verify: The pre- and post-log verification passed performance standards, $-4.2 \%$ in the shield verify.

Repeat Interval: Based on the repeat interval from 41 to 47 feet, the logging system performed according to specifications.

Environmental Corrections: The moisture levels have been corrected for casing attenuation (entire well).

\section{Observations:}

The moisture values range from $3 \%$ to $25 \%$ for depth interval from 4 feet to 47 feet. The highest moisture interval occurs from 4 to 16 feet, with a maximum reading of $25 \%$ by volume at a depth of 14 feet. . 


\section{RLS Spectral Gamma Ray Borehole Survey \\ Waste Management Federal Services NW}

\section{Log Header}

\section{Project: PNNL Vadose Zone Monitoring \\ Well: 299-E24-53}

Log Type: HPGe Spectral Gamma Ray

Borehole Information

\begin{tabular}{|c|c|c|c|}
\hline Well \# n/a & Water Depth & $\underline{n} / \mathbf{a}$ & Total Depth $52 \mathrm{ft}$ \\
\hline Elevation Reference $\underline{\mathrm{n} / \mathrm{a}}$ & Elevation & $\omega_{\mathrm{ft}}$ & \\
\hline Depth Reference Top Casing & Casing Stickup & 1.0 & \\
\hline Casing Diameter $\underline{8}$ in & Depth Interval & 0 to 52 & Thickness 0.3125 in \\
\hline
\end{tabular}

Logging Information

Log Type:

Company

Date/Archive File Name

Logging Engineers

Instrument Series

Logging Unit

Depth Interval

Instrument Calibration Date

Calibration Report
35\% HPGe Spectral Gamma Ray

Waste Management NW

July 6, 1999 H2E24053

S. Kos

RLSG035N00L00.0

RLS-1

1 to $51 \mathrm{ft}$

Prefix AP11
Jan 19, 1999

WHC-SD-EN-TI-292

Analysis information

$\begin{array}{ll}\text { Company } & \text { Three Rivers Scientific } \\ \text { Analyst } & \text { Russ Randall } \\ \text { Date } & \text { July 9, 1999 } \\ \text { Depth Reference } & \text { Ground Surface (plots depth shifted) }\end{array}$

Notes Cs-137, Co-60. U-238, U-235, and Eu-154 are the only man made radionuclides detected. 


\section{RLS Spectral Gamma Ray Borehole Survey Waste Management Federal Services NW}

Project: Vadose Zone Monitoring Log Date: July 6, 1999 Borehole: 299-E24-53

Naturally Occurring Radionuclides

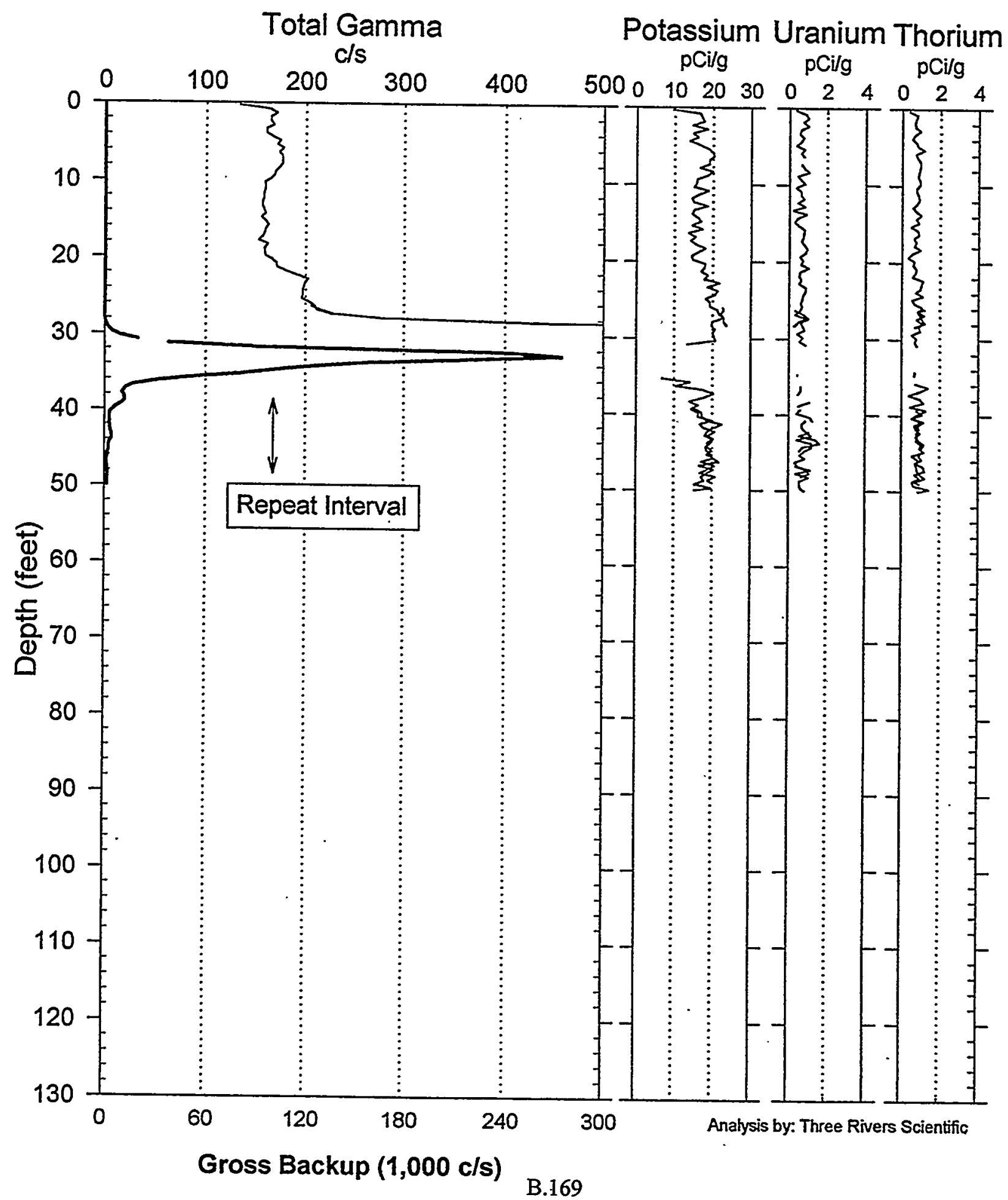




\section{RLS Spectral Gamma-Ray Borehole Survey Waste Management Federal Services NW}

Project: Vadose Zone Monitoring Borehole: 299-E24-53
Log Date: July 6, 1999 Man-Made Radionuclides

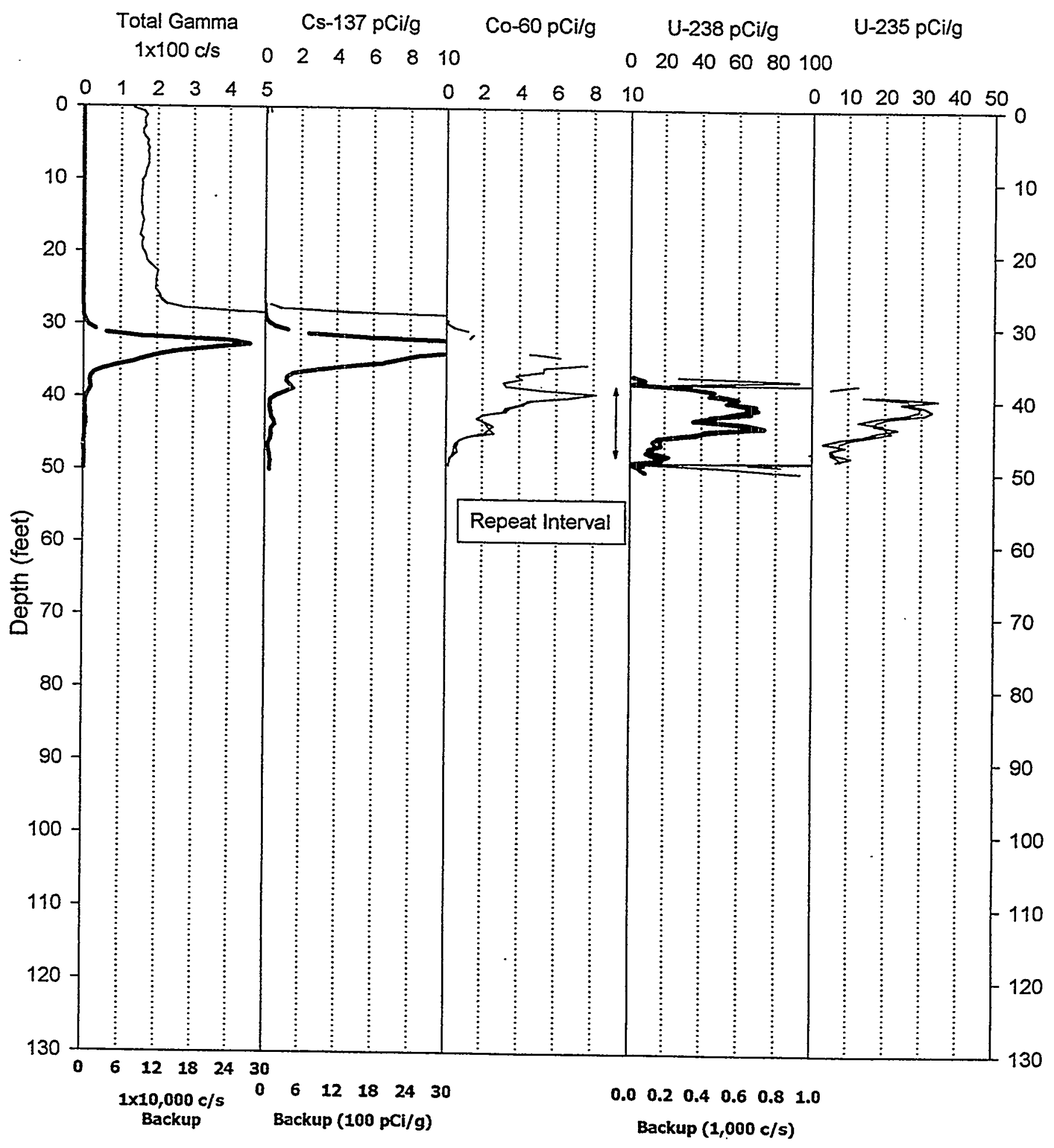




\section{RLS Spectral Gamma-Ray Borehole Survey Waste Management Federal Services NW}

Project: Vadose Zone Monitoring Borehole: 299-E24-53
Log Date: July 6, 1999 Man-Made Radionuclides

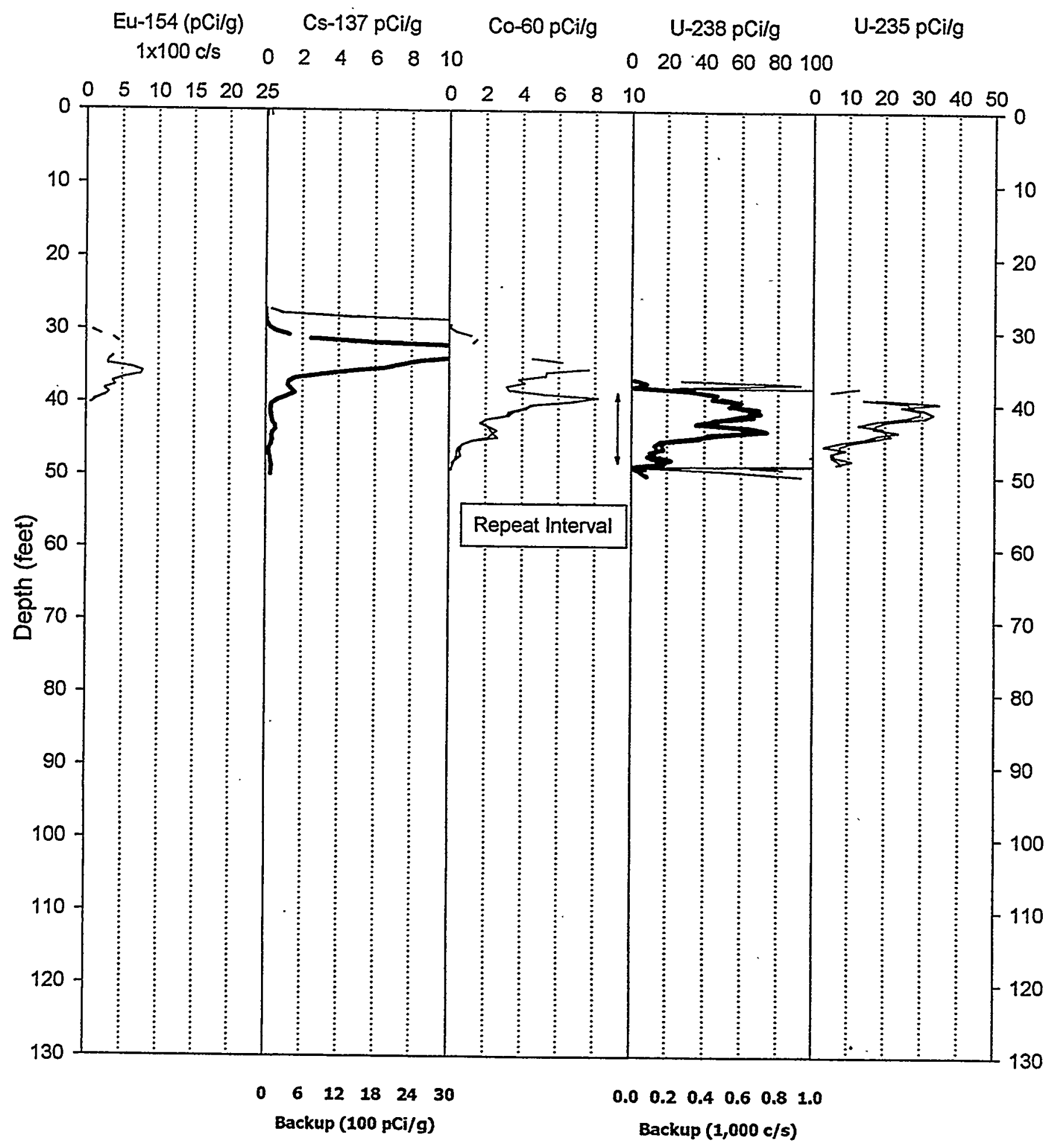




\section{RLS Spectral Gamma Ray Borehole Survey Acceptance QA Processing}

Project: PNNL Vadose Zone Monitoring Borehole: 299-E24-53
Log Date: July 6, 1999 Compare Main Log \& Repeat

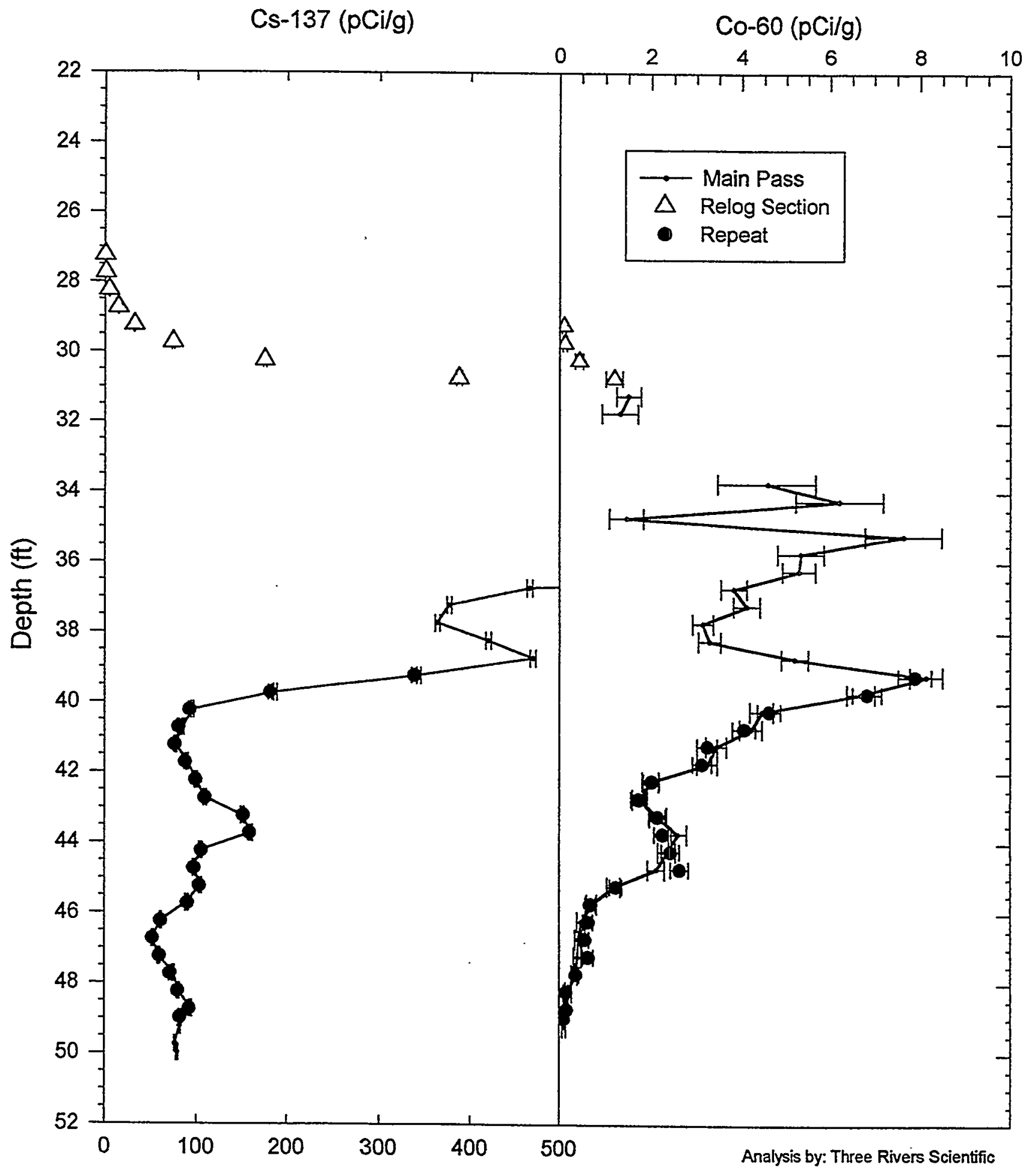




\section{RLS Spectral Gamma Ray Borehole Survey \\ Waste Management Federal Services NW}

\section{Log Analysis Summary Report}

$\begin{array}{llll}\text { Project: } & \text { PNNL Vadose Zone Monitoring } & \text { Well: } & \text { 299-E24-53 } \\ \text { Log Type: } & \text { HPGe Spectral Gamma Ray } & \text { Log Date: } & \text { July 6, 1999 }\end{array}$

\section{General Notes:}

Total gamma is a response to geologic concentrations of natural radionuclides except for the depth interval from 26-50 feet.

Log data collected with a depth reference of top of casing, and during analysis the depths were shifted to ground surface reference for all plots.

System Performance Verify: The pre- and post-log verification passed performance standards.

Repeat Interval: Based on the repeat interval, the logging system performed as per specifications. The error bars are calculated for 1 standard deviation of the net photo peak count rate statistical variance. Thus, the repeat should fall within these error bars $67 \%$ of the time.

Environmental Corrections: All radionuclide concentrations have been corrected for casing attenuation (entire well). Water level is below depths logged. No casing correction was applied to the total gamma due to Compton downscatter interference.

\section{Radionuclides:}

The minimum detection levels are higher for Co-60, U-238, U-235, and Eu-154 due to the high levels of Cs-137. The count rate limits were exceeded over the interval from 31.25 to 36.25 feet. Even though the instrument did not saturate, the dead time correction is inaccurate and the true concentrations are higher than recorded over this interval.

Cs-137 was identified over the depths from 26-50 feet. The maximum concentration of Cs-137 occurred at a depth of 32.75 feet with a concentration greater than $4190 \mathrm{pCi} / \mathrm{g}$. The gross gamma is a response to the $\mathrm{Cs}-137$ concentration over the interval from 26 to 50 feet. Cs- $137 \mathrm{MDL}$ for this borehole condition is $0.3 \mathrm{pCi} / \mathrm{g}$.

Co-60 was identified over the depths from 26-49 feet The maximum concentration of Co-60 occurs at a depth of 40 feet and exceeds $8 \mathrm{pCi} / \mathrm{g}$. Co- $60 \mathrm{MDL}$ for this borehole condition ranges between 0.2 and $1.0 \mathrm{pCi} / \mathrm{g}$, depending upon the Cs-137 concentration.

U-238 was identified over the depths from 37-50 feet. The maximum concentration of U-238 occurs at a depth of 43.75 feet, with a reading of $730 \mathrm{pCi} / \mathrm{g}$. At the bottom of the well, the U-238 is seen to begin to rise, and speculation of concentration from log data cannot extend below the depths logged. U-238 MDL for this borehole condition ranges between 60 and $140 \mathrm{pCi} / \mathrm{g}$, depending upon the Cs-137 concentration.

U-235 was identified over the depths from 38-49 feet. The maximum concentration of U-235 of $34 \mathrm{pCi} / \mathrm{g}$ occurs at a depth of 39.75 feet. At the bottom of the well, the U-235 may begin to rise, but the level of U-235 is near threshold at these depths. U-235 MDL for this borehole condition ranges between 3 and $10 \mathrm{pCi} / \mathrm{g}$, depending upon the Cs-137 concentration.

Eu-154 was identified over the depths from 31-40 feet The maximum concentration of Eu-154 occurs at a depth of 36.75 feet and exceeds $8 \mathrm{pCi} / \mathrm{g}$. The rigorous identification of Eu-154 relies on only the $1274 \mathrm{keV}$ photo peak due to interference from the other isotopic generated gammas. Eu-154 MDL for this borehole condition ranges between 0.6 and $5 \mathrm{p}, \mathrm{Ci} / \mathrm{g}$, depending upon the $\mathrm{Cs}-137$ concentration. 


\section{Moisture Logging Service Log Header}

Project: $\quad$ PNNL Vadose Zone Monitoring

Well: 299-E24-53

Log Type: Moisture Gauge

Borehole information

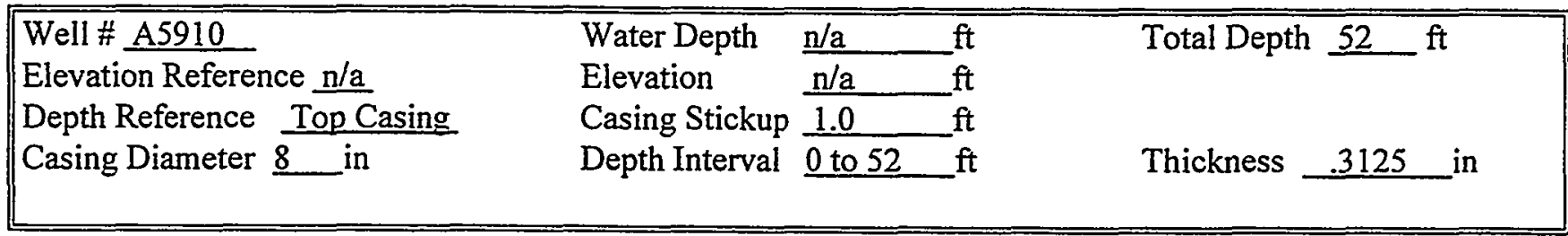

Logging Information

\begin{tabular}{lll}
$\begin{array}{l}\text { Log Type: } \\
\text { Company }\end{array}$ & $\begin{array}{l}\text { Moisture Gauge } \\
\text { Waste Management NW } \\
\text { Date/Archive File Name }\end{array}$ & \multicolumn{1}{c}{ July 12, 1999 M2E24053 } \\
$\begin{array}{l}\text { Logging Engineers } \\
\text { Instrument Series }\end{array}$ & $\begin{array}{l}\text { R.K. Price } \\
\text { RLSM3.1 }\end{array}$ & RLS-3 \\
$\begin{array}{l}\text { Logging Unit } \\
\text { Depth Interval }\end{array}$ & 1 to 52 ft & Prefix MS23 \\
& & \\
Instrument Calibration Date & May 13,1999 \\
Calibration Report & WHC-SD-EN-TI-306, Rev. 0
\end{tabular}

Analysis Information

$\begin{array}{ll}\text { Company } & \text { Three Rivers Scientific } \\ \text { Analyst } & \text { Russ Randall } \\ \text { Date } & \text { July 15, 1999 } \\ \text { Depth Reference } & \text { Ground Surface (plots depth shifted) }\end{array}$

Notes Moisture values range from $2 \%$ to $21 \%$ for the depths logged. The highest observed moisture zone occurs at the depth of 48 feet with a reading of $21 \%$ by volume. 


\section{RLS Moisture Processed Log Data}

Waste Management Federal Services NW

Project: Vadose Zone Monitoring 8" Casing Calibration Borehole: 299-E24-53

Log Date July 12, 1999
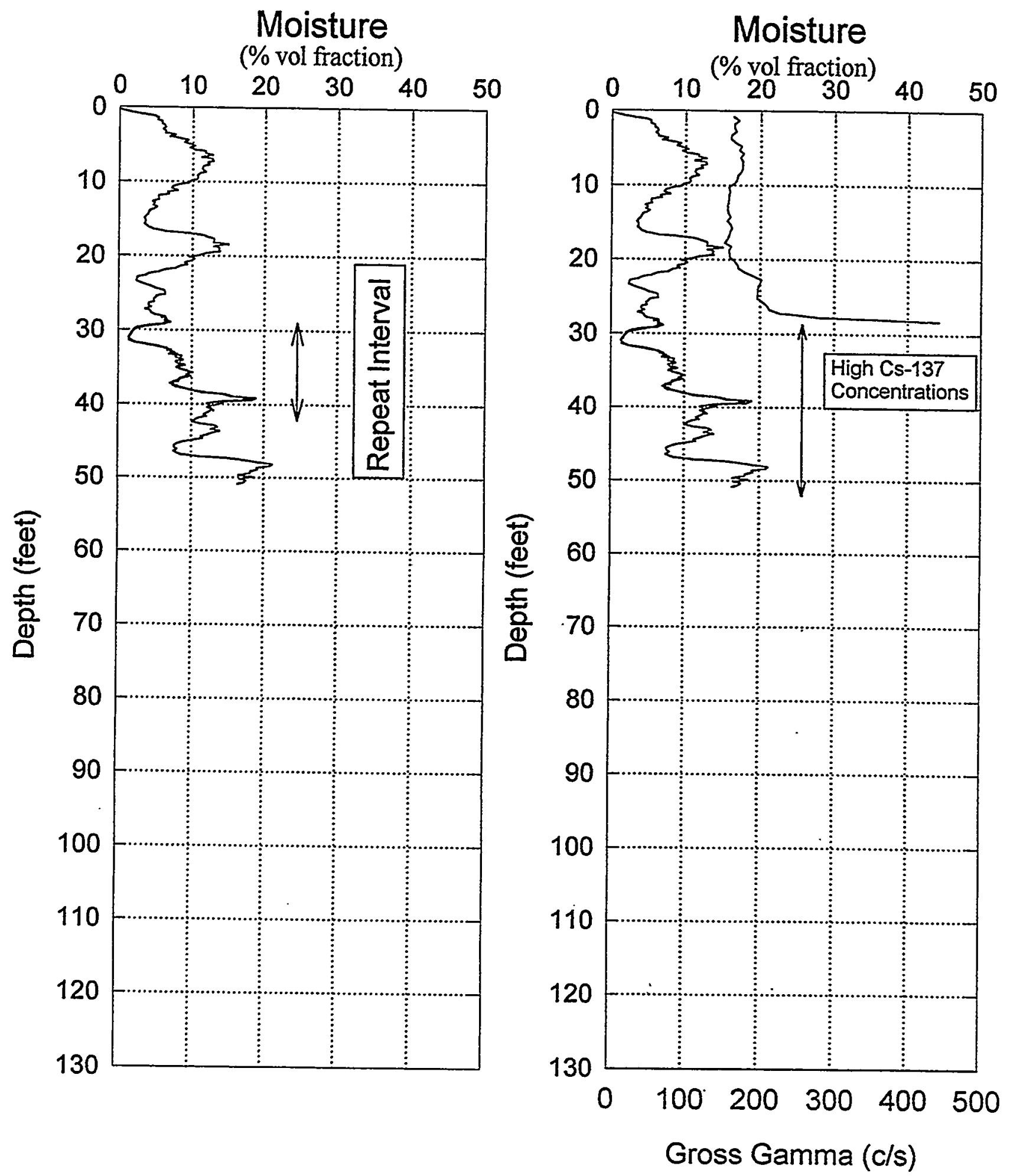

B.175 


\section{RLS \\ Log Analysis \& Summary}

$\begin{array}{lllr}\text { Project: } & \text { PNNL Vadose Zone Monitoring } & \text { Well ID: } & \text { 299-E24-53 } \\ \text { Log Type: } & \text { Moisture Gauge } & \text { Log Date: } & \text { July 12, 1999 }\end{array}$

\section{General Notes:}

The low reading from 0 to 1 feet is due to surface effects and not necessarily the moisture content of the earth surrounding the borehole.

Log data collected with a depth reference of top of casing, and during analysis the depths were shifted to ground surface reference for all plots.

System Performance Verify: The pre- and post-log verification passed performance standards, $+2.5 \%$ in the shield verify.

Repeat Interval: Based on the repeat interval from 29 to 41 feet, the logging system performed according to specifications.

Environmental Corrections: The moisture levels have been corrected for casing attenuation (entire well).

\section{Observations:}

The moisture levels show character for entire depths logged. The highest moisture interval is a thin zone at 48 feet, with a reading of $21 \%$ by volume. 


\section{RLS Spectral Gamma Ray Borehole Survey \\ Waste Management Federal Services NW}

\section{Log Header}

Project: $\quad$ PNNL Vadose Zone Monitoring

Well: 299-E24-54

Log Type: HPGe Spectral Gamma Ray

Borehole Information

\begin{tabular}{|c|c|c|}
\hline Well \# A5911 & Water Depth $\mathrm{n} / \mathrm{a}$ & Total Depth $101 \mathrm{ft}$ \\
\hline Elevation Reference $n / a$ & Elevation $\mathrm{n} / \mathrm{a} \quad \mathrm{ft}$ & \\
\hline Depth Reference Top Casing & Casing Stickup 2.1 & \\
\hline Casing Diameter $\underline{6}$ in & Depth Interval 0 to $101 \mathrm{ft}$ & Thickness \\
\hline
\end{tabular}

Logging Information

\begin{tabular}{|c|c|c|}
\hline Log Type: & \multirow{2}{*}{\multicolumn{2}{|c|}{$\begin{array}{l}\text { 35\% HPGe Spectral Gamma Ray } \\
\text { Waste Management NW }\end{array}$}} \\
\hline Company & & \\
\hline Date/Archive File Name & July 7, 1999 & $\mathrm{H} 2 \mathrm{E} 24054$ \\
\hline Logging Engineers & S. KoS & \\
\hline Instrument Series & RLSG035N00L00.0 & \\
\hline Logging Unit & RLS-1 & \\
\hline Depth Interval & 2 to $99 \mathrm{ft}$ & Prefix AP12 \\
\hline
\end{tabular}

Instrument Calibration Date

$\operatorname{Jan} 19,1999$

Calibration Report

WHC-SD-EN-TI-292

Analysis Information

$\begin{array}{ll}\text { Company } & \text { Three Rivers Scientific } \\ \text { Analyst } & \text { Russ Randall } \\ \text { Date } & \text { July } 15,1999 \\ \text { Depth Reference } & \text { Ground Surface (plots depth shifted) } \\ & \\ & \\ -60 \text { are the only man made radionuclides detected. }\end{array}$




\section{RLS Spectral Gamma Ray Borehole Survey Waste Management Federal Services NW}

Project: PNNL Vadose Zone Monitoring Log Date: July 7, 1999 Borehole: 299-E24-54

Naturally Occurring Radionuclides

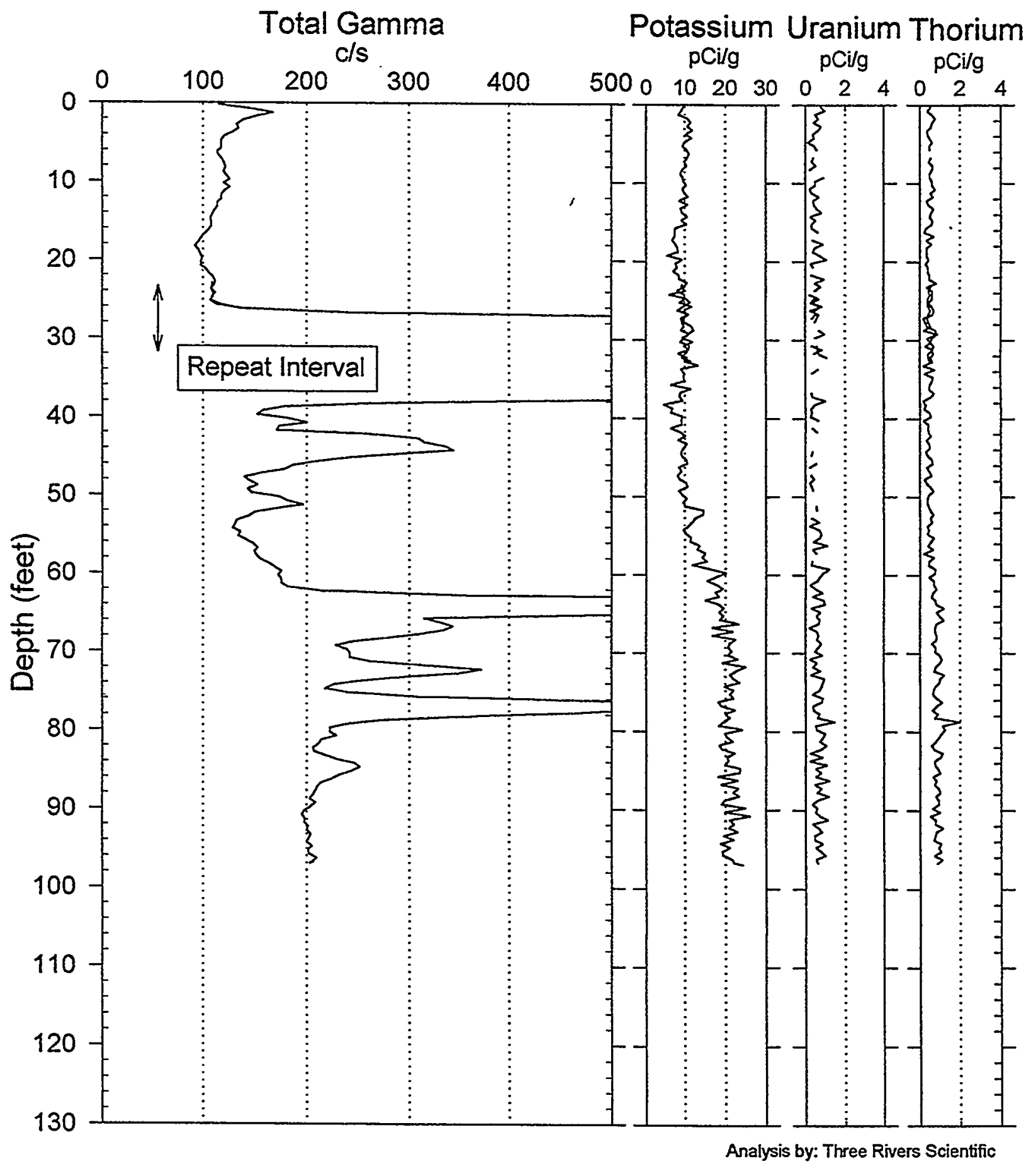




\section{RLS Spectral Gamma-Ray Borehole Survey Waste Management Federal Services NW}

Project: PNNL Vadose Zone Monitoring Log Date: July 7, 1999 Borehole: 299-E24-54 Man-Made Radio-Nuclides

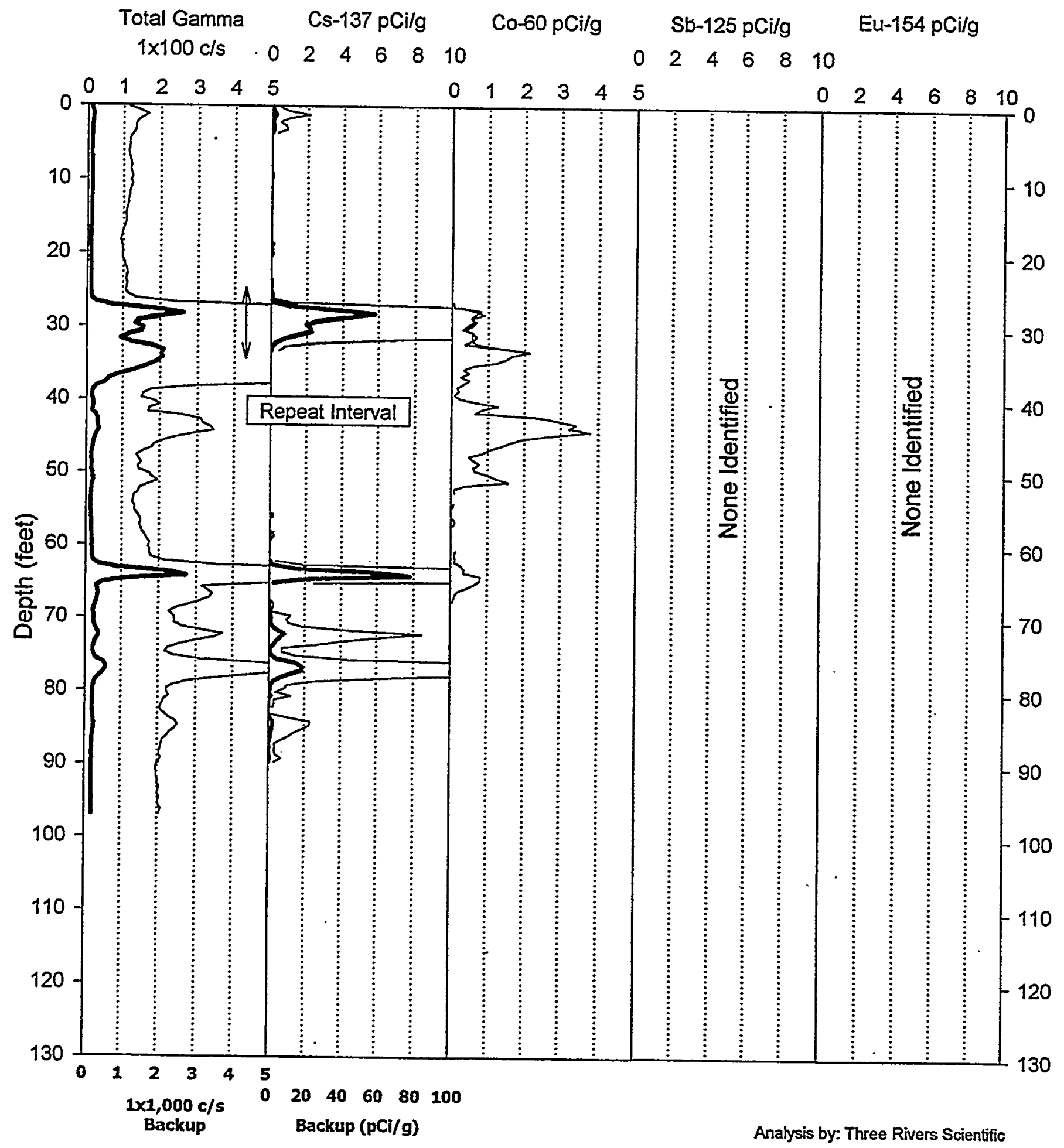




\section{RLS Spectral Gamma Ray Borehole Survey Acceptance QA Processing}

Project: PNNL Vadose Zone Monitoring Log Date: July 7, 1999 Borehole: 299-E24-54
Compare Main Log \& Repeat

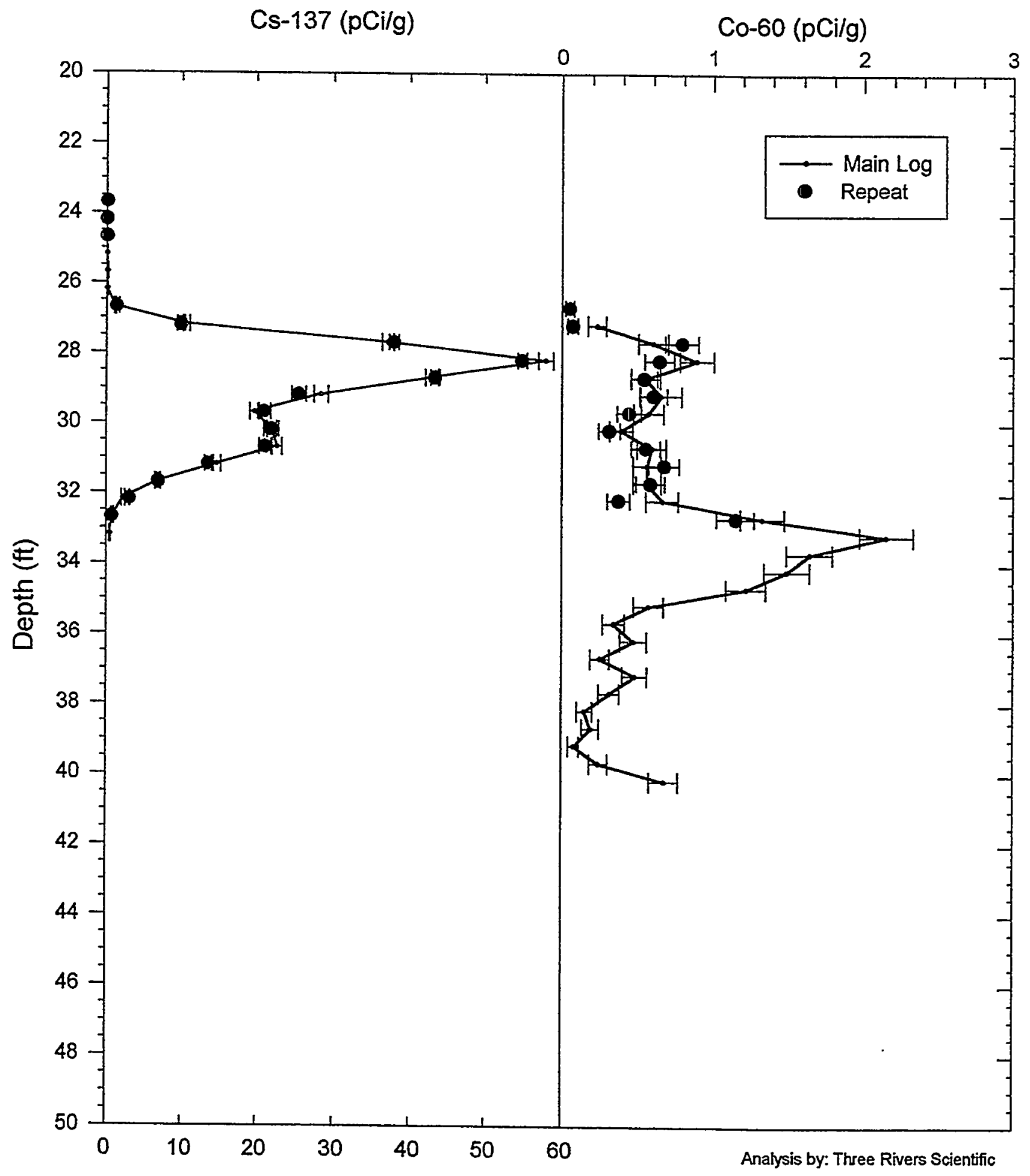




\section{RLS Spectral Gamma Ray Borehole Survey \\ Waste Management Federal Services NW}

\section{Log Analysis Summary Report}

$\begin{array}{llll}\text { Project: } & \text { PNNL Vadose Zone Monitoring } & \text { Well: } & \text { 299-E24-54 } \\ \text { Log Type: } & \text { HPGe Spectral Gamma Ray } & \text { Log Date: } & \text { July 7, 1999 }\end{array}$

\section{General Notes:}

Total gamma is a response to contaminant concentrations of Cs-137 and Co-60 for most of the depth intervals logged.

Log data collected with a depth reference of top of casing, and during analysis the depths were shifted to ground surface reference for all plots.

System Performance Verify: The pre- and post-log verification passed performance standards.

Repeat Interval: Based on the repeat interval, the logging system performed as per specifications. The error bars are calculated for 1 standard deviation of the net photo peak count rate statistical variance. Thus, the repeat should fall within these error bars $67 \%$ of the time.

Environmental Corrections: All radionuclide concentrations have been corrected for casing attenuation (entire well). Water level is unknown and no corrections were made. No casing correction was applied to the total gamma due to Compton downscatter interference.

\section{Radionuclides:}

Cs-137 was identified over the depths from 0-3 feet, from 26-33 feet, and from 54-89 feet. The maximum concentration of Cs-137 occurs at a depth of 65 feet, with a reading of $80 \mathrm{pCi} / \mathrm{g}$. The Cs- $137 \mathrm{MDL}$ value for these $\log$ data is $0.2 \mathrm{pCi} / \mathrm{g}$.

Co-60 was identified over the depths from 26-68 feet. The maximum concentration of Co-60 occurs at a depth of 44 feet, with a reading of $3.6 \mathrm{pCi} / \mathrm{g}$. The Co- $60 \mathrm{MDL}$ for these $\log$ data is $0.2 \mathrm{pCi} / \mathrm{g}$. 


\section{Moisture Logging Service \\ Log Header}

Project: $\quad$ PNNL Vadose Zone Monitoring

Well: 299-E24-54

Log Type: $\quad$ Moisture Gauge

Borehole Information

\begin{tabular}{|c|c|c|}
\hline Well \# A5911 & Water Depth & Total Depth $101 \mathrm{ft}$ \\
\hline Elevation Reference $\mathrm{n} / \mathrm{a}$ & Elevation & \\
\hline Depth Reference Top Casing & Casing Stickup 2.1 & \\
\hline Casing Diameter $\underline{6}$ in & Depth Interval 0 to 101 & Thickness .25 in \\
\hline
\end{tabular}

Logging Information

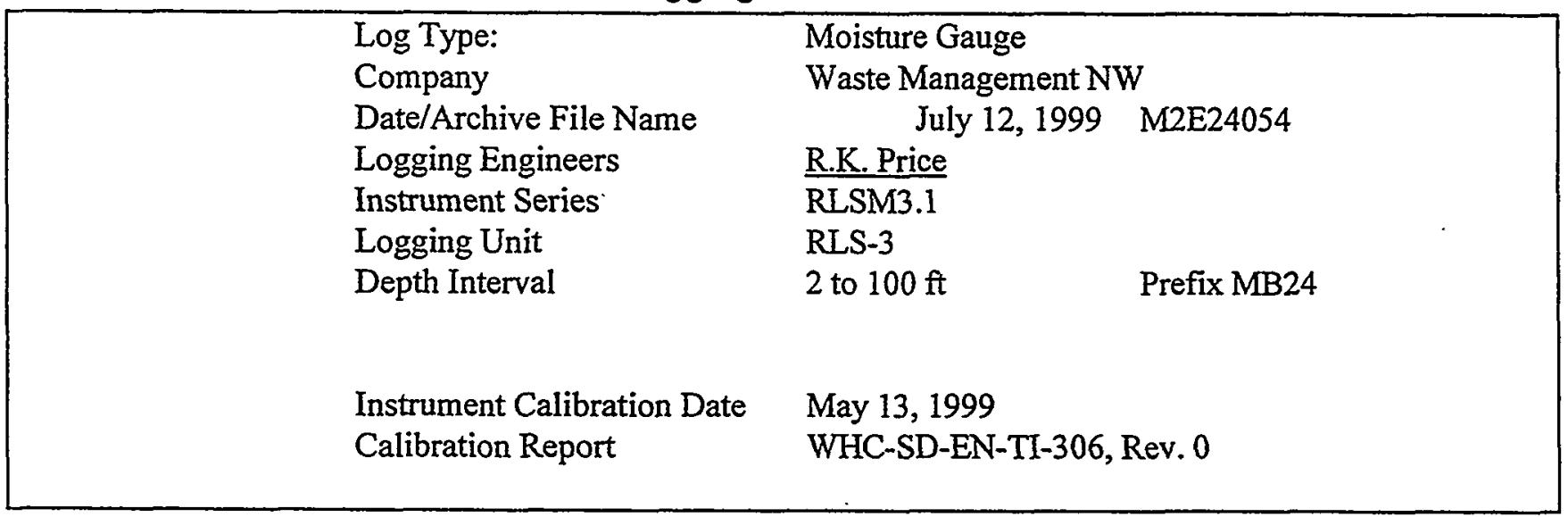

Analysis Information

$\begin{array}{ll}\text { Company } & \text { Three Rivers Scientific } \\ \text { Analyst } & \text { Russ Randall } \\ \text { Date } & \text { July 15, 1999 } \\ \text { Depth Reference } & \text { Ground Surface (plots depth shifted) }\end{array}$

Notes Moisture values range from $3 \%$ to $25 \%$ for the depths logged. The highest observed moisture zone occurs at the depth of 53 feet with a reading of $25 \%$ by volume. This highest moisture zone (from 51 to 56 feet) occurs just above the contaminated interval from 63 to 90 feet. 


\section{RLS Moisture Processed Log Data}

Waste Management Federal Services NW

Project: Vadose Zone Monitoring Borehole: 299-E24-54
8" Casing Calibration Log Date July 12, 1999
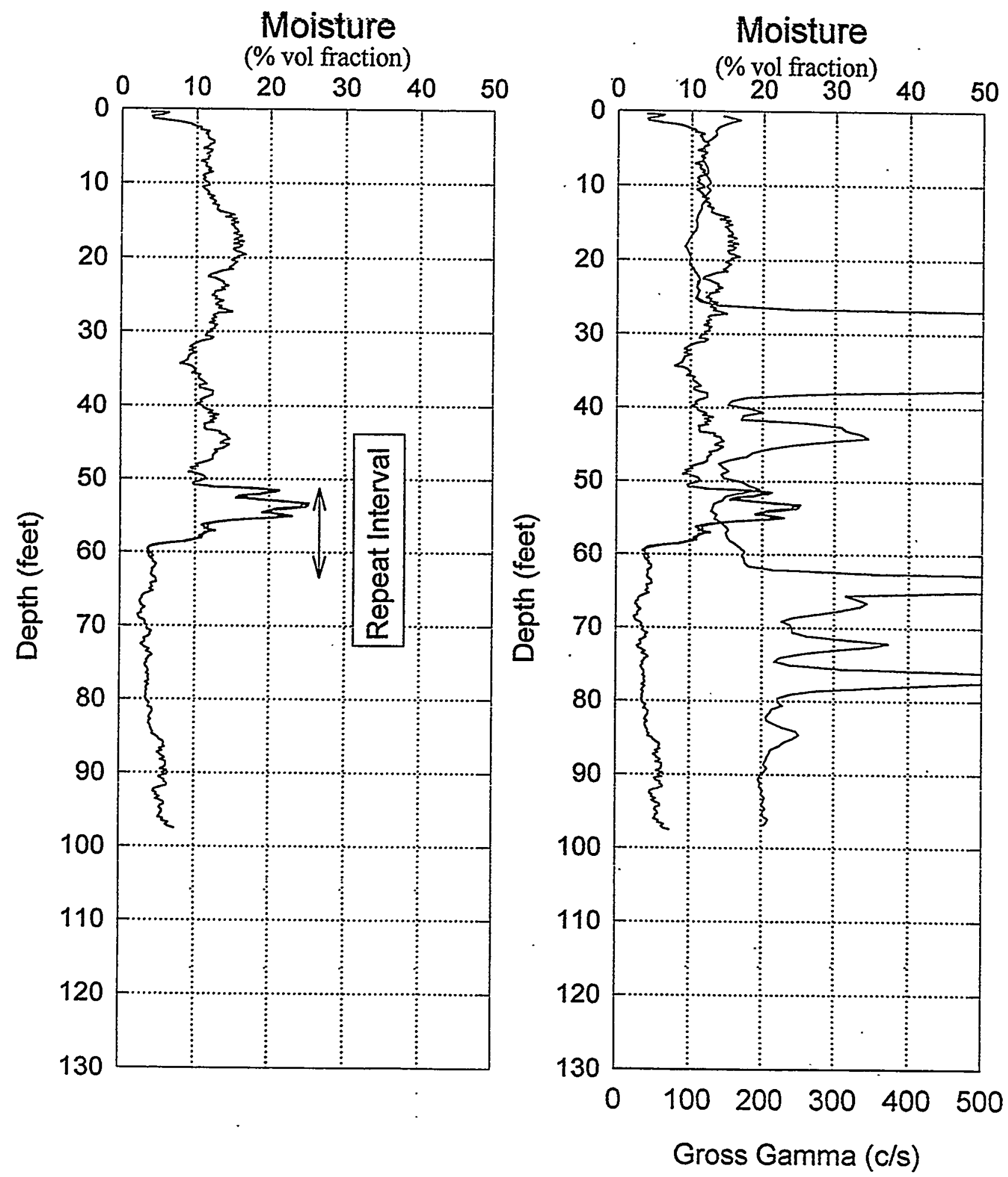


\section{RLS \\ Log Analysis \& Summary}

$\begin{array}{lllr}\text { Project: } & \text { PNNL Vadose Zone Monitoring } & \text { Well ID: } & \text { 299-E24-54 } \\ \text { Log Type: } & \text { Moisture Gauge } & \text { Log Date: } & \text { July } 12,1999\end{array}$

\section{General Notes:}

The low reading from 0 feet to 2 feet is due to surface effects and not necessarily the moisture content of the earth surrounding the borehole.

Log data collected with a depth reference of top of casing, and during analysis the depths were shifted to ground surface reference for all plots.

System Performance Verify: The pre- and post-log verification passed performance standards, $+1.2 \%$ in the shield verify.

Repeat Interval: Based on the repeat interval from 51 to 61 feet, the logging system performed according to specifications.

Environmental Corrections: The moisture levels have been corrected for casing attenuation (entire well).

\section{Observations:}

The moisture levels show values ranging from $3 \%$ to $15 \%$ for depth interval from 2 feet to 98 feet. The highest moisture interval is in a series of thin zones from 51 to 57 feet, with a maximum reading of $25 \%$ by volume. 


\title{
RLS Spectral Gamma Ray Borehole Survey \\ Waste Management Federal Services NW
}

\section{Log Header}

\author{
Project: PNNL Vadose Zone Monitoring Well: 299-E25-10 \\ Log Type: $\quad$ HPGe Spectral Gamma Ray
}

Borehole Information

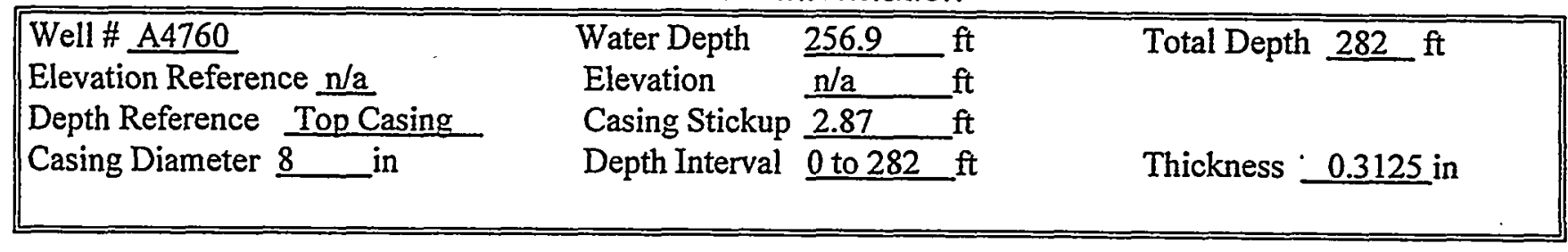

Logging Information

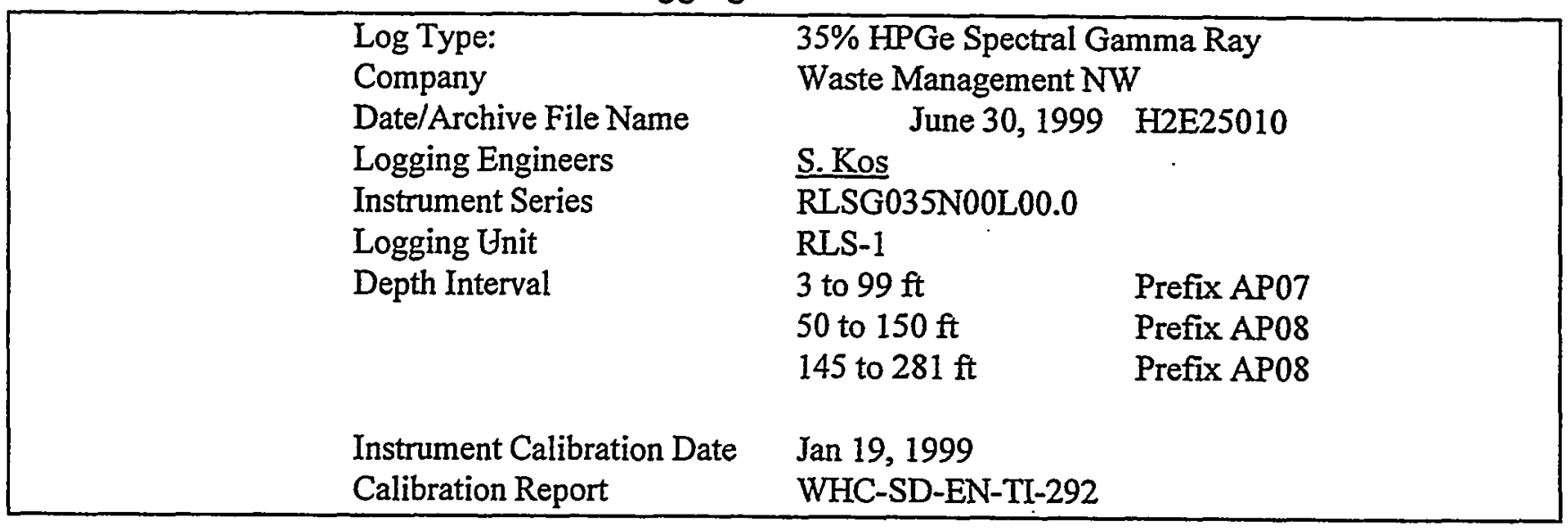

Analysis Information

$\begin{array}{ll}\text { Company } & \text { Three Rivers Scientific } \\ \text { Analyst } & \text { Russ Randall } \\ \text { Date } & \text {. July 17, 1999 } \\ \text { Depth Reference } & \text { Ground Surface (plots depth shifted) }\end{array}$

Notes No man-made radionuclides identified. 


\section{RLS Spectral Gamma Ray Borehole Survey Waste Management Federal Services NW}

Project: PNNL Vadose Zone Monitoring Log Date: June 29\&30, 1999 Borehole: 299-E25-10

Naturally Occurring Radionuclides

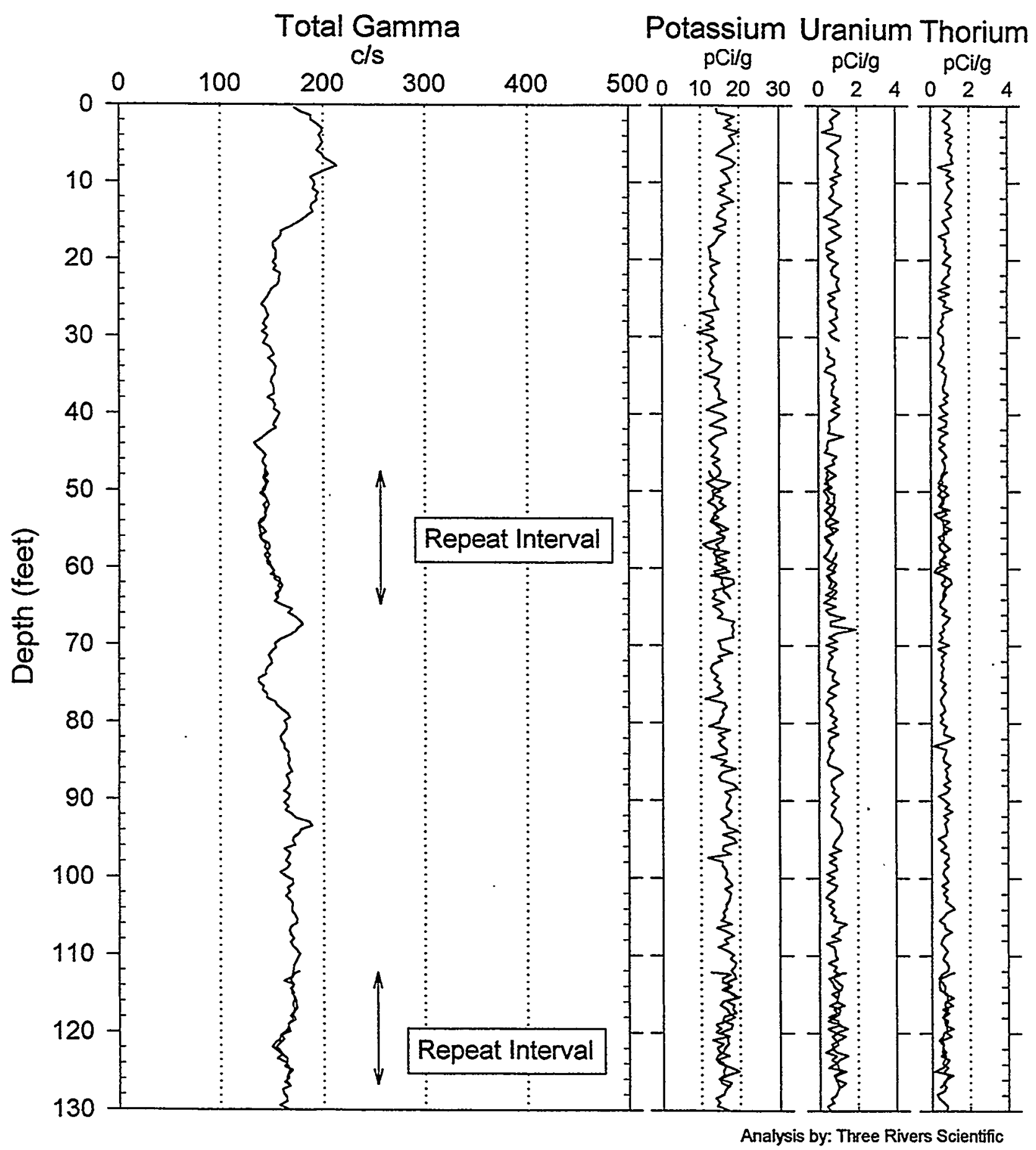




\section{RLS Spectral Gamma Ray Borehole Survey Waste Management Federal Services NW}

Project: PNNL Vadose Zone Monitoring Log Date: June 29\&30, 1999 Borehole: 299-E25-10

Naturally Occurring Radionuclides

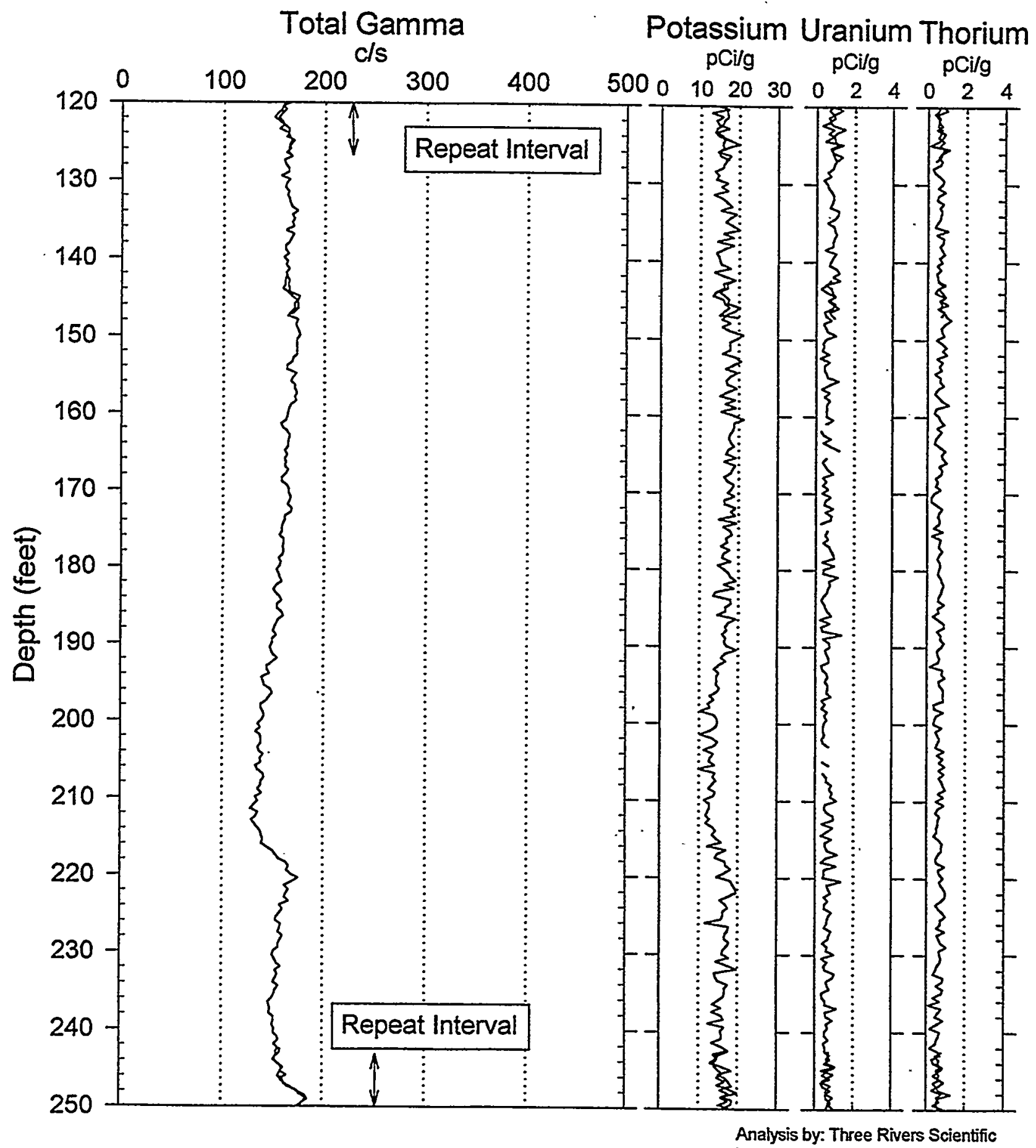




\section{RLS Spectral Gamma Ray Borehole Survey Waste Management Federal Services NW}

Project: PNNL Vadose Zone Monitoring Log Date: June 29\&30, 1999 Borehole: 299-E25-10

Naturally Occurring Radionuclides

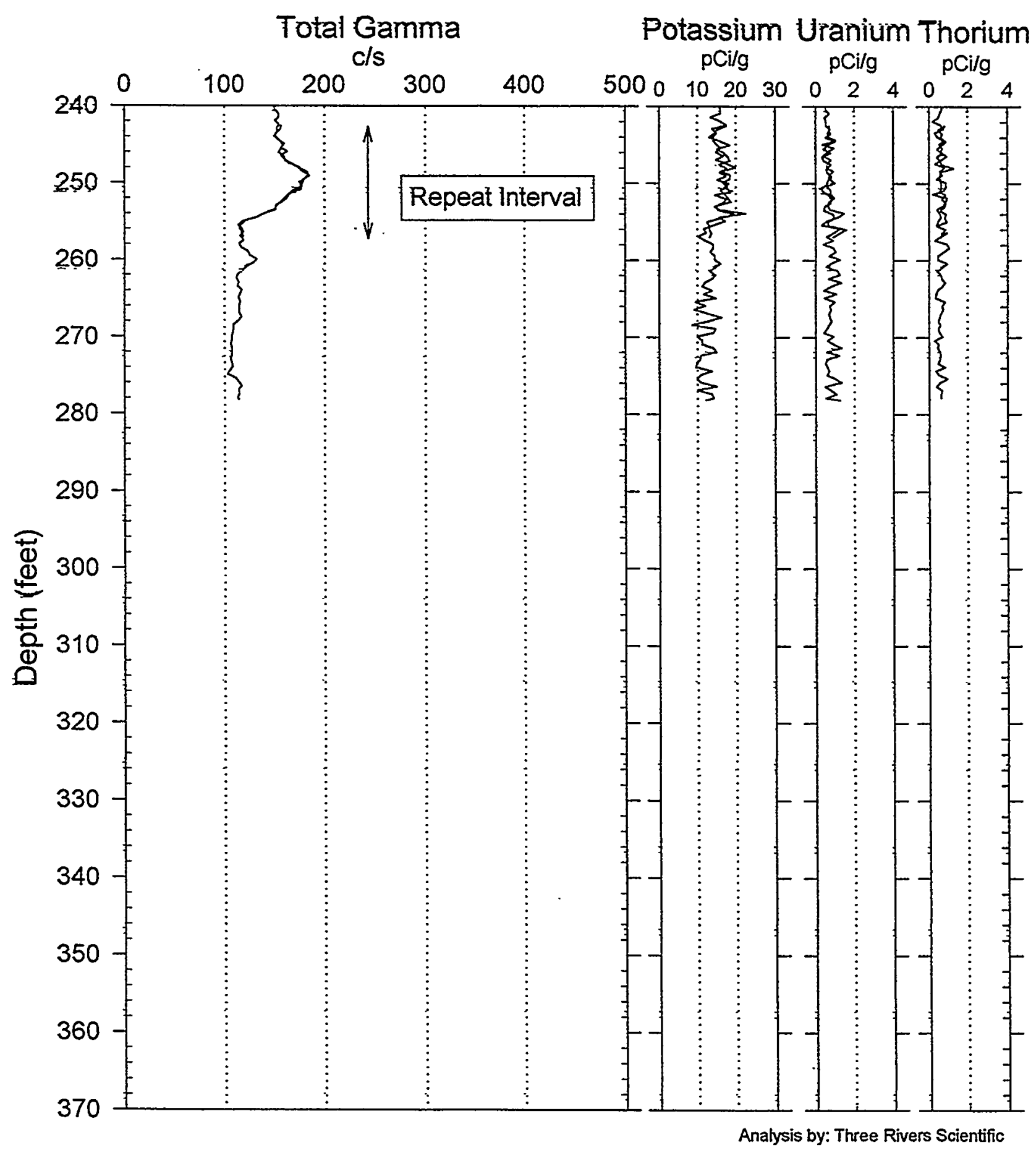




\section{RLS Spectral Gamma Ray Borehole Survey Acceptance QA Processing}

Project: PNNL Vadose Zone Monitoring Log Date: June 29\&30, 1999 Borehole: 299-E25-10 - Compare Main Log \& Repeat

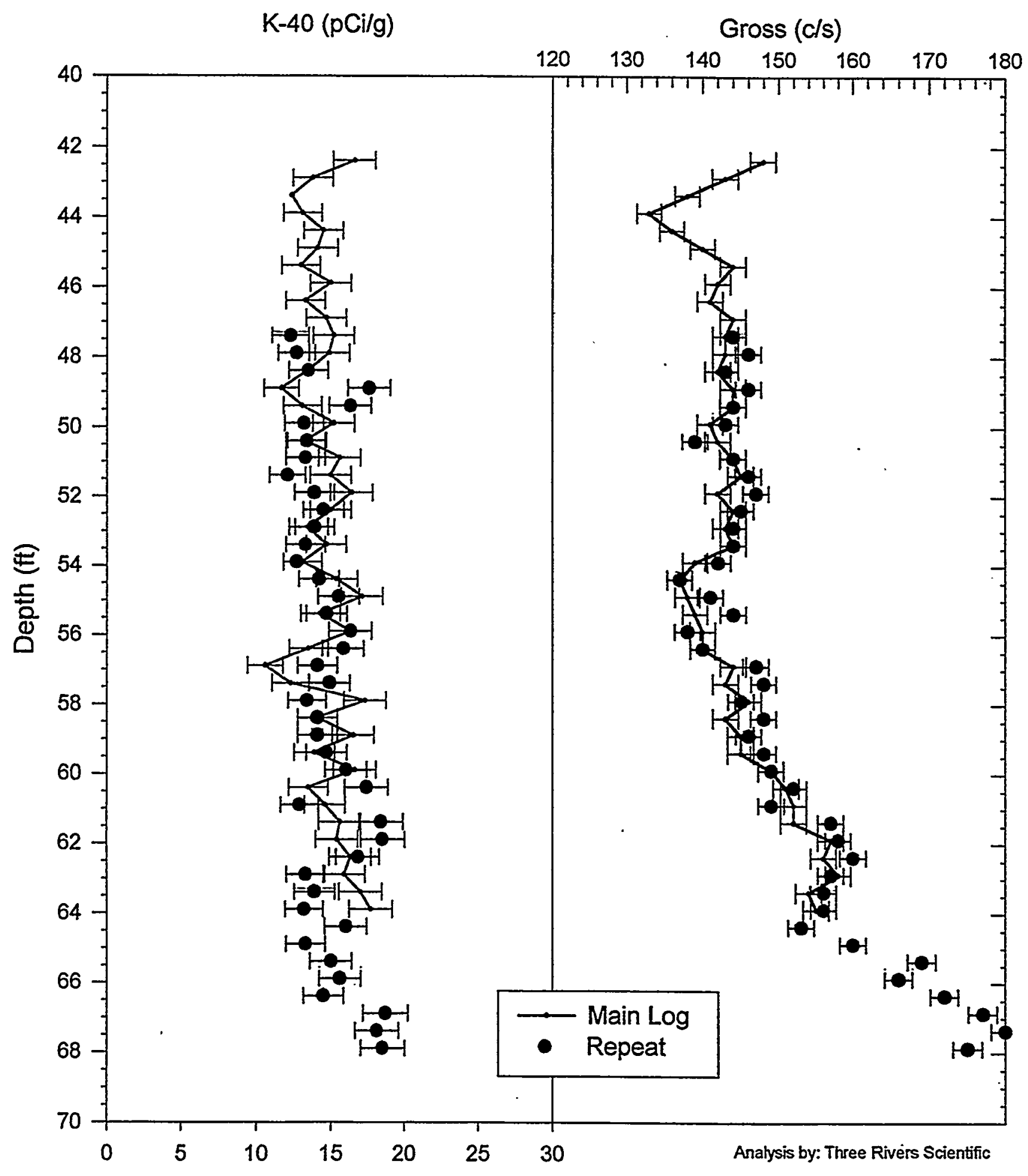




\section{RLS Spectral Gamma Ray Borehole Survey Acceptance QA Processing}

Project:PNNL Vadose Zone Monitoring Log Date: June 29\&30, 1999 Borehole: 299-E25-10 Compare Main Log \& Repeat

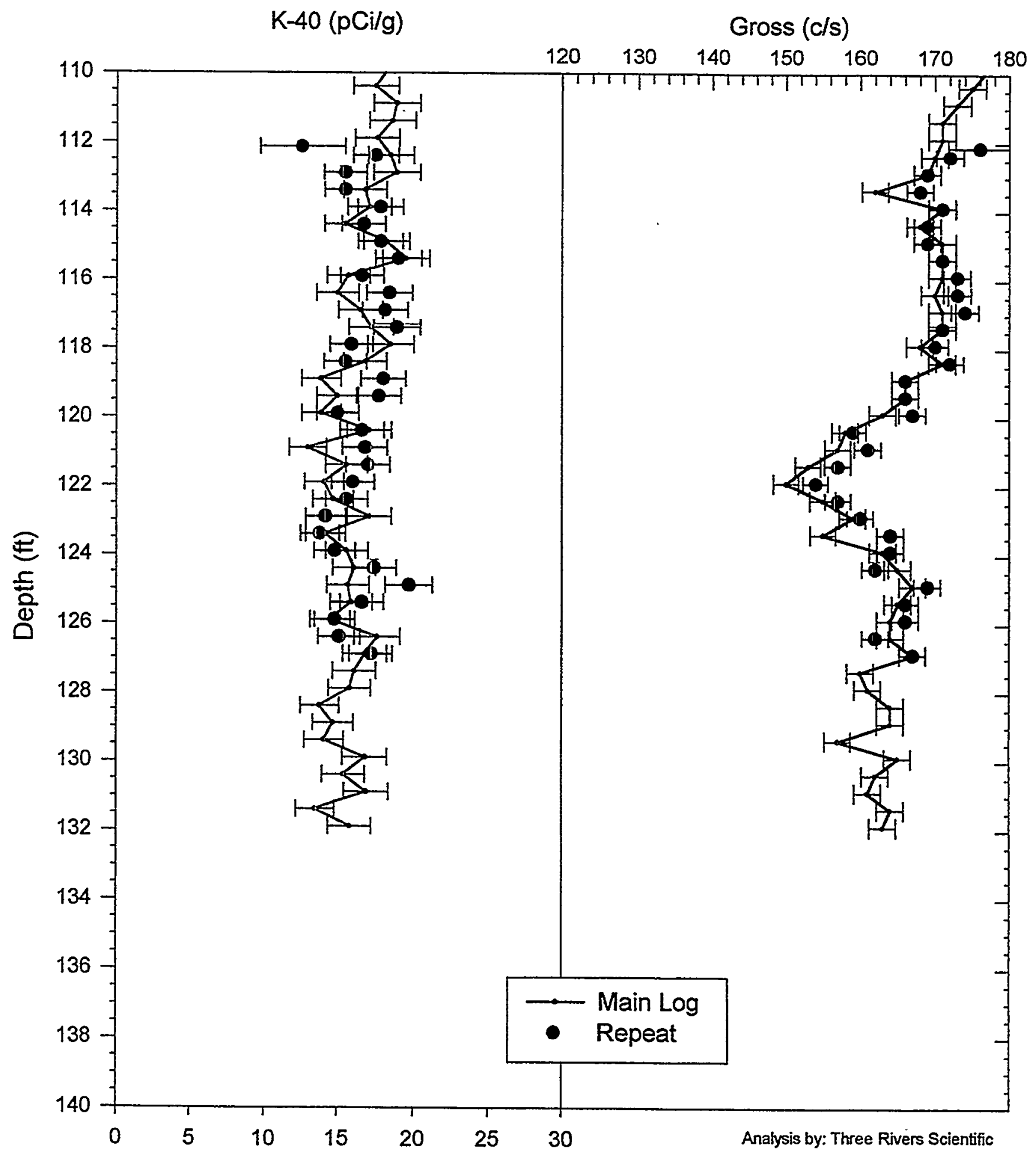




\section{RLS Spectral Gamma Ray Borehole Survey Acceptance QA Processing}

Project:PNNL Vadose Zone Monitoring Log Date: June 29\&30, 1999 Borehole: 299-E25-10 Compare Main Log \& Repeat

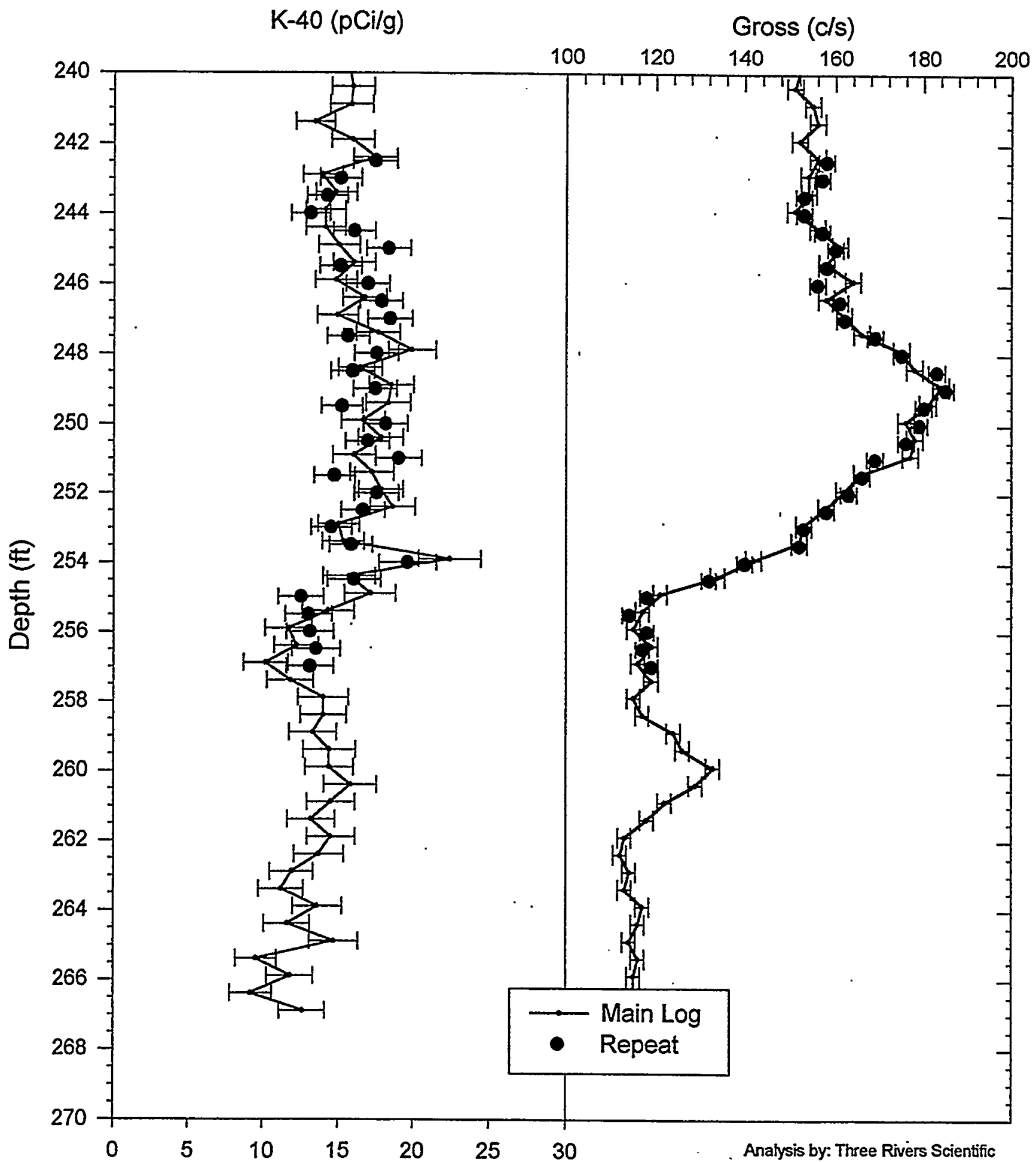




\title{
RLS Spectral Gamma Ray Borehole Survey
}

\author{
Waste Management Federal Services NW
}

\section{Log Analysis Summary Report}

\author{
Project: $\quad$ PNNL Vadose Zone Monitoring \\ Well: \\ 299-E25-10 \\ Log Type: \\ HPGe Spectral Gamma Ray \\ Log Dates: June 29 \& 30, 1999
}

\section{General Notes:}

Total gamma is a response to geologic concentrations of natural radionuclides.

Log data collected with a depth reference of top of casing, and during analysis the depths were shifted to ground surface reference for all plots.

System Performance Verify: The pre- and post-log verification passed performance standards.

Repeat Interval: Based on the repeat interval, the logging system performed as per specifications. Three repeat intervals were conducted over the two day logging program. The error bars are calculated for 1 standard deviation of the net photo peak count rate statistical variance. Thus, the repeat should fall within these error bars $67 \%$ of the time.

Environmental Corrections: All radionuclide concentrations have been corrected for casing attenuation (entire well). Water level is 254 feet, and below this depth, water corrections were calculated for the radionuclide concentrations. No casing correction was applied to the total gamma due to Compton downscatter interference.

\section{Radionuclides:}

No man-made radionuclides were detected, even using a summing by 4 technique. 


\section{Moisture Logging Service \\ Log Header}

Project: $\quad$ PNNL Vadose Zone Monitoring

Well: 299-E25-10

Log Type: Moisture Gauge

Borehole Information

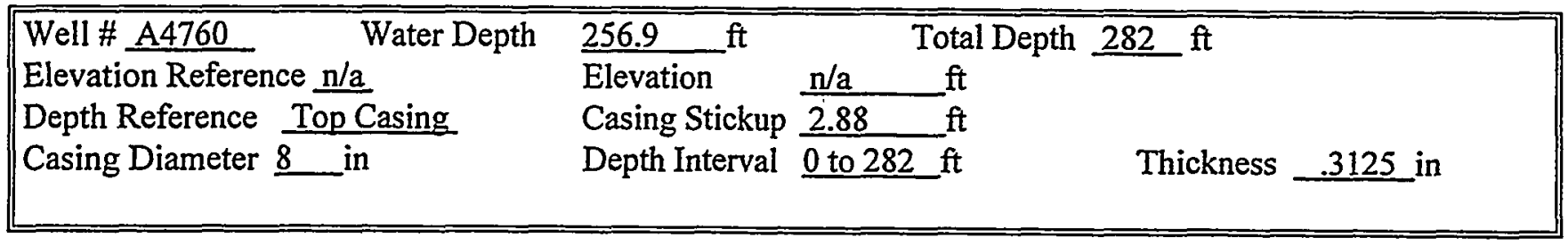

Logging Information

\begin{tabular}{|c|c|c|}
\hline Log Type: & \multicolumn{2}{|c|}{ Moisture Gauge } \\
\hline Company & \multicolumn{2}{|c|}{ Waste Management NW } \\
\hline Date/Archive File Name & July 8,1999 & M2E25010 \\
\hline Logging Engineers & R.K. Price & \\
\hline Instrument Series & $\overline{\text { RLSM3.1 }}$ & \\
\hline Logging Unit & RLS-3 & \\
\hline Depth Interval & $\begin{array}{l}119 \text { to } 257 \mathrm{ft} \\
2 \text { to } 120\end{array}$ & $\begin{array}{l}\text { Prefix MB21 } \\
\text { Prefix MB22 }\end{array}$ \\
\hline Instrument Calibration Date & May 13,1999 & \\
\hline Calibration Report & WHC-SD-EN-TI-30 & Rev. 0 \\
\hline
\end{tabular}

Analysis Information

$\begin{array}{ll}\text { Company } & \text { Three Rivers Scientific } \\ \text { Analyst } & \text { Russ Randall } \\ \text { Date } & \text { July 17, 1999 } \\ \text { Depth Reference } & \text { Ground Surface (plots depth shifted) }\end{array}$

Notes Moisture values range from $3 \%$ to $13 \%$ by volume. The high readings at 255 feet are due to entering the water level in the borehole, and not indicative of the formation moisture content. 


\section{RLS Moisture Processed Log Data}

\section{Project: Vadose Zone Monitoring}

Borehole: 299-E25-10
8" Casing Calibration

Log Date July 8, 1999
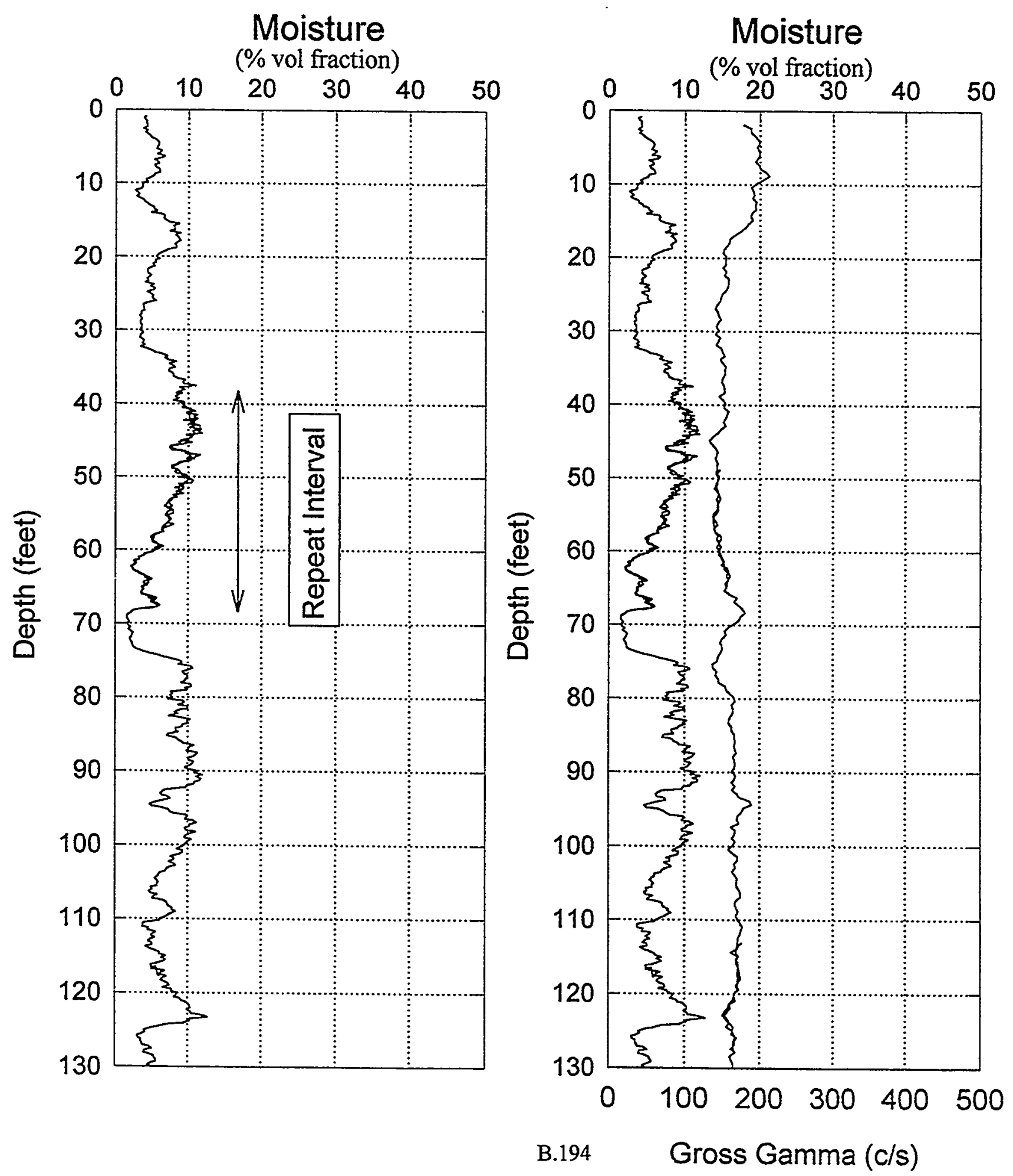


\section{RLS Moisture Processed Log Data}

Waste Management Federal Services NW

Project: Vadose Zone Monitoring Borehole: 299-E25-10

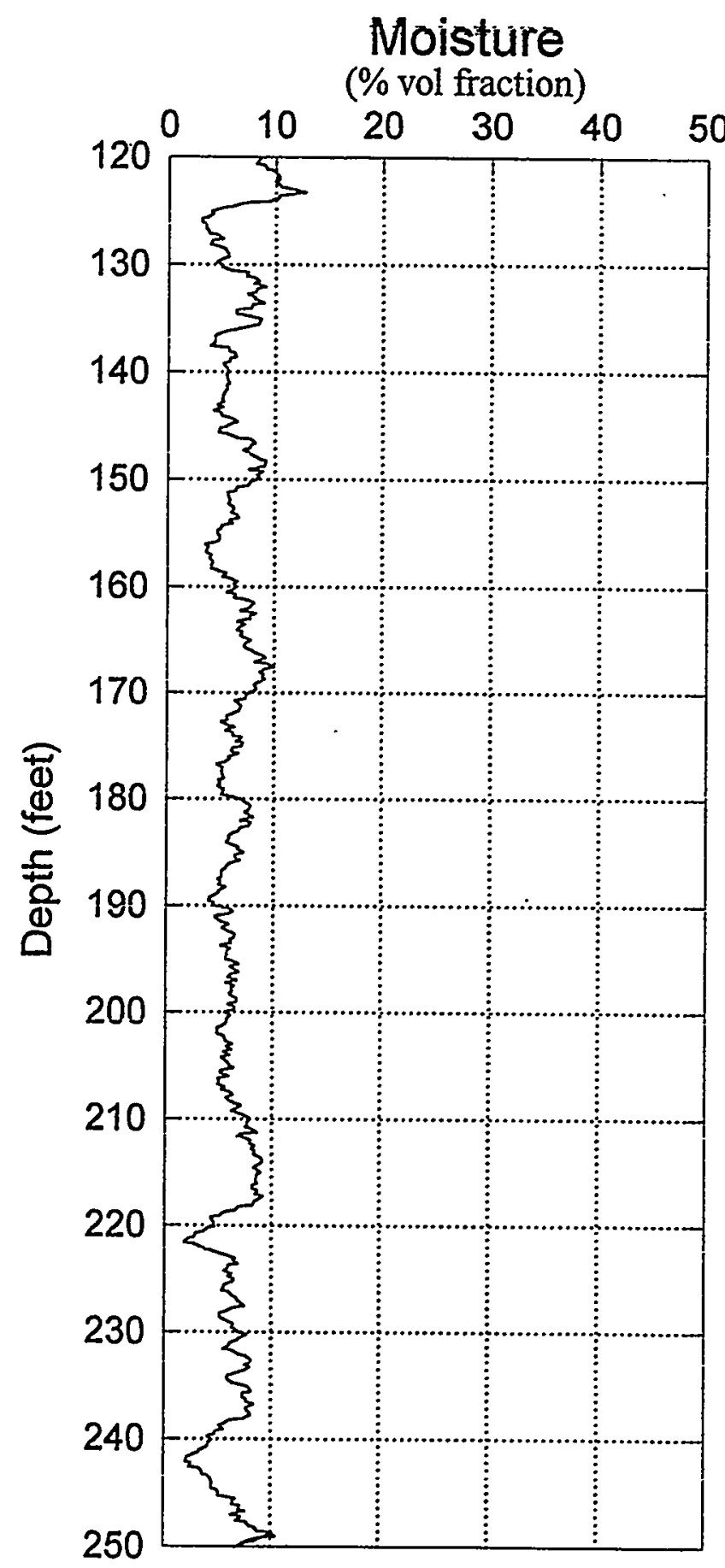

8" Casing Calibration

Log Date July 8, 1999

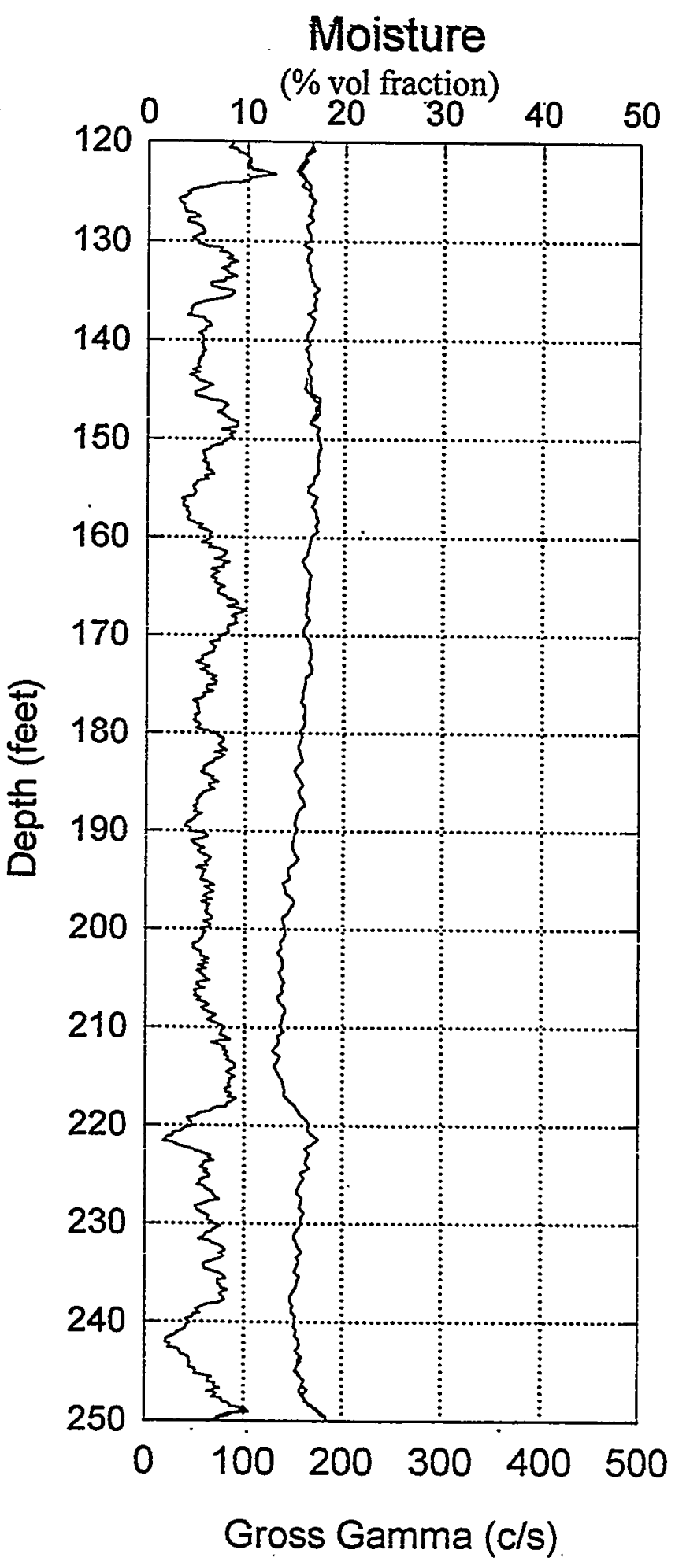

B. 195 


\section{RLS Moisture Processed Log Data}

\section{Waste Management Federal Services NW}

Project: Vadose Zone Monitoring Borehole: 299-E25-10

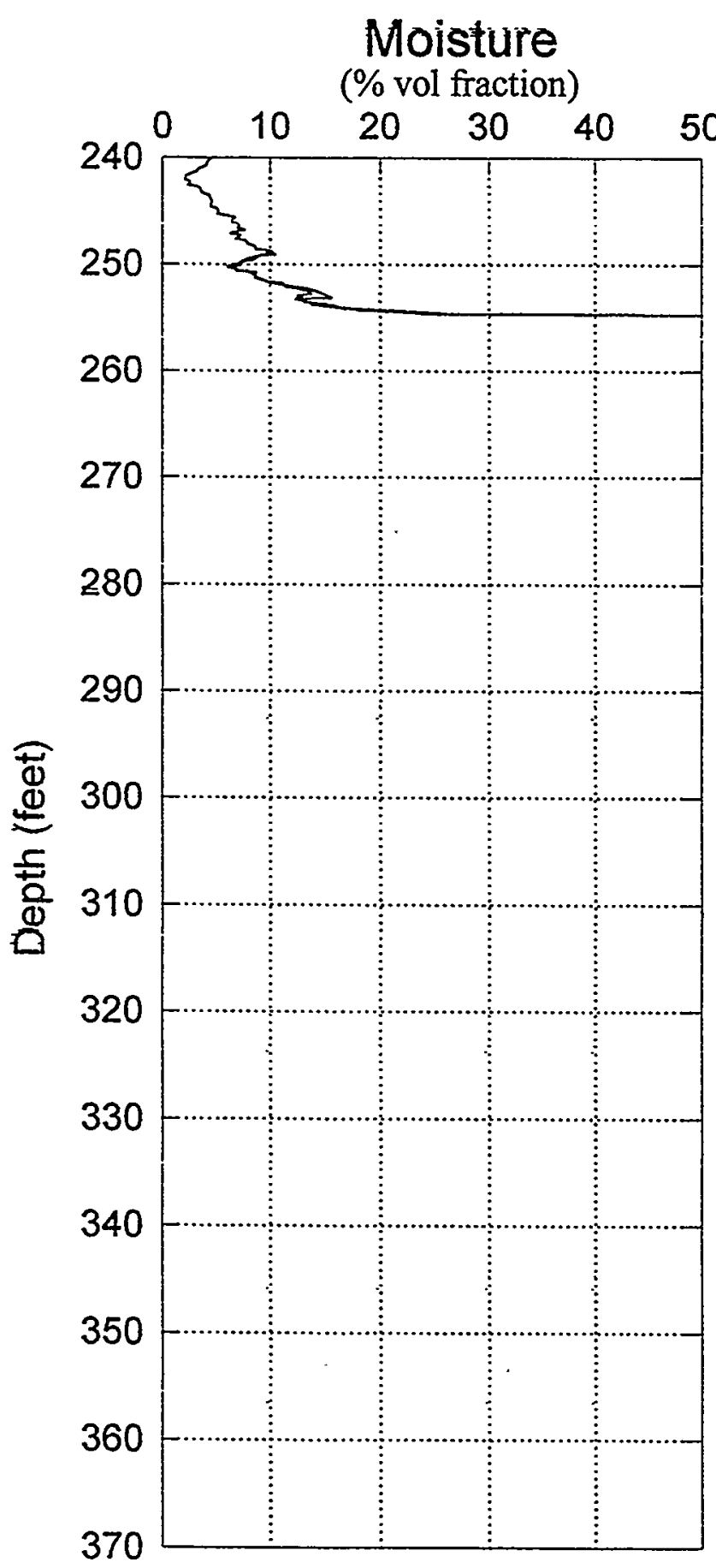

8" Casing Calibration Log Date July 8, 1999

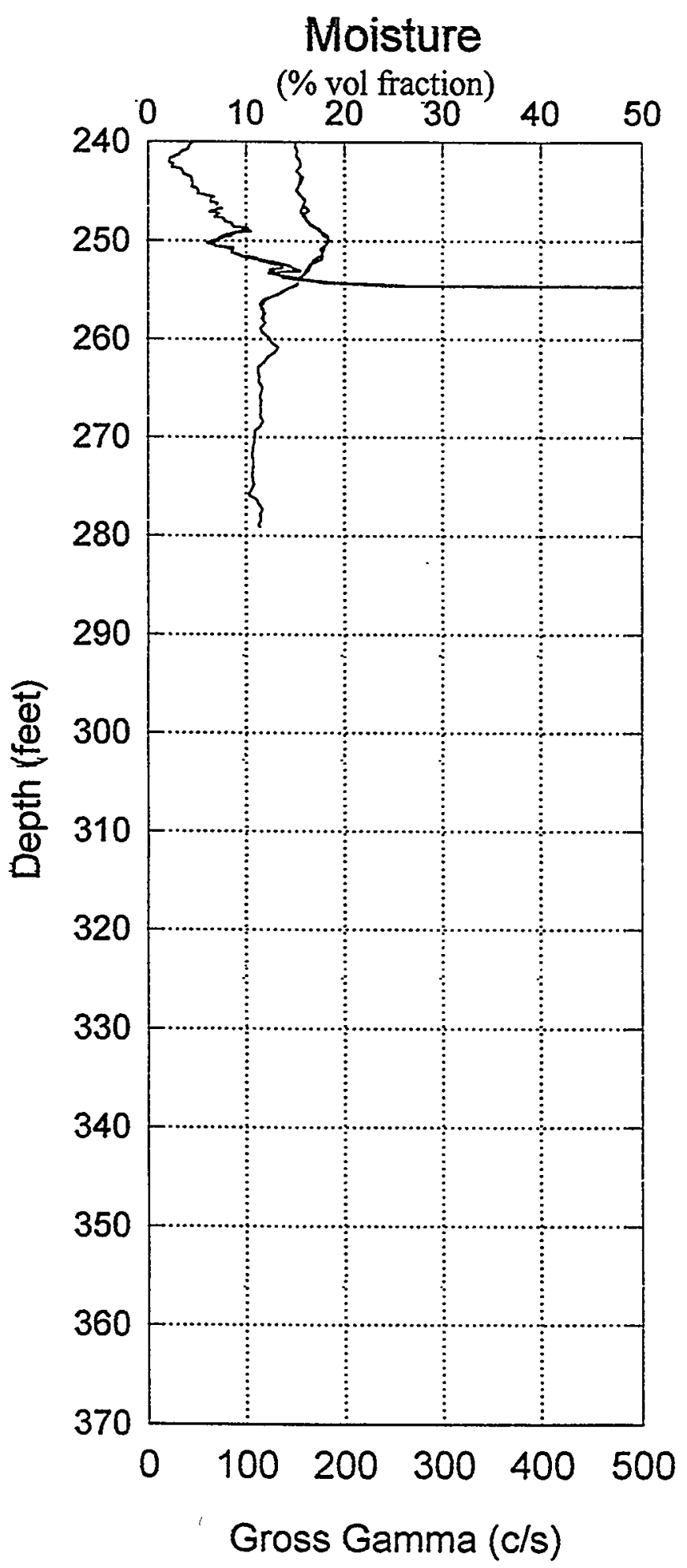

B.196 


\section{RLS \\ Log Analysis \& Summary}

Project: $\quad$ PNNL Vadose Zone Monitoring

Log Type: Moisture Gauge
Well ID:

Log Date:
299-E25-10

July 8, 1999

\section{General Notes:}

The low reading from 0 to 2 feet is due to surface effects and not necessarily the moisture content of the sediments surrounding the borehole.

Log data collected with a depth reference of top of casing, and during analysis the depths were shifted to ground surface reference for all plots.

System Performance Verify: The pre- and post-log verification passed performance standards, $-3.8 \%$ in the shield verify.

Repeat Interval: Based on the repeat interval from 39 to 69 feet, the logging system performed according to specifications.

Environmental Corrections: The moisture levels have been corrected for casing attenuation (entire well).

\section{Observations:}

The moisture levels range between $3 \%$ and $13 \%$ by volume for the entire depths logged. The maximum level of moisture occurs at a depth of 124 feet with a reading of $13 \%$ by volume. The high moisture content at a depth of 255 feet is due to the proximity of the water level in the borehole. 


\section{RLS Spectral Gamma Ray Borehole Survey \\ Waste Management Federal Services NW}

\section{Log Header}

Project: $\quad$ PNNL Vadose Zone Monitoring

Well: 299-E25-54

Log Type: $\quad$ HPGe Spectral Gamma Ray

Borehole Information

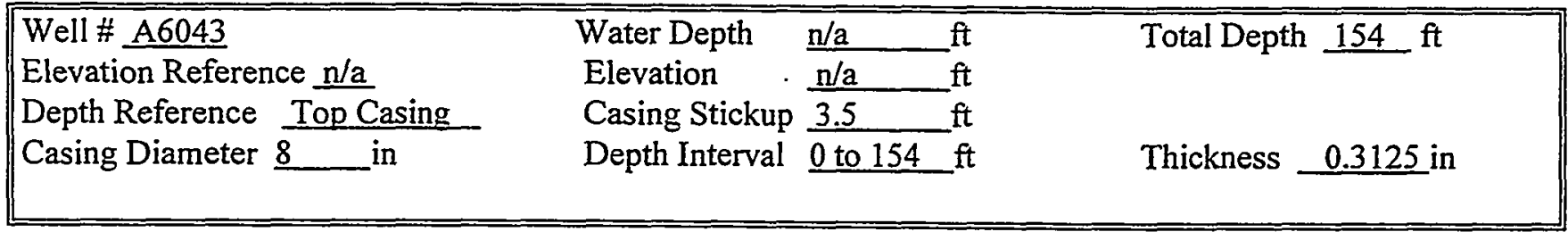

Logging Information

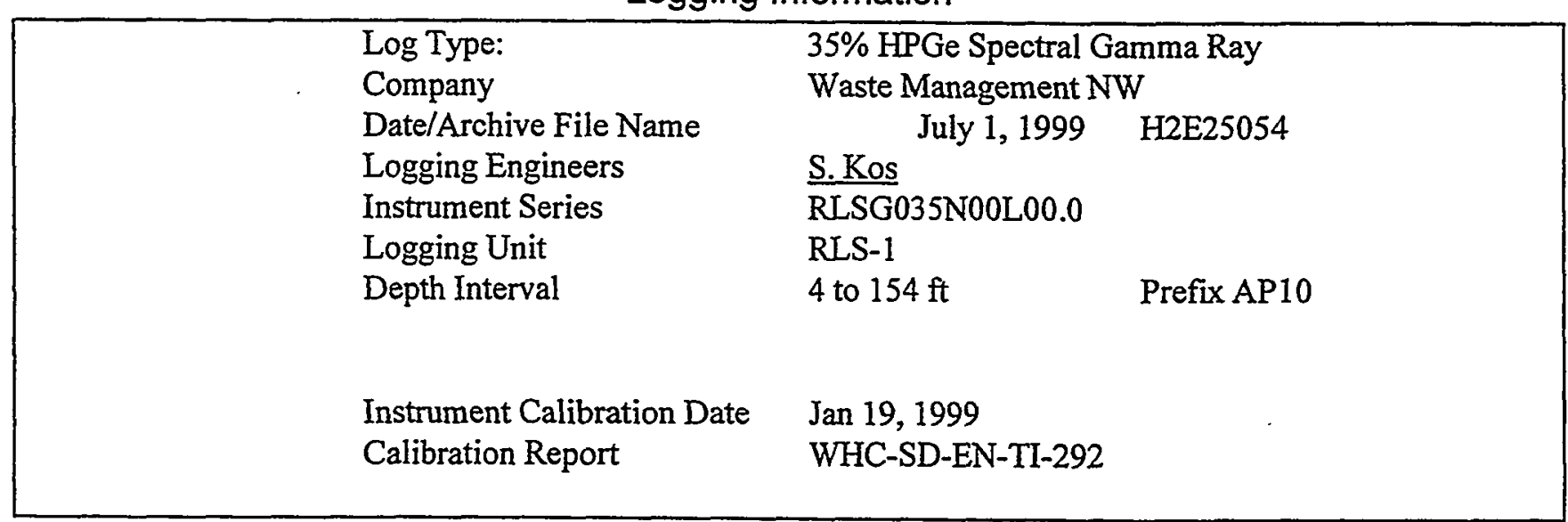

Analysis Information

\begin{tabular}{|c|c|c|}
\hline & $\begin{array}{l}\text { Company } \\
\text { Analyst } \\
\text { Date } \\
\text { Depth Reference }\end{array}$ & $\begin{array}{l}\text { Three Rivers Scientific } \\
\text { Russ Randall } \\
\text { July 10, } 1999 \\
\text { Ground Surface (plots depth shifted) }\end{array}$ \\
\hline Notes & \multicolumn{2}{|c|}{$\begin{array}{l}\text { Cs-137, Co-60, U-238, and Eu-154 are the only man made radionuclides detected. Detection of U- } \\
238 \text {, Co-60. and Eu-154 is verified using a summing technique, even though they are at or below } \\
\text { detection threshold. }\end{array}$} \\
\hline
\end{tabular}




\section{RLS Spectral Gamma Ray Borehole Survey \\ Waste Management Federal Services NW}

Project: PNNL Vadose Zone Monitoring Log Date: July 1, 1999 Borehole: 299-E25-54

Naturally Occurring Radionuclides

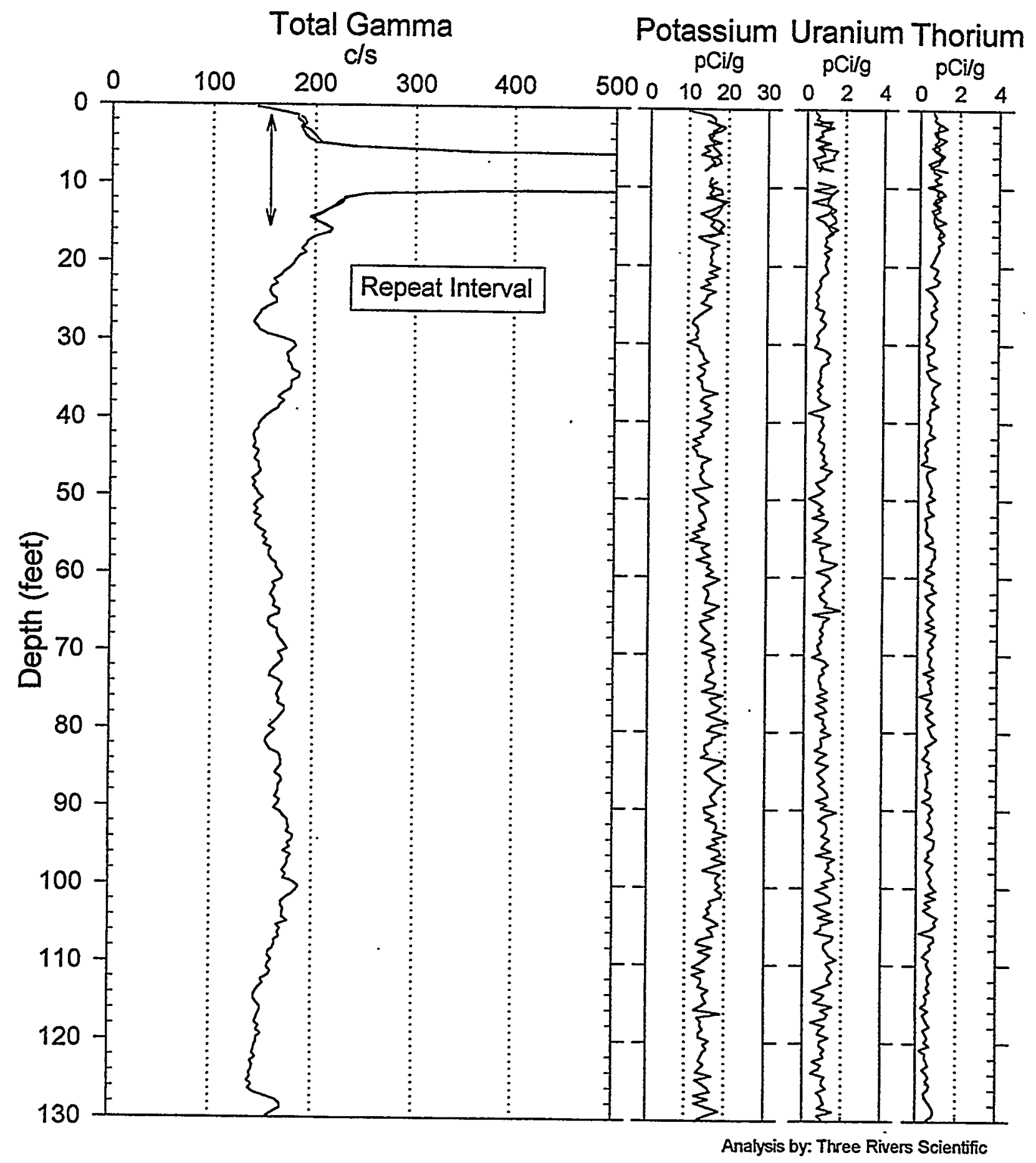




\section{RLS Spectral Gamma Ray Borehole Survey Waste Management Federal Services NW}

Project: PNNL Vadose Zone Monitoring Log Date: July 1, 1999 Borehole: 299-E25-54

Naturally Occurring Radionuclides

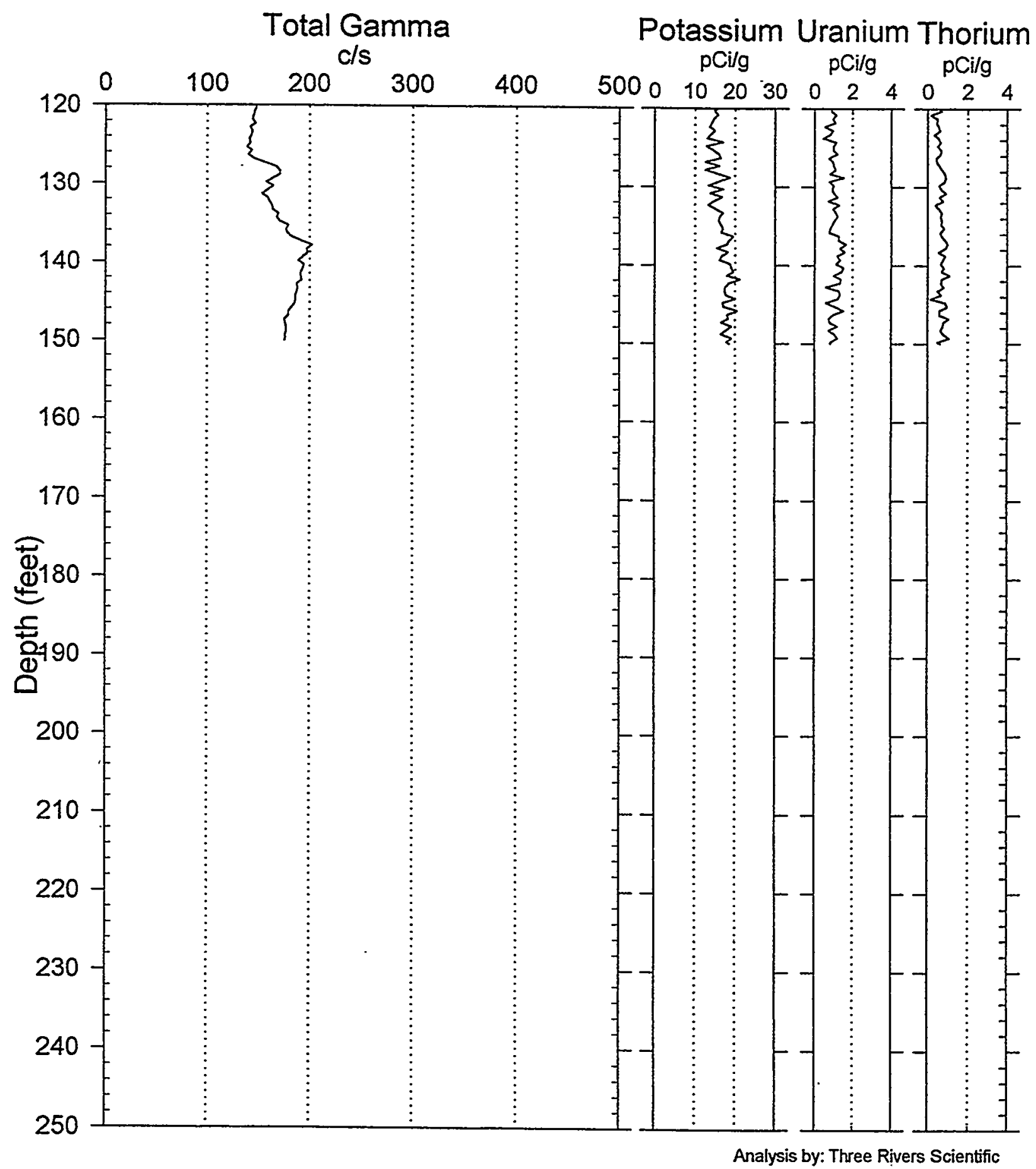


RLS Spectral Gamma-Ray Borehole Survey Waste Management Federal Services NW

Project: PNNL Vadose Zone Monitoring Borehole: 299-E25-54
Log Date: July 1, 1999 Man-Made Radionuclides

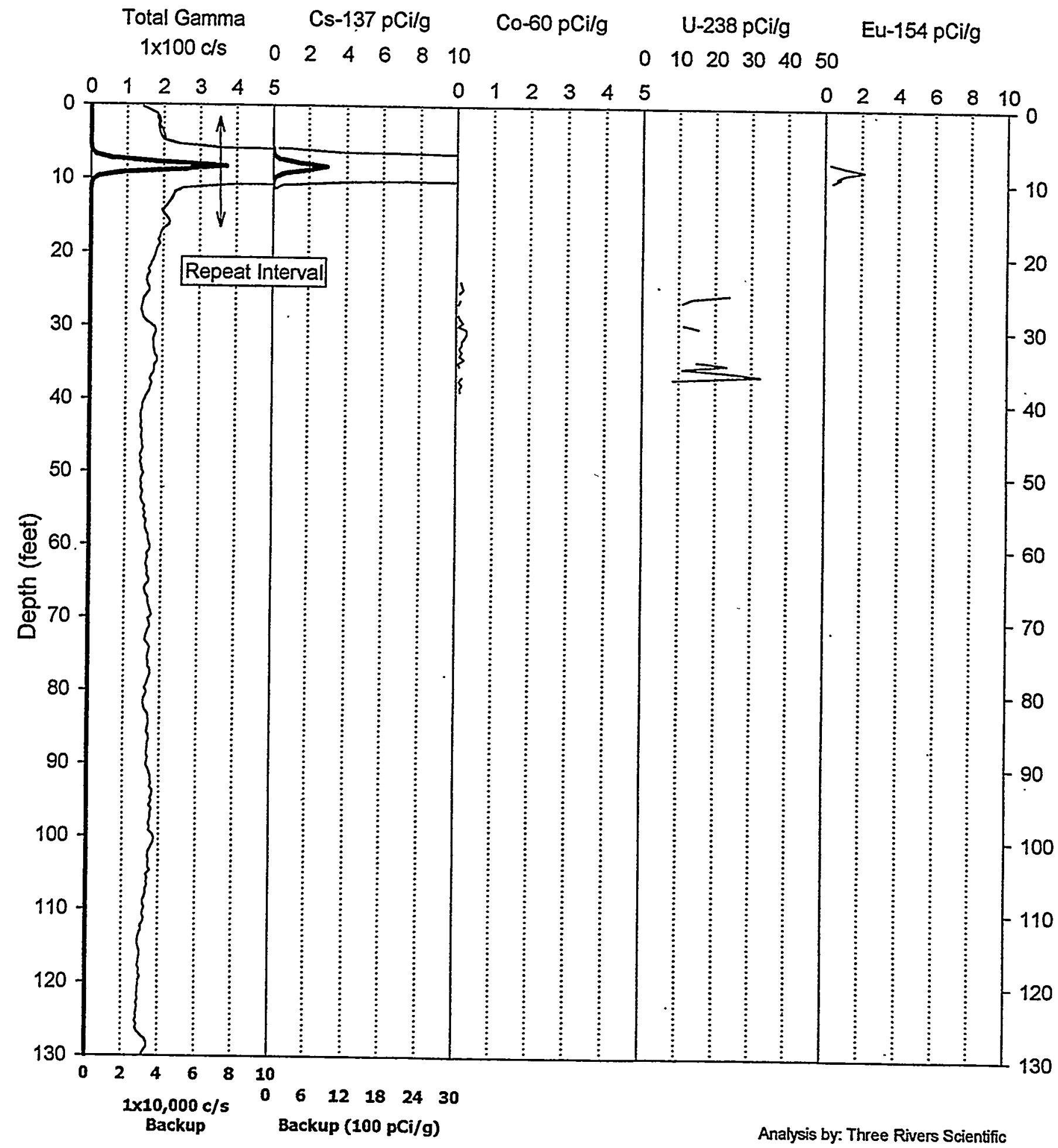




\section{RLS Spectral Gamma-Ray Borehole Survey Waste Management Federal Services NW}

Project: PNNL Vadose Zone Monitoring Borehole: 299-E25-54
Log Date: July 1, 1999 Man-Made Radionuclides

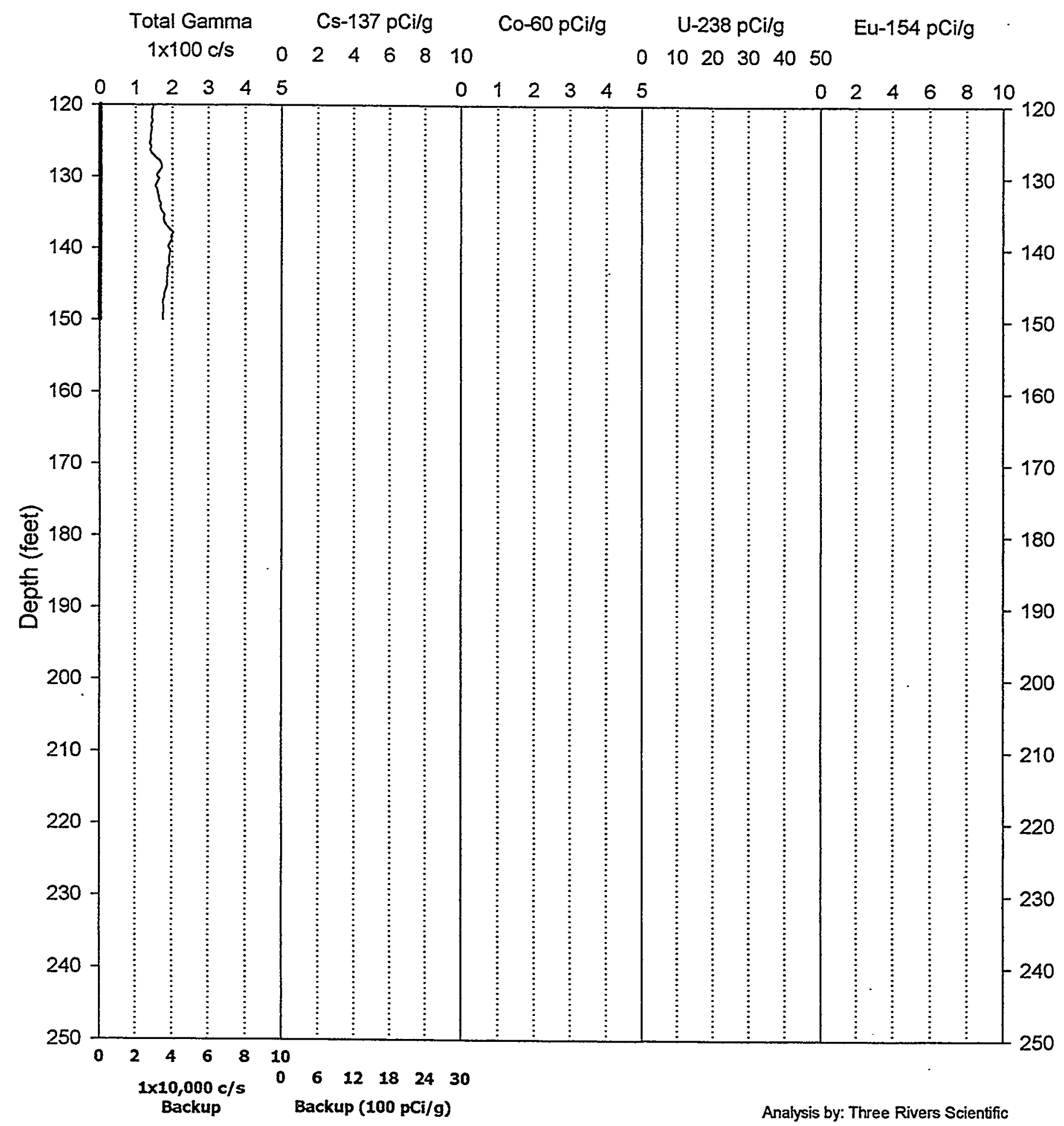




\section{RLS Spectral Gamma Ray Borehole Survey Acceptance QA Processing}

Project: PNNL Vadose Zone Monitoring Log Date: July 1, 1999 Borehole: 299-E25-54 Compare Main Log \& Repeat

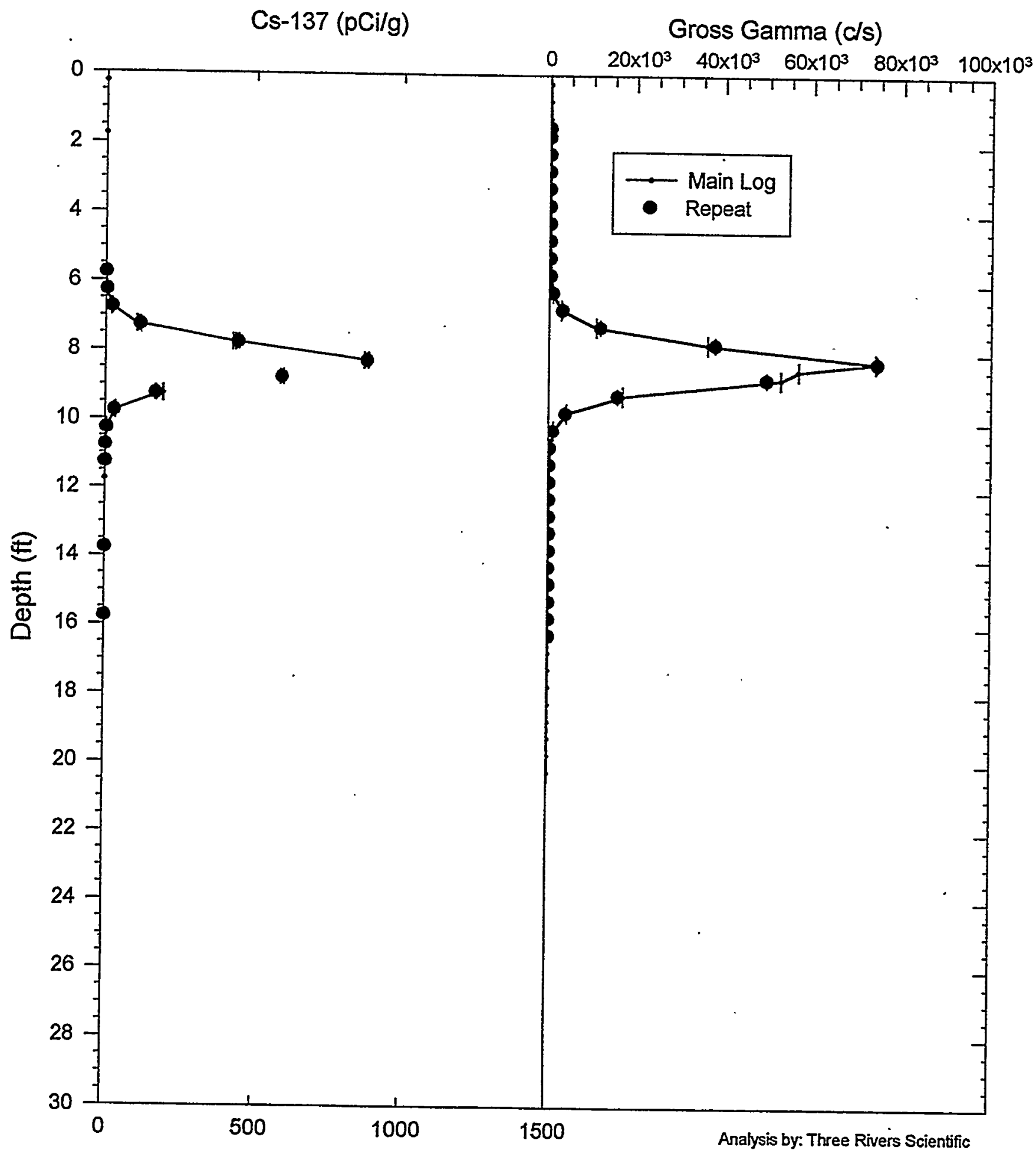




\section{RLS Spectral Gamma Ray Borehole Survey \\ Waste Management Federal Services NW}

\section{Log Analysis Summary Report}

$\begin{array}{llll}\text { Project: } & \text { PNNL Vadose Zone Monitoring } & \text { Well: } & 299-E 25-54 \\ \text { Log Type: } & \text { HPGe Spectral Gamma Ray } & \text { Log Date: } & \text { July 1, 1999 }\end{array}$

\section{General Notes:}

Total gamma is a response to geologic concentrations of natural radionuclides except for the depth intervals from 5 10 feet and from 25-35 feet. Count rate limits were exceeded from 8.25 to 9.75 feet. Even thought the instrument did not saturate, the dead time correction is inaccurate and the true concentrations over this interval are higher than recorded.

Log data collected with a depth reference of top of casing, and during analysis the depths were shifted to ground surface reference for all plots.

System Performance Verify: The pre- and post-log verification passed performance standards.

Repeat Interval: Based on the repeat interval, the logging system performed as per specifications. The error bars are calculated for 1 standard deviation of the net photo peak count rate statistical variance. Thus, the repeat should fall within these error bars $67 \%$ of the time.

Environmental Corrections: All radionuclide concentrations have been corrected for casing attenuation (entire. well). Water level is unknown and not corrected. No casing correction was applied to the total gamma due to Compton downscatter interference.

\section{Radionuclides:}

Cs-137 was identified over the depths from 10 feet. The maximum concentration of Cs- 137 occurs at a depth of 9 feet, with a reading of $880 \mathrm{pCi} / \mathrm{g}$. Cs- $137 \mathrm{MDL}$ for these $\log$ data is $0.2 \mathrm{pCi} / \mathrm{g}$. The gross gamma is a response to the Cs-137 concentration over the interval from 5 to 10 feet. The gross gamma is much higher than the concentration of Cs- 137 would generate. Since the other radionuclides are also at low levels, this relatively higher gross for the radionuclides identified indicates the presence of a strong remote source or the presence of a strong beta emitter such as $\mathrm{Sr}-90$.

Co-60 was identified over the depths from 24-39 feet. The maximum concentration of Co-60 occurs at a depth of 30.75 feet with a reading of $0.3 \mathrm{pCi} / \mathrm{g}$. Co-60 MDL for these log data is $0.2 \mathrm{pCi} / \mathrm{g}$.

U-238 was identified over the depths from $25-37$ feet, but is at detection threshold and verified by a summing by 4 technique. U-238 MDL for these log data is $25 \mathrm{pCi} / \mathrm{g}$.

U-235 is suspected, but must be below detection threshold even for the summing technique.

Eu-154 was identified over the depths from 8-10 feet. The Eu-154 response is only detected on the repeat interval and not on the main pass logging run; however, the summing by 4 technique verifies the presence of Eu-154. The maximum concentration of Eu-154 occurs at a depth of 8.75 feet and is greater than $2 \mathrm{pCi} / \mathrm{g}$ due to dead time correction under-estimates at this depth. The identification of Eu-154 for these data relies on only the $1274 \mathrm{keV}$ photo peak, due to interference from the other isotope generated gammas. Eu-154 MDL for these log data is 2.5 $\mathrm{pCi} / \mathrm{g}$. 


\section{Moisture Logging Service \\ Log Header}

Project: $\quad$ PNNL Vadose Zone Monitoring

Well: 299-E25-54

Log Type: $\quad$ Moisture Gauge

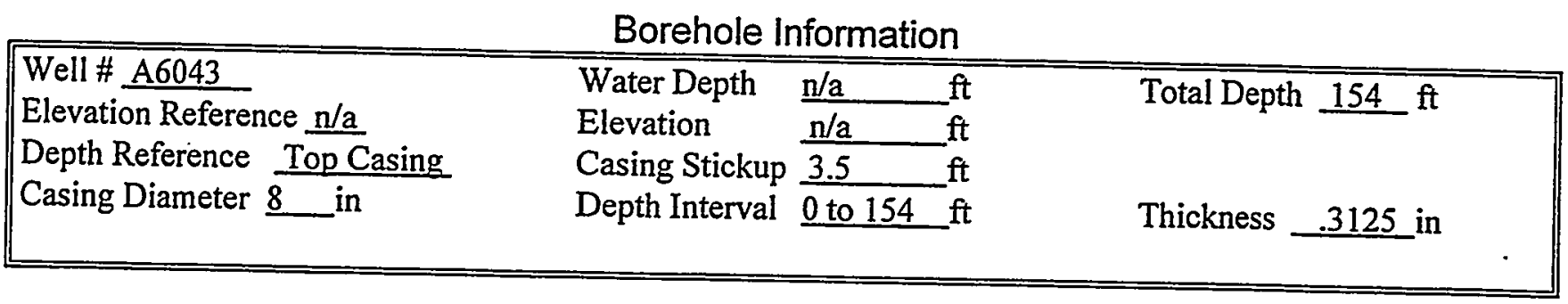

\section{Logging Information}

\begin{tabular}{|c|c|c|}
\hline Log Type: & Moisture Gauge & \\
\hline Company & Waste Management $\mathrm{N}$ & \\
\hline Date/Archive File Name & July 8,1999 & M2E33008 \\
\hline Logging Engineers & $\underline{\text { R.K. Price }}$ & \\
\hline Instrument Series & RLSM3.1 & \\
\hline Logging Unit & RLS-3 & \\
\hline Depth Interval & 4 to $154 \mathrm{ft}$ & Prefix MS20 \\
\hline
\end{tabular}

Instrument Calibration Date

May 13,1999

Calibration Report

WHC-SD-EN-TI-306, Rev. 0

\section{Analysis Information}

$\begin{array}{ll}\text { Company } & \text { Three Rivers Scientific } \\ \text { Analyst } & \text { Russ Randall } \\ \text { Date } & \text { June 15, 1999 } \\ \text { Depth Reference } & \text { Ground Surface (plots depth shifted) }\end{array}$

Notes Moisture values range from $3 \%$ to $32 \%$ for most of the depths logged. The highest observed moisture zone occurs at the depth of 131 feet with a reading of $32 \%$ by volume. There does not appear anv correlation between the gross gamma and the moisture values. 


\section{RLS Moisture Processed Log Data}

\section{Waste Management Federal Services NW}

Project: Vadose Zone Monitoring

Borehole: 299-E25-54
8" Casing Calibration Log Date July 8, 1999
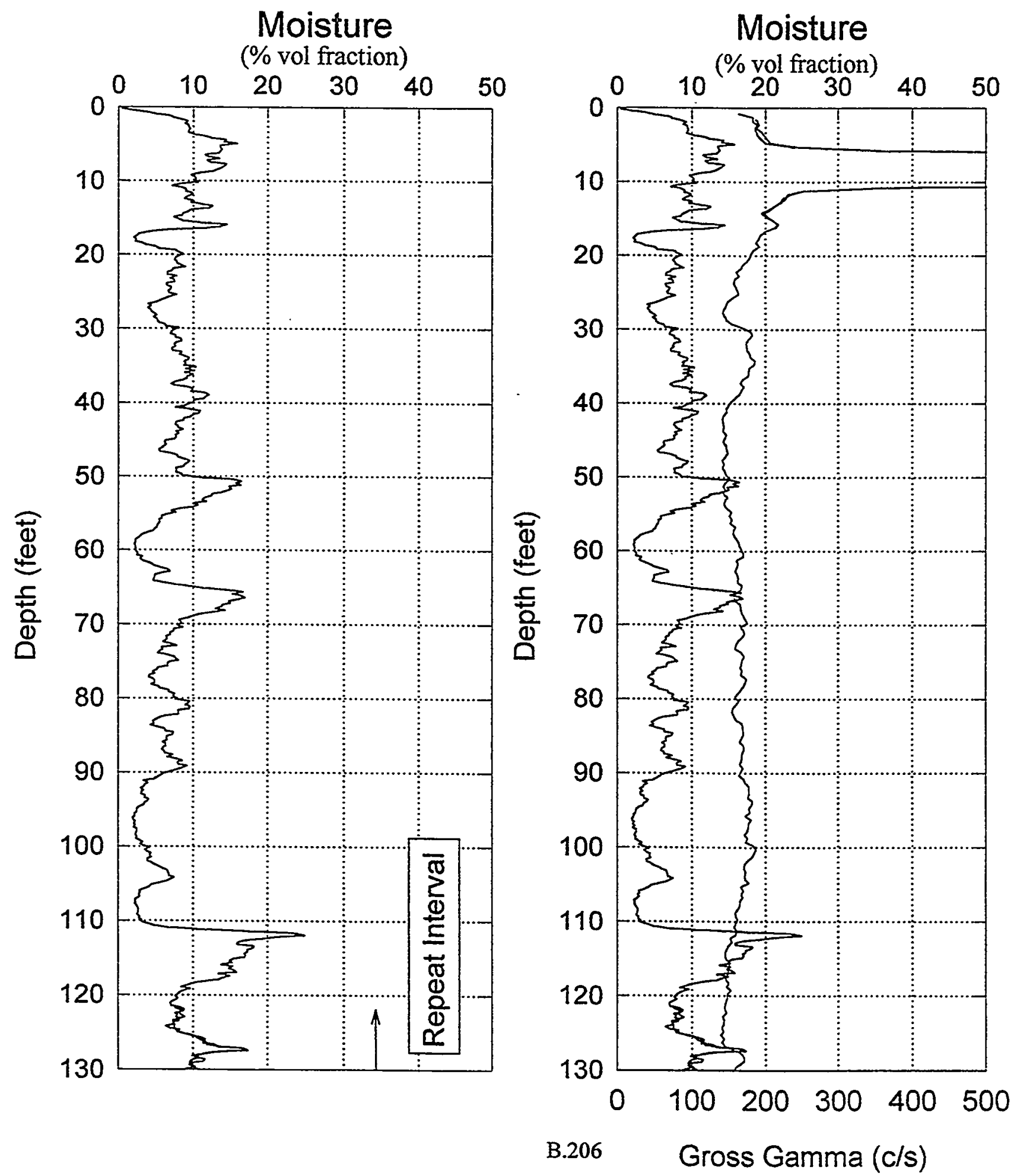


\section{RLS Moisture Processed Log Data}

\section{Waste Management Federal Services NW}

Project: Vadose Zone Monitoring

Borehole: 299-E25-54
8" Casing Calibration Log Date July 8, 1999
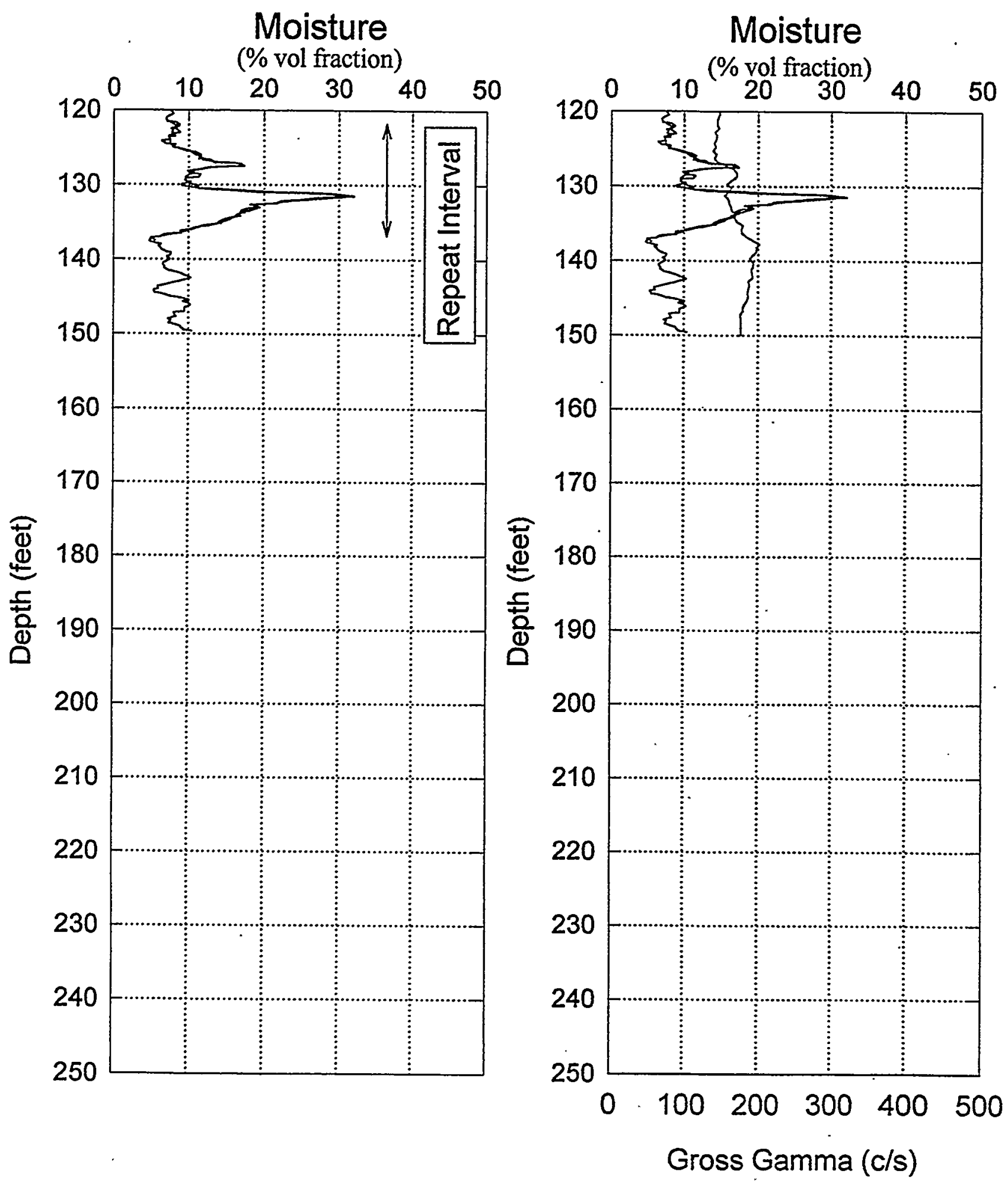


\section{RLS \\ Log Analysis \& Summary}

$\begin{array}{llll}\text { Project: } & \text { PNNL Vadose Zone Monitoring } & \text { Well ID: } & \text { 299-E25-54 } \\ \text { Log Type: } & \text { Moisture Gauge } & \text { Log Date: } & \text { July 8, 1999 }\end{array}$

General Notes:

The low reading from 0 feet to 2 feet is due to surface effects and not necessarily the moisture content of the earth surrounding the borehole.

Log data collected with a depth reference of top of casing, and during analysis the depths were shifted to ground surface reference for all plots.

System Performance Verify: The pre- and post-log verification passed performance standards, $-2.8 \%$ in the shield verify.

Repeat Interval: Based on the repeat interval from 125 to 141 feet, the logging system performed according to specifications.

Environmental Corrections: The moisture levels have been corrected for casing attenuation (entire well).

\section{Observations:}

The moisture levels show character for entire depths logged. The highest moisture interval is a thin zone at 131 feet, with a reading of $32 \%$ by volume. 


\section{RLS Spectral Gamma Ray Borehole Survey \\ Waste Management Federal Services NW}

\section{Log Header}

Project: PNNL Vadose Zone Monitoring Well: 299-E33-08

Log Type: HPGe Spectral Gamma Ray

Borehole Information

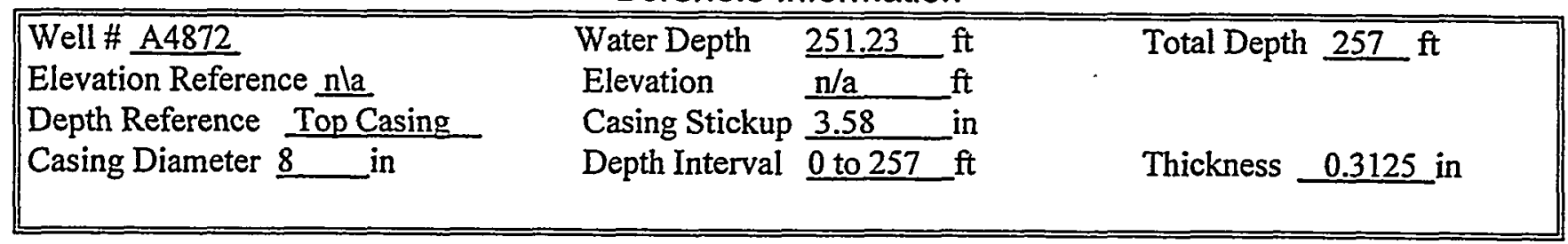

Logging Information

Log Type:

Company

Date/Archive File Name

Logging Engineers

Instrument Series

Logging Unit

Depth Interval .

Instrument Calibration Date

Calibration Report
35\% HPGe Spectral Gamma Ray

Waste Management NW

R.K. Price

June 3, 1999 H2E33008

RLSG3.2

RLS-2

2 to $257 \mathrm{ft} \quad$ Prefix B232

Jan 19, 1999

WHC-SD-EN-TI-292

Analysis Information

$\begin{array}{ll}\text { Company } & \text { Three Rivers Scientific } \\ \text { Analyst } & \text { Russ Randall } \\ \text { Date } & \text { June 29, 1999 } \\ \text { Depth Reference } & \text { Ground Surface (plots depth shifted) }\end{array}$

Notes $\mathrm{Cs}-137, \mathrm{Co}-60$, and $\mathrm{Sb}-125$ are the only man made radionuclides detected. Detection of $\mathrm{Sb}-125$ required a summing technique since the levels are at detection threshold. Co- 60 appears at threshold near the bottom of the well from 252 to 256 feet, but the summing technique confirms its presence. 


\section{RLS Spectral Gamma Ray Borehole Survey Waste Management Federal Services NW}

Project: PNNL Vadose Zone Monitoring Borehole: 299-E33-08
Log Date: June 3, 1999 Man-Made Radionuclides

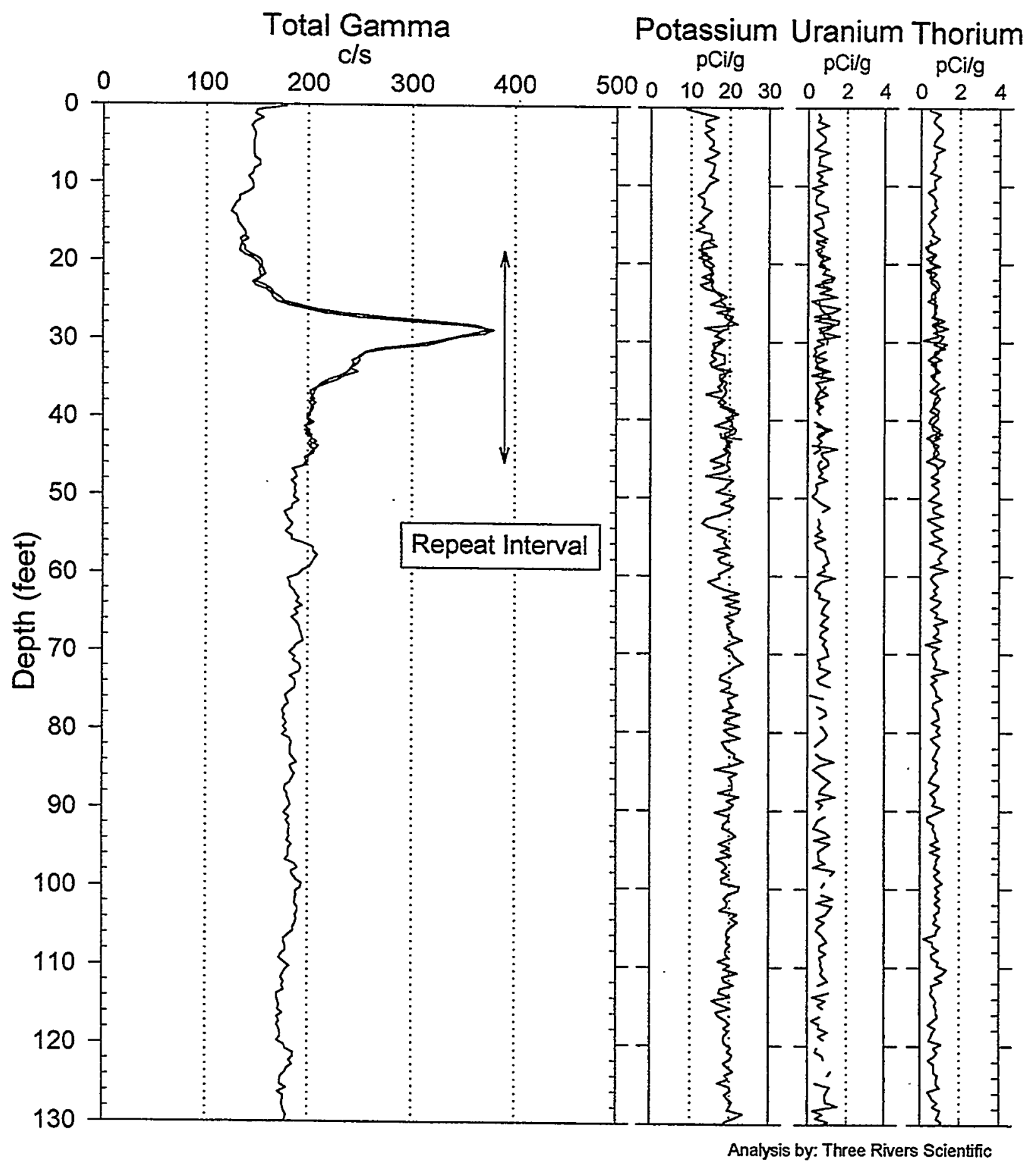




\section{RLS Spectral Gamma Ray Borehole Survey \\ Waste Management Federal Services NW}

Project: PNNL Vadose Zone Monitoring Borehole: 299-E33-08

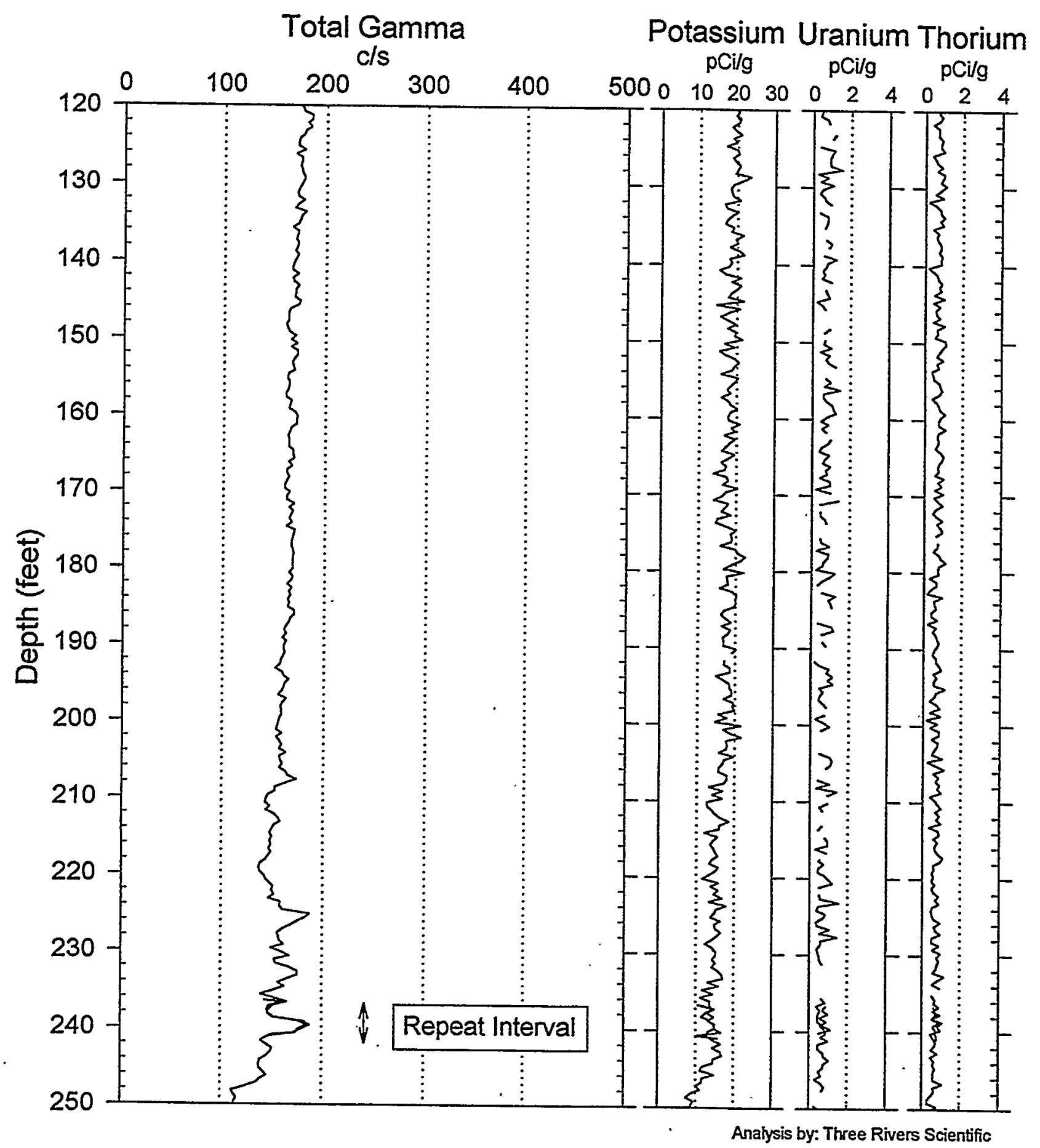

Log Date: June 3, 1999 Man-Made Radionuclides 


\section{RLS Spectral Gamma Ray Borehole Survey \\ Waste Management Federal Services NW}

Project: PNNL Vadose Zone Monitoring Borehole: 299-E33-08
Log Date: June 3, 1999 Man-Made Radionuclides

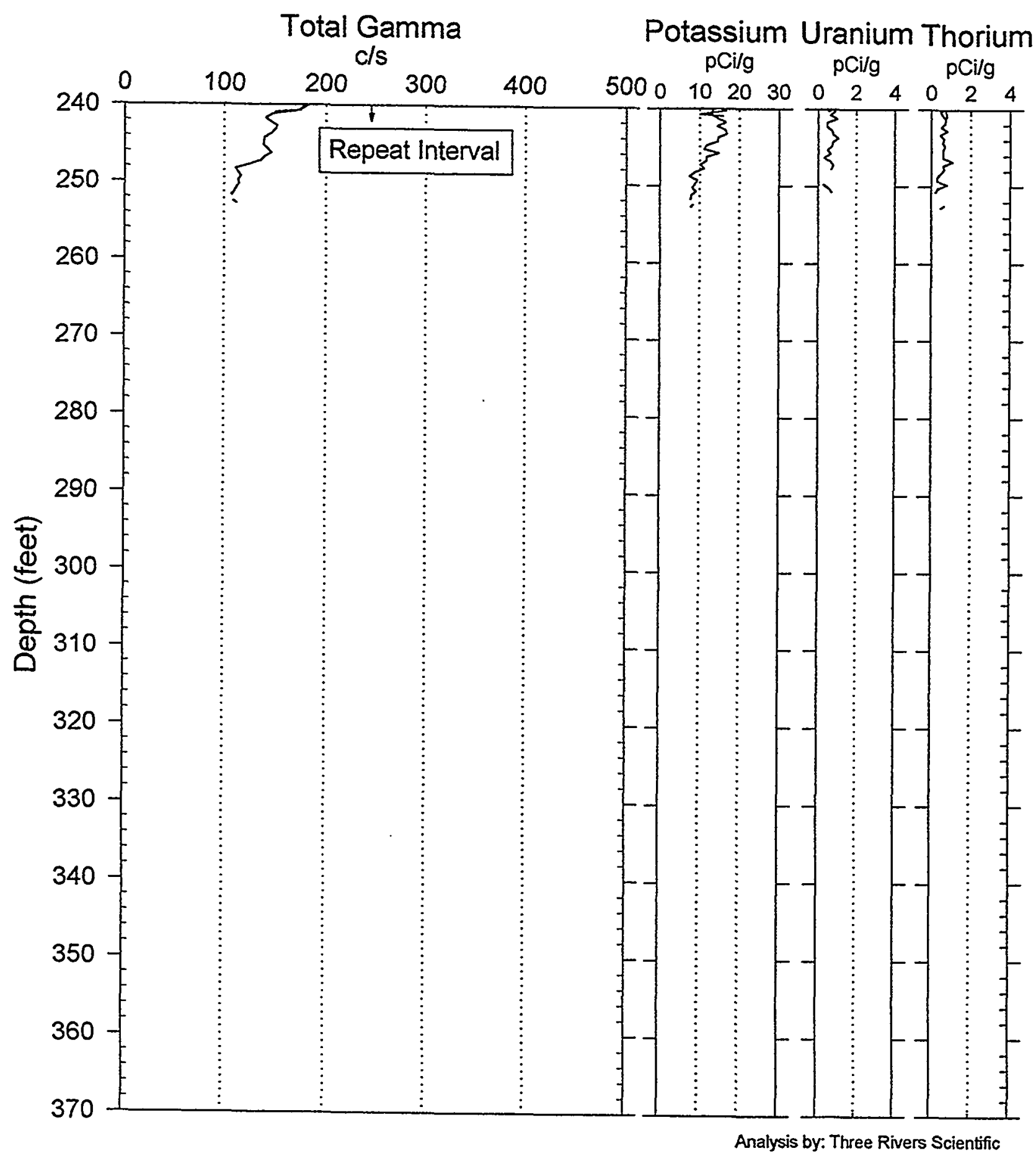




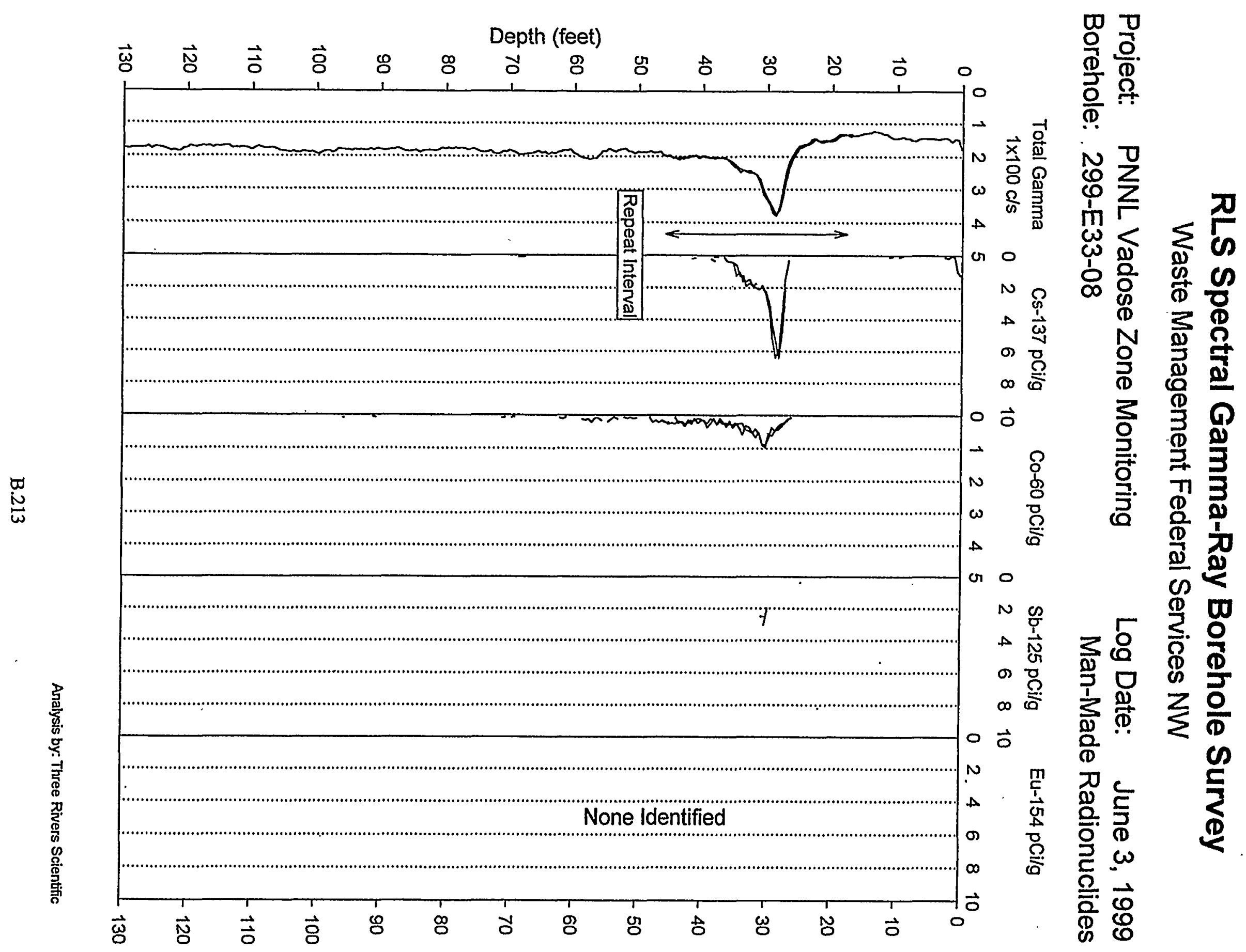




\section{RLS Spectral Gamma-Ray Borehole Survey}

\section{Waste Management Federal Services NW}

Project: PNNL Vadose Zone Monitoring Borehole: 299-E33-08
Log Date: June 3, 1999 Man-Made Radionuclides

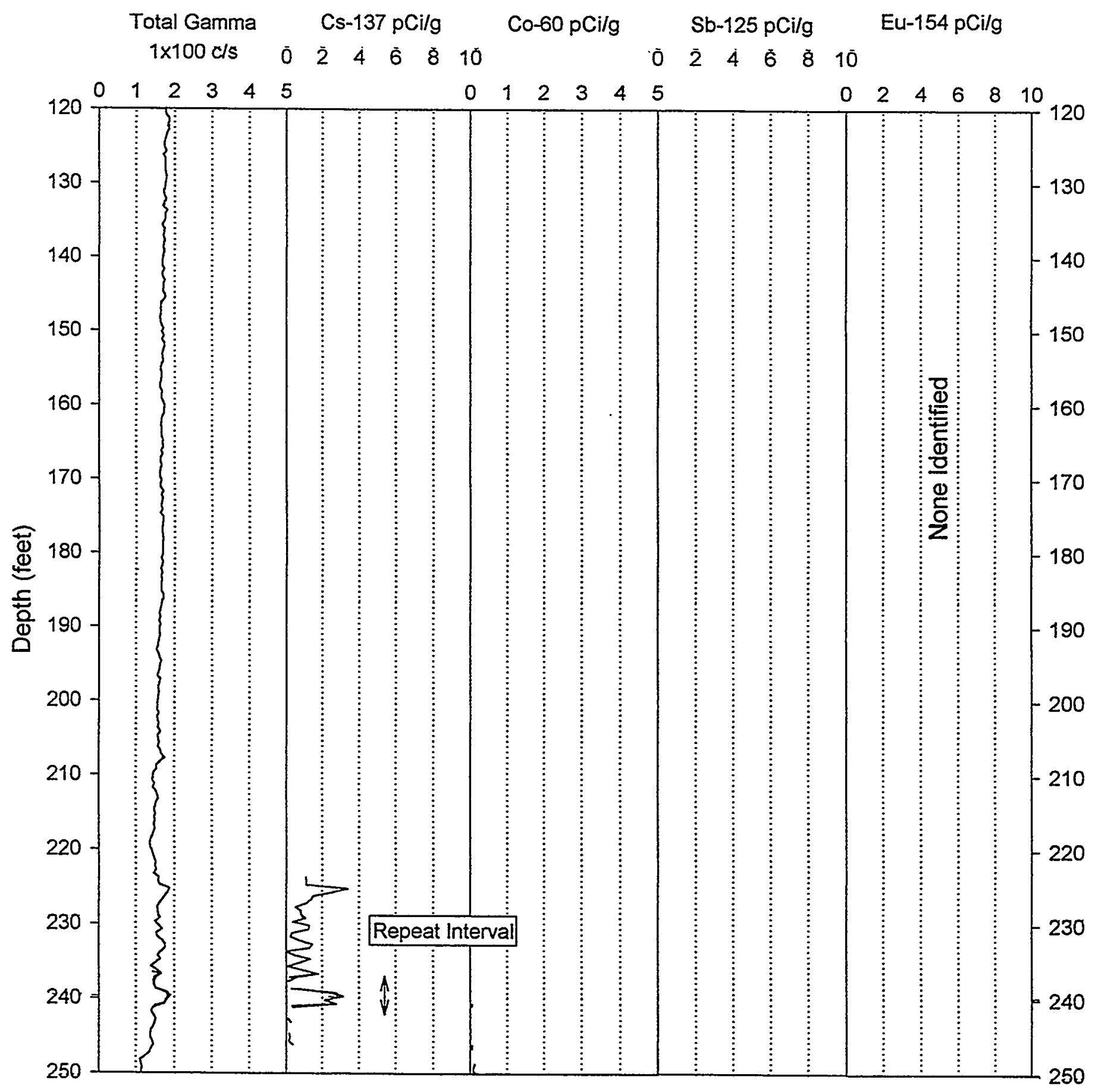




\section{RLS Spectral Gamma-Ray Borehole Survey Waste Management Federal Services NW}

Project: PNNL Vadose Zone Monitoring Log Date: June 3, 1999 Borehole: 299-E33-08 Man-Made Radionuclides

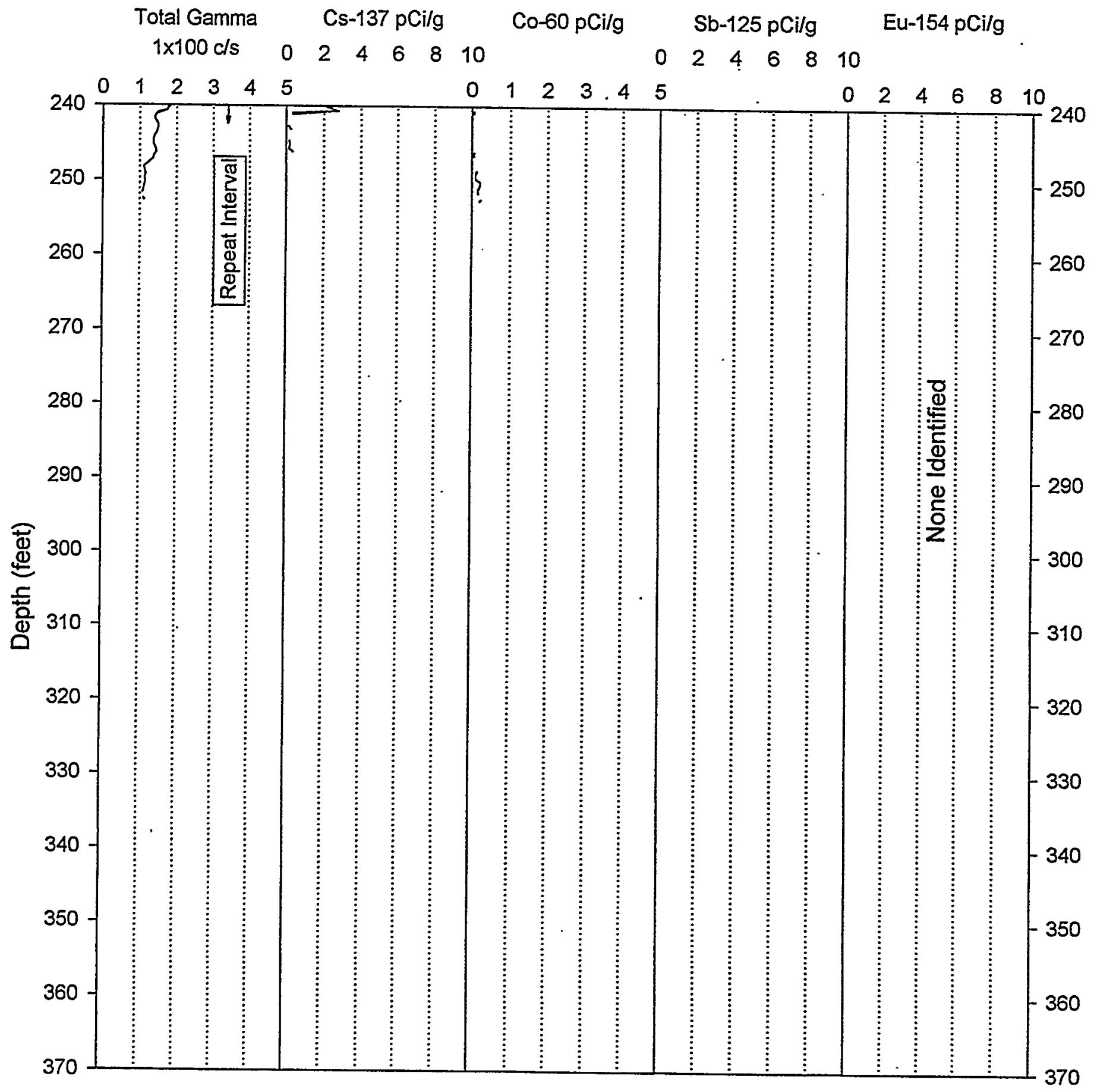




\section{RLS Spectral Gamma Ray Borehole Survey Acceptance QA Processing}

Project: PNNL Vadose Zone Monitor Log Date: June 3, 1999 Borehole: 299-E33-08

Compare Main Log \& Repeat

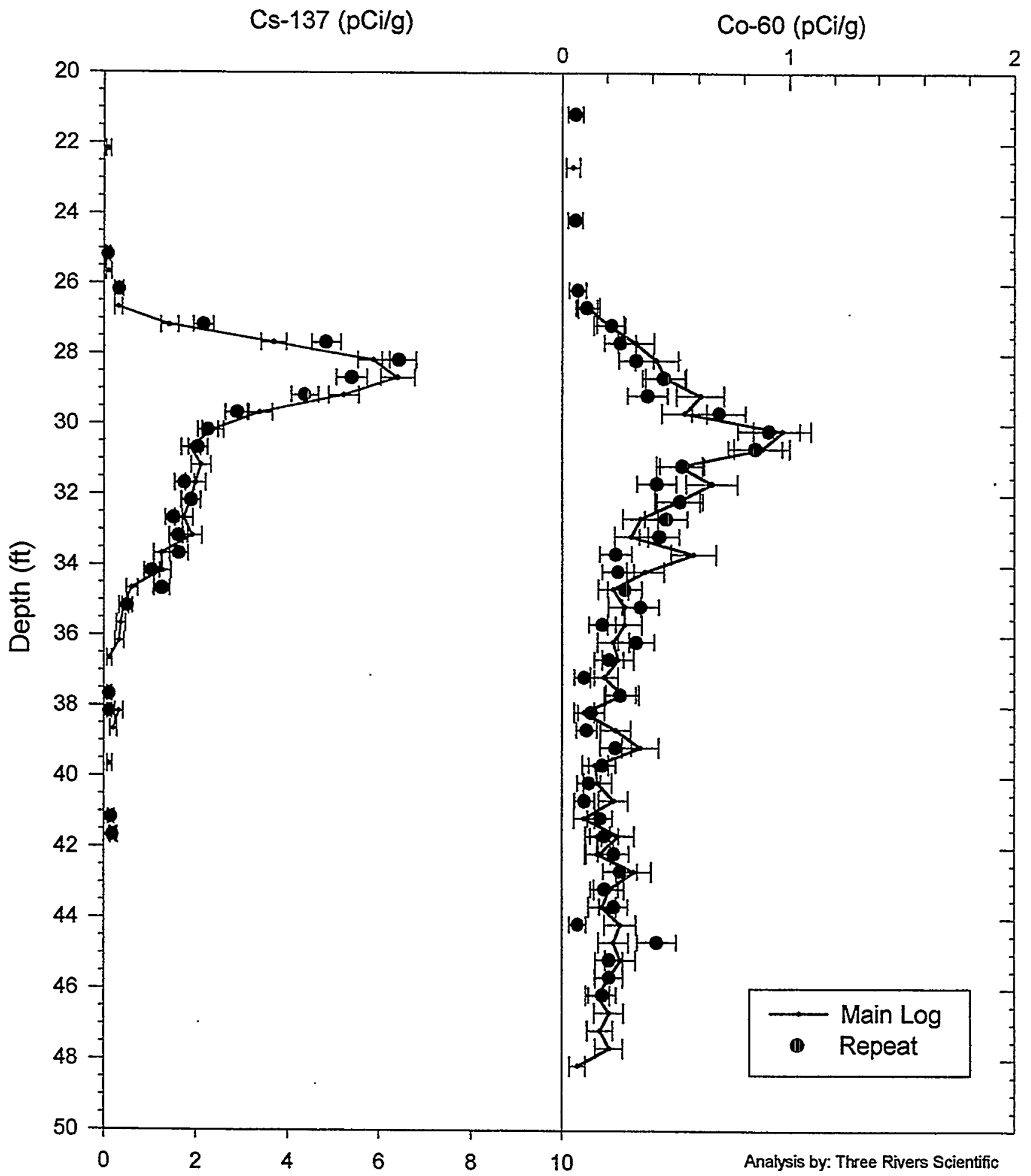




\section{RLS Spectral Gamma Ray Borehole Survey}

Waste Management Federal Services NW

\section{Log Analysis Summary Report}

$\begin{array}{ll}\text { Project: } & \text { PNNL Vadose Zone Monitoring } \\ \text { Log Type: } & \text { HPGe Spectral Gamma Ray }\end{array}$
Well:

299-E33-08

Log Dates: June 3, 1999

\section{General Notes:}

Total gamma is a response to geologic concentrations of natural radionuclides except for the depth intervals from 30-50 feet and from $228-250$ feet.

Log data collected with a depth reference of top of casing, and during analysis the depths were shifted to ground surface reference for all plots.

System Performance Verify: The pre- and post-log verification passed performance standards.

Repeat Interval: Based on the repeat interval, the logging system performed as per specifications. The error bars are calculated for 1 standard deviation of the net photo peak count rate statistical variance. Thus, the repeat should fall within these error bars $67 \%$ of the time.

Environmental Corrections: All radionuclide concentrations have been corrected for casing attenuation (entire well). Water level is below depths logged. No casing correction was applied to the total gamma due to Compton downscatter interference.

\section{Radionuclides:}

Cs-137 was identified over the depths from $26-41$ feet, and from 224-244 feet. The Cs-137 from 0-2 feet may be surface contamination. The maximum concentration of Cs-137 occurs at a depth of 27 feet, with a reading of 6 $\mathrm{pCi} / \mathrm{g}$. Cs-137 MDL for this borehole condition is $0.4 \mathrm{pCi} / \mathrm{g}$.

Co-60 was identified over the depths from 26-61 feet, and from 248-252 feet. (Note, the Co-60 from 248-252 feet is at detection threshold, but a summing by 4 technique confirms its presence.) The maximum concentration of Co60 occurs at a depth of 30 feet, with a reading of $1 \mathrm{pCi} / \mathrm{g}$. Co-60 MDL for this borehole condition is $0.2 \mathrm{pCi} / \mathrm{g}$.

Sb-125 was identified at the depth of 30 feet. This Sb-125 level of detection is at threshold, but confirmed using a summing by 4 technique. The maximum concentration of Sb-125 occurs at a depth of 30 feet, with a reading of 3 $\mathrm{pCi} / \mathrm{g}$. Sb-125 MDL for this borehole condition is $2.5 \mathrm{pCi} / \mathrm{g}$. 


\section{Moisture Logging Service Log Header}

Project: $\quad$ PNNL Vadose Zone Monitoring

Well: 299-E33-08

Log Type: Moisture Gauge

Borehole Information

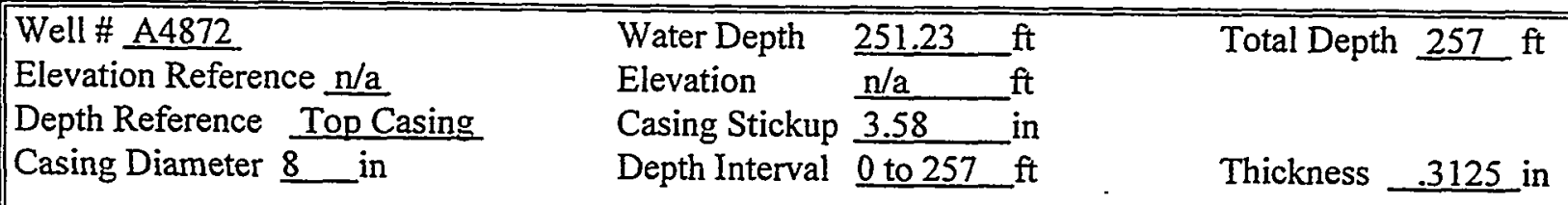

Logging Information

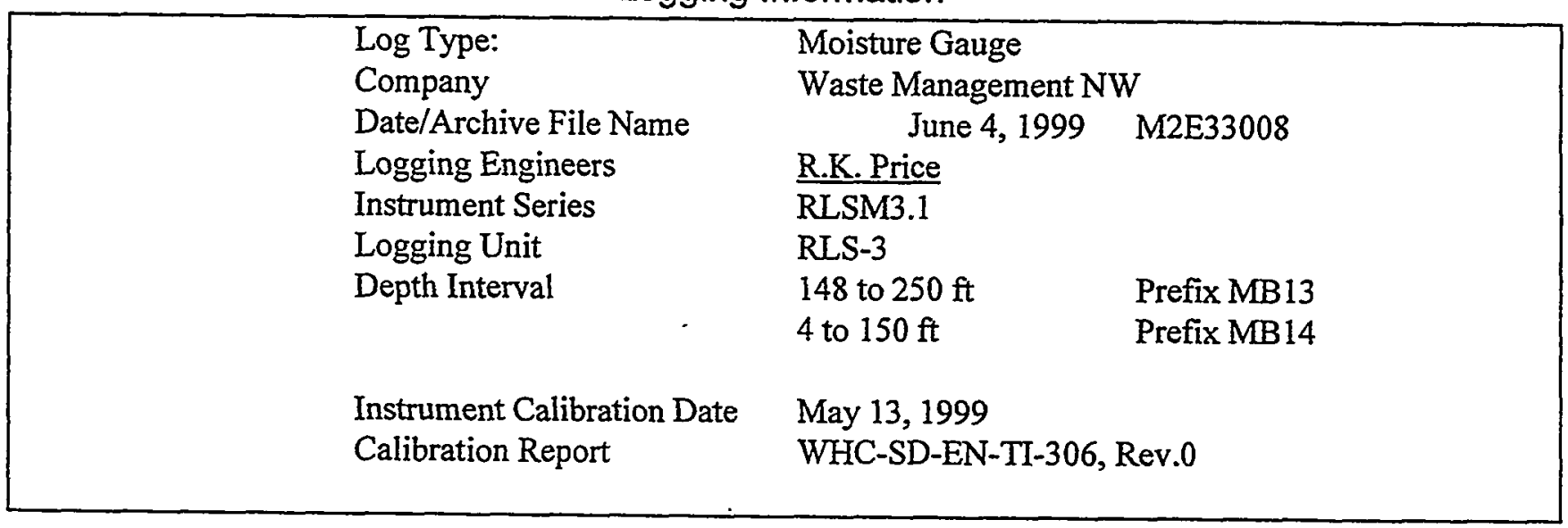

Analysis Information

$\begin{array}{ll}\text { Company } & \text { Three Rivers Scientific } \\ \text { Analyst } & \text { Russ Randall } \\ \text { Date } & \text { June 15, 1999 } \\ \text { Depth Reference } & \text { Ground Surface (plots depth shifted) }\end{array}$

Notes The moisture response has some character from 4 to 78 feet, and below 78 feet to bottom of the well. the moisture is reading is at or below $5 \%$ by volume. The high moisture reading at the bottom is due to encounter of the water level. 


\section{RLS Moisture Processed Log Data}

\section{Waste Management Federal Services NW}

Project: Vadose Zone Monitoring Borehole: 299-E33-08
8" Casing Calibration

Log Date June 4, 1999
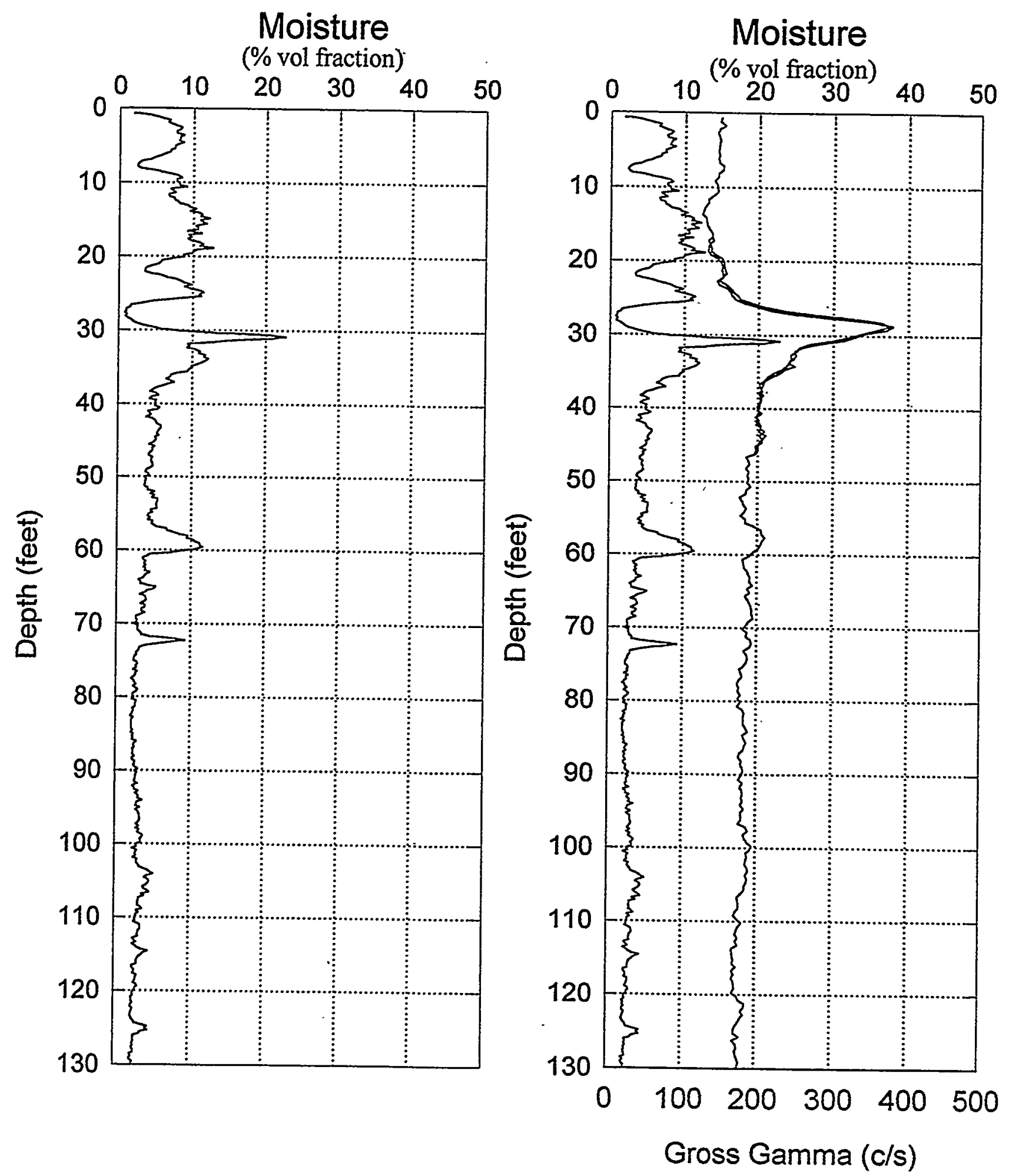


\section{RLS Moisture Processed Log Data}

\section{Waste Management Federal Services NW}

Project: Vadose Zone Monitoring Borehole: 299-E33-08

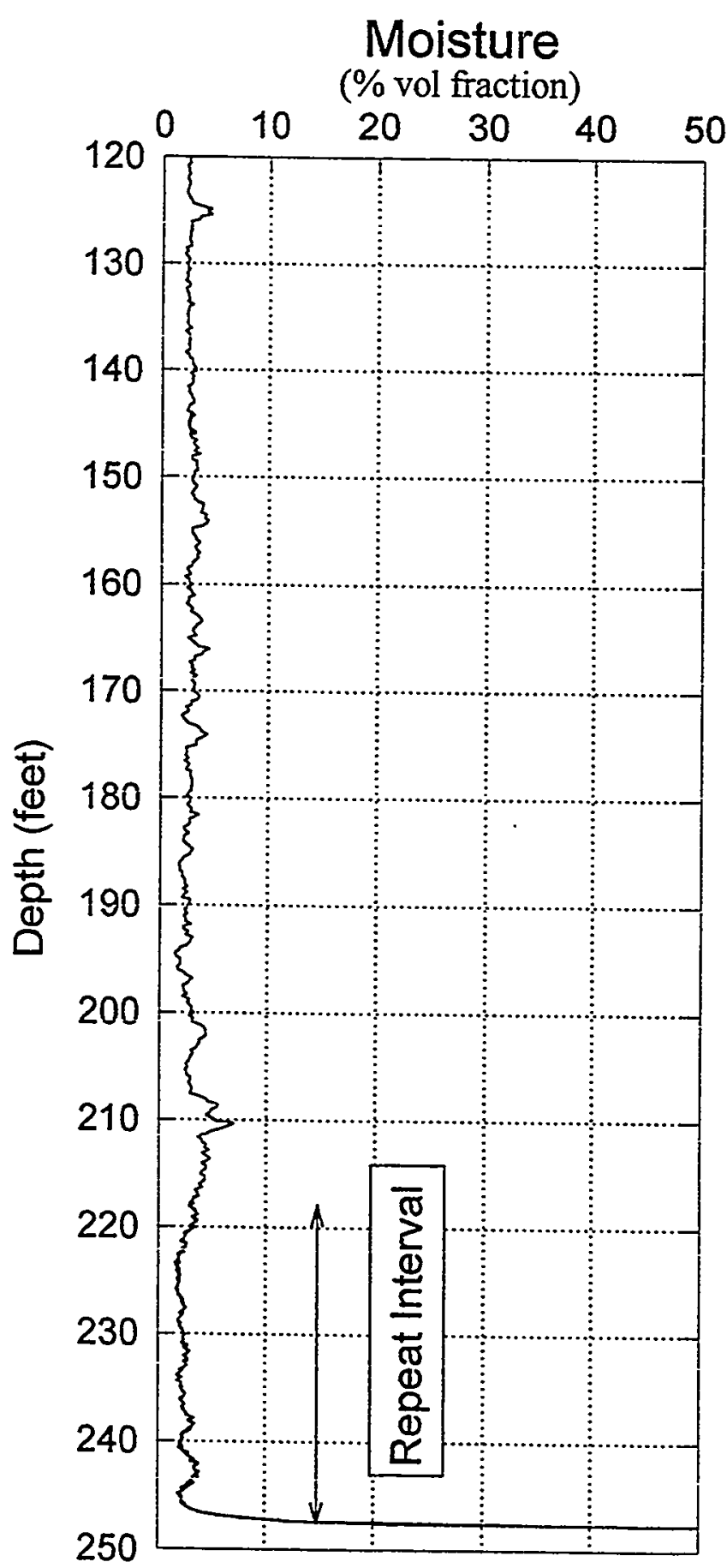

8" Casing Calibration Log Date June 4, 1999

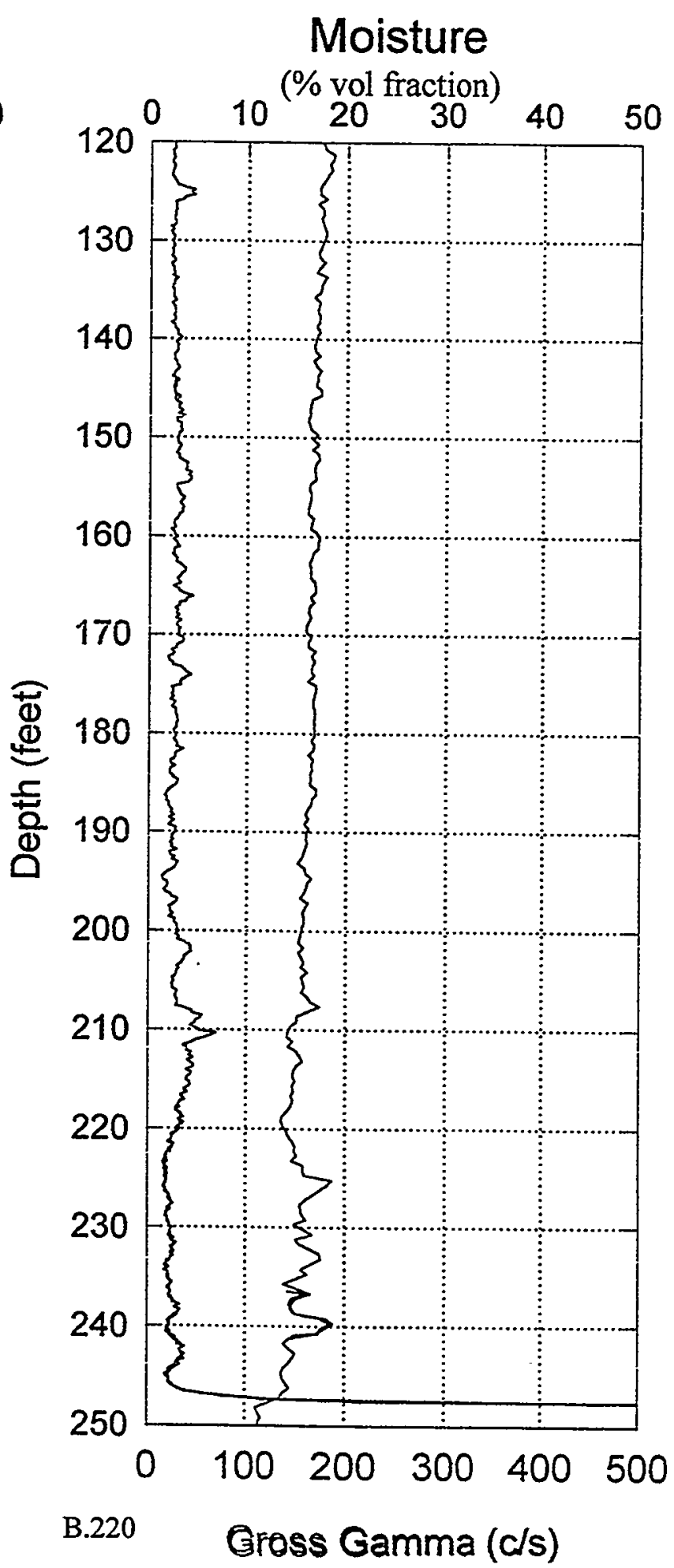




\section{RLS \\ Log Analysis \& Summary}

$\begin{array}{lllr}\text { Project: } & \text { PNNL Vadose Zone Monitor } & \text { Well D: } & \cdot \text { 299-E33-08 } \\ \text { Log Type: } & \text { Moisture Gauge } & \text { Log Dates: } & \text { June 4, } 1999\end{array}$

\section{General Notes:}

The high reading at the bottom of the well ( 248 feet) is due to the water level in the well.

Log data collected with a depth reference of top of casing, and during analysis the depths were shifted to ground surface reference for all plots.

System Performance Verify: The pre- and post-log verification passed performance standards, $-7.3 \%$ in the shield verify.

Repeat Interval: Based on the repeat interval from 218 to 248 feet, the logging system performed according to. specifications.

Environmental Corrections: The moisture levels have been corrected for casing attenuation (entire well).

\section{Observations:}

The moisture levels show character from 0 to 73 feet. Over this interval there is some correlation with the gross gamma indicative of geologic features or intervals of man-made contamination. From 74 feet to bottom of the logged interval (248 feet) the moisture readings are very low. The high reading at the 248 feet depth is due to water level in the casing. 


\section{RLS Spectral Gamma Ray Borehole Survey \\ Waste Management Federal Services NW}

\section{Log Header}

Project: $\quad$ PNNL Vadose Zone Monitoring

Well: 299-E33-10

Log Type: $\quad$ HPGe Spectral Gamma Ray

Borehole Information

\begin{tabular}{|c|c|c|}
\hline Well \# A6863 & Water Depth $274.8 \mathrm{ft}$ & Total Depth $\underline{284}$ \\
\hline Elevation Reference $\underline{\mathrm{n} / \mathrm{a}}$ & Elevation $\mathrm{n} / \mathrm{a} \quad \mathrm{ft}$ & \\
\hline Depth Reference Top Casing & Casing Stickup 2.7 & \\
\hline Casing Diameter $\underline{6 \quad \text { in }}$ & Depth Interval 0 to $122 \mathrm{ft}$ & Thickness \\
\hline Casing Diameter $\underline{8}$ & Depth Interval 0 to $284 \mathrm{ft}$ & Thickness \\
\hline
\end{tabular}

Logging Information

\begin{tabular}{|lll|}
\hline $\begin{array}{l}\text { Log Type: } \\
\text { Company } \\
\text { Date/Archive File Name }\end{array}$ & $\begin{array}{l}\text { 35\% HPGe Spectral Gamma Ray } \\
\text { Waste Management NW } \\
\text { Logging Engineers } \\
\text { Instrument Series }\end{array}$ & \multicolumn{2}{c|}{ June 28, 1999 H2E33010 } \\
Logging Unit & RLSG035N00L00.0 & \\
Depth Interval & 3 to 114 ft & Prefix AP05 \\
Depth Interval & $110-284 \& 18-42 \mathrm{ft} \quad$ Prefix AP06 \\
& & \\
Instrument Calibration Date & Jan 19, 1999 & \\
Calibration Report & WHC-SD-EN-TI-292 & \\
\hline
\end{tabular}

Analysis Information

$\begin{array}{ll}\text { Company } & \text { Three Rivers Scientific } \\ \text { Analyst } & \text { Russ Randall } \\ \text { Date } & \text { July 4, 1999 } \\ \text { Depth Reference } & \text { Ground Surface (plots depth shifted) }\end{array}$

Notes Cs-137 and Co-60 are the only man made radionuclides detected. The Co-60 is detected at the bottom of the well at detection threshold, but verified with a summing by four technique. Cs-137 only appears near the surface and at 22 feet with maximum levels of $0.7 \mathrm{pCi} / \mathrm{g}$. The gross response at 22 feet is higher than can be generated by the small level of observed Cs-137. 


\section{RLS Spectral Gamma Ray Borehole Survey Waste Management Federal Services NW}

Project: Vadose Zone Monitoring Log Date: June 22\&28, 1999 Borehole: 299-E33-10

Naturally Occurring Radionuclides

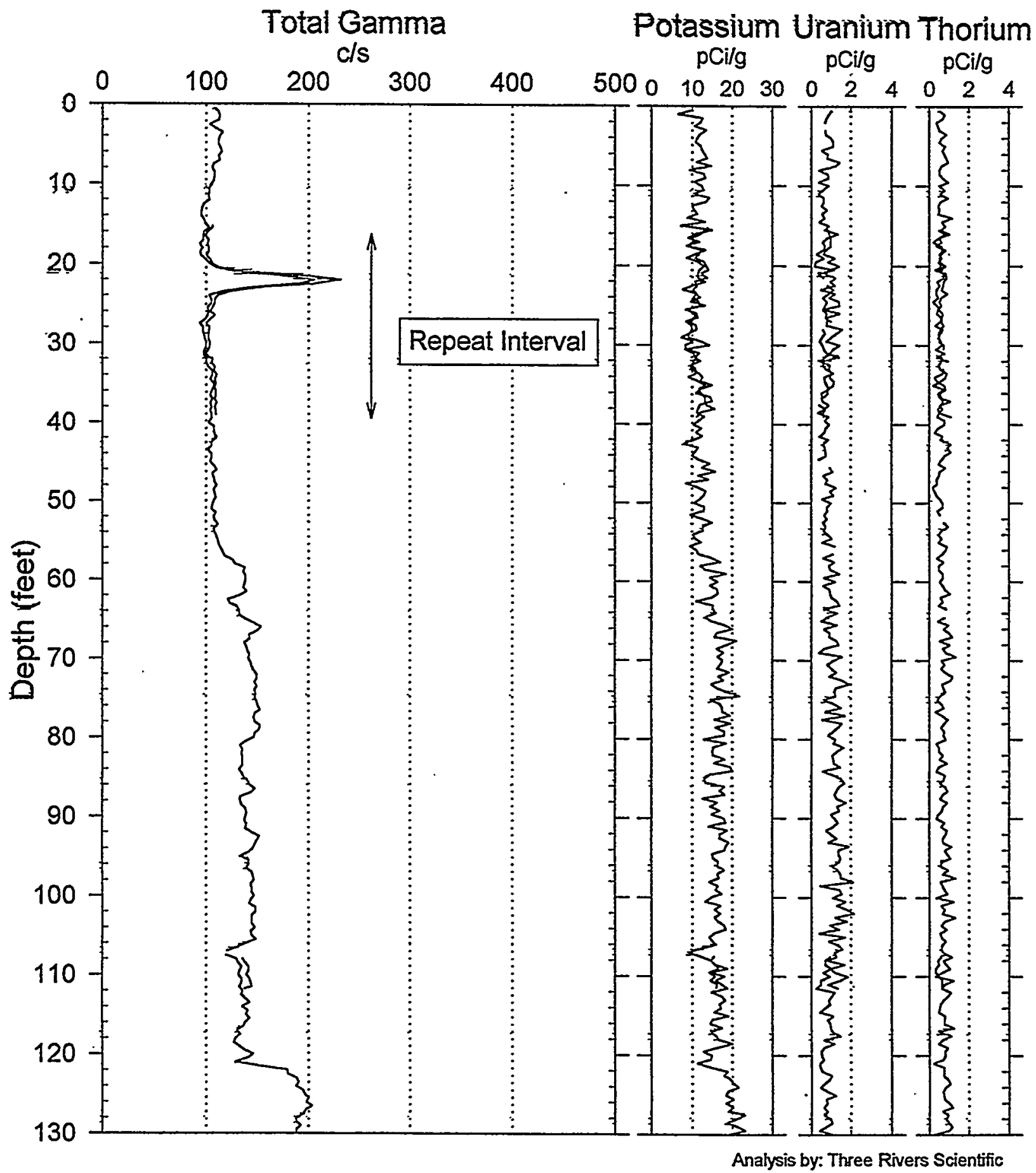




\section{RLS Spectral Gamma Ray Borehole Survey Waste Management Federal Services NW}

Project: Vadose Zone Monitoring Borehole: 299-E33-10
Log Date: June 22\&28, 1999 Naturally Occurring Radionuclides

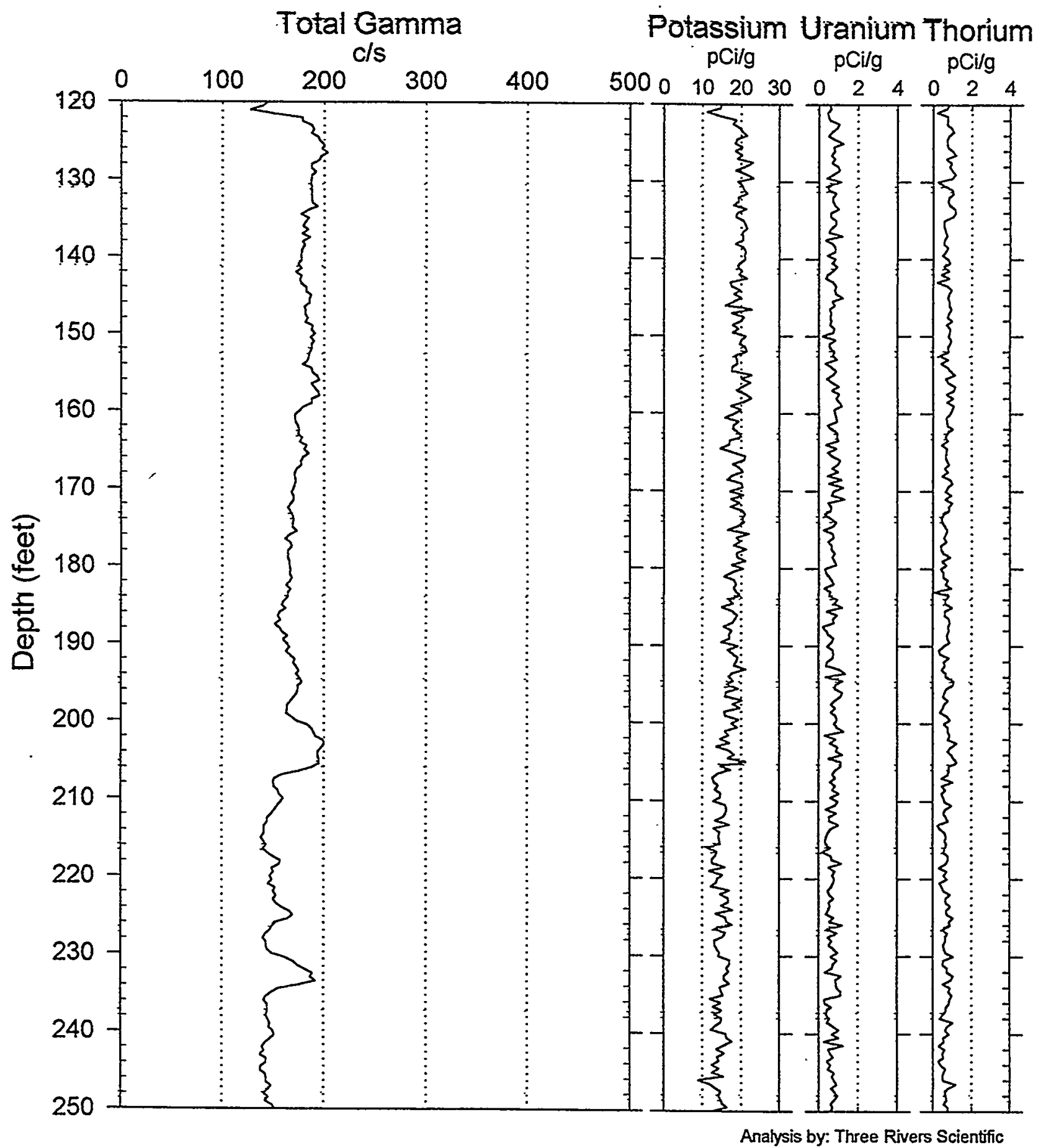




\section{RLS Spectral Gamma Ray Borehole Survey \\ Waste Management Federal Services NW}

Project: Vadose Zone Monitoring Log Date: June 22\&28, 1999 Borehole: 299-E33-10

Naturally Occurring Radionuclides

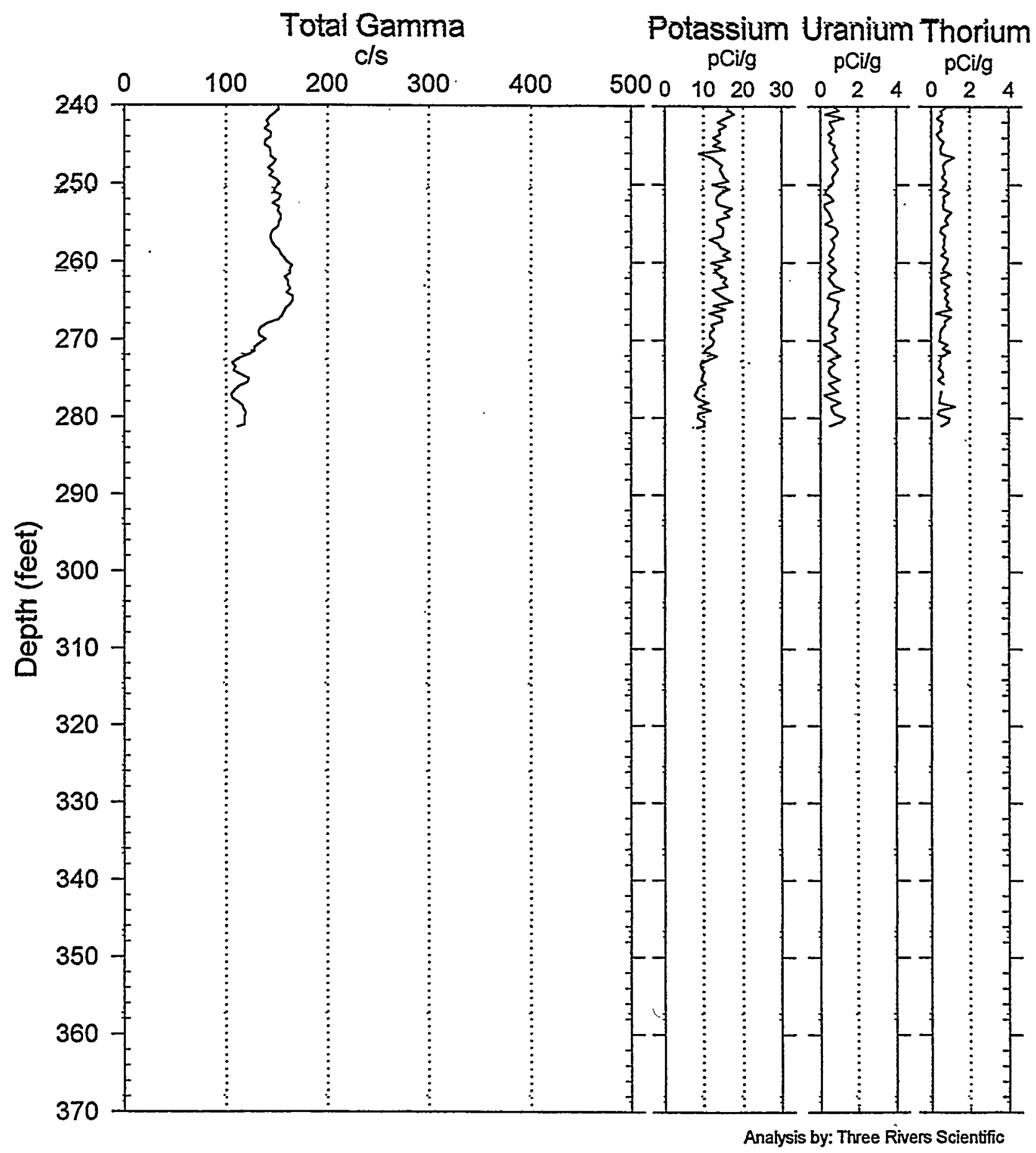




\section{RLS Spectral Gamma-Ray Borehole Survey Waste Management Federal Services NW}

Project: Vadose Zone Monitoring Log Date: June 22\&28, 1999 Borehole: 299-E33-10

Man-Made Radionuclides

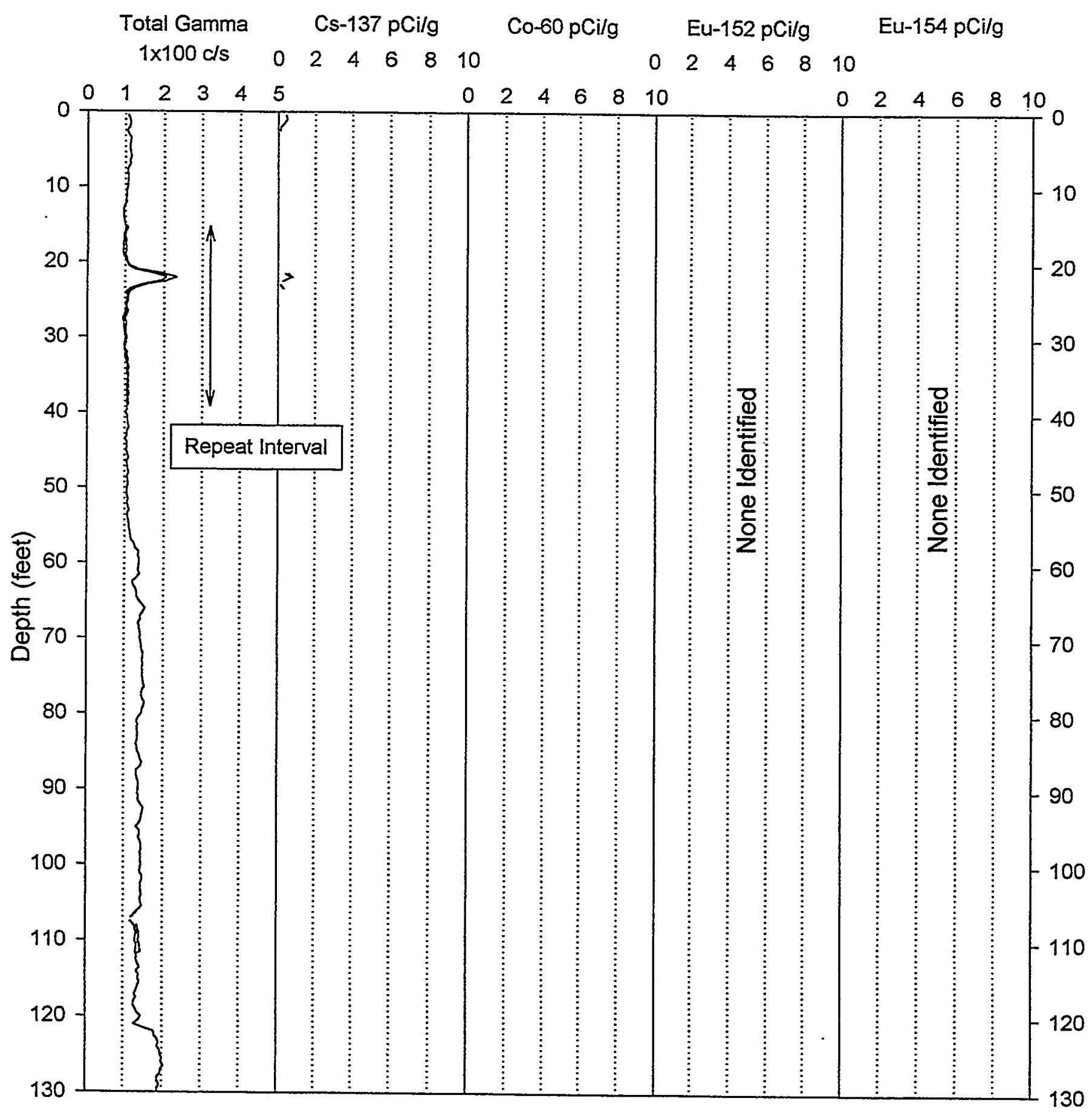




\section{RLS Spectral Gamma-Ray Borehole Survey}

Waste Management Federal Services NW

Project: Vadose Zone Monitoring Log Date: June 22\&28, 1999 Borehole: 299-E33-10

Man-Made Radionuclides

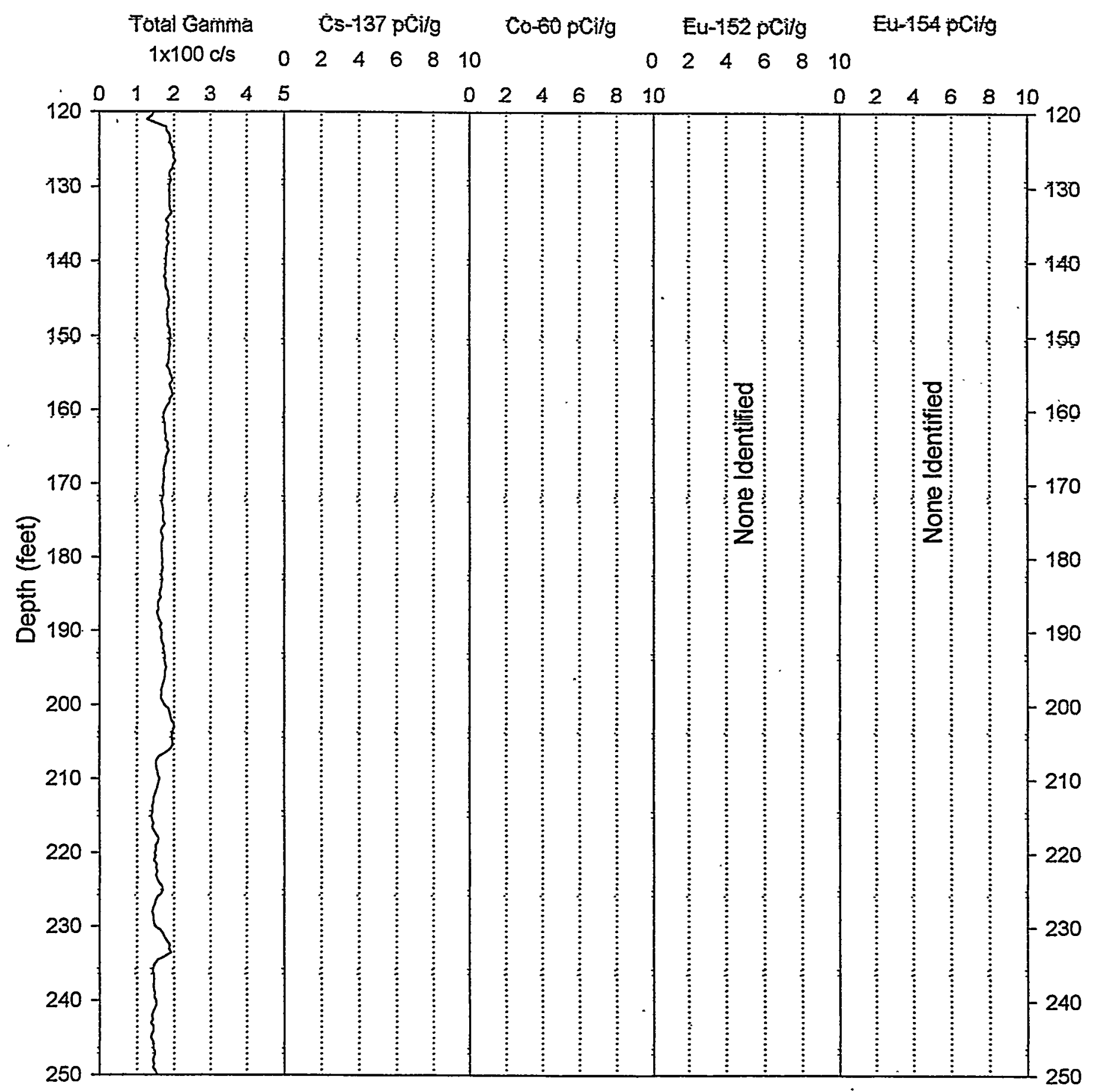


RLS Spectral Gamma-Ray Borehole Survey

\section{Waste Management Federal Services NW}

Project: Vadose Zone Monitor Log Date: June 22\&28, 1999 Borehole: 299-E33-10 Man-Made Radio-Isotopes of Concern

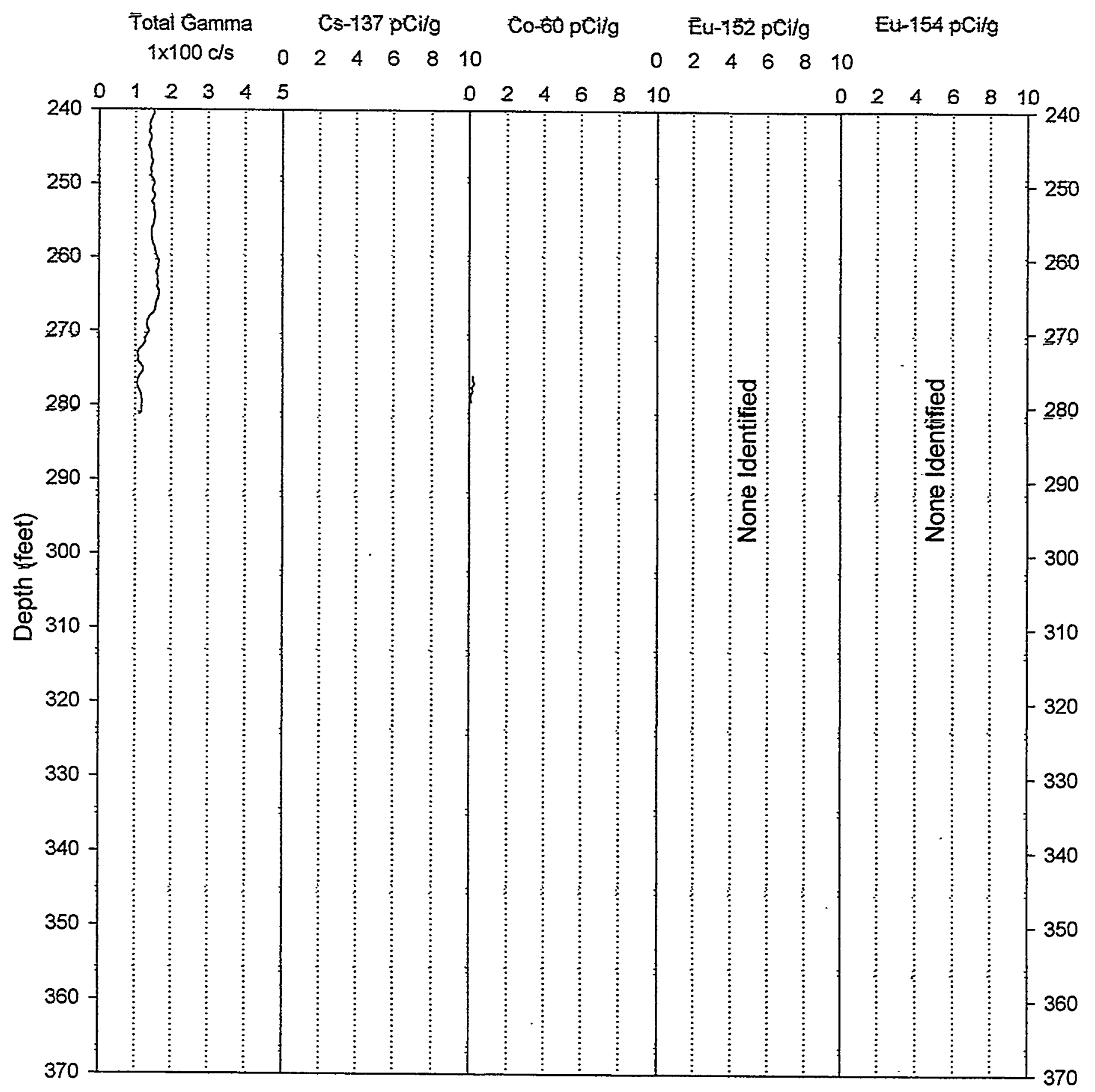




\section{RLS Spectral Gamma Ray Borehole Survey Acceptance QA Processing}

Project: PNNL Vadose Zone Monitoring Borehole: 299-E33-10
Log Date: June 22\&28, 1999 Compare Main Log \& Repeat

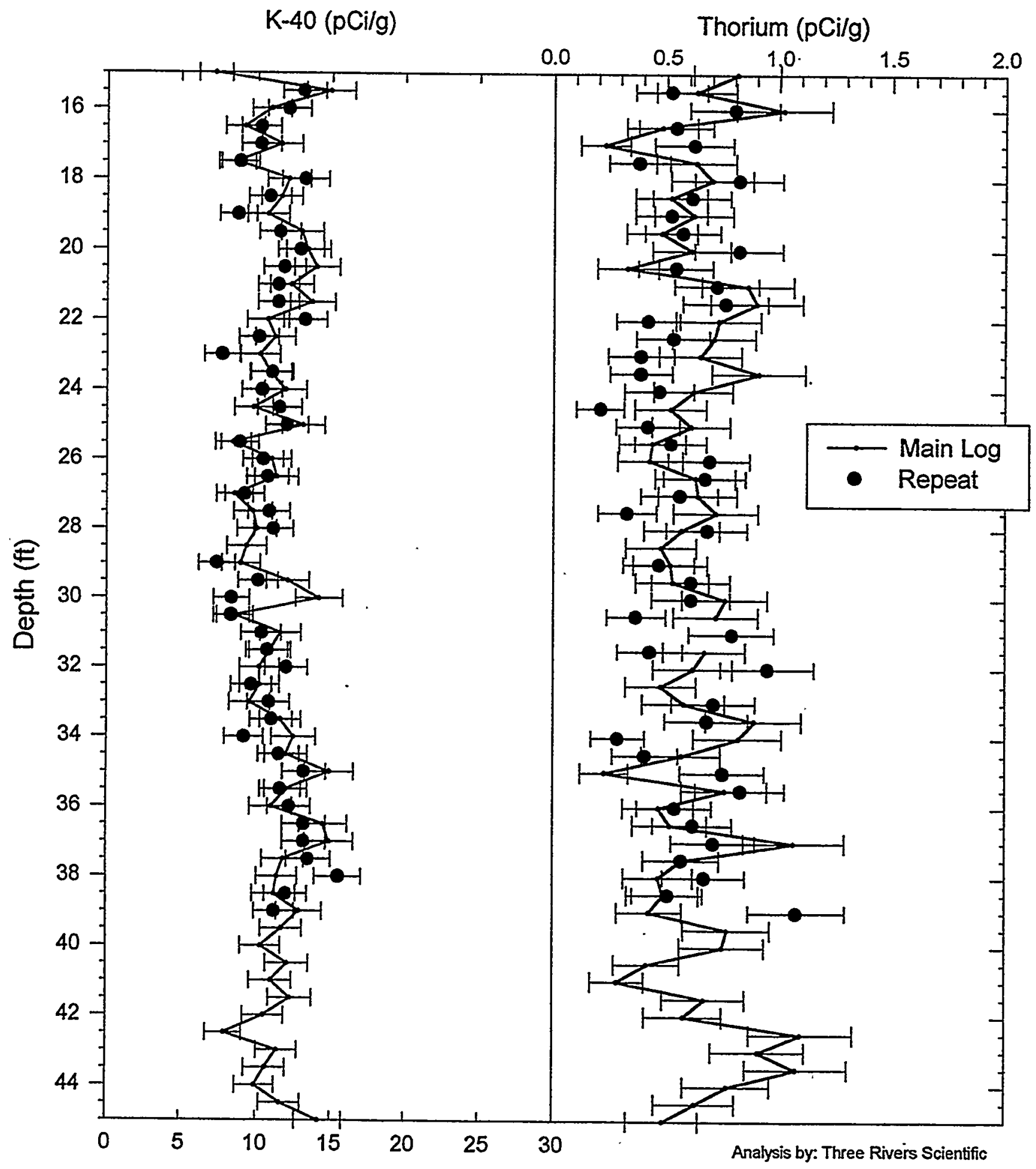




\section{RLS Spectral Gamma Ray Borehole Survey \\ Waste Management Federal Services NW}

\section{Log Analysis Summary Report}

$\begin{array}{lllr}\text { Project: } & \text { PNNL Vadose Zone Monitoring } & \text { Well: } & \text { 299-E33-10 } \\ \text { Log Type: } & \text { HPGe Spectral Gamma Ray } & \text { Log Dates: June 22\&28, } 1999\end{array}$

\section{General Notes:}

Total gamma is a response to natural radionuclide concentrations for most of the depth interval logged.

Log data collected with a depth reference of top of casing, and during analysis the depths were shifted to ground surface reference for all plots.

System Performance Verify: The pre- and post-log verification passed performance standards.

Repeat Interval: Based on the repeat interval, the logging system performed as per specifications. Different levels of radon pumping exists for the different days logged for the repeat interval. Thus the gross and uranium repeats do not match, but the $\mathrm{K}$ and Thorium repeat as per specification. The error bars are calculated for 1 standard deviation of the net photo peak count rate statistical variance. Thus, the repeat should fall within these error bars $67 \%$ of the time.

Environmental Corrections: All radionuclide concentrations have been corrected for casing attenuation (entire well). Water corrections were also applied to depths below 272 feet. No screen correction was applied due to lack of knowledge concerning the screen dimension. Thus the 8 " casing dimensions were used for the screen interval. No casing correction was applied to the total gamma due to Compton downscatter interference.

\section{Radionuclides:}

Cs-137 was identified over the depth intervals from 0-2 feet and from 21-23 feet. The maximum concentration of Cs-137 occurs at a depth of 21 feet, with a reading of $0.6 \mathrm{pCi} / \mathrm{g}$. Cs-137 MDL for this borehole condition is 0.3 $\mathrm{pCi} / \mathrm{g}$. The response of the gross gamma over this 21-23 feet is higher than the small level of Cs-137 detected, and the lack of a KUT signature. This indicates the possibility of either the presence of a strong beta emitter or the remote (from the borehole) presence of a strong Cs-137 signal.

Co-60 was identified over the depth interval 277 to 281 feet. The levels observed are at or below detection threshold for the standard logging speed used. The Co- 60 presence is verified using a summing by 4 technique and thus plotted. Co-60 MDL for this borehole condition is $0.2 \mathrm{pCi} / \mathrm{g}$. 


\section{Moisture Logging Service \\ Log Header}

Project: $\quad$ PNNL Vadose Zone Monitoring

Well: 299-E33-10

Log Type: Moisture Gauge .

Borehole Information

\begin{tabular}{|c|c|c|}
\hline Well \# A6853 & Water Depth $274.4 \quad f$ & Total Depth $284 \mathrm{ft}$ \\
\hline Elevation Reference $\underline{\mathrm{n} / \mathrm{a}}$ & Elevation $\mathrm{n} / \mathrm{a}$ & \\
\hline Depth Reference Top Casing & Casing Stickup 2.7 & \\
\hline Casing Diameter 6 in & Depth Interval 0 to 122 & Thickness .280 in \\
\hline Casing Diameter 8 & Depth Interval & Thickness .3125 in \\
\hline
\end{tabular}

Logging Information

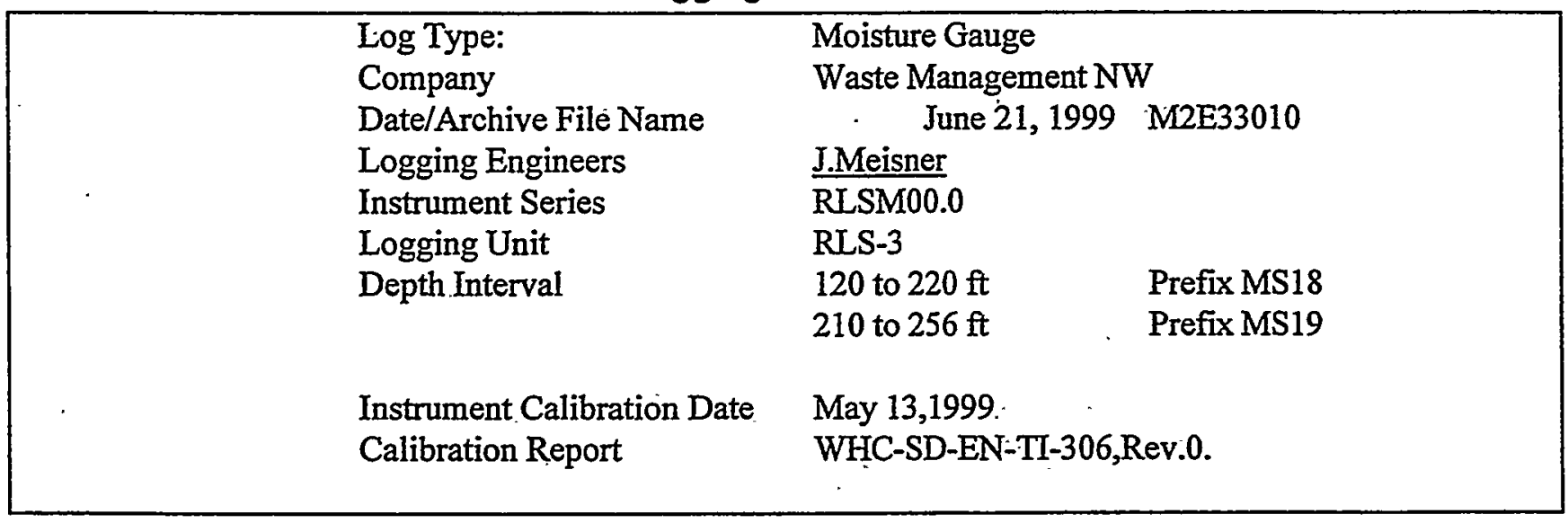

Analysis Information

\begin{tabular}{|c|c|c|c|}
\hline & & $\begin{array}{l}\text { Company } \\
\text { Analyst } \\
\text { Date } \\
\text { Depth Reference. }\end{array}$ & $\begin{array}{l}\text { Three Rivers Scientific } \\
\text { Russ Randall } \\
\text { June } 17,1999 \\
\text { Ground Surface (plots depth shifted) }\end{array}$ \\
\hline Notes & \multicolumn{3}{|c|}{ The moisture response is low from 120 to 185 feet, and below 185 feet there is some character that } \\
\hline
\end{tabular}




\section{RLS Moisture Processed Log Data}

Waste Management Federal Services NW

Project: Vadose Zone Monitoring Borehole: 299-E33-10

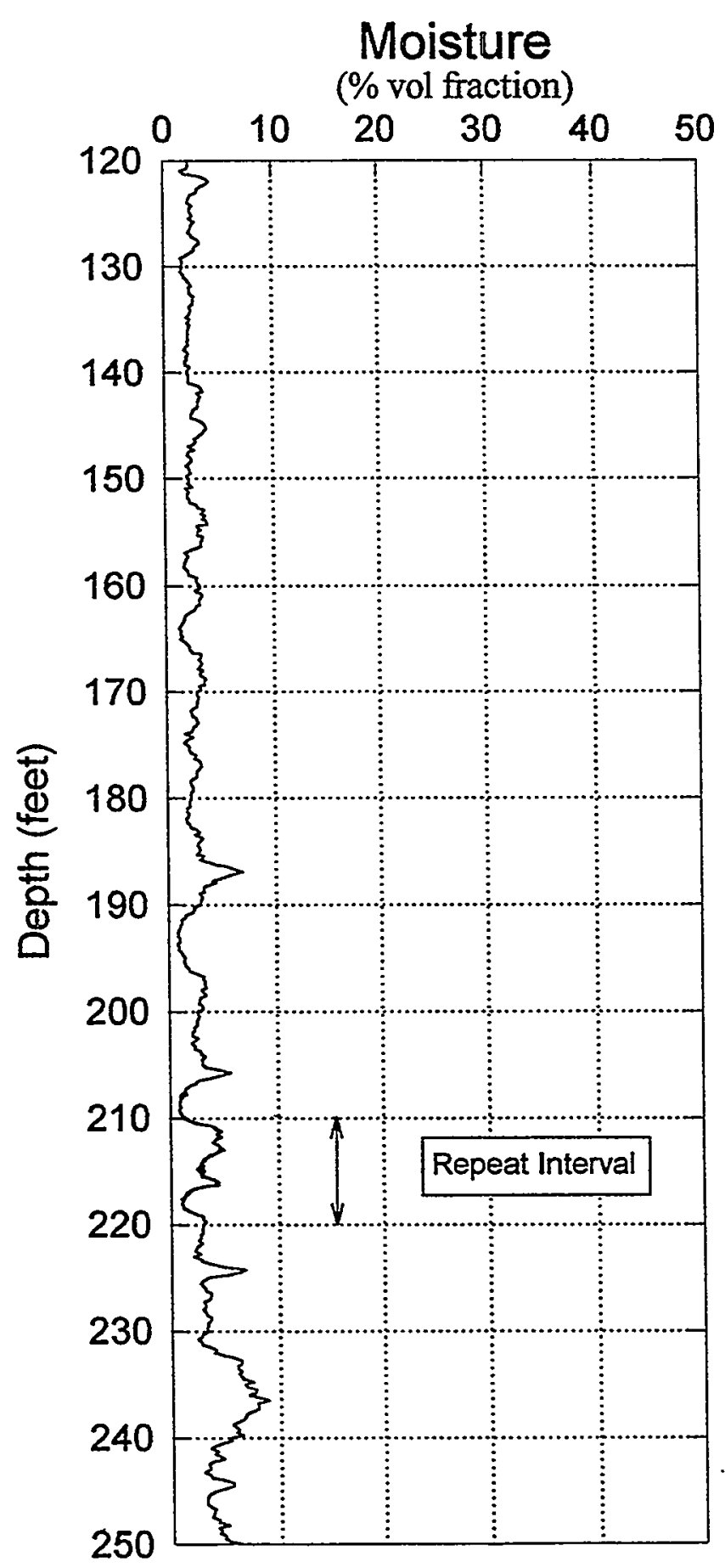

8" Casing Calibration Log Date June 21, 1999

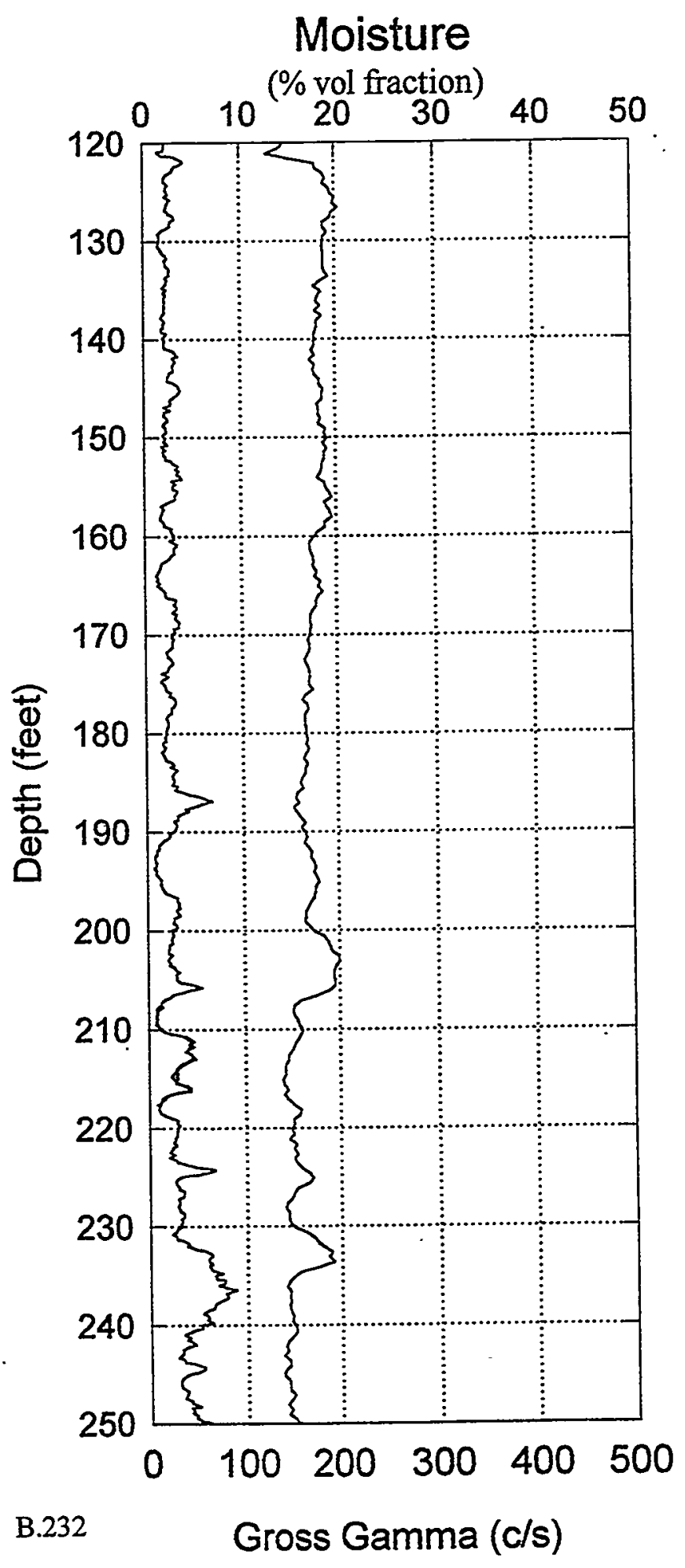




\section{RLS Moisture Processed Log Data}

Waste Management Federal Services NW

Project: Vadose Zone Monitoring 8" Casing Calibration

Borehole: 299-E33-10

Log Date June 21, 1999
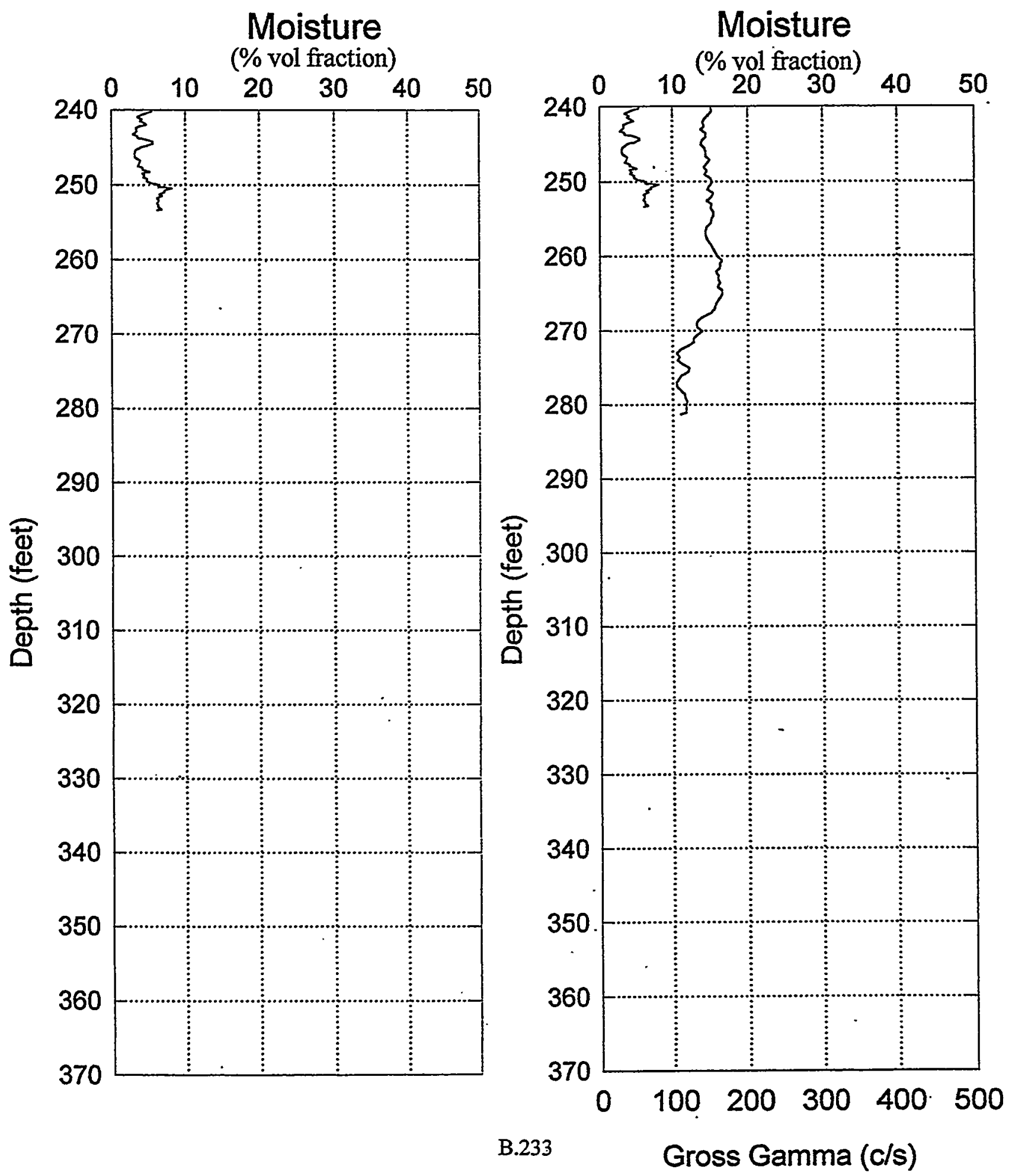


\section{RLS \\ Log Analysis \& Summary}

Project: $\quad$ PNNL Vadose Zone Monitoring

Well ID:

299-E33-10

Log Type: Moisture Gauge

Log Dates: June 21, 1999

\section{General Notes:}

Log data collected with a depth reference of top of casing, and during analysis the depths were shifted to ground surface reference for all plots.

System Performance Verify: The pre- and post-log verification passed performance standards, $-2.9 \%$ in the shield verify.

Repeat Interval: Based on the repeat interval from 210 to 220 feet, the logging system performed according to specifications.

Environmental Corrections: The moisture levels have been corrected for casing attenuation (entire well).

\section{Observations:}

The moisture levels show character from 185 to 253 feet. Over this interval there is some correlation with the gross gamma response, which is indicative of variations in lithology. From 120 to 185 feet of the logged interval the moisture readings are at or below $5 \%$ by volume. 


\section{RLS Spectral Gamma Ray Borehole Survey \\ Waste Management Federal Services NW}

\section{Log Header}

Project: $\quad$ PNNL Vadose Zone Monitoring

Well: 299-E33-286

Log Type: HPGe Spectral Gamma Ray

Borehole Information

\begin{tabular}{|c|c|c|}
\hline Well \# A7082 & Water Depth $\underline{\mathrm{n} / \mathrm{a}} \mathrm{ft}$ & Total Depth 54 \\
\hline Elevation Reference $\underline{\mathrm{n} / \mathrm{a}}$ & Elevation $\quad n / a$ & \\
\hline Depth Reference Top Casing & Casing Stickup $2.75 \quad \mathrm{ft}$ & \\
\hline Casing Diameter 8 in & Depth Interval 0 to $54 \mathrm{ft}$ & Thickness \\
\hline
\end{tabular}

\section{Logging Information}

Log Type:

Company

Date/Archive File Name

Logging Engineers

Instrument Series

Logging Unit

Depth Interval

Instrument Calibration Date

Calibration Report
$10 \%$ HPGe Spectral Gamma Ray

Waste Management NW

June 21, 1999 H2E33286

S.Kos

RLSG01000H00.0

RLS1

3 to $54 \mathrm{ft}$

Prefix AP02
June 14, 1999

WHC-SD-EN-TI-292

Analysis Information

Company

Analyst

Date

Depth Reference
Three Rivers Scientific

Russ Randall

June 15, 1999

Ground Surface (plots depth shifted)

Notes $\mathrm{Cs}-137$ is the only man made radionuclide detected. Instrument exceeded count rate limits from 35 to 37.5 feet. The maximum level of $\mathrm{Cs}-137$ is higher than $47,000 \mathrm{pCi} / \mathrm{g}$ at 36 feet. Natural KUT values are not consistently detectable with this lower sensitive instrument. 


\section{RLS Spectral Gamma Ray Borehole Survey \\ Waste Management Federal Services NW}

Project: PNNL Vadose Zone Monitoring Log Date: June 21, 1999 Borehole: 299-E33-286

Naturally Occurring Radionuclides

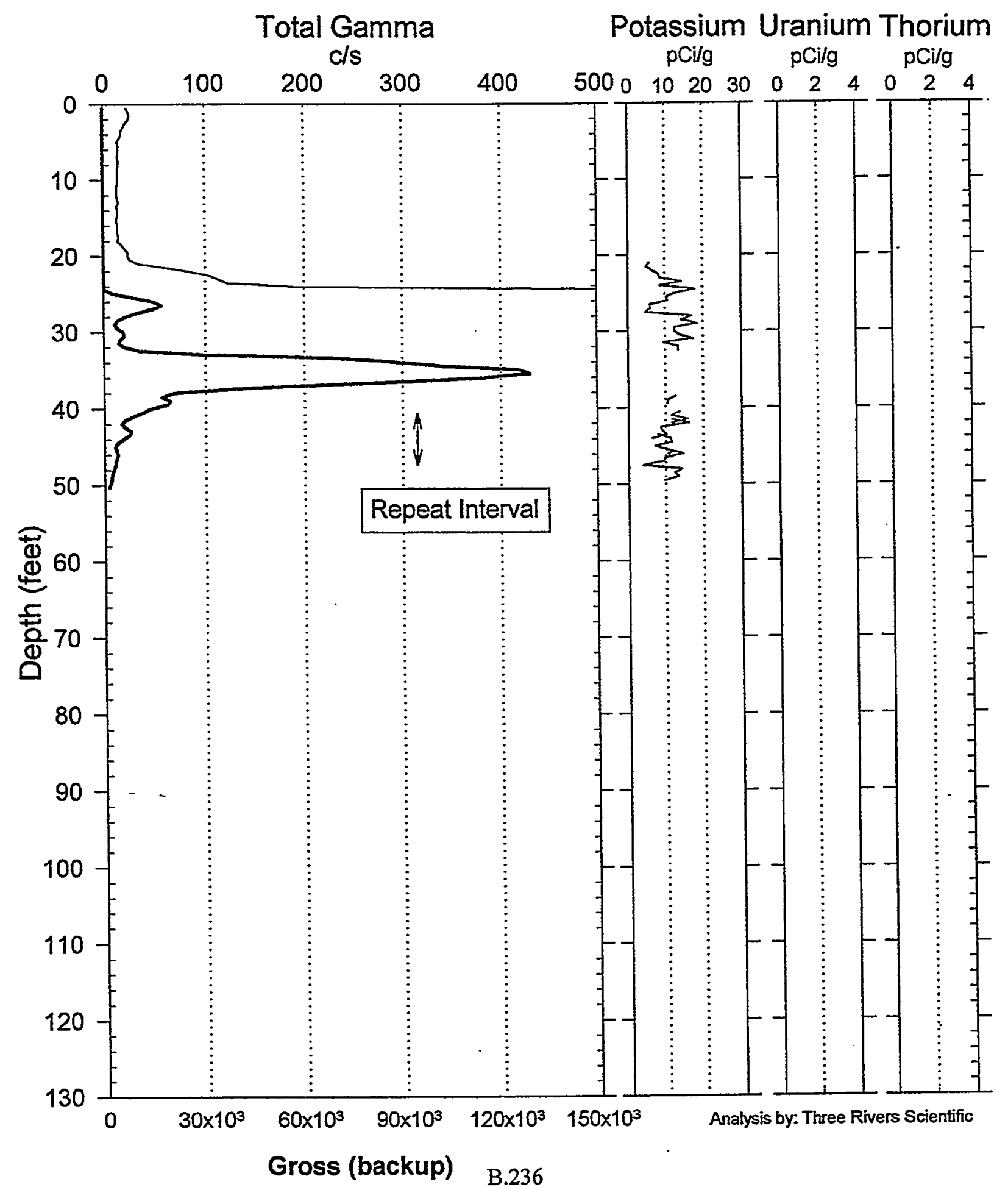




\section{RLS Spectral Gamma-Ray Borehole Survey Waste Management Federal Services NW}

Project: PNNL Vadose Zone Monitoring Borehole: 299-E33-286
Log Date: June 21, 1999 Man-Made Radio-Nuclides

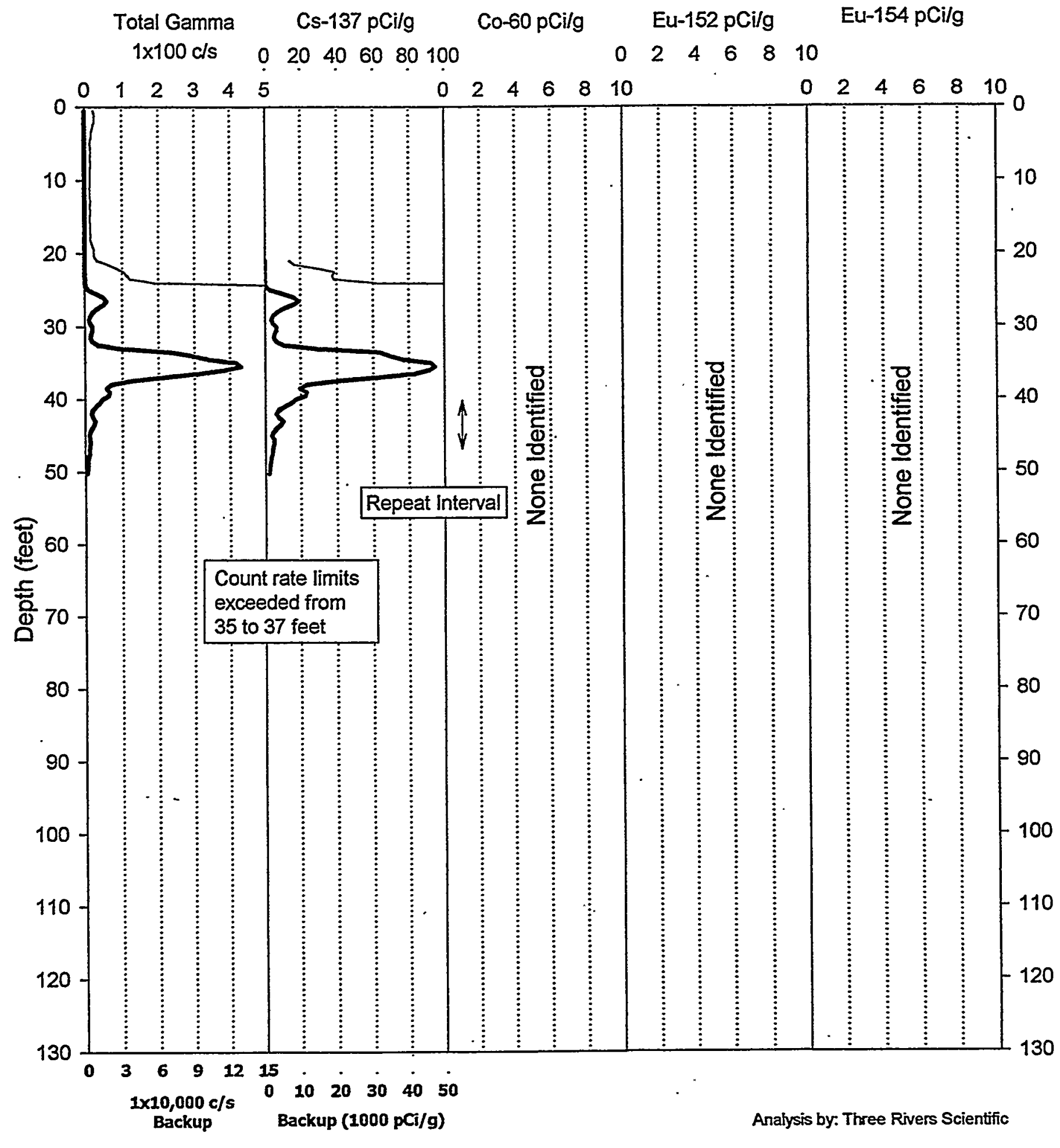




\section{RLS Spectral Gamma Ray Borehole Survey Acceptance QA Processing}

Project: PNNL Vadose Zone Monitoring Log Date: June 21, 1999 Borehole: 299-E33-286 Compare Main Log \& Repeat

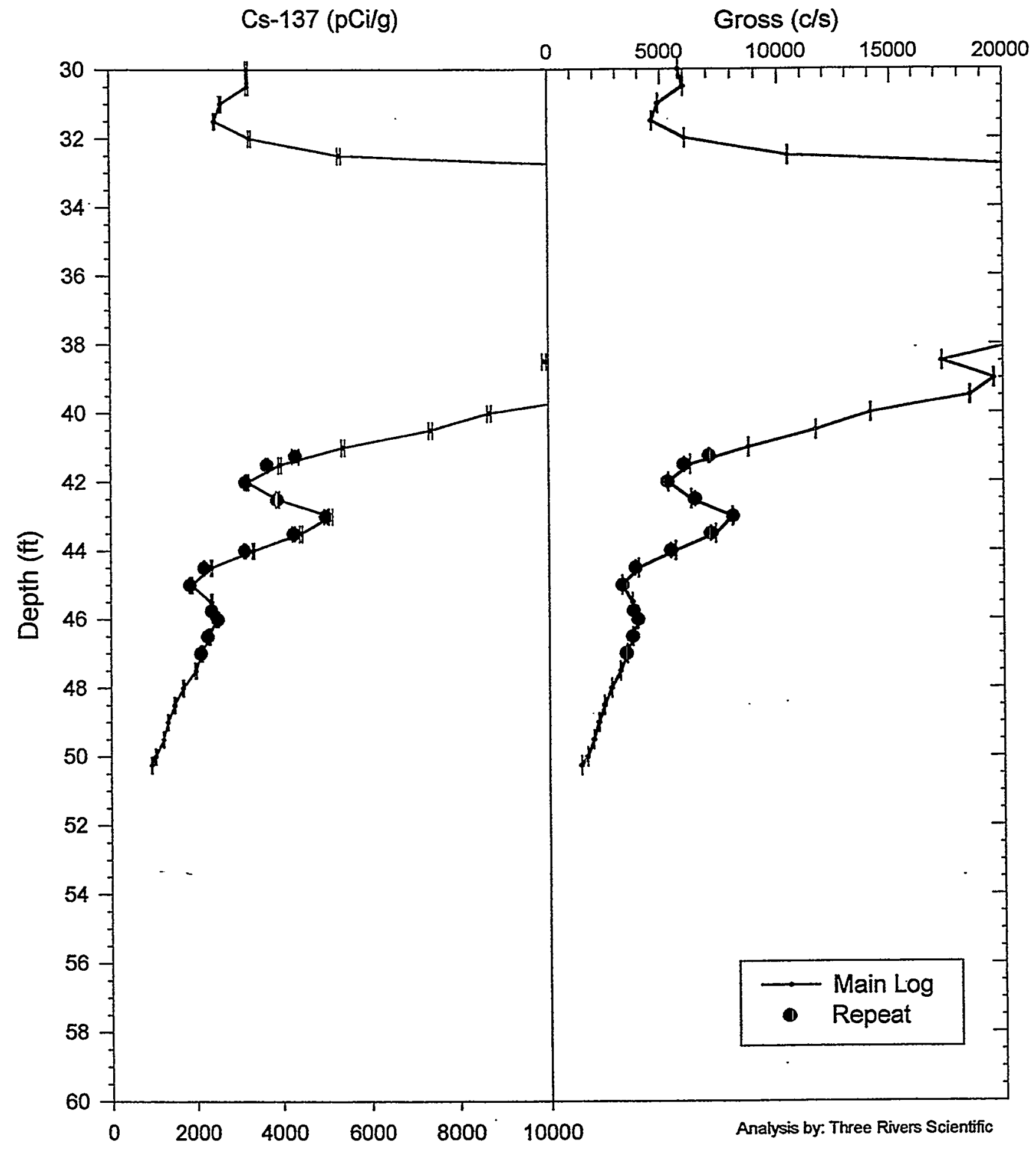




\section{RLS Spectral Gamma Ray Borehole Survey \\ Waste Management Federai Services NW}

\section{Log Analysis Summary Report}

$\begin{array}{lllr}\text { Project: } & \text { PNNL Vadose Zone Monitoring } & \text { Well: } & \text { 299-E33-286 } \\ \text { Log Type: } & \text { HPGe Spectral Gamma Ray } & \text { Log Dates: } & \text { June 21, } 1999\end{array}$

\section{General Notes:}

Total gamma is a response to geologic concentrations of natural radionuclides except for the depth interval from 20-50 feet. The KUT values suffer from low sensitivity for this instrumentation and are not always detected.

Log data collected with a depth reference of top of casing, and during analysis the depths were shifted to ground surface reference for all plots.

System Performance Verify: The pre- and post-log verification passed performance standards.

Repeat Interval: Based on the repeat interval, the logging system performed as per specifications. The error bars are calculated for 1 standard deviation of the net photo peak count rate statistical variance. Thus, the repeat should fall within these error bars $67 \%$ of the time.

Environmental Corrections: All radionuclide concentrations have been corrected for casing attenuation (entire well). Water level is below depths logged. No casing correction was applied to the total gamma due to Compton downscatter interference.

\section{Radionuclides:}

Cs-137 was identified over the depth interval from 20 to 50 feet. The maximum concentration of Cs-137 occurs at a depth of 36 feet, with a reading that exceeds $47,000 \mathrm{pCi} / \mathrm{g}$. The count rate limits were exceeded from 35 to 37.5 feet. Even though the instrument did not saturate, the dead time corrections is inaccurate, and the true concentration is higher than recorded over this interval. Cs-137 MDL for this borehole condition is $0.8 \mathrm{pCi} / \mathrm{g}$. 


\section{Moisture Logging Service Log Header}

Project: $\quad$ PNNL Vadose Zone Monitoring

Well: 299-E33-286

Log Type: Moisture Gauge

Borehole Information

\begin{tabular}{|c|c|c|}
\hline Well \# A7082 & Water Depth $\mathrm{n} / \mathrm{a}$ & Total Depth $54 \mathrm{ft}$ \\
\hline Elevation Reference $\underline{n / a}$ & Elevation & \\
\hline Depth Reference Top Casing & Casing Stickup 2.7 & \\
\hline Casing Diameter. 8 in & Depth Interval 0 to $54 \mathrm{ft}$ & Thickness _ \\
\hline
\end{tabular}

Logging Information

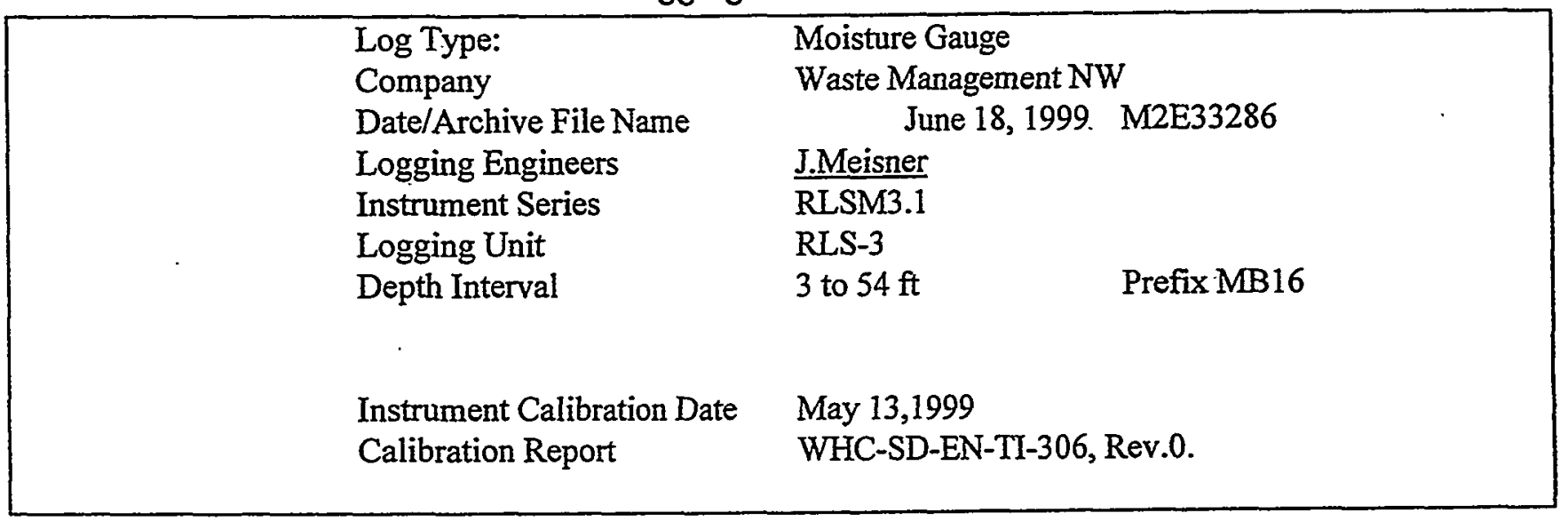

Analysis Information

$\begin{array}{ll}\text { Company } & \text { Three Rivers Scientific } \\ \text { Analyst } & \text { Russ Randall } \\ \text { Date } & \text { June 17, 1999 } \\ \text { Depth Reference } & \text { Ground Surface (plot depth shifted) }\end{array}$

Notes A high moisture zone exists just above the high level of Cs-137 contaminant. 


\section{RLS Moisture Processed Log Data}

Waste Management Federal Services NW

Project: Vadose Zone Monitoring Borehole: 299-E33-286

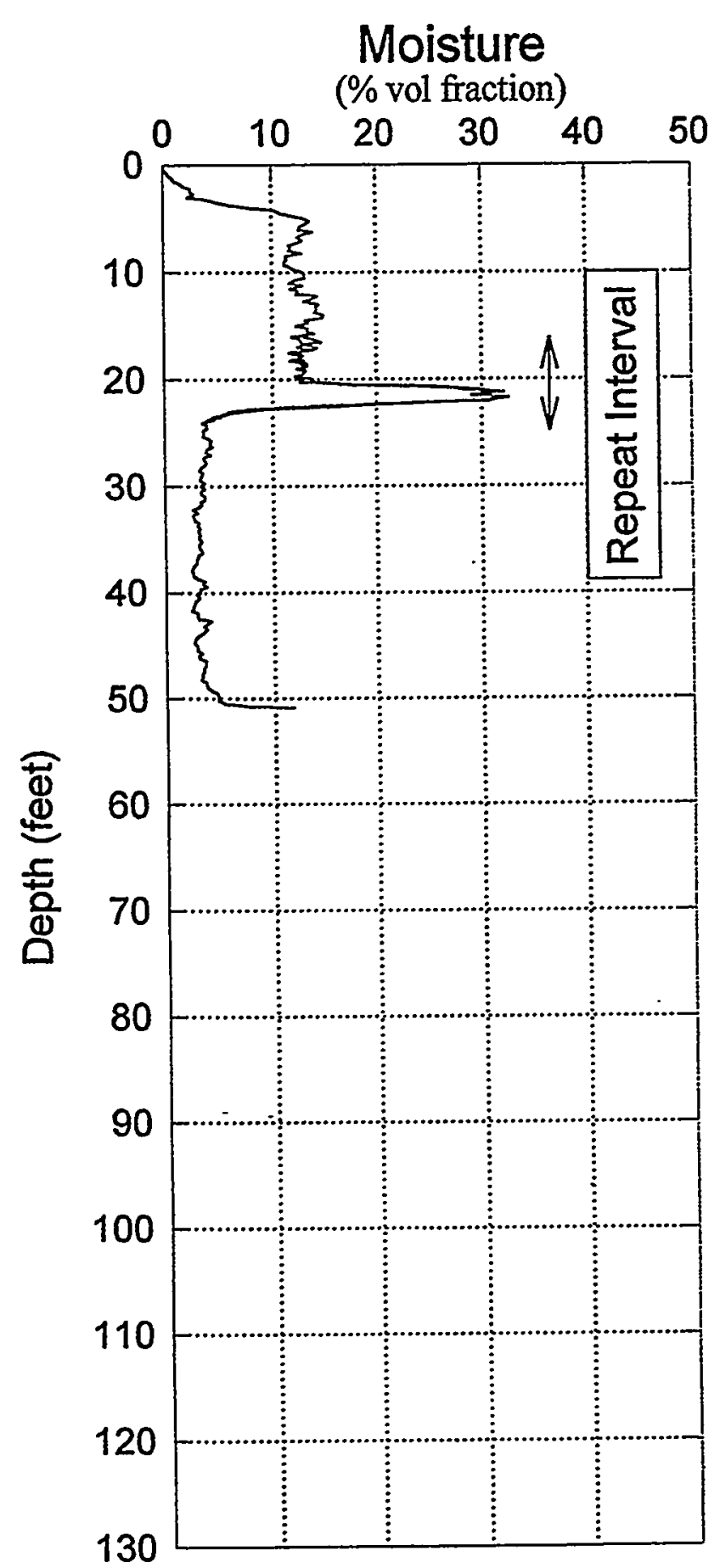

8" Casing Calibration Log Date June 18, 1999

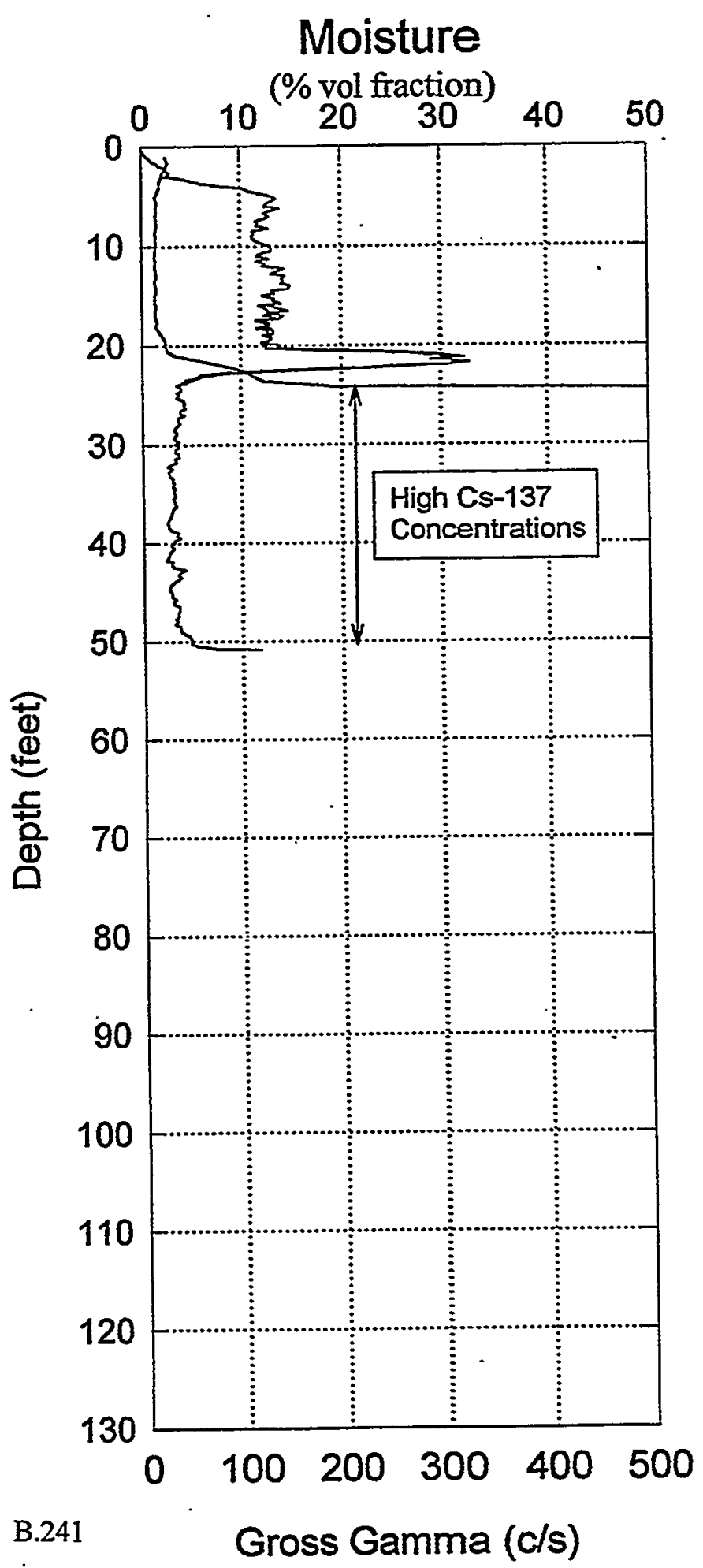




\section{RLS \\ Log Analysis \& Summary}

Project: $\quad$ PNNL Vadose Zone Monitoring

Log Type: Moisture Gauge
Well ID:

Log Dates:
299-E33-286

June 18, 1999

\section{General Notes:}

The low reading from feet to 2 feet is due to surface effects and not the moisture content of the earth surrounding the borehole.

Log data collected with a depth reference of top of casing, and during analysis the depths were shifted to ground surface reference for all plots.

System Performance Verify: The pre- and post-log verification passed performance standards, $-1.9 \%$ in the shield verify.

Repeat Interval: Based on the repeat interval from 16 to 25 feet, the logging system performed according to specifications.

Environmental Corrections: The moisture levels have been corrected for casing attenuation (entire well).

\section{Observations:}

The moisture levels above 20 feet are higher than the bottom interval from 23 to 50 feet. The high moisture lense at 22 feet is a thin zone just above the depth where the gross gamma begins to sharply increase due to the high Cs137 contamination. 


\section{RLS Spectral Gamma Ray Borehole Survey \\ Waste Management Federal Services NW}

\section{Log Header}

Project: $\quad$ PNNL Vadose Zone Monitoring

Well: 299-E33-287

Log Type: HPGe Spectral Gamma Ray

Borehole Information

\begin{tabular}{|c|c|c|c|}
\hline Well \# A7083 & Water Depth & $\mathrm{n} / \mathrm{a}$ & Total Depth $53 \mathrm{ft}$ \\
\hline Elevation Reference $\mathrm{n} / \mathrm{a}$ & Elevation & $\mathrm{n} / \mathrm{a}$ & \\
\hline Depth Reference Top Casing & Casing Stickup & 3.13 & \\
\hline Casing Diameter $\underline{8}$ in & Depth Interval & 0 to $53 \mathrm{ft}$ & Thickness $\quad 0.312$ in \\
\hline
\end{tabular}

Logging Information

Log Type:

Company

Date/Archive File Name

Logging Engineers

Instrument Series

Logging Unit

Depth Interval

Instrument Calibration Date

Calibration Report
$10 \%$ HPGe Spectral Gamma Ray

Waste Management NW.

S. Kos

RLSG01000H00.0

RLS-1

3 to $53 \mathrm{ft}$

Prefix AP01

June 14, 1999

WHC-SD-EN-TI-292

Analysis Information

Company
Analyst
Date
Depth Reference

Three Rivers Scientific

Russ Randall

June 15, 1999

Ground Surface (plot depth shifted)

Notes Cs-137 is the only man made radionuclide detected. Instrument exceeded count rate limits from 26 to 37 feet. The maximum level of Cs- 137 is higher than $55,000 \mathrm{pCi} / \mathrm{g}$ at 35 feet. Natural KUT values are not consistently detectable with this lower sensitive instrument. 


\section{RLS Spectral Gamma Ray Borehole Survey Waste Management Federal Services NW}

Project: Vadose Zone Monitoring Log Date: June 18, 1999 Borehole: 299-E33-287 Naturally Occurring Radionuclides

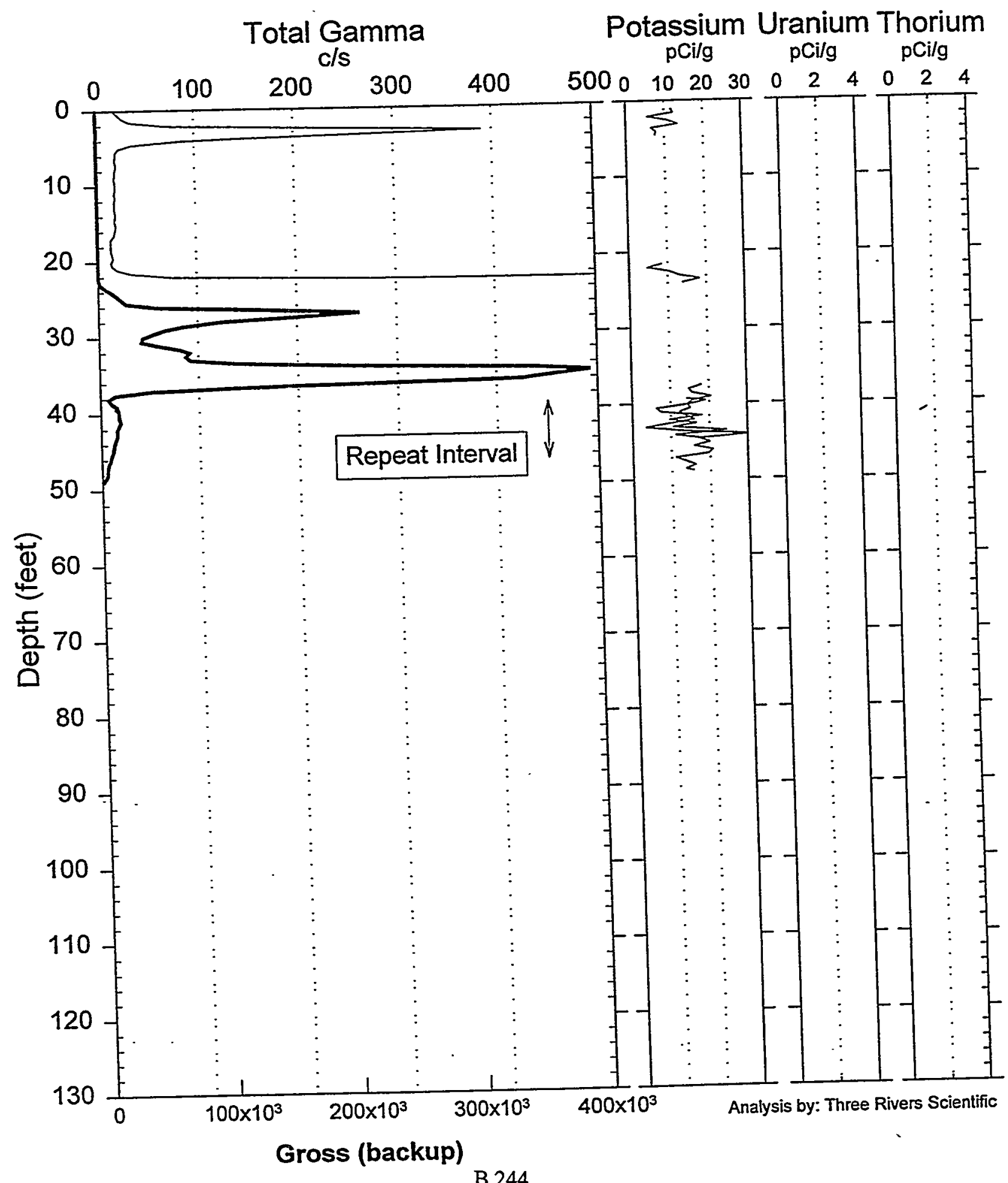




\section{RLS Spectral Gamma-Ray Borehole Survey \\ Waste Management Federal Services NW}

Project: Vadose Zone Monitoring Log Date: June 18, 1999 Borehole: 299-E33-287 Man-Made Radio-Nuclides

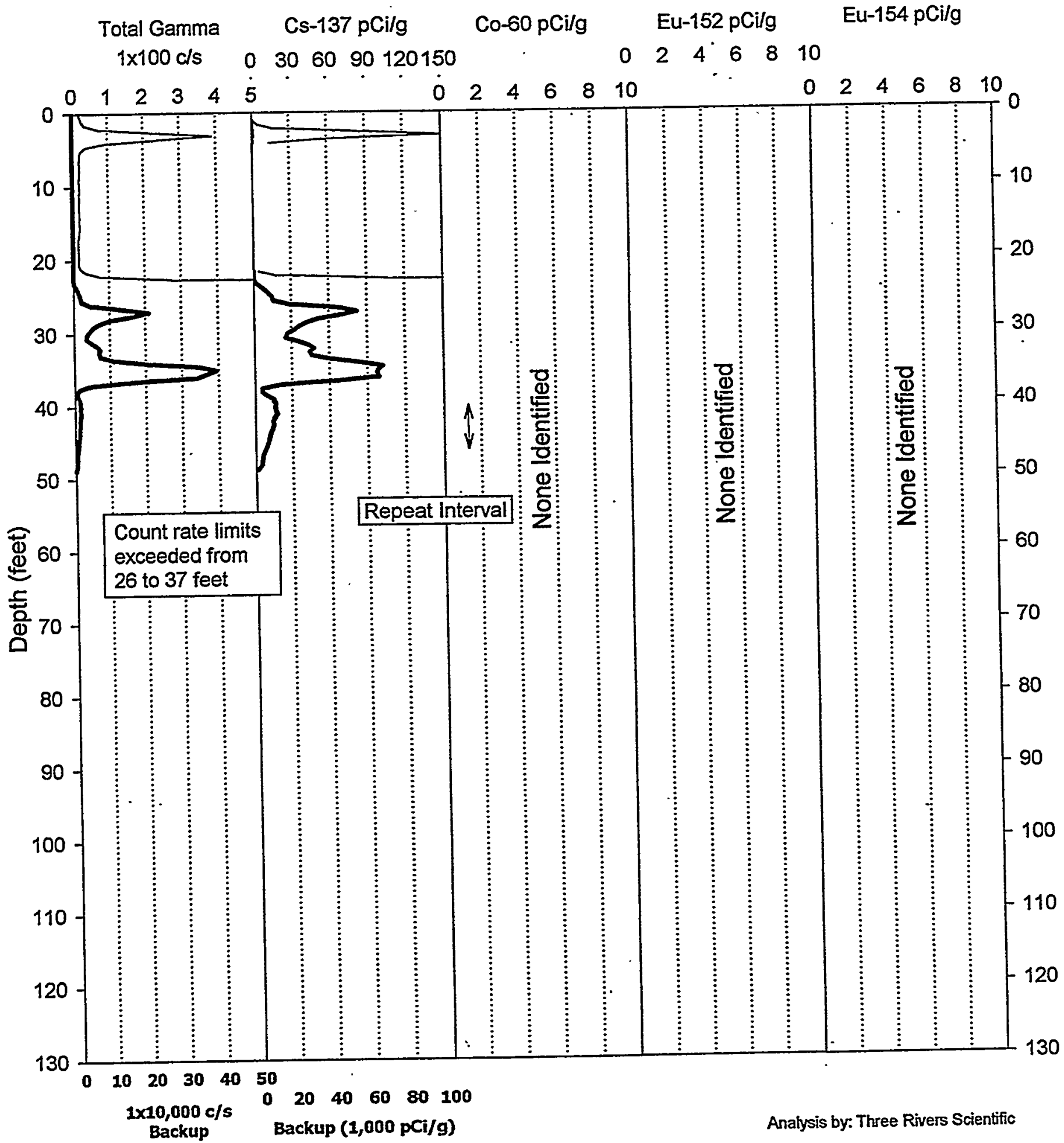




\section{RLS Spectral Gamma Ray Borehole Survey Acceptance QA Processing}

Project: PNNL Vadose Zone Monitor Log Date: June 18, 1999 Borehole: 299-E33-287 Compare Main Log. \& Repeat

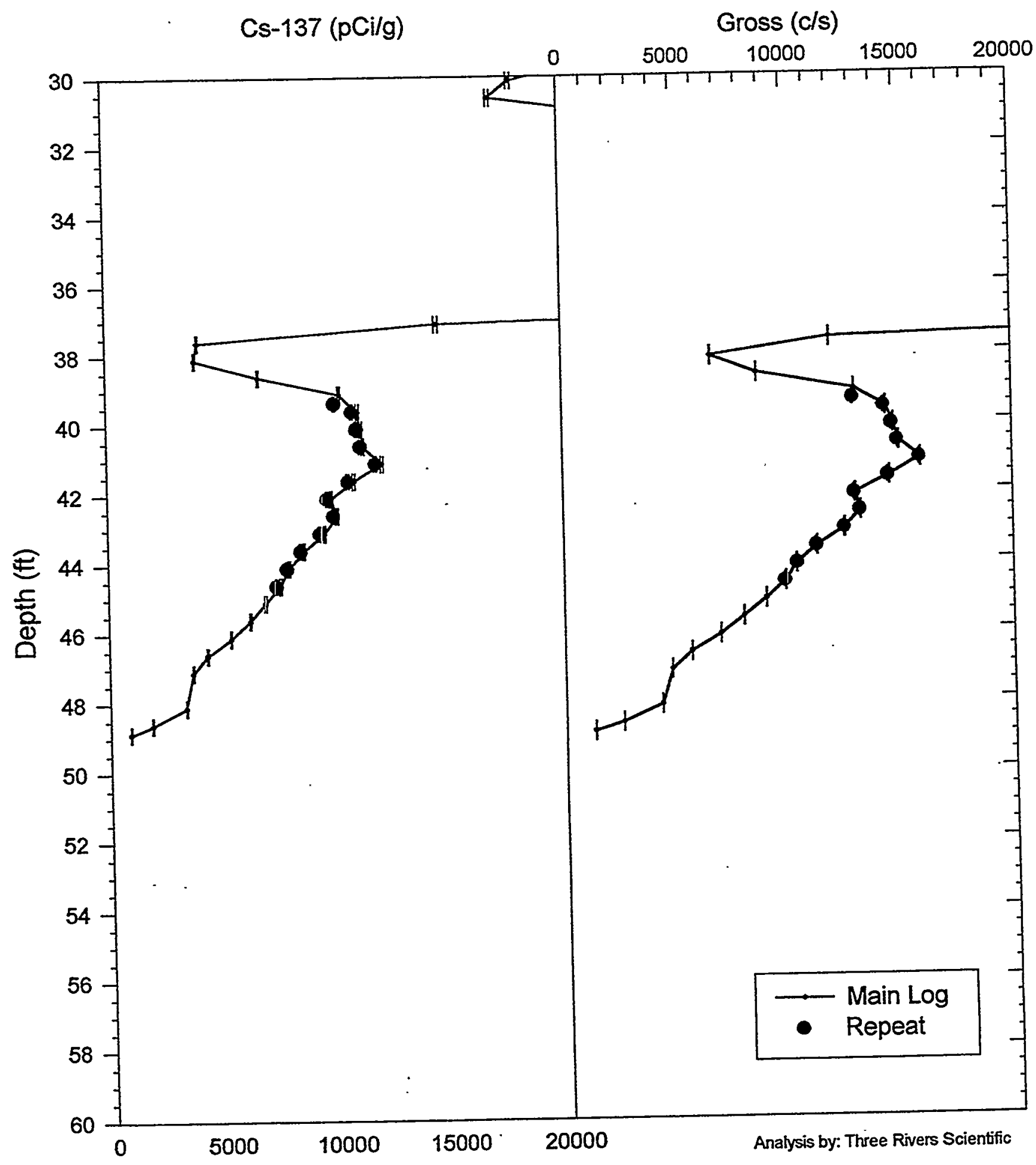




\section{RLS Spectral Gamma Ray Borehole Survey \\ Waste Management Federal Services NW}

\section{Log Analysis Summary Report}

$\begin{array}{lllr}\text { Project: } & \text { PNNL Vadose Zone Monitoring } & \text { Well: } & \text { 299-E33-287 } \\ \text { Log Type: } & \text { HPGe Spectral Gamma Ray } & \text { Log Dates: } & \text { June 18, 1999 }\end{array}$

\section{General Notes:}

Total gamma is a response to Cs-137 concentrations for most of the depth interval logged. The KUT values suffer from low sensitivity for this instrumentation and are not always detected.

Log data collected with a depth reference of top of casing, and during analysis the depths were shifted to ground surface reference for all plots.

System Performance Verify: The pre- and post-log verification passed performance standards.

Repeat Interval: Based on the repeat interval, the logging system performed as per specifications. The error bars are calculated for 1 standard deviation of the net photo peak count rate statistical variance. Thus, the repeat should fall within these error bars $67 \%$ of the time.

Environmental Corrections: All radionuclide concentrations have been corrected for casing attenuation (entire well). Water level is below depths logged. No casing correction was applied to the total gamma due to Compton downscatter interference.

\section{Radionuclides:}

Cs-137 was identified over the depth intervals from 2-5 feet and from 22-49 feet. The maximum concentration of Cs-137 occurs at a depth of 35 feet, with a reading that exceeded $55,000 \mathrm{pCi} / \mathrm{g}$. The count rate limits were exceeded from 26 to 37 feet. Even though the instrument did not saturate, the dead time correction is inaccurate, and the true concentration is higher than recorded over this interval. Cs-137 MDL for this borehole condition is 2.4 $\mathrm{pCi} / \mathrm{g}$. 


\section{Moisture Logging Service \\ Log Header}

Project: PNNL Vadose Zone Monitoring

Well: 299-E33-287

Log Type: Moisture Gauge

Borehole Information

\begin{tabular}{|c|c|c|c|}
\hline Well \# A7083 & Water Depth & $\underline{n / a}$ & Total Depth $53 \mathrm{ft}$ \\
\hline Elevation Reference $\underline{n} / \mathrm{a}$ & Elevation & $\mathrm{n} / \mathrm{a}$ & \\
\hline Depth Reference Top Casing & Casing Stickup & $3.13 \quad \mathrm{ft}$ & \\
\hline Casing Diameter 8 in & Depth Interval & 0 to $53 \quad \mathrm{ft}$ & Thickness \\
\hline
\end{tabular}

Logging Information

Log Type:

Company

Date/Archive File Name

Logging Engineers

Instrument Series

Logging Unit

Depth Interval

Instrument Calibration Date

Calibration Report
Moisture Gauge

Waste Management NW

June 18, 1999 M2E33287

J.Meisner

RLSM3.1

RLS-3

3 to $53 \mathrm{ft}$

Prefix MB15

May 13,1999

WHC-SD-EN-TI-306, Rev.0.

Analysis Information

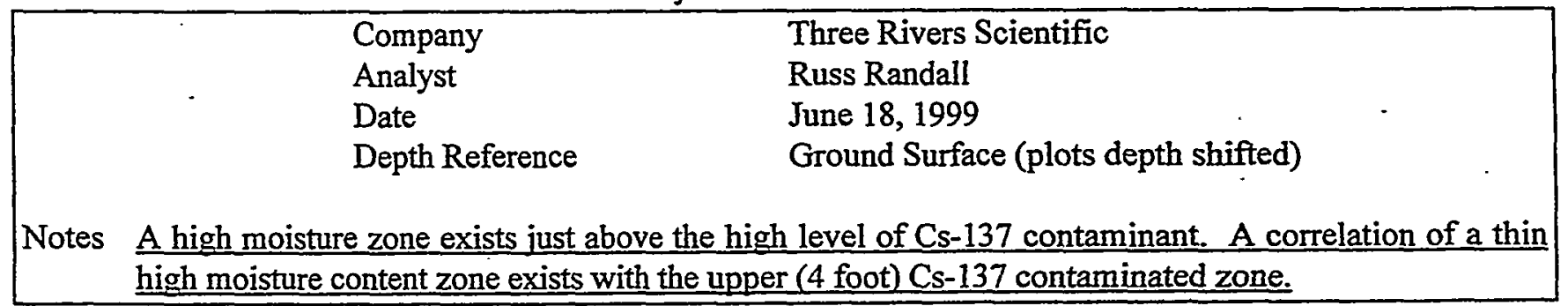




\section{RLS Moisture Processed Log Data}

\section{Waste Management Federal Services NW}

Project: Vadose Zone Monitoring Borehole: 299-E33-287

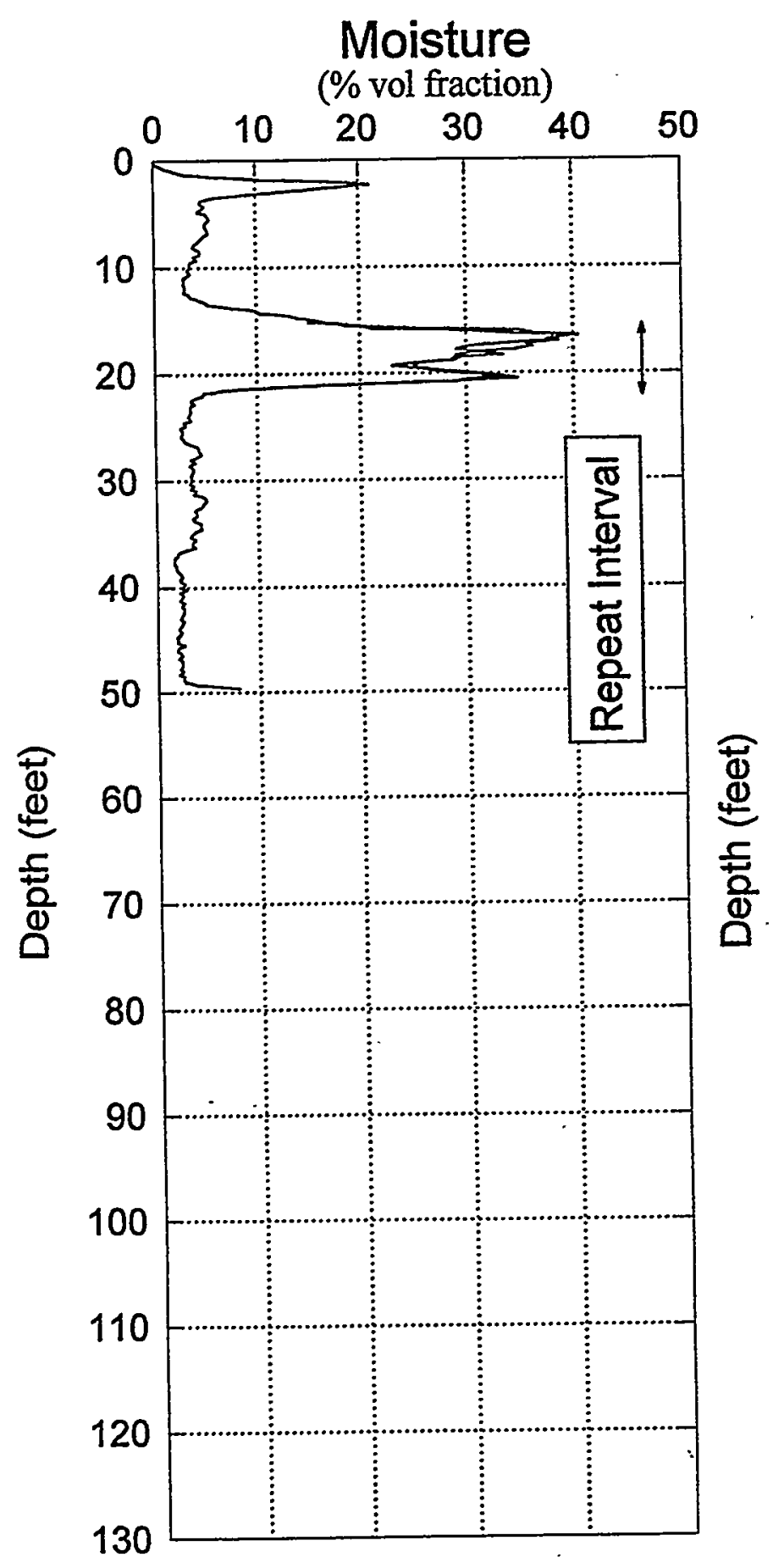

8" Casing Calibration Log Date June 18, 1999

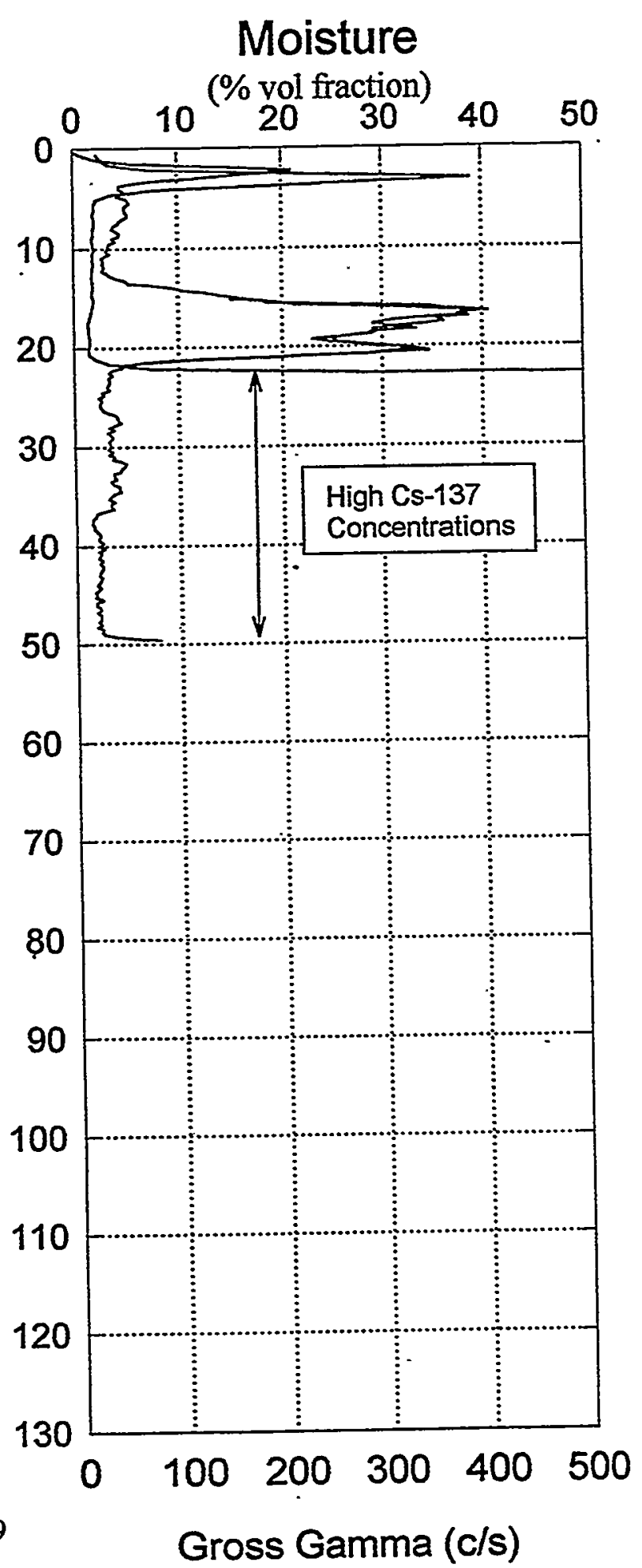




\section{RLS \\ Log Analysis \& Summary}

$\begin{array}{lllr}\text { Project: } & \text { PNNL Vadose Zone Monitoring } & \text { Well ID: } & \text { 299-E33-287 } \\ \text { Log Type: } & \text { Moisture Gauge } & \text { Log Dates: } & \text { June 18, } 1999\end{array}$

\section{General Notes:}

The low reading from 0 feet to 2 feet is due to surface effects and not necessarily the moisture content of the earth surrounding the borehole.

Log data collected with a depth reference of top of casing, and during analysis the depths were shifted to ground surface reference for all plots.

System Performance Verify: The pre- and post-log verification passed performance standards, $+2.4 \%$ in the shield verify.

Repeat Interval: Based on the repeat interval from 16 to 22 feet, the logging system performed according to specifications.

Environmental Corrections: The moisture levels have been corrected for casing attenuation (entire well).

\section{Observations:}

The thin higher moisture zone at 4 feet correlates with the gross gamma (due to Cs-137). A thicker high moisture zone from 15 to 22 feet occurs just above the very high levels of Cs-137 contaminant, where the majority of the contaminant exists. Below a depth of 22 feet the moisture is low, with readings at or below $5 \%$ by volume. 


\section{RLS Spectral Gamma Ray Borehole Survey \\ Waste Management Federal Services NW}

\section{Log Header}

Project: $\quad$ PNNL Vadose Zone Monitoring

Well: 299-E33-288

Log Type: HPGe Spectral Gamma Ray

Borehole Information

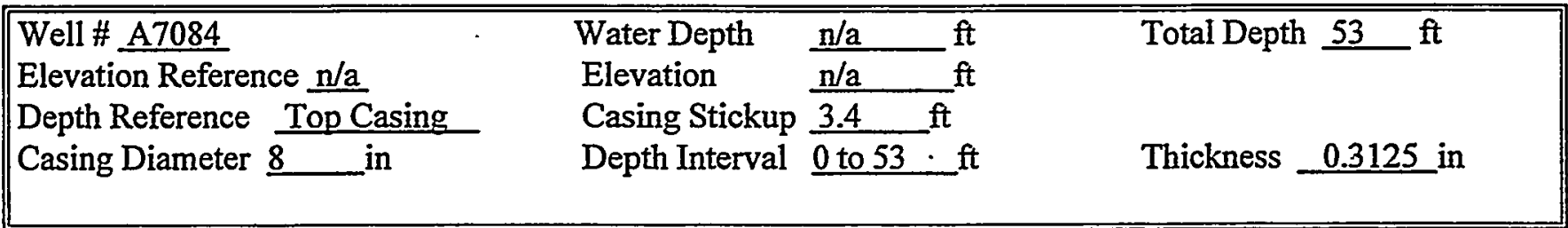

Logging Information

Log Type:

Company

Date/Archive File Name

Logging Engineers

Instrument Series

Logging Unit

Depth Interval

Instrument Calibration Date

Calibration Report
$10 \%$ HPGe Spectral Gamma Ray

Waste Management NW

$\underline{\text { S.Kos }}$

June 18, 1999 H2E33288

RLSG01000H00.0

RLS-1

4 to $53 \mathrm{ft}$

Prefix AP00

June 14, 1999

WHC-SD-EN-TI-292

Analysis Information

$\begin{array}{ll}\text { Company } & \text { Three Rivers Scientific } \\ \text { Analyst } & \text { Russ Randall } \\ \text { Date } & \text { June 15,1999 } \\ \text { Depth Reference } & \text { Ground Surface (plots depth shifted) }\end{array}$

Notes Cs-137 is the only man made radionuclide detected. Instrument exceeded count rate limits from 18.25 to 36.25 feet. The character of the gross gamma is mostly a response to the Cs-137 concentration. 


\section{RLS Spectral Gamma Ray Borehole Survey Waste Management Federal Services NW}

Project: Vadose Zone Monitoring Log Date: June 18, 1999 Borehole: 299-E33-288 Naturally Occurring Radionuclides

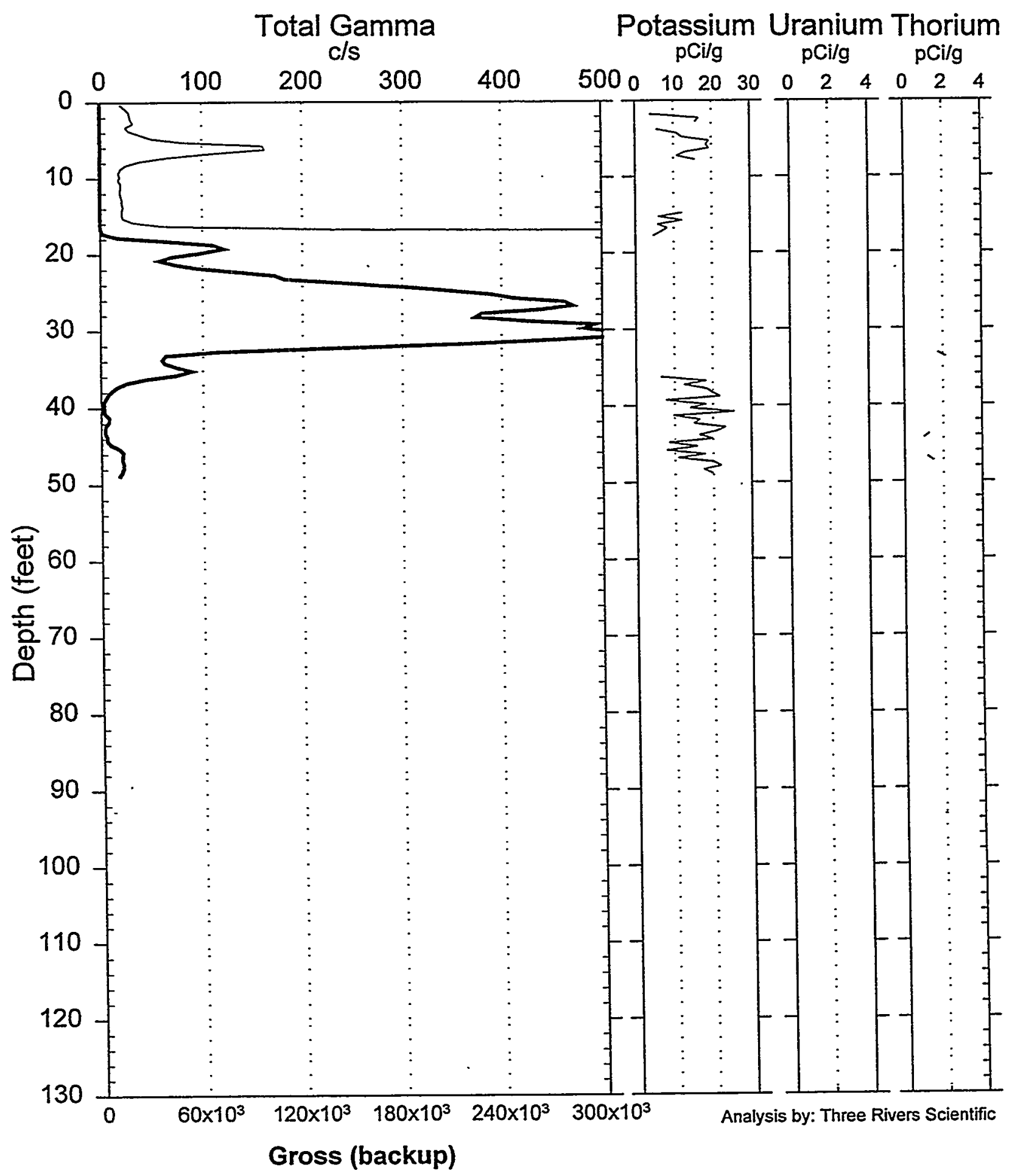




\section{RLS Spectral Gamma-Ray Borehole Survey Waste Management Federal Services NW}

Project: Vadose Zone Monitoring Borehole: 299-E33-288
Log Date: June 18, 1999 Man-Made Radio-Nuclides

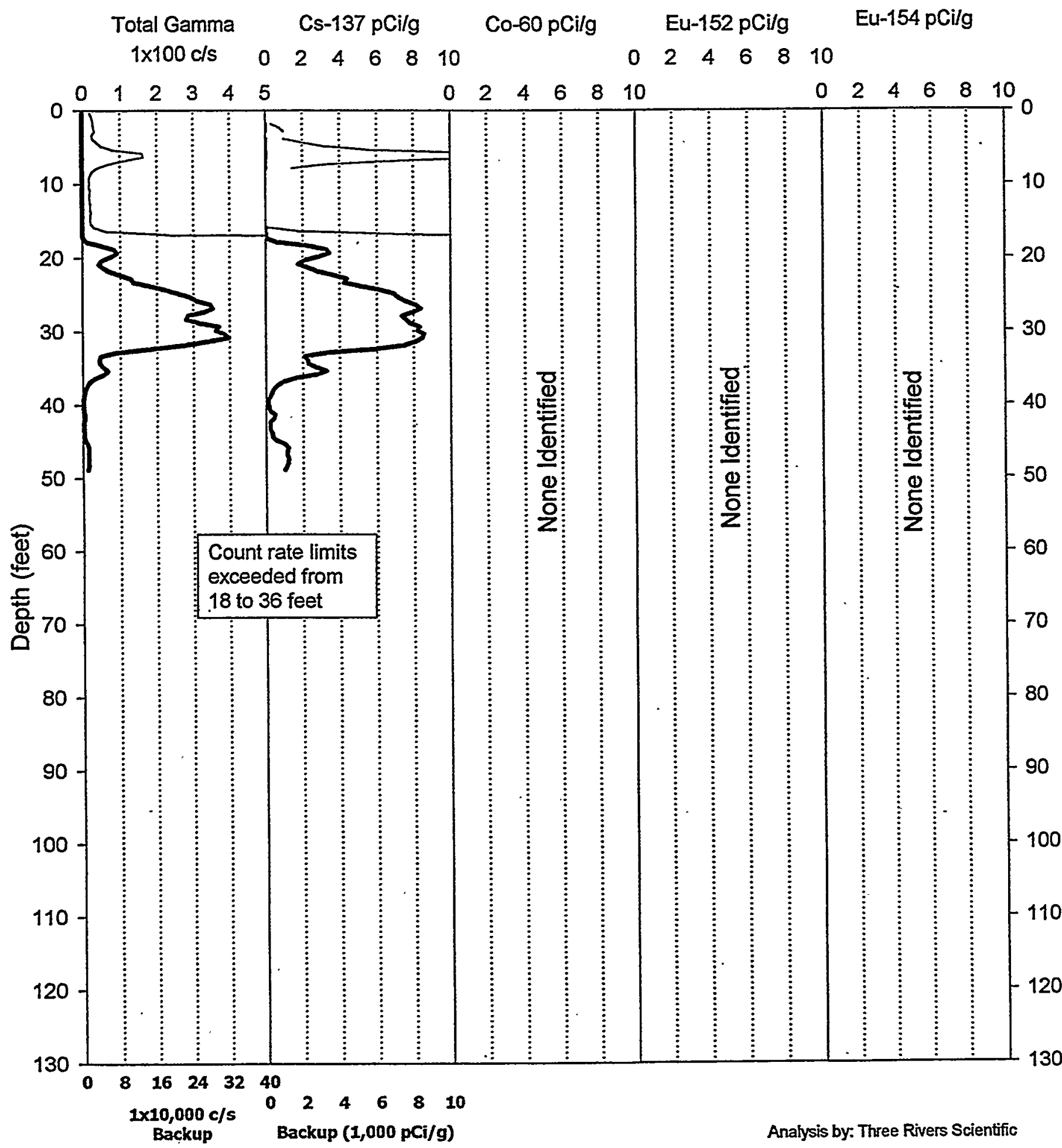




\section{RLS Spectral Gamma Ray Borehole Survey \\ Waste Management Federal Services NW}

\section{Log Analysis Summary Report}

$\begin{array}{lllr}\text { Project: } & \text { PNNL Vadose Zone Monitoring } & \text { Well: } & \text { 299-E33-288 } \\ \text { Log Type: } & \text { HPGe Spectral Gamma Ray } & \text { Log Dates: } & \text { June 18, } 1999\end{array}$

\section{General Notes:}

Total gamma is a response to Cs-137 concentrations for most of the depth interval logged. The KUT values suffer from low sensitivity for this instrumentation and are not always detected.

Log data collected with a depth reference of top of casing, and during analysis the depths were shifted to ground surface reference for all plots.

System Performance Verify: The pre- and post-log verification passed performance standards.

Repeat Interval: No repeat interval performed for this well, since two wells logged during one day.

Environmental Corrections: All radionuclide concentrations have been corrected for casing attenuation (entire well). Water level is below depths logged. No casing correction was applied to the total gamma due to Compton downscatter interference.

\section{Radionuclides:}

Cs-137 was identified over the depth intervals from 2-8 feet and from 16-49 feet. The maximum concentration of Cs-137 occurred at a depth of 31 feet with a reading that exceeded $8,500 \mathrm{pCi} / \mathrm{g}$. The count rate limits were exceeded from 18.25 to 36.25 feet. Even though the instrument did not saturate, the dead time correction is inaccurate for this interval, and the true readings will be higher than registering. Cs-137 MDL for this borehole condition is $2.4 \mathrm{pCi} / \mathrm{g}$. 


\section{Moisture Logging Service \\ Log Header}

Project: - PNNL Vadose Zone Monitoring . Well: 299-E33-288

\section{Log Type: ' Moisture Gauge}

Borehole Information

\begin{tabular}{|c|c|c|c|}
\hline Well \# A7084 & Water Depth & $\mathrm{ft}$ & Total Depth 53 \\
\hline Elevation Reference $\underline{\mathrm{n} / \mathrm{a}}$ & Elevation & $n / a$ & \\
\hline Depth Reference Top Casing & Casing Stickup & 3.4 & \\
\hline Casing Diameter $\underline{8 \text { in }}$ & Depth Interval & 0 to $53 \quad \mathrm{ft}$ & Thickness .3125 in \\
\hline
\end{tabular}

Logging Information

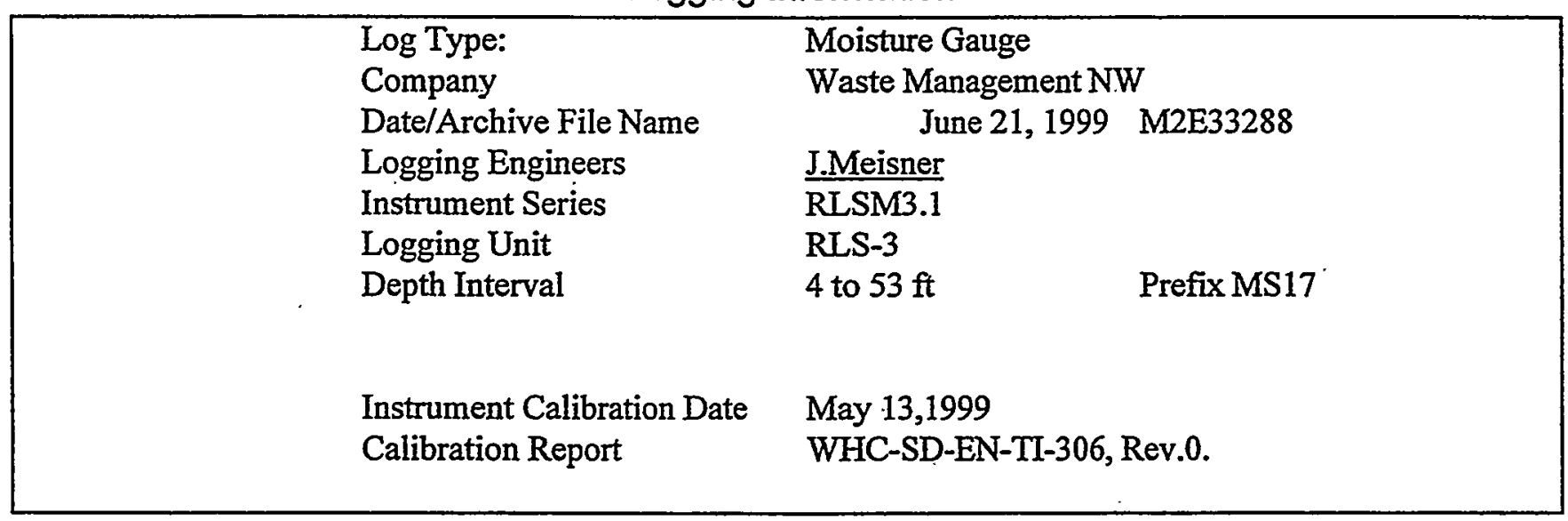

Analysis Information

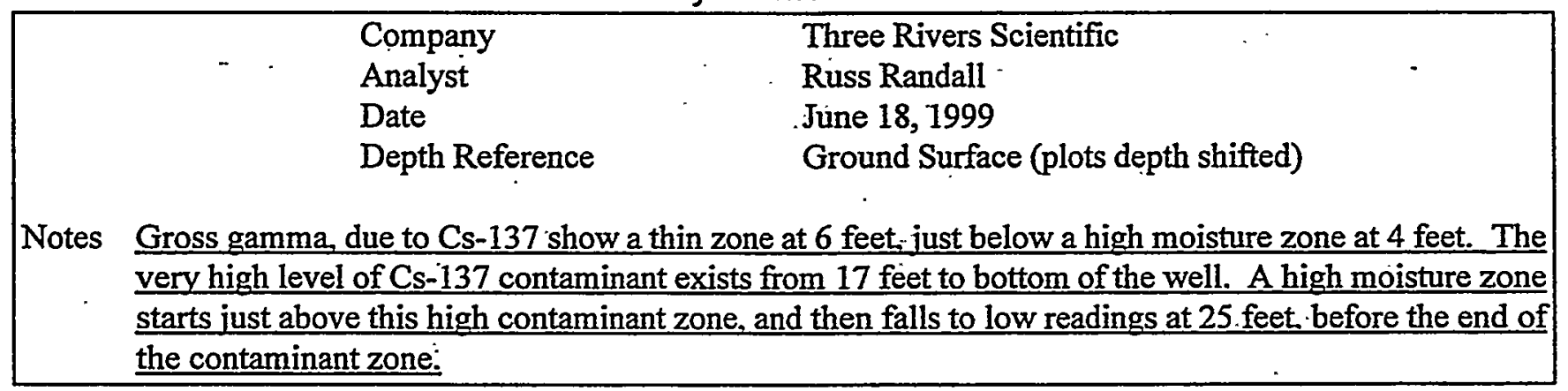




\section{RLS Moisture Processed Log Data}

\section{Waste Management Federal Services NW}

Project: Vadose Zone Monitoring

Borehole: 299-E33-288

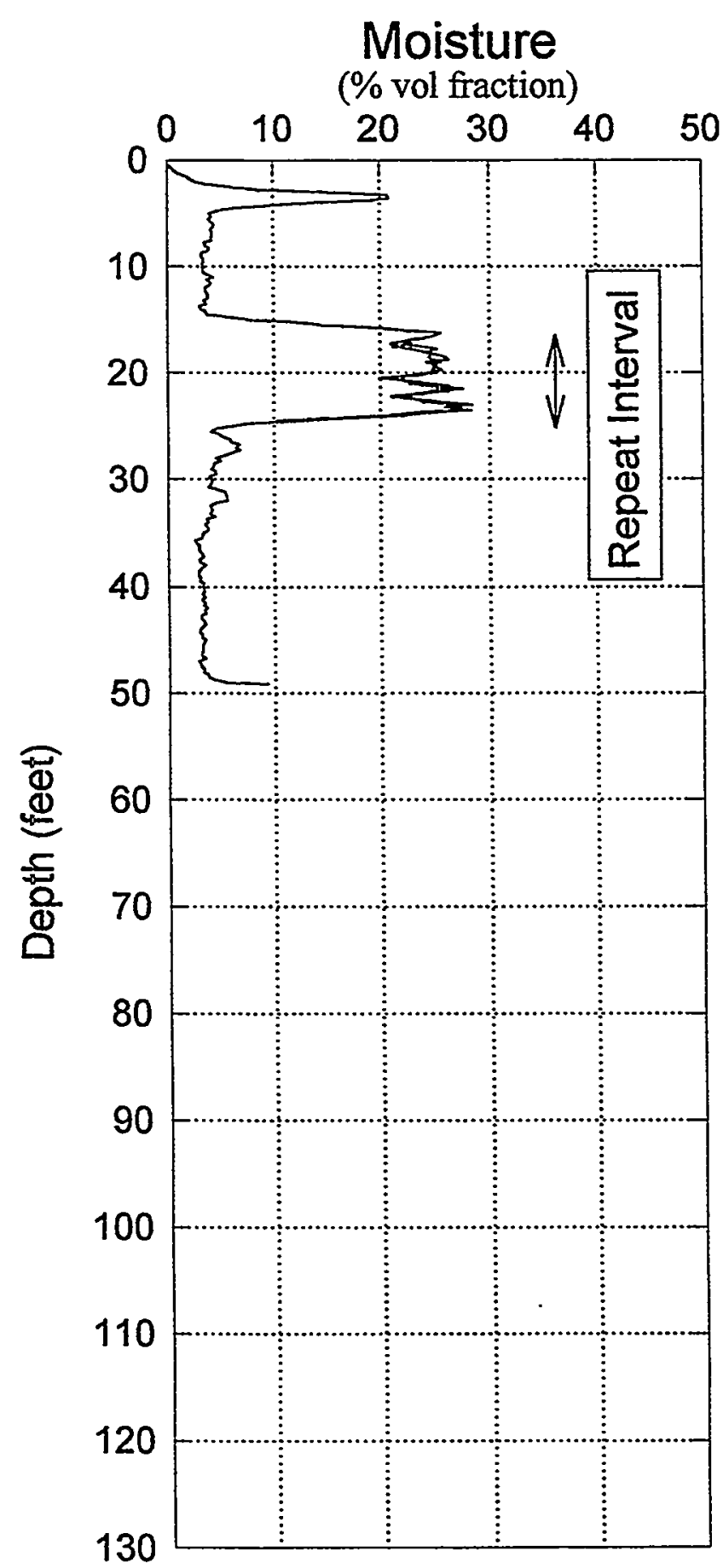

8" Casing Calibration Log Date June 21, 1999

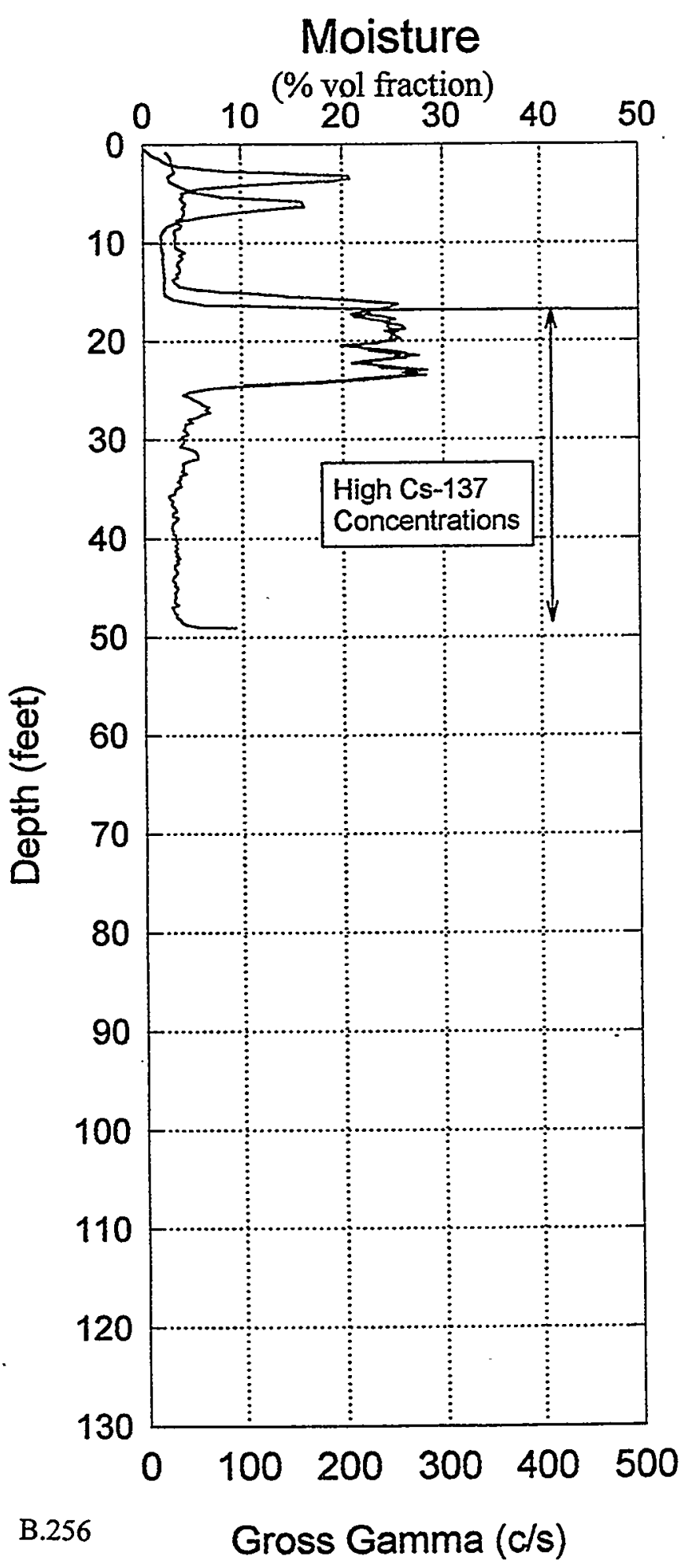




\section{RLS \\ Log Analysis \& Summary}

Project: PNNL Vadose Zone Monitoring

Log Type: $\quad$ Moisture Gauge
Well D: $\quad$ 299-E33-288

Log Dates: June 21, 1999

\section{General Notes:}

The low reading from 0 feet to 2 feet is due to surface effects and not necessarily the moisture content of.the earth surrounding the borehole.

Log data collected with a depth reference of top of casing, and during analysis the depths were shifted to ground surface reference for all plots.

System Performance Verify: The pre- and post-log verification passed performance standards, $+0.1 \%$ in the shield verify.

Repeat Interval: Based on the repeat interval from 17 to 25 feet, the logging system performed according to specifications.

Environmental Corrections: The moisture levels have been corrected for casing attenuation (entire well).

\section{Observations:}

A thin Cs-137 contaminated zone exists at 6 feet just below a high moisture interval. The majority of the Cs-137 contaminant exists from 17 feet to the bottom of the well (49 feet). Another high moisture zone exists from 15 to 25 feet which correlates with the onset of the contaminated interval. 


\section{RLS Spectral Gamma Ray Borehole Survey Waste Management Federal Services NW}

\section{Log Header}

Project: PNNL Vadose Zone Monitoring Well: 299-E33-289

\section{Log Type: $\quad$ HPGe Spectral Gamma Ray}

Borehole Information

\begin{tabular}{|c|c|c|c|c|}
\hline Well \# A7085 & Water Depth & $\mathrm{n} / \mathrm{a}$ & $\mathrm{ft}$ & Total Depth $\underline{52} \mathrm{ft}$ \\
\hline Elevation Reference n/a & Elevation & $\mathrm{n} / \mathrm{a}$ & $\mathrm{ft}$ & \\
\hline Depth Reference Top Casing & Casing Stickup & 2.9 & $\mathrm{ft}$ & \\
\hline Casing Diameter $\underline{8}$ in & Depth Interval & 0 to 52 & ft & Thickness 0.3125 in \\
\hline
\end{tabular}

Logging Information

\begin{tabular}{|c|c|c|}
\hline $\begin{array}{l}\text { Log Type: } \\
\text { Company }\end{array}$ & $\begin{array}{l}10 \% \text { HPGe Spectral G } \\
\text { Waste Management N }\end{array}$ & mma Ray \\
\hline Date/Archive File Name & June 21, 1999 & H2E 33289 \\
\hline Logging Engineers & S.Kos & \\
\hline Instrument Series & RLSG01000H00.0 & \\
\hline Logging Unit & RLS1 & \\
\hline Depth Interval & 3 to $52 \mathrm{ft}$ & Prefix AP03 \\
\hline Instrument Calibr & June 14, 1999 & \\
\hline Calibration Report & WHC-SD-EN-TI-292 & \\
\hline
\end{tabular}

Analysis Information

$\begin{array}{ll}\text { Company } & \text { Three Rivers Scientific } \\ \text { Analyst } & \text { Russ Randall } \\ \text { Date } & \text { June 15, 1999 } \\ \text { Depth Reference } & \text { Ground Surface (plots depth shifted) }\end{array}$

Notes $\mathrm{Cs}-137$ is the only man made radionuclide detected. Instrument exceeded count rate limits from 16.25 to 19.25 feet. The character of the gross gamma is mostly a response to the Cs-137 concentration. 


\section{RLS Spectral Gamma Ray Borehole Survey Waste Management Federal Services NW}

Project: Vadose Zone Monitoring Log Date: June 21, 1999 Borehole: 299-E33-289

Naturally Occurring Radionuclides

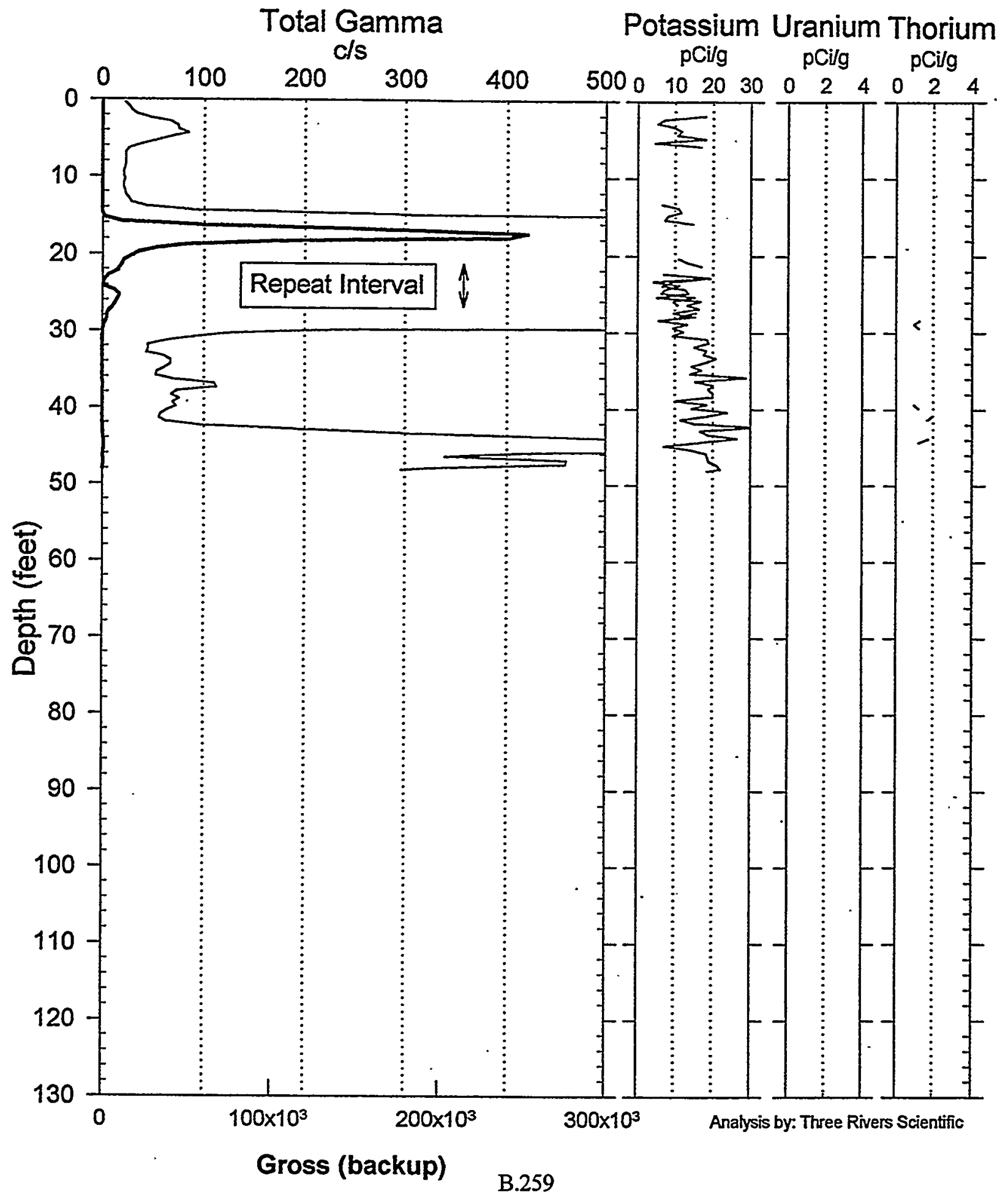


RLS Spectral Gamma-Ray Borehole Survey

Waste Management Federal Services NW

Project: Vadose Zone Monitoring Log Date: June 21, 1999 Borehole: 299-E33-289 Man-Made Radio-Nuclides

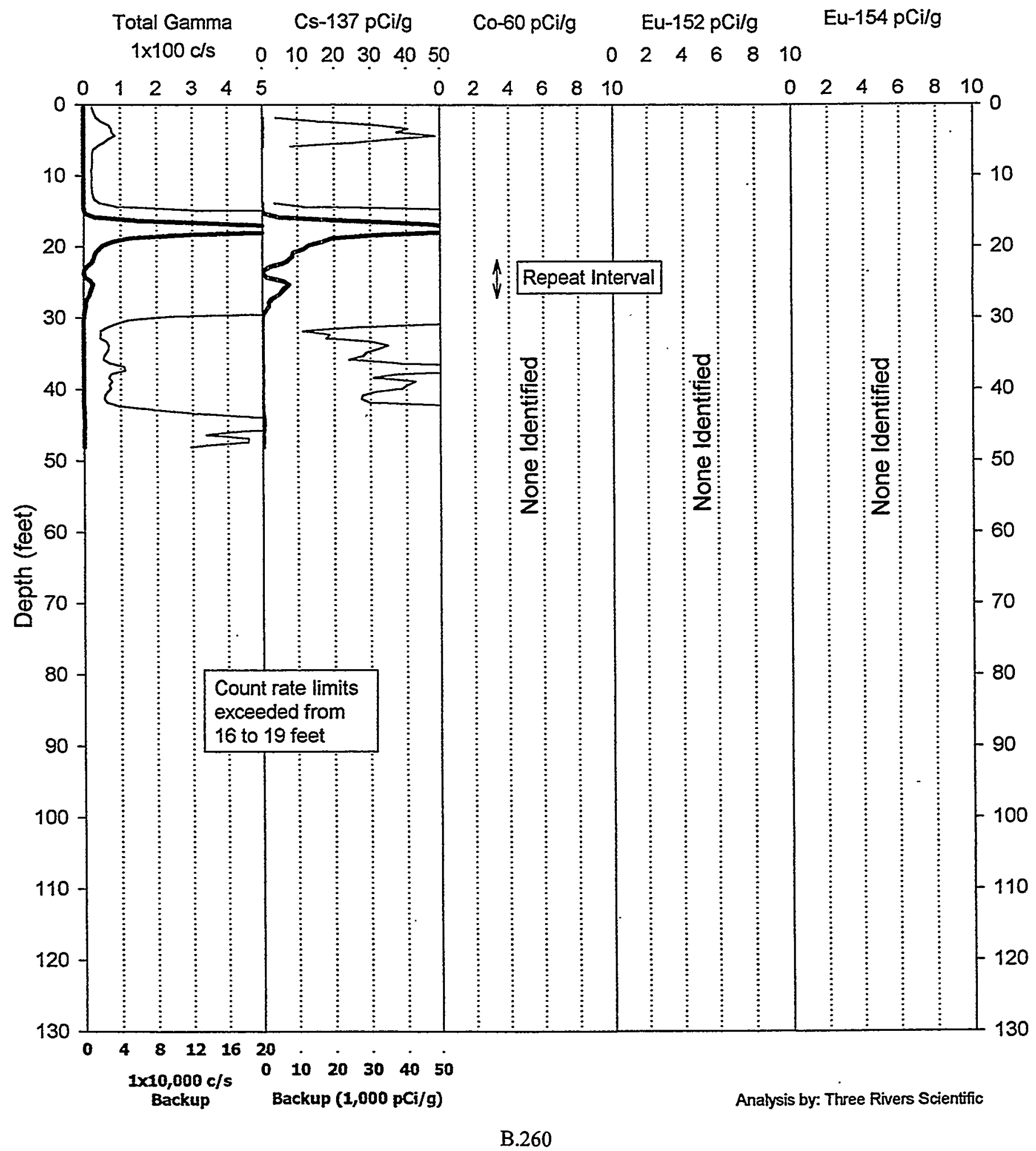




\section{RLS Spectral Gamma Ray Borehole Survey Acceptance QA Processing}

Project: PNNL Vadose Zone Monitoring Log Date: June 21, 1999 Borehole: 299-E33-289 Compare Main Log \& Repeat

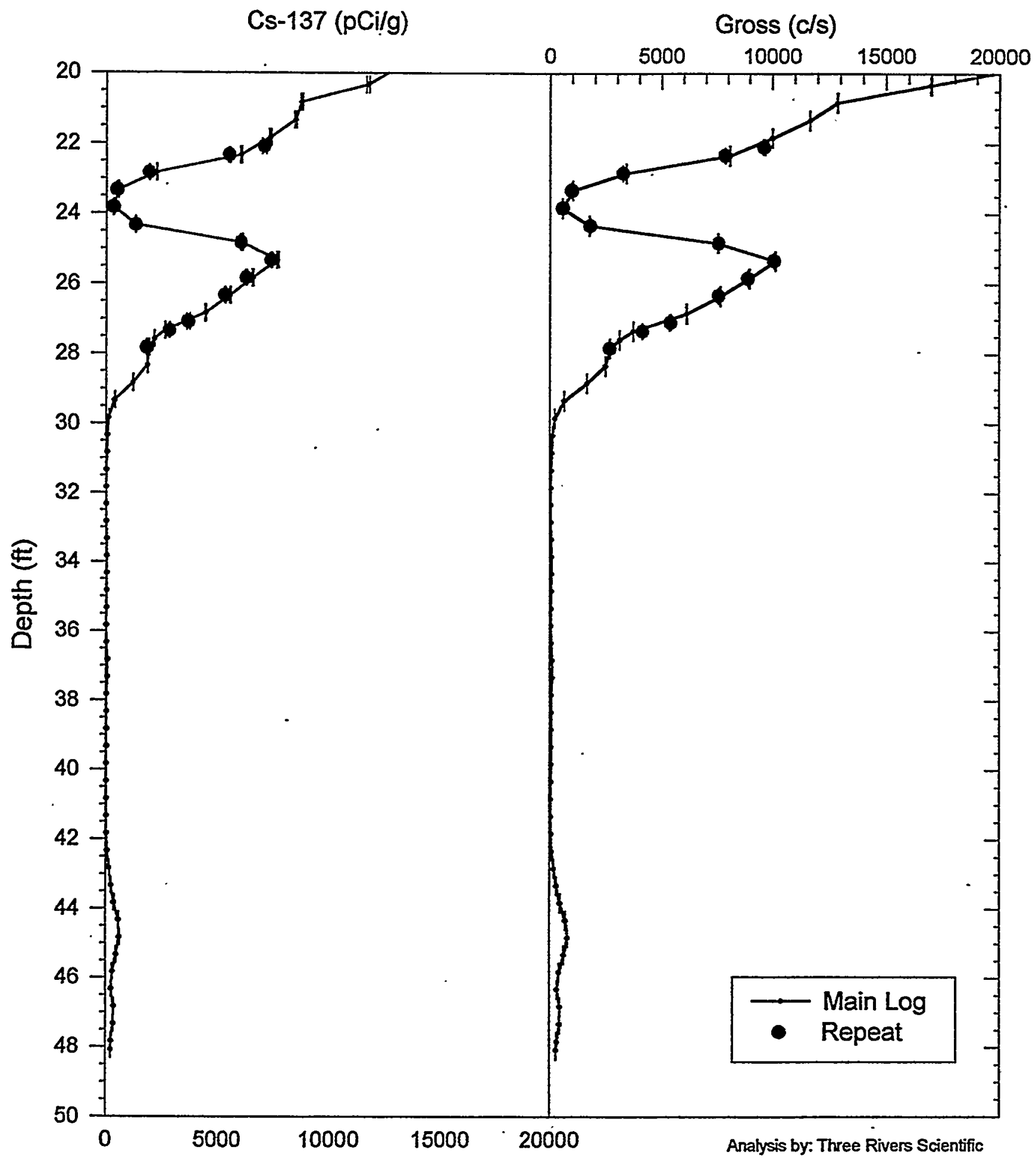




\section{RLS Spectral Gamma Ray Borehole Survey \\ Waste Management Federal Services NW}

\section{Log Analysis Summary Report}

$\begin{array}{lllr}\text { Project: } & \text { PNNL Vadose Zone Monitoring } & \text { Well: } & \text { 299-E33-289 } \\ \text { Log Type: } & \text { HPGe Spectral Gamma Ray } & \text { Log Dates: } & \text { June 21, } 1999\end{array}$

General Notes:

Total gamma is a response to Cs-137 concentrations for most of the depth interval logged. Because of the low sensitivity of this instrumentation for the presence of KUT, these natural radionuclides are not consistently detected.

Log data collected with a depth reference of top of casing, and during analysis the depths were shifted to ground surface reference for all plots.

System Performance Verify: The pre- and post-log verification passed performance standards.

Repeat Interval: Based on the repeat interval, the logging system performed as per specifications. The error bars are calculated for 1 standard deviation of the net photo peak count rate statistical variance. Thus, the repeat should fall within these error bars $67 \%$ of the time.

Environmental Corrections: All radionuclide concentrations have been corrected for casing attenuation (entire weil). Water level is below depths logged. No casing correction was applied to the total gamma due to Compton downscatter interference.

\section{Radionuclides:}

Cs-137 was identified over the depth intervals from 2-5 feet and from 15-49 feet. The maximum concentration of Cs-137 occurs at a depth of 17 feet, with a reading that exceeds $55,000 \mathrm{pCi} / \mathrm{g}$. The count rate limits were exceeded from 16.25 to 19.25 feet. Even though the instrument did not saturate, the dead time correction is inaccurate for this interval, and the true concentration is higher than recorded. Cs-137 MDL for this borehole condition is 2.4 pCi/g. 


\section{Moisture Logging Service Log Header}

Project: PNNL Vadose Zone Monitoring

Well: 299-E33-289

Log Type: Moisture Gauge

Borehole Information

Well \# A7085

Elevation Reference $\mathrm{n} / \mathrm{a}$

Depth Reference Top Casing

Casing Diameter $\underline{8 \quad \text { in }}$

\begin{tabular}{|c|c|}
\hline Water Depth & none \\
\hline Elevation & $\mathrm{n} / \mathrm{a}$ \\
\hline Casing Stickup & 2.9 \\
\hline Depth Interval & 0 to 5 \\
\hline
\end{tabular}

Elevation $\mathrm{n} / \mathrm{a} \ldots \mathrm{ft}$

Casing Stickup $2.9 \quad \mathrm{ft}$

Depth Interval 0 to 52
Total Depth $52 \mathrm{ft}$.

Thickness .3125 in

\section{Logging Information}

Log Type:
Company
Date/Archive File Name
Logging Engineers
Instrument Series
Logging Unit
Depth-Interval
Instrument Calibration Date
Calibration Report

Moisture Gauge

Waste Management NW

K.Hulse

June 2, 1999 M2E33289

RLSM3.1

RLS-3

3 to $52 \mathrm{ft}$

Prefix MB09

May 13, 1999

WHC-SD:EN-TI-306,Rev.0.

Analysis Information

\begin{tabular}{|c|c|c|}
\hline & $\begin{array}{l}\text { Company } \\
\text { Analyst } \\
\text { Date } \\
\text { Depth Reference }\end{array}$ & $\begin{array}{l}\text { Three Rivers Scientific } \\
\text { Russ Randall } \\
\text { June 21, } 1999 \\
\text { Ground Surface (plots depth shifted) }\end{array}$ \\
\hline Notes & $\begin{array}{l}\text { n extra gross gamma plot scale } \\
\text { e large range observed. }\end{array}$ & wer levels is added to demonstrate the comparison for \\
\hline
\end{tabular}




\section{RLS Moisture Processed Log Data}

\section{Waste Management Federal Services NW}

Project: Vadose Zone Monitoring Borehole: 299-E33-289

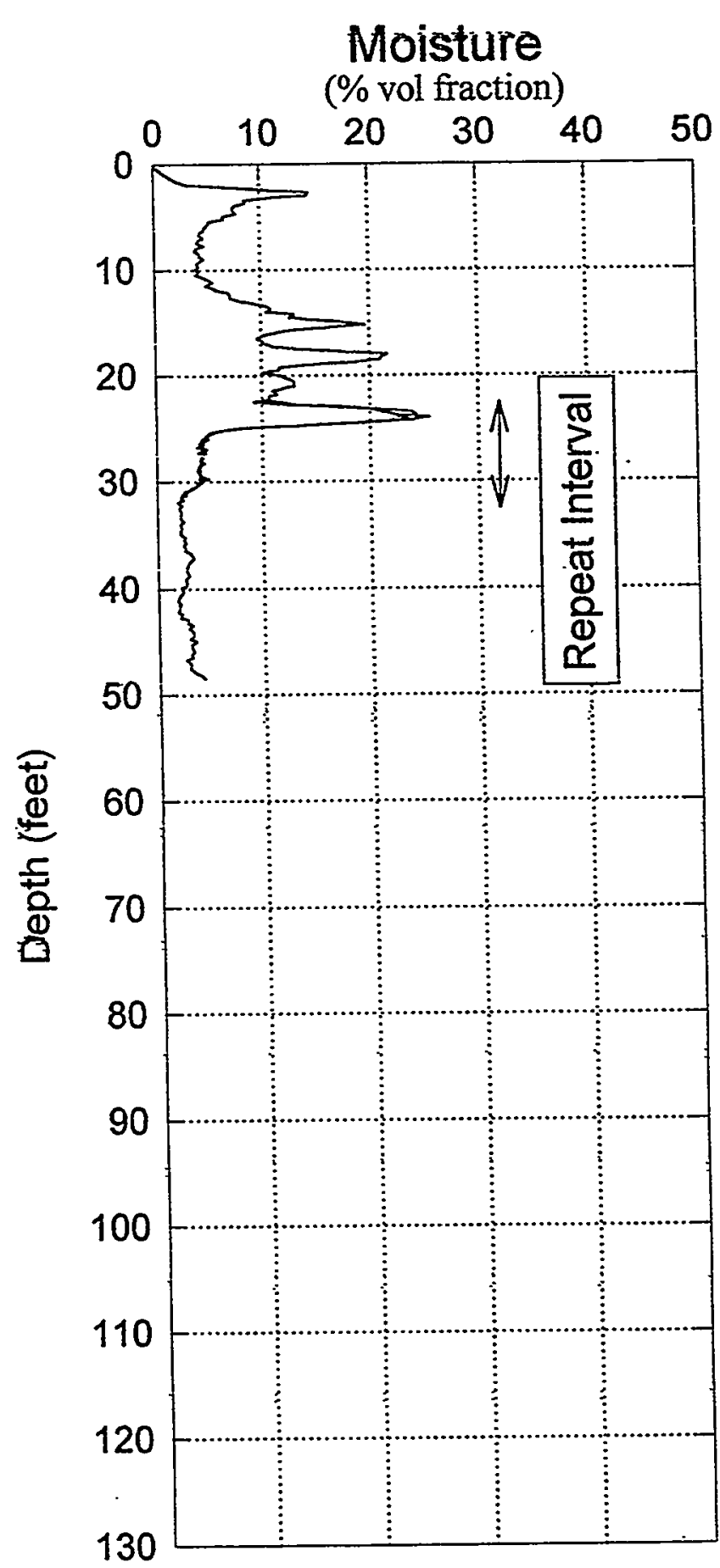

8" Casing Calibration Log Date June 2, 1999

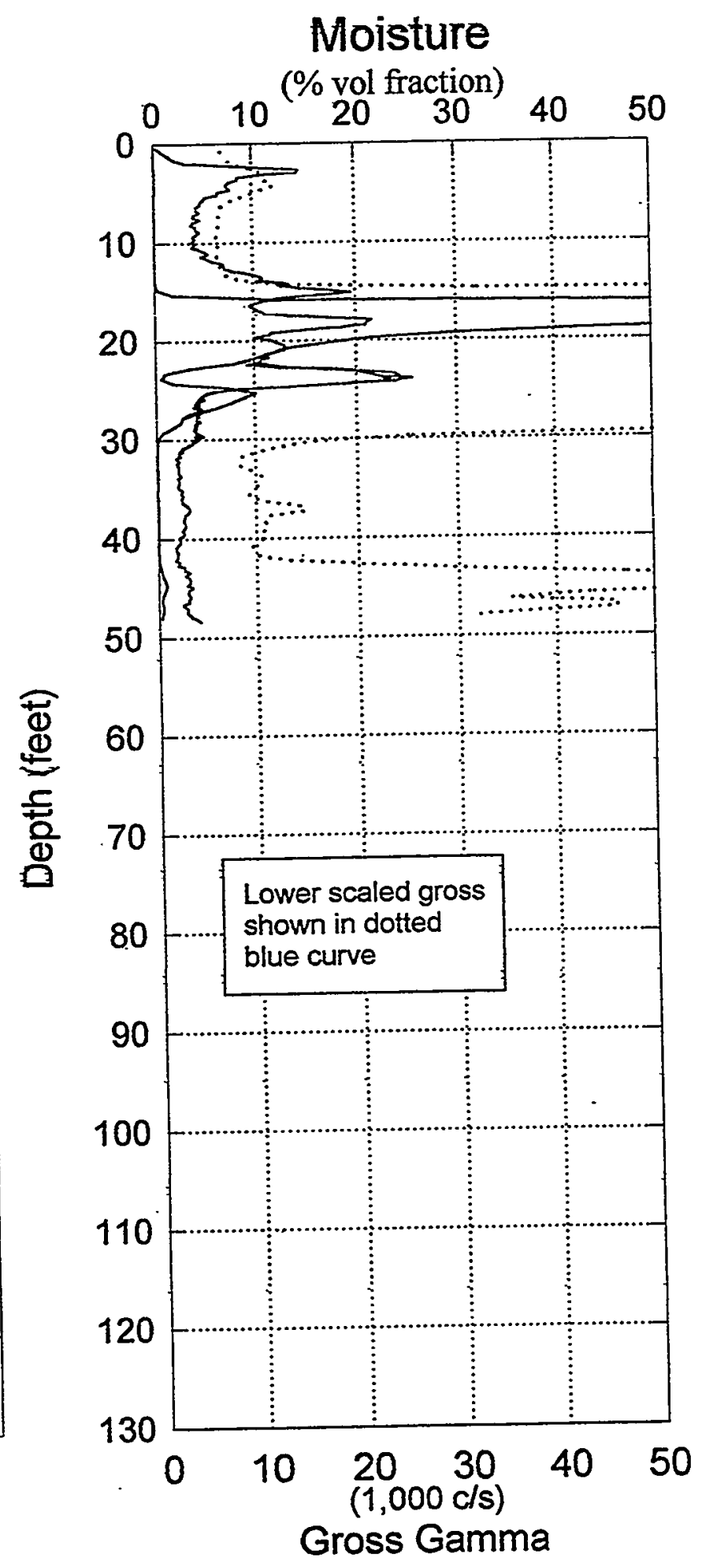




\section{RLS \\ Log Analysis \& Summary}

Project: PNNL Vadose Zone Monitoring

Well ID:

299-E33-289

Log Type: $\quad$ Moisture Gauge

Log Date:

June 2, 1999

\section{General Notes:}

The low reading from 0 feet to 2 feet is due to surface effects and not necessarily the moisture content of the earth surrounding the borehole.

Log data collected with a depth reference of top of casing, and during analysis the depths were shifted to ground surface reference for all plots.

There is more character to the moisture response in this well, and the analysis merits detail on the gross gamma. In order to view the dynamic range of the contaminants, a second gross gamma curve is plotted in a dotted blue line (scale not shown).

System Performance Verify: The pre- and post-log verification passed performance standards, $-4.2 \%$ in the shield verify.

Repeat Interval: Based on the repeat interval from 23 to 33 feet, the logging system performed according to specifications.

Environmental Corrections: The moisture levels have been corrected for casing attenuation (entire well).

\section{Observations:}

A thin contaminated zone (low activity) exists at 5 feet just below a high moisture interval. A deeper thin moisture interval exists at 15 feet just above the onset of the highest contaminated interval. Two more thin moisture zones occur at 18 and 24 feet. The moisture zone at 24 feet occurs just above another gamma contaminated zone that ranges from 26 to 30 feet. 


\section{RLS Spectral Gamma Ray Borehole Survey \\ Waste Management Federal Services NW}

\section{Log Header}

Project: $\quad$ PNNL Vadose Zone Monitoring

Well: 299-E33-290

Log Type: HPGe Spectral Gamma Ray

Borehole Information

\begin{tabular}{|c|c|c|c|c|}
\hline Well \# A7086 & Water Depth & $\underline{n} / \mathrm{a}$ & $\mathrm{ft}$ & Total Depth $\underline{52 \mathrm{ft}}$ \\
\hline Elevation Reference $\underline{n} / \mathbf{a}$ & Elevation & $\mathrm{n} / \mathrm{a}$ & $\mathrm{ft}$ & \\
\hline Depth Reference Top Casing & Casing Stickup & 3.6 & $\mathrm{ft}$ & \\
\hline Casing Diameter $\underline{8}$ in & Depth Interval & 0 to 52 & $\mathrm{ft}$ & Thickness 0.3125 in \\
\hline
\end{tabular}

\section{Logging Information}

Log Type:

Company

Date/Archive File Name

Logging Engineers.

Instrument Series

Logging Unit

Depth Interval

Instrument Calibration Date

Calibration Report
$10 \%$ HPGe Spectral Gamma Ray

Waste Management NW

June 21, 1999 H2E33290

S. Kos

RLSG01000H00.0

RLS1

4 to $52 \mathrm{ft}$

Prefix AP04

June 14, 1999

WHC-SD-EN-TI-292

Analysis Information

$\begin{array}{ll}\text { Company } & \text { Three Rivers Scientific } \\ \text { Analyst } & \text { Russ Randall } \\ \text { Date } & \text { June 15, 1999 } \\ \text { Depth Reference } & \text { Ground Surface (plots depth shifted) }\end{array}$

Notes Cs-137 is the only man made radionuclide detected. Instrument count rate limits exceeded from 21.75 to 30.0 feet. The character of the gross gamma is mostly a response to the Cs- 137 concentration. 


\section{RLS Spectral Gamma Ray Borehole Survey Waste Management Federal Services NW}

Project: Vadose Zone Monitoring Log Date: June 21, 1999 Borehole: 299-E33-290

Naturally Occurring Radionuclides

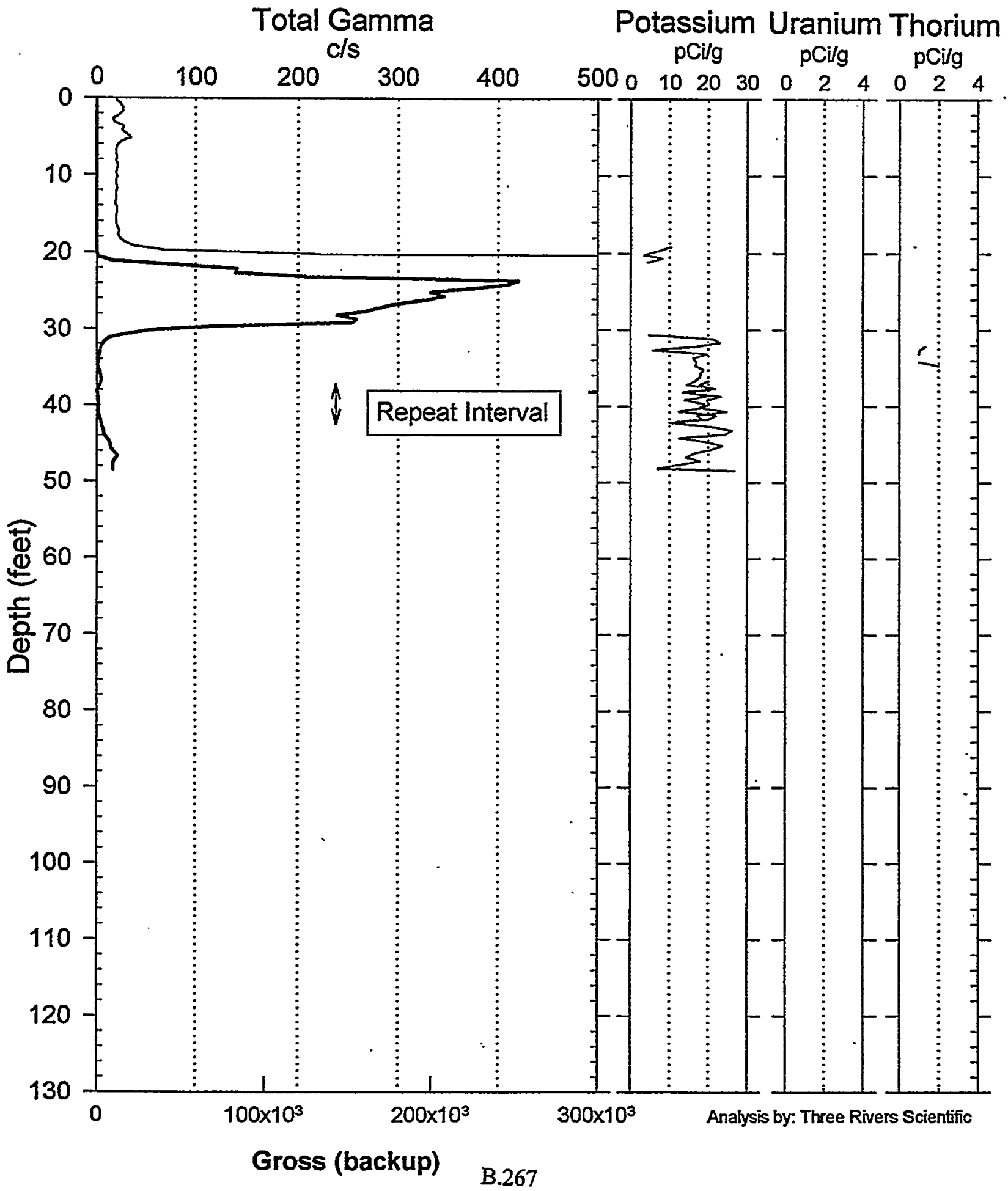




\section{RLS Spectral Gamma-Ray Borehole Survey Waste Management Federal Services NW}

Project: Vadose Zone Monitoring Log Date: June 21, 1999 Borehole: 299-E33-290 Man-Made Radio-Nuclides

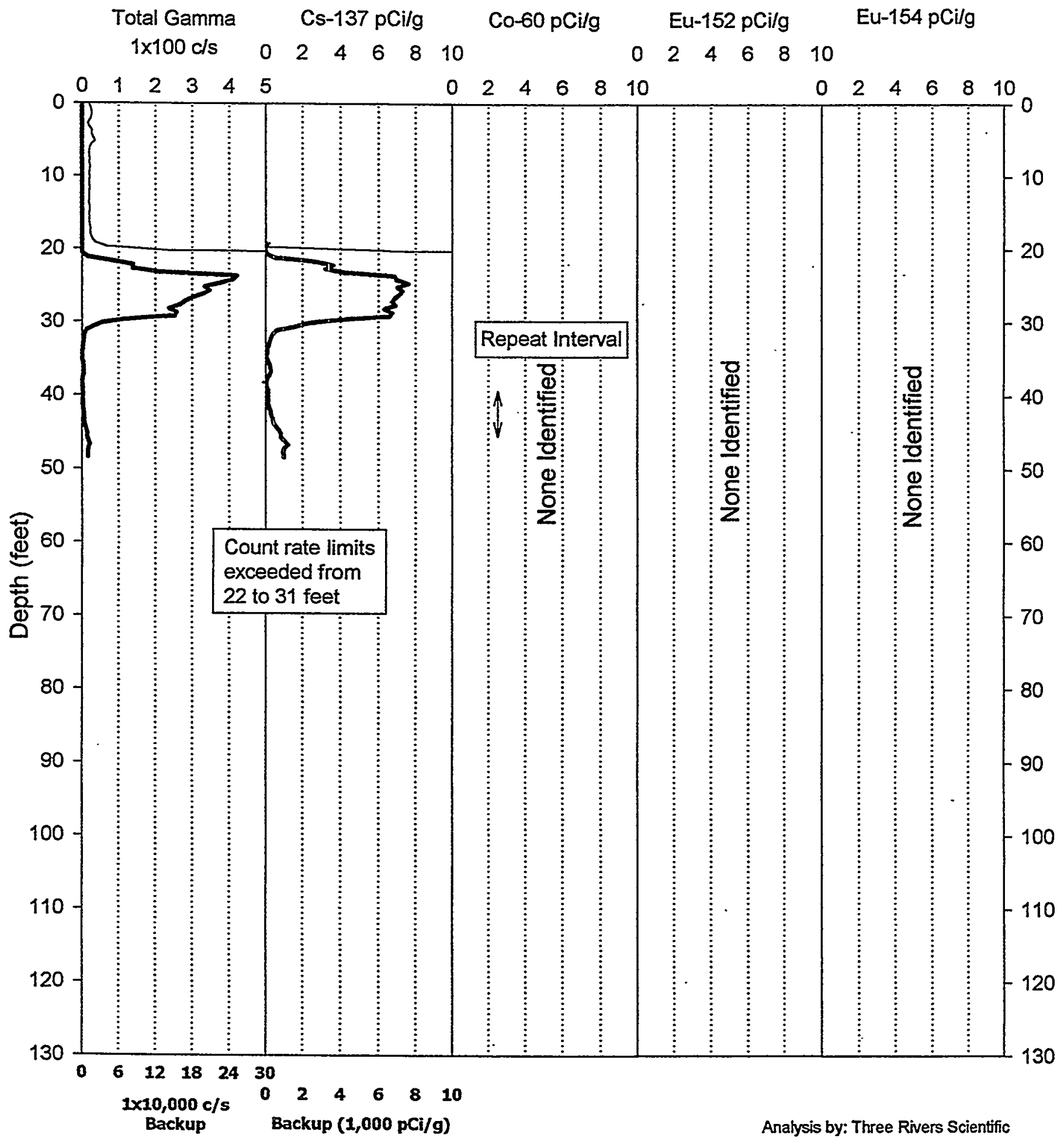




\section{RLS Spectral Gamma Ray Borehole Survey Acceptance QA Processing}

Project:PNNL Vadose Zone Monitoring - Log Date: June 21, 1999 Borehole: 299-E33-290

Compare Main Log \& Repeat

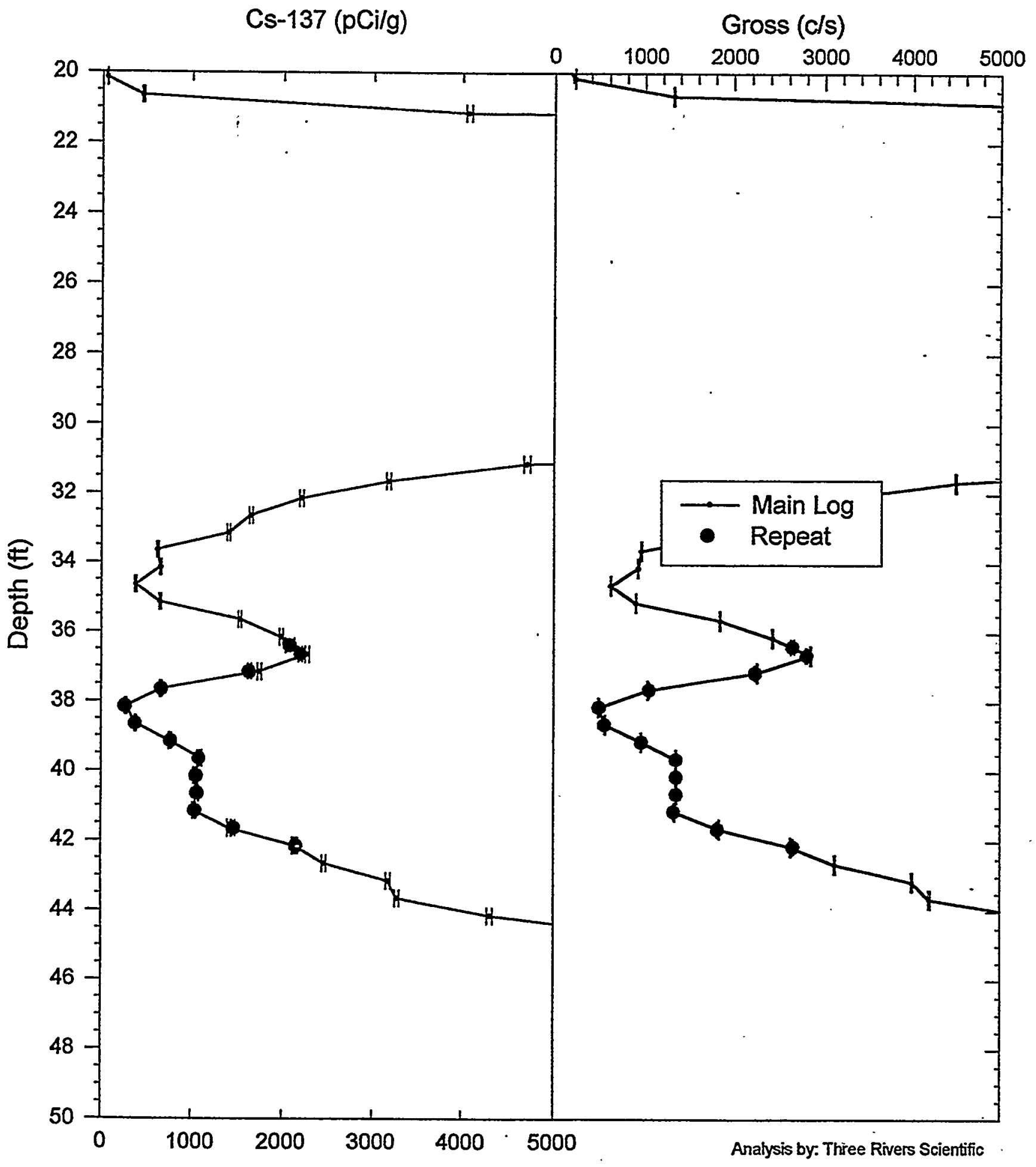




\section{RLS Spectral Gamma Ray Borehole Survey \\ Waste Management Federal Services NW}

\section{Log Analysis Summary Report}

$\begin{array}{lllr}\text { Project: } & \text { PNNL Vadose Zone Monitoring } & \text { Well: } & \text { 299-E33-290 } \\ \text { Log Type: } & \text { HPGe Spectral Gamma Ray } & \text { Log Date: } & \text { June 21, 1999 }\end{array}$

\section{General Notes:}

Total gamma is a response to Cs-137 concentrations for most of the depth interval logged. Because of the low sensitivity of this instrumentation for the presence of KUT, these natural radionuclides and are not consistently detected.

Log data collected with a depth reference of top of casing, and during analysis the depths were shifted to ground surface reference for all plots.

System Performance Verify: The pre- and post-log verification passed performance standards.

Repeat Interval: Based on the repeat interval, the logging system performed as per specifications. The error bars are calculated for 1 standard deviation of the net photo peak count rate statistical variance. Thus, the repeat should fall within these error bars $67 \%$ of the time.

Environmental Corrections: All radionuclide concentrations have been corrected for casing attenuation (entire well). Water level is below depths logged. No casing correction was applied to the total gamma due to Compton downscatter interference.

\section{Radionuclides:}

Cs-137 was identified over the depth interval from 19-49 feet. The maximum concentration of Cs-137 occurs at a depth of 25 feet, with a reading that exceeds $60,000 \mathrm{pCi} / \mathrm{g}$. The count rate limits were exceeded from 21.75 to 30.0 feet. Even though the instrument did not saturate, the dead time correction is inaccurate and the true concentration is high than recorded. Cs-137 MDL for this borehole condition is $2.4 \mathrm{pCi} / \mathrm{g}$. 


\section{RLS \\ Log Header}

Project: $\quad$ PNNL Vadose Zone Monitoring

Well: 299-E33-290

\section{Log Type: $\quad$ Moisture Gauge}

Borehole Information

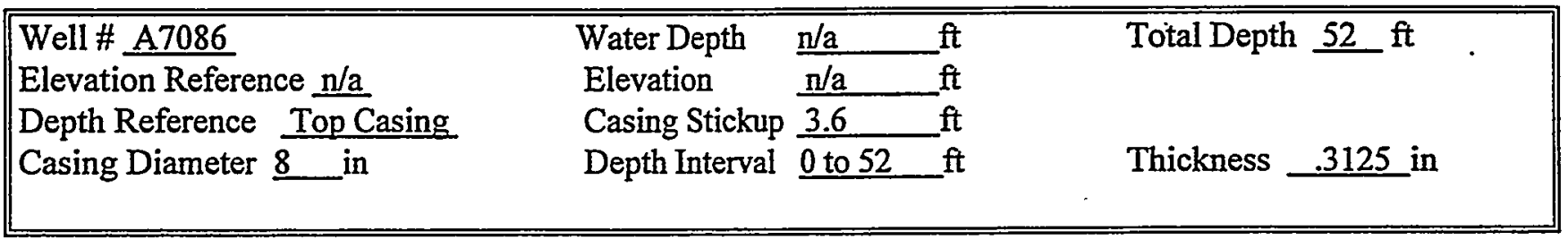

Logging Information

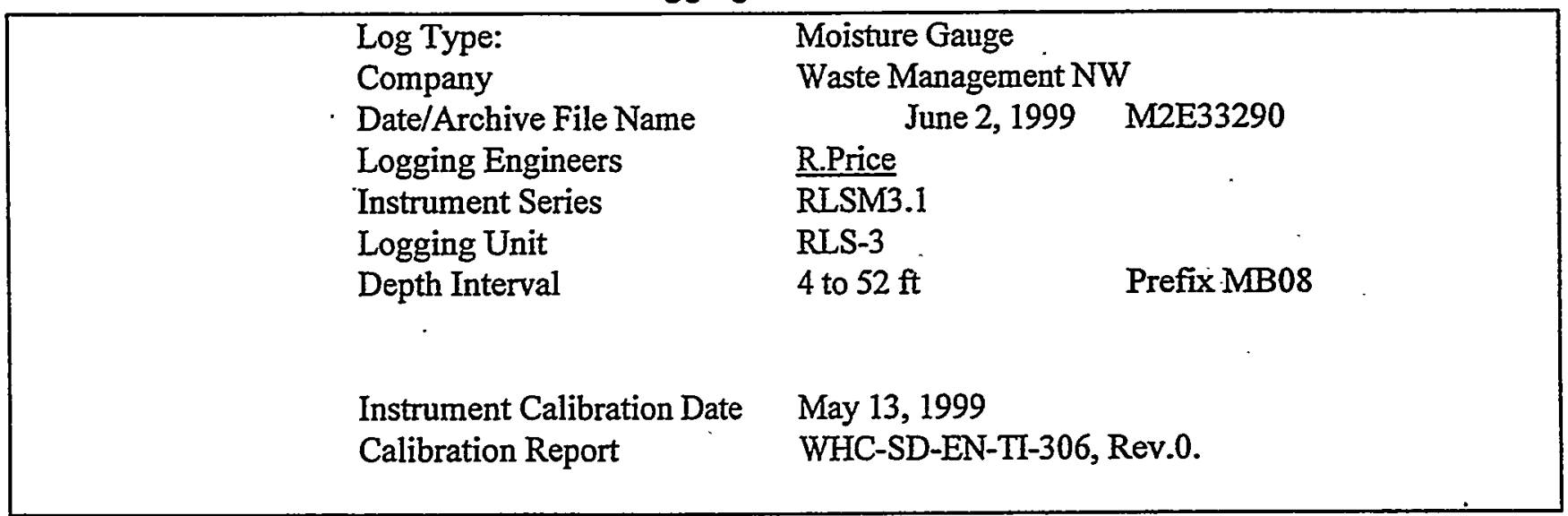

Analysis Information

$\begin{array}{ll}\text { Company } & \text { Three Rivers Scientific } \\ \text { Analyst } & \text { Russ Randall } \\ \text { Date } & \text { June 21, 1999 } \\ \text { Depth Reference } & \text { Ground Surface (plots depth shifted) }\end{array}$

Notes An extra gross gamma plot scaled to read the lower levels is added to demonstrate the comparison for the large range observed: 


\section{RLS Moisture Processed Log Data}

\section{Waste Management Federal Services NW}

Project: Vadose Zone Monitoring

Borehole: 299-E33-290

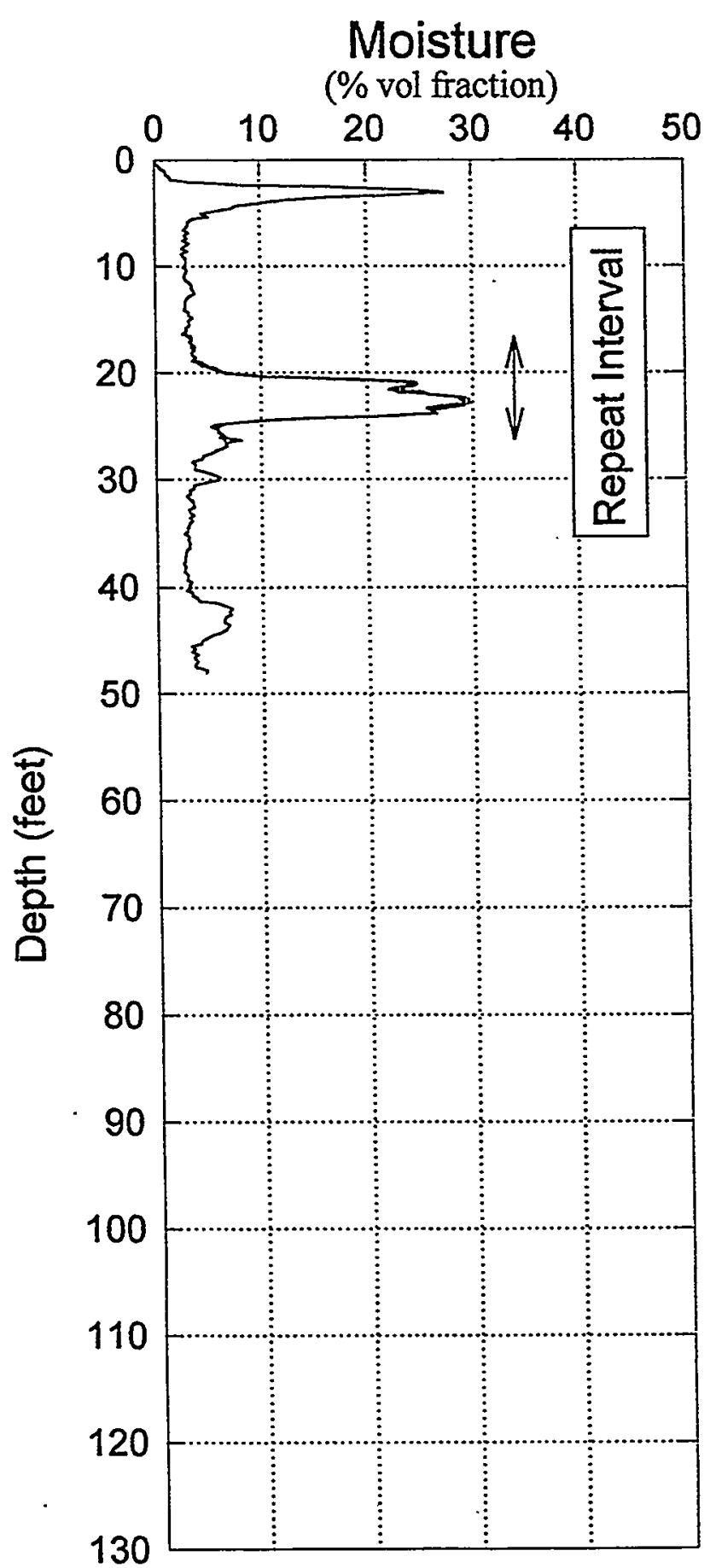

8 " Casing Calibration

Log Date June 2, 1999

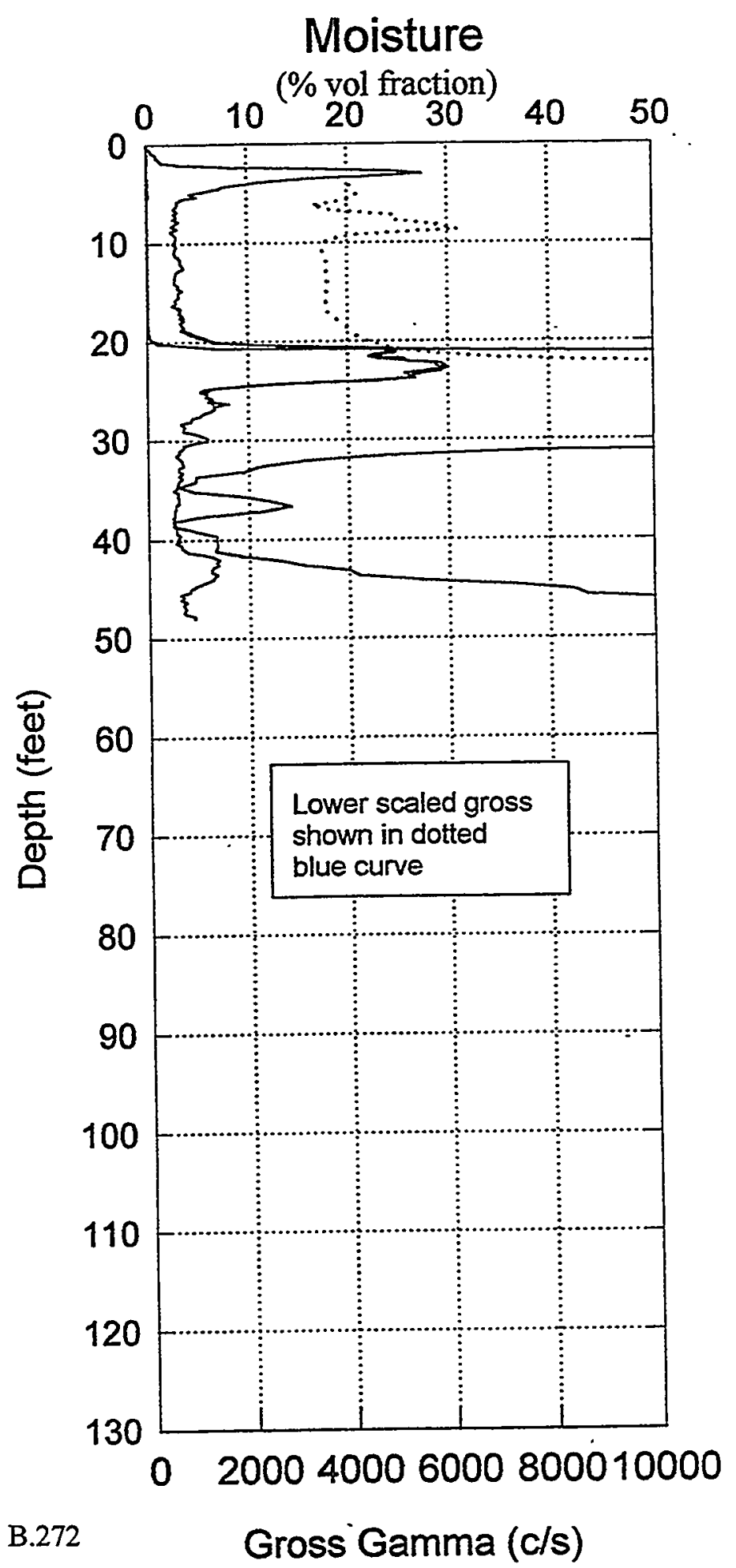




\section{RLS \\ Log Analysis \& Summary}

Project: PNNL Vadose Zone Monitoring

Well ID:

299-E33-290

Log Type: Moisture Gauge

Log Date: June 2, 1999

\section{General Notes:}

The low reading from 0 feet to 2 feet is due to surface effects and not necessarily the moisture content of the earth surrounding the borehole.

Log data collected with a depth reference of top of casing, and during analysis the depths were shifted to ground surface reference for all plots.

There is more character to the moisture response in this well and analysis merits more detail on the gross gamma. In order to view the dynamic range of the contaminants, a second gross gamma curve is plotted in a dotted blue line (scale not shown).

System Performance Verify: The pre- and post-log verification passed performance standards, $+1.6 \%$ in the shield . verify.

Repeat Interval: Based on the repeat interval from 16 to 26 feet, the logging system performed according to specifications.

Environmental Corrections: The moisture levels have been corrected for casing attenuation (entire well).

\section{Observations:}

A thin contaminated zone (low activity) exists at 9 feet just below a high moisture interval. A deeper thin moisture interval exists from 20 to 24 feet that correlates to the onset of the highest contaminated interval. The deepest moisture interval from 42 to 45 feet also correlates with the onset of a highly contaminated interval. At this depth, the conditions are unknown since the well is only 49 feet deep. 


\section{Distribution}

No. of

Copies

OFFSITE

10 R. R. Randall

Three Rivers Scientific

3659 Grant Court

West Richland, WA 99353

ONSITE

4 U.S. Department of Energy

B. L. Foley

$\mathrm{H} 0-12$

M. J. Furman

R. D. Hildbrand

K. M. Thompson

2 Bechtel Hanford, Inc.

K. R. Fecht

B. H. Ford

CH2M Hill Hanford, Inc.

V. J. Rohay

Fluor Daniel Northwest, Inc.

F. M. Mann

$\mathrm{H} 0-12$

$\mathrm{H} 0-12$

H0-12

$\mathrm{H} 0=02$

H0-21

H0-22
No. of

Copies

Lockheed Martin Corporation

D. A. Myers

$\mathrm{H} 0-22$

2 Waste Management Federal Services, Inc., Northwest Operations
S. E. Kos
H1-11
J. E. Meisner
H1-11

27 Pacific Northwest National Laboratory

K6-75

M. J. Fayer

K9-33

G. W. Gee

K9-33

G. R. Holdren

K6-81

D. G. Horton (10)

$\mathrm{K} 6-81$

V. G. Johnson

K6-96

S. J. Kowall

K8-12

G. V. Last

K6-81

S. P. Luttrell

K6-96

S. P. Reidel

K6-81

R. J. Serne

K6-81

Information Release Office (7)

K1-06

Distr.1 